


\section{OAK ST. HDSF}

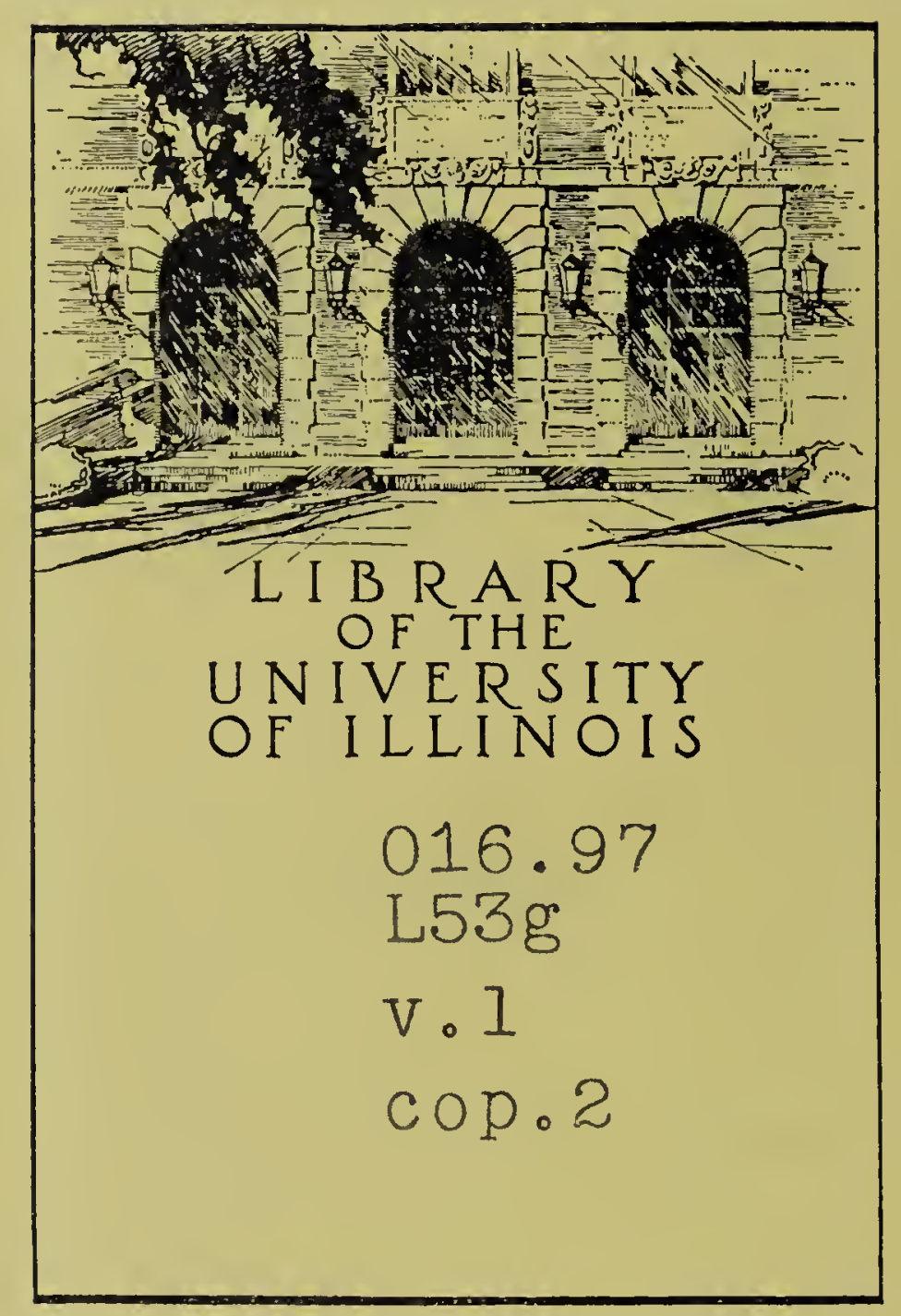


Return this book on or before the Latest Date stamped below.

University of Illinois Library

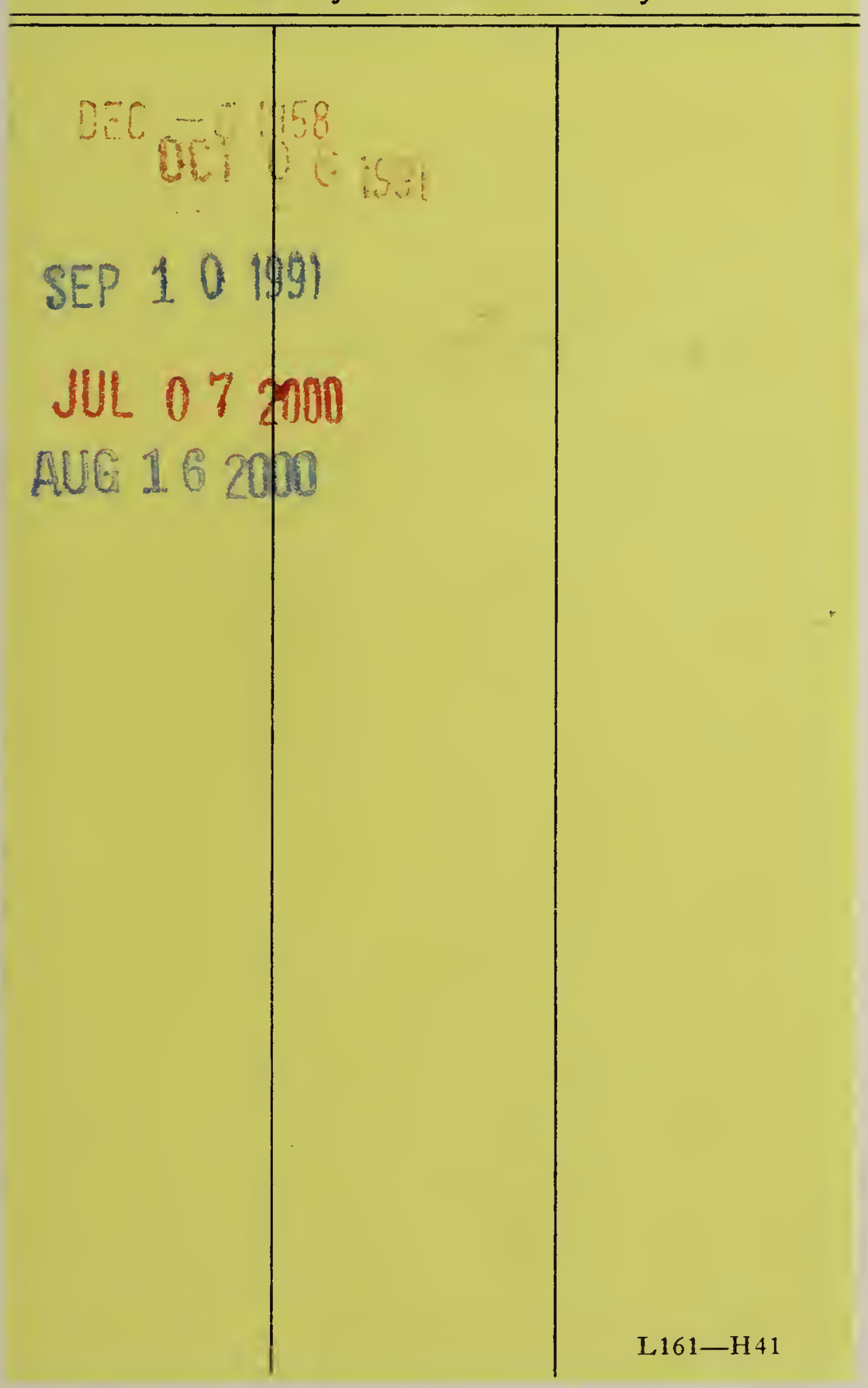







\title{
Guide to Materials for American History in the Libraries and Archives of Paris
}

\section{int}

\author{
BY \\ WALDO G. LELAND
}

Volume I

LIBRARIES

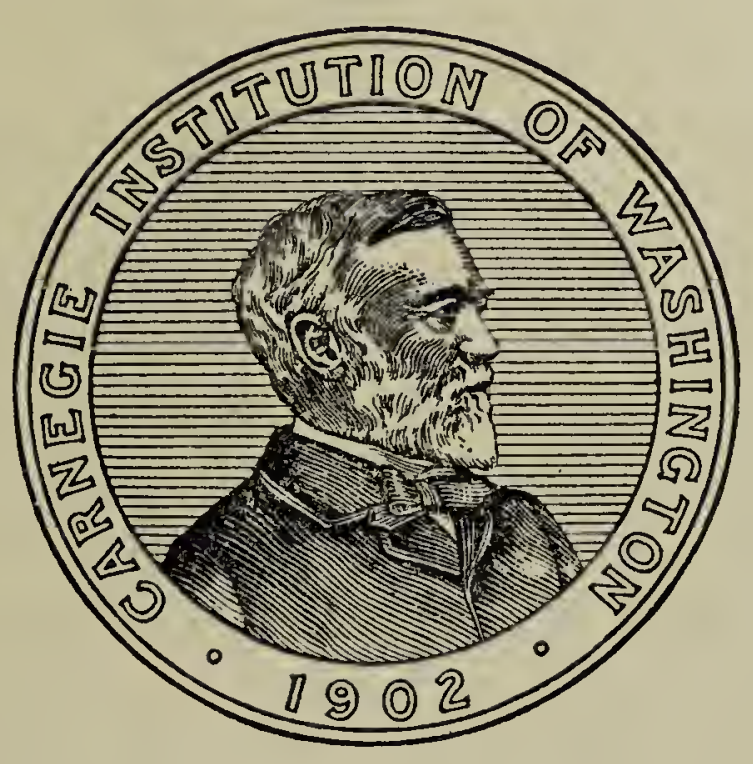

WASHINGTON, D. C.

Published by the Carnegie Institution of Washington 
CARNEGIE INSTITUTION OF WASHINGTON PUBLICATION No. 392, VOL. I

Papers of the Division of Historical Research 


\subsection{7}

\section{GENERAL PREFACE}

When the Bureau of Historical Research (as it was originally designated) was established in 1903 by the newly founded Carnegie Institution of Washington, the first of its permanent departments, one of the most urgent needs of scholarship in the field of American history was of systematic and comprehensive information respecting the great masses of unpublished primary source-material that lay in the archives and libraries of those countries that had been active in exploring and colonizing the New World, or that had long maintained important relations with the United States. Such information as was available was fragmentary, casual, not easily accessible, and did not afford that guidance without which historical research must proceed blindly and hesitatingly, following false trails and missing much that is most important. The amelioration of this situation was one of the first concerns of the new Bureau, which organized a series of systematic explorations in those foreign archives and manuscript collections that were known to be most rich in sourcematerial for the history of the areas now occupied by the United States and its dependencies. These explorations, conducted by numerous scholars temporarily connected with the Carnegie Institution as well as by members of its permanent staff, have resulted in the publication, to date, of some fifteen volumes, or Guides, as they are termed, relating to materials in Great Britain, Spain, Italy, Russia, Germany, Austria, Switzerland, Canada, Cuba, and Mexico.

That the first of the volumes describing the important materials in the depositories of Paris should be appearing only now, twenty-five years after the writer of the present lines was entrusted with the French " mission", is cause for chagrin and regret. It is not easy to present adequate apologies for a delay of a quarter of a century, but it is only fair to explain that during the greater part of this period other and quite different duties and activities have had to receive first attention. In order to mitigate so far as possible the evil effects of this long delay, every effort has been made to place at the disposal of those who might have need of it the information collected for this Guide, and the original notes have been freely loaned or otherwise made accessible to students and institutions. Especially the notes on some 20,000 documents relating to the history of the Mississippi Valley have been utilized in the two-volume Calendar of Manuscripts in Paris Archives and Libraries relating to the History of the Mississippi Valley to I803, edited by Mrs. N. M. Miller Surrey, and issued by the Department of Historical Research of the Carnegie Institution in a planographed edition (1926, 1928). This Calendar is in fact a by-product of the work on the present Guide. Similarly, the titles of all printed royal or ministerial acts relating to America that were discovered 
during the course of the "mission" have been included in Acts of French Royal Administration concerning Canada, Guiana, the West Indies, and Louisiana, prior to I79I, compiled by Lawrence C. Wroth and Gertrude L. Annan (New York Public Library, I930). Finally, when the monumental task of copying the documents in French archives and libraries relating to the history of the United States was inaugurated in I9I3 by the Library of Congress the notes that had been made for the Guide furnished the basic information for the selection of the material to be copied.

It would be superfluous to present to those for whose use this Guide is designed even the briefest account of those phases of American history that depend upon the sources herein described. Let it suffice to point out that in general the scope of the Guide corresponds to the history of French action in North America from the early part of the sixteenth century to about the middle of the nineteenth. The material that is described bears especially upon such aspects and episodes of French-American history as discovery and exploration, the operations of the early trading companies, the colonization of Canada and Louisiana and the establishment of the intervening settlements, the commerce of the continental and West Indian colonies with the metropole, with each other, and with the English and Spanish colonies, the American phase of the Seven Years' War, the participation of France in the War of American Independence, the American episodes of the Napoleonic wars, and, finally, the commercial and political relations between France and the United States from 1783 to about 1850 .

Geographically the Guide is in principle restricted to material bearing upon the history of the area now comprised within the United States and Canada, but many documents relative also to Mexico, Central and South America, and the West Indies have been noted, although not systematically nor comprehensively. Canadian material has been included because of the difficulty, not to say impossibility, of attempting to establish a sort of international boundary line between the documents relating to Canada and those relating to the northern part of the United States. It was more practical, as it was certainly more historical, to treat the French régime in North America as a whole. Nevertheless it was possible to deal more summarily with material chiefly Canadian than with that relating to the area now within the United States, for the reason that the Public Archives of Canada have printed detailed inventories of certain important sections of it. The arrangements for the complete exchange of information between the missions of the Carnegie Institution and of the Canadian Archives, generously entered into by the latter, greatly facilitated the task of the former.

So far as depositories are concerned it has been necessary to limit the Guide to those of Paris, namely, the Bibliothèque Nationale and the other Parisian libraries that possess collections of manuscripts, the Archives Nationales, and the archives of the ministries of Foreign Affairs, War, Marine, and Colonies. For the libraries outside of Paris information respecting manu- 
scripts relating to America in their collections is to be found in David M. Matteson, List of Manuscripts concerning American History preserved in European Librarics and noted in their Published Catalogues and Similar Printed Lists (Carnegie Institution, I926). For information respecting local archives the investigator must depend upon the large though still incomplete series of Inventaires Sommaires of departmental and communal archives, a list of which, by Robert Doré, is published in the Revue des Bibliothèques (July-September, I9I9).

The methods followed in the preparation of the Guide have varied according to the character of the material encountered. In general, historical manuscripts have received individual notice, while archival material, being usually found in groups or series of related documents, has been described more summarily. Printed material has been described only as it has been found among manuscript documents.

Throughout the Guide, with one or two exceptions that are noted where they occur, the volume or the carton (file-box) is the unit of description, and the order followed is that of the official classification.

The exploitation of the French sources of North American history has been carried on for nearly a century by private scholars and by governmental agencies of Canada and the United States. The most systematic and complete of these exploitations are those of the Public Archives of Canada and of the Library of Congress. It is just fifty years since the former undertook to inventory and copy all material relating to Canadian history in French archives and libraries. From 1883 to 1905 detailed calendars were printed in successive annual Reports of the Canadian Archives, the documents themselves being transcribed by a small force of copyists. The work of transcription continues to the present time, and has resulted in the accumulation upon the shelves of the Public Archives in Ottawa of a substantial and steadily increasing proportion of the French materials for Canadian history. In I9I I the Public Archives issued a comprehensive Rapport sur les Archives de France relatives à l'Histoire du Canada, compiled by J. Edmund Roy, chiefly from published inventories and catalogues and from a few manuscript lists. This survey, though superficial and marred by errors and by failure to indicate sources of information, is useful.

Systematic exploitation by the Library of Congress was commenced in I9I3 with the copying of documents relating to the history of the Mississippi Valley selected by those in charge of the Carnegie Institution's mission. Transcription by hand proceeded slowly for more than a decade, being extended to some of the more important West Indian material, but in 1927 it was superseded by photographic copying at a greatly accelerated rate, a change made possible by a special gift to the Library of Congress from Mr. John. D. Rockefeller, jr.

This vast collection is supplemented by earlier collections of transcripts acquired by the Library, notably the twenty-four portfolios of B. F. Stevens's 
Facsimiles of Manuscripts in European Archives relating to America, I775$I 7 S_{3},{ }^{1}$ of which a substantial part is drawn from French sources, and the thirtyseven portfolios of additional Stevens Transcripts relating to the French alliance, I778-I784, and to the peace negotiations, I782-I784, which likewise include a large number of French documents, especially from the archives of the Ministry of Foreign Affairs. Mention should also be made of the monumental "Benjamin Franklin Stevens Catalogue Index of Manuscripts in the Archives of England, France, Holland and Spain relating to America, I $763^{-}$ I 783 ", in I 80 manuscript volumes containing the titles of ror,000 documents, which was purchased by the Library of Congress in 1906 .

Thus it is seen that there are being formed in Ottawa and Washington two master collections of copies of documents in French repositories relating to American history that are rapidly approaching completion in their respective fields.

While the two general collections just noted overshadow in their importance for purposes of research the smaller collections formed for more special objects, the latter are nevertheless worthy of notice. To mention first those that have been published, there are, for the history of French Canada and of the contiguous areas now within the United States, the following principal collections :

Collection de Manuscrits, contenant Lettres, Mémoires et autres Documents Historiques relatifs à l'Histoire de la Nouvelle-France, recueillis aux archives de la Province de Québec ou copiés à l'Étranger (4 vols., Quebec, I883-1885). This publication includes a large number of documents in the ten volumes of transcripts made in France in I844-I848, by Benjamin Perley Poore, for Massachusetts and preserved in the archives of that state.

Documents relative to the Colonial History of the State of New York, E. B. O'Callaghan, editor. Volumes IX. and X. of this series (Albany, I855, I858) contain in English translation the documents copied in Paris about 1843 , under the direction of John B. Brodhead; they range from I63I to I774 and are chiefly from the archives of the ministries of Colonies and of War, with a few from the Bibliothèque Nationale.

The French Régime in Wisconsin, I634-I760, edited by Reuben Gold Thwaites, in Wisconsin Historical Collections, vols. XVI.-XVIII. (I902I908), is a collection of documents and extracts, in English translation, selected from various sources but largely from the transcripts in the Canadian Archives of the archives of the French Ministry of the Colonies.

The Cadillac Papers, I669-1742, edited by Clarence M. Burton, in Michigan Pioneer and Historical Society, Historical Collections, vols. XXXIII.-XXXIV. (I903, I904), is a collection of documents relating to the French régime in Michigan, copied in the archives of the Ministry of the Colonies and in other depositories in Paris, and printed in English translation.

${ }^{1}$ Two hundred sets were printed and are to be found in the principal libraries. 
The great collection of documents relating to the Mississippi Valley is that edited by Pierre Margry, and published with the aid of a subvention from the government of the United States: Découvertes et Etablissements des Français dans l'Ouest et dans le Sud de l'Amérique septentrionale, I6I4-I754, 6 vols. (Paris, I876-I886). This contains a great variety of documents from the archives of the ministries of Colonies and Marine, and of the Hydrographic Service, and from the manuscripts of the Bibliothèque Nationale. They relate largely to voyages and explorations - to La Salle, Iberville, La Vérendrye, and others-and to the fur trade, western posts, relations with the Indians, etc. While the documents are often abridged and although they contain rather too many textual inaccuracies, the collection is of great value. Supplementing Margry in a most useful way for the lower Mississippi is the series of Mississippi Provincial Archives, French Dominion, published in English translation and edited by Dunbar Rowland and A. G. Sanders, for the Mississippi Department of Archives and History, of which volume I., I729-I740 (Jackson, Miss., I92 7 ), has appeared. The documents are selected from the series "Correspondance générale, Louisiane" $\left(\mathrm{C}^{13}\right)$, in the archives of the Ministry of the Colonies.

For the period of the War of American Independence must be mentioned the monumental work by Henri Doniol, published by the French government: Histoire de la Participation de la France à l'Établissement des Etats-Unis de l'Amérique, in six volumes including a supplementary volume (Paris, I886I900). This is a collection of extracts of documents connected by narrative, with appendixes of integral documents. The material is taken chiefly from the archives of the ministries of Foreign Affairs, War, and Marine.

Finally, there should be noted the valuable collection of documents edited by Professor Frederick J. Turner and published in French in the Annual Report of the American Historical Association, I903, vol. II.: Correspondence of the French Ministers to the United States, I79I-I797. These documents are from the series Correspondance politique, Etats-Unis, in the archives of the Ministry of Foreign Affairs.

Of the collections of manuscript transcripts only a few need be noted. The "Poore Transcripts" in the Massachusetts archives have already been mentioned as forming a substantial part of the Collection de Manuscrits . . relatifs a l'Histoire de la Nouvelle France. The Massachusetts Historical Society has preserved the forty or more volumes of transcripts bequeathed to it by Francis Parkman, which were made for him over a period of many years and constitute the principal source of his monumental history. Although overshadowed by the more comprehensive collection in Ottawa, they include much Canadian and New England material that is not to be found in the Library of Congress. The Library of Harvard University possesses the papers of Jared Sparks, which include 22 volumes of documents copied from various Parisian archives, as well as six volumes of transcripts of Lafayette papers, and one volume of Beaumarchais correspondence. Similarly, the New York Public Library con- 
tains the papers of George Bancroft, among which are about I Ioo transcripts of French diplomatic correspondence relating to America between 1765 and I 783 ; but this collection is now superseded by the Stevens Transcripts and Facsimiles in the Library of Congress. Some few other small collections exist in Albany, in Portland, Maine, in New Orleans, in Detroit, and in Madison, Wisconsin, but they have for the most part been published or are superseded by the collections at Ottawa and Washington.

The pleasant and considerable duty remains of making acknowledgment of the courtesies and assistance that have been extended to the "mission" during its long history.

First and foremost should come the name of the one who would have written this preface had he not retired from the directorship of the Department of Historical Research before the delayed completion of the present volume. The helpfulness and patience of Dr. J. Franklin Jameson could not be surpassed, and it is not without emotion that this slight tribute is paid to his friendship and to his wise and inspiring guidance. It is given to few scholars, in any field of learning, to render such services to scholarship as he has performed for historical studies, and the complete unselfishness with which they have been given has heightened their value and increased the obligations of their beneficiaries.

'To the Canadian Archives, to Dr. Arthur G. Doughty their director, to Dr. Henry P. Biggar in charge of their operations in Great Britain and Europe, to M. Théodore Beauchesne, head of their Paris bureau, as well as to M. Edm. Buron and his other collaborators, the compiler of this Guide is especially indebted, not only for valuable information and advice, but for assistance and collaboration.

To his Excellency M. Jean Jules Jusserand, Ambassador of France to the United States when the work was commenced and during the greater part of its duration, thanks are due for official introductions and kindly interest. Officials of the American embassy in Paris have also been unfailingly helpful, although it has seldom been necessary to have recourse to their good offices since the early days of the "mission" when the late Henry Vignaud, First Secretary and Counsellor of the embassy, in his own name a scholar of high rank, secured for the Guide the benevolent interest of ministerial, archival, and library officials and himself took the trouble to be mentor and friend to the inexperienced and (then) youthful American in charge of the undertaking.

It is impossible to name all the officials of ministries, archives, and libraries who have been helpful with advice and information; some will be mentioned in succeeding volumes in connection with the depositories to which they were or are attached. Nevertheless this general enumeration should include the late M. Charles V. Langlois, former director of the Archives Nationales, MM. Charles Schmidt (now General Inspector of Archives), Pierre Caron, and Georges Bourgin, of the same establishment; MM. Abel Rigault and Georges Espinas, of the archives of the Ministry of Foreign Affairs, and their 
former colleague, the late M. A. Tausserat-Radel; M. O. Wirth of the Ministry of the Colonies; M. Charles Braibant, chief of the archives of the Ministry of the Marine; the late M. Martinien of the archives of the Ministry of War; and MM. Henri Omont, Charles de La Roncière, Ph. Lauer, and Léon Vallée, of the Bibliothèque Nationale.

Of French scholars not officially connected with depositories of archives and manuscripts the late Senator Richard Waddington and the late Professor P. Cultru of the Sorbonne were most helpful, as have also been M. Paul Mantoux and especially Professor Bernard Faÿ, now of the Collège de France, whose research uncovered much material of importance for the Guide.

American scholars whose sojourns in Paris occurred during the work on the Guide furnished useful suggestions and information and in some cases contributed lists and notes; among them may be mentioned Dr. Stewart L. Mims, lately professor in Yale University, Professor Samuel E. Morison of Harvard University, Dr. Verne Blue, now of the Department of State, Professor Samuel F. Bemis of George Washington University, the late Professor Claude H. Van Tyne, and especially the compiler's colleague, the late Dr. Frances G. Davenport, of the Carnegie Institution.

Especial thanks are due to Mr. James Hazen Hyde of Paris and Versailles, who placed his fine library of publications bearing upon the history of FrenchAmerican relations at the disposal of the "mission", and himself extended many personal courtesies.

When it became necessary for the writer of these lines to leave Paris, in September, I9I4, M. Louis Doysié undertook the custody of the formidable accumulation of notes and saw to its being safely shipped to Washington before the risk from submarine warfare became acute. After the war the European Center of the Carnegie Endowment for International Peace, directed by Dr. Earle B. Babcock, provided accommodation for the notes, and still later the International Institute of Intellectual Co-operation, then under the directorship of M. Julien Luchaire, hospitably furnished space and accommodations for work in the offices of M. Michel Lhéritier, attache of the Institute and general secretary of the International Committee of Historical Sciences.

Finally, a word must be said of those who collaborated in the preparation of the Guide. First of these was M. Abel Doysie, now in charge of the work in Paris for the Library of Congress, referred to above, whose association with the "mission" commenced in I908 and continued until the outbreak of the war, after which it was resumed until the copying for the Library of Congress took on such proportions as to require his entire attention. His natural qualities of intelligence, industry, and accuracy, enhanced by his enthusiastic devotion to the undertaking, made his collaboration exceedingly valuable and indeed indispensable. He performed an important share of the original note-taking, supervised the work of several assistants, and in short rendered invaluable services. His name is associated with those parts of the Guide to which his contributions were most important. 
Mr. David W. Parker, lately of the Public Archives of Canada, devoted over a year to editorial work on the volume with which his name is associated, dealing with the Colonial and Marine archives, and with series of the Archives Nationales. His experience, critical judgment, and historical knowledge were generously made available, and he solved many difficult problems of method and presentation.

Mrs. N. M. M. Surrey, during the period that she was engaged in editing the Calendar of Manuscripts . . . relating to the History of the Mississippi $V$ alley, was most helpful in checking and amplifying notes already taken, and in completing the notes for certain series, especially in the Colonial archives.

The assistants who worked at various times for longer or shorter periods, mostly under the direction of M. Doysié, were Mmes. Mathilde Breuil, Valentine Jouhet, and Léa Vila; Mlles. Jeanne Bossard and Marie Antoinette Mairesse; and MM. Victor Edard, A. Montoux, and J. Wielhorski. To this group, although working independently of it, should be added Miss Sybil Norman of Edinburgh, then a resident of Paris.

In conclusion it remains only to express the hope that the Guide-this present volume and the two or three that are to follow as rapidly as the collected material can be prepared for publication-may usefully serve the purposes of scholarship, and may stimulate interest and research in those important chapters of American history which are also chapters in the history of France and of the French people.

Waldo G. Leland.

Washington, D. C., April r7, i932. 


\section{INTRODUCTORY NOTE TO VOLUME I}

The first volume of the Guide to Materials for American History in the Libraries and Archives of Paris is devoted to the collections of manuscripts in thirteen libraries. Its scope, both chronological and topical, is broader than that of any of the succeeding volumes, and its contents are far more miscellaneous. It is impossible to apply methods of summary description to volumes and cartons of heterogeneous papers, of which an accurate description can be given only by listing the individual pieces. Accordingly this section of the Guide more nearly resembles a calendar than will the later volumes, which deal with groups of homogeneous documents.

While most of the note-taking for this volume, especially in the Bibliothèque Nationale, was done by the compiler, an important share was performed by M. Abel Doysié, who prepared the "Classified List of Manuscript Maps" (pp. 22I ff.) and who also examined the manuscripts in most of the smaller libraries. Dr. Henry P. Biggar, of the Public Archives of Canada, generously allowed use to be made of a list of manuscripts in the Bibliothèque Nationale that he had prepared for his own use, and the Paris bureau of the Canadian Archives made.other lists available and furnished many important suggestions. The lists in this volume are however based upon a fresh examination of the documents.

The index, which presented unusual difficulties, has been made by Mr. David M. Matteson, who has identified and supplied many proper names and corrected numerous errors.

Miss Cornelia M. Pierce, secretary of the Division of Historical Research, has rendered services in seeing the manuscript through the press that are acknowledged with sincere gratitude.

Finally, Dr. Frank F. Bunker, editor of Carnegie Institution's Division of Publications, and the Lord Baltimore Press, printers of this volume, who furnished the first proofs in 1928, have exhibited a degree of patience that is believed to be unsurpassed in the history of publishing.

W. G. L. 



\section{CONTENTS}

PAGE

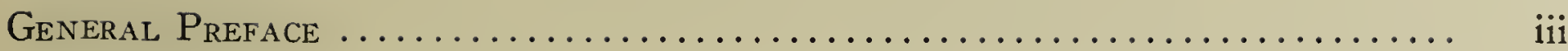

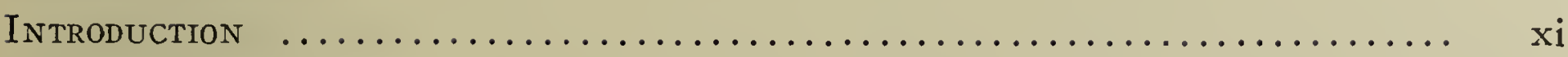

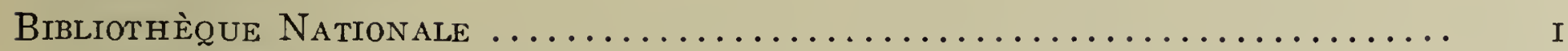

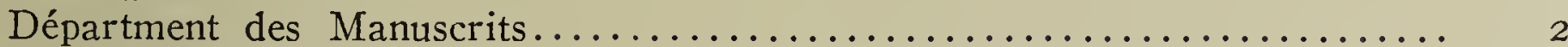

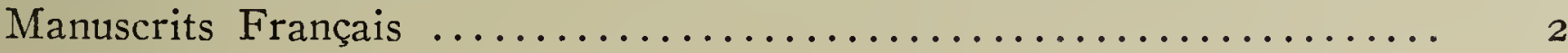

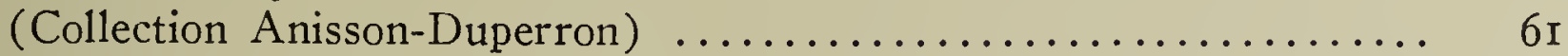

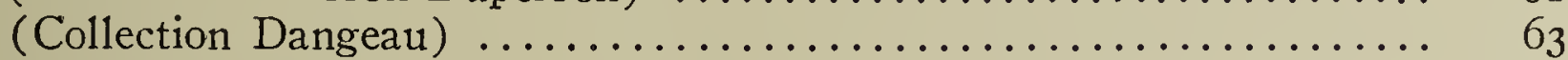

Manuscrits Français: Nouvelles Acquisitions................... 73

(Collection Brienne) ................................. 95

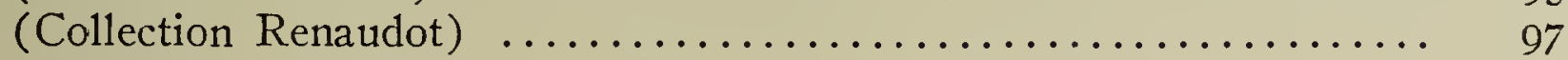

(Collection Margry) $\ldots \ldots \ldots \ldots \ldots \ldots \ldots \ldots \ldots \ldots \ldots \ldots \ldots \ldots \ldots \ldots \ldots$ IO

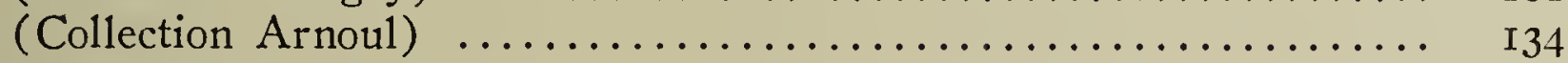

Collection Baluze ................................. I 49

Collection Clairambault $\ldots \ldots \ldots \ldots \ldots \ldots \ldots \ldots \ldots \ldots \ldots \ldots \ldots \ldots \ldots \ldots \ldots \ldots$ r 5 I

Mélanges de Colbert................................ I79

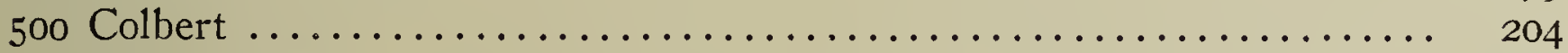

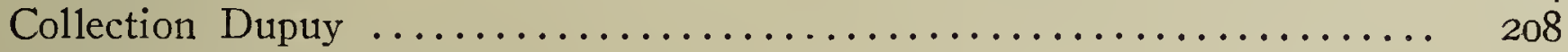

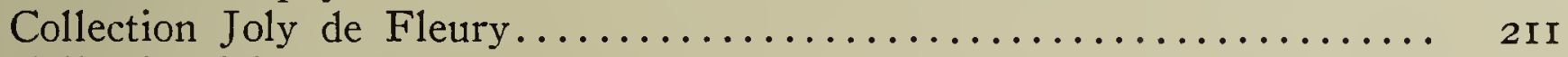

Collection Moreau ................................... 2 2 6

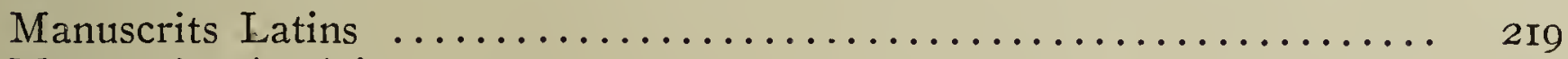

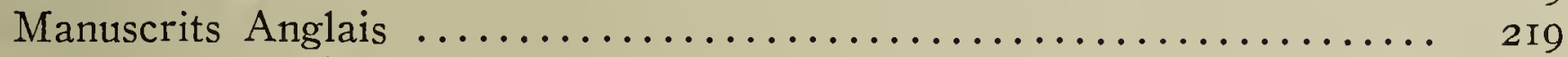

Section des Imprimés................................... 220

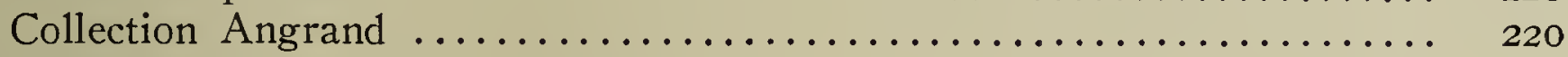

Section des Cartes et Plans................................ 22I

Classified list of Manuscript Maps relating to North America, and the

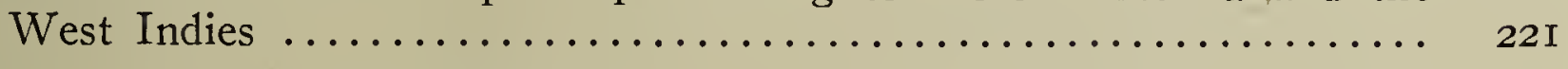

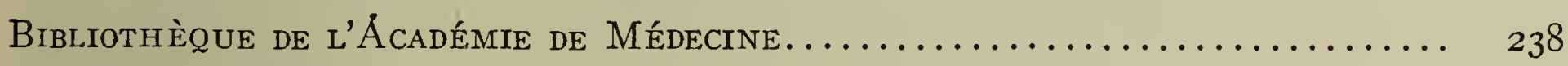

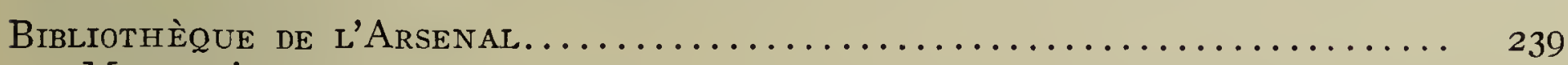

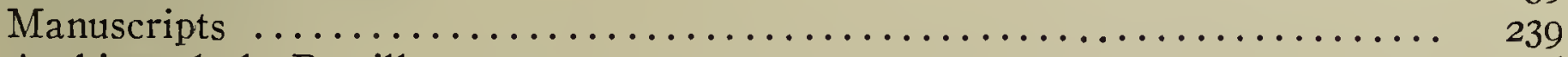

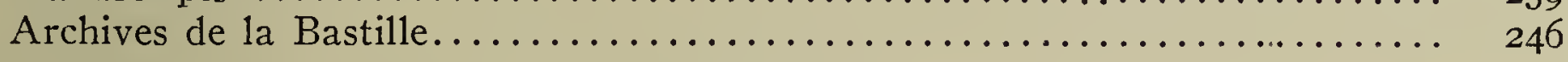

Bibliothéque de la Chambre des Députés....................... 25 I

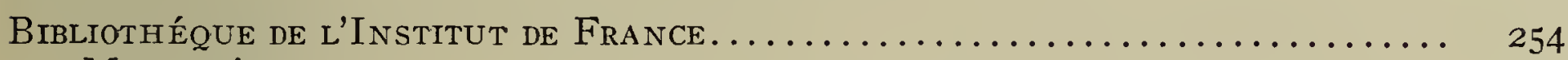

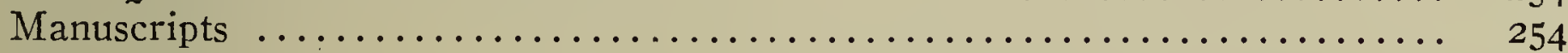

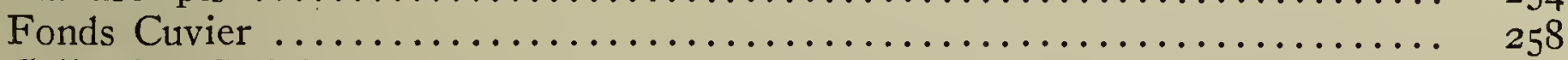

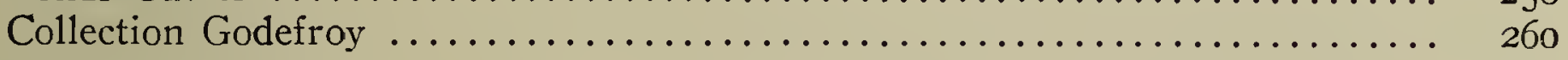

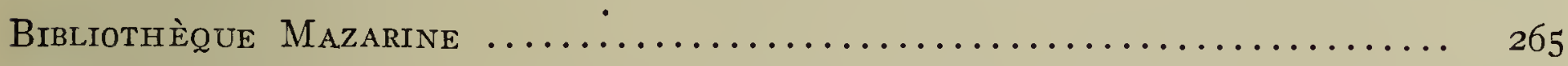

SÉminatre des Missions Étrangères........................ 268

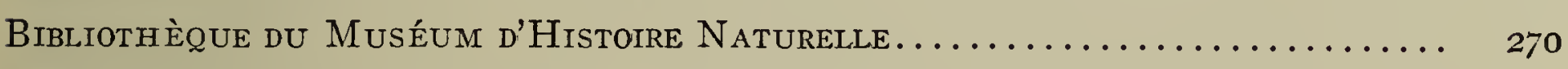

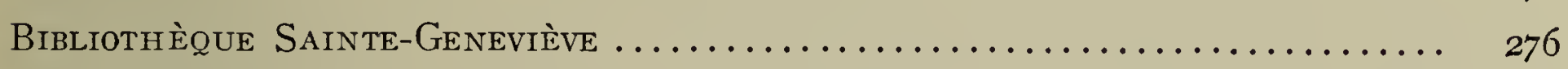

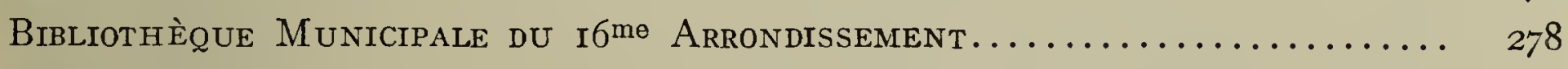

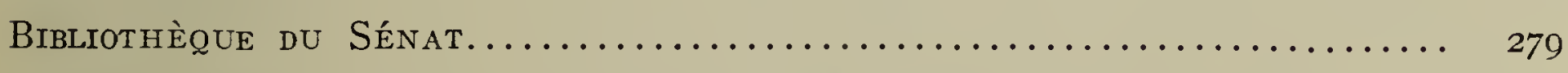

Bibliothèque de l’Université de Paris (Sorbonne) ................... $28 \mathrm{I}$

Bibliothèque Victor Cousin (Sorbonne) ...................... $28 \mathrm{I}$

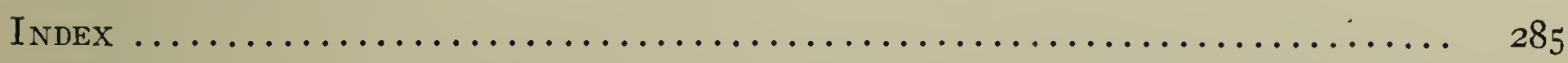





\section{BIBLIOTHĖQUE NATIONALE. ${ }^{1}$}

The Bibliothèque Nationale, whose origins, as the Bibliothèque du Roi, go back to Charles V. and the fourteenth century, began to assume a position of pre-eminence among Parisian libraries under the administration of Colbert during the latter part of the seventeenth century. In the French Revolution it became the Bibliothèque Nationale and received large and important accessions from the sequestered libraries of émigrés and religious establishments. To-day it is one of the great treasure houses of the world, approached only by the British Museum as a centre of research.

The Bibliothèque Nationale, entered through the court of honor at 58 , Rue de Richelieu, occupies the quadrilateral between the Rues des Petits Champs, de Richelieu, Colbert, and Vivienne, part of which, at least, has been the site of the library for two centuries or more. It is essentially and primarily a scholars' library. A small part of it is utilized for a public readingroom, to which admission may be had by any one, without formality, but admission to the more important and larger research rooms, or salles de travail, is by card, issued by the secretariat of the library. Foreign scholars may secure these cards upon applying to the secretariat, and presenting a form of introduction from their consulate, legation, or embassy. Two photographs, passport size, of the applicant must also be presented. A small fee is charged for the cards, which are good for five years, but which must be visaed annually at the secretariat.

A brochure of practical information and instructions, especially useful to those who resort to the library for the first time, may be had at the secretariat or at the entrance to the principal reading-room: Guide $d u$ Lecteur à la Bibliothèque Nationale.

The Bibliothèque Nationale is organized in four departments, as follows:

(I) Département des Imprimés, Cartes et Plans, divided into a Section des Imprimés and a Section des Cartes et Plans;

(2) Département des Manuscrits;

(3) Département des Médailles, Pierres Gravées, et Antiques;

(4) Département des Estampes.

The resources of the Section des Imprimés, so far as American history is concerned, are most valuable for the seventeenth and eighteenth centuries. They may be known through the printed author Catalogue Général (commenced in I897 and in I930 nearly through the letter L) with its manuscript supplements, through the manuscript subject catalogues of books entered since I882, and through the printed Catalogue de l'Histoire de France, chapter L. Especially useful are the poly-copied Catalogue de l'Histoire de l'Amerique, by G. A. Barringer, in five volumes (I903-I9II), and the similar Catalogue de l'Histoire de la Grande Bretagne ( 1878 ) and Catalogue de l'Histoire d'Espagne et de Portugal ( 1883 ). The Section des Imprimés contains, exceptionally, a few manuscripts, of which those deposited by Angrand relate to America, and are described below.

${ }_{1}$ Among descriptions and historical accounts of the Bibliothèque Nationale may be noted the following: A. Franklin, Précis de l'Histoire de la Bibliothèque du Roi, aujourd'hui Bibliothèque Nationale (2d ed., I875); $\mathrm{H}$. Marcel et al, La Bibliothèque Nationale (1907) ; C. Couderc, "Bibliothèque Nationale", in the Grande Encyclopédie ( 1888 ). 
The Section des Cartes et Plans contains many important American maps, which are listed in the present volume.

The collections of the Département des Manuscrits, which in the making of this book have been explored with great care, contain a very large number of documents relating to America, some of first importance, as will be seen from the detailed lists that have been compiled and are here printed.

Neither the Département des Médailles nor the Département des Estampes has been explored, as their contents do not fall within the scope of the Guide. Suggestions as to the sort of American material to be found in these departments are offered by J. E. Roy in Rapport sur les Archives de France, pp. 78I827 (Ottawa, Archives of Canada, I9II).

\section{DEPARTMENT OF MANUSCRIPTS.}

The Department of Manuscripts contains one of the largest collections of manuscripts in the world. It comprises 122,000 volumes, and is organized in various categories or fonds, according to language: Oriental, Greek, Latin, French, and modern languages. Most of the manuscripts have been described in published catalogues, which, as well as a large collection of reference works, are at the disposal of those who work in the salle de travail of the department on the first (second) floor of the Library.

Very little material relating to North America appears to be found in other than the French manuscripts (Fonds Français). There may be noted, however, though they have not been examined, certain collections, described in the following works:

Catalogue des Manuscrits Américains de la Bibliothèque Nationale (Paris, I925, 25 pp.; reprinted from the Revue des Bibliothèques, I925). Describes 77 manuscripts in various native American languages or dialects.

Catalogue des Manuscrits Mexicains de la Bibliothèque Nationale (Paris, I899, 64 pp. ; reprinted from the Revue des Bibliothèques, I898, I899). The annotated copy in the salle de travail describes 426 manuscripts, comprising the Fonds Mexicain, of which nos. I-384 are the manuscripts collected in Mexico by Joseph Aubin, and presented to the library by the widow of E. Eugène Goupil.

Documents pour servir à l'Histoire du Mexique. By Eugène Boban (Paris, I89I, 2 vols.). This catalogue contains a full description and analysis of each manuscript, nos. I-372 of the Aubin-Goupil collection.

Catalogue des Manuscrits Espagnols et des Manuscrits Portuguais. By Alfred Morel-Fatio (Paris, I892). A list of 685 Spanish manuscripts, including not only the contents of the Fonds Espagnol, but also the manuscripts in Spanish found in other collections, and of Io6 Portuguese manuscripts. A few items relate to South America, the West Indies, or Mexico.

The history of the Department of Manuscripts is set forth in the monumental work of Léopold Delisle, Le Cabinet des Manuscrits de la Bibliothèque Impériale (Paris, I868-I874, 3 vols.), while a Résumé de l'Histoire du Département des Manuscrits de la Bibliothèque Nationale, also by Delisle, serves as an introduction to the Inventaire Général et Méthodiques des Manuscrits Français de la Bibliothèque Nationale, I. xiv-xxxvi (Paris, I876).

\section{MANUSCRITS FRANÇAIS.}

The Manuscrits Français constitute a third or more of the collections of the Department of Manuscripts. They are in two series, the first of which, designated as Manuscrits Français, is a closed series (nos. I-33264), while the second, continuing the first but with a new numbering, is open to receive 
new accessions ( since I 862) and is designated as Manuscrits Français, Nouvelles Acquisitions. At present this second series includes about I5,000 volumes of manuscripts, to which additions are constantly being made.

The printed catalogues of these two series present an excellent account of their exceedingly miscellaneous contents: (I) Catalogue des Manuscrits Français, Ancien Fonds ( 5 vols., I868-1902). In this catalogue are calendared in detail the documents constituting the original collection of miscellaneous French manuscripts of the Bibliothèque du Roi (nos. I-6I70). (2) Catalogue Général des Manuscrits Français, by H. Omont, C. Couderc, L. Auvray, Ch. de La Roncière, and others ( $1895^{-}$). Of this catalogue, which continues the preceding, vols. I.-III. contain the manuscripts constituting the Ancien Supplément (nos. 6I7I-I 5269) ; vols. IV.-VI. contain the French manuscripts coming from the Abbey of St. Germain-des-Prés (nos. I 5370-20064); vols. VII.-IX. contain the French manuscripts coming from suppressed Parisian convents, from private libraries, from the archives of the Chambre des Comptes, from the former Cabinet des Titres, and from other sources, this ensemble of groups being known as the petits fonds (nos. 20065-33264); vols. X.-XIII. commence the catalogue of the Nouvelles Acquisitions, or accessions since I862, together with a number of small groups (Brienne, Decamps, Fontanieu, Parlement, Renaudot, Visconti) that formerly were kept as independent collections (nos. I-I I 353, 2000I-228I I).

Continuations of the Catalogue Général are published at irregular intervals in the periodical Bibliothèque de l'Ecole des Chartes.

A manuscript index of the catalogues of the Manuscrits Français, in ten volumes, is available in the room where the manuscripts are consulted: Table Générale Alphabétique du Catalogue des Manuscrits Français.

150. "Les premières Euvres de jacques Devaulx, pillote en la marine au Havre de Grace l'an MDLXXXIII."-Also MSS. Fr. 9175. American maps are as follows: globe showing western Africa and eastern South America (f. $3 \mathrm{v}$ ); globe showing North America and South America to tropic of Capricorn (f. 9, similar map f. 25v) ; globe showing North and South America with northwest coast clearly traced (f. 26) ; globe showing North and South America from Florida to Brazil (f. 27) ; globe showing southern part of South America (f. 27v) ; map of Atlantic Ocean with coasts of Europe, Africa, and North and South America to tropic of Cancer (ff. 28v-29). Cf. a map of similar extent by Pierre Devaulx, I6I3, in Arch. Service Hydrog., "Grande portef., cartes précieuses I I6-7".

385. Log-books.

I686, May I9-1690, June 8. Log-book of a piratical vessel, containing accounts of encounters with vessels, depredations on shore, etc.: Panama, Long Island, Narragansett Bay, Newfoundland, Africa, South America, and Bay of California. Ptd. by E. Ducéré in Bulletin de la Société des Scicnces et Arts de Bayonne, XVI. (I894) 477-520, XVII. (I895) 3-27 [ff. I-35 I690, June 8-I694, Sept. 4. Log-book kept by "F. Massertie"; details of navigation only. Extracts ptd. ibid.

386. Navigation guide for coasts of South America. (I 7 th century.)

646. "Traitté historique et politique du commerce de touttes les nations dans les divers endroits du monde, particulièrement par rapport aux Hollandois." (Late I7th century.) -Occasional references to commerce, with America, West Indies, Virginia, Barbados, etc. (ff. 78, 190, 219, 264, 443, 452).

676. "Cosmographie" of Jean Alfonse [Fonteneau]. I 545 [I 544].-Ptd. by Georges Musset, La Cosmographie . . par. . Alfonse de Saintonge, 
in Recueil de Voyages et de Documents pour servir à l'Histoire de la Géographie, XX. (Paris, I904).

704. Collection of copies.

I 585, "Voyages du Sr. Drack sur la côte de la Florida." Cf. Richard Hakluyt, Principal Navigations and Discoveries of the English Nation (Glasgow, r903-r905), X. 97-I34.

I 587 , July I 5, London. "Compte-rendu de la fin du voyage du capitaine Drack et de son retour en Angleterre." Cf. id., VI. 438-443.

[f. 68

1381. "Epitome de la cosmographie de Jacques Chauvet, avec l'usage et pratique universel de la Mappe ou Miroir du Monde." (I6th century.)

"De l'Amérique, quatrième partie de la terre." Another copy, with variations, is in MSS. Fr. 2108.

[ff. 3 I v-32

1382. "Premier livre de la description de tous les portz de mer de l'univers ...", by Jehan Mallart, [I546-I547.]-In verse, based on the Voyages Aventureux of Jean Alfonse. Described, with extracts, in H. Harrisse, Jean et Sébastien Cabot (Paris, r882), pp. 222-229; cf. H. P. Biggar, Early Trading Companies of New France (Toronto, I9OI), Pp. 22I-222, and Georges Musset, ed., La Cosmographie...par...Alfonse de Saintonge (Paris, I904), pp. 42-44. MSS. Fr. 13371 and 25375 are other copies of this work.

2033. "Histoire naturelle et memorable de Lindie ocidentalle . . . ", by Vincent Leblanc, ( I6th century.) - Relates to West Indies and South America. Incorporated in part in Louis Coulon, Les Voyages Fameux du Sieur Vincent Leblanc . . . aux Quatre Parties du Monde (Paris, I648). Cf. below, MSS. Fr. 5652.

2108. See above, 1381.

2110-2111. "Les origines des divers peuples qui ont habité l'hemisphère inférieur...", by Jean Baptiste Poisson, r646.-A work in which the author attempts to show that the first inhabitants of Peru and Mexico were descended from Oriental peoples, such as Assyrians and Israelites. (Two copies.)

2145. "La Reprise de La Floride Par Le Cappne. Gourgue."-Four other copies of this document are among the MSS. Fr.: 3884 (ff.3I8-344), 6124, 19899, and 20794 (ff. 728-738). Of these five the oldest is that in 20794, which bears annotations in the hand of Henri Lancelot Voisin de La Popelinière (obiit I608), and is among the papers of François Eudes de Mézeray ( I6ro-1683). A summary of it is given by La Popelinière in Les Trois Mondes (Paris, I582), liv. II., and is repeated by Martin Basanier, in L'Histoire Notable de la Floride (Paris, I 582, reprinted 1853 ), under the title "Le quatriesme voyage des françois en la Floride sous le capitaine Gourgues, en l'an I 567 ". Three of the copies, 2145, 6124, 19899, are of the late sixteenth or early seventeenth century and are from the hand of the copyist Robert Leprevost. Of these, 19899 has been printed by Paul Gaffarel, with foot-notes showing the principal variations of 2145, 3884, and 6124, in his Histoire de la Floride Française (Paris, I875), pp. 483-5I5, and also, according to Gaffarel, op. cit., pp. 340-34I, by Henri Ternaux-Compans in his Recueil de pièces sur la Floride (Paris, I84I), pp. 30I-366. The copy in 3884, ff. 3 I8-344, is of the later seventeenth century, and, according to Gaffarel, loc. cit., is printed by Jules Antoine Taschereau in the Revue Rétrospective, II. (I835) 32I-358; while the version printed by Philippe Tamizey de Larroque in Publications de la Société des Bibliophiles de la Guyenne (Bordeaux, I868), I. I ff., is said to be based on $\mathbf{2 1 4 5}$ and $\mathbf{6 1 2 4}$. For full discussion of the various manuscripts and of the incident itself, see Gaffarel, op. cit., pp. $340 \mathrm{ff}$.; Charles de La Roncière, Histoire de la Marine Française, IV. 63-70; Maurice Delpeuch, "Un glorieux Épisode Maritime et Colonial : . : ", in Revue Maritime, CLV. 
(I902) I882-I93I, 2I5O-2I9I; Francis Parkman, Pioneers of France in the New World ; and Charles Samaran, "Dominique de Gourgues", in Revue Historique, CVIII. 276-293, where are also printed "De la vie et mort de Dominique de Gourgue ", by Pierre de Vaquieux, I 582, from .MSS. Fr. 20794, ff. 736-737, and the will of de Gourgues, dated Paris, Dec. 5, I 58I, from Arch. Nat., Y, I23, f. 4I5.

2482.- “L'Usage de la Mappemonde.” ( I6th century.) Examples for ascertaining latitude of various places; difference in time between Paris and Florida, etc.

[f. 27

2524.-Extracts relating to cosmography. (I 7 th century.) Brief treatise on geography, the three parts of the world, including America, etc.

[f. I 59

2954-2955. Correspondence of Louis de Pineau, Sieur de Castillon (I 537I538), and of Charles Marrillac ( I 539-I 540), ambassadors in England. Not examined. See J. Kaulek et al, Correspondance Politique de Castillon et de Marillac... I537-I542 (Paris, I885). Note also MSS. Fr. 4130, 17970, and 17971 (not examined), and Arch. Affaires Etrangères, Corr. Pol., Angleterre, vols. 3-5.

3884. See above, 2145.

4128. Copies of the correspondence of Jean de Thumery, Sieur de Boissise, ambassador in England I598-I60I.-List of contents in Catalogue. The volume contains rare references to commerce with the West Indies, depredations by English against French vessels in the Newfoundland fishery, etc. The material has been thoroughly exploited and most of the letters of Henry IV. to de Boissise printed by P. Laffleur de Kermaingant, L'Ambassade de France en Angleterre sous Henri IV.: Mission de Jean de Thumery, sieur de Boissise, I598-1602 (Paris, I886).

4569. Artillery and war in $\mathrm{I} 666$.

I665, Aug. I7-i666, Sept. I4. "Mémoire de M. de Salière des choses qui sont passées en Canada les plus considérables depuis qu'il est arrivé." Regiment of Carignan-Salières; war with the Indians.

[f. 98

4586.-I776, A pr. 4, I I. Register of the destruction of Canadian paper and card money, conformably to decrees of June 29, I765, and Jan. I7, I776. (Copy.)

[f. 122

4826. Collection of documents relating to French marine and commerce, about I630.

"Mémoire touchant la navigation." Advantages of a colony in New France; proposal to send thither the poor and criminal; cod fisheries ; necessity of retaking Maragnon, founded by Razilly and Ravardier; capture of Florida by the Spaniards; fisheries on the coasts of Newfoundland, Acadia, and New France. (Copy, early I7th century.) Attributed to. Claude de Razilly by Biggar, Early Trading Companies, p. I35, note.

[ff. I-4v

"Mémoire sur le commerce et la navigation." Commerce in Spain ; Newfoundland fisheries ; commerce with Guinea and Brazil (this last part in different hand). (Minute, marginal notes in different hand; early I 7 th century; endorsed, "M. de Razilly".) Attributed to Claude de Razilly by Biggar, loc. cit.

[ff. 5-I $2 \mathrm{~V}$

[1632.] "Articles arrestés entre les députés des deux Roys pour la liberté du commerce entre leur subjects." Eight articles relating to letters of marque, captures, visit of vessels, etc. ; apparently a copy of a project serving in the formulation of the articles of similar import signed at St. Germain-enLaye, Mar. 29, I632, and printed in J. Dumont, Corps Diplomatique, vol. VI., pt. I., p. 33 ; also in Collection de Manuscrits relatifs à l'Histoire de la Nouvelle France, I. 94-96.

[ff. I7-20v 
[i628.] "Discours sur la vériffication du contract concernant le commerce et traficq général sur la mer que l'on veult establir en France, présenté par M. Bouguier."

[ff. $2 \mathrm{I}-3 \mathrm{OV}$

[I63I-I632.] "Mémoire touchant la navigation présenté au Maréchal [Antoine Coiffier, Marquis] d'Effiat." Proposing an expedition to Brazil.

[ff. $37-38 \mathrm{v}$

Plainte Publique sur l'interruption du Commerce (2I pp., no imprint). Importance of commerce, its decline and ruin in France, depredations of the English on French commerce, necessity of provisioning and defending colonies in America, etc.

[1627?] "Mémoire touchant la navigation." Memoir prepared at request of Richelieu and the Marquis d'Effiat, proposing that the commerce assigned to the company [of the de Caens?], the cod fisheries, and the trade with Canada and Acadia be placed in the hands of the king or of Richelieu and d'Effiat.

[ff. $54-55 \mathrm{v}$

[1627.] "Minutte du contract du commerce général." Contract between Cardinal Richelieu and the Compagnie de la Nouvelle France. Cf. MSS. relatifs à la Nouvelle France, I. 7I-74.

[ff. $58-6 \mathrm{Iv}$

4925. Memoirs on navigation and commerce, probably for use in negotiations of St. Germain-en-Laye, I632.

I6II-I62I. "De la pesche et du commerce des François en l'Amérique, devers la rivière de Canada ou de Sainct Laurent et devers l'Isle de Terre Neuve ou Neufondlande, et comme les Anglois les y peuvent empescher." Memoir based on works of Champlain and Purchas.

[ff. I 5-I $5 \mathrm{v}$

"Des usurpations des Anglois sur les François en la Nouvelle France ... depuis l'an I6I I." Substantially as in preceding document. [ff. I7-I7v I62I, Sept. Io, Windsor. "Don de la Nouvelle Ecosse . . . par Jacques, roy de la Grande Bretagne, à Guillaume Alexandre." (Latin copy.) Ptd. in D. Laing, Royal Letters, Charters, and Tracts relating to the Colonization of New Scotland (Edinburgh, I867).

[ff. $18, \mathrm{igv}$

"Que la Nouvelle France et l'isle de Terre Neuve ont esté descouvertes par les François dès l'an I 504." Extracts from Petrus Plancius, and from Bertrand d'Argentré, L'Histoire de Bretaigne (Paris, I588, third ed., I6I8).

[ff. $20-20 \mathrm{~V}$

5085.-[ [ 1548, Sept. 30, Lyon.] Grant by Henry II. to Jean François de La Rocque, Sieur de Roberval, of exclusive mining rights for nine years. Ptd. in Isambert, Anciennes Lois Françaises (Paris, I828), XIII. 57-60.

[ff. $27 \mathrm{IV}-273$

5503.-I540, Oct. I7, St. Pris. "Charge de cappitaine et pillote général des navires que le roy. envoie au Sagueney", conferred by Francis I. on Jacques Cartier. Ptd. in H. Michelant et Alfred Ramé, Voyage de Jacques Cartier an Canada en I534 (Paris, I865), pt. II., pp. I2-I7.

5581. Collection relating to marine and colonies, I643-1769.

I7I7, Dec. 2, Paris. "Mémoire général de l'estat et scituation de l'isle St. Domingue", signed " de la Boulaye".

[ff. I8-23

[1697 ca.] Petition addressed to the Comte de Pontchartrain, secretary of state for the marine, by the wife of Jean Baptiste Ducasse, complaining of the conduct of the Baron de Pointis, commander of the expedition against Cartagena. [ff. 24-26

I697. Account of the siege and capture of Cartagena by de Pointis and Ducasse. Cf. de Pointis, Relation de l'Expédition de Carthagène faite par les François en I697 (Amsterdam, 1698), and [Ducasse], Relation Fidèle de l'Expédition de Carthagène (1699).

[ff. $27-30$ 
I663, Mar. Edict creating the Sovereign Council of New France at Quebec. (Copy.) Ptd. in Edits et Ordonnances, I. $37 . \quad$ [ff. 4I-42 5589._."Seconde navigation faicte ... par Jacques Cartier . . ", I536.

[ff. I-62

Two other versions are in MSS. Fr. 5644, and 5653, ff. I-56; a fourth version is printed, Bref Récit et Succincte Narration (Paris, I645). An elaborate discussion of these four versions is to be found in Biggar, Early Trading Companies, pp. 210-220. According to Biggar, MSS. Fr. 5589 is the earliest version, and served as the original or base of the other three. The printed edition of Paris, I645, has been reprinted by Armand d'Avesac, Bref Récit et Succincte Narration de la Navigation faite en 1535 et 1536 par le Capitaine Jacques Cartier (Paris, I863), with indication of the variations in the three manuscript versions. The narrative printed by $\mathrm{H}$. Ternaux-Compans, $A r$ chives des Voyages (Paris, I840), vol. II., pt. I., pp. 5-66, is based on MSS. Fr. 5589 and 5644. According to Biggar, also the version in Lescarbot is from MSS. Fr. 5589, while that printed by the Quebec Literary and Historical Society, Voyage de Découvertes au Canada (Quebec, I843), pp. 24-69, is a modernized copy of MSS. Fr. 5653.

French-Indian glossary: "Ensuite le langaige des pays et royaumes de Hochelaga et Canada. ...." Also in MSS. Fr. 5653, ff. 56v-59. Ptd. in the Paris edition, I645, noted above, and in the reprint of this latter by Armand d'Avesac.

5644. See above, 5589.

5652. "Segon livre de la monarchie articane et antarticane ensemble les voyages et perigrinassions de Vincent Leblanc . . ." (I 578-I 584?) -Deals with India and the eastern hemisphere, but has outline maps in ink showing North and South America (f. 8I), and parts of the coast of South America (ff. 245, 284). Incorporated in part in Les Voyages Fameux du'Sieur Vincent Leblanc; $c f$. above, MSS. Fr. 2033.

5653. See above, 5589.

5682.- [ $\mathrm{I} 784 \mathrm{ca}$.] "Mémoire sur le commerce étranger et maritime." (Marginal note: "Remis à M. le Comte de Vergennes. Je crois que le Sr. de Limon est autheur du Mémoire.") Contents: present state of French commerce, India and America; French have had to abandon the whale fisheries, should make the most of the reconquered cod fisheries; importance of colonial commerce, necessity of reform in legislation relating thereto; importance of largest possible development of commerce with United States by liberal provisions, reciprocity, etc.

[ff. 224-264

5765. Formulary of letters written in the name of the king by Paul Phélypeaux, Comte de Pontchartrain, I 588-I 594.- - Letters to the Queen of England, the admiral of England, and to the French ambassador in England, on behalf of Nicolas Missent, sea-captain of Pont Audemer, whose vessel the Diane, bound from Newfoundland laden with dried fish and oil, was seized by the English. (Copies.)

[ff. 93v-94v

6116-6117. Extracts from narratives of voyages and works of history, etc. For detailed list of contents see Catalogue.

6116. Extracts from and notes relating to voyages of Columbus (ff. I-40); New' France, Newfoundland, Gaspar Corte-Real (f. 4I); "discours d'un grand capitaine Dieppois, I 539" (ff. 42-43) ; Alvaro Nuñez, I 527-1536 (ff. 56-57); Guzman, I 530 (ff. 76v-79) ; Coronado (ff. 93-95).

6117. Extracts from and notes relating to voyages of Pigafetta, I5I9 (ff. 5-I8); Magellan (ff. 23V-30); Vespucci, I5OI (ff. 3I-32); Magellan (ff. 62- 
63) ; Jean Gaëtan, I 542 (ff. 64-7I) ; Peter Martyr, West Indies (ff. 79-I47) ; Oviedo, History of the Indies (ff. 208-21 5).

6124. See above, 2145.

6198. État de la France, I785-I788.

I788. "Apperçu de la Balance du Commerce de la France." Statistics showing population, white and slave, and value of imports from the Philippines, Mexico, Louisiana, Florida, Canada, Acadia, Hudson Bay, Newfoundland, Bermuda, and the United States (by states).

6233-6256. Colonization of French Guiana, I763-1764 [1775]. 24 vols.

Records of the disastrous settlement of French Guiana under the Chevalier Étienne François Turgot, governor, and Thibault de Chanvalon, intendant, in $1763-1764$, and of the investigations resulting therefrom ("affaire de Cayenne", "expédition du Kourou", "affaire de M. de Chanvalon"). They include lists of persons going to Cayenne, I763-1764 (6233-6234), memoirs and lists of supplies, I763-1764 (6235-6238), correspondence of Turgot with the French government, I763-1775 (6239-6241), administrative correspondence of the colony, I763-1765 (6242), regulations respecting justice, police, and finance, $1763-1765$ (6243), various documents relating to the administration of the colony (6244-6247), proofs of charges against de Chanvalon, I764 (6248-6250), memoirs and letters relating to Guiana and the administration of Turgot and de Chanvalon (6251), explanations furnished to the Duc de Praslin by Turgot, Feb. I2, I768 (6252), memoirs by Morisse, ordonnateur (6253), documents relating to the "affaire de M. de Chanvalon" (6254), report on the "affaire de M. de Chanvalon", Sept. I3, I767 (6255), and domestic affairs of Turgot, I763-1765, with plans and maps of concessions (6256). Here and there are documents relating to North America, trade with English colonies, trade with St. Pierre and Miquelon, Acadians emigrating to Cayenne, English designs on the West Indies, etc. The episode of Guiana (or Cayenne or Kourou) has been variously dealt with: Précis Historique de l'Expédition du Kourou, I763-I765 (Paris, 1842) ; E. Daubigny, Choiseul et la France d'Outremer a après le Traité de Paris (Paris, I892), ch. III. Cf. MSS. Fr., nouv. acq., 3605-3606 ; Bib. Mazarine, MSS. 3446-3448 ; Bib. Arsenal, Bastille, 12324.

6347. "Le globe terrestre et toute sa surface . . .", by [Louis de Courcillon, Abbé de] Dangeau. (Early I8th century.)

Geographical tables and enumeration of all the countries of North and South America.

[f. 8

6348. - r706, Jan. I4. Petition of Guillaume Delisle to the king and council: charges of plagiarism against [Jean Baptiste] Nolin, with general observations on plagiarism in geography. $C f$. the printed factums relating to these charges, listed in A. Corda, Catalogue des Factums, II. 28-29. [ff. 3-I6
[6.

6349. Papers of Gabriel de Bory, lieutenant de vaissean, member of the Académie de la Marine and of the Académie des Sciences, governor of Santo Domingo, I $76 \mathrm{r}$.

I746, June 24, Placentia. "Journal de ma campagne sur le Castor, fregatte, ... faite au'Canada en $1746, \ldots$ commandée par Mr. Saliès."

[ff. $2-38$

1782, Apr. 20. Report by [Pierre Charles] Lemonnier, by direction of the Académie des Sciences, on a memoir by [Rigobert] Bonne respecting the determination of the positions of Boston and New Cambridge in New England.

6431: Papers of Abbé Guillaume-Thomas Raynal. [ff. 438-439 commerce. 
I682. Extract from a memoir by Lefèvre, former échevin of Marseilles, on the state of the French, English, Venetian, and Dutch trade in the Levant, and of the French trade in the Mediterranean and beyond the Straits. References to the French cod fisheries at Newfoundland, and to voyages from Marseilles and Provence to the West Indies.

[ff. I $4-87$

I725-I77I. Prices in the branches of the Compagnie des Indes: Canada, prices of beaver; West Indies, prices of raw products taken in exchange for Senegal negroes.

[f. I84

I774. Extracts from replies by — Payte to queries by the Earl of Dartmouth respecting the English possessions in North America, and remarks on the Virgin Islands. (English.)

[ff. I88-I97

Extract from a memoir on the Levant trade: estimates of French commerce, exports, manufactures, products of American colonies, etc. [f. $209 \mathrm{v}$

6453. Canadian missions, letters from Jesuits, etc.

I692, Nov.-I693, Sept. Account of relations between the French and the Iroquois.

[ff. $2-4 \mathrm{~V}$

I693, Feb. 28. Quebec. Father [Claude] Dablon to the provincial. Death of Father Pierre Joseph Marie Chaumonot, Feb. 2I [28], I693, and some account of his life; death of Father Antoine Dalmas. [ff. 8-i6v

I694, Feb. I 5, Quebec. "Lettre du Père Jacques Gravier en forme de Journal de la mission de l'Immaculée Conception de N. D. aux Illinois ", 1693, Mar.-r694, Feb. Ptd., Thwaites, Jesuit Relations, LXIV. I 58-236.

[ff. I $8-43 \mathrm{v}$

I694. Report of parley at Quebec, May 23, between Frontenac and Teganissorens on behalf of the Five Nations, and summary of a report of a parley at Montreal on Sept. 22. See N. Y. Col. Docs., IX. 579-585. [ [ff. 44-46

I694, Oct. 29. Letter from one Jesuit to another containing an account of the state of religion at the mission of St. François de Sales. (Three copies, one of which, ff. 65-72, bears corrections as if for publication.) [ff. 50-73

6556.-Group of five printed documents relating to the attempt by the Compagnie de la France Equinoctiale to found a colony at Cayenne in 1652 . A contemporary account of this enterprise is in Antoine Biët, Voyage de la France Equinoxiale en l'Isle de Cayenne entrepris par les François en l'année MDCLIII (Paris, I664). The documents are as follows:

I65I, Sept., Paris. Lettres Patentes . . accordées aux Sieurs de l'Isle Marivault, de Royville et leurs Associez . . . (7 pp.). [ff. 299-302 I65 I, Aug. Acte d'Association .. . entre les Srs. De la Boulaye, le Roux de Royville, de l'Isle Marivault, et F. Dolu . . . (8 pp.). Also in Bib. Nat., Imprimés, 4to, $\mathrm{Lk}^{12}, 8 \mathrm{I} 8$. [ff. 303-306 I652, May 3, Paris. Articles et Statuts . . arrestez entre les Seignenirs Associez de la Compagnie de Terre Ferme de l'Amérique ou France Équinoctiale . . (37 pp.). Also in Bib. Nat., Imprimés, 4to Lk ${ }^{12}$, 8I9.

[ff. $307-325$

Lettre escrite de Cayenne contenant ce qui s'est passé en la Descente des Francois dans ce pays ... (Paris, Guillaume de Luyne, I653, I4 pp.). Also in Bib. Nat., Imprimés, 4to, Lk ${ }^{12}, 82 \mathrm{I}$ [ [ff. 326-332

Mémoire pour servir de brève Instruction tant aux Directeurs . . . de la Grande Compagnie de l'Amérique qu'à ceux qui s'y voudront intéresser (Paris, Guillaume de Luyne, I653, 34 pp.). Also in Bib. Nat., Imprimés, 4to, $\mathrm{Lk}^{12}, 822$.

[ff. $334-35$ I

6569.-I733 [May I2]. Royal ordinance for the emission of 200,000 livres of monnaie de carte in Canada. Ptd. in Edits et Ordonnances, I. 544. [f. 30 
6652-6658. Registre du secrétariat du cabinet du roi, I670-I70I. Cf. Arch. Nat., O, I3-I28.

6652.-I669, Aug., St. Germain-en-Laye. Edict permitting gentlemen and nobles to engage in sea-borne commerce without prejudice to their privileges. Ptd. in Isambert, Anciennes Lois Françaises, XVIII. 2I7-2I8.

[ff. $2 \mathrm{I}-22$

I670, Jan. II, St. Germain-en-Laye. Royal order directing the Grand Conseil to register and publish the above edict.

[ff. $22-22 \mathrm{~V}$

I669, Aug., St. Germain-en-Laye. Edict forbidding the king's subjects to become domiciled abroad. Preamble printed in Isambert, op. cit., XVIII. 366. Purpose of this edict was to retain in the kingdom navigators, pilots, sailors, fishermen, ship-builders and riggers, etc.

[ff. $23 \mathrm{v}-24 \mathrm{~V}$

I670, Feb. 20, St. Germain-en-Laye. Royal order directing the Cour des Monnaies to register the déclaration [of Feb. 19, I67o, ptd. in Moreau de St. Méry, Loix et Constitutions, I. I88] which provides for the manufacture of a special money for use in the Islands of America.

[ff. IO2V-IO3

I670, Mar. 25, St. Germain-en-Laye. Permission to Bertrand Pallu, Sieur du Ruau, to reside for three years in the Antilles as general agent of the Compagnie des Indes Occidentales.

[ff. I $37 \mathrm{v}^{-1} 38$

I670, May I4, Arras. Royal order directing the Parlement de Paris to register the letters of naturalization granted to Capt. Van Hemskirke, who is to explore between $50^{\circ}$ and $34^{\circ}$ in North America and to discover the passage to the South Sea.

[ff. I $84 \mathrm{~V}-\mathrm{I} 85$

I670, May 28, St. Germain-en-Laye. Royal permission granted to Nicolas Quentin, councillor of the presidial of Tours, to reside for three years in the West Indies and America (Terre Ferme).

[f. I93

6653.-167i, May, Dunkirk. Confirmation of the establishment (Montreal, I653) of the Congrégation des Filles in Canada.

[f. $224 \mathrm{v}$

I671, July I8, St. Germain-en-Laye. Letters granted to Perrot, captain in the regiment of Picardy, serving in Montreal, Canada. I67I, Aug., Fontainebleau. Letters of naturalization granted to Jean Vanoolle, Dutch subject, that he may reside and continue his commerce in the Islands of America.

[f. $316 \mathrm{v}$

6656.-I675, May I7, Camp of Château de Cambrésis. The king to Frontenac, instructing him to receive the Bishop of Petraea, who is leaving for Canada.

[f. Ior

I675, May, St. Germain-en-Laye. Royal act erecting Les Islets, in Canada, into a county, in favor of [Jean] Talon. Cf. Th. Chapais, Jean Talon (Quebec, I904), p. 502.

[f. 105 I675, June 5, Camp of Luting. Confirmation of the creation of the Sovereign Council at Quebec. Ptd. in Edits et Ordonnances, I. 83. [f. II7] I675, June 8, Camp of Luting. Sieur Du Chesneau, intendant of justice, police, and finance in Canada, appointed councillor of state.

[f. II

.1675. Aug. 4, Versailles. Letters to the Sovereign Council of Quebec, granting permission to the hospital nuns of St. Joseph, Montreal, to accept dowries.

6657.-I68I, May, Versailles. Edict granting amnesty to the coureurs de bois in Canada. Ptd. in Edits et Ordonnances, I. $249 . \quad$ [f. I28 I68I, May, Versailles. Edict respecting punishment of the coureurs de bois in Canada who trade with the savages. Ptd. ibid., p. 248.

6680-6687. I763-1789. "Mes Loisirs", by Siméon Prosper Hardy.-These bulky and closely written volumes constitute a daily record of events, by S. P. Hardy, a bookseller of Paris. The MS. is fully described and copious extracts 
from it (I764-I773) are printed by Maurice Tourneur and Maurice Vitrac in Siméon Prosper Hardy: mes Loisirs, I. (Paris, I9I2). An earlier account of the MS. by Charles Aubertin is printed in the Revue des Deux Mondes (Nov. I, I87I), “Le Bourgeois de Paris au XVIIIe siècle”. From I775 on, the journal contains frequent references to American events, which indicate the form in which American news circulated in Paris. By way of illustration, a few of these references are here noted:

6682. I775-I778, June I2.-I776, Sept. 22, news of British defeat at Boston; British losses, 3000 killed, 5000 prisoners ; American losses, 6000 (p. 276).Sept. 29, effect of news of British defeat on French finances (p. 278). - Oct. I, rumors of impending war on France by England as a result of reverses in America (p. 279).-Dec. I8, arrival of Franklin, rumors as to character of his mission (p. 308).- I777, Apr. ro, rumors of American successes, fears of revolution in London; English selling out their affairs and coming to Paris ("les hôtels garnis du fauxbourg Sainct Germain en étaient remplis ") ; news of surrender of Cornwallis; rumor that vessels of St. Malo have been forbidden to depart (p. 345).- June 28, news of orders to armateurs to attack English vessels (p. 373).-July 6, reported desertion of Hessian and Hanoverian troops (p. 375).-July 27, English ambassador quits the court (p. 384). - Sept. 5, report from London of capture of Ticonderoga (p. 397).Sept. 7, news of surrender of Burgoyne (p. 398).-Dec. 7, MS. bulletin in circulation announcing surrender of Burgoyne; reported success of Gen. Howe, "on ne craignoit rien tant que de voir les Anglois faire leur paix avec l'Amérique, et l'on se préparoit à leur opposer des forces puissantes dans le cas où débarrassés, ils chercheroient à nous attaquer subitement et sans nous avertir" (p. 423).- I778, Mar. I8, report of declaration of war against France by England (p. 469).-Mar. 20, Englishman killed in duel after publicly insulting French in a café (p. 470).-Mar. 23, Franklin, Deane, and Lee presented to the king by Vergennes (p. 472).-Apr. 4, rumored arrival of an English nobleman for the purpose of negotiating a truce of eight years ( $\mathrm{p}$. 477).-Apr. Io, rumors of American successes, report of impending attack on Quebec by the French under Lafayette, "un de nos officiers généraux partis depuis quelque temps pour se mettre à la tête des insurgens" (p. 48o).-Apr. $2 \mathrm{I}$, rumors that Gérard, en route to embark for America, has been arrested and confined in the Bastille on accusation by the King of Prussia that he had betrayed secrets of the French cabinet to the emperor (p. 483).-May I3, report of announcement posted on Exchange in London that war would be declared against France on Apr. 24 (p. 48I).- June Io, rumor of doubtful truth that d'Estaing's fleet has arrived in America (p. 500).

6684. July 24, I78I-Sept. 21, I784.-I78I, Nov. 20, bulletin being circulated, announcing surrender of Cornwallis (p. 53).- - 782, Nov. I9, Comte de Grasse hissed and forced to retire at the Comédie because of his disgraceful defeat in the Antilles (p. 236).-1783, Feb. 4, public opinion respecting the preliminary articles of peace (p. 267).

6793. Dépenses pour les subsistances, l'agriculture, la marine, I7I4-I790. I732, Jan. 2, Versailles. Maurepas to the controller general. Special payment to Raudot for his work in I730 on fisheries and abuse of flag. [f. 200
[f. 206

1732, Dec. 9. Same as above, for work in I73I. [f. 206

I747, Apr. I I, Versailles. Warrant for payment of expenses of lodging a company of cannoneers, formerly of the garrison Ile Royale, at Rochefort. 
I75I, July I7. Warrant for payment of salary for I 746 to Lieut. Lambert, in command of artillery in Santo Domingo.

[f. 2 I 3

I 789-I791. Orders, certificates, etc., respecting payments of bonus of 50 livres per ton to Nantucket ship-owners established at Dunkirk for purpose of carrying on whale fisheries. Names of ship-owners and masters: Benjamin McTosh Alexander, Walter Brooks, Mark Coffin, Thadeus Coffin, Benjamin Hussey, George Gorham Hussey, Isaac Hussey, Silas Jones, Francis Macy, William Rotch, Thaddeus Swain, and Coffin Whippey [sic]. [ff. 232-246

6800. Travail du régent avec le Conseil de Regence: Marine et colonies, I7 I 5-I729.-Cf. below, MSS. Fr. 23633-23673.

[I7I6.] Appeal by [Antoine] Crozat from decisions of the Superior Council of Louisiana of July 2, I 7 I 5, seizing and confiscating his vessel Notre Dame de La Trappe. Includes following documents: brief of case, opinion of Conseil de Marine, decision of Conseil de Régence ; deliberation of Conseil de Régence; Instruction pour etablir les Habitations à la Louisianne, a printed document constituting a programme for the organization and operation of a concession in Louisiana; extract from registers of Conseil d'État, Sept. I4, I7 I2, containing provision which allowed Crozat to abandon his concession of Louisiana upon notice of one year. $C f$. below, MSS. Fr. 23664, f. 77.

[ff. I - Io

I7I6, Dec. 22. Account of voyage of the Charente, Capt. de Barrailh, to Ile Royale. (Two copies.)

[ff. $86-86 \mathrm{v}, 88-88 \mathrm{v}$

I7 6 , May 5. Deliberation and decision on petition of M. d'Auteuil, to be restored to his functions as procureur général of Canada, of which he was deprived in I705.

I716, June.21. Deliberation and decision on complaint of Descaseaux, merchant of Nantes, respecting his vessel the Union, wrecked on the Mexican coast, the crew captured, and the cargo confiscated by the Spaniards.

[ff. I I 2 -I I 3

I7 I6, May i2. Deliberation and decision on contract of Neret and Gayot (June 7, I7 I5) with Pascaud and Le Clerc, merchants of La Rochelle, for discounting drafts sent to the latter by their correspondents in Canada, in course of beaver trade.

[ff. I I4-I I 5v.

I 7 6, Sept. Deliberation on prolongation of permission to inhabitants of Cayenne to trade with the English, in order to purchase horses. [ff. I 34-I 36

[I7I7.] Deliberation on appeal by Thomas and Daniel Macnemara, merchants of Nantes, from imposition of fine for failure to transport four engagés on their vessel to Martinique.

[I7I7.] Deliberation on damage caused by floods in Santo Domingo.

I7I6-I7I7. Estimates of expenditures for marine and colonies. [ff. I $57-160$ [ff. I65-I74v

I7I7, Jan I9. Deliberation on authorization to Captain Cassard to operate as privateer against the pirates of the Islands of America. [ff. I83-I9I I 7 I7, May. Memoir of instructions to Vaudreuil and Bégon respecting fortifications in Canada.

[ff. 2IO-2I 3

I7I8, Oct. 3I. Deliberation on seizure of the frigate the Royale, Capt. René Pognian, for engaging in negro trade within the concession of the Compagnie Royale du Sénégal. Annexed documents include "Estat des marchandises qu'il faut pour la Traitte de deux cent negres".

[ff. $227-234$

Memoir of general instructions to Vaudreuil and Bégon. [ff. 264-27ov

I7I6. Nov. I7-I7I7, May 27. Account of voyage of the frigate Valeur, Capt. de Ricoüart, La Rochelle to Martinique, Grenada, Guadeloupe, and Nantes.

「ff. 274-274v 
Memorandum respecting opposition by Brizacier and Tiberge of the Séminaire des Missions Etrangères of Paris, to the decision of May Io, I7 I4, requiring them to render an account of the revenues of the chapter of Quebec.

7065-7069. Copies of instructions to ambassadors, etc.

7065.- “Extrait de la Relation de l'estat des Provinces Unies des Païs-bas, en l'année I665." Interest which the Dutch have to maintain friendship with England in order to assure the freedom of their commerce in the new world, etc.

[ff. I 5-I6

I669, Dec. 22, St. Germain-en-Laye. Instructions to Bishop of Béziers, ambassador in Spain. Spanish negligence in West Indies is source of profit to England. Ptd. in A. Morel-Fatio, Recueil des Instructions . . . aux Ambassadeurs de France: Espagne, I. 233.

[ff. 2I I-2I 2

7080-7084. Embassy at Rome of Cardinal de Marquemont, i6i7-1625.

7080.-I6I7, Aug. Io, Paris. The king to Cardinal de Marquemont. Has sent a few Recollects to Canada to enlighten the savages; would be glad if the pope would order the provincial of the province of St. Denis to send a sufficient number of Recollects to that country.

[ff. 2I 2v-2I $3 \mathrm{~V}$

7086-7090. Negotiations of the truce of Antwerp of Apr. 9, I6o9, between Philip III. of Spain, the Austrian archdukes, and the States General of the United Provinces. I607-I609.-These volumes contain copies of the correspondence between the King of France, the Duc de Sully, and de Villeroi on the one hand, and President Pierre Jeannin, de Buzanval, and de Russy on the other, during the years I607-I609. The documents have been printed in various collections, e.g., in Négociations du Président Jeannin (Paris, I8I9, 3 vols.), and in Michaud et Poujoulat, Nouvelle Collection des Mémoires pour servir à l'Histoire de France (second series, vol. IV, Paris, I837). The documents contain many references to commerce with the West Indies, which was an important subject of negotiation; $c f$. F. G. Davenport, Europcan Treaties bearing on the History of the United States . . . to 1648 (Washington, I9I7), Doc. 28.

Other MS. copies of the negotiations are in the Bib. Nat., as follows: MSS. Fr. 10688-10697, 15951, 15952 (contain originals), 17922-17933, 1989219893, 23402-23404, 23551-23555, 23577-23588; MSS. Fr., nouv. acq., 70727075.

7108-7109. Embassy of Antoine Lefèvre de La Boderie in England, I605I609.-Copies of letters from La Boderie to de Villeroy and de Puisieux, containing occasional references to commerce of West Indies, English colonization of Virginia, etc. These despatches are lacking in Arch. Affaires Etrangères. Cf. Ambassades de Monsieur de la Boderie en Angleterre . . . I606-I6II (I750, 5 vols.). Other copies in MSS. Fr. 23594-23596; MSS. Fr., nouv. acq., 7013-7014.

7120.-Extract from memoir by the Comte de La Vauguyon during his embassy in Spain, I682-I683. Art. 23, the governor of Campeche sends a French subject, Simon Bonneau, as prisoner to Spain to be tried by the Council of the Indies. Art. 53, a vessel from Martinique, with crew of thirty Frenchmen, wrecked on coast of Campeche and crew made prisoners by the Spaniards.

[ff. 25,37

7121. - I688, May 20, Versailles. Extract from instructions to François de Pas de Feuquière, Comte de Rébenac, ambassador in Spain. Commerce with West Indies.

[ff. I $4 \mathrm{v}, 20$ 
7142-7143. Letters from Paul Choart, Seigneur de Buzanval, to de Villeroy during his embassy in Holland, I602-I605.- These contain a few references to America: 7142, 1602, Apr. I2, formation of Dutch company for trade with East and West Indies (f. 2) ; Oct. 23, Dutch plans for trade with the Indies ; search for Northwest Passage (f. Iorv). 7143, I606, Apr. 28, Dutch India Company prepares active campaign against Spaniards in West Indies (f. 209); May 3I, States General propose to send a fleet of war vessels to attack Spaniards in America (f. 224); I605, Mar. 9, hopes of States General for successful operations against Spanish treasure fleet (f. $357 \mathrm{v}$ ). These letters just noted are not included in the printed correspondence of Buzanval: Lettres et Négociations de Paul Choart, Seigneur de Buzanval, ed. G. G. Vreede (Leiden, I 846$)$.

7146. Original letters from Louis XIV., countersigned Colbert, to Cardinal d'Estrées, ambassador at Rome, I686.

I686, May ro, Versailles. Union of abbey of Lestrée to bishopric of Quebec.

[f. 53

I686, June 6, Versailles. Promise of King of Spain to return the 500,000 écus levied upon French goods in Mexico.

[f. $72 \mathrm{~V}$

7220-7221. List of edicts, déclarations, and principal arrêts relating to finance, I7I 5-I722, arranged by subjects.--Under the headings amirauté, commerce, fermes générales, marine, monnoyes, etc., are listed the titles of numerous acts relating to Canada and the other French colonies in America. The texts of the acts are to be sought elsewhere, as in Arch. Nat., E, Arch. Colonies, A, B, etc.

7222-7223. Interleaved copy, with MS. additions, of Guillaume Blanchard, Compilation Chronologique... des Ordonnances, Edits, Déclarations, et Lettres Patentes, des Rois de France, qui concernent la Justice, la Police, et les Finances ... depuis . . 987 jusqu’à présent [I7I2] (Paris, I7 I 5, 2 vols.). The second volume contains the titles of numerous acts relating to America.

7227. Chronological list of titles of edicts and of arrêts of Parlement, I 55 II $72 \mathrm{I}$.- A few of the acts listed relate to America.

7228-7235. Chronological list of titles of edicts and of arrêts of the Council, I690-I725.-Many acts listed relate to America.

7516.-Memoir by [Cabart] de Villermont respecting the succession of governors and intendants of Canada, the Antilles, Cayenne, etc. [ff. 25v-26

7718. Edicts, etc., registered in the Cour des Aides, I635-I7I6.

I664, Sept. 22. Registration of déclaration of Aug. 27, permitting officers of courts to hear cases between the companies of the East and West Indies, although having interests in those companies. Ptd. in Moreau de St. Méry, Loix et Constitutions, I. I22.

[ff. $757-762$

7719-7723. Extracts from registers of the Cour des Aides, I630-I779. Cf. Arch. Nat., $Z^{1 \mathrm{a}}$.

7719.-I757, Sept. 30. Invitation to attend a Te Deum in celebration of the victories of Montcalm in Canada.

[f. 53 I

7725. "Recueil de pièces sur les finances."

r69r, Sept. "Table générale des produits et dépenses des fermes de M. Pierre Domergue." Includes expenses and receipts of the domaine d'Occident in Canada and the West Indies.

7726.-I7I6. Rates of exchange for America and Canada allowed for in the price of the ferme du domaine d'Occident.

†f. 186 
7769.-I7I7, June, I9. Report to the Conseil de Régence by the Duc de Noailles on the domaine d'Occident, revenues from Canada and America. 7799.- [ I I733 ca.] "Mémoire sur la Compagnie des Indes." [ff. 54-59 torical account with defense of company and exposition of its utility; statement of expenditures on account of Louisiana (I7I7-I73I), I9,450,000 livres.

7800. "Mémoires sur le commerce et les finances de France, def. 207-224
[Ol' de l'Angleterre, et de 1'Espagne." (I8th century.)

"Mémoire concernant le commerce de France." [ "Situation du Comme et en particulier." Discussion of the utility of the Compagnie des Indes.

[ff. 236-247

[Post I733.] "Observations sur la perception du Domaine d'Occident et autres Droits qui se perçoivent tant en France que dans les Colonies."

[ff. $248-257$

8022. "Recueil de plusieures pièces concernant la juridiction de la Marine

"-A register of copies, "tiré du cabinet de M. Foucault le père, ce I3 avril, I682".

"Du nom et de l'estendue des Costes . . . du nouveau monde."

[ff. $5 \mathrm{v}-8 \mathrm{v}$

"Observations sur les traictez de paix entre la France et l'Angleterre sur le fait du commerce de la Mer, ensemble sur ceux de France et d'Espagne."

[ff. I 5 OV-I 55

I620, Nov. 8. "Articles accordés par le Duc de Montmorency . . viceroy . . au pays de la Nouvelle France . . . au Sieur Guillaume de Caen . . . tant pour luy que pour le Sieur de Caen, son oncle ...", with ratification by the king, Jan. I2, I62 I. Cf. MSS. Fr. 16738, f. I48, analyzed in Biggar, Early Trading Companies, p. II 5.

[ff. I8I-I86v

I 588, May 5, July 9. Extracts from registers of the Conseil d'État: arrêt declaring that the monopoly accorded to Chatou and Noël does not prohibit others from engaging in the fisheries or fur trade; letters patent to the estates of Brittany, revoking the monopoly of Chatou and Noël. Listed in Biggar, op. cit., Sources, part. I.

"Des usurpations des Anglois sur les François en la Nouvelle France depuis l'an i6ri."

[ff. I $87 \mathrm{v}-\mathrm{I} 88$

"Que la Nouvelle France et l'isle de Terre Neuve en l'Amérique ont esté descouverte par les Français depuis l'an I 504."

I66I Aug 8 Fontainbleau. "Arrest . 1504." [1. 188 -189 des Colonies en l'Amérique."

[ff. $189-190$

8025-8030. "Collection de pièces originales sur la marine, consistant en lettres, notes, instructions, ordres, ordonnances, projets et mémoires minutés de la main de Colbert et du marquis de Seignelai son fils . . I667-1677." This collection of autograph minutes by Colbert was utilized by P. Clément in Lettres, Instructions, et Mémoires de Colbert, vol. III., pts. I., II. The record copies of many of the documents are to be found in Arch. Marine, B2, vols. 8, 9, 10, 14, and in Arch. Colonies, B, vol. 1. A complete calendar of the documents in the collection is in the first volume, 8025, from which the list here given of documents relating to America has been drawn off. For letters received see 500 Colbert, below.

8027. Minutes in hand of Colbert.-Unless otherwise indicated, these are minutes of letters from Colbert to Colbert de Terron, intendant of marine at Rochefort. In most instances only a paragraph or a few lines relate to American affairs. 
I669, May 24. Shipyard in Canada, and search for iron and copper mines.
[f. 22 I669, June 14. Transfer of part of St. Kitts to the English. [f. 29 I669, June 20. Delay of Talon, intendant in Canada, in arriving at Rochefort.

I669, June 27. Awaits memoir on Canada.

66. July 27. Awaits 35 parture of Talon for Canada; necessity of peopling Acadia. I669, July 29. Peopling of Acadia. I669, Aug. 7. Peopling of Acadia; workmen to be sent to Canada for shipbuilding. r669, Aug. ro. To the Comte d'Estrées. Necessity of suppressing private trade in West Indies carried on by officers of his fleet.

[f. $5^{2}$ I669, Sept. 8. The Normand and the Gallant will remain at least eighteen months in the West Indies; plans for establishments in Acadia. I669, Sept. I3. Choice of person to found establishments in Acadia.

I669, Sept. I6. Squadron for West Indies should leave in Jan. 1669, Sept. 30. Awaits news of departure of American fleet.
1669, Oct. 7. To send I 50 or 200 girls to Canada next year. I669, Oct. 21. American fleet should leave without loss of time. I669, Oct. 28. Hasten departure of American fleet. I669, Nov. I4, Necessity of driving foreigners from American possessions.

I669, Nov. 20. Departure of American fleet; things to be clo $\{1.97$ Canada. i669, Dec. I3. King to Colbert de Terron. Departure of fleet for Canada. I669, Dec. I 3. King to Colbert de Terron. Talon must return to Canada in February. I669, Dec. 23. King to Colbert de Terron. Girls to be sent to Canada. 1671, Mar. 9. Funds for Placentia and Acadia.

8028. Minutes in hand of Colbert.

I668, Apr. 5 Instructions to intendant in Canada. Ptd. in Clément, vol. III., pt. II., p. 402.

[f. 108

r669, Apr. 3. Edict for encouragement of large families in Canada. Ptd. in Clément, vol. III., pt. II., p. 657. Accompanied by minutes of king to Sovereign Council of Quebec respecting the edict, king to de Courcelles, governor of Canada, respecting organization of militia, and king to de B [outeroue], intendant in Canada, recalling him.

[f. I27

I669, June I3. King to de Baas; Colbert to de Baas; king to d'Estrées. All ptd. in Clément, vol. III., pt. II., pp. 453-455.
[ff. I 3O-I 3Ov r669, July Io. King to de Baas. Freedom of trade for French vessels having permits from the Compagnie des Indes.

[f. I33 [1669, Aug. 8?] King to de Baas. To recognize Du Lion, reinstated as governor of Guadeloupe.

[f. I 34 I669, Aug 8. King to de Baas. Freedom of trade for French vessels having permits from Compagnie des Indes. Ptd. in Clément, vol. III., pt. II., p. 452 .

[f. I34

I669, July 22. Letters patent authorizing Talon to receive Acadia and forts from hands of the English, in accordance with the Treaty of Breda. 
p. 456 .

I669. July 3I. Colbert to de Baas. Ptd. in Clément, vol. III., pt. II.,

[1669, Aug. 30.] Memoir for Abbé de Bourlemont respecting the bulls for creating the bishopric of Quebec.

r669, Sept. I 5. King to de Baas. Ptd. in Clément, vol. III., pt. II., p. 460.

[f. I40

[f. I42

I669, Oct. I. King to Gabaret. Instructions respecting the West Indies.

[f. I 44

I669, Dec. I 5. King to de Baas. Method of dealing with insubordinate colonists.

[f. I 55

I670, Jan. 5. Colbert to Colbert de Terron. Girls from Rouen for Canada.

[f. I 59

I670, Aug. 5. Colbert to Colbert de Croissy, ambassador in England.

Ptd. in Clément. vol. III., pt. II., p. 49I.

[f. 166

I670, Nov. I7. Colbert to Colbert de Croissy. Response to Lord Arlington, respecting English complaints against the French in America. [f. I73

N. d. Instructions to Capt. Michaud respecting escort of French vessels in slave-trade from Guinea to West Indies.

[f. I75

8036. " Histoire abrégée des Compagnies de Commerce qui ont esté établies en France depuis l'année i626, avec la collection générale de tous les Privilèges qui ont été accordés depuis I664 ... ", by Dernis, employee of the Compagnie des Indes, I742. This work, frequently cited by Pierre Bonnaissieux in Les Grandes Compagnies de Commerce (Paris, 1892 ), is stated by him (p. $35 \mathrm{I}, \mathrm{n} . \mathrm{I})$ to be borrowed largely from Savary, Dictionnaire $d u$ Commerce. The MS. contains numerous pages on the American colonies and on companies trading in America (pp. I-2, 5-II, 2I-23, 55-62, 407-4II). Another copy is in Arch. Colonies, F2, vol. I8.

8038. “Mémoires présentés à M. le Duc d’Orléans, Régent, par les Députés du Commerce, I7or."

"Mémoire sur le Commerce de France." Sections on French commerce with America by way of Cadiz, commerce with the. West Indies and Canada, and the Newfoundland fisheries.

[ff. 5-39

r 7or, June I. "Griefs du Commerce de la Bretagne et de Nantes en \begin{tabular}{l} 
particulier par rapport à la Régie des fermes du Roy." [ff. I 79-220 \\
\hline
\end{tabular}

"Mémoire des habitans de Saint Malo pour le rétablissement du Commerce", by M. de la Motte Gaillard, deputy of St. Malo. [ff. 29I-3I4

8153. "Mémoire sur la Bretagne", by the intendant Gallais de la Tour.Not examined; analyzed by H. Sée, in Annales de Bretagne, XXXV. I87-208, $433-455$.

8290-8293. "Précis des delibérations des Etats [de Bretagne], I 567-1762." These four volumes contain an analysis, arranged alphabetically by subjects, of the proceedings of the États de Bretagne. The proceedings themselves, procèsverbaux, are in Arch. Départementales, Ille-et-Vilaine, at Rennes (C. 26402704). The printed inventory (Inventaire Sommaire des Archives Départementales Antérieures à I79o: Ille-et-Vilaine, Archives Civiles, Série C, vol. II.) contains a chronological summary of the proceedings but omits most of the references to American matters found in this précis. The American items mentioned in the précis under the headings Caffée des Isles, Canada, Colonies françaises, Commerce, Compagnie des Indes, Gouverneur, Huilles, Terre Neuve, and Vaisseaux $x$ are herewith indicated, consolidated, and rearranged in chronological order. Cf. Arch. Nat., H I, 218-645. 
I 588, Mar. I7, I603, Oct. 22. Opposition to exclusive privilege of trade with Canada.

I604, Dec. 4. Deputies at court charged to secure entire freedom of commerce.

I607, Nov. I2. Deputies at court charged to oppose exclusive privileges of trade with Newfoundland and Canada.

I6I6, Nov. 5. Opposition to exclusive privilege of trade with Canada. King revokes privileges accorded to private individuals of Rouen.

I6I7, Oct. 28; I6I8, Oct. 23. Deputies at court charged to secure effect of revocation of privilege.

I6r9, Oct. 3. Liberty of commerce with Canada will be maintained.

I622, Dec. 3r. Respecting proposal to establish a royal trading company. I626, May I9, July 20. Demand communication of contract made by trading company to be established at Morbihan.

I628, Jan. 27. Deliberation respecting letters patent of Aug., I626, establishing a trading company at Morbihan. revoked.

I639, Jan. 5. Demand that commerce be free and that all privileges be

I645, Mar. 3. Opposition to tax levied on all those going to Newfoundland to defray expense of convoy. land.

1655, Aug. I3. Opposition to appointment of a governor of Newfound-

I667, Oct. 26. Recommendation that Compagnie des Indes be established at Port Louis.

I669, Oct. 3, 7, 8, I 5, 28. Proceedings respecting freedom of trade with America and removal of tonnage duties imposed by the Compagnie des Indes.

I67I, Aug. 8. Reception of déclaration permitting nobility to engage in commerce.

I67I, Aug. 25, Sept. 5. Request that merchants coming from America may land their goods in their own ports without being obliged to go outside the province [of Brittany].

I674, Jan. Io; I675, Dec. I 5; I677, Oct. 9; I679, Oct. 7; I681, Sept. Io. Same subject, with refusal of king to accede to request.

1683, Aug. 3I. Complaint that goods from America, entering by the Loire, pay higher duties than in the neighboring provinces.

I724, Dec. I6; I726, Nov. I6. Complaint that commerce is no longer free since creation of Compagnie des Indes.

I 728 , Oct. 23. Opposition to duty of $1 / 2$ per cent. on goods from colonies. commerce.

I728, Oct. 30. Complaint that Compagnie des Indes is prejudicial to

I730, Nov. 16. Opposition to duty of $1 / 2$ per cent. on goods from colonies, and complaint that commerce is not protected by governors and intendants.

I732, Oct. 6, I3; I734, Oct. I6. Opposition to duty of $1 / 2$ per cent. on goods from colonies. colonies.

I734, Oct. 28. Opposition to allowing foreign vessels to trade with the

I736, Nov. I6. Appointment of commission on commerce. colonies.

1736, Nov. I8. Opposition to duty of $1 / 2$ per cent. on goods from

I736, Dec. I2. Instructions to deputies at the court respecting tobacco, duty on coffee from the French iglands, foreign commerce in the colonies, duties on oils from Ile Royale, free port of St. Malo, duty of $1 / 2$ per cent. on goods from the colonies. 
I738, Oct. 7. Opposition to duty on oil from Ile Royale. colonies.

I738, Oct. IO; I740, Oct. 5. Opposition to foreign commerce in the

I740, Oct. 30. Deliberation on report of commission on commerce; duty on cod fish, duty on coffee, evaluation of raw products from the Islands.

I 742, Oct. 5 ; I744, Oct. 3I ; I746, Dec. 3; I748, Oct. 3I ; I750, Nov. 5 ; I752, Oct. I2; I754, Oct. 26; I756, Dec. I2; I758, Dec. 24. Opposition to foreign commerce in the colonies.

I759, Feb. I7. Demand that beaver trade in Canada be free.

I 760, Sept. I 5. Opposition to foreign commerce in the colonies.

I760, Oct. 27. Demand that beaver trade in Canada be free; reply to argument of Compagnie des Indes.

I 762, Sept. 8. Opposition to foreign commerce in the colonies.

8306-8307. "Précis par ordre de matières des mémoires, pièces et rapports de Commissions déposés au greffe des États [de Bretagne]."-Under the title Commerce a few documents bearing on American matters are noted, as follows :

I73I. Memoir by merchants of Nantes respecting duties on sugar from the colonies.

I736. Memoir from St. Malo respecting cod fisheries and duties on cod.

I738. Memoirs respecting duty on coffee from the Islands.

I739, July I4. Arrêt of the Council, laying duty on cod entered in the ports of Normandy by the merchants of St. Malo.

I742. Memoir by merchants of Brittany respecting duty on coffee from the colonies.

I760, July I6. Memoir by the Compagnie des Indes respecting exclusive trade in beaver.

I770. Memoir respecting foreign commerce in the colonies.

I780. Memoir respecting excessive duties laid on products from Santo Domingo.

8752.-I68o, June 4, Fontainebleau. Colbert to Le Blanc, intendant of the généralité of Rouen. To ascertain if tobacco is planted in vicinity of Rouen, such practice being prejudicial to the colonies in America.

[f. 250

8968.-Draft of an edict in 36 articles providing distinctive marks for free people of color and for slaves in the French colonies, by Douin, I775, with explanatory comments.

[ff. 3-34

8972.-Compagnie pour l'Amérique. A printed prospectus at the end of the volume; not examined.

8973.-I722, Apr. I 5. "Tableau général de la Compagnie des Indes." Statement of assets and liabilities, with numerous items relating to Louisiana.

[ff. I-7

[ $1720 \mathrm{ca}$.$] "Mémoire sur ce que la Compagnie des Indes peut tirer de$ bénéfice de son commerce, année commune." Estimate of average annual profits of the company's trade in Canada, Louisiana, Santo Domingo, and elsewhere.

[ff. 60-107v

I72I, Apr. I5-I722, Apr. I5. Receipts and expenditures of the Compagnie des Indes, including Louisiana and West Indian items. [ff. I08-I I8

[I722, Sept. I.] “Projet par estimation de la dépense à faire par la Compagnie des Indes pour ses différentes parties de commerce." Detailed estimate of expenditures for the year Sept., I722-Sept., I723. Numerous items relating to Louisiana, West Indies, etc.

[ff. I $20-140$

[I720.] "Colonie de la Louisiane." Memoir [for the directors of the Compagnie des Indes] on the importance of Louisiana from both material and 
political points of view, reform of government, posts and forts, and future development of the colony.

Five memoirs on the Guinea slave-trade.

[ff. I $42-149$

[ff. $207-238$

[I723.] "Mémoire des Régisseurs de la Compagnie des Indes." Changes in the programme of operations; necessity of sending supplies and negroes to Louisiana; reinforcement of garrisons ; Spanish trade in Louisiana.

[ff. $240-245$

I7or, Madrid, Aug. 27. Traité fait entre les deux Roys, Catholique et Très-Chrétien, avec la Compagnie Royale de Guinée établie en France, concernant l'Introduction des Nègres dans l'Amérique pendant le temps de dix ans... (Paris, Christophe Bellard, 59 pp., fo.). Treaty of Assiento.

I7or. Mémoires pour le Rétablissement du Commerce en France, rédigez par le Sr. Jean le Pelletier, ancien Juge Consul, par ordre de Messieurs les Juges et Consuls de Roüen, pour être présentés à Nos Seigneurs du Conseil $d u$ Commerce. Opposition to privileged companies, tobacco and beaver trade, etc.

[ff. $276-295 \mathrm{v}$

8974. Papers relating to a suit between the Compagnie des Indes and investors in the expedition of I705 against Nevis, under Iberville. I736I748.-These documents do not contain information respecting the expedition.

8978. Collection of documents relating to the Compagnie des Indes.

I730. Oct. I. "Réflexion sur la Compagnie des Indes." Includes arguments for leaving Louisiana in the possession of the company. [ff. 20-37,
[

"Mémoire pour faire connoitre la Situation du commerce maritime." Losses in the trade with the colonies and America, capture of vessels by English, lack of protection; Canadian trade and its losses since the capture of Louisbourg, and Newfoundland fisheries.

[ff. I I 5-I 33

8986-8988. Letter-books of the "correspondance particulière du Citoyen [L. F.] Sonthonax, membre de la Commission déléguée par le gouvernement français aux Iles-sous-le-Vent", I796, May I8-I797, Aug. 21.-Copies of the letters written by Sonthonax during his second mission in Santo Domingo. The letters are to officials in the island, military and naval officers, Toussaint Louverture, French consuls and diplomatic agents in the United States, captains of vessels, etc. They relate to a great variety of affairs, such as military matters, English prisoners, death of Polverel, arrests, plots, privateers, operations against the English, relations with the Spaniards, etc. Of interest for American affairs are numerous letters relating to seizure of American vessels, supplies from the United States, etc., a few of which are here noted by way of illustration. See also MSS. Fr., nouv. acq., 6846-6847.

8986. I796, May i8-1797, Jan. I6 (An IV., Flor. 29-An V., Niv. 27). Letters of Sonthonax to various persons.

I796, July 2 (An IV., Mess. I4). To Goujon. His return to the United States; cargo of the Maria.

[f. I 5

I796, July 27 (Therm. 9). To delegates in the south. Return of \begin{tabular}{l} 
Raboteau to New England. [f. $43 \mathrm{v}$ \\
\hline
\end{tabular} I796, Aug. I5 (Therm. 28). To Lacoste and Bouteille, ship-owners at Charlestown.

[f. 67

I796, Sept. 27 (Vend. 5). To Gen. Léveillé. Purchases in the United States.

[f. $125 \mathrm{v}$

I796, Nov. I5 (An V., Brum. 25). To Barney, chef de division. Arrest of American sailors for murder of their captain.

[f. I8Iv 
I796, Dec. 8 (Frim. I8). To Westphal. Return of Capt. John May to the United States.

[f. 212 I796, Dec. 9 (Frim. I9). To Bessière, administrator at Gonaïves. Affair of the Abigail, powder of the Washington.

[f. 215

I797, Jan. 7 (Niv. I8). To Gen. Bédos. Supplies of food from American prizes.

American vessels referred to in various letters as follows: Captain Anderson (ff. 83, 95v), Ceisia (f. 5v), Friendship (f. 5v).

8987. I797, Jan. I6-May i9 (An V., Niv. 27-Flor. 30). Letters of Sonthonax to various persons.

Jan. I7 (Niv. 27). To French consul general at Philadelphia. Passage of Labatut to the United States. [p.3 Feb. I2 (Pluv. 24). To Laussat, American supercargo. Cargo of the Patriot.

[p. 63

Feb. 26 (Vent. 8). To commandant of the station. To escort the Ameri\begin{tabular}{l} 
can vessels loaded with flour from Port de Paix to Le Cap. [p. I08 \\
\hline
\end{tabular} Mar. I8 (Vent. 28). To Jumelle, sous-controleur de la marine. Respecting Dodge, Gorham, and Co.

Mar. 22 (Germ. 2). To Le Borgne, agent central de la comptabilité. Supplies furnished by the American merchant Sibbald. [p. 197

Mar. 25 (Germ. 5). To Bessière. Petition of American supercargo Seal.

Tp. 213 can vessels.
[p. 226

Mar. 29 (Germ. 9). To Bessière. Contract with the American Jones [?].

Apr. I. (Germ. I2). To Mayer, American merchant at Le Cap. Customs duties.

Apr. 9. (Germ 20). To the Société des Amis des Noirs, at Phit [p. 255 Admission of Sonthonax to membership. Apr. I3 (Germ. 24). To Cazenave, merchant at Baltimore. His schooner, the Purviance.

[p. 302

Apr. I3 (Germ. 24). To William Trenholm, supercargo of the American vessel Polly, at Léogane.

Apr. I7 (Germ. 28). To Randall, American merchant at Le Cap.

[p. 303

Apr: 8 (Flor 9). To Toussaint Louverture. Privateering ap. 326 Apr. 8 (Flor. 9). To Toussaint Louverture. Privateering against
[p. 38I

American vessels referred to in various letters as follows: Fanny (p. I46), John, Philadelphia (p. 5), June, New York (p. I64), Lucretia, Baltimore (p. 346), Olive Branch (p. I46), Polly (pp. I02, 107, I I3), and Venus, Charleston (p. 285).

8988. I797, May 20-Aug. 2I (An V., Prair. I-Fruct. 4). Letters of Sonthonax to various persons.

May 23 (Prair. 4). To the minister of marine. Randall, American, going to France to secure payment for supplies furnished by him. [p. I I

May 23 (Prair. 4). To Hussey, American merchant. Purchase of sugar.

May 24 (Prair. 5). To Thélémaque, judge at Le Cap. Deportation to United States of Auguste Morel.
[p. I8

May 27 (Prair. 8). To Bonnard, chief administrator, Department of the West. Cargo of the Williams, of Baltimore.

[p. 22

May 29 (Prair. Io). To the French minister in the United States. Departure of Warner for the United States. [p. 28 
June 2 (Prair. I4). To Maillart, commissaire des guerres. Passage of Valdony to the United States. [p. 38 June 19, 21, 22 (Mess. I, 3, 4). To the municipal administration of Le Cap. American cartel ship, Georgia Packet. [pp. 87, 91, 95 June 26 (Mess. 8). To Thélémaque, judge at Le Cap. Imprisonment of American sailor, Smith Offman.

[p. IO3

July io (Mess. 21). To John Nicholas Reynolds, captain of the cartel ship Georgia Packet, of Philadelphia. [p. I43 July I 3 (Mess. 24). To the commandant of the port at Le Cap. Return of de Millière to the United States. [p. I54 July I3 (Mess. 24). To de Millière. His voyage to Canada. [p. I 55 July 26 (Therm. 8). To Golden Langford, captain of the Harek. American obedience to English orders causes condemnation of American vessels. [p. 196

Aug. I (Therm. I4). To the municipal administration of Port de Paix. \begin{tabular}{l} 
Arrival of passengers from the United States. [p. 2083 \\
\hline
\end{tabular} Aug. 7 (Therm. 20). To Billiet. American trade with English cruisers. [p. 224

Aug. 9 (Therm. 22). To the Marqués de Santa Clara, governor of Havana. In behalf of the American Sibbald. [p. 228
[ Aug. 9 (Therm. 22). To Lohier-Baupuy, commandant at Fort Liberté. His trade with the Americans.

Aug. I8 (Fruct. I). To the French consul general in the United States. Return of the Gerbier family to the United States.

American vessels referred to in various letters as follows: Alfred, New York (p. 232), Ardent, Baltimore (p. 203), Ark, New York (p. 243), Betsy (p. 21), Betsy, Portsmouth (p. I7I), Boston, Philadelphia (p. 204), Brothers, Charlestown (pp. 79, 94), Charlotte, Capt. Bool [?] (p. 203), Defiance (pp. 5o, 56), Déon, Charleston (p. 238), Eagle, Philadelphia (p. 232), Eliza, Baltimore (p. 237), Eliza, New York (p. 24I), Franklin (pp. 91, I 36bis), Friendship (pp. I68, I89, I9o), Friendship, New Haven (p. 204), General Greene (p. I 57), Hannah, Newbern (p. I4), Happy Return, Baltimore (pp. I 5, r7), Harmony, Capt. Bailey Chase (pp. 50, 55), Harmony, Norfolk (p. IO2), Harmony, New York (pp. I 18, I20), Hope, Alexandria (pp. I 58, I60), Industry (p. 55), Industry, Boston (p. I6r), Juno, New York (p. 5), Katy (pp. I47, I 49, I 55, I67), Kitty (p. I96), Lovely Lass (pp. 67, I00, I 36), Libia, Baltimore (p. 227), Lucy, Boston, (p. 22I ), Maria, Capt. Tate (p. 236), Mary, Charleston (p. I 5), Mary, Philadelphia (pp. I47, I 49, I 55, I67, I86, 202), Mercury, Philadelphia (pp. 5o, 5I), Mitty [Milly?], Charleston (p. I6I), Molly, Baltimore (p. 56), Nancy (p. 33), Nancy, Capt. Ebenezer Woodward (p. 64bis), Nancy, Alexandria (p. 193), Nancy, Charleston (p. 204), Nancy, Baltimore (pp. 232, 233), Nehemiah Burr, Philadelphia (p. 244), Olive (p. I74), Peggy (p. 183), Polly, Alexandria (pp. 55, I28, I6o), Polly, Newbern (p. I8I), President, New York (p. 67), Prudent, Philadelphia (p. I7I), Rebecca, Boston (pp. 109, I I2, I46, I66), Redress (pp. 109, I I2, 146, I66), Sally, Philadelphia (p. 181). Thetis, Baltimore (pp. 232, 233), and Venetia (p. 49).

8989.-I7I6-I722. " Journal du Voyage de la Louisianne fait par le Sr. Benard de La Harpe et des découvertes qu'il a faites dans la party de l'ouest de cette colonie." Extracts ptd. in Pierre Margry. Découvertés et Etablissements des Français dans l'Ouest et le Sud de l'Amérique Septentrionale (Paris, I879-1888, 6 vols.), VI. I93-194, 200-202, 243-306, 309-31 2, 357-382. 
8990-8992. “Mémoires pour l'histoire de l'isle de St. Domingue”, by J. B. Le Pers, S. J.-A descriptive and critical account of these three volumes is in Jacques de Dampierre, Essai sur les Sources de l'Histoire des Antilles Françaises, pp. I 59-167. According to Dampierre, 8990 contains the material which served as one of the sources of Charlevoix, Histoire de l'Isle Espagnole écrite particulièrement sur les mémoires MSS. du P.J. B. Le Pers (Paris, I 732, 2 vols.). 8991 is a rougher copy of the same material with certain parts lacking; both volumes are in the hand of Le Pers, and were composed not later than I727. 8992, only part of which is in the hand of Le Pers, is a revision of 8990, continuing the narrative from I 726 to I 730 . It was composed after the publication of Charlevoix, and contains an attack upon the latter.

9036. - I7I9, Dec. I5. Engagement of the Swiss regiment of [François Adam], Chevalier de Karrer, in the service of the King of France. A contract in fourteen articles: art. Io deals with agreement to secure families for Louisiana; art. II contains conditions of embarking troops for Louisiana. (Copy.)

9093. Voyages.

[ff. $48 \mathrm{I}-484$

"Relacion general y historica del commercio y contratacion de las islas Philipinas."

"Discubrimientos echos por Pedro Hernandez de Quiros" in the Pacif.

f. I3

[f. 45

"Extrait de la relacion de la découverte du Nouveau Monde et Isles Occidentales du Pérou adressée à Philippe Second par Alvare de Mendaña, général de la flotte." I 567-I569.

[f. 7 I

9097. "Ce Portefeuille est un recueil de quelques mémoires historiques concernant l'Amérique. Les isles adjacentes sont dans un autre portefeuille. Fr. Léonard de Ste. Catherine de Sienne, Augustin deschaussé indigne. Priez Dieu pour moy, I699."

[16I8, Feb.?] Mémoire en Requeste de Mr. Champlain touchant ses Découvertes dans l'Amérique Septentrionale, Canada, etc. sur la fin du Règne de Louis I3 et le Commencement de Louis I4. Reprinted by Gabriel Marcel, Mémoire en Requête de Champlain (Paris, I886). Cf. N. E. Dionne, Samuel Champlain, II. 499.

[ff. 2-I 5

Notes on the bishopric of Quebec, St. Vallier, de Quélus, etc. [ff. I6-I7 I700, Sept. 4, Lisbon. Extract from a letter from de Rouillé, ambassador, relating to gold from Brazil.

[ff. I8-I9

I694, May I3, Villemarie [Montreal]. Mandate of the Bishop of Quebec to the Recollects.

f. 20

I694, Oct. I7, Villemarie. Déclaration of Callières, governor of Montreal, respecting the mandate of May i3.

[f. $20 \mathrm{v}$

1695, July I 5, Paris. Protest by the provincial of the Recollects of the province of St. Denis against the mandate of May I3, I694.

Notes on the burning of the seminary of Quebec in I7OI. [f. 2Iv
[

Notes on the relations of St. Vallier, bishop of Quebec, with the Benedictines and Jesuits, and on his capture by the English. Notes on the etymology of the word Canada, on Montreal, on the boundaries of Hudson Bay, etc.

[ff. $22-23$

I700-I 70I, Extracts of letters from Rochefort and La Rochelle on the \begin{tabular}{l} 
peace with the Iroquois and on the plague in Canada. [ff. $23 \mathrm{v}, 26$ \\
\hline
\end{tabular} I70I, Sept. 20, Detroit. Copy of a letter relating to Tonty, route of an expedition, character of the country, etc.

[ff. $24-25$

Extract from a factum on the dispute between the filibusters and $\mathrm{M}$. de Pointis, who captured Cartagena in I697.

[ff. $27-28 \mathrm{v}$ 
I699, July 24, Paris. Note on the Mémoire servant de Débats pour les Srs. intéressez en l'Armement du Sr. Pointis et de Vanolles . . . rendant compte.

[ff. 29-30

I700, Nov. 3, La Rochelle. News brought by La Galissonière respecting Cartagena.

[f. $30 \mathrm{v}$

Notes on the Scottish colony of Darien, I699-I700. [ff. 3I-3IV, 36

Transcript of a printed document: Information concernant l'Affaire de Darien, I699.

[ff. $32-35 \mathrm{v}$

Description de la Découverte des Missisipi, Par N. de Fer, with engraved map: Les Costes aux Environs de la Rivière de Misisipi . . Par $N$. de Fer... I TOI.

[ff. $37-38$

I699, June 26, July 20, Paris. Extracts from two letters relating to the voyage of Iberville and Châteaumorand to the Mississippi.

[ff. 39-39v

[1699, June 23, Port Louis.] Copy of a letter from —, who was on the vessel of Châteaumorand on his voyage to the Mississippi. [ff. 40-43

I699, July 29, Paris. Extract from a letter on the preparations by Iberville at Port Louis, for settling a colony on the Mississippi. [f. 44

"Lettre de Mons. d'Iberville, ou Relation de son voyage fait par ordre de la Cour à l'embouchure du Fleuve de Mississipy dans l'Amérique au commencement de l'année I699. Il y a beaucoup de fautes dans cette relation mais je n'ay pu en avoir une plus correcte." (Copy.) [ff. 45-48 r698, Oct. 24-I699, July 2. "Journal du voyage fait par deux frégates du Roy, la.Badine commandée par Mr. d'Iberville, et le Marin par M. le Chevalier de Surgères ... " Ptd., Margry, IV. 2I3-289. [ff. 49-96

Journal des Savans (I700, pp. 2II-2I7): "Lettre de M. Delisle à M. Cassini sur l'embouchure de la rivière de Mississipi." [ff. 97-100

I700, Feb. 27. "Lettre écrite à 45 lieues de l'embouchure du Mississipi." Departure from Santo Domingo, news of Montigny and Bienville, fort constructed by Iberville, writer to proceed to country of the Sioux. (Copy.)

[ff. IOI-IO4V

"Relation de la rivière de Mississipy et des rivières qui s'y jettent avec les noms des nations voisines, etc. tirée de deux lettres escrites par Mr. Tonty ... à Mr. son frère le 28 février I700 et le 4 mars suivant" (copy); with a MS. map: "Croquis du Mississipy et des rivières qui s'y jettent avec les noms des nations voisines pour servir d'intelligence aux relations cy-jointes escrites par le Sr. Tonty ... C. D. V."

[ff. IO5-IO7

"Campagne du vaisseau la Renommée en I699 et I700 dans l'Amérique sur la rivière de Mississipi." "Relation . . . envoyée par M. Ricoüart, lieutenant du vaisseau." (Copy.)

[ff. I08-Iogv

I700, Aug 23, à bord de la Renommée. Memoir on the Mississippi, description of the river and the Indians. (Copy.)

[ff. I IO-I IOV

I700, Oct. I3, Quebec. Extract of a letter from Tonty to [Cabart] de Villermont. Voyage of Iberville to mouth of the Mississippi ; peace with the Iroquois.

[ff. I I I-I I 2V

I70o, Nov. I5 [I3?], Rochefort; Oct. 28, La Rochelle. Extracts of letters [from Bégon to Cabart de Villermont]. Conversations with Iberville. Originals in MSS. Fr. 22808, ff. 204, I69.

[ff. I I3-II 4

I700, Dec. I8, 26, La Rochelle. Extracts of letters: Mississippi Indians favorably disposed to religion; jealousy of Spaniards aroused by Iberville's settlement on the Mississippi; progress of the sugar industry in Santo Domingo.

[ff. I I4-I I 5

I70I, "vers la my janvier". Note on Iberville's sojourn in Paris; manifesto to the Spaniards which he is preparing, etc.

[f. II $5 \mathrm{~V}$ 
I70 I, Feb. Note on details communicated by Iberville respecting the religion of an Indian village on the Mississippi.

[f. II6

I7OI, June 2, Rouen. "Mémoire concernant la rivière du Mississippi." Details furnished by a missionary respecting the journey by land from Quebec to the mouth of the Mississippi.

I7OI. "Extrait de la relation des aventures et voyages de Mathieu Sagean", with comments by Fr. Léonard. Cf. Margry, VI. 93-I74.

[fols. II8-I22v; an abrégé of this relation is at ff. I68-I70v

I702, Mar. I5, Mobile. "Extrait d'une lettre du neveu de Mr. Lefevre." Arrival at Biloxi, losses caused by fever, arrival of Iberville, and of Bienville and Boisbriant, governors of the two forts.

I702, July Io, Rochefort. " Extrait d'une lettre contenant les réponces à diverses questions faites à $M$. d'Iberville sur son voyage au Mississipy, depuis qu'il est de retour."

I702, Aug 6 Paris " Tettre historique touchant le Missi [ff. I25-I 26
sipi, écrite par M. de Rémonville intéressé dans la compagnie du Mississip avec M. Le Sueur." Cf. Margry, VI. 89, I79.

[ff. I27-I $28 \mathrm{v}$ Note by Fr. Léonard on the departure of Iberville for the Mississippi in Aug., I703.

[f. I 29

I698-I70I. Narratives of the voyage of Beauchesne to Chile and the South Sea.

[ff. I30-I3I, I 32-I39v, I42-I67v

I704, Sept. ro, "Fort Louis de la Louisiane". Copy of a letter containing a narrative of the writer's sojourn in Louisiana. Replaces St. Denis, loss of the Alibamon alliance, destruction of the Spanish port at Apalache, Pére Du $\mathrm{Ru}$, arrival of colonists.

[ff. I 40-I 4 I I699 or I700. "Mémoire pour la découverte et la conqueste des pays de Quivira et de Thequaye dans l'Amérique Septentrionale." $C f$. MSS. Clairambault 1016, f. 2I I.

[ff. I7I-I 78 I702, Sept. 25, Cartagena. Account of the expedition of Ducasse against Cartagena.

[ff. I79-I86v

9175. "Les premières oeuvres de Jacques de Vaulx." See above, MSS. Fr. 150 .

9181-9183. "Caractères d'écriture de toutes les nations . . . "-A collection made for the Description de l'Airt de l'Imprimerie, by Jaugeon, Desbillettes, and P. Sébastien Truchet, in the series of the Académie des Sciences, Description des Arts et Métiers. 9183 contains, ff. I I-47, notes, illustrations, etc., on Peruvian and Mexican writing.

9516. "Mémoire historique des principales découvertes, voyages et navigations de long cours", by Abbé Renaudot. (Autograph MS.) - See below, MSS. Fr., nouv. acq., 7485, where three copies of this MS. are described.

9557. I540/I, Jan. I 5. Letters patent commissioning Roberval as lieutenant general in Canada. (Parchment.)-Ptd. in H. Harrisse, Notes pour servir. . à l'Histoire de la Nouvelle France, pp. 243-253, and in MSS. relatifs à la Nouvelle France, I. 30-36. Cf. Biggar, Voyages of Jacques Carticr (I924), p. 249, 11. 7.

9667. "Parallèle de la Géographie ancienne avec la Nouvelle." (I7th century.) - Section relating to America.

9668. "Traité général de géographie." (I 8th century.)

[ff. I 49-I 70

"Le tour du monde en l'un et en l'autre hémisphère, le long des côtes d'Amérique ..." " [ [ 527 "Carte de l'Amérique corrigée et augmentée dessus toutes les autres cy devant faites par P. Bertius, I66r." (Engraved in color.)

"Du Nouveau Monde en général." 
9669. Portulan of the Mediterranean coasts of Portugal, Spain, France, etc., and of North and South America. At the end: "Angelus me fecit in Masillia, I 575."

Illuminated map of the Western world known to the ancients, showing Newfoundland.

f. IO

9670. - French versions, by Samuel de Beauvais, of Sir Walter Raleigh, Discoverie of Guiana, and Laurence Keymis, Relation of the Second Voyage to Guiana. Both are printed in English in Hakluyt, Principal Navigations (Glasgow, I904), X. 338-500.

[ff. 6-74

9671-9678. MSS. of the geographers Guillaume Delisle and Joseph Nicolas Delisle.

9671.-Memorandum, mentioning the Journal Historique du Dernier Voyage de M. de la Sale . . . par Mr. Joutel . . . rédigé . . . par M. de Michel (Paris, I7I3).

9672.-Explanations of the Mappemonde. vations of latitude and longitude.

9678. "Nouvelles découvertes au nord de la Mer du Sud", followed by biographical notes on J. N. Delisle. Not examined.

9695-9711. History and geography. Claude Delisle.

9709. "Introduction à l'histoire universelle en ce qui regarde la Géographie et la Chronologie." Chap. VI., "De l'Amérique", contains sections on New France, Virginia and Florida, Mexico, New Mexico and California, the Antilles, Central America, Peru and Chile, Brazil and Paraguay. Chiefly an account of discoveries and early settlements drawn from various histories; the discovery of Canada is attributed to Verrazano, I 524, and no mention is made of Jacques Cartier.

9710.-Notes on American geography and history, I496-I700: Florida, Ribaud and Gourgues, Virginia (Indians, legends, flora), Mexico, Panama, California, Canada, West Indies, discoverers and explorers, etc. [ff. 96-I I9

9711.-Miscellaneous notes on American history: arrival of fleet from New France, English attack on Fort Louis at Placentia, capture of the English Hudson Bay fleet, capture of English vessels by Iberville, death of Jean Talon, etc.

[ff. I $83,199 \mathrm{v}, 200,24 \mathrm{I}, 284 \mathrm{v}$

9719.- I686, Nov. I6. Treaty of London for the neutralization of the American possessions of France and England. (Printed.) Ptd. in Dumont, Corps Diplomatique, vol. VII., pt. II., p. I4I.

[f. 168

9771. Documents relating to missions in China, Cochinchina, and Manila in the seventeenth century.

I686, June I 5, July 2, Nov. 29, Manila. Dom Philippi Pardo to Pope Innocent XI. (Copies, Latin.) [ff. 8I-85v I7Io, Jan. I8, Apr. 26, Macao. Cardinal de Tournon to the governor of Manila. (French translation.)

[ff. $87-88 \mathrm{v}$

I7 Io, June 26, Manila. Governor of Manila to Cardinal de Tournon. (French translation.)

[ff. $88 \mathrm{v}-89$

I710, June I9, Manila. Governor of Manila to the Emperor of China. (French translation.)

[ff. 89-9ov

9772. Documents relating to missions in China, Cochinchina, and Manila.

I649, July Io-Nov. 29. Relation of the voyage of Antoine de Sainte Marie, of the order of St. Francis, from Manila to China. (Spanish, followed by French translation.)

[ff. 76-90v 
9773.- I673, Apr. 6. Brief of Pope Clement X. prohibiting the publication, without license of the Propaganda, of works dealing with missions (i.e., Jesuit Relations). Ptd. in Bullarium Romanum, VII. 2 I2.

10207.- - 645, Mar. 6. Articles accordés entre les directeurs et associés en la Compagnie de la Nouvelle France et les Députés Habitans dudit Pays (Paris, Cramoisy, I645). Also in Bib. Nat., Imprimés, $\mathbf{L k}^{12}, 778$.

Memoir on means of exterminating the Iroquois.

[f. 202

I7Io, [Oct.]. Capitulation of Port Royal, Acadia, with letters [03-204 Nicholson and Gov. Subercase], and a list of the vescels takters [of Gen. siege. See B. Murdoch, History of Nova Scotia ( I 865), I. 3I8. [ff. 205-209
[

10250-10259. Registres des expéditions de déclarations, provisions, brevets, et autres lettres du Secrétariat d'État. I68I-I690.

10250.-1659, Mar. 27. Déclaration establishing a vicar apostolic in Canada.

[ff. $55^{-56}$

10251. - 1663 , Dec. I I, Paris. Ordinance for the maintenance of the guards of the king's lieutenant general in America [Alexandre de Prouville, Marquis de Tracy].

[ff. $40 \mathrm{OV}-4 \mathrm{I}$

[I663.] Ordinances for the salaries of de Tracy and of his secretary, chaplain, and surgeon.

[ff. 4I, 4IV

10252.-[166r.] Commission as viceroy in America for Godefroi, Comte d'Estrades. Includes considerations respecting the extension of French colonies in North and South America. (Copy.)

[ff. I4-I 5

I652, Nov., Paris. Commission to the Sieur Dolu to establish a colony in New France, and to make himself master of as great an extent of territory as he may be able to occupy. Includes considerations respecting efforts of Louis XIII, to populate New France. (Copy.)

I656, Dec., Paris. Commission to Jérémie Deschamps to hold command in Tortuga and other islands in America. (Copy.)

[ff. $20 \mathrm{~V}-2 \mathrm{I}$

I648, Mar. 2 [sic], Paris. Commission to the Sieur de Lauzon as governor and lieutenant general throughout the extent of the St. Lawrence. (Copy.)

[ff. 2 I v-22

I647, Paris. Commission to the Baron d'Ormeilles as perpetual governor of the unoccupied islands and lands of America. (Copy.)

[ff. 22-23

10569. “Actes primitifs concernant l’Établissement du Séminaire des Missions Étrangères, sa constitution et la forme de son gouvernement, contre les prétentions nouvelles de M. de Martilliat, Evêque d'Échinée."-Cf. a printed pamphlet ( 1750,30 pp., in Bib. Nat., Imprimés, pièce in $\mathrm{f}$. $\mathrm{Ld}^{53}, \mathrm{I}$ ) bearing the same title and signed "Cardon, Procureur".

I663, July. Letters patent establishing the Séminaire des Missions Etrangères.

[f. 50

I669, Sept. 4. Extract of will of M. de Morangis, leaving a bequest to the seminary.

[f. 93

1675, June 19. Decree uniting the seminary of Quebec to that of the Missions Etrangères.

History of the seminary of Quebec.

[f. IOOV

[f. I 36 ; see also ff. $209 \mathrm{v}, 210,232 \mathrm{v}, 27 \mathrm{Ov}, 320 \mathrm{v}$

I763, Nov. 28. Petition of the Sieur Le Loutre, missionary in Acadia, in the case brought on appeal against the seminary of the Missions Etrangères by Girard and Manach, former missionaries in Acadia. 
10640.- - 657 . “ Description de l'estat présent des Affaires de l’Europe en l'année I657." Considerations on discovery of America; Spanish and French navigators; discovery of Florida by Verrazano; voyages of Jacques Cartier, Villegagnon, Admiral de Chastillon, Cabot, Walter Raleigh, and others ; voyages of the Dutch and Portuguese; desire of the English to secure from Spain the exclusive commerce of the Indies.

[pt. I., ff. I $30-185$

10644-10652. Correspondence and documents relating to the negotiations of Münster and Osnabrück, I643-I648. Cf. J. LeClerc, Négociations Sécrètes touchant la Paix de Munster et d'Osnaburg (I725-I726, 4 vols.), and F. G. Davenport, European Treaties, I. 353-366.

10666-10667. Memoirs of Jean Baptiste Colbert, Marquis de Torcy, I687I7I4. (Original MS., in part autograph.) Printed under title Mémoires de $M$. de * * * pour servir à l'Histoire des Négociations depuis le Traité de Riswick jusqu'à la Paix d'Utrecht (the Hague, I756, 3 vols.). The account of negotiations with England, I7II-I7I2, in vol. III. of the printed text (MS. 10667) deals largely with American matters, viz., Newfoundland, Acadia, fisheries, Hudson Bay, slave-trade, West Indies, etc. See below, MSS. Fr., nouv. acq., 744-745.

10670-10672. Memoirs of Jean Baptiste Colbert, Marquis de Torcy, I7 I5I7I8.-Continuation of above. Contains slight references to America, e.g., court of Spain asks permission of King of England for Spaniards to engage in Newfoundland fisheries (10607, p. 640) ; dissatisfaction of Spain and England respecting observance of Treaty of Utrecht, abuses in West Indies and slave-trade (10672, p. 9IO). (Original MS., with autographic corrections.)

10688-10697. Copies of negotiations of the truce of Antwerp, Apr. 9, I609, by President Jeannin, I607-I609. See above, MSS. Fr. 7086-7090.

10712. Copies of despatches of Jean Baptiste Gaston, Comte de Cominges, during his embassy in England, I662-I665.-Cf. Arch. Affaires Etrangères, Corr. Pol., Angleterre, vols. 80, 83. An interesting account of this embassy, not dealing, however, with any American matters, is by J. J. Jusserand, $A$ French Ambassador at the Court of Charles the Second (London, I892).

I663, Nov. I6, Dec. I4. The English try to avoid restitution of Acadia; they contest the ownership of Acadia and of all New France except Quebec.

[ff. I 39, I 47

I664, Oct. I7, 27. Rumor that the Dutch have expelled the English from forts in New England; report of capture of New Amsterdam by the English.

[ff. 232, 235

10714. Copies of despatches to and from Louis, Duc d'Aumont, during his embassy in England, I7I2-I7I3.-Cf. Arch. Affaires Etrangères, Corr. Pol., Angleterre, vols. 240-249.

I7I3, Jan. I8, 26, Feb. 7, 24, Mar. 8. The king to d'Aumont. Claim of English to exclude French from Newfoundland fisheries; Cape Breton retained, Sable Island given up; Hudson Bay.

I7I3, Jan. 3I, Feb. 24. D'Aumont to the king. Same subjects.

$[\mathrm{ff} .3 \mathrm{I}, 37,55, \mathrm{I} 00$

\begin{tabular}{l} 
[ff. 42, 73 \\
\hline
\end{tabular}

10716. I760, Sept. "Mémoire sur la France et l'Angleterre ”, by François de Chaumont.-Comparison of France and England; necessity of falling back on Louisiana if Canada should be lost (f. 27).

10751-10752. I565-I 572. Copies of correspondence of Raymond de Pavie, Sieur de Fourquevaux, French ambassador in Spain.- The major part of this correspondence has been published by Mgr. C. Douais, Dépêches de $M$. de Fourquevaux, Ambassadeur du Roi Charles IX. en Espagne, I565-I572 (Paris, I896, I90I, I904, 5 vols.), and Lettres de Charles IX. ̀̀ M. de Four- 
quevaux (Paris. I897). These four volumes are published from the original minutes of de Fourquevaux's despatches, preserved in the Chateau de Fourquevaux, and from Bib. Nat., MSS, Fr. 10751-10752, 16103. A considerable number of the documents relate to the destruction of the French colony in Florida by the Spaniards, and to the West Indies and Spanish America. Paul Gaffarel, Histoire de la Floride Française, pp. 409-455, has printed extracts from 54 documents in 1075, relating to the Florida affair, as follows: ff. 23 , $37,4 \mathrm{I}, 43,50,58,60,70,102, \mathrm{I} 3 \mathrm{I}, \mathrm{I} 37, \mathrm{I} 4 \mathrm{I}, \mathrm{I} 44, \mathrm{I} 56, \mathrm{I} 62, \mathrm{I} 67, \mathrm{I} 72, \mathrm{I} 8 \mathrm{o}$, I8I, I82, I98 (2 letters), 207, 219, 225, 257, 286, 292, 31 3, 31 4, 323, 334, $363,378,397,458,470,494,571,575,587,687,694,761,766,780,901,904$, 975, I008, I030, I083, I091, I285. Cf. above, MSS. Fr. 2145, and below, MSS. Fr. 16103.

10764-10770. Papers of Beliardi. I758-I770.-Beliardi, an Italian by birth, went to Spain in 1746 , where he held a position in the tribunal of the nunciature, later becoming internuntius. Attracting the attention of the French ambassadors he was induced to enter the service of France, and from Apr. 3, I758, to Oct., I77 I, he held the position of chargé des affaires de la marine et du commerce de France at Madrid. He had some part in negotiating the Family Compact, and in 1762 he went for the first time to France, where he served in the Ministry of Foreign Affairs until 1765. In April of the latter year he was appointed commissioner to negotiate the treaty of commerce and navigation between France and Spain, which was concluded at Madrid on Jan. 2, I768. He was a second time in France in $1767-1768$, and returned there finally in I77I, after the disgrace of Choiseul. He was commonly called abbé, for although not a priest he was tonsured and in 1767 was made titular abbot of Saint Florent de Saumur. See Mémoire et Pétition à l'A ssemblée Nationale, pour le Sieur Beliardy (in Bib. Nat., Imprimés, 8vo., Pièce, K, 454). Other papers of Beliardi are in MSS. Fr. 13417-13419.

10764. "Journal de la correspondance de l'abbé Beliardi ", I758-I766.Copies of letters written from Madrid to the minister of marine.

(f. $16 \mathrm{v})$.

I758, July 3, capture of an English vessel laden with Virginia tobacco

I759, Jan. 29, interview at Gibraltar between the English commandant and Capt. Murat of the marine troops in Louisiana; weakness of those forces (f. $52 \mathrm{v}$ ) ; Apr. I6, convoy from Bordeaux to Canada sighted off Spanish coast (f. 72) ; May 7 , good news of the expeditions en route for Canada (f. 78v) ; May I4, English think the squadron of Toulon is to go to defense of Canada (f. 80); July 30, safe arrival of French convoy at Quebec; supposes the Outarde will go to Louisiana if she learns in time of the arrival of the English in the St. Lawrence; despatch of the St. Bruno to Quebec (f. Ioov); Oct. 8, report received by Spanish vessel being equipped at San Sebastian that many wounded and sick have been landed from the squadron in the St. Lawrence (f. I I 7v) ; Oct. 22, capture of two vessels from New England by a French privateer; news that the siege of Quebec has been raised ( $f$. I I $g v$ ).

I 760 , Jan. 28, danger to French colonies, proposal to furnish them with Spanish munitions (f. I37) ; Feb. 18, annoyances to which Spanish captains of vessels engaged in service of American colonies are subjected on their return to Spain (f. I4I) ; Mar. 3, an officer from the French colonies has left Madrid to go to see the minister of marine (f. I43) ; Mar. 3, letters from Martinique opened at Halifax (f. I 44) ; July I4, means of sending munitions and supplies to Quebec (f. I69); Sept. I5, same subject (f. I82); Nov. I7, Cuban tobacco to be imported directly into Spain; competition with Virginian tobacco (f. I93v). 
I76I, [Sept. 2I], "Mémoire sur les facilités accordées par l'Espagne pour le ravitaillement de nos colonies" (f. 236v) : Nov. 2, respecting procurement of supplies for Louisiana in Cuba (f. 243v) ; Dec. 7, supplies for Louisiana from Havana and Vera Cruz (f. 25Iv).

I762, Nov. 8, supplies for Louisiana requested by Kerlérec, refused by governor of Cuba (f. 300) ; Dec. I3, consequences of the cession of Louisiana (f. 305 ).

I765, July I, conduct of Spain with respect to France (f. 354) ; Sept. 9, overtures of English ambassador in Spain; cod fisheries (f. $380 \mathrm{v}$ ).

10765. "Journal de la correspondance de l'abbé Beliardi", I767-I771.Copies of letters from Madrid to minister of marine.

I768, Mar. 7, news from Mexico (f. 40) ; I769, Feb. 6, respecting mismanagement of plantation of $M$. d'Aunoy, artillery officer, in Louisiana ( $\mathrm{f}$. 89) ; I 77 I, May 2, French vessels leaving Cadiz for Newfoundland, Apr. 8-22 (f. 206v).

10766. Papers and memoirs bearing on negotiation of treaty of commerce and navigation of Jan. 2, I768.

[ I765.] Memoir from the court to serve as instructions to Beliardi, " commissaire du Roy en Espagne pour le commerce et la navigation", relating to the interpretation of the Family Compact: American commerce, English contraband trade, contraband trade of French in Gulf of Mexico as one of the reasons for the cession of New Orleans, growth of New England through contraband trade, cultivation of rice in Carolina, and what the French colonies import from the English colonies.

Memoir on English designs to control the wealth of the New World.

[ff. 9-6o

[f. 67
[

Memoir on illicit English commerce along the American coast; profits derived from Pensacola.

[f. 98

"Memoire pour l'Espagne." Defense of Gulf of Mexico, Mexico menaced by establishments of Pensacola and the Mississippi, Newfoundland fisheries, English "conseil des plantations", tobacco purchased by France from England.

"Mémoire sur le Combenio d’Eminente." Duties on beaver skins.

10767. Papers of Beliardi.

[f. 405

Memoir by Barthès on the Family Compact and the opportunity it offers to France and Spain for the restoration of their naval power and maritime commerce.

[ff. $231-258$

Résumé of the correspondence of Beliardi. A few brief notes on letters relating to American affairs, I76I-I766.

10768. Papers of Beliardi: memoirs on finance and commerce.

"Essai sur diverses branches du Commerce que la France fait à Cadix." References to bois de Campêche, leather from the colonies, etc.

[f. $267 \mathrm{v}$

"Mémoire sur différents objets relatifs au commerce de Pampelune avec la France." References to Spanish consumption of French colonial products.

[f. $285 \mathrm{~V}$

Memoir on "Commerce du Royaume de Murcie". Reference to New England wheat supplied to Spain.

[f. 4I 5

"Réflection sur la possession de l'Amérique-Colonies et Amérique, surtout système des Anglois." Writer foresees early independence of English colonies in America.

[f. 465

"Conclusion sur l'union de la France et de l'Espagne contre l'Angleterre." Means of restoring former American possessions to France and of seizing some of those of England.

[f. $48 \mathrm{I}$ 
"Réflexions sur la position actuelle de l'Espagne en égard aux Indes." English colonies in the Gulf of Mexico.

"La Pesche de la Morue."

I768, Mar. 23, El Pardo. Real Decreto, que previene las Reglas y Condiciones con que se puede hacer el Commercio desde España a la Provincia de la Luisiana (9 pp.).

10769. Papers of Beliardi: memoirs on the Spanish and French colonies and on commerce.

"Idée générale du commerce de toutes les Indes Espagnoles." Buenos Ayres, Mexico, reasons for English success in Canada.

[ff. 3-53

"Mémoire sur les Colonies." Comparison of French and English colonies, Louisiana timber and shipbuilding.

[f. 59

I765, June 22. Memoir by the chamber of commerce of Bayonne, in reply to memoir entitled, "Sur l'étendue et les bornes des lois prohibitives du commerce étranger dans nos colonies". References to cod fisheries, importation of New England timber into French colonies, New England horses and cattle. "Reflexions sur la Colonie française de la Louisiane." Canada and Louisiana afford protection to the Spanish colonies; difficulties of the commerce of New Orleans; advantage that England would derive from the possession of the French colonies; relations between the French and Spaniards thrown back upon the right bank of the Mississippi.

[ff. 8o-87

I735, Aug. I9; I759, June 16, July 20; I761, Mar. Io, June 4. Extracts and copies of diplomatic correspondence relating to refusal of governor of Havana to allow French vessels from Louisiana to take supplies. [ff. 88-98

"Reflexions sur la Louisiane par un citoien espagnol." Respecting proposal for colonization of Louisiana by a French company. [ff. IOO-IO9

Mémoire des Habitans et Négocians de la Louisianne sur l'Evénement $d u 29$ Octobre, I768 (New Orleans, I768, 2 I pp.).

I768, Oct. 31, On board Le Volant, New Orleans. Don Antonio de Ulloa \begin{tabular}{l} 
to Aubry, respecting the revolt in Louisiana. (Copy.) [ff. I2I-I 22 \\
\hline
\end{tabular}

Memoir on the boundaries between French and Spanish possessions in Santo Domingo.

"Exposition des nouveaux règlements pour les colonies angloises." Summary and text, in French.

[ff. $187-269$

"Description des voyages par terre depuis Commayagua capitale des Ondours jusques à Sombretrette au delà de la Nouvelle Espagne en tirant du côté de la Louisiane." Itinerary, with distances, from Mexico to Louisiana ; means of separating Texas from Mexico with aid of Canadians. (Incomplete.)

10770. Papers of Beliardi.

[ff. 272-309

[I770.] Memoir for the Duc de Choiseul on the defense of Santo Domingo and the Iles du Vent. (Copy.) [ff. 5I-57

"Reflexions sur une guerre particulière entre la France et la Grande Bretagne." Disastrous results of loss of French colonies; plan of war in Europe and America; difficulty of defense of the English colonies in America.

[I758.] "Projet sur la Jamaïque", [by the Marquis d'Aubeterre].

[ff. 63-II7

[ff. I $28-148$

[I762.] "Recueil des pièces et mémoires qui ont paru dans le public au sujet de la rupture de l'Espagne avec la cour de Londres." [ff. I 53-I99

I 6 I, Sept. 2I, Versailles. Duc de Choiseul to the Marquis d'Ossun. Provisioning of French colonies. (Copy.)

[ff. 208-209 
I756-I762. "Recueil de documents concernant les rapports entre la France et l'Espagne relativement à la relâche des vaisseaux français dans les ports d'Espagne pendant la guerre, au versement d'effets français sur les vaisseaux espagnols ou neutres, à l'approvisionnement des colonies françaises, aux prises." Copies of letters of Comte de Valdeparaiso, Marquis d'Aubeterre, Marquis d'Ossun, Richard Wall, Marquis de Squillacé, Sieur Dommengé, and others, contracts, memoirs, etc.

[ff. $210-269$

I762, Madrid. Edict forbidding all commerce of the subjects of Spain with those of England. (Printed text, in Spanish.) [f. 27 I

" Projet fait en I 62 pour reprende en moins de six mois la supériorité par mer sur les Anglois."

[ff. 282-293

10991-11082. Collection relating to the Chambre des Comptes, formed by Clément de Boissy: First series, Extracts.-A second series of this collection is in MSS. Fr., nouv. acq., 1565-1660. See Clément de Boissy, Juridiction et Jurisprudence de la Chambre des Comptes (Paris, I787), and also C. Couderc, "Inventaire sommaire de la Collection Clément de Boissy", in Rev. des Bibliothèques, I895, Apr.-June. A few extracts relating to America are noted below.

11056.-I749. Account of receipts and expenditures for the colonies: Canada, Ile Royale, Louisiana.

[ff. 9I -97

I603-I785. Chronological list of edicts, letters patent, arrêts, déclarations, regulations, etc.

I749-I777. Extracts from proceedings of the Chambre des Comptes.

[ff. 99-I I 7v

[ff. I I9-I 32

11061.-I664-I785. Chronological list of edicts, arrêts, letters patent, déclarations, etc., relating to the Compagnie des Indes.

I690, I7I8, I773. Extracts from procès-verbaux of the Chambre des Comptes.

[ff. $373-382 \mathrm{v}$

Extracts from Véron de Forbonnais, Recherches et Considérations sur les Finances de France (Liége, I758, 6 vols.).

[ff. 383-4I I

11248. - I758, July I 5, Carillon. Letter from the Chevalier de Lévis, with plans of Fort Carillon.

I758, Oct. I9. "Nouvelles du Canada du camp de Carillon."

[ff. 247-249

[ff. 250-25'I
"

"Relation de la victoire remportée par les troupes du Roy à Carillon le 8 juillet I758." Cf. N.Y. Col. Docs., X. 74I.

"Relation de la victoire remportée sur les Anglois le 8 juillet, I 758 ."

[ff. $256-265$

11300-11301. Correspondence and original documents relating to the marine and to artillery, I7I6-I778 (especially I746).-A few letters of Oct., I746, contain slight references to the squadron of the Duc d'Anville, e.g., 11300, ff. 207, 21 2, 2 I6; 11301, ff. 4, I I.

11315-11318. Correspondence of Patoulet, intendant of marine, and documents relating to the marine and colonies.-In 11315 a few letters from the king and from Seignelay of I68I and I685 contain references to commerce with the West Indies and with Canada (ff. I25, 236, 250, 26I, 284). In 11317 an order from Pontchartrain of July 26, I69I, relates to the visit of vessels coming from the colonies by the agent of the fermes (f. I63). Cf. G. St. Yves, "Les Antilles Françaises et la Correspondance de l'Intendant Patoulet", in Journal de la Société des Américanistes de Paris, IV. 55-7I. 
11319-11321. Accounts of the receipts and expenditures of the treasurer general of the Marine de Ponant, for the years I632, I633, and I634.-Among the items of expenditure are a few relating to America: salaries of Commander de Razilly, Capt. Launay de Razilly, the pilots Guillaume and Jean Levasseur ; expenditures for vessels despatched to Canada in 1632 ; reimbursement of expenses incurred by Guillaume de Caen, etc.

11325-11329. Summary of the policy and practices of the administration of the marine, I669-I 723.-Each volume deals with a distinct period: Colbert, I669-I684 ; Seignelay, I684-I69o ; Pontchartrain, I691-I699; Jérome Pontchartrain, I700-I7I 5; Conseil de Marine, I7 I5-I723. The summaries are based upon a large collection of extracts from the despatches of the various secretaries and indicate briefly the policy and practice of the department with respect to the various matters treated. A table of contents in each volume makes the arrangement of subjects clear. The general subjects of interest for America treated in these volumes are as follows: armaments, American war; commerce; colonies; fisheries.

11331. Extract made in I 7 Io by Deslandes from the journal of the voyage of the royal vessel Sphère in I707-I709 to the coast of Guinea and to Buenos Aires, with a map of the River La Plata.

11332. "Règlemens, traités, mémoires aians rapport au service de la Marine, commerce maritime, aux colonies, etc., et faits depuis I7I 5 jusqu'en I 730, lesquels n'ont pas été rendus publics par l'impression."

I7I6, Mar. I4, Paris. Ordinance granting amnesty to freebooters in the waters of the Orient who shall return to France or to the French colonies whence they came, within the space of four years.

[pp. 6r -65

I716, July 28, Paris. Ordinance granting amnesty to the filibusters of Campeche who shall return to the French part of Santo Domingo within the space of two years.

[pp. 7 $1-75$

Observation on the regulation governing the admiralties in the colonies, and a list of their seats.

I7 18, Aug., Paris. Concession of St. Lucia to Marshal d'Estrées.

[pp. $77-80$

[pp. I I 7 -I 37

I7 I8, Aug. 28, Paris. Appointment and commission of Marshal d'Estrées as proprietor of St. Lucia, and of the Sieur de St. Martin as commandant.

[pp. I $39-\mathrm{I} 4 \mathrm{O}$

I718, Aug. 29, Paris. Letters patent commissioning the Sieur de St. Martin as commandant of St. Lucia.

[pp. I4I-I 44

I7I8, Dec. I5. Act of cession and transfer of the privilege of the coast of Senegal to the Compagnie d'Occident.

[pp. I45-I $5^{\mathrm{I}}$

I722, Mar., Paris. Letters patent conferring upon the Comte de St. Pierre the exclusive fishing privilege of the islands granted to him, and regulating its extent.

I722, Apr. I I, Paris. Arrêt assigning 300,000 livres to the Compagnie des Indes for the expenses of Louisiana.

[pp. I65-I69

1722, May 16, Paris. Ordinance of the commissioners for the administration of the Compagnie des Indes, regulating the establishment of the Capuchins in Louisiana.

[pp. I75-I 79

I722, Dec. 19. Ordinance of the commissioners for the administration of the Compagnie des Indes, for the establishment of a parish church and a hospice of the Capuchins at Mobile.

[pp. $18 \mathrm{r}-\mathrm{r} 83$

I723, Jan. I8, I9. Copy of the treaty for the evacuation of St. Lucia by the English.

[pp. I85-190 
I723, Sept. 7, Versailles. Commission of the Comte de Champmeslin as lieutenant and commandant general for the king throughout the islands, seas, and mainland of South America.

[pp. $193-206$

I723, Sept. 7. Memoir of royal instructions to the Comte de Champmeslin for the suppression of the disturbances in Santo Domingo directed against the Compagnie des Indes.

[pp. $207-260$

I723, Nov. I4, Paris. Transfer of the ferme du tabac to the Compagnie des Indes. [pp. 265-275

I725, June 27. Regulations by the Compagnie des Indes for the establishment of the Capuchins in Louisiana. [pp. 277-28I I725, July I 5, Chantilly. Royal brevet authorizing the establishment of the Capuchins in Louisiana. [pp. $283-284$ I725, Oct. I 3, Fontainebleau. Arrêt revoking the letters patent of Mar., I722, granted to the Comte de St. Pierre. [pp. 285-297

I725, Dec. 4, Versailles. Letters patent forbidding the detention or interception of letters and packets sent from Europe to the French colonies and vice versa.

[pp. 317-3I9

I725, Dec. I I, Versailles. Arrêt respecting the sale of negroes in Louisiana. [Pp. 32I-323

I725, Dec. II, Versailles. Arrêt validating contracts of mutual gifts [marriage contracts under the régime of dons mutuels] made in Louisiana, though they may not have been registered.

[pp. 325-327

I725, Dec. 27. Extract from the registers of the Bureau de Commerce. Merchants permitted to secure goods from Holland for use in the Guinea trade.

[pp. 39I-402

I725, Dec., Versailles. Déclaration establishing a judicial chamber at New Orleans having jurisdiction over cases involving Ioo livres or less.

[pp. 403-406

I726, Feb. 20, Paris. Agreement of the Compagnie des Indes with the Jesuit missionaries in Louisiana.

[Pp. $42 \mathrm{I}-436$

I726, Aug. 9, Versailles. Commission of the Sieur Perrier as commandant general in Louisiana.

[pp. 44I-443

I726, Aug. 9, Versailles. Commission of the Sieur Diron d'Artaguiette as second royal lieutenant in Louisiana.

I726, Aug. I3, Versailles. Arrêt naming M. Raudot, intendant of marine, as the representative of the Comte de Maurepas in the assemblies of the directors of the Compagnie de l'Assiente.

[pp. $449-450$

I726, Aug. I7, Versailles. Brevet for the Jesuit missionaries in Louisiana, confirming their agreement of Feb. 20 with the Compagnie des Indes.

[pp. 45I-452

I726, Sept. I3, Paris. Agreement of the Compagnie des Indes with the Ursulines for their establishment in Louisiana. [pp. 453-466
[ I726, Sept. I8, Fontainebleau. Brevet for the Ursulines of Louisiana, confirming their agreement of Sept. I 3 with the Compagnie des Indes.

[pp. $467-469$

I726, Dec. I8. Proceedings of the general assembly of the Compagnie des Indes respecting its exclusive privilege of the sale of coffee. [pp. 483-490 I 27 , Mar. 4, Versailles. Arrêt commissioning the Sieur Baron to proceed to Louisiana and the Islands of America for observations and research.

I727, July I, Versailles. Letters patent commissioning the Sp. 505-506 to conduct observations in astronomy, navigation, and natural history in Louisiana and the other colonies of America.

[pp. 507-510 
I727, Oct. I, Fontainebleau. Two ordinances relating to the militia in the Islands of America.

[pp. 519-526 I 728, Sept. 25, Madrid. Cédula for the establishment of the Company of Carácas.

I728, Nov. I7. Proceedings of the Company of Carácas. [pp. 559-589

I730, Oct 3 Versailles. State of the external Comas. 59I-604 as presented by the Comte de Maurepas in the Conseil du Commerce.

[pp. 663-700

11334-11339. Minutes of proceedings and correspondence of the commission appointed in accordance with the arrêt of Oct. I8, I758, to examine and verify the debts of the marine, I758-I $76 \mathrm{I}$.- This commission passed on claims against the marine, presented by shipowners, shippers, charterers, furnishers of supplies, etc., with respect to freights, cargoes, charter parties, supplies, and services. Cf. Arch, Nat., $\mathrm{V}^{7}, 360-365$.

11334. Minutes of proceedings of the commission on debts of the marine, I758, I759.

I758, Oct. I8, 29. Printed arrêts creating the commission and regulating the presentation of evidence by claimants.

[ff. I $2, \mathrm{I} 4$

"Considérations sur les Commissions dans les Colonies." [f. 44

I759, Apr. Io, May I. Proceedings of the commission with respect to the deficit of the treasury of Canada, and a memoir by M. de Cotte, member of the commission, on the same subject and on the conduct of the intendant Bigot.

[ff. 79,87

I759, May 22, July Io, Aug. I4, Sept. 4, II. Minutes of proceedings with respect to claims on account of vessels and supplies for Quebec, Ile

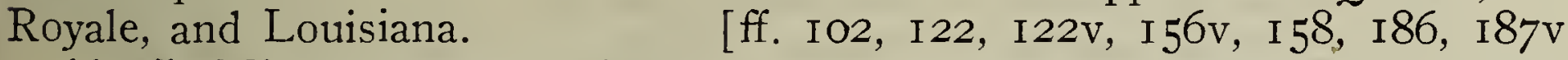

11335. Minutes of proceedings of the commission on debts of the marine, I759-1 760 .

I759, Nov. 27, Dec. 4, I I, I8, 28 : I760, Jan. 8, Feb. I2, Mar. I8, 28; Apr. 22, May I3, 20, June 3, I0, I9, 25, July I, 8, I 5, Aug. 5, I9. Minutes of proceedings with respect to claims for freight and vessels, supplies and munitions, transportation of soldiers and passengers, etc., for Louisbourg, Quebec, and Louisiana. [ff. I8, 23, 23v, 3Iv, 32, 38, 43v, 44, 52, 53v, $54 \mathrm{v}, 77 \mathrm{v}, 78$, $93 \mathrm{v}-97,97 \mathrm{v}, 98 \mathrm{v}, 103 \mathrm{v}$, I07v, I $23 \mathrm{v}$, I 26 , I 30, I 39, I $4 \mathrm{IV}$, I 47 , I 5 I, I 58, I65I80, 194, 195v, I96, I99, 201, 21 3, 216.

11336. Minutes of proceedings of the commission on debts of the marine, I760-I76I.

Protest by merchants of La Rochelle against arbitrary reductions of claims by the commission, with reply of the latter.

[ff. 4-I 4

I760, Nov. I8, 25, Dec. 2 ; I76I, Jan. 6, I3, 27, Feb. Io, Mar. I7, Apr. I, 21, 28, May I9, 26, June 23, July 7, I4. Minutes of proceedings with respect to claims, etc.; as in preceding volumes. [ff. $24,30,4 \mathrm{Iv}, 42 \mathrm{v}, 75 \mathrm{v}, 77 \mathrm{v}$, $84,86,99$, I00, Iо6, I $36 \mathrm{v}-145$, I 50, I62v-164, I7 1, I78, I83, I94, I98v, 202, 205,225 .

Lists of supplies transported by the Sieur Le Moyne of Rouen to Ile Royale, Cayenne, Louisiana, and Quebec, in I756-I 757.

[ff. I $36 \mathrm{~V}-\mathrm{I} 45$

11337-11339. Correspondence of the commission on the debts of the marine: chiefly letters from Berryer, secretary of state for the marine.-These letters are for the most part formal and of small interest. Letters relating to American affairs of I759-I 760 are noted as follows: 11337, ff. $77,87, \mathrm{I} 37$, I $97 ; 11338$, ff. I05, 272, $275 ; 11339$, ff. 22, 29, 47, 53, 72 . 
11340-11342. “Recueil de mémoires concernant la Marine de France”, I758I760.-A prefatory note (11340, ff. D-F) states that the memoirs in this collection have been inspired by the disorder into which the marine had fallen in I758: "Ce sont les ouvrages de Patriotes zélés qui ont été consultés ou qui ont regardé comme un devoir de communiquer les vües que des connaissances fondées sur l'experience leur ont fournies."

11340._- " Mémoire contre les Projets des Anglois sur nos Colonies Méridionales de l'Amérique, par M. de la Galissonnière." A prefatory comment states: "On prétend que ce Mémoire formé dans des vues peu pacifiques, a esté une des principalles causes d'une guerre dans laquelle nous éprouvons tant de malheur." " [Pp. I-66

I758, Feb. "Mémoire sur l'Etat présent de la Marine du Roy", by M. Le Normant. A prefatory comment states that Le Normant was attached to the Ministry of the Marine, and that he lost his position because in this memoir he exaggerated the debts of the marine by a third in order to secure funds from the Ministry of Finance.

" Essai d"A of . [pp. 69-114 Mirabeau." Maintenance of colonies. [p. I I7-2 I I
[

[pp. 69-II 4

I75I. "Mémoire sur les Colonies de la France dans l'Amérique Septentrionale." Utility of colonies; American colonies are attached and profitable to France; necessity of fortifying Canada and Louisiana as a barrier to the English colonies, which, if not held in check, will eventually possess the continent and the islands. $C f$. Arch. Affaires Etrangères, Mém. et Doc., Amérique, vol. 2 , ff. $2 \mathrm{I}-27$.

"Mémoire sur la Régie des Finances." A study of the provisions effects of the déclaration of Mar. A study of the provisions and

I744, Mar. 4, Versailles. Déclaration du Roy, concernant les Comptes des Trésoriers Généraux de la Marine ( Io pp.). Includes also the arrêt of Aug. 5, I732, setting apart the domaine d'Occident from the ferme générale.

$[\mathrm{pp} \cdot 587-596$

11342._ “ Mémoire sur l'arrêt du Conseil du XV Octobre I759 concernant le payement des lettres de change tirées des Colonies françaises de l'Amérique sur les Trésoriers desdites Colonies."

[pp. 9I-I75

"Mémoire dans lequel on propose quelques moyens de rétablir le crédit des lettres de change des Colonies et de les rendre moins onéreux à l'Etat."

[pp. I75-I94 Berryer.

1758, Aug. I2; I759, May I6, Oct. 25. Three letters from Bigot to

11344.-Journal of Jean-François de La Pérouse, Oct. 31, I779-Apr. I8, I780. Contains the end of his campaign with de Rions and the beginning of his campaign with de Ternay. (A. D'.)

[ff. $2-24$

Biography of La Pérouse. References to destruction of English establishments in Hudson Bay in 1782 .

11735. - "Facture des castors mis en dépôt à La Rochelle le I7 novembre I695 par M. d'Hiberville, capitaine du vaisseau Le Poly venant de la baye d'Hudson."

[ff. 209-2I I

11907.-Address of John Adams to Louis XVI., on presentation of his credentials as minister of the United States, and response of the king. [f. 282

12081-12085. Memoirs on the administration of the French colonies in America, and projects of legislation for them, by M. Petit. Cf. [Emilien Petit], Dissertation sur le Droit Public des Colonies Francaises, Espagnoles et 
Angloises, d'après les Lois de ces trois Nations comparées entre elles (Geneva and Paris, I778), and M. Petit, Droit Public, ou Gouvernement des Colonies Françaises (Paris, I77 I, 2 vols.).

12081. - "Mémoire sur le Gouvernement des Colonies." Historical, descriptive, and critical essay on the administration of the French colonies in North America and the West Indies.

[pp. I-I 30

"Tableau de l'Administration de la justice dans les Colonies, I758."

“Mémoire sur le service des Consuls dans les Colonies." [pp. I 35-I76

"Mémoire sur la Population des Colonies." [pp. 245-3I8

"Mémoire sur l'approvisionnement des Colonies." [pp. 319-334

"Moyens de faire servir le Commerce des Colonies au rétablissement de la Marine au retour de la Paix, I759." [pp. 339-377

"Mémoire sur la déffense des Colonies." [pp. 379-465

"Mémoire sur le Commerce des Noirs." [pp. 467-550

"Mémoire sur la conservation des Noirs pour l'exploitation des terres dans les colonies."

[pp. $555^{-622}$

12082.- " Projet de Règlement sur la discipline dans les Tribunaux des Colonies."

[pp. I- 238

"Projet d'Édit sur le Droit Public des Iles sous le Vent en forme de règlement sur le dépot et l'usage de l'autorité dans les differentes parties de l'administration de ces Colonies." Executive, military, police, justice, and finance.

[pp. $24 \mathrm{I}-560$

"Projet d'Édit en forme de Règlement sur les concessions des terres dans les Iles sous le Vent ..." " [pp. 56I-570 12083.- " Projet de règlement sur les sièges d'Amirauté dans les Colonies." An historical and critical study of admiralty law and procedure.

"Projet de Règlement sur les Payemens Forcés dans les "Colonies", Study of colonial law and practice respecting the recovery of debts.

"Projet de Règlement pour rétablier la confiance dans le Commerce de la France avec ses Colonies insulaires." Formal draft of legislation.

12084. " Projet de Code Civil pour toutes les Colonies."

[pp. 513-639

12085. "Projet d'Ordonnance criminelle pour les Colonies françoises de l'Amérique Insulaire et de terre ferme."

12099. "Tableau de l'Administration des Isles sous le Vent par M. [J. A.] Le Brasseur, Ancien Administrateur par interim des dites Isles."-Written after I783, this relates to Santo Domingo. Historical treatment of certain phases of colonial administration, e.g., "destination et utilité des colonies", "tribunal terrier"; "réparation et entretien des chemins"; " recensements"; "troupes"; "itravaux publics"; "justice"; "importations et finance"; "commerce étranger", including commerce with the United States, etc.

12100. Correspondence relating to settlement of the estate of Raymond Balthazard Phélypeaux, governor general of Martinique, I7I3-I7I4.-Of personal interest only.

12101. "Lettre écrite du Fort-roïal de la Martinique au sujet de la Revolte arrivée en la Colonie de la Martinique en MDCCXVII." (I5 pp.) -Details respecting the rebellion, the organizers of it, their plans, its causes, etc. Freedom of trade for foreigners, introduced by Phélypeaux and Du Quesne, and its rigorous suppression by their successors are indicated as the chief causes of the revolt. Cf. MSS. Fr., nouv. acq., 2549, f. 49. 
12102-12104. Collection of original letters and documents relating to Santo Domingo, I764-I799.-According to V. Schoelcher, Vie de Toussaint-Louverture (Paris, I889), p. 39, n. 2, these volumes are from the estate of General Etienne Laveaux, commander and governor of Santo Domingo in I794-I796. They consist of letters to Laveaux from French officers in Santo Domingo, from English and Spanish officers in the island, from French diplomatic and consular officials in the United States, and of II7 letters from Toussaint Louverture. Schoelcher has made much use of this collection, op. cit., and prints many of the documents in extract or in full. Among the documents relating to the United States are those noted below, all being letters addressed to Laveaux, unless otherwise indicated. C $f$. Arch. Nat., D, XXV.

12102. Letters to Etienne Laveaux.

I794, July I (An II., Mess. I3). Fonspertuis, consul at Charleston. Obstacles placed in his way by the Federal government.

[f. 88

I794, Sept. 4. List of supplies purchased by Fonspertuis for the French Republic, enumerating all the orders, and indicating the prices and the names of the furnishers.

[f. I 30

I794, Dec. 24 (An III., Niv. 7). Thomas, vice-consul at Baltimore. Sends surgical instruments.

[f. 168

12103. Letters to Etienne Laveaux.

I796, Jan. io (An IV., Niv. 20). Delauney, consul at Philadelphia. Advances to French officers; the consulate will no longer pay debts which they may incur in the United States.

[f. 4

I 795, Feb. 5 (An III., Pluv. I7), Charleston. Fonspertuis. Sends powder and medicines.

[f. 2 I bis

I795, Feb. Io, Kingston, Jamaica. Address of 260 French prisoners. Their distress ; they do not wish to be deported to New England.

[f. 27

Petition of Dias de Castro, asking for reimbursement for transport of refugees.

[f. 53

I795, July I6 (An III., Mess. 28). Toussaint Louverture. Sends papers found on the Betsey of Philadelphia by a French privateer.

[f. I 80

I795, Aug. 5 (An III., Therm. I8), Philadelphia. Adet, minister to the United States. Recommends Hugh Wason, captain of the Betsey. [f. I8I

I795, Aug. I2 (An III., Therm. 25), Alexandria, [Va.]. Cherni, viceconsul. Complaints against the authorities of Cap Français by Capt. Cushman of New Bedford, which have prejudiced Americans against Santo Domingo.

[f. 185

I795, Aug. 3I (An III., Fruct I4), Philadelphia. Létombe, consul general. Will send munitions; privateers must not enter ports of the United States.

[f. 20I

I795, Aug. 5 (An III., Therm. I8), Philadelphia. Létombe. Money is exhausted; the sick must be sent to New York only. [f.205

I795, Sept. 4 (An III., Fruct. I8), Philadelphia. Adet. Complaints by American merchants; policy with respect to American vessels must not be changed because of the treaties between England and the United States.

[f. 206

I795, Sept. 5 (An III., Fruct. I9), Philadelphia. Létombe. Case of the Cassins; the debt of the United States to France no longer exists ; only strictly necessary purchases can be made.

[f. 2 II

I795, Sept. 29 (An IV., Vend. 7), New York. Rozier, consul. Requests blank forms of commissions for republicans [French] of New York who wish to engage in privateering. 
I795, Oct. 2 (An IV., Vend. Io), Boston. Gariseau, commanding the Brutus. Left Charleston for Port de Paix, was chased and obliged to return to Philadelphia; complains of conduct of Fauchet towards him. [f. 239

I795, Oct. I6 (An IV., Vend. 24), Philadelphia. Adet. Sends certificates of residence of refugees in the United States.

[f. 245

I795, Nov. 3 (An IV., Brum. I2), Baltimore. Duhail, consul. Recommends the schooner Hawk of Baltimore, which is carrying provisions; list of passengers on board the Hawk.

[ff. 278,279

I795, Nov. I8 (An IV., Brum. 27), Philadelphia. Létombe. Sends papers relating to James Hard; case of the Cassius; the fugutive Daré has left Charleston; the consul Fonspertuis has been relieved; attention to affairs of Santo Domingo in the United States.

[f. 296

I795, Dec. 7 (An IV., Frim. I6). Toussaint Louverture. Arrival at

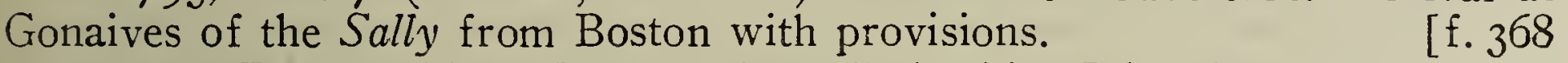

I795, Dec. 25 (An IV., Niv. 4), Philadelphia. Létombe. Recommends Davis; enquires if vessels from New York and Philadelphia have arrived.

12104. Letters to Étienne Laveaux.

[f. 423

I796, Jan. 2I (An IV., Pluv. I), Philadelphia. Delauney, consul. French officers in Philadelphia.

[f. 4 I

I796, Mar. I8 (An IV., Vent. 28), Alexandria, Va. Cherni. Vessels fitted out for the English in the United States; purchases of horses to be transported by American vessels; merchants of Norfolk have purchased for England all the American vessels to be found in the ports of the United States; purchases of contraband articles for the English; the Federal executive has permitted these manoeuvres in spite of French protests. [f. I32

List of vessels loaded in the port of Alexandria for the account of the English government.

[f. I 34

I796, May I I (An IV., Flor. 22), Philadelphia. Adet. Exaggeration of troubles of Santo Domingo in the United States; French refugees fear to return to the colonies.

[f. 234 I795, Oct. Io (An IV., Vend. I8), Philadelphia. Adet. Opposes capture of American vessels.

[f. 367

I798, Nov. I7. Ordinance of Toussaint Louverture, respecting commerce with Americans and Danes.

[f. 4I 5

Observations by the vice-consul of France at Alexandria, Va., respecting claims presented to the French minister by owners of the cargo of the schooner Abigail, Capt. Cushman.

[f. 453

12105. "Mémoire sur la Louisiane pour estre présenté avec la carte de ce pais, au conseil souverain de Marine par F. Le Maire. P. P. Miss. ap."A volume of 2I pages, signed "François le Maire, prêtre parisien, missionnaire apostolique de la maison et séminaire des missions étrangères de Paris,- - au Fort Louis de la Louisiane ce $\mathrm{I}^{\mathrm{er}}$ Mars I7 I7." The text deals with the situation, discovery, ports, lands, mines, rivers, savages, and colonists of Louisiana, its commerce, the results obtained, the best means of settlement, the company of Crozat, etc. An engraved and colored map accompanies the text: Carte de la Nouvelle France où se voit le Cours des Grandes Rivières de S. Laurent et de Mississippi ... aux Environs desquels se trouvent les Etats, Pais . . etc . . . de la Floride, de la Louisiane, de la Virginie . . . de la N'elle Angleterre... . du Canada. . . dressée sur les Mémoires . . . recueillis pour l'Établissement de la Cie. Françoise d'Occident. 
12129-1725, Feb. I7, St. Petersburg. W. de Wilde, Dutch minister in Russia, to the States General. Departure of Capt. Bering the previous day for Kamtchatka, where he will construct vessels for his search for the northwest passage. (French translation.)

[f. 395

12162. "Observations sur les finances, le commerce et la navigation d'Angleterre en Octobre I747, par M. [Étienne] de Silhouette."-English desire to possess Canada and Louisiana; materials for naval construction drawn from America; fur trade with the Indians; fisheries and navigation; importance of Canada and Louisiana to England in effort to secure mastery of North America; means of assuring prosperity of French colonies in North America.

12223. "Traité des animaux à quatre pieds terrestres et amphibes, qui se trouvent dans les Indes occidentales ou Amérique septentrionale."

12224. Memoirs on Louisiana.

[Post I 746.] "Description des côtes de l'Amérique espagnole depuis la Marguerite jusqu'à la côte des Mosquites." Endorsed, “communiqué par M. de Forebonnés". [Véron de Forbonnais]. Commerce between Tampico and the Mississippi; description of the coast of Louisiana; shipwreck of the Chevalier Grenier.

[Pp. I-Io6

"Détail du Mississippi, de son commerce, et de celui qui s'y pourroit faire, de ses produits et de la façon de pouvoir les mettre à profit." Cultivation of indigo, tobacco, etc.; proposal to settle French Protestants from New England in Louisiana; clandestine trade with the Spaniards; description of the coast.

[Pp. IO9-I 57

"Description des terres de l'Amérique par où j'ay parcouru." Guiana, Carácas, Cartagena, Portobello, etc.

[pp. $169-235$

I739. " Mémoire sur l'importance du commerce du tabac, sur les moyens d'en établir des plantations dans les colonies françoises, et sur la facilité d'y réussir et de supplanter les Anglois dans cette branche de commerce." "Je crois que ce mémoire est celuy de M. de Silhouette."

[pp. 24I-264

I747, Nov. "Mémoire sur les établissements, le Gouvernement, les fortifications, les troupes, la navigation, les dépenses, les monnayes, le commerce et la population de la colonie de la Louisiane, où l'on propose les moyens de rendre cette colonie plus puissante, plus riche et plus peuplée en diminuant de moitié les dépenses qui s'y font." "Je crois ce mémoire de M. Fabri." [pp. 265-303

Memoir addressed to M. Rouillé, minister of the marine, on Louisiana, proposing to import negroes and to produce tobacco. "Ce mémoire me paroit être celuy de M. Le Normand."

Observations made at Nantes on the above memoir. [Pp. 309-3 I 5 [pp. 317-322

[Post I759.] "Mémoire sur la Louisiane et sur l’Amérique en général." Commerce before the war; utility of Louisiana to French manufacturers, and for the maintenance of the French West Indies ; cultivation of tobacco.

[pp. 325-342

Memoir on Louisiana ; population, agriculture, negroes and cultivation of tobacco, cattle raising, and timber.

"Etat des dépenses de la Louisiane." (Two copies.) [pp. 349-362 [pp. $365-375$

[I756.] "Mémoire sur la rivière de l'Amérique Septentrionale dite Oyo ou Ouabache par le Sr. d[e] 1[a] G[range] d[e] C[hessieux], avocat au Parlement, auteur de la Conduite des François justifiée." [pp. 377-400

Memoir sent from Cadiz on the missions of Paraguay. [PP. 4OI-404

12225. "Traduction du plan du gouvernement, proposé aux États-Unis par l'Assemblée fédérale, tenue à Philadelphie, i7 Septembre, I787."

12226. "Eloge funèbre de feu Mgr. François de Montmorency Laval, premier et ancien évesque de Québec, prononcé à Montréal le - juin I708, par M. de Belmont, supérieur du séminaire de St. Sulpicẻ de Ville Marie 
12227. "Mémoire sur le différend qui est entre le prince régent de Portugal et le roy Catholique touchant la colonie du St. Sacrement dans la rivière de la Plata."

12305.- I780, Oct. I8, Passy. Benjamin Franklin to P. J. Macquer, chemist. Recommends a young American doctor, Foulke, who has come to Paris to study. (L. S.)

[f. 3 IO

12394. "Mémoire historique des principales découvertes voyages et navigations de long cours." See below, MSS. Fr., nouv. acq., 7485, and above, MSS. Fr. 9516.

12454-12455. Letters and fragments of works of Chateaubriand.-Various notes and extracts relating to the United States. See E. Buron, "Chateaubriand en Amérique", in Revue Canadienne, I903, Jan.-Feb.

12506. "Cantique et chansons sur la prise du fort Chouagen."

12758. Autographs and notes.

Notes on the United States, I844-I852: emigration from Europe, railways, population, production of coal and gold, list of presidents, militia, public debt, etc.

[ff. I05-I 30,273

Clippings from French newspapers containing American items of news, I 85 I-I 852 .

12759. Autographs and notes.

[ff. I $38-150$

Note on Gen. Milfort and his sojourn among the Creeks.

Mémoirs ou Coup d'oeil rapide sur mes différens Voyages et mon Séjour dans la Nation Crëck par le Gal. Milfort ( I802, fragment).

12760. Autographs and notes.

Note on Thomas Paine and his sojourn in the United States. [f. 223

12763. Autograph letters.

An VIII., Flor. I2, New York. Dupont de Nemours to the Institute of France, transmitting the first memoir on his travels.

[f. 246

Autograph letters of Benjamin Franklin to Abbé de la Roche (Passy, Dec. 7, I778), and to Mme. Helvétius (Havre, July I9, I785; Southampton, July 27, I785; Philadelphia, Oct. 20, I785, Apr. 23, I788; "Vendredi" ).

[ff. 279-289

I794, Oct. 3, London. W. T. Franklin to Mme. Malacholle. Arrival in Paris of William Morris and other Americans.

12768. Autograph letters.

I781, Mar. 23, New Windsor. George Washington to François de Barbé-Marbois, respecting a certificate requested for a friend. (A. L. S.)

[f. 233

I78I, July I3, Headquarters near Dobbs Ferry. George Washington to Barbé-Marbois, respecting letters and packages received for French officers and distributed to them. (L:S.)

[f. 235

I785, Aug. I6, Norwich. Samuel Huntington, president of Congress, to Barbé-Marbois, expressing regret at failure to meet brother of latter. (A. L. S.)

[f. 242

I78I, Mar. 4, Dec. 20 ; I783, Dec. 5. Thomas Jefferson to Barbé-Marbois. (A. L. S.) Ptd. in Amer. Hist. Rev., XXI. 76-77.

I779, Oct. I7, Braintree. John Adams to Barbé-Marbois. Acknowledging congratulations. (A. L. S.)

I780, Mar I, Paris. John Adams to Barbé-Marbois. Arrival in Paris, naval activity at Brest. (L. S.)

[f. 253

13057.-I664, Dec. 5. Arrest du Conseil de Commerce . . en faveur des Marchands et de tous autres qui feront cy-après bastir des Vaisseaux, ou traffiqueront sur Mer (Paris, I664). Also in Moreau de St. Méry, Loix et Constitutions, I. I3I.

[ff. 324-327 
I669, June I2. Arrest du Conseil d'Etat, Portant que les Passeports pour les Vaisseaux François qui iront oux Isles de l'Amérique seront donnés par le Roy (Paris, r669). Also ibid., p. I78.

[ff. 357-359

I674, Dec., St. Germain-en-Laye. Édit . . p portant Révocation de la Compagnie des Indes Occidentales (Paris, 1675). Also ibid., p. 283, and in Édits et Ordonnances, I. 63.

[ff. $37 \mathrm{I}-374 \mathrm{~V}$

13068. - [ [ I76r ca.] "Précis pour le sieur, Penniseauld, cy-devant interessé dans la traite des vivres du Canada contre M. le Procureur du Roy."

13090.-Lists of vessels passing through the Sund, r780-1802, including American vessels.

[ff. $43-44$

13357. Legislative and administrative documents respecting negroes, mulattoes, and other persons of color in France and the colonies, I776-1778. $\mathrm{Cf}$. Isambert, Anciennes Lois Françaises, XXIV. I05, I14, XXV. 81, I3I, I89.

13359. “Introduction à la Géographie," I773.-Contains sections relating to America, New France, New England, Florida, Mexico, California, West Indies, South America, etc. (ff. Ior et seq.) ; "Itinéraire maritime pour aller au Mississippi " (f. r84).

13362. "Introduction à la géographie, Tome III."- Some sections are devoted to history and geography of North and South America (ff. I68-200).

13363. " De la division du Monde Universel."-Treatise of the seventeenth century containing brief sections devoted to America (ff. 5, 9, 90-98).

13365. "Recueil des Inscriptions des remarques historiques et géographiques qui sont sur le Globe Terrestre de Marly."-The "globe de Marly" was constructed by Father Vincent Coronelli and presented to Louis XIV. by Cardinal d'Estrées in r683. It is now in the Bibliothèque Nationale. This compilation of the historical and geographical legends inscribed upon the globe includes a summary of the information then available respecting America. See Philippe de La Hire, Description et Explication des Globes qui sont placés dans les Pavillons du Château de Marly (Paris, I704).

13366. "Explication des figures qui sont sur le globe terrestre de Marly", by F. Le Large.-Numerous passages devoted to American history, geography, ethnology, etc.

13371. "Dernier livre de la description de tous les portz de mer de l'univers", by "Jean Mallart, escripvain du Roy". See above, MSS. Fr. 1382.

13373. "Papiers du Père [Louis Bertrand] Castel [I688-r757], sur le passage de la mer d'Ouest en Asie avec des lettres des Missionnaires sur ce sujet."

I750, May I5. Copy of letter to Father Bonnécamps, relating to the search for a passage to China by Hudson Bay; estimates of distances from the sources of the Mississippi and the Missouri to the sea.

[ff. I $-4 \mathrm{~V}$

"Carte conciliatrice de toutes les Découvertes et relations anciennes et modernes." Louisiana, New Mexico, and the western part of North America.

I750, Nov. 3, Quebec. Letter from Father Bonnécamp, relating to the search for the Western Sea. (A.L.S.)

[ff. 7-8

I750, Oct. I5, Quebec. Letter from Father Coquart, correcting the errors of Bellin (I745) with respect to Lake St. John and the surrounding country.

[f. 9

Undated letter from Father Coquart, presenting a detailed account of his information respecting the western part of North America, physical geography, tribes of Indians, etc. (A. L., conclusion missing.)

[ff. IO-I2 
[I750, Mar.?] Father Castel to Father Coquart, communicating information respecting the Missouri and the West. (Draft.) [ff. I3-I4
[fi.

"Lettres de *** Membre des Sociétés Royales d'Angleterre à Mr. l'Abbé Raynald auteur du Mercure sur la perfection générale de la Géographie et sur celle de l'Amérique Septentrionale en particulier." Autograph drafts of letters of Father Castel, comprising varying versions, which reveal an editorial process.

"Concernant le passage de la Baie d'Hutson à l'est de l'Asie." [fo graph draft by Father Castel.)

(Auto-

Thirty-two maps and sketches by Father Castel, illustrating [1]-74

Thirty-two maps and sketches by Father Castel, illustrating his views as to the physiography of the western part of North America, the American coast, the "Northwest Sea", and the passage to Asia.

[ff. 76-108

13374. "Notice historique des principaux voyageurs modernes depuis l'an 507 jusqu'au commencement du I6 ème siècle”, by [Edme] Mentelle.-Includes brief references to discoverers and early explorers of America.

13380-13381. Voyages of Jean Godot.-Include descriptions of Santo Domingo, Guadeloupe, and Martinique, ca. I696-i704.

13417-13419. Papers of Abbé Beliardi.-These volumes contain memoranda of travel, and notes and extracts relating to a great variety of miscellaneous matters. $C f$. above, MSS. Fr. 10764-10770. In 13418 may be noted Franklin's remedy for colds (p. I I I), a copy of the American "declaration of rights" (pp. I 55-I 58), observations by Abbé de Mably on the Constitution of the United States (pp. I 59-I60), and tables showing the state of the French navy in I76I-I766 and I770 (pp. 38I, 423).

13423. Chronology, history, and geography.-Notes and extracts, largely from printed works, relating to discovery and exploration of Canada, Jacques Cartier, Champlain, fisheries, Greenland, and polar regions, etc. (ff. I44, 283, 339-354).

13424. Notes and extracts.-Résumé of discovery and exploration of America (ff. 57-6ov) ; present state of America, I740 (ff. 6ov-64).

13515. [Post I673.] "Ordre pour ceux qui vont en mission."-Manual for the conduct of a mission: "ce qu'il faut faire avant que de la commencer; ordre du jour pendant qu'on est en mission: avis généraux pour les prédicateurs et catéchistes, pour le directeur d'une mission."

13516. Collection of documents relating to the history of Canada, dedicated to Abbé Le Pelletier by Abbé Belmont.

"Histoire du Canada", by Abbé Belmont. Ptd. in Collection de Mémoires et de Relations sur l'Histoire Ancienne du Canada. Literary and Historical Society of Quebec (Quebec, I840), no. 4.

"Histoire de l'Eau de vie au Canada." Ptd. ibid., no. 8.

iff. $2-44$

" "Les [ff. 45-93 Les trois principales raisons pour lesquelles l'Évesque de Québec, Mgr. de Laval, s'est réservé le péché qui se commet dans la traite des boissons aux sauvages du Canada."

[ff. 95-100

"Réponses aux Raisons par lesquelles on prétend prouver qu'il faut laisser la liberté de traiter des boissons aux sauvages, et premièrement aux chefs qui regardent la Rélligion.-Réponse aux chefs qui regardent le pays.Résponse aux chefs qui regardent le commerce."

[ff. IOO-I IO dians."

"Extrait des Loix de Boston contre la traite d'eau-de-vie, titulo In-

"Extrait des registres du Conseil d'Etat." Assembly at Quebec, May I2, I678, for consultation on sale of brandy to the Indians.

[ff. I I 3 -I I $5 \mathrm{~V}$

I678, May 24. "Mémoire fait par ordre du Roy sur la difficulté de la traite des boissons aux sauvages dans le Canada ou Nouvelle France." By Colbert.

[ff. I I 5V-I I $9 \mathrm{v}$ 
"Deux sermons sur l'yvrognerie des sauvages." [ff. I23-162

I698, Dec. I9, Quebec. Funeral oration for Frontenac, by Father Olivier Goyer.

"Entretien charitable d'un Missionaire et d'un vendeur d'Eau de vie."

[ff. $198-206 \mathrm{v}$

r67r. "Récit de ce qui s’est passé au voyage que M. de Courcelles, gouverneur de la Nouvelle France a fait au Lac Ontario ou des Iroquois." A note, apparently by Pierre Margry, states that this document is in the hand of Abbé Dollier. Ptd. in Margry, I. r69-I92.

[ff. 207-2r $7 \mathrm{v}$

13561. Miscellany.- " Belle description d'un temple dans un roc, du livre des Isles Antilles" (f. 97) ; notes on the Appalachian mountains (f. 99v-roo).

13669. Copies of letters of Henri IV.

I608, Feb. 26, Paris. Duc de Sully to President Jeannin, setting forth his views as to colonial policy.

[ff. 2r $3-215$

13714-13716. "Déportation du XVIII fructidor an V [Sept. 4, I797], ou journal d'un déporté", I797-1800, by Barbé-Marbois. Original MS. with plans and printed and MS. documents. See François de Barbé-Marbois, Journal d'un Déporté (Paris, 1834, 2 vols.).

13792. "Tableau Historique de la Martinique", by Abbé Halma, librarian of the Empress Josephine.

13794. "Traicté de la politique de la France dédié et présenté au Roy, par Mre. p. h. seigneur du C. l'an de grace I667." The presentation copy, in manuscript, of Traicté de la Politique de France (Cologne, I669), by Paul Hay du Chastelet. References to Canada and to the West Indies.

13862.-La Grande Victoire remportée en Amérique sur les Anglois, tant sur Terre que sur Mer, par les Troupes du Roi avec le Journal des Opérations du Corps François sous le Commandement du Comte de Rochambeau depuis le I5 Août I78I (Boston, imprimé du' Congrès, 8 pp., 4to).

Mandement de Monseigneur l'Archevesque de Paris du 26 Novembre I78I qui ordonne que le Te Deum sera chanté le 27 Novembre dans toutes les Eglises de son Diocèse, en Actions de Graces de la Victoire et des autres Avantages remportés sur les Anglois en Amérique (Paris, r78r, 8 pp., 4to).

13875. "Table générale de tous les religieux Recollets morts depuis l'érection de la province de Paris." (Eighteenth century.)

14265-14278. General table of edicts and ordinances relating to the marine, I66I-I756.-These lists of edicts, arrêts, règlements, déclarations, letters, etc., constitute a useful guide to the history of French colonial legislation and administration. Some 200 documents relating to the North American colonies, directly or indirectly, between I66I and I756, are here listed; their texts are to be found in Arch. Colonies, A, B, in Arch, Nat., E, and elsewhere. A few are printed in Isambert, Anciennes Lois Françaises, in Moreau de St. Méry, Loix et Constitutions, and in Edits et Ordonnances.

14279. "De la Juridiction de la Marine."

1656. Regulations by M. de Vendosme, respecting permits granted by the admiral to engage in the fisheries of Newfoundland, Canada, and elsewhere.

I66I, Aug. r6. Arrêt respecting new colonies and concessions. [f. I 5

14286-14287. "Liste générale des officiers . . . de la Marine et des Vaisseaux du Roi ", I757, r759.

14289-14290. "Idée générale de la fourniture des vivres", for the marine.

14609. "Traitté de la défense et de la conservation des colonies par M. Dumas, Brigadier des Armées du Roy, ancien commandant des Isles de 
France et de Bourbon, I775."-References to the loss of Canada, the importance of Louisbourg, commerce of the former American colonies, etc. (pp. 8, 2I, 72, I32, I82, 201).

14610. "Précis sur les colonies ..." By C. Dumas, I775.-A copy of the preceding volume, 14609, with the addition of an autobiography of the writer, setting forth his services in Acadia, on the Ohio, at Montreal and Quebec, I752-I 756.

14611. "Principes sur l'administration, l'amélioration, et le commerce des Colonies françoises de l'Amérique, selon les suites prévues de la guerre présente des Colonies." By the Chevalier de Ricard, colonel of infantry, Jan. I, r 778. Relates to the West Indies.

14612. "Mémoires politiques et militaires sur la situation respective de la France et de l'Angleterre à l'occasion de la guerre des colonies." By the Chevalier de Ricard, colonel of infantry.

1776, Dec. " 'Réflexion sur l'usage des moyens que la guerre des colonies semble rendre indispensables."

[pp. I-8I

I 776 , Dec. 30. Chevalier de Ricard to the minister of foreign affairs, respecting the American war and referring to military operations in America.

I777, May. "Idée de l'origine de la puissance de l'Anglet [pp. 82-97 I77, May. "Idée de lorigine de la puissance de l'Angleterre, de sa situation et de ses ressources relativement à la France à l'occasion de la guerre des colonies."

I777, May “Nouvelles considérations sur l'etat présent le lpp. 98-I 58 de l'Angleterre." "

[pp. $98-$ - 58

14613. "Relation ou annalle véritable de ce qui s'est pascé [pp. 159-293 14613. "Relation ou annalle véritable de ce qui s'est passé dans le pais de la Louisiane pendant vingt-deux années. . . . depuis . . . I699 . . . jusqu'en I721 ... Par Pénicaut." (374 pp. of text, in addition to the dedication and the avertissement; the map referred to in the text is missing.) - Ptd. in Margry, V. 375-586; the dedication and avertissement are printed ibid., pp. 689-69I. In the Library of Congress, Division of MSS., will be found the printed text from Margry, corrected and omissions supplied by collation with the present MS. A contemporary MS. copy is in the library of the Massachusetts Historical Society, Boston, among the Parkman MSS.

14694. "Relation du prince de Broglie" of his travels with the Chevalier de Lameth in the United States and Venezuela, I782-I783.-See Journal du Voyage du Prince de Broglie ... aux Etats-Unis d'Amérique et dans l'Amérique du Sud, I782-I783, in Société des Bibliophiles Français, Mélanges, part 2 (Paris, 1903) ; translation in Magazine of American History, I. (1877).

14695. "Voyage au continent américain par un Français en 1777 , et réflexions philosophiques sur ces nouveaux républicains." (I08 ff.)-Draft of a narrative, in the form of a letter, by an unidentified civilian traveller. The writer sailed from Bordeaux [?] on an American privateer and landed at Charleston, S. C., whence, after a short stay, he proceeded by water to Chesapeake Bay and thence, through Virginia and Maryland, to Philadelphia. After a sojourn in this latter place he went on horseback to Boston, and sailed for Bilbao after the surrender of Burgoyne. The narrative contains an interesting and detailed account of people, manners, institutions, religious customs, etc., especially with regard to Charleston and Philadelphia. Some account is given of the American army, but not of military operations.

14760. "L'art et manière de trouver certainement et en tout temps la longitude ou différence longitudinale de tous lieux proposés... par Oronce Finé." I 543. 
15449. Geographical miscellany, I8th century.-Notes on Ile Royale, Newfoundland, Hudson Bay, Canada, the Mississippi, the English colonies, customs of the Indians, and commerce (ff. I86v-Igo).

15450. "Description subcincte des quatre partyes du monde . . ."-Generalities with respect to America (f. 5).

15451. "Remarques géographiques et historiques", by Michel Antoine Baudrand. ( I 7 th century.) - Passages relating to Canada (ff. 3, I I-I7, 2I-25, 72 ) and to Santo Domingo (f. 47) ; extract from the voyage of Raveveau to the South Sea (f. 79).

15452-15453. I 586. "Le grand Insulaire et pilotage d'André Thevet, Angoumoisin, cosmographe du Roy, dans lequel sont contenus plusieurs plants d'isles habitées et deshabitées et description d'icelles." (Autograph, 4I 3 and $230 \mathrm{ff}$.) -Use is made of this MS. by Parkman, Pioneers of France (section on "Champlain and his Associates", ch. II.), and part of it, relating to "Isle de Haity ou Espaignole", "Isle Beata", and "Isles du Chef de la Captive", is printed in Le Discours de la Navigation de Jean et Raoul Parmentier de Dieppe, ed. Ch. Scheffer (Paris, I883). A critical account of the work of André Thevet and of his MSS. in the Bib. Nat. (MSS. Fr. 15452-15453, 15454, 17174, 17175, 19031) is in Biggar, Early Trading Companies, pp. 23I24I. Cf. also André Thevet, Les Singularitez de la France Antarctique, ed. Paul Gaffarel (Paris, I878).

15454. Narrative of two voyages by André Thevet to the East and West Indies. (Autograph.)-According to Biggar, loc. cit., this MS. is an autograph copy of MSS. Fr. 17175, with a few unimportant modifications.

15466. Miscellany.

I635. Aug. I8, Guadeloupe. Copy of letter from Father Pierre Pélican to

Father Jean Baptiste Carré of Paris. [ff. 85-88

"Mémoire des choses à Considérer en faveur des Colonies et Compagnies et qui se peuvent establir aux contrées et pays esloignez par Les français soubz l'auctorité du Roy en vertu de patentes ou concessions de son Eminence soubz le bon plaisir de sa Majesté." Endorsed: "Mémoire de Mr. Rozée" [de Roissy]. [ff. 89-92

"Mémoire de ce qui s'est passé le long de mon voyage de France aux Isles de l'Amérique et depuis mon arrivée en Icelles le XXe Mars I639." Voyage from Dieppe to Martinique, Guadeloupe, and St. Christopher. Endorsed: "Pour les seigneurs de la compagnie." [ff. 208-2 I I

"Suyttee des Mémoires envoyées à Monsieur Fouquet . . . directeur gñal des Compagnies d'Amérique." [ff. 2I3-22I II. 93-IO2.

"Voyage de Monsieur de la Salle à la Rivière Mississipi." Ptd., Margry,

15523. [ff. 224-225v

15523.- - 697. Printed text of the Treaty of Ryswick. [f. I06
[15528.

15528.- I68I, July. Letters patent confirming the privileges of the Compagnie du Sénégal. Ptd. in Moreau de St. Méry, Loix et Constitutions, I. 356.

15532.-I686, May. Edict creating and regulating a general company "pour les asseurances et grosses aventures". Ptd. in Isambert, Anciennes Lois Françaises, XIX. 549.

15621. " "Mémoire touchant la conduite du Sr. de la Tour dans la Nouvelle France depuis i624 jusqu'en I643: contre ce que le Sr. D'Aulnay Charnisay a advancé dans lesdit païs contre ledit La Tour." (Copy.) [ff. 265-270

I643. "Mémoire de ce que le Sr. d’Aulnay Charnisay Lieutenant général et gouverneur pour le Roy en la Nouvelle France a fait pour le service de S. M. dans la défense des costes d'Accadie, qui tiennent plus de I50 lieues de pais contre les Anglais et la Tour." (Copy.)

[ff. 27 I -272 
15628.-I533, Mar. I2 (o.s.). Warrant for payment of 6000 livres for equipment of vessels for Jacques Cartier.

15632.-I 534, Mar. 25 (o.s.). Warrant for payment of 3000 livres for equipment of vessels for Jacques Cartier.

15782.- "Effigies et nomina quorundam e Societate Iesu qui pro fide vel pietate sunt interfecti, Ab anno I549 ad annum I607." Portraits of Jesuit martyrs, including several who met death in Florida, I 566-I 568. [ff. 423-427

15795.- "Martirologe de la Compagnie [de Jésus] tel qu'il se lisoit au réfectoire, l'an I666." Includes Jesuit missionaries who suffered martyrdom in Canada, I648-1649.

[ff. 85-I I 8

15850-15864. Despatches and memoirs relating to the negotiations of Münster and Osnabrück, I643-I648. See above, MSS. Fr. 10644-10652.

15866-15868. Negotiations of Ryswick, Mar.-Nov., I697.-References to commerce, the American colonies, Acadia, Hudson Bay, etc., as follows: 15866 , ff. $25,83 \mathrm{v}, 87$, I08, II 7 , I 30 , I 59v, $388 \mathrm{v} ; 15867$, ff. 504, 509, 529, 538, 55 I, 626, 639, 65Iv, 657, 680; 15868, ff. I 74v, 2I 4. Cf. Actes et Mémoires des Négociatiations de la Paix de Ryswick (the Hague, I707, 5 vols.).

15883. Negotiations and treaties.

I694, Dec. 6, Versailles. The king to MM. de St. Germain and de Gigny. Restitution of English conquests in America.

[f. I62

I694, Noy. I I, Versailles. The king to MM. de Harlay and de Callières. Restitution of English conquests in America.

[f. I8I I709, May 28, the Hague. Preliminary articles of peace: art. XVI. relates to New foundland and the American colonies. 1664, July 3I. Extract of the Treaty of Breda: art X., restitution of Acadia to France.

References to commerce, fisheries, beaver, etc.

[f. 276

15888. Documents relating to England.

[ff. 295, 302, 304v, 317v

I586, Sept. I6. Copy of a letter relating to Drake's voyage to the West Indies.

[f. $3^{\text {I } 3}$

I604, Aug. I8/28. Latin text of Treaty of London. See Davenport, op. cit., Doc. 27.

15889. Documents relating to England.

[f. 4 I I

I666. Two memoirs by the Comte de Cominges, containing references to American commerce and colonies.

[ff. 382,398

15951. First volume of negotiations of President Jeannin, I607. See above, MSS. Fr. 7086-7090.

15952-15954. Correspondence of the French ambassadors in Holland, I 5941623.- Occasional references to search for a northern passage to the East Indies: 15952 , ff. $259,263,264 ; 15953$, f. 47 .

15961-15962. Embassy of Pomponne II. de Bellièvre, Sieur de Grignon, in Holland, I650-165I.- Memoir respecting intervention of States General to secure the liberation of a captive of the Iroquois in New Netherland (15961, f. 8I) ; instructions to insist that the officers of New Netherland shall not aid Indians who are at war with the Indians under French domination (15962, f. I4).

15968. Treaties between France and England and Scotland.

1632, Mar. 29. Treaties of St. Germain-en-Laye. See Davenport, op. cit., Doc. 36.

[ff. 603, 615, 619

Project of a treaty with reference to an understanding by France and England respecting all expeditions in the Indies and in America. (Latin.) 
I655, Nov. 3. Printed copy of Treaty of Westminster (Paris, I655).

I667, July 3I. Printed copy of Treaty of Breda (Paris, I668).

15973. Embassy of Michel de Castelnau, Sieur de La Mauvissière, in England, July 4, I 578 -June 20, I 58I.

Despatches to the king from M. de La Mauvissière, of July 4, 7, I3, Oct. I7, I 578, and Nov. 2, I 580, relating to Frobisher, Drake, and Gilbert. Ptd. in Amer. Hist. Rev., XXXI. 285-296. Cf. Bib. Nat., 500 Colbert, 337.

$[\mathrm{ff} .2,3,3 \mathrm{v}, \mathrm{I} 9 \mathrm{v}, 358 \mathrm{v}$

15980. Documents relating to commercial and maritime relations between France and England, I 559-I605. References to Ferdinando Gorges (f. 63), to seizure of a Newfoundland vessel (f. 94), and to the sending of the St. Esprit from St. Jean-de-Luz to New foundland, I 59I (f. I80).

15987. Despatches and other diplomatic documents from the French ambassador in England, I6 $13-16$ I 4.

Despatches and memoirs of Samuel Spifame, Sieur de Buisseaux, at London between June I6, I6I3, and Nov. I9, I6I4, relating to the following matters: interference by the English with the French fisheries at Newfoundland, whale fisheries, Greenland, search for a northern passage to the East Indies, attack on the French at Port Royal by Argall in the Treasurer, capture of the French vessel sent out by Mme. de Guercheville, destruction of Port Royal, arrival in Welsh port [Pembroke] of the captured French vessel with Jesuits and French prisoners on board, detention of French subjects in Virginia, reply of the Privy Council to complaints of English acts of violence, etc. [ff. 85, 91, I 37, I 53, I 57, I69, I 79, I 85, I90, 206, 210, 23I, 247, 249, 255, 265, 279, 286, 359, 400, 405, 408, 410

16008-16010. Letter-books of despatches to Brienne, minister of foreign affairs, by Antoine de Bordeaux, Sieur de Neufville, ambassador in England, I652-I 656 .

16008. I652-I654.-A number of despatches of Apr.-Nov., I653, relate to complaints of English merchants as to prizes brought into the port of Nantes by "Prince Robert" [Rupert].

16009. I654, Feb.-Dec.

[ff. I09, I I9, I 24, I 50, I60, I79, I 83, I86v, 202, 265v, 293v

Despatches of May i I, Nov. 5 and 9 refer to claims of the Kirkes respecting Canada.

[ff. I $26 \mathrm{v}, 395 \mathrm{v}, 4.00$

I654, June I, Aug. I3. References to captures of French vessels bound to or from New foundland.

16010. I655- 656 .

I655, Feb. 4, I I, 25, Mar. I, I 5, 25, Apr. 5, 8, May 20, 27, Oct. 7, I4. Despatches containing references to negotiations with Cromwell respecting Canada.

[ff. 42, 5 I, 7 I, 75, 83. I06v, I I 4, I 2 I, I 35v, I6 I v, 279. 285

16103. Embassy in Spain, I56I-I572.-A section of this volume contains originals and copies of the correspondence of Raymond de Pavie, Sieur de Fourquevaux, ambassador in Spain, Sept., I 567-Apr., I 572. Most of the documents have been printed from this or from other sources by $\mathrm{Mgr}$. C. Douais (see above, MSS. Fr. 10751-10752), including the "Discours d'un estranger desireux de servir le Roy et s'employer vers les Indes " (f. 637, ptd. in Douais, op. cit.. III., I30), and "Mémoire touchant douze françois venans de la floride faits prisonners à Seville et condamnez aux gallaires pour dix ans" (f. 639, ptd. in op. cit., II. I92). For a list of the contents of this volume see MSS. Fr. 17019, ff. I69-I75. 
16112.-I603, Sept. 23, Seville. "Memoria de lo que hace [?] la flotta de la nueva españa este anno I603." Erroneously described in catalogue as "flotte de 12 Nouvelle France".

[f. I37

16207.- [I773.] Memoir in defense of the conduct of François Bigot as intendant of Canada, with especial reference to the charges on which he was tried and condemned in 1763 . Presented in support of his petition for revision of his case.

[ff. 47 - I 29

[I773.] Petition of François Bigot to the king, appealing from the sentence against him of Dec. IO, I763, and praying for a revision of his case.

[ff. I3O-I 32v ; a corrected copy is at ff. I34-I $36 \mathrm{v}$

16736. Documents relating to commerce, navigation, colonies, etc. ( 17 thI8th centuries).

[Post 1697.] "Mémoire des causes de la diminution du commerce en France et des moyens de l'y rétablir" by "Mr. Anisson" [?]. [ff. I9-26

[1697.] "Mémoire par raport au traitté de la paix généralle concernant les Colonies, la navigation, et le commerce." Endorsed : "Reçu avec la lettre du 27 mars I697." A statement of the objects to be sought for by the French negotiators at Ryswick, under the heads Canada, Acadia, Newfoundland, Hudson Bay, Islands of America, Pondichery, Guinea coast, navigation, and commerce.

I697. "Second mémoire concernant le co port 1497. "Second mémoire concernant le commerce et la navigation par raport au traitte de la paix générale." For use of negotiators at Ryswick; headings are Spain, Holland, England, and colonies.

[1697.] "Prétentions réciproques des francois [1697.] "Prétentions reciproques des françois et des hollandois sur les colonies." A memoir for the negotiators at Ryswick, containing an outline of proposed colonial adjustments between France, Holland, England, and Spain, West and East Indies, Hudson Bay, etc.

[ff. $45-47 \mathrm{v}$

[1697.] "Extrait des mémoires et lettres envoyés à Messrs. les Plénipotentiaires concernant les restitutions à faire de part et d'autre dans les colonies." Much of this is included in the memoir at ff. $27-35 \mathrm{v}$.

[ff. $47-5 \mathrm{I}$

Extracts from Lescarbot and Champlain respecting the northern part of North America.

[ff. $76-77$

I698, Sept., Versailles. Letters patent establishing the Compagnie de St. Domingue. Ptd. in Moreau de St. Méry, Loix et Constitutions, I. 6Io.

[Pf. 78-82
[Post I70I] [ff. $78-82$ of Philip V. of Feb., levying certain sums on the fleet from the Indies in reprisal against the English and Dutch. Contains an analysis of the interests in the treasure fleet held by English, Dutch, French, and Italian merchants.

Iff. I $46-$ I $53 \mathrm{v}$
69, Sept. I3, Fontainebleau. Ordinance regulating the respective functions of the controller general of finances and the secretary of state for the marine.

[ff. $160-164$ I632, Sept. I. "Au bureau de la Compagnie de la Nouvelle France." Resolution convoking the associates to a general assembly on Saturday, Sept. 4, 1632, with blank form of notification. (Ptd. broadside.)

[f. I 45

I632, Jan. 20, Metz. Agreement between Richelieu and de Caen for the reception of the restitution of New France by the English. (Ptd. fragment, pp. I, 2). See also in Bib. Nat., Imprimés, $\mathrm{Lk}^{12}$, I057. [ff. I45bis-I45bis v

I632, Dec. 2, Saujon. Approval by Richelieu of the vote of the Compagnie de la Nouvelle France to organize a special company for a period of five years. (Ptd. fragment, p. 7.)

[f. I45ter 
I628, May, camp before La Rochelle. Edict establishing the Compagnie de la Nouvelle France. (Ptd., 27 pp.) Also in Isambert, Anciennes Lois Françaises, XVI. 216.

[ff. I 46-I46M

I634, Aug. 27, Chantilly. Arrèt condemning the Compagnie de la Nouvelle France to pay to the associates of the Compagnie de Montmorency I7,600 livres, as the proportional part of the sum paid to the Prince de Condé, together with I4,300 livres as interest on the principal sum, and to pay to de Caen and his associates 20,000 livres as an indemnity for their unexpired privilege, together with 28,00o livres to de Caen for provisions, wages, and rights in certain funds and lands. The preamble cites over a hundred pertinent documents. (Ptd., I4 pp.)

[ff. I $43-\mathrm{I} 43 \mathrm{Fv}$

I633, Dec. I. Sommaire de l'instance pendante au Conseil Privé du Roy. Entre les Associez en la Compagnie de la Nouvelle France Defendeuse. Et le sieur Guillaume de Caën Demandeur en Requeste. (8 pp.) [ff. I44-I $44 \mathrm{Cv}$ I638, Jan. 27, St. Germain-en-Laye. Arrêt confirming the vote of the general assembly of the Compagnie de la Nouvelle France of Jan. 15, 1638, for the organization of a special company for four years for the maintenance of the colony of New France.

[ff. I36-I 36 bis v

I639, Jan. I I, I8. Resolutions of the general assembly of the Compagnie Particulière de la Nouvelle France respecting measures for financing the venture of the present year. (Ptd., 4 pp.)

[ff. I40-I 4 IV

I640, Feb. 27, Paris. Order by the commission for the settlement of the debts of the Compagnie Générale de la Nouvelle France, setting Mar. 5, I640, as the date for hearing those associates who have not yet appeared before it. Signed, Langlois, Daligre, Bouthilier, Le Gras. (Ptd. broadside.) [f. I42

[163I.] Memoir for Richelieu [by the directors of the Compagnie de la Nouvelle France?], respecting the indemnity to be paid to Guillaume de Caen and his associates for the unexpired period of their privilege. (Ptd., 6 pp.)

[ff. I $32-\mathrm{I} 32 \mathrm{Bv}$

I635, Sept. I8, Charonne. Arrêt requiring each of the associates of the Compagnie de la Nouvelle France to pay 800 livres into the hands of the receiver, Cheffaut, according to the arrêt of Aug. 27, I634. (Ptd., 3 pp., including blank form of notification to associates.)

[ff. I $33 \mathrm{~B}-\mathrm{I} 33 \mathrm{Cv}$

I638, Jan. 9. Resolution of the directors of the Compagnie de la Nouvelle France, convoking a general assembly for Jan. I5, I6 38 , to consider ways and means of securing I20,000 livres, either from the 120 associates or by the organization of a special company, for the expenses of the venture (embarquement) of the present year. (Ptd., 3 pp., including blank form of notification.) [ff. I $35^{-1} 35$ bis

16738. Documents relating to commerce, consulates, etc. (I 7 th century.) I62I, June 3. French copy of charter from the States General to the Dutch West India Company, and memoir on its organization. [ff. 36-5I I64I, July Io. Convocation of the associates of the Compagnie de la Nouvelle France to a meeting for deliberation and action respecting the first "embarquement" of 1642 , for the account of the general company. (Ptd. broadside.)

[f. I29

I64I, Aug. 6, Paris. Order by the commission for the settlement of the debts of the Compagnie de la Nouvelle France, respecting the meetings of the commission, with a blank form of notification for the associates of the company. (Ptd. broadside.) [f. I3I

I628, Jan. 26, camp before La Rochelle. Arrêt directing the Sieur de Roquemont and his associates to proceed with all diligence in despatching vessels and colonists to New France during the present year, and forbidding 
the de Caens and their associates to send vessels or merchandise to New France, and further forbidding all pilots, sailors, and others to enter the employ of the de Caens for the purpose of making the voyage to Canada. (Ptd. broadside.)

[f. I 47

I620, Nov. 26. Articles accordez par Monseigneur le Duc de Montmorency. . . au sieur Guillaume de Cä̈n.. . pour les Voyages, Commerces, Traictes, et Traftics an dit Pays de la Nouvelle France. (8 pp.) See Biggar, Early Trading Companies, p. I I 5.

[ff. I $48-\mathrm{I} 48 \mathrm{Gv}$

I626, June I4, Stockholm. French copy of letters patent establishing the Royal Swedish Company for trade with Africa, Asia, America. etc. [ff. 2I2-22OV
17174. "Description de plusieurs isles, par M. André Thevet." (Original MS.) -North Sea, English Channel, Atlantic, Africa, and America. According to Biggar, Early Trading Companies, pp. 23I et seq., this MS. contains parts of MSS. Fr. 15452-15453, and 17175. Cf. above, MSS. Fr. 1545215453.

17175. "Second voyage d'André Thevet dans les terres australes et occidentales." (Contemporary copy with autograph corrections.)-According to Biggar, loc. cit., this MS. is taken from MSS. Fr. 15452-15453, q. v., and from Thevet's published works, Singularitez de la France Antarctique, and Cosmographie Universelle.

17329. Miscellany relating to finance, marine, fisheries, etc.

I673, Aug. 20. Règlement des Droits et Salaires des Officiers des Sièges de l'Amirauté (Paris, Cramoisy, I673, I3 pp.). West Indies, Canada, Newfoundland.

[ff. I43-I49

I623. Advis et Resolution de ce qui s'est passé aux Estats derniers tenus à Nantes, sur le fait de la Royalle Compagnie de la Navigation et Commerce pour les voyages de Long Cours (Rennes, Jean Durand, I623). ${ }^{2}$ [ff. 2I 5-233 1623. Offres, Articles et Privilèges accordez au Conseil du. Roy pour l'Etablissement de la Royale Compagnie de la Navigation et Commerce, pour les Voyages de Longs-cours, ès Indes...établissement de Collonnie, ès nouvelles Frances ... (Rennes, Durand, I623).

I634. Edict du Roy pour l'Establissement de sa Compagnie Royalle des

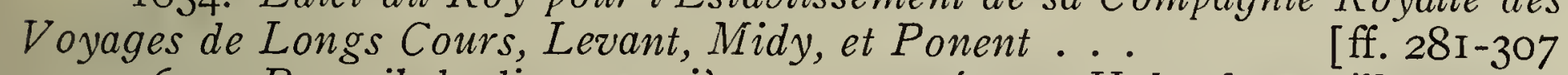
I635. Recueil de diverses pièces recouvrées en Holande et ailleurs, par lesquelles il appert très clairement, que les François ont Droict, de chasser et pescher les Baleines ès Pays du Nord . . .

[ff. 308-333 I656, Oct. 7. Proclamation by the Duc de Vendôme respecting issuance of marine passports and congés. (Ptd.)

Memoir on French explorations and discoveries, including those in North America.

"Mémoire pour régler la pesche des molues."

17871. Papers of Chancellor Séguier.

[ff. $454-462$

[ff. $504-505$

I657. "Mémoire touchant le Traict des Pelleteries du Canada pour la Compagnie Généralle du dit Pays." History of the Canadian fur trade, I627I657.

"Mémoire pour l'ambassadeur de l'Angleterre sur la restitution 37 quelques forts à La Cadie et ce qui a esté pris aux Capucins de Port Royal."

"Mémoire de ce que les Anglais ont pris au Port Royal aux $R$. I P Capucins de la province de Paris, Missionaires en la nouvelle france." A detailed list, with estimated values, totalling 27,244 livres.

I657, Mar. 23. Treaty between England and France.

[ff. I90-I9I

[ff. $236-238$ 
[1655.] Memoir entitled, "L'Estat Sommaire du pais d'Accadie dite la nouvelle france, dont partye a esté envahie par les anglais l'Esté dernier en vertu de la commission décernée par Le sieur Cromuel leur protecteur".

[f. 250

17722-17933. Negotiations of President Jeannin for the truce of Antwerp, I607-I609.- See above, MSS. Fr. 7086-7090.

18160-18204. Collated copies of arrêts, etc., in the registers of the Conseil d'Etat, I597-1626.-A catalogue of the arrêts of the reign of Henry IV., I 592-I6IO, constituting an inventory of vols. 18160-18177 of this collection, has been published by Noël Valois, Inventaire des Arrêts du Conseil d'Etat: Règne de Henri IV. (Paris, 2 vols., I886-1893), which reveals a limited number of documents relating to American affairs. An examination of vols. 18178-18204 would doubtless reveal a larger number of such documents for the years i610-1626. $C f$. Arch. Nat., E.

18258. Cahiers of the Third Estate in the States General of 1664.

Request by Third Estate for freedom of trade with Canada. Ptd. in L. Deschamps, Histoire de la Question Coloniale en France, p. 63. [f. I73

18591.-Factum, pour Julien Artur . . . [et al.], Propriétaires du Navire le S. Paul ... contre Jacob du Quesne ... (8 pp.). Capture of vessel returning from Newfoundland laden with cod. [ff. 44-47v

18592.-Edict du Roy pour l'Establissement de sa Compagnie Royalle de Voyages de Long Cours, Levant, Midy, et Ponent, et autres Effects et Admenagements en France dans sa Ville de Paris, et par Correspondance par toutes les autres Villes du Royaume ( 1634,56 pp.).

[ff. 5-3 I v

Articles, Moyens et Raisons approuvez par les Estats Généraux, que présente au Roy François du Noyer Escuyer, Sieur de S. Martin, pour la première partie de ses Propositions et Offres, afin d'establir à Paris, pour toute la France, la Royale Compagnie Françoise pour faire le Commerce Général, tant par Mer que par Terre . . . (Paris, I616, II4 + 8 pp.).

Requeste présentée an Roy par Francois Du Noyer [ff. 48-105v en la Ville de Paris la Compagnie Royalle... (Paris, i6i5, I5 pp.).

18593. - i628, May, Camp before La Rochelle. Edict du Roy pour l'Etablis-
[ff. IO6-II sement de la Compagnie de la Nouvelle France, avec l'Arrest de Vérification de la Cour de Parlement de Bordeaux (Bordeaux, I629, I6 pp.). [ff. 335-342v

Noms, Surnoms, et Qualitez des Associez en la Compagnie de la Nouvelle France suyvant les jours et dates de leurs Signatures (8 pp.).

[ff. $343-346 \mathrm{v}$

I642, June 2, Paris. Letters patent establishing the Compagnie des Isles de l'Amérique. (Collated copy.)
[f. 347

I627-I628. Articles accordez par le Roy, à la Compagnie de la Nouvelle France (23 pp.). Includes articles of Apr. 29, I627, signed by Richelieu, de Rocquemont, Hoüel, and others ; "Articles et conventions de Société et Compagnie", Paris, May 7, I627 ; and notarial acts of May 6, I628. [ff. 353-364v

I643. Proposal to appoint a commission of the Conseil d'Etat for the \begin{tabular}{l} 
consideration of matters relating to New France. [f. 365 \\
\hline
\end{tabular}

"Avis donné par un Jesuite, comme il semble, touchant l'estat des Isles de l'Amérique, de la Guradeloupe, et autres, occupées par les français."

[ff. $367-368$

I645. Mar. 3. Agreement between the "seigneurs des isles de l'Amérique " and the Jesuits of Martinique.

[ff. 369-369v 
"Extraict et mémoire instructif des choses que le sr. De La Tour a faictes en la nouvelle france." [ff. 373-385
[ france."

"Extraict et Mémoire de ce que le sieur d'Aulnay a faict dans la nouvelle

"Mémoire de l'estat auquel est le sieur D'Aulnay Charnizay [ff. 386-388 Les Costes et pais D'Acadie en la Nouvelle france où il a l'honneur de Commander soubs l'auctorité du Roy, Avec ce qui s'est passé en la deputation que les Anglois qui touchent son Gouvernement luy ont faicte pour traitter de paix avec luy."

Inventaire des Pièces que produit le sieur de Thoisy . . . contre le Com mandeur de Poincy. . . (8 pp.).

A pologie pour la Defense des Habitans de l'Isle Sainct Christo 394-397 (28 pp.).

I647, Feb., Paris. Déclaration in favor of "Charles de Menou, sieur

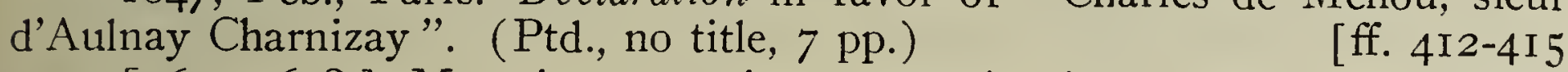

[1647-1648.] Memoirs respecting matters in dispute between de Poincy and Patrocles.

[ff. $416-425$

18596.-1627, Mar. 27-June 4. Report by Nicolas Langlois on his tour of the ports of Normandy, in execution of his commission of Nov. 29, I626, to investigate matters of commerce and navigation. Brief details respecting the Newfoundland fisheries as carried on from Havre, Harfleur, and Honfleur.

I626, July, Nantes. Edict establishing the Compagnie du Morbihan.

[ff. I-I $8 \mathrm{v}$

[ff. $33-39$

18597. [First part.] "Mémoires sur le commerce de France, des causes de sa decadence, et des moyens de le rétablir, dressés et envoyés par les Députés des Provinces de Commerce, en l'année I7OI, à la Chambre de Commerce à Paris." trade.

Memoir by the Sieur Ménager, deputy of Rouen. Reference to slaveMemoir by Picourt, deputy of Dunkirk. Slave-trade, West Indies.

[ff. 3-3v

[ff. I $2-\mathrm{I} 3$

Memoir by the Sieur Des Cazeaux Du Halley, deputy of Nantes. Slavetrade, beaver, Canada, cod fisheries, Newfoundland. [ff. 50-54 Memoir by the deputy of La Rochelle. West Indies, Canada. [fff. 60v-62

Memoir by the deputy of Bordeaux. Slave-trade, West Indies, Canada, New foundland, and fisheries.

18984. "Réflexions sur le commerce qui s'est fait en Canada." (8 pp.) Covers the period I 744-I 763; ptd. in Quebec Lit. Hist. Soc., Collection de Mémoires et de Relations (Quebec, 1840 ), no. 7.

19031. Fragments of the "Histoire naturelle et générale des Indes", and of the "Histoire du Mexique", of André Thevet. (Autograph MS.) See above, MSS. Fr. 15452-15453.

19032. "Description du Nouveau Monde ou du continent et des isles de l'Amérique, avec les bayes, les rivières, les caps . . . comme ils etoient en l'année I649, fidellement descrite par Georges Gardiner de Peskam [Peckham] escuyer, traduit de l'anglois [London, I657] en françois." (70 chapters.)

19112. "Traicté de la Géohydrographie, ou Art de naviguer." By Guillaume Le Vasseur of Dieppe (I 7 th century).

19474.-Extracts with drawings from Jean de Laet, Histoire du Nouvean Monde (Leiden, Elzevirs, I640).

[ff. $3 \mathrm{I}-\mathrm{I} \mathrm{I} 6 \mathrm{v}$ 
19683. "Jesuites, Martyrs en Amérique." I763. A small volume bound in parchment, containing copies in uniform handwriting.

"Prima relatio seu informatio. Le Martyre de René Goupil par les Iroquois [Sept. 29, I642], escrit par le p. Isaac Jogues qui estoit captif avec lui." Cf. Thwaites, Jesuit Relations, XXVIII. II6-I35, and A. Carayon, Documents inédits concernant la Compagnie de Iésus, XIII. I85-I97. [ff. 2-7v

"Secunda Relatio. Récit de l'heureuse mort du P. Anne de Nouë" [Feb. I646], and "Abbrégé de sa vie." Cf. Thwaites, op. cit., XXIX. I6-29.

[ff. 8-IIv

"Tertia Relatio seu Informatio: Des souffrances et de l'heureuse mort du Père Isaac Jogues [Oct. I8, I646]: Brief narré de la vie, et des voyages que le Père Isaac Jogues a faites aux hiroquois.-Narré de la prise du P. Isaac Jogues par les Iroquois en l'année I644 . . Escrits par le Père Jacques Buteux au Révérend Père Jerosme L'Allemant. . . . - Mémoire touchant le Père Jogues du P. Jacques Buteaux." Cf. Thwaites, op. cit., XXXI. I6-I 37 .

[ff. $12-63$.

"Récit de la mort du Père Antoine Daniel " [July 4, I648]. [ff. 63v-67v

"De 1'heureuse mort du Père Jean de Breboeuf et du Père Gabriel L'allemant" [Mar. I7, I649]. Cf. Thwaites, op. cit., XXXIV. 24-37.

"Ouelques Remarques [ff. 68-74

"Quelques Remarques sur la vie du P. Gabriel L'allemant." [ff. 74v-76v

"Quelques Remarques sur la vie du Père Jean de Brebeuf." [ff. 76v-89

"De la prise et désolation de la Mission de St. Jean par les Iroquois et De la mort du Père Charles Garnier [Dec. 7, I649], qui y estoit en mission."

"Abbrégé de la vie du Révérend Père Charles Garnier" [ff 89v-93v

"De la mort du Père Noël Chabanel" [Dec. 8, I649] [ff.93V-IO2V

19892-19893. Negotiations of the truce of Antwerp, I609. See above, MSS. Fr. 7086-7090.

19899. "La reprinse de la Floride par le cappitaine Gourgue." See above, MSS. Fr. 2145.

19942. "De la Sphère du monde, par Jacques Chauvet, Champenoys, professeur et lecteur ordinaire ès mathematiques en l'Université de Paris." $C f$. above, MSS. Fr. 1381.

20165.- Rough lists of viceroys or governors of Mexico, Peru, and Brazil.

[ff. I $39-\mathrm{I} 48$

20625.- "Voyage de Monsieur le Comte de Frontenac au Lac Ontario en I673." Translation in N.Y. Col. Docs., IX. 95-I I4. [ff. I85-Igov I673, Mar. 23, Quebec. Ordinance for the government and police of Quebec. Also in Arch. Colonies, F3, 4, f. Io9.

[ff. I9I-I92v

Narratives of French naval operations against Tobago, I677, and St. Christopher, I69o.

[ff. 202-206, 29I-293, 444-453

20784.- [ [658.] Copy of nomination by the king of Laval de Montigny, bishop of Petraea, as vicar apostolic with power to perform episcopal functions in New France. (The appointment was by papal bull of June 3, I658.)

[ff. $595-595 \mathrm{v}$

20794._ “La reprinse de la Floride." See above, MSS. Fr. 2145. [f. 728

20973.- " Récit simple de ce qu'un Religieux Benedictin a soufert en Canada." An account, by Dom Georges Poulet, Benedictine of St. Maur, refugee from France because of the bull Unigenitus, of his life in Canada, Aug. 3, I7I5-Nov. I9, I7I8, and of his dispute with the Bishop of Quebec. Cf. Gosselin, L'Église du Canada: Mgr. de Saint-Vallier, pp. 324-33o. 
"Addition à L'histoire abrégée de mon voyage en Canada. Sujet de ma fuite de France." [By Poulet.]

[ff. I $26-$ I 28

I7 I8. Bishop of Quebec to "Mr. Du Pont, alors solitaire chez Mr. Riou à la rivière des trois pistoles, en Canada et à présent connu sous le nom de Dom Georges Poulet". (Copy.)

[ff. I 29 -I 30

"Propositiones ex Theologia morali datae in Collegio Quebeccensi Soc. Jesu Anno I7I9", by Father Gerard.

[ff. I 3 I-I $32 \mathrm{~V}$

I719, Nov. I3. [Joachim] Fornel to the seminary of Quebec, enclosing the preceding document, and complaining of the theology of the Jesuits. (Copy.) Cf. Gosselin, op. cit., p. $36 \mathrm{r}$.

[ff. I $33^{-I} 33 \mathrm{v}$

Extract from a letter respecting the complaint made by Le Clerc, curé of Cap de St. Ignace, against the Bishop of Quebec and the Jesuits. [f. I34

I7oo, Oct. Io, Quebec. Letters of [Louis Ango] Des Maizerets, superior of the seminary of Quebec, and of "François, ancien evesque de Québec", to the Archbishop of Paris, respecting the general hospital of Quebec, and expressing thanks for aid in securing support from the king for the missions of the Mississippi.

$[$ ff. $158-163 \mathrm{v}$

I700, Oct. I6, Quebec. "Mémoire touchant 1'hôpital général Etably proche de Québec."

[ff. I68-I7 I

20977. - I565, May 2. Order, signed by Coligny [?], for the voyage of the Esmerillon, Capt. Vincent Collas of Dieppe, "prins en nolleage. . . pour porter vivres au pais de la nouvelle france, autrement la Floride."

[f. I $84 \mathrm{v}$

20984-20989. Negotiations of Münster, I644-I648. See above, MSS. Fr. 10644-10652.

20990. Copies of documents relating to the negotiations preliminary to the Treaty of Utrecht, I709-I7I2. Not examined.

21544. Collection of original documents relating to artillery and the - marine, I 545-I 574.-Group of original documents, with autograph signatures, relating to the Florida expedition of ${ }_{5} 6_{5}$ under Jean Ribaut, as follows:

Inventory of artillery and munitions to be placed on board the Esmerillon, Capt. Nicolas d'Ornano dit Corsette, with order for delivery of same, signed by Coligny, Chastillon, Apr. 28 , I $56_{5}$, and receipt of Nicolas d'Ornano, May 6, I565.

[ff. $3^{\mathrm{I}-33 \mathrm{~V}}$

Inventory of artillery and munitions to be placed on board the Trinité, Capt. Jean Ribaut, with order for delivery of same, signed by Coligny, Chastillon, Apr. 28, I 565 , and receipt by Jean Ribaut and Jean Le Blanc, his lieutenant, May 28, I 565 .

[fi. $35-38$

Inventory of artillery and munitions to be placed on board the Levrière, Capt. Vincent Maillard, with order for delivery of same, signed by Coligny, Chastillon, May Io, I565, and receipt of Vincent Maillard, Dieppe, May 28, I 565 .

[ff. $40-42 \mathrm{v}$

Inventory of artillery and munitions to be placed on board the Perle, Capt. Jacques Ribaut, with order for delivery of same, signed by Coligny, Chastillon, May Io, I 565, and receipt by Jacques Ribaut and Etienne Mareval, May 28, I565; followed by certificate respecting artillery and munitions returned to the king's stores at Dieppe, signed, Jacques Ribaut and Étienne Mareval, Dieppe, Dec. 28, I565, and certified inventory of artillery and munitions lost at sea or expended in the king's service, signed, Jacques Ribaut, Dieppe, Dec. 28, I 565 .

[ff. 45-5I

Inventory of artillery and munitions delivered to Jean Ribaut, to be employed in the king's service in Florida, with order for delivery of same, 
signed by Coligny, Chastillon, Apr. 28, I565, and receipt of Jean Ribaut, Dieppe, May 25, I 565 .

[ff. $53-56 \mathrm{v}$

21690.-I70I [I700], May 28-I702 [I7OI, May]. Journal of exploration and events in Louisiana [by Levasseur-Russouelle, commanding the Canadian soldiers at Fort Biloxi?]. Commences: "Le 28 May I70 [I [700]. Du Fort des Billochies, Mr. d'Tberville est parti de cette rade pour France après avoir laissé les ordres du Roy à M. de Sauvolle, Commandant de ce fort .... . Le I9 Juin je suis parti de ce fort en Canot d'écorce avec quatre Canadiens pour aller faire la découverte de la Rivière de la Mouvilla qui est à dix lieues à l'est de ce Fort." Ends: "Il y a ici 40 de ces voyageurs qui attendent l'arrivée des Vaisseaux." The writer refers to prevalence of fever in July [I700], and dangerous illness of Bienville, and to eclipse of the moon on Aug. 28-29. On Aug. 29 he went to Fort Mississippi for the transport, in order to go to Santo Domingo for provisions. In Nov. and later months he went at various times to the Mobile villages for corn. (Copy.)

[ff. 3IO-32 Iv

I734. "Extrait de l'Histoire des conquêtes et découvertes des Portugais dans le Nouveau Monde. Par le Père Lafitau, mis au jour en I733." "Tiré du Journal de Trévoux, fev'r. I 734."

[ff. $340-34$ Iv

I670, Dec. I 5-167I, June Io. Journal of navigation along the coast of Chile and Peru, by Captain John Narbrough. (Fragment, translated from English.)

[ff. $272-295$

21773. - I698. Series of memoirs on the commerce and manufactures of France. References to American commerce are to be found in the memoirs for the généralités of Lyons (f. 42), Brittany (ff. 46-47, 55-57), Rouen (ff. 59-6I), and La Rochelle (ff. 79-8ov).

[I707?] " Mémoire pour prouver que le commerce à droiture aux Indes par des navires françois convient aux deux couronnes [France and Spain] et à leurs sujets pendant le cours de cette guerre.” By "M. de Granville Locquet" [?]. [two copies, ff. I 78-I8I, I82-I85

"Second mémoire pour répondre aux demandes que les anglois font avant l'ouverture des Conférences pour la paix."

21776 [two copies, ff. 305-31 2, 3I 3-3I9v 21776.-1726, July I6, Versailles. Arrest. . qui proroge pendant un an, à compter du vingt-trois Octobre prochain, la Permission ci-devant accordée aux Négocians François qui font le Commerce des Isles et Colonies François de l'Amérique, de faire venir des' Païs Etrangers des Lards, Beurres. Suifs, Chandelles et Saumons salez, sans payer aucuns Droits (Paris, I726, 4 pp.).

[ff. $53-54 \mathrm{v}$

I7or, June i2. "Mémoire des députez du Commerce sur la Compagnie de Guinée et sur le commerce des Colonies françoises de l'Ámérique, et leurs sentiments sur les ports et commerce exclusifs."

[ff. $203-216$

I7I6, Jan., Paris. Lettres Patentes du Roy, pour la Liberté du Commerce de la Coste de Guinée (Paris, I7I6, I I pp.). [ff. 218-223

I7I9, Jan., Paris. Lettres Patentes du Roy, pour permettre aux Négocians de Languedoc de faire le Commerce de Guinée (Paris, I720, 8 pp.). It appears from this document that the Guinea trade must be conducted from Rouen, La Rochelle, Bordeaux, Nantes, and Cette, while the West India trade was conducted from Calais, Dieppe, Havre, Rouen, Honfleur, St. Malo, Morlaix. Brest, Nantes, La Rochelle, Bordeaux. Bayonne, and Cette.

21777. - I 7or, June I2. Mémoires des députez du Commerce sur la Compagnie de Guinée," etc. (Identical with 21776, ff. 203-216.) [f. I

I702, Dec. I2 (date of translation). "Mémoire traduit de L'anglois en françois qui contient des propositions faites au Roi d'Angleterre pour ruiner 
touttes les colonies françoises et espagnolles en Amérique, et les moiens pour en faciliter la Conqueste."

[ff. I9-25

I7I7, Paris. Lettres Patentes du Roy, portant Règlement pour le Commerce des Colonies Françoises (Paris, I7 I7, I6 pp.).

[ff. $40-47 \mathrm{v}$

I7I7, Nov. I6, Paris. Arrest . . qui ordonne que le Règlement du mois d'Avril I7 I7, pour le Commerce des Colonies Françoises, sera exécuté par les Marchands et Négocians de Bayonne, et casse une Ordonnance renduë par le Sieur Intendant de la Généralité d'Auch contre la Disposition dudit Règlement ( 8 pp.).

[ff. 48-5Iv

I7 I7, Dec. I I, Paris. Arrest ... qui ordonne que les Lettres Patentes du mois d'Avril dernier seront communes pour le Conmerce de Canada (4 pp.).

[ff. $52-53 \mathrm{v}$

I718, Aug. 26, Paris. Lettres Patentes sur Arrest [of June 20, I718, accepting the retrocession of Louisiana by Crozat] concernant le Commerce de la Nouvelle Colonie de la Louisianne ( 4 pp.).

I7I7, Jan. II, Paris. Arrest... pour le Commerce des Colonies Françoises (4 pp.).

[ff. 54-6ov

[ff. 6I-62v

I7 I9, Nov. 7, Paris. Ordonnance du Roy qui déffend aux Gouverneurs et Lieutenans Généraux, Gouverneurs Particuliers et Intendans des Colonies, d'avoir des Habitations [i.e., plantations for cultivation of colonial products] (4 pp.).

$[\mathrm{ff} .63-64 \mathrm{v}$

I720, Feb. I 5. Paris. Arrest . . . pour affranchir de tous Droits d'Aydes et autres, dans les Ports destinez aux Embarquemens, les Marchandises qui y sont arrivées par Mer, pour estre entreposées et conduites aux Isles Françoises de l'Amérique (8 pp.).

[ff. 65-68v

I720, July 23. Paris. Règlement du Roy, concernant le Commerce Estranger dans les Colonies (4 pp.).

[ff. 69-7ov

I720, Sept. Io. Paris. Arrest . . . qui ordonne que les Droits de Trois pour Cent sur les Marchandises du Crû des Isles Françoises de l'Amérique, arrivées dans les Ports de France, pendant l'année du Bail de Lambert, commencée pour le Domaine d'Occident au premier Janvier I IIg, et ceux du 40 s. $d u$ Cent pesant des Sucres terrez et des $33 s, 4 d$. des Sucres bruts destinez pour la Consommation du Royaume pendant ladite année I7IO, seront payez audit Lambert, ses Commis et Préposez (4 pp.).

[ff. 7 I $-72 \mathrm{~V}$

I72I, May 2I, Paris. Arrest...qui ordonne que les Pelleteries et Denrées provenant du Crû et Fabrique de Canada, de quelque Nature qu'elles puissent estre, à l'Exception du Castor, joïiront du Bénéfice du Transit (4 pp.).

[ff. $73-74 \mathrm{v}$

I722, Mar. I4, Paris. Déclaration du Roy, concernant les Marchandises des Colonies Françoises (4 pp.).

[ff. $75-76 \mathrm{v}$

I722, Mar. 26, Paris. Arrest . . . qui ordonne que, conformément aux Lettres Patentes du mois d'Avril I7I7, toutes les Marchandises du Crî des Isles et Colonies Françoises, même celles provenantes de la Traite des Noirs, paveront le Droit de Trois pour Cent, dề $\grave{a}$ la Ferme du Domaine d'Occident (4 pp.).

[ff. $77-78$

I722, May I5, Paris. Arrest.. concernant les Marchandises de Fabrique Estrangère, qui seront saisies en Canada (3 pp.).

[ff. $79-80$

I723, May 2I, Versailles. Lettres Patentes sur Arrest [of May 3. I723], qui fixent à un An le Tems de l'Entrepost des Marchandises venant des Isles et Colonies Françoises dans les Ports y dénommez, et de celles qui seront déclarées par Entrepost pour lesdites Isles (4 pp.).

[ff. $8 \mathrm{I}-82 \mathrm{~V}$

I723, Dec. 28, Versailles. Arrest.. concernant le Payement des anciennes Dettes des Colonies (3 pp.).

[ff. $83-84$ 
I724, Sept. I2, Fontainebleau. Arrest . . portant Prorogation pendant un An, de la Permission cy-devant accordée aux Négocians François qui font le commerce des Isles Françoises de l'Amérique, de faire venir des Pays Estrangers des Lards, Beurres, Suifs, Chandelles et Saumons salez, sans payer aucuns Droits (3 pp.). Similar arrêts, of Oct. 23, I725, Aug. 2, I729, Aug. 22, I730, and Sept. 27, I733 (the last two extending the permission for three years each), are at ff. 89, 99, I03, and I I7. [ff. 85-86
[

I724, Nov. I4, Fontainebleau. Ordonnance du Roy, portant que le Produit du Dixième des Prises qui seront faites à l'avenir en Commerce Étranger dans les Colonies, continuera d'estre déposé entre les Mains du Commis du Trésorier de la Marine pour estre employé suivant les Ordres Particuliers de Sa Majesté (3 pp.).

[ff. $87-88$

I726, Sept. 3, Fontainebleau. Arrest... qui exempte de Droits de la Doüane de Lyon, les Marchandises, Drogueries et Epiceries du Crû des Isles Françoises de l'Amérique, qui seront conduites en Droiture dans ladite Ville de Lyon, d'un des Ports de Mer désignez par les Lettres Patentes des mois d'Avril I7I7, Février I7I9, et Octobre I72I, etc, (8 pp.). [ff. 9I-94V

I726, Dec. 3I, Versailles. Arrest . . q qui ordonne que les Marchandises du Crû des Isles du Vent de l'Amérique, qui seront destinées pour estre transportées à l'Isle Royale, seront exemptes pendant dix Années à commencer du premier Janvier I727, du Droit de Poids d'Un pour Cent. Et que celles du Crû desdites Isles destinées lant pour ladite Isle Royale, que pour le Canada, seront déchargées du Droit de Trois pour Cent du Domaine d'Occident, ensemble du Droit de Quarante Sols par Quintal sur les Sucres qui y seront envoyez desdites Isles ( 3 pp.).

[ff. $95-96$

I728, Dec. I4, Marly. Arrest ... qui accorde aux Négocians des Sables d'Olonne pour leur Commerce de l'Isle Royale les mêmes Privilèges qui sont accordez aux autres Négocians du Royaume pour le Commerce des Isles et Colonies Françoises (3 pp.). [ff. 97-98

I730, Feb. 7, Marly. Arrest . . . qui proroge pendant un An la Faculté accordée aux Négocians des Ports et Villes Maritimes du Royaume, d'envoyer leurs Vaisseaux directement en Irlande, pour y acheter des Boeufs Salez, et les transporter ensuite aux Isles et Colonies Françoises (3 pp.). Similar arréts of Feb. 27, I73I, Aug. 29, I734, and June I8, I737 (this last extending the permission to salted salmon, butter, tallow, and candles), are at ff. I I I, I2I, and 123 .

[ff. IOI-IO2

I730, Oct. 22, Versailles. Arrest . . qui ordonne pendant trois Ans, à compter du premier Janvier I73I, l'Exécution des Arrests du Conseil des I I Novembre I727, et 29 Mars I729, qui chargent le Sieur le Cordier de la Recette Générale du Droit d'Un pour Cent, qui se perçoit sur les marchandises des Isles et Colonies Françoises et d'en rendre Compte au Conseil (3 pp.).

[ff. IO9-I IO

I716, Dec. I4, Paris. Déclaration du Roy concernant la Guinée, qui ordonne que trois Négrillons ne seront payez que sur le Pied de deux Nègres,

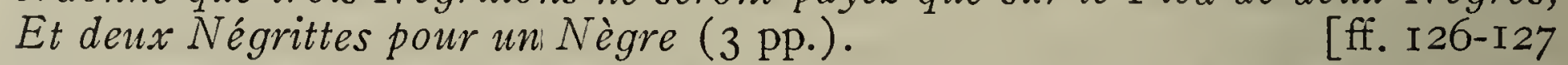

I72I, Dec. I5, Paris. Déclaration du Roy, qui règle la Manière d'élire des Tuteurs et des Curateurs aux Enfants, dont les pères possédoient des Biens, tant dans le Royaume, que dans les Colonies, et qui défend à ceux qui seront émancipez de vendre leurs Nègres (4 pp.).

[ff. I 28-I $29 \mathrm{v}$

I724, July 25, Chantilly. Ordonnance du Roy, en Interprétation de celle du 3 Avril, I7IS, au sujet des Vaisseaux qui font la Traitel des Nègres aux Isles Françoises de l'Amérique (3 pp.).

[ff. I 3O-I3I 
I7 I8.-Printed edicts and arrêts regulating the ferme générale du tabac, the importation of tobacco, its manufacture, etc.

[ff. $152-238$

21778.-I664, May, Paris. Édit du Roy pour l'Éstablissement de la Compagnie des Indes Occidentales. Vérifié en Parlement le unzième iour de Inillet I664 (Paris, René Baudry, I664, 22 pp.).

[ff. $239-249 \mathrm{v}$

I7I9, June I7, Paris. Arrest . . concernant la Réunion des Compagnies des Indes Orientales et de la Chine à la Compagnie d'Occident ( I 2 pp.). Includes edict of May, I7I9, and letters patent of Aug. 26, I718. Another copy, in different type and with a title-page, is at ff. 35 I-358. [ff. 306-3I Iv

I7r7, Aug., Paris. Lettres Patentes en forme d'Édit portant Establissement d'une Compagnie de Commerce, sous le nom de Compagnie d'Occident (Paris, I7I7, I9 pp.).

[ff. 324-333

I7r7, Sept. 12, Paris. Arrest . . . qui nomme les Directeurs de la Compagnie d'Occident (4 pp.). The directors appointed were Law, Dartaguiette, Duché, Moreau, Piou, Castaignière, and Mouchard.

I7I8, Nov 8, Paris Arrest [1. 334-335v autres Gens engagea autres Gens engagez au Service de la Compagnie d'Occident, à des Habitants qui passent à la Louisianne pour s'y establir (4 pp.).

[ff. 343-344

I7I8, Dec. 3I, Paris. Arrest . . pour la Prise de Possession de la Ferme des Domaines d'Occident, sous le nom d'Aymard Lambert, pour six Années qui commenceront le premier Janvier I7I9 (8 pp.).

[two copies, ff. $345-348 \mathrm{v}, 35 \mathrm{I}-358$

I726, Sept. Io, Fontainebleau. Arrest . . pour la Prise de Possession de la Ferme des Domaines d'Occident, sous le nom de Me. Pierre Carlier, pour six Années qui commenceront au premier Janvier I727 (8 pp.). [ff. 36I-364v

I727, Nov. Io, Fontainebleau. Déclaration du Roy concernant les Droits du Domaine d'Occident ( 3 pp.). Increase from 3 to $3 \frac{\mathrm{I} / 2}{2}$ per cent. for three years, to provide for the execution of the laws against foreign trade with the Islands of America.

21779.-1719, July 16, Paris. Arrest ... en fareur de la Compagnie des Indes (4 pp.). Assigning 25,000,000 livres in bank-notes to the Compagnie des Indes for use in Louisiana.

[ff. $3-4 \mathrm{~V}$

I7 I9, Oct. I. Journal du Travail de Messieurs les Directeurs de la Compagnie des Indes, pour l'Année qui commencera le premier Octobre I7IO (4 pp.). Schedule of the stated meetings of the various committees and of the general assemblies. The Committee on Louisiana (Dartaguiette, Gilly de Montaud, Corneau, de La Haye, Perinet, Savalete, de La Porte-de-Feraucourt) met daily from 8 a. $m$. to noon; the Committee on Beaver and Guinea (Mouchard, Piou, Le Gendre, Le Normant) met daily at the same hours; the Committee on the Cinq Grosses Fermes and on the Domaine d'Occident met on Fridays from 6 to $8 \mathrm{p}$. m.; the general assembly of the directors was held daily at noon.

[ff. $27-28 \mathrm{v}$

I719, Oct. 2. Départements de Messieurs les Directeurs de la Compagnie des Indes, en conséquence de leur Déliberation du 2 Octobre, I7Ig (7 pp.). The departments of Louisiana and of Beaver and Guinea were composed of the two committees listed in the preceding document; the department of Senegal and the Compagnie d'Afrique was composed of Fromaget, Gastebois, Morin, Raudot, Berthelot, La Porte, and Chevalier; the department for the administration of the Cinq Grosses Fermes, the Domaine d'Occident, and the Ferme Générale du Tabac was composed of Law, Berthelot, Piou, Le Gendre, \begin{tabular}{l} 
Mouchard, Desvieux, Raudot, La Live, and Gilly de Montaud. [ff. 29-33 \\
\hline
\end{tabular}

I7r. A printed document similar to the preceding document, but showing a separate department for the Ferme Générale du Tabac, composed of 
Mouchard, Piou, Raudot, Morin, Hardencourt, Le Gendre, Berthelot, Desvieux, La Live, and Lallemant.

[ff. 46-49

i719, Oct. 26, Paris. Arrest... pour la Prise de Possession de la Ferme des Domaines d'Occident, par la Compagnie des Indes, sous le nom d'Armand Pillawoine pour neuf Années, qui commenceront au premier Janvier I720 ( 8 pp.).

[ff. $38-4 \mathrm{IV}$

I720, May 16. Arrest . . qui ordonne que le Commerce du Castor demeurera libre et Convertit le Privilège Exclusif de la Compagnie des Indes cn un Droit qui luy sera payé à l'Entrée du Royaume, à raison de neuf Sols par Livre pesant de Castor gras, et six Sols de Castor sec (4 pp.).

[ff. I I6-II 7v

I720, July 2I, Paris. Arrest . . . qui ordonne l'Exécution de l'Édit du présent mois, qui accorde à la Compagnie des Indes la Jouissance à perpépuité de tous les Droits et Privilèges concernant son Commerce (I 2 pp.). Included in the privileges confirmed were the commerce with Louisiana, in accordance with the edicts of Aug. and Dec., I7I7, and the duties on Canadian beaver.

[ff. I $29-\mathrm{I} 33 \mathrm{v}$

I720, Aug. 29, Paris. Arrest . . . qui ordonne l'Establissement d'un Conseil pour la Régie et Administration Générale de la Compagnie des Indes, et contenant Règlement pour les Directeurs et Actionnaires de ladite Compagnie (8 pp.). [ff. I48-I5IV I720, Sept. Io, Paris. Arrest . . . qui subroge la Compagnie des Indes aux Droits et Prétentions appartenant à la Compagnie de Saint Domingue, tant en France qu'à l'Amérique et autres Lieux, avec le Privilège exclusif de fournit à l'Isle de Saint Domingue Trente Mille Nègres tirez de l'Estranger (4 pp.).

[ff. I 52-I 53v

1720, Sept. 27, Paris. Arrest . . . qui accorde et réiinit à la Compagnie des Indes le Privilège Exclusif pour le Commerce de la Côte de Guinée (4 pp.).

[ff. I 54-I 55v

I725, June, Versailles. Édit du Roy portant Confirmation des Privilèges accordez, Concessions et Aliénations faites à la Compagnie des Indes ( I p.). Including exclusive privilege of slave-trade, the concession of Louisiana, the beaver trade, sale of tobacco, etc.

[ff. 206-2 I I

I73I, Jan. 23, Marly. Arrest . . concernant la Rétrocession faite à Sa Majesté par la Compagnie des Indes de la Concession de la Louisiane et du Pays des Illinois (3 pp.).

[ff. $242-243$

21813-22060. Archives of the Chambre Syndicale de la Librairie et Imprimerie de Paris. (I 7 th and 18 th centuries.)

22014. Censorship reports on works for which license or permission is requested, I767-1788.-Reports, chiefly by Cadet de Saineville, on the following works relating to America are noted: Le Voeu de toutes les Nations et l'Intérêt de toutes les Puissance dans l'Abbaissement et l'Humiliation de la Grande Bretagne [I778, attributed by Barbier to Beaumarchais] (ff. I3-I4) ; Discours [Politiques, Historiques et Critiques] sur quelques Gouvernemens de l'Europe, by Comte [Claude Camille François] d'Ablon [Neuchâtel, I779I7SI] (ff. 35-36) ; Histoire de la Dernière Guerre commencée l'an I756 et finie par la Paix d'Hubertsbourg le I5 Février I763, Cologne, I769 (ff. 38 . 39v) ; Réponse à la Déclaration du Congrès Américain, translated from the English of Linde by M. Fréville [London, I777] (ff. 66-66v); Observations sur le Gouvernement et les Loix des Etats de l'Amérique, by Abbé [Gabriel Bonnot de] Mably [I784] (ff. I 59-I6I). 
22015. Censorship reports, continuation of 22014.-Reports by Bruys des Gardes, de Serionne, and Cadet de Saineville on the following works relating to America are noted: Voyage d'un Suisse dans différentes Colonies d'Amérique .. [attributed by Barbier to Girod-Chantrans], Neuchâtel, I785 (ff. 30-30v); De la France et des Etats-Unis ou de l'Importance de la Révolution de l'Amérique pour le Bonheur de la France ... . by Étienne Clavière and J. P. Brissot de Warville, London, I787 (ff. 4I-43); Réflections [sic] sur le Droit Public des Colonies Françoises, Espagnoles, et Angloises, d'après les Lois des trois Nations comparées entre elles, by [Émilien] Petit [Geneva and Paris, I778] (ff. I47-I47v); Des Avantages et des Inconvénients de la Découverte de l'Amérique: [Infuence de la Découverte de l'Amérique sur le Bonheur du Genre Humain, Paris, I787], by Abbé Genty (ff. I5I-I5Iv); La Science du Bonhomme Richard, ou Moyen Facile de payer les Impôts, Traduite de l'Anglois ["A Philadelphia et se trouve à Paris, I777"; translation by Quétant and Lecuy]. See B. Faÿ, Bibliographie Critique des Ouvrages Français relatifs aux Etats-Unis, I770-I800, p. Io (ff. 257-257v); Histoire du Gouvernement d'Angleterre avec la Description de ses Colonies .... . , by Vincenzo Martinelle, Florence, I776, translation from Italian (f. 306 ).

22016. Censorship reports, continuation of 22015.--Reports by Marshal de Ségur, Cadet de Saineville, and Bralle, on the following works relating to America: MS. entitled "Histoire de la dernière guerre dans les quatre parties du monde" (ff. 6-II); Le Commerce de l'Amérique par Marseille, by Chambon, Avignon, I764 (ff. 46-47v) ; Recueil des Loix Constitutives des Colonies Anglaises Confédérées ... . [traduit de l'Anglois, Paris, I778, by Regnier] (ff. 49-49v); memoir on an economical stove invented by Franklin and $M$. Desarnold of Lyon, I788 (f. 56) ; MS. entitled "Lettres d'un membre du Congrès Américain à divers membres du Parlement d'Angleterre ", by Vincent of Rouen [L'Américain aux Anglais, Philadelphia, I 78I] (ff. 72-73v); Essais Historiques et Politiques sur les Anglo-Américains, by Hilliard d'Auberteuil [Brussels, I78I] (ff. 200-202v).

22047.- "Calendrier de Boston pr l'année I777, No. 2." Translation. A precept or observation for each day, e.g., Jan. I, "Que d'amis aujourdhuy!

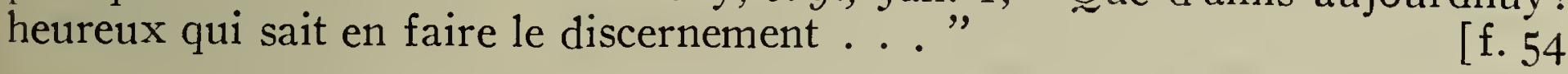

\section{(COLLECTION ANISSON-DUPERRON.)}

22061-22193. Collection Anisson-Duperron. This collection is composed of the archives of the service of inspection of books and printing; it was formed by Joseph d'Hémery, inspecteur de la librairie, I748-1773, and by Etienne Anisson-Duperron, director of the Imprimerie Royale. A full account of the service of inspection as well as a detailed list of the documents in the collection are to be found in the Inventaire de ia Collection Anisson sur l'Histoire de l'Imprimerie et la Librairie principalement à Paris (MSS. Fr. 2206I22193), by Ernest Coyecque (Paris, I900, 2 vols.). The items listed below, which have an interest for American affairs, have been selected from the Inventaire, no examination of the MS. volumes having been made.

22073. Privilèges et permissions, I729-I 789.

I77I, Apr. 20, Paris. Circular from the syndic addressed to printers, enquiring if they have any MSS. relative to the Voyage en Califormie, of Abbé Chappe. (Broadside.)

22096. Libelles deffamatoires et livres prohibés, I 595-1767.

[no. I 33

I 764 , Apr.-July. Correspondence of d'Hémery, Sartine, Duval, Kerlérec, and others, relating to a satire by [Grondel?] against Kerlérec, late governor 
of Louisiana; Lettre d'un Officier de la Lonisiane à $M$. . . commissaire de la Marine à... (New Orleans, I764).

22098. Libelles deffamatoires et livres prohibés, I766-1 768 .

I767, Mar. Correspondence of Sartine and d'Hémery respecting the prohibition of the work Quand et comment l'Amérique a été peuplée, and procès-verbaux of its seizure in book-stores.

22102. Libelles deffamatoires et livres prohibés, I 7 I 7 -I 789.

1778, Dec. 21, Versailles. Arrêt ordering destruction of Apologie du Commerce. (Ptd., I779, 2 pp.)

[110. I7

I78I, May 25. Arrêt of the Cour de Parlement condemning the Histoire Philosophique... des Établissemens ... dans les deux Indes, of Abbé Raynal. (Ptd., I78I, I2 pp.)

[no. 26

1786, May 5, Versailles. Arrêt revoking the license of the Triomphe $d u$ Nowvean Monde. (Ptd., I786, 3 pp.)

[no. 4I

22119.-1704-I706. Arrêts relating to the plagiarism of Delisle's maps by Nolin. [nos. 49, 5I, $5^{2}$

22137. Jugements des censeurs sous l'administration de Malesherbes: A-R, I749-I759.

Judgment by Butel Du Mont on MS. entitled, "Sur les véritables limites des possessions anglaises et françaises en Amérique".

[nos. 74-76

I75I, Mar. 4, Paris. Judgment by Abbé Geinnz on MS. entitled, "Histoire militaire des Suisses au service de la France".

[no. I04

I75I, Aug. 20, Paris. Abbé Geinoz to Malesherbes. Favorable judgment on MS. entitled, "Histoire de l'Établissement de l'Hôtel-Dieu de Québec".

[no. 105

22139. Jugements des censeurs sous l'administration de Malesherbes: $\mathrm{D}-\mathrm{V}$, I748-I759. Louisiane".

Judgment by Simon on MS. entitled, "Mémoires historiques de la

22144.-I757, I759. Corespondence of Malesherbes, Berryer, and others respecting the publication by Bellin, Antilles Anglaises (nos. 52, 53), the translation of the MS. by Father Gumilla entitled, "Histoire de l'Orénoque" (no. 56), and the MS. "Histoire des Pêches" (no. 74).

22147.-I759, I760. Correspondence of Berryer, Malesherbes, and others relating to MS. of de Régis "sur la Louisiane" (nos. I6I-I63), and to request for license for La Virginie (nos. I93-I94).

22154.-I772, May 22. Order by Sartine against Histoire Philosophique et Politique des Etablissements et du Commerce des Européens dans les deux Indes [by Abbé Raynal].

22179.-1772, Dec. I9, Versailles. Arrest . . . qui supprime Histoire Philosophique et politique des Établissements et du Commerce des Européens dans les deux Indes.

[no. 2 II

22180.-1777, June I3, Versailles. Arrêt against printers of the abstract of Abbé Raynal's Histoire Philosophique des ... deux Indes. (Ptd., 3 pp.) [no. 64

I778, Dec. 21, Versailles. Arrêt ordering destruction of Apologie du Commerce. (Ptd., 2 pp.)

[no. 195

22313.- " Relation d'un naufrage arrivé le 3 I Aoust sur les côtes du Canada dans le fleuve St. Laurent en mil sept cent vingt-neuf." $C f$. various documents relating to the wreck of the Eléphant, in Arch. Colonies, CII, A, 5 I. 


\section{(COLLECTION DANGEAU.)}

22593-22822. Collection Dangeau. The collection of papers formed by Louis de Courcillon, Abbé de Dangeau (I643-1723), is of interest for the purposes of this Guide chiefly for the correspondence of Esprit Cabart de Villermont (I628-I 707). Cabart de Villermont assiduously collected news of all sorts, which he used for the Mercure or for gazettes à la main, and has a great number of correspondents. Among them was Michel Bégon, intendant of the marine at Rochefort, who kept Villermont informed with regard to interesting matters that came to his attention, particularly those relating to the French colonies, the projects of Iberville, etc.

22623.-Dated lists of early governors, intendants, etc., of French possessions in America.

[ff. 7I-72, 477

22684.-I697, Mar. I3, Feb. Lists of vessels and naval forces under command of the Marquis de Nemond and of Du Magnon, fitted out at Brest and Rochefort "pour aler sur les cotes de l'Amérique septentrionale".

[ff. I 78v, I95v, 300, 300v

I697, Jan. Note on news of capture of Fort St. Jean, Newfoundland, by a French force.

[f. 284

I697, Feb., Mar. 29. Lists of vessels with names of officers, etc., for Placentia, Acadia, and Canada.

22768. "Marine I."

[ff. 290, 292

I659-I68I. "Marine Gazette." Information, extracts from gazettes, etc., relating to affairs of the marine and related matters. Numerous items relate to America: e.g., I663, June I6, Bishop of Petraea has embarked on the vessel of Capt. Gargot for New France; I664, Mar. 2, Marquis de Tracy goes to West Indies as lieutenant general; I667, Jan. 28, arrival of La Barre at Martinique, capture of Antigua from the English. Of slight value.

[ff. $35-80$

Rough notes, lists, etc., of officers and officials of the marine and of the colonies.

22769. "Marine II."

[ff. 8I-I 22,236

I664-I689. Lists of vessels in commission, rosters, armaments, etc. Slight value.

22770. "Marine III."

[ff. $3^{8}$ and passim

I696, Mar. I7. List of vessels, rosters, and armaments for Acadia and Canada.

[f. II $5 \mathrm{v}$

I698. "Armements pour les Colonies." Lists of vessels, etc., for North and South America.

[ff. I $38-138 \mathrm{v}$

I70I. List of vessels, rosters, armaments, etc., of various squadrons: squadron of de Coëtlogon for Mexico; squadron of Châteaurenault for the West Indies; squadrons for the Mississippi, Cayenne, and the West Indies.

[ff. 20I-204v

I 702. Similar lists: vessels for the Mississippi, West Indies, and Canada.

22771. "Marine IV."

[ff. 277-28I

[I II8?] Lists of officers in the colonies: Iles du Vent, Santo Domingo, Canada, and Ile Royale.

[f. I75

I I I8, June 28. List of colonial officers created chevaliers of the order of

St. Louis: Iles du Vent, Santo Domingo, Canada, Ile Royale, and Louisiana. 
22772. "Mémoire sur le Commerce des Hollandois."-Ch. XIV. is clevoted to the trade of the Dutch West India Company.

22799. Letters to Cabart de Villermont, r652-1684. 462.

[1684.] Villermont to Abbé Bernou. (A. L. S.) Ptd. in Margry, II.

[ 684 ] Abbé Bernour to Villermont. (A. L. S.) Ptd, ibid., [ff. 76-76 p. 464 .

[ff. $77-77 \mathrm{v}$

[1684.] Abbé Renaudot to Villermont. (A. L. S.) Ptd., ibid., p. 460.

[f. 78

r684, May 5, Rochefort. Beaujeu to Villermont. (A. L. S.) Ptd., but under erroneous date of June, I684, ibid., p. 426.

I684, July ro, La Rochelle. Beaujeu to Villermont. (A. L.) Ptd., ibid., p. 448.

[ff. 92-95

I684, Mar. I4, Martinique. [Michel] Bégon to Villermont. News, silkworms, hospital nuns, price of sugar. (L. S.)

[ff. I $34^{-1} 35$ I684, May 2I, June 8, I5, I8, 29, Rochefort. Beaujeu to Villermont. Ptd. in Margry, II. 421, 43I, 433, 436, 440. [ff. I43, I45, I47, I49, I 58 r684, July 7, [Paris]. Villermont to [Abbé Renaudot]. (A.L.S.) Ptd., ibid., p. 46r.

[f. I64 1684, July 22, Aug. I3, 27, Rochefort. Machault Rougemont to Villermont. (L. S.) Ptd., ibid., pp. 454, 457, 458 [ff. 179, r98, 208 I684, July 22, [Rochefort]. Machault Belmont to Villermont. (L.S.) Ext. ptd., ibid., p. 456 .

[ff. I8I-I8Iv r684, Oct. 29, Rochefort. [Machault Rougemont] to Villermont. Conjecture as to La Salle.

[ff. $254^{-2} 54 \mathrm{v}$

"Mémoire des Curiositez de l'Amérique envoyées par Monsieur de Chasteau du Bois à Monsieur de Villermont fils." List of natural history specimens from the West Indies and South America.

22800. Letters to Cabart de Villermont, I685-1689.

I685, Apr. 8. Villermont to $\longrightarrow$. Refers to La Salle's search for mouth of Mississippi. (A. L. S.)

[ff. I $3-\mathrm{I} 3 \mathrm{v}$

r685, Apr. ro, May r, Sept. 4, Oct. r6, Rome. Abbé Bernou to Villermont. Small store which the court sets by the French colonies; desire for success of the Mississippi colony; blamable conduct of La Salle with his friends; observations on the Radissons. (A. L. S.) An extract of the letter of Sept. 4 is ptd. in Margry, II. 609.

[ff. I6, I8, 71, 85 1685, Aug. 7, Toulon. Chevalier de St. Geniès to Villermont. (A. L. S.) Extract relating to La Salle ptd. in Margry, loc. cit.

[ff. $56-57$ r686, May 4, Marseilles. Michel Bégon to Villermont. Embarkation of faux sauniers for Santo Domingo and Cayenne. [ff. I I6-I i 8 1687, Jan. 25, Aug. r 5, Fort St. Pierre, Martinique. Dumaits de Goimpé to [Villermont]. Complaints against the Pères de la Charité ; news of La Salle brought by a French prisoner escaped from Vera Cruz. (A. L. S.)

[ff. I $46, \mathrm{I} 64$

I688, Dec. I9, La Rochelle; r689, Jan. 9, Rochefort. Michel Bégon to Villermont. News from Canada; list of curious objects received from Canada. (L. S.)

[ff. 180,186

1689, Mar. 27, La Rochelle. Denys Fronçac to Villermont. Complains of extension of jurisdiction of the government of Acadia. (A. L. S.)

[ff. 222-223v

r689, June I3, Toulon. Courcelles to [Villermont]. References to Frontenac and La Salle.

[ff. $250-252$ 
I689, July 4, Quebec. "Copie d'une lettre escrite . . . à la Rochelle par son frère." Success of Iberville against the English on Hudson Bay.

22802. Letters to Cabart de Villermont, I692.

[ff. $26 \mathrm{I}-262 \mathrm{v}$

I692, Mar. I I, Rochefort. Michel Bégon to Villermont. Iberville commands the 36-gun frigate Poly; has not yet arrived; convoy for Canada leaves in a month.

[f. I7 I692, Mar. 25, Rochefort. Iberville to Villermont. Asks for information respecting the English Hudson's Bay Company and Damien [Bering] Strait. (A. L. S.)

[ff. $27-28$ I692, Apr. 26, La. Rochelle. Longueuil to Villermont. Hopes to leave in four or five days; Iberville too busy to write; will send news of the country whither they are going. (A. L. S.)

[1692, Oct.] Memoir on the Joly, lost near Placentia with cargo.

[ff. 63-64

I692, Nov, 6, St. Martin de Rhé. Michel Bégon to Villermont. [f. 210 from Canada of Iberville's fleet. (A. L. S.)

22803. Letters to Cabart de Villermont, I693.

I693, Feb. 3, Dec. 28, Fort St. Pierre, Martinique. D'Harbourville to \begin{tabular}{l} 
Villermont. Naval operations, no danger from English, etc. [ff. 30, 406 \\
\hline
\end{tabular} 1693, Apr. 19, Dec. 24, Rochefort. Michel Bégon to Villermont. Histories of Mexico and Florida ; arrival of vessels from Canada. [ff. I2I, 402 I693, July 8. Martinique. De Vassor to [Villermont]. Affairs of West Indies; English attack on Martinique.

[f. 209 I693, Sept. 2, Montreal. Henri de Tonty to Villermont. (A. L. S.) Ptd., under date Sept. II, in Margry, IV. 3-5. [ff. 285-285bis I693, Sept. I2, Montreal. Henri de Tonty to Villermont. Obliged to leave in haste for the Ottawa; sends this letter by M. de La Mollerie, who will give him news of the country; hopes for news of Villermont. (A. L.S.) [f. 290 I693, Sept. 20, Rochefort. — to Villermont. News from West Indies and America; English fleet has departed for New England, but does not think it will go to Quebec.

[f. 30I

I693, Sept. 27, Montreal. [Alphonse] de Tonty to Villermont. Thanks him for his letters; his brother-in-law, M. de La Mollerie, who takes this letter, will give him all the news of the country; bespeaks his protection. (A. L.S.)

22804. Letters to Cabart de Villermont, I694.

I694, Mar. I7. Mission of the Immaculate Conception, Fort St. Louis of the Illinois. Father Jacques Gravier to Villermont. Flattered by his desire to correspond with him; is far from centres of news; [Alphonse] de Tonty is at Montreal, his brother [Henri de Tonty] is commandant here; scandalous life led by M. Deliette, cousin of Tonty, during the two years absence of the latter. (A. L.S.) Cf. MSS. Fr. 6453, f. I8.

[ff. $59-60 \mathrm{v}$ 1694, Mar. 21, Rochefort; Apr. 20, Dec. I4, La Rochelle. Michel Bégon to Villermont. News of Iberville; vessels for Acadia ; arrival of Father Bigot to embark for Canada; arrival of vessels from Canada, and news from that country.

[ff. $65,92,32$ I

I694, Oct. 30, Quebec. Frontenac to Villermont. Glad to continue correspondence with him; refers him to his former secretary, Le Barrois, for an account of events in Canada; attitude of the Iroquois. (A. L.S.)

I694, Nov. II, Martinique. De Vassor to [Villermont]. Damage caused by hurricane in Sept.; hostilities with the English.

[ff. 292-293 
I694, Sept. 29, Montreal. [Alphonse] de Tonty to Villermont. Failure of his brother-in-law, M. de La Mollerie, to see Villermont; is sending an account of affairs to $M$. de Callières, who will communicate it to him; his brother [Henri de Tonty] will go to France next spring, and he himself will take his brother's place in the Illinois. (A. L..S.)

[ff. 309-309v

22805. Letters to Cabart de Villermont, I695.

I695, Jan. 4, 29, Rochefort. Michel Bégon to Villermont. Sends scalp of Indian chief Kakavet, who deserted to the English. Report of deer in the Mississippi country as large as elephants, with antlers I8 feet in length.

22806. Letters to Cabart de Villermont, I696-1698.

$[\mathrm{ff} .7,40$

I696, Apr. 3, Rochefort; I697, Mar. 9; I698, Nov. 27, La Rochelle. Michel Bégon to Villermont. Has delivered letters to Iberville. Fleet for protection of Newfoundland. Indecision of directors of the Compagnie de la Mer Pacifique.

[ff. I 8, I06, 336

I69I, Sept. 3I, Montreal. "Marie anne de bailai de Tonty" [Anne Picoté de Bellestre, wife of Alphonse de Tonty] to Villermont. M. de Tonty is still at Michilimackinac; danger of ruin because of restrictions on the fur trade; gratitude for his aid in the "affaire de Lion". (A. L. S.) [ff. 278-279

I698, Nov. 8, I9, Havre. Beaujeu to Villermont. Extracts ptd. in Margry, IV. 293.

22807. Letters to Cabart de Villermont, I699.

[ff. 305,320

I699, May 3, July I3, Nov. 6, Havre. Beaujeu to Villermont. News from Martinique. Doubts success of Iberville's establishment on the Mississippi. Loss of the Marin, from Canada. An extract from letter of July I 3 is ptd. in Margry, IV. 299.

[ff. I 44, 21 4,336

I699, June 30, July 5, La Rochelle. Michel Bégon to Villermont. Iberville's establishment on the Mississippi. Extract from letter of July 5 is ptd. in Margry, IV. 298.

22808. Letters to Cabart de Villermont, r 700.

[ff. 20I, 205

I 700, Aug. 8, Sept. 2, Oct. 3, Oct. 28, Nov. I3, 29, Rochefort or La Rochelle. Michel Bégon to Villermont. Fears for Iberville, now overdue.Arrival of Iberville, his illness and plans for support of his colony.-Iberville's men do not appear pleased with the colony, which is at mercy of Spaniards. Has seen Iberville and the "curiosities" he will send to the court.-Conversations with Iberville and his officers; miserable condition of Indians on the Mississippi, regrettable that leaders of expeditions of discovery are not sufficiently learned to take necessary observations and to make maps.-Iberville goes soon to the court to take orders for his next voyage; his wife, who will remain in Paris, is " une Canadienne très raisonnable et bien faite".

22809. Letters to Cabart de Villermont, I 700.

[ff. I6, 62, I I $3,169,204,225$

I700, Jan. I9, 26, 3I, June 8, I2, Rochefort or La Rochelle. Michel Bégon to Villermont. Ignorance of Nolin's intentions as regards the map of the Mississippi.-News from the West Indies.-Vessels fitting out for Newfoundland and Canada.-Return of $M$. de Surgères from the Mississippi.Communicates 'extract of letter to Marshal d'Estrées. [ff. 32, 4I, 49, 246, 254 I700, Mar. 5, Lorient. L'Anrivaud to Villermont. News of revolt of filibusters in Santo Domingo.

I70o, Mar.-May. Letters from La Courbe and Gallifet, in Santo Domingo.

[ff. 94, I $72,183,203$

[I700, Apr. 12.] "Liste des officiers qui embarquent sur 1'Escadre commandé par M. De Pointis.”

[ff. I 4I-I 4IV 
[I700, June I2.] Bégon to Marshal d'Estrées. Information relating to the Mississippi, obtained from M. de Surgères. (Ext.) [ff. 255-256
[ I700, June 21, Havre. Beaujeu to Villermont. Recalls that he had always foretold the failure of the Mississippi settlement, " mais, ma foy je me suis moqué d'eux [Iberville and his associates?] et ne leur ay dit que ce que j'ay voulu qu'ils sceussent".

[ff. $274-275 \mathrm{v}$ I joo, June 23, Lorient. Mauclerc to Villermont. Opinion as to success of the Mississippi colony.

[f. 276

22810. Letters to Cabart de Villermont, I7OI.

I701, Jan. 22, Feb. 8, Mar. 5, Apr. I3, 23, May I0, I4, I7, June 2I, 25, July 3, 7, Aug. 7, 9, II, Sept. 4, I 7, 22, Oct. 2, Nov. I9, 29, Dec. 3, I3, 27 , Rochefort or La Rochelle. Michel Bégon to Villermont. The vessel for Biloxi detained by contrary winds.-Departure of the Enflammé, Capt. La Ronde, relative of Iberville, for the Mississippi.-Vessels fitting out for various American destinations.-Iberville expected at any moment.-Arrival of Brouillan, appointed to command in Acadia.-Changes in officers for Cayenne and Canada.-Departure of the Gironde for Acadia, carrying Brouillan.News of pirates in waters of Santo Domingo.-The Avenant sails for Placentia or Acadia.-Equipment of another fleet for Quebec; news from West Indies.-Vessels for Quebec and the Mississippi.-Letter for Tonty will go by the Jeanne Cornélie; examination of Mathieu Sagean, who sticks to his narrative, and who has been sent to the Mississippi on the last vessel.-Narrative of Mathieu Sagean; news from West Indies; vessels fitting out for the Mississippi.-Discoveries of Beauchesne in the Pacific and South Atlantic.Report of large squadron cruising off Havana.-Iberville has received his orders; composition of his fleet.-Iberville detained by contrary winds.-Departure of Iberville; Mathieu Sagean.-Departure of Iberville from La Rochelle, Sept. 2I.-The Seine to bring masts from Canada; news of peace with the Iroquois.-Epidemic at Quebec ; news of settlement of Detroit.-Dissatisfaction with masts from Canada.-Colony at Detroit.-La Mothe [Cadillac] to command at Detroit; prospects of the colony. [ff. $22,39,70, \mathrm{I} 32$, I $55,195,206,212,245,249,253,257,304,306,310,343,354,358,370$, 4IO, 4I7, 42I, 427, 444

I 7oI, Nov. I4, Cap Français, Santo Domingo. De Vernoy to Villermont. Voyage from Brest; will go to Pensacola with Iberville, who is taking on supplies, and thence to Vera Cruz.

22811. Letters to Cabart de Villermont, I702.

I702, Jan. IO, 21, 31, Feb. I8, 24, Mar. I4, June I, 27, July II, 27, Aug. I5, Nov. 4, Dec. IO, 24, Rochefort or La Rochelle. Michel Bégon to Villermont. Small value of discovery of maple sugar; has seen a MS. history of all the wars in Canada with the Indians.-Opinion of a man from Quebec that Detroit will be prejudicial to Canada.-Mathieu Sagean found no one on the Mississippi to credit his narrative.-The Enflamme returning from the Mississippi, has put in at Falmouth; has not learned of confirmation of narrative of Sagean at either Manates [New York] or Boston.-Arrival of Marquis de La Mina, former president of Panama, after imprisonment.-Death at Rochefort of the governor of Porto Rico; the governor of Cuba is still there.Arrival of Beauharnois, newly appointed intendant of Canada; to sail for his post.-Mathieu Sagean an impostor; news from the Mississippi.-Arrival of a Jesuit from the Mississippi.-English reported to have heard of gold in country west of the Mississippi.-Iberville purchases a fine estate six leagues from La Rochelle, and his brother M. de Sérigny offers 86,000 francs for an estate, “ce qui nous fait co[nvenir] que le Mississipi n'est pas un si mauvais 
pais qu'on l'a voulu dire".-Corrects news of attacks on the Gironde and on Port Royal by the English.-News of defense of Acadia.-Arrival of M. and Mme. de Champigny on the Loire; news of Canada.

[ff. 7, I2, 24, 36, 42, 5I, I4I, I72, I76, I 98, 21 4, 305, 347, 358 I702, Jan. I2, Falmouth. Roche de Crassay, clerk [?] of the Enflammé, to Villermont. Voyage from Santo Domingo; news of hurricane at mouth of Mississippi in Aug., I 700.

[ff. 9-9v

I702, July I9, Paris. De Grimarest to [Villermont]. News from Beaujeı of arrival of Iberville and his brother on May 9 at Havana from the Mississippi. The officers of their vessels had little good to say about the colony.

[f. 192

r702, Sept. 25, Cartagena. Mauclerc to his father at Lorient. Naval action in Gulf of Mexico between English and French. (Copy.) [f. 359

22812. Letters to Cabart de Villermont, I7O3. Acadia.

I703, Mar. 22. Report of assay of minerals from various parts of

I703, Apr. I6, St. Renan. - to [Villermont]. News of attack on St. Augustine, Florida, by English and Dutch vessels. [ff. 7I-72v

I703, Apr. 27, Rochefort. Extracts from a letter of M. d'Angeville, garde de la marine in the squadron of Du Casse, containing an account of the voyage to Cartagena, Porto Bello, Havana, etc.

[ff. $8 \mathrm{I}-82$

r703, May I3, 22, 27, July ro, Rochefort. Collinet to Villermont. The Hercule, laden with building materials, is reported to be bound for the Mississippi.-Respecting plan to send respectable girls to the Mississippi.-Same subject.-Survey of the Héros. [ff. I I 4, I 26, I38, 236

I703, May 20, June 24, Rochefort. The Loire has sailed for the Mississippi; knows nothing of girls to be sent there.-English operations in the West Indies.

22813. Letters to Cabart de Villermont, I 703.

I703, Sept. 8, Rochefort. Collinet to Villermont. Work on vessels composing squadron of Iberville; conjectures as to its destination. [ff. $65-65 \mathrm{v}$

I703, Sept. 27, Oct. 9, I3, 30, Rochefort. Gallinet to Villermont. Squadron of Iberville; conjectures as to its destination.-Lists of vessels and officers in squadron.-Iberville secures sailors and supplies.-Expedition of Iberville is abandoned; girls for the Mississippi.

[ff. 85, IO2, II 2, I $4 \mathrm{I}$

I703, Oct. 30, Nov. 7, r8, Dec. I, 27, Rochefort. Michel Bégon to Villermont. Illness of Iberville; arrival of girls for the Mississippi.-Grave nature of Iberville's illness.-Brother of Abbé Boutard, waiting to sail for the Mississippi, is wholly without money.-News from New foundland fisheries.-Has orders not to embark marine guards on vessels for the Mississippi.

22814. Letters to Cabart de Villermont, I704.

[ff. I $40,158,184,207,250$

I7or, Feb. I, May 3I, July 8, Rochefort. Michel Bégon to Villermont. The Pelican, Capt. Du Coudray, goes alone to Louisiana; no guards are on board because of the girls and the passengers.-Vessels for Canada, Placentia, and Acadia.-Since the first of the year I 5 vessels have arrived safely at La Rochelle from the colonies, and 4 have been captured. [ff. 35, 207, 267

I704, Feb. I8, Rochefort. Renonville to Villermont. Du Coudray, commanding the Pelican, bound for Louisiana, is not of the Iberville faction.

[f. $5^{2}$

I705, Mar. 24, Rochefort. Michel Bégon to Villermont. Return of the Pelican; the girls who went out on it to the Mississippi were married at 
once; Du Coudray is brother of Mme. Bégon, the writer's sister-in-law ; bad condition of Spanish colonies; danger from the English.

22815. Letters to Cabart de Villermont, I705-1707.

I705, June 27, La Rochelle. Michel Bégon to Villermont. M. Raudot is awaited; vessels for North America cannot leave without him.

[f. I2I

I 706, Sept. I 5, Brest. De Montholon to [Villermont]. Has learned of arrival of Iberville's squadron at La Rochelle, and that Iberville is dead.

22819. Letters to Abbé Dangeau, r676-I707.

[f. 237

1692, Apr. 28, Paris. Villermont to [Abbé Dangeau]. News of the West Indies in a letter from Father de La Nourse in Martinique.

[f. 98

I7oo [Jan. II], Paris. News from London of an English company organized for recovering treasure from a Spanish galleon wrecked near Jamaica 20 years before.

[f. I 39

I70I, Aug. I5, Paris, Villermont to Abbé Dangeau. Observations on narrative of Mathieu Sagean.

[ff. I76-I $79 \mathrm{v}$

'r706, Nov. 4, Rochefort. Michel Bégon to Villermont. The Chevalier de Torsi, on the Profond, should return from Placentia and Canada before the end of the year. Escort of a merchant fleet for America.

[f. 287

23022. "Traité historique et politique du Commerce de toutes les Nations dans les divers endroits du Monde ..." r694.-Of slight interest for American commerce.

23042.-[ [6IO-1643 ca.] "Advertissement qu'on donne touchant la navigation, traffic, pescheries, commerce et autres choses appartenants à la mer du Nort et de la Mer Oceane et des Indes où traffiquent les Rebelles de . . . Holande, Zélande, et Frize . . ." Except for a section devoted, to Brazil (ff. $67-67 \mathrm{v}$ ), of slight interest for American commerce.

[ff. $55 \mathrm{v}-90 \mathrm{~V}$

[1610-1643 ca.] "Mémoires et advis donnéz au Roy sur le faict de la Navigation et commerce de l'Amérique et les ordres des armées d'Espagne." Deals in part with the revenue accruing to the Spanish crown from its American possessions.

[ff. 105-I 22

23203. Papers and letters of Henri Auguste de Loménie, Comte de Brienne.

I65I, Jan. io. Extract from the deliberations of the Compagnie de la Nouvelle France, nominating three associates to the king, one of them to be appointed governor of New France for a term of three years; accompanied by a collated copy of commission to De Lauzon, Mar. 20, I65I, as governor in all the extent of the St. Lawrence in America.

[ff. 33-34

Commission to Louis Dailleboust as lieutenant general in the St. Lawrence in place of Montmagny. (Undated copy.)

[ff. $37-37 \mathrm{v}$ Commission to Brisonnier as commander of Acadia. (Undated rough draft.)

[f. 39

23225.-I705, Jan. 22, Mar. I4, Farnham, [England] ; I706, Oct. 3, Nov. 21 ; I707. Jan. 8, Feb. 28, Mar. 24, Apr. 26, June 25, July I3, Petersfield, [England]. Jean-Baptiste de St. Vallier, bishop of Quebec, prisoner in England, to [Cardinal de Noailles]. Ecclesiastical affairs of Quebec; appointment of coadjutor during his absence : organization of the chapter of Quebec ; revenue of the chapter and the seminary, etc. (A. L.) [ff. 280-299v

[I705-1707.] "Mémoire de ce qui c'est passé entre l’Évêque de Québec et Mrs. des Missions Étrangères de Paris et de Québec depuis le dernier voyage que j'ay fait dans mon diocèse" [by St. Vallier, bishop of Quebec], accompanied by copies of various pertinent documents.

[ff. $300-302 \mathrm{v}$ 
“ Mémoire de la conduite que j'ay gardée depuis vint et deux ans d'épiscopat avec Mrs. des Missions Étrangères et de celle que ces messieurs ont gardée avec moy." [By St. Vallier, bishop of Quebec.] Cf. C. de Rochemonteix, Les Jésuites et la Nouvelle-France an XVIIme Siècle (Paris, I895I896, 3 vols.), III. 3i6-3i $\mathrm{n}$.

23551-23555, 23577-23588. Copies of the negotiations of President Jeannin for Truce of Antwerp, I607-1609. See above, MSS. Fr. 7086-7090.

23594-23596. Letters of Antoine Lefèvre de la Boderie, ambassador in England i606-1610. See above, MSS. Fr. 7108-7109.

23663-23673. Copies of the register of minutes of the Conseil de Régence, I7I5-I7I9,-Cf. above, MSS. Fr. 6800.

23663. Minutes of the Conseil de Régence, I7I5, Sept. 28-Nov. 30.

I7I 5, Oct. I. Permission to Cassard to make use of royal vessels in transporting from Martinique and Santo Domingo effects of vessels captured as prizes.

[f. 6

I7I 5, Oct. I 5. Decision to take action with respect to the property of the inhabitants of Placentia which has been taken by the English.-Decision to grant a moratorium of three months to merchants on whom bills of exchange have been drawn, in consequence of the reduction by 50 per cent. of the Canadian card money.

[ff. 29-29v

I7I 5, Oct. 22. Decision to grant permits to vessels to go to America, subject to penalty of confiscation if they go to the South Sea.

[f. $46 \mathrm{v}$

I 7 15, Nov. 19. Decision respecting vessels of St. Malo engaged in trade in the South Sea.-Decision to appoint a new commission to settle the affairs of the Iberville expedition.-Decision respecting complaints by merchants of Nantes and La Rochelle against the exaction of excessive duties by the governor and intendant of Martinique and Guadeloupe.

[ff. I I9-I $20 \mathrm{~V}$

I715, Nov. 26. Decision against admission of Protestants to Santo Domingo.

[ff. I $48 \mathrm{v}-149$

23664. Minutes of the sessions of the Conseil de Régence dealing with matters presented to it by Marshal d'Estrées, president of the Conseil de Marine, I7I 5, Dec. 3-17I9, Aug. 28.

I7I5, Dec. IO. Decision respecting protection of merchants against abusive measures by governors and officers in America.

[f. $4 \mathrm{~V}$

I7I5, Dec. I7. Decision to instruct the governor of Martinique to negotiate for the cession of English claims in St. Lucia in return for cession of islands of St. Martin and St. Bartholomew.

[f. 7

I7I6, Feb. II. Decision to approve a memoir proposing that 4 companies, Ioo faux sauniers, and Ioo girls be sent to Louisiana for the maintenance of the colony.

I7I6, Mar. I7. Decision to protest against seizure of a French vessel by the governor of Porto Rico, and to demand his removal.

I 716, Mar. 3I. Decision on request for hearing by Thibout, Thiberge, and Brisacier of Quebec.

I 7 16, Apr. 28. Decision to grant letters patent to the Brothers of Charity for the administration of the hospital at Ile Royale.-Decision to revoke commissions given by La Mothe Cadillac, former commandant of Detroit, in his own name, and to substitute for them commissions running in the name of the king.-Decision to limit to 25 the number of congés (trade permits) to be granted annually by the governor of Canada, and to require them to be signed by the governor, the intendant, and one councillor.-Decision to approve pro- 
posal to empower the governor, intendant, and council of Canada to pass on claims by the Indians for timber taken from them.

[ff. $38 \mathrm{v}-40$

I7I6, May 5. Refusal of appeal by d'Auteuil.-Decision to permit the Seminary of St. Sulpice at Montreal to present claims for unclaimed estates of deceased persons.-Decision to authorize the raising of 4000 livres from the inhabitants of Montreal for the construction of ramparts of masonry.Decision to grant request for letters patent authorizing the Recollects to found an establishment in Ile Royale.

[f. 4I

I7I6, May I9. Approval of draft of an arrêt to prevent trade between the Indians of Canada and the Dutch of Orange.

I7I6, June I6. Decision to refer to the Conseil Supérieur of Quebec the dispute between the Sieur L'Artigue and the Sieur de Costebelle, over the capture of the fort of St. John.

[f. 50

I7I6, Oct. 5. Decision to renew the order against sending merchandise to Louisiana.

I7I6, Oct. I2. Decision to unite all lands in Louisiana to the domain, and to issue new grants.

[f. 73

I7I6, Oct. 26. Decision to annul, at request of Crozat, two arrêts of the Conseil Supérieur of Louisiana against his right to confiscate vessels importing merchandise in infringement of his privilege.

[f. 77

I7I7, Jan. II. Decision to consider the organization of a company to carry on the enterprise in Louisiana which Crozat declares himself unable to continue.

[f. 93

I7I7, Mar. 8. Decision respecting dispute between the Bishop of Quebec and the superior of the seminary of the Missions Etrangères. [f. IOOV

I7I7, Apr. I2. Decision to retire the card money of Canada. [f. I04

I7I7, May IO. Decision respecting the insertion in Canadian contracts of land tenure of clauses contrary to the custom of Paris.

[f. I08

I7I7, May 3I. Approval of draft of edict establishing a judicial tribunal in Ile Royale.

[f. I Io

I7I7, Dec. 20. Decision to grant lands to the Jesuits for their Iroquois mission, and Iooo livres for a fort.

[f. I32v

I7I8, Mar. I4. Decisions respecting the creation of courts of admiralty in the American colonies, the participation of merchant vessels in the Labrador fisheries, Canadian card money, and supply of copper money to the colonies.

[f. I42

I7I9, Feb. 27. Permission to the Sieur Vincelot to transfer his banalité from watermills to windmills, on condition that inhabitants shall have the right to have recourse to neighboring watermills when wind is lacking.

[f. I72

24221-24222. Fragments of narratives of the voyages of [Michel Jajolet] de La Courbe in the West Indies, I696-1699.

24224. "Navigation et discouvernement de la Indie supérieure, faicte par moy Anthoine Pigaphete, Vincentin, chevalier de Rhodes", I 5I9-I 522.-One of the three French MSS. of Pigafetta's narrative of Magellan's circumnavigation. Cf. J. A. Robertson, Magellan's Voyage around the World (Cleveland, I906). MS. Fr. 5650, not examined, is another copy.

24225. "Histoire Naturelle; ou la fidelle recherche de tout ce qu'il y a de rare dans les Indes occidantalles; où il est traité en général et an particulier. des simples, des fleurs, des grains, des fruits, des arbuisseaux, des grands arbres, des animaux ... des Oyzeaux ... des poissons ... de divers in- 
sectes et de plusieurs reptiles . . . Divizé en douze livres. Par M. L. N. P."Relates to North America: Canada, Illinois, Virginia, Louisiana, etc. (I8th century.)

24226. "Relation de ce qui s'est passé en la Nouvelle France sur le grand fleuve de Sainct-Laurens en l'année I634." By Father Paul le Jeune. Cf. Thwaites, Jesuit Relations, VI. 94-3I7, VII. 6-235.

24227. "Nouveaux Mémoires touchant la Nouvelle Espagne, recueillis sur les lieux avec une attention particulière les années I707 et I708 . . par Don Juan de Monsegur, Capitaine des vaisseaux . . . Redigez et mis en ordre à Madrid en I7og per Mr. Da ... "-Deals with city of Mexico, Porto Rico, Santo Domingo, Cuba, parts of Central and South America, California, etc. Attention is paid to the character of Spanish rule, to science, art, handicrafts, commerce, mining, government, defense, etc.

24228. Revision of 24227.

24229. Additions to 24227, including maps of the Lake of Mexico, the Philippines, the port of Pensacola, etc.

24269. "Regyme pour congnoistre la latitude de la region et aussi la haulteur de la ligne eqinotialle sur nostre orison." (I6th century.)

"Le langaige du Bresil et du francoys."

"Mémoire de la mercque de mes basteaux et barques que je laisse en la Terre Noeufve, au havre de Jehan Denys, dict Rongnoust." [f. 55

24445.-I644, July 20, Aug. 3I, Nov. I6. Letters or extracts of letters from Father Francisco Giuseppe Bressani, relating to his captivity among the Iroquois, and his replies to questions relating thereto. Cf. Breve Relatione d'alcune Missioni de' PP. della Compagnia di Giesi nella Nuova Francia del $P$. Francesco Gioseppe Bressani (1653), or its French translation, Relation Abrégée, by Father F. Martin (Montreal, I852).

[ff. $238-248 \mathrm{v}$

24507.- ( I8th century). "Mémoire méchanique, pour les opérations de la bourse commune, dont les fonds seront employez à faire refleurir toute sorte de commerce en France . . . " Plan for a company; deals in a general way with commerce of the French colonies in America and the West Indies. [ff. I 50-I 55

Notes on "des Castors et des Renards de l'Amérique Septentrionale".

[ff. I69-I 70

24974. - "Relation de l'isle de la Guadelouppe faite par les missionnaires Dominicains à leur général en $1647 . "$

25053.-[I658-I689.] Extracts and precepts from the writings of Father Claude Jean Allouez on the Canadian missions.

[ff. $59 \mathrm{v}-6 \mathrm{I}$

25055.-Biographies of Jesuit missionaries. Biographical notes respecting some seventy missionaries who had served in North and South America and the West Indies.

Memoir on ecclesiastical affairs of Canada.

[pp. I-468

25081.- "Description succinte du Canada en Febvrier I671." Anonymous memoir on geography, Indians, natural resources, Talon's brewery, industries, etc. First and last words: "J'ay cru ne devoir mettre ici que ce qui est nécessaire . . . tant de déplorables vestiges en France."

25163. Commerce of the Indies.

I692, Jan. 29. "Mémoire touchant le commerce des Indes occidentales par Cadiz."

[ff. I-40

"Mémoire touchant les Colonies que les Hollandais ont aux Indes occidentales en Affrique, et le commerce qu'ils y font à présent." [ff. 4I-47

"Description des Isles de Curaçao, de Bonnaires, Arouba, et St. Eustache, et du commerce particulier qui se fait en ces Colonies." [ff. 49-62 
"Mémoire concernant le commerce des isles Françaises de l'Amérique méridionale appellées Antilles."

[ff. 65 -I 33

25312. - "Traité de géographie." Eighteenth-century compendium of geographical information. Chap. V., devoted to North and South America, includes two maps, 1705, by Sanson: Amérique Septentrionale and Amérique Méridionale; chap. VI., "Des Terres Nouvellement Découvertes", mentions the "Terre de Feu", Greenland, the whale fishery, etc.

25375. "La description de tous les portz de mer de l'univers . . " By Jehan Mallart. See above, MSS. Fr. 1382.

25670. "Bibliothèque historique et critique des Géographies et des Voyageurs, par le P. Niceron", I727.- Includes an alphabetical list of works on travel and discovery, of which many relate to America (pp. I48-23I).

26412.-I687, Sept. 30, Versailles. "Arrest qui fait main levée au sr. Audiette de la saisie sur luy faite par fauconnet de Castors qui sont à la Rochelle, et du prix de ceux qui ont esté vendus en Hollande, et en conséquence que les deniers en provenans luy seront rendus par le sr. Palesme caissier de fauconnet aves les interests du jour qu'ils ont esté vendus." [ff. $53^{-56}$ I687-I688. Various documents dealing with legal proceedings in connection with the Canadian fur trade, including a "délibération de la Compagnie de Canada" of Jan. 27, I688.

32902.-I712, Sept. I4, Fontainebleau. Lettres Patentes... [qui permettent au Sieur Crozat, Secrétaire du Roy, de faire seul le Commerce dans toutes les Terres possédées par le Roy, et bornées par le Nouveau Mexique. (8 pp.)

[no. 406

\section{MANUSCRITS FRANÇAIS, NOUVELLES ACQUISITIONS.}

31. Collection of autograph letters.

I757, July 22, Compiègne. Abbé Comte de Bernis to MonseigneurRecommends M. de Silhouette for position as councillor of state because of his services in the settlement of the boundaries between English and French possessions in America.

[no. 19

I785, Sept. 29, Paris. Comte de La Luzerne to Marshal de Castries, minister of marine. In behalf of a gentleman serving as private soldier in Santo Domingo ; legislation relating to commissioning of officers in the colonial regiment.

[no. I02

61-63. Negotiations of the truce between the King of Spain and the States General of the Netherlands, by Jeannin and Buzenval, I607-1623.-Copied from Arch. Nat., KK, 1385-1387. See above, MSS. Fr. 7086-7090.

92. "De l'Esprit de conquête et de son influence sur les Progrès de la Civilization. Des avantages attachés à l'existence des grands Etats fédérés." By Pierre Laboulinière.-Copied from Arch. Nat., MM, 888. Written after I803; on ff. I 52-I89 are various considerations on the discovery and conquest of America, the people of the United States, the territorial expansion of the United States, cession of Louisiana, etc.

126. [Post I752.] Memoir on the services and administration of the naval port and arsenal of Rochefort. By the intendant of Rochefort.- Copied from Arch. Nat., MM, 1051. Various details relating to the colonial services at Rochefort, such as storage of munitions and supplies, loading of vessels, recruiting colonial troops, the regiment of Hallwyl, etc., are to be found on pp. 56, $60,68,189,203,274,304,306$. On p. 359 is a plan of the town and port.

306. "Voyage au détroit de Magellan, par le capitaine Pedro Sarmiento de Gamboa, dans les années I 579 et I 580 , et relation de la campagne dans laquelle il entreprit de le peupler; traduit de l'Espagnol." 
339. Papers of Haillet de Couronne and Noël de La Morinière on the his. tory of Normandy.

I746. "Memoire sur le port et le commerce du Havre. I746, No. 32, Mr. Du Bocage, lu à l'Académie le 22 novembre." .Enlargement of the port by Francis I. because of commerce with America; commerce with Canada and the Newfoundland fisheries under Colbert; fisheries in the Gulf of St. Lawrence; commerce with the West Indies; companies for trading with Canada.

[ff. 336-36ov

744-745. "Relation des causes de la Guerre de la Succession, commencée en I 70I, et mémoires pour servir à l'histoire des négociations depuis le traité de Riswick jusqu'à la paix d'Utrecht, en I7I3, par Jean Baptiste Colbert, Marquis de Torcy."-See above, MSS. Fr. 10666-10667.

885. "Memoire de l'état présent du commerce de France, des causes de sa décadence et des moyens de le rétablir, dressé et envoyé par ordre du Roy à la Chambre du Commerce établie à Paris, par les Députés des provinces en I701."

Memoir on the commerce of Normandy. French commerce with Spanish America ; cod and whale fisheries; trade in tobacco and negroes. [.pp. I-9

Memoir on the commerce of France in general, by Piedcourt, deputy of Dunkirk. Harm caused by the privileges of the Compagnie de Guinée; mistakes of Colbert with respect to the trade in tobacco.

[pp. IO-44

Memoir by the Sieur Descazeaut du Halley, deputy of Nantes. Loss of the whale fisheries to the Dutch; harm caused by the exclusive privileges accorded to the various companies of Guinea, Senegal, Acadia, etc.; tobacco, beaver, cod, sugar, and the slave-trade.

[pp. 44-I06

The chief reasons for the ruin of commerce and the means of reviving it, by the deputy of La Rochelle. Duty upon sugar; commerce with Canada.

[pp. ro6-r 22

Memoir on the revival of commerce in France, by the deputy of Bordeaux. Trade with Senegal, Guinea, the West Indies, Canada, and Newfoundland.

General reflections on commerce, by the deputy of Bayonne. Opposition to the companies having exclusive privileges; slave-trade.

[PP. I $43-170$

1041.- - 69r. "Breve noticia de las misiones de la Compañia de Jesus de la America Septentrional que estan acargo de la provincia de Mexico, y del estado que al presente tienen; para las quales este presente anno de I69I ha comedido la Magestad de nuestro Catholico Rey Carlos II sesenta sujetos que se puedan llevar de las provincias de Su Real Corona y de las del Imperio. Dirigala a los RR. PP. de las provincias de Europa el P. Juan de Estrador, procurador à Roma por dicha provincia de Mexico."

[ff. I-2

Extracts from Baron de La Hontan, Voyages dans l'Amérique Septentrionale.

Notes on the languages of Brazil.

[ff. 3-4

[ff. 5-6

I75I. "Courte relation de la Guyane françoise . . . " by Père Fauque.

[ff. 7-43v

r759, Dec. “Memoire fait dans l’intervalle entre la prise de Québec et celle de Montréal par ordre de M. le Duc de Choiseul, et dont ce ministre me dit avoir lu au feu Roy un extrait à la même époque." By [Jean Louis] Favier. -Object of memoir is to point out the consolation for the inevitable loss of her North American possessions that France may find in the increased strength and growing desire for independence of the English colonies in America. 
Notes by a missionary on names of Indian nations in Canada and neighboring regions.

[ff. $64-65 \mathrm{v}$

Tracings of drawings of Indian villages and native animals of Canada.

[I7th century.] Dissertation on the origin of the negroes and of the [ff. 69-93v
Americans.

Extract from [Oviedo]. Histoire Naturelle des Indes Occidentales, lib. VI., cap. VIII., on the method of finding and extracting gold.

Notes on American languages: Esquimaux, Mexican, and Peruvian.

[ff. $94-99 \mathrm{v}$

[ff. I00-105

Huron and Algonquin dictionary, from La Hontan, Voyages. [ff. IO9-I 27

1217. " Journal de la première campagne gue $\mathrm{j}$ 'ai faite sur le vaisseau du Roy, Le Formidable, commandé par M. de Macnemara et ensuite par M. le comte Du Guay." I754, Dec. II-I755, Sept. 3.-Transport of troops to America; capture of the Alcide by Boscawen, etc.

1301-1309. Collection of original letters of various personages of the eighteenth and especially of the nineteenth centuries, from the estate of the bookdealer, Lefèvre.

1304.-An X., Vent. Io. Le Cap, Santo Domingo Adm. Ganteaume to Marguerittes, commissioner of the naval force, in behalf of Roubeaud.

[8ff. I23-124V tails of a biographical character, respecting his conduct towards Napoleon.

[ff. 304-305v

"Biographie du Comte Hyde de Neuville." His retirement in New York with General Moreau; his second residence in New York until I8I4; minister to the United States.

[ff: $306-307$

1305.-I830, July 28, Paris. Lafayette to Betou. Recommends "deux braves de juillet ".

An X., Mess. 29, Le Môle. Adm. Latouche-Tréville to Lequai de Mongiraud. Bad conditions of the squadron.

[ff. I 3 I-I $32 \mathrm{v}$

1307. Remedies employed by the Tcharlokees [Cherokees] against snake bites. By Palisot-Beauvois.

[ff. 8-9v

I792, Oct. 27, Le Cap. François Polverel to the Société Patriotique de la Section du Luxembourg. Recommends Captain Deslandes of the Papillon.

[ff. I $27-\mathrm{I} 27 \mathrm{v}$

I837, July 8, Hackney, London. Thomas Price to A. Guilbert. Desires to publish in French an article by D. Lee Child on the Texas question.

[ff. I 5 I-I 52

An XII., Frim. 26. Rochambeau to the minister of war. His son's dispute with the minister of marine; negligence of French ministers during his service in the United States ; "miracle du blocus et da la prise de Cornwallis".

[ff. $245-245 \mathrm{v}$

1371. French translation, by A. F. Sorret, of Antonio Sanchez Valverde. Idea del Valor de la Isla Española (Madrid, I785).

1411. "Mémoire sur le Paraguay en I773."

1419. "Catalogue de quelques martyres et autres personnes plus signalées en sainteté de la Compagnie de Jesus lesquels, selon leur jour, après le martyrologe, se lisent au réfectoire de la Maison professe à Rome et ailleurs."-Lists of Jesuits who suffered martyrdom in Canada, Florida ( $157 \mathrm{I}$ ), Mexico, West Indies, Cayenne, Brazil, Uruguay, and elsewhere. [ff. 3-34 passim 
1479. “Armées de Terre et de mer en i779 et i780.” By J. A. Du Coudray.

Table of changes in the French and English navies in 1779 , with a list of the American islands conquered and lost.

Comparative table of the French and English navies, as of Jan. I, I780, with a list of officers serving in the colonies.

1565-1660. Collection formed by Clément de Boissy relating to the jurisdiction and jurisprudence of the Chambre des Comptes: second series, Bulletins.

The first series of this collection is in MSS. Fr. 10991-11082, q. v. Cf. C. Couderc, "Inventaire Sommaire de la Collection Clément de Boissy", in Revue des Bibliothèques, Apr.-June, I895, and also Clément de Boissy, Juridiction et Jurisprudence de la Chambre des Comptes (Paris, I787). An alphabetical index to this second series is in MSS. Fr. 11081-11082.

The volumes of the second series (two of which, 1641 and 1647, have been examined and are here described) are composed of slips (fiches), each of which bears one of the headings in the classification adopted by Clément de Boissy, and contains references to the edicts, letters patent, ordinances, and other documents bearing upon that heading.

1641.- "Comptes de la Marine." Under this general subject the following headings are noted as representative: droits perçus dans les colonies ; indemnités pour pertes par des particuliers (losses of vessels and cargoes in colonial service or trade) ; comptes des colonies par les trésoriers de la marine ; droits d'octroi dans les isles; vues politiques; vaisseaux armés en course ; pêcheries en mer, etc.

[slips 94 et seq.

"Comptes des colonies françaises de l'Amérique." Under this general subject the following headings are representative : impositions dans les colonies; trésoriers généraux; domaine du roi dans les colonies, aneçdotes; établissement des colonies; règlements militaires ; règlements pour le commerce; domaine d'Occident; dettes des colonies ; esclaves ou commerce des nègres ; droits et impôts sur le commerce; contrebande ; monnaies; jurisprudence; engagements des terres; religieux et gens de mainmorte, etc.

[slips 300-344

1647.- "Compagnie des Indes." Under this general title the following headings are representative: caution des fermes générales; avances faites par ladite compagnie ; établissement de la compagnie d’Occident ; rentes créées pour faire un fond de commerce à la Compagnie d'Occident; fixation des produits de la ferme du tabac; lettres sur les traittes des nègres ; réunion de la Compagnie du Sénégal à celle des Indes; établissement au Canada; droits de l'amiral ; compagnies générales des deux Indes, etc.

[slips I-97

1700. First volume, I643-I647, of the autograph journal of the Congress of Münster, by François Ogier, chaplain of the Comte d'Avaux, Cf. F. Ogier, Journal du Congrès de Münster, ed. A. Boppe (I893). See also F. G. Davenport, European Treaties, vol. I., Doc. 40.

1753-1757. Catalogue in chronological order, of ordinances, arrêts, etc., relating to the marine, I23I-1690.

1757.-1684, Aug. I4-I690, Mar. I7. List of ordinances, etc., relating to the marine. The titles only are given, without indication as to the location of documents; among the subjects catalogued are: West Indies, French companies of Senegal, Guinea, and the West Indies, beaver, cod, whale fisheries, emigration of Protestants, domaine d'Occident, etc. 
1827. Collection of funeral orations.

I703, June 26, Quebec. Oration pronounced at the funeral of Callières, governor of New France.

[f. $8 \mathrm{I}$

1856.-I637-I644. Reports of Count John Maurice of Nassau-Siegen, governor of the Dutch settlements in Brazil. (French translation from the originals in the Royal Archives at the Hague.)

1908. Autograph MS. of the Histoire de Beaumarchais, by Gudin de La Brenellerie, ed. Maurice Tourneur (Paris, I885).

2019. Memoirs on the commerce of the different countries of the world. I8th century. From Arch. Nat., KK, 1005.

Commerce of France; dearth of gold and silver due to slight commerce with America; whale and cod fisheries; emigration of inhabitants of French West Indies to English colonies.

Commerce of Holland.

[ff. $2-6 \mathrm{v}$

Commerce of Spain.

Commerce of England.

Commerce of the West Indies.

Commerce of Brazil.

[ff. $7-26$

[ff. $26-37$

[ff. $37-49 \mathrm{v}$

[ff. $50-55$

[f. 55

Commerce in the Mediterranean in sugar and codfish.

Commerce of Africa; slave-trade.

Commerce of the Islands of America.

Commerce of Canada.

[pt. 2, f. 2

[pt. 2, f. $19 \mathrm{v}$ [pt. 2, ff. 24-29 [pt. 2, ff. $29-40$ [pt. 2 , ff. 4 OV- 47

2549-2552. Historical notes and memoranda, copies of documents, and extracts, relating to the marine and colonies, I667-I 735 .

2549. Marine and colonies, I667-1 722.

Note on the Dutch settlements on the River Ouyapoc [Oyapok] in I667.

[f. 2

Note on the capture of the island of Cayenne and part of Guiana from the Dutch in 1677.

I699. Sept. I3, Fontainebleau. Copy of ordinance regulating the respective functions in commercial matters of the controller general of finance and the secretary of state for the marine, assigning to the latter matters relating to Canada, the West Indies, the slave-trade, the Senegal and Guinea companies, etc.

Historical note on the operations of Châteaumorand against the Spanish colonies in America, I7 $16-1718$.

[f. I 5

I716-I722. Annual lists of royal vessels and galleys in commission, indicating vessels in the various American services.

[ff. 20, 68, 8I, 86, I I I, II 5, I I9

Memorandum on the order of Jan. 29, I7 16 , prohibiting the despatch of merchant vessels to the South Sea.

Memorandum on the edict of Oct., I 716 , respecting the status of negro slaves introduced into France. Cf. below, f. 34 . [f. 23 I7 I6, May, Paris. Copy of letters patent for the establishment in Ile Royale of Recollects of the province of Brittany.

[f. 24

I716, Apr., Paris. Copy of letters patent for the establishment of the Brothers of Charity in Ile Royale, for the service of the hospital. [f. 26

I7I7, June, Paris. Copy of letters patent establishing the Recollects of the province of France in Ile Royale, and limiting the letters granted to the Recollects of the province of Brittany. 
I7 I7, June, Paris. Copy of edict establishing a Conseil Supérieur and three bailiwicks in Ile Royale.

[f. 3 I

I7I6, Oct., Paris. Copy of edict providing that negro slaves belonging to residents of the colonies may be introduced into France without thereby becoming free.

[f. 34

"Punition des sauvages Natchez en I7I6 et établissement d'un fort françois chez eux." Cf. "Mémoire . . . de ce qui s'est passé dans la première expédition que M. de Bienville fit aux Natchés en I7I6 . . " ", in Arch. \begin{tabular}{l} 
Colonies, C I3, vol. 4, p. 785 . [ff. 40-47 \\
\hline
\end{tabular}

Account of the revolt in Martinique, I7I7. Cf. MSS. Fr. 12101. [f. 49

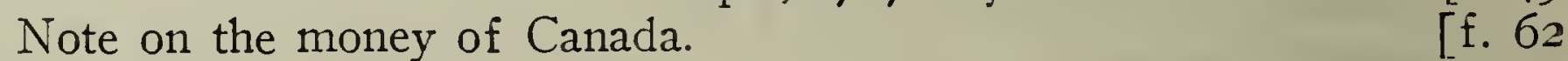

Note on the customs of the Natchez Indians. [f. 63

Note on the trade in beaver skins. [f. 65

I7I7, Sept. I4; I7I9, Aug. I3. Notes on the amnesties granted by the King of England to the pirates of Providence Island.

$[\mathrm{ff} .66,83$

Narrative recounted to Mme. de Courtemanche in I7I7 by an Eskimo woman.

[f. 67

I7I7, Feb. Address to the king by M. de Breslay, missionary, in the name of the Nepissiryniens [sic].
[f. 699

I7I7, Apr. 26. Note on the filling up with sand of the harbor of Ile Dauphine; soundings by the Paon, commanded by Du Sault. [f. 7I

I7 I8, Aug. Copies of letters granting the island of St. Lucia to Marshal d'Estrées, and appointment of St. Martin as commandant. [f. 72

I7I9, Aug. Note on the concession of the islands of St. Jean [Prince Edward] and Miscou to the Comte de St. Pierre. If. 84

[I7I9.] Memoir on the island of St. Martin. [f.90

I720, July 29. Account of the murder committed by the Iroquois, Sautogou, of Sault St. Louis. [f. 94

I720, Jan. Note on the concession of the Magdalen Islands to the Comte de St. Pierre.

[f. 96

I7 I8, Mar. Memorandum on the amnesty granted to the inhabitants of Martinique.

[f. 97

Account of the revolt in Santo Domingo in I723, against the employees of the Compagnie des Indes, with the song "Chanson sur la Reine de St. Domingue".

[f. Ioo

Memorandum on the claims of Spanish bishops to jurisdiction over territories in South America inhabited by the French.

[f. IO4

Note respecting the slaughter of loups marins at the Magdalen Islands.

[f. II 2

Note on the negotiations of 1722 over the boundary between Cayenne and Surinam.

[f. II 8

I719-I720. Memorandum on the foundation of New Orleans and Biloxi. [f. I2I I 722 ".

Narrative of the "Émotion populaire arrivée à Marie Galante . . . en

2550. Marine and colonies, I $722-\mathrm{I} 728$.

Note on the fishing rights granted to the Comte de St. Pierre in Mar., I722, of the Magdalen, St. Jean [Prince Edward], and Brion islands, and on the arrêt of Oct. I3, I 725 , respecting them. [f. I

I723, Sept. 29-I724, Sept. 27. "Punition des Natchez en I723." Account of second expedition against the Natchez, under Bienville. [ff. 3-IO 
I723-I728. Annual lists of royal vessels commissioned.

[ff. II , I5, 28, 47, 78, I03

I722, May I6, Dec. I9, Paris. Copy of ordinance regulating the establishment of the Capuchins in Louisiana, and açt respecting their church and house at Mobile.

I725, June 27, Paris. Copy of act of the Compagnie des Indes respecting the establishment of the Capuchins in Louisiana.

$\begin{array}{ll}\text { Notes on the reoccupation of Tobago in I725: } & {[\mathrm{f} .22}\end{array}$

[f. 20 differenemoire concernant les coliers de porcelaine des Sauvages, leurs differens usages, et la matière dont ils sont composés." West Indies, New York, Long Island, Rhode Island, and Virginia.

[ff. $24-27$

i725-I 728. Annual lists of merchant vessels commissioned and out of commission in all the ports of France, including vessels in the different American services: West Indies, Louisiana, Canada, Ile Royale, Newfoundland, etc.

[ff. $29 \mathrm{v}, 48,76,100$

I726, July 3, Paris. Copy of proceedings of the Compagnie des Indes, respecting the reduction of the duty on Guinea negroes from 20 to Io livres.

I726. Memorandum on tribes of Indians in Guiana.

I726, Montreal. Speeches of the Iroquois to Gov. Beauharnois.

[f. 33

[f. 34

[ff. 36-4I

[I726.] Note on funeral ceremonies of the Iroquois, and explanation of a drawing (not here) of the tomb of the chief, Beausoleil.

[ff. $42-45$

I726, Sept. I3, Paris. Copies of contract between the Compagnie des Indes and the Ursulines for the establishment of the latter in Louisiana, and brevet of Sept. I8, Fontainebleau, accorded to the Ursulines. Also in Arch. Colonies, C I3, vol. 10, f. 88; the brevet is printed in Louisiana Hist. Soc., Publications, IV. IOI.

[ff. $52-56$

I727, Oct. I, Fontainebleau. Copies of ordinances relating to the militia of the Iles du Vent; the first of these is printed ibid., p. Io3. [ff. 59, 6I
[ I727, Nov. 7. Treaty with the Caribs of St. Vincent. [f. 72

I727, July 28, Quebec. Copy of permission of the Bishop of Quebec to a member of the order of the Sisters of the Congregation to go to Ile Royale, together with letters patent, Dunkirk, May, I671, confirming the establishment of the order in Canada.

[f. 85

I727, Apr. 29, Versailles. Maurepas to governor and ordonnateur of Cayenne, respecting the despatch of Sisters of Charity to that colony. [f. 88

I 727, Nov. IO, Fontainebleau. Copy of the déclaration of the king increasing the tax of the domaine d'Occident in order to provide funds for maintaining French commerce in the West Indies and excluding foreign commerce therefrom.

I728. Commerce of the Iles du Vent.

I 727, Nov. 7. Note on earthquakes in Martinique.

I728, June-Aug Account of de Iignery's expedition againt the Rents [Foxes] and Puants [Winnebagoes].

I728. Note on Natchez Indian, "Grand Soleil". [f. I I5

[f. IIO

ff. II 5

[1728.] "Relation de la decouverte d'une grande rivière qui a flux et reflux et qui, courant à l'ouest du lac Supérieur par le Nord, peut beaucoup servir à la découverte de la mer de l'Ouest." Declaration made to La Vérendrye by Pako, an Indian, transmitted from Canada in 1728 .

[ff. I23-I 24

Note on the negotiation of I 723 over the boundaries between Cayenne and Brazil.

f. I26

Discovery of forests of cocoa trees in Cayenne. 
2551. Marine and colonies, I729-I732.

I729, Nov. 28. "Coup des Sauvages Natchez sur les François." $C f$. "Relation du Massacre des Natchez", in Arch. Colonies, C I3, vol. 12, f. 37.

I729, Dec. 8. "Coup des François sur les Sauvages Tchimachas [Chickasaws] au dessous de la Nouvelle Orléans fait par Tixerant et 80 nègres."

I729. Revolt of soldiers in Martinique.

ff. 25

I729-I732. Annual lists of royal and merchant vessels, in commission and out of commission, etc.

[ff. 29-32, 83-86, I 56-I 59, I82-I85

I729, May 22. Letter of Maurepas, giving permission to establish salt marshes in Cayenne.

[f. 33

I729, Nov. 4, Le Cap. Regulation of festivals to be observed in the establishments of the Jesuits.

[f. 37

I729. Census of the parishes, hospitals, religious houses, mills, and sugar refineries in Martinique.

[f. 40

Memoir on the French rights to the island of St. Croix and on the English enterprises against it in I729.

[f. 4 I

I729, Sept. I. Procès-verbal of the loss of the Eléphant in the St. Lawrence.

[f. 46

I730, Mar. 25, Versailles. Brevet granted to Poulin de Francheville for the opening and exploitation of iron mines in Canada. Cf. below, f. 80. by Tunica Indians,

[f. 53

I730, Oct. 3, Versailles. Report by Maurepas on sea-borne commerce and the merchant marine: Santo Domingo, whale fishing, Ile Royale, Canada, Newfoundland, etc.

I730, Nov. 27, Quebec. Mandement of the bishop coadjutor of Quebec against the sale of liquor to the Indians. Ptd. in Mandements ... . des Evêques de Quebec, I. 535.

[f. 73

I730, Oct. 2I, Dec. 26. Ministerial correspondence and royal order respecting dispute with England over the Iles du Vent.

[f. 77

I730. Note on the exploitation of iron mines in Canada by Poulin de Francheville. $C f$. above, f. 49 .

[f. 80

I725. Note on the Indians of Louisiana brought to France by de Bourgmont, and addresses to the king at Fontainebleau, Nov. 22, by the chiefs of the Michigamea and the Three Nations.

[f. 8 I

I730, May 27. Ordinance creating a company of cadets at Rochefort for colonial service.

I730, Sept. 9. " Relation de la défaite des Renards par les François du Canada et de la Louisiane." Cf. Wis. Hist. Coll., XVII. rog-I I3. [ff. 98-100 I730, Nov. 7, Quebec. Letter from M. d'Auteuil de Monceaux respecting the defeat of the Fox Indians.

[ff. IOO-IO3

I73I, June. "Notice sur la défaite des Natchez près du poste des

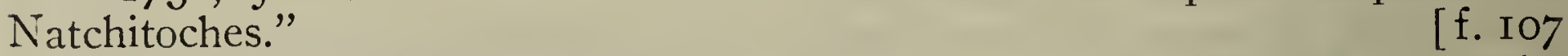

I73I, May 8, Marly. Ordinance prescribing the appointment of a cadet in each of the 28 companies of troops in Canada. [f. Iog

I73I, Jan. Account of the attack on the Natchez fort by the French.

[ff. III-II3

I73I. Note on the return of Louisiana to the king. [f. II 4

I73I, Jan. 23, Marly. Arrêt respecting the retrocession of Louisiana and Illinois to the king. Ptd., Dernis, Recueil des Arrêts, IV. $202 . \quad$ [f. II 5 
I73I, Oct. I ; I732, May 23. Extracts from letters of Beauharnois, respecting the defeat of the Fox Indians.

[f. I I 9

I730, Nov. 27, Quebec. Mandement of the bishop coadjutor of Quebec forbidding absolution to those who intoxicate the Indians. $C f$. above, f. 73 . [I732, Apr. 22?] Extract from memoir of the king to Beauharnois and
[f. Hocquart, respecting the mandement of the bishop coadjutor of Quebec on intoxication of the Indians. Cf. Wis. Hist. Coll., XVII. I 58.

I73I, Aug. 24-25. Account of the storm on the island of Grenada.

[f. I 23

[f. I 24

I73I. "Journal de la guerre des Capotil[le]s proche le Fort Dauphin en St. Domingues."

I73I, Oct. "Coup des Natchez sur les Tonicas pour se venger de la vente de leurs chefs et de leurs femmes à St. Domingue."

I73I, Sept. Arrival of two Fox chiefs in Canada to submit nois.

I73I, Nov. Arrival of galleons at Santo Domingo.

eauhar-

I73I, Nov. 26, Marly. Letters patent for the establishment of a community of nuns at Cap Français, Santo Dlomingo.

[f. I46

I73I, Dec. I8. Extract from a letter from a merchant of Lisbon, respecting precious stones found in Brazil.

[f. 148

"Enterprise de M. de la Vérendrye pour la découverte de la mer de l'Ouest avec ce qui s'est passé à ce sujet jusqu'en I732." $C f$. "Mémoire du Sieur de la Vérendrye" in Margry, VI. 585.

[ff. I60-I63

Census of Louisiana, transmitted by Perrier and Salmon in Jan., I732. Cf. Arch. Colonies, G I, carton 464.

Spanish proposal with respect to the assiento.

[f. I66

News from Martinique respecting the conduct of the Jesuits in

[f. I68

[f. I69
[6.

I 732, June 26, Compiègne. Arrêt respecting port dues of vessels anchoring at Ile Royale.

I732. Ordinances respecting burials in Santo Domingo.

[f. I70

7732. List of vessels from Bayonne and whale fisheries; proceeds of the fisheries.

I732, Aug., London. Advertisement of the trustees for the colony of Georgia.

2552. Marine and colonies, I732-I735.

"Abrégé de ce qui est arrivé de plus remarquable en l'île françoise de St. Domingue depuis sa découverte jusqu'en I732."

[f. I-3

I732, Feb. Duties paid to the King of Spain on the silver and other cargo of the fleet from America.

[f. 4

I732, June I9, Compiègne. Ordinance prescribing the appointment of two cadets in each of the companies in Ile Royale.

[f. 28

I732, Aug. 5. Assignment to the marine of the duties collected in the colonies on the domaine d'Occident.

I732, Sept. I6. Earthquake at Montreal.

[f. 37

[f. 38

I732, Nov. Extract from a letter from Detroit, relating the defeat of the Fox Indians by a party of Iroquois and Hurons. $C f$. Boishébert to Beauharnois, Nov. 7 , in Wis. Hist. Coll., XVII. I73.

[ff. 39-44

I733, Dec. 29, Versailles. Letters patent assigning to Mgr. Dosquet, bishop of Quebec, the revenues of that bishopric, and granting permission to dispose of its benefices.

[f. 57 
I733, I734. Statements of vessels of Bayonne and St. Jean-de-Luz engaged in whale fisheries and of proceeds of the fisheries. [ff. 59, I 36

I733, I734. Lists of royal and merchant vessels in commission and out of commission in the ports of France, etc. [ff. 60-63, I44-I 49

I733, May 26. Conflans to Maurepas, respecting the English vessel Ludlow Castle, at Martinique.

I733. Sept. 28, Quebec. Beauharnois to Maurepas. Extract relating to the expedition of La Vérendrye in search of the Western sea. [f.73

I733, Sept. I. Account of the fête at Lorient on the occasion of laying the corner-stone of the warehouses of the Compagnie des Indes. [f. 75

Cod fishery carried on by vessels from Sables d'Olonne. [f.83

I733, Apr. 28, Versailles. Maurepas to M. de Beauvais Le Fer, merchant and mayor of St. Malo, interpreting art. XIII. of the Treaty of Utrecht, respecting cod fisheries off the coast of Newfoundland. [f. 84 I733, June I5, Copenhagen. Sale of St. Croix to the Danish West India Company.

[f. 85

I734, Apr. Account of the negro revolt in the island of St. John, Danish West Indies.

I734, Sept. 14, Lisbon. Extract from a letter relating to the fleet from Rio de Janeiro and to news from Brazil. [f. I20 I734. Effort by vessels of St. Jean-de-Luz to engage in whale fishery in the Gulf of St. Lawrence.

I734. Cod fisheries at Ile Royale with statement of vessels from France, West Indies, Canada, Acadia, and New England engaged therein. [f. I4I I735. Note on cultivation of cocoa in the West Indies and South America.

I735. Note on the first cultivation of wheat in the Illinois country in I7 18 , by Zébédée de Bréda, in the service of the Jesuits. [f. I6I

2558. Documents relating to the reign of Louis XV.; treaties of commerce.

I660-I720. War with the negroes of St. Vincent, and treaties with the Caribs of that island.

[ff. $43-49$

I720, May 16. Freedom of trade in beaver skins accorded by arrêt of May 16, I720. Cf. memoir of Nov. 6 in Arch. Colonies, Ci I, A, vol. 42, f. 137 .

[f. 69

I723, Feb. 8, 9. Treaty for the evacuation of St. Lucia by the English.

Company [f. II 5 Memoir on the privileges of the Dutch West India Company in Guinea.

[ff. I 3O-I 39

I729. Memoir on the death of the Bishop of Oran, and on the disadvantage of having bishops in the colonies. [f. I50

I729, Nov. 9. Treaty of Seville.

2559. Documents on the reign of Louis XV.; treaties of commerce.

I7I3, Mar. 26, Madrid. Treaty of assiento between Spain and England, regulating importation of negroes into Spanish America for 30 years.

[ff. $43-58$

I701, Aug. 27, Madrid. Treaty of assiento between Spain, France, and the French Guinea Company, regulating the importation of negroes into America for Io years.

[ff. $59-7$ I

I733, Apr. Extract of debates in the House of Commons on excise tax on tobacco and wines.

[ff. IO7-I II 
2560. Documents on the reign of Louis XV.; finance.-The first half of this volume relates chiefly to the bank of John Law, the Compagnie des Indes, etc.

I735. Sept. I4, Versailles. Ordinance relating to sale of munitions and merchandise and to payment therefor in Louisiana. (Fragment.) [f. I

I720. Note on the riots in the Faubourg St. Antoine caused by violent methods of recruiting colonists for Louisiana, and on the arrêt of May 9, I 720, forbidding the transportation of vagabonds to Louisiana.

I730, Nov. 27. Establishment of Fort Dauphin in Santo Domingo.

[f. 47

I720, July. Note on the edict conceding to the Compagnie des Indes the commerce of Louisiana and the commerce in beaver skins in perpetuity.

[f. 57

I720-I72I. Plan of the Compagnie des Indes to provide currency for the colonies; shipment of copper money to Louisiana.

[f. 69

I722, Apr. II. Note on the arrêt appropriating 300,000 livres from the royal treasury to the Compagnie des Indes for the expenses of the garrisons and fortifications of Louisiana, etc.

[f. 84

I722, Dec. 29. Demands acceded to by Sorel and Montholon in Santo Domingo during the riots over the granting to the Compagnie des Indes of the exclusive privileges of the slave-trade.

[f. II I

I723, Sept. 7, Versailles. Commission and instructions to the Comte de \begin{tabular}{l} 
Champmeslin for the restoration of order in Santo Domingo. [f. II 5 \\
\hline
\end{tabular}

I729. Commerce of France with the West Indies.

[f. I 57

I73I, July I7, Fontainebleau. Concession of the island of St. John to Claude Cottard et al.

[f. IgI

I730, Sept. 26, Oct. 3. Note on arrêt and letters patent relating to the domaine d'Occident.

[f. I9I

I 732, Apr. 26. Decree of King of Spain, establishing the Company of the Philippines.

[ff. $193-204$

I732, Aug. 5, Versailles. Arrêt and letters patent setting apart from the contract of the fermes générales the duties of the domaine d'Occident that \begin{tabular}{l} 
are collected in the colonies. [f. 206$]$ \\
\hline
\end{tabular}

I732, June 9. Charter of the colony of Georgia.

I732, Revolt in Paraguay.

[f. 210

[f. 224

I732, Sept. 24, The Hague. Resolution of the States General, forbidding Dutch subjects to take part in foreign companies of commerce. [f. 225

I733, July 23. Ordinance against foreign commerce in Santo Domingo.

[f. 238

I733, Mar. 29, Seville. Charter for the establishment of the Royal Company of the Philippines.
[ff. 243-256

Memoir on copper mines discovered in Canada in June I735. [ff. 257-260

I735, Aug. Memoir on the manufacture of 200,000 livres of card money for Louisiana.

[ff. $262-265$

I 735, Sept. I4, Versailles. Ordinance for the manufacture of card money in Louisiana. (End is missing.)

2561. Documents on the reign of Louis XV.; statistics.

Commerce of France with the West Indies in I730.

[f. 265

[f. 21

2571-2583. History of French Guiana and documents relating thereto.

2571-2572. "Histoire des colonies françoises de la Guiane", I633-I777, by Artur, a doctor on service at Cayenne. 
2573-2574. "Mémoire pour servir à l'histoire des colonies françoises de la Guyane”, I674-1752, by Artur.

2575-2577. Miscellaneous documents relating to the administration of Guiana and Cayenne, I 540-1 767.

2578. Extracts from registers of the Superior Council of Cayenne, I724I734.

2579. Memoirs on the discoveries and settlements in Guiana by European countries, I $498-1688$.

2580. Tables of expenditures for Guiana and Cayenne, I603-1757.

2581. Journal of events in Cayenne, I685-I7II.

2582. Extracts from the "registre nouveau des concessions" and regulations for Guiana and Cayenne, I667-1730.

2583. Miscellaneous documents relating to the history of Guiana.

2584. "Description de la province et des missions de Maynas au royaume de Quito, par le R. P. Magnin, ancien missionnaire à Borja."-French translation from author's manuscript in Spanish, by Artur.

2610. Miscellaneous documents relating to Guiana and to the French colonies in America, I 504-1758.

[Post 1657.] "Abrégé des voiages, découvertes, et habitations faits en l'Amérique Septentrionale par les François, et ensuite celles faites par les Anglois.",

I540-I 543. "Découverte des pays de Canada, Ochelaga, et Saguenay."

[ff. 5-10

I 58I-I583. "Du descouvrement du Nouveau Mexico."

[ff. I $2-15 \mathrm{v}$

1664. "Articles accordés par le Duc d'Anville . . . à Henri de Gournay

e . pour aller faire colonie dans les terres et pays des Amériques Australe
[ff. I6-23v et Septentrionale."

[ 1664 ca.] Memoirs on the concessions in Guiana requested by the electors of Mainz and Bavaria.

[ff. $24-27,29$

[1644.] Memoir by Du Fresne for Colbert, on commercial relations between the Compagnie des Indes and the Bavarian Company. [f. 28

r644, Nov. I3, Erfurt. Du Fresne to Colbert. Desire of the elector of Mainz to engage in trade with the West Indies under the protection of the king.

[ff. $30-34$

I685, May 20. Memoir on the French West Indies and on the creation of a bishopric to have jurisdiction over them. By M. le M[arquis] de S[eignelay?].

Memoirs on the creation of a bishopric in the French West Indies. Cf. MSS. Fr., nouv. acq., 7497, f. 220, and MSS. Clairambault 1016, f. 633 .

[ff. $38-39,40-43$

I688, Nov. 29, Quebec. De Chabaud, missionary, to M. de Lancet, Paris. Map by Franquelin; poor harvest; peace with Iroquois prevented by the English; Cavelier goes to France to present the account of his brother's [La Salle] discovery of the Illinois country; losses sustained by the Acadians; beaver trade at Hudson Bay. (A. L. S.)

[ff. $44-45$

r698-170r. Account of the expedition of Beauchesne to the South Sea.

I7 16, Oct. 8. Proposals relating to Louisiana; troops; Ile Dauphine,

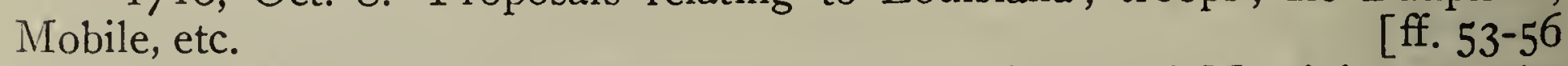

I7I7, May 23, 24. Letters from the inhabitants of Martinique to the $\begin{array}{ll}\text { king and to the Duc d'Orléans. } & \text { [ff. } 57,58\end{array}$ 
I7 18, Feb. I8, Paris. Memoir on the domaine d'Occident, by La Boulaye. [ff. $59-62$

I73I, Mar., New Orleans. Guy to Lancelot, of the Académie des Inscriptions. Capture of the Natchez fort and sale of prisoners as slaves; situation of New Orleans; products, money, commerce, and cost of living. (A. L. S.)

[ff. 63-64bis

History of the Marianas Islands. Conquest of the Philippines by the Spaniards.

[ff. 68 bis- 72

2721. "Troisième registre contenant les avis qui ont été donnés sur les affaires du commerce", i $768-1787$.

Memoir by Sabatier on the return of import duties paid on crude sugar from Brazil, that is re-exported after being refined.

I78I. Opinion of the députés du commerce on the request of Boisnard Brothers, shipping merchants at Granville, respecting the sale of their cargoes of Newfoundland fish in Marseilles.

[ff. IO3V-I 28

2842-3060. Collections of plays.

2859. - L'Amériquain. Incomplete translation from the English.

2886.-Christophe Colomb ou la Découverte du Nouveau Monde. Historical melodrama in three acts, by Guilbert de Pixérécourt, I8I 5.

2921.-La Géorgienne ou les Heureux Esclaves. Heroic comedy in three acts.

2929. - Le Huron. One-act vaudeville.

2954. - La Mexicaine ou les Francais à la

3012.-Les Vaches Américaines. A parade in one act, $\mathrm{I} 772$.

[f. I 45

[f. 54

3155.-I702, Feb. 21, Barcelona. [French ambassador?] to Pontchartrain. Has communicated to the King of Spain the memoirs and letters transmitted to him respecting the measures to be taken to assure the safety of the Spanish possessions in America.

[ff. $32-36$
Memoir on French West Flanders Cod fishing, foreign commerce carried on from Dunkirk.

[ff. I $32-157$

"Mémoire touchant le commerce des Indes Occidentales par Cadix." History, commerce carried on by foreigners, French commerce in beaver hats. Cf. MSS. Clairambault 1016, f. 453 .

[ff. I9I-2I9

"Mémoire touchant les colonies que les Hollandais ont aux Indes Occidentales, en Afrique, et le commerce qu'ils y font à présent." [ff. 2I $7 \mathrm{v}-234 \mathrm{~V}$ "Mémoire des isles françoises de l'Amerique méridionale appelées Antilles." History, description, commercial companies, and present state of commerce.

[ff. $235-282$

I706, Feb. I7, Madrid. Deliberation of the Junta on ruin of the commerce of the Spanish Indies and on methods of reviving it. (Spanish copy with French translation.)

[ff. $426-467,468-5$ IO

3173. "Extrait de l'Inventaire du Dépôt des Plans des Colonies à Versailles au premier septembre I787."-A summary, giving for each portfolio the number of maps of different regions which it contains. Five portfolios contain 3 I I maps and plans of North America, and 23 portfolios contain 679 maps and plans of the West Indies, Central and South America, the Pacific, and the West coast of North America.

3344-3348. Correspondence and other documents relating to the control of publications under Malesherbes. See also MSS. Fr. 22061-22193, and MSS. Fr., nouv. acq., 5001-5002. 
A complete inventory of the contents of these volumes is in E. Coyecque, Inventaire de la Collection Anisson, II. 477-544. For accounts of Malesherbes' administration as directeur de la librairie see $i d$. . I. lxxxi et seq., and F. Brunetière, "La Direction de la Librairie sous M. de Malesherbes", in Rev. des Deux Mondes, I882, reprinted in Études Critiques sur l'Historie de la Littérature Française, second series (Paris, I889). The following notes are taken from the inventory by Coyecque.

3344.- - 757. Correspondence of Malesherbes and Gilbert Lagrange de Chessieux respecting the latter's work, La Conduite des François justifiée, ou Observations sur un Écrit Anglois intitulé: Conduite des François à l'égard de la Nouvelle Écosse (Utrecht, Paris, I756), and a dissertation on the Ohio which he proposes to add to a second edition. [ff. 248, 250, 359, 36I

3345.-I754. Correspondence of Machault, Malesherbes, Rouillé, and O'Héguerty, respecting the publication of the work by the last named, Essai sur les Intérêts du Commerce.

[ff. 290, 292, 294-296

Estimate of expense of engraving and printing six volumes of Histoire des Plantes de l'Amérique.

[f. 383

3347.-1756, Apr. 7, Paris. Malesherbes to de Brou, intendant at Rouen, respecting a Mémoire sur le Commerce Maritime, which Lallemand, fils, printer of Rouen, desires to publish.

[f. II4

I755, Sept. 2, Paris. "Traité sur Lettres Patentes entre la Compagnie des Indes et les Capucins de Champagne concernant la Mission de la Louisiane (Paris, I2 pp. quarto).

[f. I23

I759, June I7, Cambray. Comte de Lannion to Malesherbes. The plague at Guadeloupe; defense of Martinique.

I 60 , June Io, Versailles. Letter to Malesherbes, respecting Mémoires pour servir à l'Histoire de Louisbourg.

3530. "Description méthodique, historique, et chronologique des Papiers contenus dans le Dépôt de la Marine et des Campagnes sur Mer, depuis i6ro jusqu'en I750." By Hocquet d'Hamecourt, chief of the dépôt des archives de la marine.-Also in Arch. Marine, B8, vol. 26. This volume is useful as an introduction to the archives of the marine. It contains historical accounts, with documents, of the principal offices, amiral, grand maitre, conseiller de la marine, etc., and on pp. 500-509 is a very summary description of the different categories of documents in the dépôt, relating to the American colonies, the commercial companies, etc.

3539-3542. "Plantae Antillanae." [I77 I ca.]-Collection of drawings of plants, fish, insects, etc., with explanatory" notes.

3605-3606. Papers of the Chevalier Etienne François Turgot, governor general of Guiana.-Vol. 3605 contains correspondence, I763-1 768; vol. 3606 contains administrative documents, and papers relating to the affaire Chanvallon (Chanvallon was intendant during Turgot's administration). C $f$. MSS. Fr. 6233-6256.

3610-3611. "Recherches sur les maladies des races qui ne souffrent pas de la fièvre jaune, et études particulières: sur la maladie des sucreries de Cuba, ou hinchazon des nègres et des Chinois." By Dr. Henri Dumont, I865-I866.The second volume contains photographs.

3615-3622. Biographical notes relating to various personages of the sixteenth-eighteenth centuries.-These notes, on 9oI9 cards (fiches), arranged in alphabetical order, were made by $A$. Rochebilière from the parish registers of Paris, which were destroyed by fire in $187 \mathrm{I}$. They are noted in this Guide be- 
cause of their possible value for details (dates of birth, baptism, marriage, death, place of burial, etc.) respecting the lives of persons connected with the American colonies.

3629-3636. Collection of nineteenth-century documents made by Victor Schoelcher, relative to the administration of French colonies, slavery, the navy, etc.-Vols. 3628-3631 relate to Martinique; 3632 to Guadeloupe, Jamaica, Dominica, and Cayenne ; 3633 to Haiti ; 3634 to Senegal and Gabun; 3635 to Réunion, India, and Cochinchina; and 3636 to the navy. None of these volumes contains documents relating directly to the history of the United States.

4156. "Voyage au Canada dans le nord de l'Amérique Septentrionale fait depuis l'an I75I à I76r. Par J. C. B."-Discovery of Canada; New England; French aid during the American war of independence; description of Quebec; administration of Gov. Duquesne; description of Montreal ; Presqu'ile ; Michilimackinac; capture of Acadia; capture of Quebec; customs of inhabitants of Canada; savages, etc.

4372. "Considérations politiques sur la révolution des Colonies françaises mais particulièrement sur celle de Saint-Domingue, par G. T. Dufresne, colon de cette Isle, I805."

5001-5002. Procès-verbaux of the censorship of books, I8II-I8I3. Cf. MSS. Fr. 22061-22193, and MSS. Fr., nouv. acq., 3344-3348.

5001. Censorship of books, I8I I-I8I2.-The following books relating to America (titles copied as they occur) are reported on:

Voyage dans l'Amérique Méridionale, by Ant. Z. Helms. (Translation from English by B. Barrère.)

[no. 18

Voyage dans les Provinces Septentrionales du Nouveau Mexique, by

Major Z. M. Pike. (Translation from English by Breton.) [nos. 22, 27, 30, 35

Voyage aux Iles Trinidad, Tobago, et Marguerite et dans diverses parties... de Caracas et de Vénézuela, by Dauxion La Vaysse.

[nos. $42,47(18 \mathrm{I} 2)$

Histoire du Brésil, by Alphonse de Beauchamp.

[nos. 49, II (I8I2), 2I (I8I2)

Histoire de la Guerre de l'Indépendance des Etats-Unis d'Amérique, by Botta. (Translation from Italian by Sévelinges.) [no. I5
[

Histoire des Troubles de Saint-Domingue depuis I789 jusqu'en I794, [by

Bryan Edwards], translated from English into French, with notes by "M. P.

D. B., membre de l'Institut".

[nos. 56, I 50 ficativa.

Viaggi d'Amerigo Vespucci con la Vita, l'Elogio e la Dissertazione Giusti-

[no. 86 Anglais tels qu'ils sont, by A. de Clairanville.
[no. I56 5002. Censorship of books, I8I3.

Voyages aux Antilles et à l'Amérique Méridionale, by Le Blond.

[nos. $26,36,65$

Histoire de la Guerre de l'Indépendance des Etats-Unis d'Amérique, by Botta. (Translation from Italian by Sévelinges.) [no. 33

Voyage à la Côte Nord-ouest de l'Amérique Septentrionale en I792. (Translation from Spanish by Desjardins de Fontvanne.) [no.6I

Apperçu des Etat-Unis au Commencement du Ige Siècle depuis I80o jusqu'en I810, by Félix Beaujour.

Histoire du Brésil, by Alphonse de Beauchamp.

[nos. 82, 90

[nos. I $34-\mathrm{I} 37$ 
5052-5069. Collection of documents on various subjects formed by Emmanuel Miller (obiit I 886).

5052. "Mémoire pour la découverte et la conqueste des pais de Quivira et de Théguayo dans l'Amérique Septentrionale." $C f$. document with identical title in MSS. Clairambault 1016, f. 2 I I.

"Description de la Carolline, imprimée à Londres en I684." [ff. I76-I84

5113. "Observations de la campagne que vient de faire M. de Frondad, capitaine, commandant le Saint-Antoine . . . parti du Port Louis le $30^{\mathrm{e}}$ Janvier I 7o7 pour la rivière de la Platte, le Pérou, la Chine, les Isles de Mollüe et l'Amérique."-A log-book.

5214-5215.-Collection of autograph letters, I6th-I8th centuries.

5214.-I756, May 8, I3, I6, 23, June I, Dunkirk. [F. C. ?] Bart to Machault, minister of marine. News of military movements in America; declaration of war between England and France, etc.

[ff. 40-43, 45

i 666, July 9; I 67, Apr. 8, Dec. Io, New Orleans or Balize. Ulloa, Spanish governor of Louisiana, to Bory, capitaine de vaisseau, at Paris. Visit to the frontier of Louisiana, personal affairs, forts, relations with the English etc. (A. L. S.) [ff. 78, 80, 83
[

I 784, Nov. Io, Passy. B. Franklin to Anisson. Sending new characters of type. (A. L. S.)

[f. 224

5273. -Document bearing on a suit brought at Quebec against Péclavé by the widows La Magnière and Coche, of La Rochelle.

[f. 48

5398. Collection of documents relating to the French colonies in the eighteenth century.

"Apperçu sur l'état présent de l'Amérique. Journal de notre conduite; quelques observations sur ce continent, le Congrès, caractères [de] quelques généraux, et les principaux événemens de la campagne de I777." [ff. 24-39

"Précis pour Charles Deschamps . . . sieur de Boishébert, cy devant commandant de l'Acadie et autres parties du Canada."

[f. 40

"Précis pour M. de Vaudreuil ... ancien gouverneur général du Canada." Defense against charge of having traded for his own account with the merchandise sent to Canada as presents for the Indians.

$[$ f. 46

"Réponse aux objections des agens de la Compagnie des Indes; qui prouve que le Sr. Drouot de Val-de-Terre avait carte blanche pour établir le poste général du vieux Biloccy à la Louisiane, et tout ce qui s'en est ensuivy."

[ff. 48-49v

I7I4, Jan. 5, Port Louis, Louisiana. M. Varlet, missionary, to his brother. His voyage from France; description of the country; small chance for success of Crozat's enterprise. [ff. 50-52v

"Précis des détails contenus dans le mémoire que j'ai remis à $M$. le duc de Choiseul. Plaintes des marchands françois et mes réponses."-Commerce with the colonies, especially the Iles-du-Vent.

[f. 55

I787-I794. "Précis des principaux événements arrivés à la Martinique."

By "Leroy, déporté de la Martinque". [ff. 66-100

5399. Acts of sovereign power relating to the French colonies and marine, I663-I769.

I663, Apr., Paris. Ordinance establishing a sovereign council in New France. Ptd., Edits ct Ordonnances, I. 37. [f. 48 
I674, Dec. Edict abolishing the Compagnie des Indes Occidentales, Ptd., ibid., p. 74 .

[f. 52

I698, Aug. 20. Regulation of the commerce and navigation of the French islands of America.

[f. I32

I718, Jan. 8, Paris. "Ordonnance sur la retenue des 4 deniers pour livre en Canada."

[f. I 43

I724, Feb. I5. "Déclaration du Roy pour le règlement des pistoles et piastres d'argent qui ont cours aux isles et colonies de l'Amérique." [f. I64 ingue."

I724, Oct. I7. "Déclaration du Roy au sujet de l'octroy de St. Dom-

I724, Nov. 24, Fontainebleau. "Ordonnance du Roy portant que le produit du Iome $^{\text {eme }}$ des prises qui seront faites à l'avenir en commerce étranger dans les colonies continuera d'être déposé entre les mains du commis du trésorier de la Marine."

[f. I74

I727, Oct. Fontainebleau. "Lettres patentes en forme d'édit concernant le commerce étranger aux isles et colonies de l'Amérique."

[f. I75

I728, May 3I. "Arrêt nécessaire pour autoriser le bénéfice revenant au Roy des monnayes de carte, suivant l'état arresté par M. Bégon, intendant de la Nouvelle France."

[f. I86

I730, Oct. 3, Versailles. "Déclaration du Roy concernant la régie et perception du droit de capitation aux isles et terre ferme de l'Amérique."

[f. 194

I745, Mar. I9, Versailles. “Ordonnance au sujet des droits du Domaine d'Occident aux colonies d'Amérique."

[f. 240

"Tableau général des dépenses effectives de la marine, des galères, et des colonies, depuis i678 jusqu'à ı 8 io."

[f. 306

5873-5892. Correspondence of the military surgeons, D. J. Larrey (obiit I842), and his son, F. H. Larrey (obiit I895). - In two of the volumes of this collection, noted below, are numerous letters from American doctors or others. For the most part, however, they are letters of pure form-letters of introduction, letters acknowledging the receipt or announcing the sending of publications, letters announcing election to membership in American medical societies, etc.

5880. Letters from foreign doctors addressed to the elder Larrey.-The following American letters are noted:

B. H. Coates, Philadelphia, July I 5, I 842.

Dupuy, New Orleans.

George Frick, Baltimore, Sept. 2I, I823.

Gerardin, New Orleans, Apr. 7, I8I8.

Jos. G. Mancrede, Philadelphia, Dec. 2, I840.

J. Kennicott, New Orleans, Apr. 23, I832.

Felix Pascalis, New York, Dec. I6, I830.

[f. III

[f. I 3 I

[f. I 49

[f. 289

[f. $29 \mathrm{I}$

[f. 298

L. Spalding, New York, June I8, I8I5; Dec. I, I8I8; Feb. 9, I820. Medical subjects.

[ff. 4I I, 632

D. B. Warden, U. S. consul general, Paris, May 26, I8I8; Dec. 22, 1824; Mar. I 5, I830; Apr. 29, I831 ; Jan. 6, I835; Feb. 26, I84I. Letters of introduction.

[ff. $464,542-547$

Richard P. Willmott Hall, Baltimore, Aug. 27, 28, I8I8; Apr. 30, I838. Development of Baltimore, prospects of the U. S., medical department of the University of Maryland.

J. K. Kane, Philadelphia, Oct. 2I, I83I.

[ff. $470-475$

[f. 497 
5887. Letters from foreign doctors, addressed to the younger Larrey.

J. K. Barnes, U. S. surgeon general, Washington, Mar. 6, I866; Nov. I8, I 869 ; Aug. I 5, I870; Mar. 29, I875. Medical and surgical history of the Civil War; bibliography by Dr. Billings; paper for presentation to Académie des Sciences.

[ff. $38-4$ I, 508

D. Brainard, Paris, Mar. 22, I854; Chicago, Sept. I6, I858; Mar. I, I859; May 23, I860. Medical matters; visit to Paris.

[ff. $8 \mathrm{I}-86$

Charles B. Brigham, Vienna, Mar. I8, I872; Paris, July 6, I872; San Francisco, Mar. 8, I873. Great Boston fire; voyage from Panama to San Francisco; establishment in San Francisco.

A. Clarck, New York, July 30, I840.

[ff. 90-94

[ff. I 36

Edward A. Crane, secretary of the American International Committee, Paris, Mar. I3, I8, I87I. Service in France.

[ff. $164-167$

C. H. Crane, U. S. surgeon general, Washington, Oct. 4, I882. [f. I68

John J. Crane, New York, June 7, I867. Introducing his son. [f. I7o

Wm. Detmold, New York, June 8, I867. Sends a memoir for the Académie de Médecine.

[f. 185

Robley Dunglison, Philadelphia, Apr. I9, I853; July 5, I859; May I3, I868. Introducing Franklin Bache, Paul F. Eve; and Dr. Gross.

Thomas W. Evans, Paris, Oct. I, I873.

Paul F. Eve, St. Louis, May 21, 1870. His losses in the Civil War; re-election to Nashville University.

[ff. I96, 66I, 662

[f. 210

William A Hammond, U.S. surgeon general, Washington, Aug. I9,

Nov. 30, I862. Exchange of works.

[ff. 295-296

B. W. Holl, Baltimore, Apr. 30, I838. Introducing his pupil, Thomas

W. Jamieson.

[f. 319

Benjamin Howard, Paris, July 22, I856; New York, June 14, I867. His inventions for the improvement of ambulances.

Elliot F. Shepard, Paris, July I4, I868.

[ff. 320,321

[f. 322

Joseph Jones, Nashville, Nov. 26, I867; New Orleans, Dec. 2, 1869; Apr. 28, 1876 . Service under Gen. Lee; loss of property; his works on the Civil War and on the mound builders.

[ff. $330-333$

Charles A. Lee, Paris, Dec. I7, I862. Wishes to visit the military bakeries.

[f. 402

J. Marion Sims, Paris, Oct. I, Nov. 2, I864; Oct. 25, I866; Mar. I6, 1868. Desires decoration of Legion of Honor; introduces Dr. Schatz, U.S. army surgeon, who wishes to settle in France.

Valentine Mott, New York, Feb. I3, I863; Oct. 23, I864; Apr. 6, I865.

Henry K. Oliver, Boston, Nov. I9, Dec. 30, I867.

Joseph Pancoast, Philadelphia, Oct. 20, I857.

Wm. H. Pancoast, Paris, Aug. 2, I878.

[ff. $593-595$

[ff. $606-607$

[f. 6 I 2

[ff. 6I 3

Stephen H. Perkins, Paris, Nov. I, I I, I862; Florence, Feb. 26, I863; Bello Sguardo, Mar. Io, I863. Retirement pensions; military hospitals.

Alfred C. Post, New York, Nov. 30, I867.

[ff. $623-629$

[f. 646

J. Schatz, Paris, Mar. I7, I868. Desires to be authorized to practise medicine in France.

[f. 680

T. H. Squire, surgeon 89th N. Y. Volunteers, Elmira, Feb. 27, Oct. Io, I86I ; Locust Spring Hospital, battlefield of Antietam, Nov. 27, I862 ; Fortress Monroe, Va., June 5, July 22, I863; Morris Island, S. C., Jan. 20, I864; Elmira, Dec. 8, I871; Mar. 5, I872; Aug. I4, I873. Loose cartilages in the 
knee joint ; military hygiene ; surgical cases ; shooting of Lieut.-Col. Kimball; introduces $\mathrm{Wm}$. Woodward.

A. B. Tucker, Washington, Nov. 2I, 1838 .

[Dr.] Van Buren, New York, Nov. 28, I865.

Clinton Wagner, New York, Nov. 6, I884.

Alfred A. Woodhull, Savannah, Aug. 19, Dec. 20, 1876.

[ff. 723-749

[f. 820

[f. 828

[f. 872

[ff. 902, 910

59445964. Registres de la Régie-Générale des Vivres et Subsistances Militaires, I778-I790.

5945. Régie Générale des Vivres. Compte au Roi, I779.

Accounts of the expeditionary force in America under Rochambeau.

5946. Régie Générale des Vivres. Compte au Roi, I780.

Extraordinary funds for supply of the expeditionary force in America under Rochambeau.

Advance by the Régie Générale des Vivres for expenses on behalf of the expeditionary force under Rochambeau.

Expenditures for various items of supplies for the expeditionary force under Rochambeau: white flour, rice, hogsheads and barrels, empty sacks, kitchen utensils, tents and camp furnishings, materials and tools for construction, wagons, harnesses, drugs and medicines.

5947. Régie Générale des Vivres. Compte au Roi, I78I.

Accounts of funds and expenditures for supply of the expeditionary force under Rochambeau.

5948. Régie Générale des Vivres. Compte au Roi, I783.

Receipt of empty sacks for the expeditionary force under Rochambeau.

[ff. $6,22,57,58$

[ff. $62-77$

2051. Vivres du Royaume. 3 I

5951. Vivres du Royaume. Régie de Barthélemi Marchandis, du premier May I 778 au dernier Décembre, I784. Liquidation générale.

Note explaining that the service of subsistence of the expeditionary force under Rochambeau was not under the Régie des Vivres. Proceeds of sales of various supplies to the service of subsistence of the expeditionary force under Rochambeau.

Various items relating to the service of subsistence of the expeditionary force under Rochambeau.

[f. 24 , and unnumbered ff.

6189. Procès-verbaux du conseil général de la Martinique en novembre, I879, Cf. MSS. Fr., nouv. acq., 3629-3636.

6264.-I822, Dec. 23, Mexico. Letter from Iturbide to José Calderon, with portrait of Iturbide.

[ff. $43-45$

6293. - I635, July Io, Havre. Fortescuyère to the Marquis du Pont de Courtelay. Slight reference to commerce of Newfoundland. (Copy.) [f. I75
[

6360-6363. MS. copy of the memoirs of Talleyrand.-Vol. 6360 contains references to the war of American independence (ff. I43, I97) and to Talleyrand's sojourn in the United States (ff. 303 et seq.). See, however, the published Mémoires, edited by the Duc de Broglie (Paris, I89I-I892, 5 vols.).

6447-6448. Works of G. P. F. de Lamardelle, commissioner of justice in Martinique, on the organization of the judiciary and on the legislation suitable for Martinique and Guadeloupe.--Nothing in these volumes relates to North America.

6464-6497. Collection of notes, extracts, and transcripts made by H. Doniol for his Histoire de la Participation de la France à l'Établissement des Etats-Unis 
d'Amérique. - This collection, covering the years I774-I785, is composed mainly of the documents used by Doniol, and printed by him, in whole or in part. Some of the transcripts are in MS. while others are on printers' proofsheets. Whereas Doniol, in his publication, breaks up most of his documents, printing extracts here and there as they best fit into his text, in this collection the unity of the different documents has been preserved, and the transcripts are arranged in the order in which their originals are found in their respective depositories. While this collection is fragmentary, it is fairly representative of the material to be found in French archives relating to the American Revolution, and is more convenient to use, for the purpose of studying the documents, than the published work. Inasmuch as the originals of the documents included in the collection are described in other parts of this Guide, under the depôts in which they are respectively found, it has not been thought expedient, in this place, to list the contents of the 34 volumes. The provenience of the documents in each volume is however indicated, approximately, so far as it can be deduced from the printed catalogue, no attempt at verification having been made, except for vols. 6464, 6465, 6466, 6470, 6471, and 6473.

6464. Archives, Ministère des Affaires Etrangères, Correspondance Politique, Angleterre, vols. 506-513 (I774-I775).

6465. Idem, vols. 514-516 (I776, Jan.-May).

6466. Idem, vols. 517-519 (I776, June-Dec.)

6467. Idem, vols. 521-526 (I777).

6468. Idem, vols. 528-534 ( I $778-178 \mathrm{I})$.

6469. Idem, vols. 536-546 (I782-I 783 ).

6470. Extracts and transcripts from British archives and collections. British Museum : Add. MSS. 24163, 24174-24176, 24321, 29237 ; Egerton MSS. 2135. Public Record Office: F. O., France, 557, 558 [now 2, 3] ; St. Pap. For., Spain, 347 [now 207].

6471. Archives, Ministère des Affaires Etrangères, Correspondance Politique, Etats-Unis, vols. 1-2 (I775-I777).

6472. Idem, vols. $5-6$ (I778).

6473. Idem, vols. 7-8 (I779, Jan.-June).

6474. Idem, vols. 9-10 (I779, July-Dec.).

6475. Idem, vols. $11-12$ (I 780 , Jan.-June).

6476. Idem, vols. 13-14 ( I 780 , July-Dec.).

6477. Idem, vols. 15-16. (I78I, Jan.-May).

6478. Idem, vols. 17-18 (I781, July-Dec.).

6479. Idem, vols. 20-22 ( 1782 ).

6480. Idem, vols. 23-30 ( I783-1785).

6481. Idem, Supplément, vols. 1, 3; Mémoires et Documents, Etats-Unis, vols. $1-4$ ( I765-I789).

6482. Archives, Ministère des Affaires Etrangères, Correspondance Politique, Espagne, vols. 573-578 (I774-I775).

6483. Idem, vols. 579-582 (I776).

6484. Idem, vols. 583-584 (I777, Jan.-June).

6485. Idem, vols. 585-587 (I777, July-Dec.).

6486. Idem, vols. 588-589 (I778, Jan.-June).

6487. Idem, vols. 590-591 (I778, July-Dec.).

6488. Idem, vols. 592-594 (I779, Jan.-July)

6489. Idem, vols. 595-596 (I779, Aug.-Dec.).

6490. Idem, vols. 597-598 (I780, Jan.-Apr.).

6491. Idem, vols. 599-601 (I78o, Apr.-Dec.).

6492. Idem, vols. 602-609 (I78I-I782). 
6493. Archives, Ministère des Affaires Étrangères, Correspondance Politique, Prusse, Vienne, Russie, Hollande, and Suède. (I776-I782.)

6494. Archives, Ministère des Affaires Étrangères, various series ; Archives Nationales; Bibliothèque Nationale; miscellaneous. (I774-I795.)

6495. Archives, Ministère de la Marine. Especially series B 4. (1776I 782.$)$

6496-6497. Archives, Ministère de la Guerre, Correspondance ; Correspondance de Rochambeau.

6561. Two letters, written on birch bark, and preserved in a glass-covered case.

I647, July 28, Ste. Marie-des-Hurons. Father Joseph Poncet, S. J., to Father Claude Martin, Benedictine. Relating to his mission among the Indians. (A. L. S.)

1676, Oct. Letter of thanks, in Huron and in French, addressed to M. Sain, receveur général des finances at Bourges, by young Huron women.

6577. Correspondence of Mme. Dupont de La Motte.

Verses on Benjamin Franklin and American independence. [ff. I 53, I55

"Invocation à la Liberté." [f. r6r

Biographical notes on Franklin, Penn, and Washington. [ff. 162, I66, I7 I

6658. -N. d. Problems in physics, with figures, addressed to "citoyen Eisenman", by Robert Fulton.

[f. 5 I

6785. Collection of documents relating to the French colonies and to the slave-trade, I797-I830.

An V, Frim. 26. Memoir by Mentelle on agriculture and population of Cayenne.

[ff. I -7

1828, Oct. Memoir by Gen. Desfourneaux on means of finding compensation for the loss of Santo Domingo.

I828, Apr. I8. Circular of Hyde de Neuville, minister of the marine, on the execution of the law of Apr. 25, 1827, for the suppression of the slavetrade.

[f. 92

I828, May 29, Paris. "Exposé de la législation relative aux gens de couleur libres dans les colonies ..." since r685.

[ff. 93-I04

r828, Aug. 26, Paris. Memoir by Aug. Billiard on the abolition of slavery in the French colonies.

[ff. IIO-I 35

1828, Nov. 7. Hyde de Neuville to the minister of foreign affairs, relating to the suppression of the slave-trade in the West Indies.

[ff. I40-I42

6846-6847. Correspondence and papers of Sonthonax relating to Santo Domingo, I792-I801. Sonthonax was civil commissioner to Santo Domingo in I782-I794 and in I796-I797. The letter-books of his private correspondence, I 796-r 797, are in MSS. Fr. 8986-8988.

6846. Correspondence, arranged alphabetically.

An VI, Therm. 25, Le Cap. Albert to Sonthonax. Disposition of various American firms to deal with the commissioner.

I793, Dec. 23, New York. Galbaud, governor general, to Genet. Denounces him for his slanderous statements.

[f. 44

An V, Vend. I6, I7, Philadelphia. Henry Perroud, general maritime agent, to Sonthonax. Impression produced in the U. S. by events in Santo Domingo; recommends Philadelphia firms.

6847. Miscellaneous documents, r792-r8or.

[ff. 77,82

An IV, Therm. 2, Le Cap. Extract from the deliberations of the civil commission. Deliveries by the New York firm of Peter William Livingston; supplies by neutrals. 

an IV.

Petition respecting prizes, including American vessels, captured 20 Fruct.

I797, Aug. 21, Le Cap. Captains and supercargoes of American 4 f. 40 sels to Sonthonax, expressing their regret at his departure. [f. 85

6864. Collection of letters and other documents relating to Toussaint Louverture. Correspondence of Isaac Louverture, son of Toussaint, respecting his father's life, imprisonment, and death; biographical memoranda; recollections of Plaisir, servant of Toussaint, Dubois, and Bonnet, aide-de-camp of Rigaud ; descriptions, plans, and photograph of the Fort de Joux, where Toussaint Louverture was confined, etc. ; certificate of death of Toussaint. $C f$. MSS. Fr. 12102-12104.

6946-6971 Résumés of and extracts from the despatches of the imperial [Austrian] ambassadors in France, I7I5-I792, and inventories of various series in foreign archives relating to the history of France, I4I6-I792.-This collection, formed by Jules Flammermont, is in three groups as follows : 69466951 , résumés (analyses) of the despatches of the Austrian ambassadors in France, I7I5-I792; 6952-6964, extracts from the same despatches; 69656971 , inventories and miscellaneous. The first group presents an interest for American history; the résumés, in German, are fairly full and appear to be carefully made, and they contain, especially for the years I776-I783, many references to American affairs as observed at the court of Louis XVI. and reported to Prince Kaunitz by the ambassador, Mercy-Argenteau. Lists of annexed documents (beilagen) accompany the résumés. The second group is of less interest for American affairs because the extracts which compose it are confined much more closely to purely French matters. The third group appears to have little or no interest for the purpose of this Guide.

In the following list, taken from the printed catalogue, such fragmentary notes as were made during a hasty examination of four volumes are incorporated for the purpose of illustrating the utility of this collection, more especially as a guide to the French series in the archives of Vienna. $C f$. Jules Flammermont, Les Correspondances des Agents Diplomatiques Etrangers en France avant la Révolution, conservées dans les Archives de Berlin, Dresde, Genève, Turin, Gênes, Florence, Naples, Simancas, Lisbonne, Londres, La Haye et Vienne (Paris, I896: ext. from Nouvelles Archives des Missions Scientifiques, vol. VIII.), and also A. von Arneth, Correspondance Secrète du Comte de Mercy-Argenteau avec l'Empereur Joseph II. et le Prince de Kaunitz, I780I790, with appendix, I766-I780. (Documents Inédits sur l'Historie de France, Paris, I889, I891, 2 vols.)

6946. Résumés of despatches of the imperial ambassadors in France, preserved in the archives of Vienna, I7I5-I733.

6947. Idem, I736-I744.

6948. Idem, I 750-I 766.

6949. Idem, I766-I 777.-Despatches from Mercy-Argenteau of Dec. I8, 25, I776, Jan. 8, I7, Feb. 5, I9, Mar. 5, 12, Apr. 2, 25, Aug. 27, I777, and numerous others contain references to the American Revolution, the policy of Vergennes, Franklin's mission to France, news of military operations in America, etc.

6950. Idem, I778-I784. Despatches from Mercy-Argenteau of Jan. I7, 30, Mar. 20, Apr. 20, May 5, I778, and others refer to American affairs, conversation with Arthur Lee, etc.

6951. Idem, I785-I792. 
6952. Extracts from the despatches of the imperiai ambassadors in France, preserved in the archives of Vienna, I 7 I 5-I743.

6953. Idcm, I $750-\mathrm{I} 766$.

6954. Idem, I $766-1769$.

6955. Idem, I $770-1772$.

6956. Idem, I $773-\mathrm{I} 774$.

6957. Idem, I775-I 777. E. g., Mercy-Argenteau to Kaunitz, Jan. I7, I 777 : American affairs and Beaumarchais.

6958. Idem, I778. E.g., Mercy-Argenteau to Kaunitz, Jan. 30, I778: conference with A. Lee.

6959. Idem, I779-I78I.

6960. Idem, I $782-1783$.

6961. Idem, I $784-\mathrm{I} 786$.

6962. Idem, I $787-1789$.

6963. Idem, I $790-1792$.

6964. Idem, I79I-I 792 .

6965. Documents relating to Florimond de Mercy-Argenteau.

6966. Résumés of despatches of Mercy-Argenteau, I766-I794.

6967. Despatches of Mercy-Argenteau, I767-1776.

6968. Despatches of Mercy-Argenteau and other imperial ambassadors, I $780-I 793$.

6969. Despatches of the Prussian ministers, von der Goltz and Alvensleben, I772-I 788 .

6970-6971. Inventories, Vienna and Simancas; transcripts from the Hague, etc.

\section{(COLLECTION BRIENNE.)}

6972-7328. Collection Brienne.-Collection of copies of documents relating to foreign affairs, commerce, and other matters, formed by Antoine de Loménie, seigneur de La Ville-aux-Clercs ( I572-I638), secretary of state of Henry IV. and Louis XIII. Of the volumes noted below, only 7287 and 7290 have been examined; the others are mentioned because of their possible interest for the purposes of this survey, though it seems unlikely that they should contain material not already well known and more accessible elsewhere.

7003. Treaties of peace between the kings of France and the kings of England, I 527-I629.- All such treaties having any bearing upon American history are printed in F. G. Davenport, European Treaties.

7005. "Meslanges contenans plusieurs lettres, tiltres, actes et autres mémoires concernant les affaires entre les rois de France et les rois d'Angleterre." I I $90-1625$.

7009-7012. "Despatches de messire Christophe de Harley, Comte de Beaumont, escrites pendant son ambassade d'Angleterre au Roy et à Mr. de Villeroy, avec les responces." I60I-I605.-Most of these despatches are lacking in Arch. Affaires Étrangères, where are to be found only those of Jan. 23-Mar. I9, I603 (Corr. pol., Angleterre, vol. 24). Cf. Laffleur de Kermaingant, L'Ambassade de France en Angleterre sous Henri IV., Mission de Christophe de Harlay, Comte de Beaumont, I602-1605 (Paris, I895, 2 vols.).

7013-7014. "Lettres escrites par M. de La Boderie au roy et à M. de Villeroy, lors de son ambassade en Angleterre, ès années I606-I6Io."--See above, MSS. Fr. 7108-7109. 
7015. "Lettres escriptes par le roy et par Mr. de Villeroy, secrétaire d'estat, à Mr. de La Boderie, ambassadeur ordinaire en Angleterre." I606-I6r I.Cf. idem.

7023. "Mémoires, actes et traictez concernans les affaires entre les roy de France et d'Angleterre en l'année I587 et ès années I627-r630."-Cf. Davenport, op. cit.

7072-7075. “ Négociation de la trève entre le roy d'Espagne et les archiducs de Flandres, d'une part, et les Estatz généraux des sept provinces unies des Pays Bas, d'autre, traitée . . par Mrs. le président Jeannin, Buzenval et Russi, ses ambassadeurs ", I607-1609.-See above, MSS. Fr. 7086-7090.

7287. Memoirs and edicts relating to commerce.

I603, Jan. [Nov. ?] 8, Fontainebleau. "Lettre par laquelle le Roi fait son lieutenant général le Sr. de Montz au pais et confins de la terre de la Cadie." Cf. MSS. relatifs à la Niouvelle France, I. 43.

[ff. 87-92

I603, Dec. I8, Paris. "Autre lettre patente en faveur du Sr. de Montz pour le fait de son entreprise des Indes." Cf. ibid., p. 46.

[ff. 93-95

r603, Nov. 6, Fontainebleau. "Articles proposés au Roi par le Sr. de Montz pour la descouverte et habitation des costes et terres de la Cadie."Ptd., ibid., p. 40.

[ff. 97-100

r603, Dec. 18, Paris. "Remonstrances faictes au Roy par le Sr. de Montz sur les articles" of Nov. 6. Ptd., ibid., p. 44 . [ff. IOI-IO2v I626, July, Nantes. "Edit du Roy pour l'establissement du commerce général en France par mer et par terre, Levant, Ponant, et voiages de longs cours."

[ff. I I8-I27v

r626, Mar. 3r, Charonne. "Contrat fait entre le Cardinal de Richelieu et les Cent Associés pour le commerce general . . . pour tenir leur demeure à Morbihan."

[ff. I 48 -I 59

I627, Apr. 29. “[Acte pour] 1'établissement d'une nouvelle compagnie pour trafiquer en la Nouvelle France." Ptd. in Édits et Ordonnances, I. 5 .

[ff. 160-I70

1627. "Forme des lettres de congé ... pour le fait de la navigation et du commerce."

[ff. I 72-I $72 \mathrm{~V}$

"Advis donnés au Roi sur le fait de la navigation et commerce de l'Amérique et les ordres des armes d'Espagne."

I606, Apr. ro. "Lettres patentes du Roy d'Angleterre ... pour la plantation et habitation de la Virginie." [ff. 284-286v I6ro, Apr. 27. "Lettres patentes du Roy d'Angleterre pour la Terre Neufve et la plantation faite en icelle par les Anglnis." [ff. 288-290v r6r.9, July 9, Westminster. "Lettre du Roi d'Angleterre au Comte de Southampton et au Conseil de la Cie. de la Virginie . . . sur les ouvrages de la soie et plantes de vigne en la Virginie." [ff. 292-292v

[r6rg.] The council of the Virginia Company to the governor and council of Virginia, respecting silk and wine. (French.) [ff. 293-294v I620, Nov. I I, Cape Cod. "Acte d'association entre ¿es Anglais pour le voyage de Virginie" [Mayflower Compact]. [ff. 296-296v I627, Nov. 8, Lubeck. Proposals made by the Emperor and the King of Spain to Hanseatic and maritime towns of Germany for the formation of a company for commerce with Spain, the Indies, etc. [ff. 304-3 rov I627. Similar proposals to the city of Danzig. [ff. 3I 2-3I 5v

"Avertissement touchant la navigation et commerce des Hollandais rebelles." Whale fisheries, St. Thomas, Brazil, and Guinea. [ [ff. 320-350v "Discours sur le fait des Indes." Spanish and Dutch interests in the West Indies.

[ff. $363-36 \mathrm{gv}$ 
7290. Privileges of foreign merchants in France, etc.

I555, Moscow. " Premiers privilèges octroyés par l'Empereur de Russie aux marchands anglais." Privileges to Sebastian Cabot and the Merchant Adventurers.

[ff. 3I6-32I

I555, Feb. 6, Westminster. "Charte des marchands de Russie à eux concédée par le Roy Philippe et la Reyne Marie."

[ff. $322-335 \mathrm{v}$

\section{(COLLECTION RENAUDOT.)}

7483-7497. Collection Renaudot.-This collection, formed by Abbé Eusèbe Renaudot (I648-I720), is composed in part of documents relating to geography and voyages, explorations in the interior of America, diplomatic affairs, etc. Renaudot was particularly a friend of Henri de Tonty, from whom he received letters and memoirs, and was also in close correspondence with Abbé Bernou. See Bibliothèque de l'École des Chartes, LI. 270, and articles on Rendaudot in Gros de Boze, Histoire de l'Académie des Inscriptions, and in the Nouvelle Biographie Générale.

7483 (formerly Renaudot 28). "Descriptions de medailles à faire par Mr. l'Abbé Renaudot: r. Sur ce que les Anglais ont esté repoussés en Canada, 1690. 2. Sur les prises faites par les armateurs, 1695."

7485 (formerly Renaudot 30). Geography and voyages.

"Mémoire historique des principales découvertes, voyages, et navigations de long cours", by Renaudot. (See autograph MS. in MSS. Fr. 9516.) Columbus, savages at Lubeck in I353, the Cabots, Vasco da Gama, CorteReal, Pinzon, Vespucci, Cortez, Drake, Verrazano, Cartier, Roberval, Champlain, etc. (3 copies.)

[pt. I., ff. I-34, 85-I09, I88-223

"An extract of the voyages and discoveries by land and by sea that are to be found in the collection of them by Mr. Hacluyt." [pt. I., ff. I I8-r36v I669-1670. "Ce qui s'est passé de plus remarquable dans le voyage de Mrs. D’Olier et Galinée." Ptd., Margry, I. I I2-I66. [pt. I., ff. I-25v

"Mémoire pour Mgr. Le Marquis de Seignelay concernant l'estat de la colonie de Saint Domingue ", with a memoir on the filibusters and a list of them and their vessels.

[pt. II., ff. 91-94v

"Description de l'Isle Saint Domingue et Projet pour s'en emparer fait par feu Monsieur Daugeron [Ogeron] apres le Passage de Monsieur de Tracy aux Isles en I665."

[pt. II., ff. 95-98

I678-I690. Narrative, signed by Henri de Tonty, of the explorations of La Salle and himself in the valley of the Mississippi. This document is also in Arch. Colonies, Ci 3, c, vol. 3, ff. I28-I4Iv, where it is accompanied by the copy of a letter from Tonty of Sept. 12, 1693. Ptd. in French, Hist. Coll. of Louisiana, I. 52 .
[pt. II., ff. IO3-II8

Henri de Tonty to [Renaudot]. Topographical details of the Mississippi Valley; location of rivers and tribes of Indians; memorandum of men and supplies necessary for the exploration of the country. (Copy.)

[pt. II., ff. I I 9-I 20

[ I699. Father François Jolliet de Montigny, S. J.] to " Monseigneur". Account of his voyage with Father [Julien] Binneteau, May 4-Aug. 20, from the Illinois country to the Gulf of Mexico; visit to Fort Maurepas at Biloxi; establishment of mission among the Taensa; peace between the Taensa and the Natchez; customs of these tribes. (Copy.) [pt. II., ff. I2I-I $27 \mathrm{~V}$ I700, July I7, New York. [Father François Jolliet de Montigny, S. J.] to Monseigneur. Expedition of Le Sueur to the Sioux; illness of writer during his stay with Father Davion at the mission of the Tonica; visit of Iberville 
and Bienville to the mission of the Taensa (cf. Margry, IV. 4I3-4I7); death of the chief of the Natchez; voyage to the fort on the Mississippi and to the fort at Biloxi; voyage from the Mississippi to New York; brief notice of New York and Pennsylvania; Scottish establishment at Darien; Capt. "Jean Bar" [Bank] turned back from the Mississippi by Bienville; English supply the Arkansas Indians with guns; visit of Spanish vessels from Pensacola to the establishments on the Mississippi. (Copy.) [pt. II., ff. I27v-I3IV I686, Aug. 24, Montreal. Henri de Tonty to Cabart de Villermont. (Copy.) Ptd., Margry, III. 559.

[pt. II., ff. I 32-I 33 I689, July I. Extract from the Gazette de Hollande: news of the establishment of La Salle on the Mississippi.

[pt. II., f. I 33

"Voiage de Mr. de la Salle à la Rivière de Missipi." Not a narrative, but a summary of geographical information. Also in Arch. Colonies, $\mathrm{C}_{13}, \mathrm{c}$, vol. 3 , ff. $23-26$, where it is said to have been enclosed with the letter of Frontenac of Nov. 9, I680. Ptd., Margry, II. 93-IO2. [pt. II., ff. I34-I38v I685, Jan. 20, Martinique. Memoir for the king by St. Laurent and Bégon. Commerce, filibusters, etc. Also in Arch. Colonies, C8, A, vol. 4.

[pt. II., f. I 39

1676, Sept. 24. Speeches of Frontenac to the Iroquois deputies in the assembly held at Fort Frontenac, and their replies. [pt. II., ff. I47-I6Iv I687, June I3-Aug. I3. "Mémoire du Voiage de Mr. le Marquis de Denonville contre les Sonontouans" [Senecas]. Ptd., N. Y. Col. Docs., IX. 358.

1683. "Relation de la découverte de l'embouchure de la Rivière de Mississipi dans le Golphe du Mexique faite par le Sr. de la Salle, l'année dernière I682." Also in Arch. Service Hydrog., 67, no. I 5. Copy of a summary account of La Salle's descent of the Mississippi to its mouth in I68I-I682.

[pt. II., ff. I70-I75v

"Relation de la Nouvelle France, I673." Voyage of Joliet to the Mississippi. Ptd., Margry, I. 259-262.

[pt. II., ff. I76-I $77 \mathrm{v}$

I69I, Sept. 3, Pentagouet. Extract from a letter from St. Castin to Frontenac; English at Boston; death of the governor of Manhattan; disposition of the Acadian Indians.
[pt. II., ff. I78-I $78 \mathrm{v}$

7488 (formerly Renaudot 33).- "Indes occidentales. Quelle a esté la manière dont les Espagnols ont gouverné?" [ [f. 354

7491 (formerly Renandot 36).- " Relation de la découverte de plusieurs pais scituez au midy de la nouvelle france faite l'année I673." Voyage of Louis Joliet and Father Marquette. Ptd., from a document in Arch. Service Hydrog., in Margry, I. 262-270.

[ff. $35^{\mathrm{I}-355}$

7497 (formerly Renaudot 42). A volume of autograph letters from Abbé Bernou to Renaudot. These letters, written mostly during the years 1683 I686, while Bernou was in Rome, are exceedingly interesting for the light they throw on various aspects of La Salle's enterprises, and on other American matters. Frequently they will be found to explain documents in the Collection Clairambault, especially those in vol. 1016, which is composed of papers of Bernou. A few of the letters, or extracts from them, have been printed by Margry, III. 73-87. The following letters, all autographs and all but two dated at Rome, contain passages relating to American matters, chiefly to $\mathrm{La}$ Salle.

I683, May I8.

[ff. 9-IOv

I683, June 27, Frascati. References to map of New Mexico made by Bernou, and a map of North America made by Bernou and Father Coronelli 
for Seignelay; use to be made of the work of Father Zenobe [Membré] and of Bernou's relation of the discoveries of La Salle.

I683, July 20.

I683, July 27.

I683, Aug. Io.

I683, Aug. 24.

I683, Aug. 3 I.

[ff. I $8-20$

[ff. $25-27 \mathrm{v}$

[ff. $28-3 \mathrm{IV}$

[ff. $38-39 \mathrm{v}$

[ff. $40-4 \mathrm{I}$

I683, Sept. 7 .

[ff. $42-43 \mathrm{v}$

[ff. $44-45 \mathrm{v}$

I683, Oct. I9. Hopes that La Salle may have the government of the Mississippi.

[ff. $54-55 \mathrm{v}$ I683, Dec. 7.

[ff. $72-73 \mathrm{v}$

I684, Jan. 25. Glad that interests of La Salle are in the hands of Renaudot; La Salle must receive the support of the " robes noires" [Jesuits] if he goes to the Illinois and Arkansas countries by way of Canada; plan for expedition by the Gulf of Mexico; interest of the cardinal [Benedetto Pamphili] in voyages of La Salle.

[ff. 86-88v I684, Feb. I. Bernou will correct or rewrite his relation of La Salle's discoveries, being careful to take vengeance on Hennepin; advice respecting the map with which La Salle should accompany his narrative. I684, Feb. 8.

I684, Feb. I5.

[ff. 89-9I

[ff. $94-95 \mathrm{v}$ I684, Feb. 22. Wants to be confirmed as agent of La Salle if the latter's affairs are successful. I684, Feb. 22.

I684, Feb. 29. Ptd., Margry, III. 73-77. I684, Mar. I4. Wishes to see La Salle before his departure.

[ff. 96-96v

[ff. 97 -IOOV

[ff. IOI-IOZV

I684, Mar. 2I. Complains of silence of La Salle.

[ff. I04-105v

[ff. I06-107v I684, May [sic] 23. Money which La Salle should pay to him; bad form in which he found $\mathrm{La}$ Salle's narrative. I684, Mar. 28. Ptd., Margry, III. 78-81.

[ff. I08-109v

[ff. IIO-IIIV I684, Apr. 3. Memoir by the new Bishop of Quebec [Saint Vallier], respecting jurisdiction over the Mississippi, and his reply thereto in another memoir. Cf. MSS. Clairambault 1016, f. 629.

[ff. I I 2 -I I $3 \mathrm{~V}$ I684, Apr. 4. Glad to have letter from La Salle; does not advise La Salle to delay his departure from France for fear lest R [obe] N [oire] should discover his plans and oppose them; La Forest should be sent to trade with the Indians along the Mississippi. I684, Apr. i i. Ptd., Margry, III. 82-84. I684, Apr. I8. Asks for return of his notes against Marquette.

[ff. I I 4 -I I $5 \mathrm{~V}$

[ff. I I6-I I 7 v

[ff. II 8 -I $20 \mathrm{~V}$ I684, May 2. Urgent that La Salle should leave this month; wishes to know the state of La Salle's affairs after his departure, and promises secrecy.

I684, May 9.

[ff. I $23-124 \mathrm{~V}$

I684, May I6 Bonus, vessels, and munitions accorded Ia Salle by the king; regrets that La Salle is going to land at Quebec [sic]. [ff. I28-129v I684, May 27. I684, June 3 . I684, June Io. [ff. I $30-13 \mathrm{I}$

[ff. I $32-\mathrm{I} 33 \mathrm{~V}$ I684, July 8. 
I684, July I2. Stay of Ontcouantagueté [La Salle] at La Rochelle; has received La Salle's map; La Salle's suspicions aroused by manoeuvres of $\mathrm{R}$ [obe] N[oire]; which is regrettable, for the latter could be of service.

I684, Aug. I9.

[ff. I $42-\mathrm{I} 44 \mathrm{~V}$

[ff. $15 \mathrm{I}-\mathrm{I} 52$

[ff. $\mathrm{r} 5 \mathrm{I}-\mathrm{I} 52$
52 by him, and hopes that Renaudot will secure forgiveness of La Salle from the priests of the rue de la Victoire; La Salle's delay places his life and plans in danger; Gambacorta [Cabart de Villermont?] has become his enemy, through interest in one of the Tontys.

r684, Sept. 9. Ptd., Margry, III. 85-87.

1684, Sept. I6. La Salle spoiled by flattery.

I684, Sept. 23.

I684, Oct. I4.

I684, Nov. 4.

[ff. I 53 - $154 \mathrm{v}$

[ff. 155 - I 56

[ff. I 57 - I 58

[ff. I $59-160 \mathrm{ov}$

[ff. I65-166v

[ff. I69-170v

I684, Nov. I I. Renaudot should forgive La Salle, as he forgave Radisson for having pillaged the English, and Groseillers for having eaten human flesh; it is necessary to have patience.

[ff. I I I-I $72 \mathrm{v}$ 1684, Nov. 18. Thinks La Salle guilty of only a part of the things of which he is accused.

r684, Dec. 9.

[ff. I $73-\mathrm{I} 74 \mathrm{v}$

[ff. $177-178 \mathrm{v}$

r684, Dec. I6. Useful to send Frontenac to Canada; praise of La Barre.

[ff. I8I-I82v

1685, Jan. 20. The Recollects accompanying La Salle have been accorded the powers of apostolic missionaries.

1685, Feb. 3. Arrival of La Salle at Santo Domingo.

[ff. I I I-I92v

[ff. $195^{-196 \mathrm{v}}$

1685, Feb. Io. Treaty with the Iroquois; the Illinois should not be abandoned; attitude of Bishop of Quebec with respect to appointment of curés.

[ff. $197-\mathrm{I} 98 \mathrm{v}$

1685, Feb. 24. Congratulates Renaudot for having delivered Canada from its first bishop.

I685, Mar. 3 .

[ff. 201-202v

[ff. $203-204 \mathrm{~V}$ skins.

1685, Mar. 17. Opinion on the new ferme in America; trade in beaver

1685, Apr. Io. Sends memoir by Abbé de Saint-Vallier, which, as well as the memoir by La Barre, was dictated by the R. N. in the design of detaching the upper Mississippi from the colony of Canada.

[ff. $2 \mathrm{r} 3-2 \mathrm{r} 4 \mathrm{v}$ England.

I685, Apr. 24. A mistake to recall Radisson, who is a scoundrel, from 1685, May 8.

[ff. $216-2 \mathrm{I} 7 \mathrm{v}$

168. May 8. 3 . the Islands [West Indies] ; the court is not opposed and the R. N. agrees. Cf. MSS. Clairambault 1016, f. 633 .

1685, June I9.

I685, July 3 .

[ff. 220-221

[ff. 224-225

[ff. 226-227

1685, June 5. Asks if Radisson has become a Huguenot, like his wife and father-in-law.

[ff. 228-229v I685, June I2. Beauvieu [Beaujeu] loaned 200 pistoles to La Salle at Santo Domingo.

[ff. 23o-23IV I685, Aug. 7. Asks for news of $\mathrm{La}$ Salle in order to reply to falsehoods circulated by Gambacorta. 1685, Aug. I4.

[ff. $243-244 \mathrm{~V}$

[ff. $245-246$ 
I685, Aug. 21. Has no letters from Villermont, doubtless because the latter knows nothing bad to say about La Salle.

[ff. $247-248$ I685, Aug. 28. Arguments employed by Villermont against La Salle, and by Bernou in combating them.

I685, Sept. 25. Anger of Villermont against Bernou. [ff. 257-258v I686, Apr. I6.

I686, June Io, Marseilles.

[ff. 249-250v

[ff. 3I 3-3I4

[ff. $324-325$

7510. Voyages of Jean and Raoul Parmentier of Dieppe to Sumatra in I 529, and to Santo Domingo.-Published from this MS. by Ch. Schefer, Le Discours de la Navigation de Jean et Raoul Parmentier de Dieppe (Paris, I883), in Recueil de Voyages et de Documents pour servir à l'Histoire de la Géographie.

7525. Articles on La Salle by P. Lenot in the Nouvelle Biographie Générale (I862), and by Th. Lebreton in the Revue de Rouen (I852), given to Margry by G. Gravier.

\section{(COLLECTION MARGRY.)}

9255-9510. Collection Margry. This collection of 255 volumes was formed by Pierre Margry (I8I8-I894) with the purpose of documenting and writing the history of French navigation, exploration, and colonization. Margry commenced work in his chosen field as the collaborator of J. R. Brodhead in the compilation of Documents relative to the Colonial History of the State of New York (1853-1883) ; he finished with the publication of his own collection, Découvertes et Établissements des Français dans l'Ouest et dans le Sud de l'Amérique Septentrionale (I879-I888). Margry's exploitation of the immense mass of material that he gathered together was confined to the lastnamed publication and to a small number of minor works and articles; his major design was not realized. The MS. collection is a formidable, ill-arranged mass of material. For the most part it is composed of rough notes, badly made copies by Margry, fair copies by copyists, extracts, lists of documents, etc., all of which were drawn chiefly from the archives of the Marine and Colonies, then united, of which Margry was for many years the custodian, from the archives of the Hydrographic Service, the archives of the ministries of War and of Foreign Affairs, and from the MSS. of the Bibliothèque Nationale. There are also extracts and copies from the Archives Nationales and certain departmental archives, from MSS. in provincial libraries, and from MSS. in private hands. Finally there are a few original documents, presented to Margry, or purchased or "borrowed" by him. There is much repetition of material, and the sources of most of it are indicated insufficiently or not at all. Such indications as to sources as are given in the following pages are based mainly on personal acquaintance with them and not on information contained in the collection. The value of the collection lies, in the first place, in the original documents which it contains, in the second place, in the copies of documents of which the originals have disappeared or are not readily accessible, and finally, in the numerous suggestions scattered throughout the volumes as to the location of documents relating to America. There are also a few autobiographical notes by Margry, and a considerable number of letters written to him by historians, especially by Francis Parkman. For a brief, rather patronizing biographical memoir of Margry, accompanied by a bibliography of his writings, see Gabriel Gravier, Mélanges: Comptes-Rendus, III. 2I-47 (Rouen, I894). 
In the following notes it should be remembered that all documents listed are copies unless otherwise indicated.

9256. Champlain.

Transcript made by Margry at Dieppe in Oct., I847, of the original MS. of the "Brief Discours des Choses les plus remarquables que Samuel Champlain, de Brouage, a reconneues aux Indes Occidentales. . . " I 599, I600 (now in the John Carter Brown Library at Providence, R. I.). [ff. 5-37 "Portrait" of Champlain, with note. [f. 40 Copies of 56 illustrations, in color, from the "Brief Discours". [f. 42

Copy by A. Feret (then owner of the MS. of the "Brief Discours"), Dieppe, Oct. 6, I847, of the picture of a festin d'Indiens, by Champlain. [f. 98 Documents inédits sur Samuel Champlain... publiés par Etienne Charavay (Paris, J. Charavay ainé, I875, 8 pp.).

[f. 99

Original document of Mar. I5, I6I9, bearing signature of Champlain.

9257. Champlain.-Transcript of Des Sauvages ou Voyage de Samuel Champlain ... I603 (Paris, Claude de Monstr'oeil).

9258. Champlain.-Transcript of Les Voyages du Sieur de Champlain (Paris, Jean Berjon, I6 3 ).

9259. Champlain.-Transcript of Voyages et Découvertes faites en la Nouvelle France... I6I5 ... I6I8, par le Sieur de Champlain (Paris, Claude Collet, I620).

9260. Champlain.-Les Voyages du Sieur de Champlain (Paris, I632). Fragment of the printed volumes, viz., pp. 2I7-3IO of part I. and all of part II.

9261. Transcripts of parts of Marc Lescarbot, Histoire de la Nouvelle France, as follows: three dedicatory letters to the king, to Jeannin, and to France; ch. XXXI., "Plainte sur notre inconstance..."; ch. XXXII., "Voyage du Marquis de la Roche . . ." ; Quatrième Livre", chs. I-XVIII.; "Cinquième Livre", chs. I-XV.

9262. Transcript of Denys, Description Géographique des Côtes de l'Amérique Septentrionale; Histoire Naturelle des Peuples, des Animaux, des Arbes et Plantes de l'Amérique Septentrionale ... (Paris, Claude Barbin, I67I).

9263. Transcript of Pierre Boucher, Histoire Véritable et Naturelle des Moeurs et Productions du Pays de la Nouvelle France (Paris, Florentin Lambert, I664).

9264-9266. Transcript of Gabriel Sagard-Théodat, Histoire du Canada, et Voyages que les Frères Mineurs Recollets y ont faits (Paris, I636).

9267. Transcript of tome II. of Chrestien Le Clercq, Premier Etablissement de la Foy dans la Nouvelle France (Paris, Amable Auroy, I66I).

9268. Canada, Acadia, Jesuits, and miscellaneous.

Carte de la Nonvelle Angleterre, Nouvelle Yorcke et Pensilvanie, pour servir à l'Histoire Générale des Voyages, par M. B., Ing. de la Mar[in]e, I757.

Map of Ancient Nova Scotia . . compiled by John Wilkinson Fredericton, $N . B ., J u l y, I 840$.

[f. I

$[\mathrm{f} .2$

Tracings of autograph signatures of governors of Canada, bishops of Quebec, and other personages.

Census of Quebec, I799.

[ff. 3-6

N. d. Gen. Cass to Marshal Soult, respecting the Indians of North America. (A. L. S., in English.)

[ff. I 3-29

I 843 , Feb. 20. Request by [Louis Joseph] Papineau for permission to consult the archives of the Marine and Colonies.

A la Claire Fontaine. Words and music.

[f. 30

[f. 32 
I885, July 31, Aug. 2, 4. Clippings from La Minerve, Montreal.

[ff. $33-36$

I 594, July 3, Rennes. Copy of letter from Marshal d'Aumont to the king on behalf of Thomas Gravé of St. Malo.

[f. 38

Historical and biographical notes respecting Champlain: list of notarial papers relating to Champlain and his wife; extracts from printed works; notes relating to contest of Champlain's will, etc.

Copies and extracts from Le Clerc, Premier Etablissement de la Foy; Sagard-Théodat, Voyage du Pays des Hurons; and Charles Daniel, Voyage du Capitain Daniel de Dieppe.

Copies and extracts of documents relating to the Compagnie de la Nouvelle France ; articles of Apr. 29, I627; edict of May, I628; "Etat au vrai de la dépense faite par la Compagnie ", I628-1663; extracts from deliberations of the company of Jan. I 5, I636, Jan. 2, I65 I, Mar. 5, I657; "Etat général des dettes passives ", I642; reunion of New France to the crown, I663.

[ff. 206-214, 216-218, 233, 259-262, 297, 332, 353

Extracts from Jesuit Relations, I633-1664. $265^{-272}, 282-284,293-296,298-312,326,33 \mathrm{I}-337,345-347,356$

Copies and extracts relating to Montreal: concession of Jan. 15,1636 ; transfers of April 30, I638, Aug. 7 and Dec. I7, I640; acts of Mar. 25, I644. and Mar. 2I, I650; concessions of Apr. 21, I659, Jan. 9, I673, etc.

[ff. $233-235$

Copies and extracts relating to Port Royal: letters of d'Aulnay Charnisay, Jeanne Nolin, Cinq-Mars, etc., I644-I65I [ [ff. 276-28o, 288, 328

Copy of parts of Mémoire pour faire connoistre l'Esprit et la Conduite de la Compagnie establie en la Ville de Caen appellée l'Hermitage ( $\mathrm{I} 66 \mathrm{O})$. [ [f. $3^{\mathrm{I}} 5$

9269. Canada, I534-I685.

Copies of commissions, letters patent, powers, judicial papers, etc., relating to early voyages and trade: Chabot, Jacques Cartier, Roberval, Paul d'Auxillion, Etienne Chaton, Jacques Noël, Chauvin, Chefdhôtel, I 534, I 540I 544, I 575, I 588, I598, I602, I603. Nearly all these documents are to be found in print; see H. P. Biggar, Early Trading Companies, Bibliography, pt. I.

[ff. I- 35 I6I3.

Letters patent relating to de Monts and the Prince de Condé, I604, I612-

Documents relating to the Recollects in Canada, some copied from Arch.
[for Départementales, Seine-et-Oise, I62 I, I635, I684, I685.

[ff. $45-48,5$ I- 59,5 I $8-522$

Memoir on the origins of Montreal, I640-1672, by Dollier de Casson.

[ff. $61-176$

I6I9. "Etat des personnes qui doivent estre menées et entretenues en l'habitation de Québec."

1622. Union of the companies of de Caen and Montmorency. [f. I83

I628-1657. Documents relating to the companies of the Ioo associates and of New France, opposition of de Caen, restitution of Quebec, police regulations, etc. In part from Arch. Affaires Etrangères, Mém. et Doc., Amérique,
vol. 4.

Correspondence and papers of Pierre Voyer d'Argenson, governor of Canada, I657-1660.

[ff. $325-359$

Administrative correspondence of Canada, memoirs and other documents: de Mézy, Colbert, Talon, and others, 1661-1674. In part from Arch. Colonies, CII, A, vols. 2, 3 .

[ff. $360-502$ 
Extracts relating to the bishopric of Quebec, I664-1674, from Arch. Affaires Étrangères, Rome.

9270. Canada, I67I-I68I.

[ff. 508-5I4

Copies of memoirs and letters of Frontenac, Duchesneau, and d'Auteuil from Canada, I67I-I68I, taken from Arch. Colonies, CiI, A, vols. 3, 4, 5.

[passim

Extracts from the Registres du Conseil Souverain, I679, Feb.-Oct. Ptd., Jugements et Délibérations du Conseil Souverain de la Nouvelle France.

9271. Canada, I66I-I702, I 724.

Copies of declarations of lands owned by the Jesuits in New France, I663, I667.

[ff. I $30-226$

Copies and extracts of documents relating to the Compagnie des Indes Occidentales; edict of May, I664; letters of directors, I664-1665; memoir of what has been done, etc.

[ff. $9-24,85$

Copies and extracts of censuses of Canada, I666-1668, I685, I688.

[ff. 40, $57,346-35^{\mathrm{I}}$

Copies and extracts of proceedings and arrêts of the Conseil Souverain, I668-1670.

[ff. 106, 107, I 19

Copies of letters from Jesuits: P. J. M. Chaumonot, Nov. I I, I680; Martin Bouvart, Nov. I2, I680 ; Jacques Bigot, Jan. 27, Oct. 7, 1692; Oct. 27 , I694; Sept. 25, I699; Oct. I I, I 702 ; Jos. Aubery.

[ff. $339-345$

Copies and extracts from Arch. Colonies, B, CII, A, and $\mathrm{F}_{3}$ : letters and memoirs of d'Avaugour, Frontenac, Talon, Colbert, Callières, and miscellaneous documents, I66I-.

9272. Canada. I638-I752.

Extracts from an inventory of the Dépôt des Cartes et Plans, I73I. [f. I

Extract from register of the Dames de la Sainte Famille, at Montreal.

[f. 6

1658, Apr. 10. Appointment of Jean Madry as master barber surgeon at Quebec.

[f. 8

Notes on sources for the history of discovery in Louisiana. [f. 9

List of prices at which goods from Canada should be sold. [ [f. 2 I

Letters from Father Jean de Lamberville, Sept. 20, I682, Feb. Io, I684; and Father Julien Garnier, Apr. I2, I684. [ff. 35, 49, 50

Notes, extracts, and copies of documents, chiefly from Arch. Colonies, B, and CiI: letters from Meulles, La Barre, Barillon, Dongan, Andros, Frontenac, Denonville, Champigny, Lagny, Callières, and others. [passim

9273. Canada.

T. Nelson and Son's American Views: Scenery of the St. Lawerence. Text and I 2 illustrations.

Map of Lower Canada (Walton and Gaylord, 1835).

[ff. I-20

Bibliothèque Canadienne, ou Annales Bibliographiques, par Bibaud jeune (Montreal, 52 pp.). Ends with publications of 1858.

$\begin{array}{ll}\text { Mémoire de Canada, I697, by La Chesnaye. } & \text { [ff. } 48-55 \\ \text { Mémoire sur la Domination des Français jusqu'en r687. } & {[\mathrm{ff} .56-72}\end{array}$

Collection de Mémoires et de Relations, published by the Quebec Literary and Historical Society (Quebec, I840). The following separates from this collection are in the present volume:

I. Mémoire sur l'État présent du Canada. M. Talon, I667. [f. 73

2. Mémoire. [I736.] [f. 202

3. Considérations sur l'État présent du Canada, 1758 . [f. 383 
4. Histoire du Canada, par M. L'Abbé de Belmont.

8. Histoire de l'Eau-de-Vie en Canada.

Estat présent de l'Église et de la Colonie Française dans la Nouvelle France par M. l'Evêque de Québec. (Quebec, 1856 , reprinted from the Paris edition of $\mathrm{I} 688$.)

[ff. $77-\mathrm{I} 34$

Copies of memoirs: the fur trade (I699); clothing of soldiers in Canada ( 1688 ); the cost of a company of 50 men in America (I705); state of the seigneuries (I II2), by Catalogne; the state of Canada and the trade in beaver skins (I715, I719), by Ruette d'Auteuil; drunkenness among the savages (I693); the state of New France (ca. I756-1763), by Bougainville; the forts and posts of Canadia.

[ff. I 56-I65, I68-20I, 253-256, 362-382

[1683.] État des Curés et Missions qu'on peut faire en Canada. [f. I66

Census of Canada, I685; of Indian tribes, I736.

[ff. I67, 23I

Extracts from "Relation par Lettres de l'Amérique Septentrionale". This Relation has since been printed by Father C. de Rochemonteix (Paris, I904), who attributes it to Father Silvy. Margry, however, reproduces a note on the back of the MS. from which he copies his extracts, which reads as follows: "Mr. de Fontanieu. Ceci est fait par M. Raudot fils. Je vous ay déjà envoyé la premiere partie. Cela mérite d'être examiné et gardé avec soin. Rien n'est plus capable de donner une connaissance du pays." [ff. 257-36I Notes on documents in Bib. Nat.

[f. 400

List of arrêts relating to America, presumably from Arch. Nat., E.

[f. 4I 2

9274. America: miscellaneous notes, memoranda, extracts, and copies. [I540-I788.]

Rough notes, chronologies, outlines of proposed chapters, extracts from printed works, fragmentary bibliographies, lists of documents, etc., relating to America in general and to Canada (ff. 5-33, 56-70), admiralties in Normandy (f. 45), André Thevet (f. 47), Iberville (f. 73), careers and families of Villeray, d'Artigny, Repentigny, St. Ours, and others (ff. I89-2I 7) ; Seven Years' War (ff. 225-277); expulsions of Jesuits (f. 278).

Memoranda of documents relating to America found or to be searched for in various depositories: Bib. Nat., Arch. Colonies, Guerre, Affaires Etrangères, Dépôt des Cartes et Plans [Service Hydrographique], archives of the prefecture at Versailles (Arch. Départementales, Seine-et-Oise), English de-

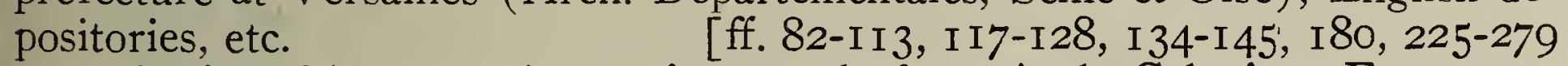

Copies of letters and memoirs, mostly from Arch. Colonies: Frontenac, Oct. I5, I69I (f. 7I), instructions to Cadillac, May I3, I7 Io (f. I46), Villars, New Orleans, Feb. IO, I788 (f. I96v). Villeray to Father Paul Ragueneau, Oct. I I, I664 (f. 208), Father Paul Ragueneau, Oct. I4, I8, I664 (ff. 294, 295 ), instructions to Villeray, general agent of the fermes in Canada, May 24, I687 (f. 298), information respecting Villeray, I688 (f. 299).

9275. Canada and Labrador, I693-1744.

I732, May I3-Aug. I8. Copy of journal by Joseph Laurent Normandin, of his tour of the royal domain in Canada.

[ff. I-I79

I694, Apr. 28-Aug. I. Copy of journal by Louis Jolliet of his exploration of Labrador and the Eskimo country.

[ff. I85-199

Tracings of the sketches contained in the journal of Jolliet, of I694.

Description of the Eskimo coast, by Courtemanche.

[ff. 204-210

I7 17. "Relation des Esquimaux . . . à Labrador."

[ff. $2 \mathrm{II}-2 \mathrm{I} 2$

I7I7. "Relation des Esquimaux . . à Labrador." Tff. 2I 5, 2I8 journal of Louis Fornel.

[ff. $223-228$ 
[I744.] Arrêt forbidding the exploitation by the Sieur de La Porte of the concession of Phélipeaux Bay. [ff. 23I-234

9276-9278. Extracts from the parish registers of marriages and baptisms of Montreal, I647-I728._9276: list of marriages, Nov. 3, I647-1657; extracts from marriage registers, Sept. 3, I657-Oct. 29, I681, Feb. I 5, I700-Nov. 24, I709; extracts from registers of baptisms, Sept. 29, I657-Dec. I8, I679, Jan. 9, I695-Dec. 27, I699, May I 5, I705-Oct. 26, I7 12, Oct. I5-Nov. 26, I727, I728. 9277: extracts from marriage registers, Sept. I7, I68I-Dec. I 5, I699, Nov. 24, I7I2-June I5, I722; supplementary extracts of I683-I710 ; extracts from registers of baptisms, Nov. I3, I68I-Oct. 23, I694, Jan. 23, I700-Dec. 2, I704; supplementary extracts of r682-I710, including baptisms of New England captives. 9278 contains an alphabetical index to the extracts in the two preceding volumes.

9279. Places of origin of French Canadians : genealogical and biographical notes.

I640-I768. Lists of Canadian marriages, classified by districts in France in which contracting parties had their origins.

[ff. I-45

I639, Sept. 7. Inventory of goods and chattels of Philippe Amiol and Anne Couvent.

[f. 47

Notes on the family of Beauharnois, and letters of the Chevalier de Beauharnois of Sept. I4, Oct. 26, I707.

[ff. 52-60

Rough notes, extracts, etc., relating to Bizard, Robert, Boishébert, La Salle, Charon, Denys, Boucher, La Forest, etc.

[ff. 86-I I I

Notes relating to Frontenac: letter from Frontenac to M. de Chavigny, St. Germain, Jan. 30, I649; oration at funeral of Frontenac, Dec. I9, I698.

[ff. I I $3-142$

Rough notes, biographical and genealogical, relating to Giguière, Godefroy, Louis Hébert, de Goutin, François Hertel, Cadillac, Juchereau de St. Denys, Peronne Dumesnil, Raudot, Bécancourt, Talon, Rouer de Villeray, etc. ; notes communicated by Abbé Ferland of Canada; notes on the études of the notaries Pierre Duguet, Michel Fillion, and Claude Aubert. [ff. I43-end

9280. Cape Breton (Ile Royale), I706-I7I7, and Montreal, ca. I640-1672.

Documents relating to Cape Breton: memoirs on the establishment of the colony of Cape Breton, I706-I709 (ff. 3-73) ; correspondence, largely from Arch. Colonies, Cri, B, of Denys de La Ronde, Costebelle, and Vaudreuil, I7I3, I7I4 (ff. 77-85, I00-I06); religious establishments, I7I6-I7I7 (ff. I07-I09).

Précis of negotiations of Utrecht, I7II-I7I3, relating to Acadia.

[ff. 87-97

Rough notes on the history of Montreal, on documents relating to it, and on Paul de Chomedy, Sieur de Maisonneuve, etc.

[ff. I IO-I I 3, I 53 -I 55,2 I 8-227

Copy of Latin address to the pope asking for his benediction on the project of the Société de Villemarie [from Arch. Départementales, Seine-et-Oise, series $\mathrm{H}]$.

[f. II7

Copies and extracts from Les Véritables Motifs de Messieurs et Dames de...Montréal, and Dollier de Casson, Histoire de Montréal.

[ff. I I 8-I 52, I 56-2I7

"Rolle des Escouades de Soldats ... de Montréal, I663." [ff. 23 I-233

I642, Feb. 3. "Enquete faite sur l'ordre de Charles Huault de Montmagny", respecting the conduct of the Sieur de Maisonneuve. Communicated by Abbé Ferland.

[f. 250 
I672, Mar. I 2. "Procès verbal de la position des bornes et rues de Montréal. ." Communicated by Abbé Faillon. [f. 25 I 9281. Acadia, I603-I760.- Notes, extracts, copies, and correspondence. Most of the copies are roughly made, and are to be found in a fair hand in vol. $9282, q . v$.

Letters of 1847 from the Marquis de Biencourt to Margry, respecting the Biencourt-Poutrincourt family papers, most of which, he says, were burned in 1845 .

Copies of Biencourt-Poutrincourt papers: genealogy of family of Biencourt; notes on Jean and Charles de Biencourt; letters to Biencourt from Marie de Médicis, Oct. 2, 7, I6Io, Louis XIII.,. Oct. I, 7, I6ı, Pierre Cotton, S. J., Oct. 6, I6ı, "Anthoinette Despont". [Marquise de Guercheville]; letter from Biencourt to the prévôt des marchands and the échevins of Paris, Sept. I, I6I8. These letters may have been copied from the Biencourt papers, but a note by Margry says " elles sont dans le factum contre les Jesuites"; see Factum du Procès entre Messieurs Jean de Biencourt appellant d'une part et Pierre Biard, г6 3.

Notes, extracts, copies, etc, relating to Razilly, history Razilly, history of Acadia, fisheries, boundaries, relations with English of Boston, extracts from works of Hutchinson, Hazard, and William Hubbard.

9282. Acadia, I603-I 767 ; Newfoundland, I66I-I 792.

[ff. 40-end

This volume is composed in large part of fair copies of documents, chiefly from Arch. Colonies, CI I, C, CI I, D, and Arch. Affaires Etrangères, Mém. et Doc., Amérique, vol. 4, relating to Acadia, I603-I68I (ff. I-2I2), and to Newfoundland, I660-I68I, I687, I 7 I0-I7 I6 (ff. 215-267). Other documents are noted as follows:

Transcripts from Bib. Institut, MSS. Godefroy: hearing of Pierre Guerard before the admiralty court of Dieppe, Sept. 2, I623 (f. 22); La Tour to the king, July 25, I627 (f. 40); concession of Placentia, Newfoundland, to Nicolas de Gargote (f. 2I5).

Transcripts of documents in the papers of the family of Razilly: Razilly to the king, July 25, I634 (f. 48); Grand Master of Malta to Razilly, Feb. 20, I636 (f. 58).

I64I-I642. Orders and judicial documents relating to Desjardins, Marie d'Auvergne, La Tour, etc., probably from Arch. Nat., V ${ }^{6}$. [ff. 68-77
[ Rough notes, extracts, lists of documents, etc., relating to Acadia, Ile Royale, and Newfoundland. [ff. 269-299, I-I 33 (second foliation)
[

9283. Acadia, I605-I752; Newfoundland, I6I6-I7 I7.

Rough notes, extracts of memoirs, etc., chiefly from Arch. Colonies, CII, D, vol. 2, relating to Acadia.

[ff. I-20I

Rough notes, extracts, etc., chiefly from Arch. Colonies, CI I, B, relating to Newfoundland, Ile Royale, St. Pierre, and Miquelon. [ff. 203-393 I7I7, June 22, July 7. Two original letters from Philippe de Costebelle, governor of Newfoundland and Ile Royale, I706-17 16, to his wife, relating to personal affairs.

I7I 7, Sept. 6. Copy of will of Costebelle.
9284. Hudson Bay and Labrador, I656-I744; Cape Breton, I706-г7 3.

Copies of documents relating to Hudson Bay and Labrador, 1656-1697, I7I3-I 744, chiefly from Arch. Colonies, B, vol. 2, Ci I, A, vols. 2, 3, 5, 6, 7, 33, Ci I, E, vol. 9, and Arch. Affaires Étrangères, Mém. et Doc., Amérique, vols. 4, 5. E. g.: voyages and journeys by Capt. Jean Bourdon, 1656, Louis Dablon $_{5}$ 
and Denis de La Vallière, I662, Louis Jolliet, I679, I694, Father Silvy, I684, Courtemanche, I7 I3, Louis Fornel, I 743 ; correspondence of Van Heemskerck, I670, I697, and his "Registre Journalier du Voyage du Nord de Florida, pour découvrir le Passage du Nord West", I670; documents relating to and by Pierre Esprit Radisson and Médard Chouart des Groseilliers, I669, I680, I685; memoirs respecting French and English claims to Hudson Bay.

[ff. I-I9I

Copies of documents relating to Cape Breton, I706-I7I3, all from Arch. Colonies, CI I, B, vol. 1, CI I, C, vol. 8, CII, D, vol. 8.

[ff. I95-267

9285. Canada, Hudson Bay, I608-I755.

Extracts from printed works of Bancroft, the Négociations of Jeannirl,

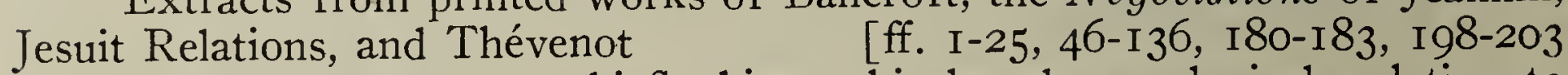

Notes, extracts, etc., chiefly biographical and genealogical, relating to Jean Nicolet, Nicolas Perrot, Guillaume and Jean Couture, Bourdon, and $\begin{array}{ll}\text { Louis Jolliet. } & \text { [ff. 26-45, I69-I 75, I86-I95, 2 I 3-2 } 53\end{array}$

List of documents relating to Canada, in the possession of the Jesuits, I8 rue des Postes, and a note by Margry on the history and nature of the Jesuit papers.

Rough copies of documents, fair copies of which are in vol. 9284 .

[ff. I $40-142$

[ff. I66-I68, I 76-I 77, 256-284, 288-289, 29 I-3I2

9286. Exploration of the West, I663-I753; Louisiana, I784-I802 ; Michigan, I86I; American Indians.

Rough notes and extracts of documents, chiefly from Arch. Colonies, CiI, A, CII, E, vol. 16, and F3, relating to the career of Pierre Gaultier de Varennes, Sieur de La Vérendrye, and his explorations in search of the western sea, I663-I752. Cf. Margry, VI. 583-632. [ff. I-2I6
[

Extracts and copies of letters and memoirs relating to western posts and explorations, I750-I753: De Noyelle, journal of Legardeur de St. Pierre. I750, De Lisle, Father Coquart, Father de Bonnécamps, La Condamine, and Chevalier de Cherisey. Cf. Margry, VI. 636-654. [ff. 219-246, 265, 280 Notes on the family and services of Boucher de Niverville, on the papers of Father Castel, and on the services of Marin. [ff. $248-257,263,273$

Notes, memoirs, etc., relating to Louisiana, I784-I802: Imlay, Bonnevie, and Louis Vilemont.

[282-298

Mines de Cuivre du Comté d'Ontonagon . . Michigan, by François A. Arnault (Paris, I86I, 3 I pp.). [f. 299 Notes from George Catlin, Letters and Notes on North American Indians (London, I842).

[ff. 3I 5-323

9287. Exploration of the West, Louisiana, etc., I679-I740.

Notes, extracts, copies of letters and memoirs, etc., relating to exploration of the West, Louisiana, mines, Lake Superior, search for the western sea, posts among the Sioux and other western Indians, etc.: Daniel Greysolon Du Lhut, Iberville, Riverin, the narrative of Sagean, Le Sueur, Cabart de Villermont, Danycan, La Salle, St. Denis, Bégon, Derbanne, Hubert, Bourgmont, Bienville, Fabry, Charlevoix, La Noue, Bobé, Vaudreuil, and Denis de La Ronde, I679-I740. The greater part of these documents are printed in Margry, $\mathrm{V}$. and VI.

「ff. I-27 I

Biography of General Cass, by Pierre Margry: "Vie du G1. Cass mon

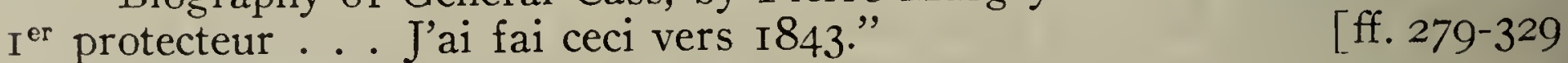

8288. Enterprises of La Salle, I668-I7oo.

Rough notes, extracts from printed works, etc., relating to Lachine, founded by La Salle, maps, concessions to Recollects, donation of La Salle, and coureurs de bois.

$[\mathrm{I}-4,43-46,93-95, \mathrm{I} 85-\mathrm{I} 87,269-278,326-33 \mathrm{I}$ 
(Copy.)

I668, Jan. 3I. Iroquois mission of St. François Xavier. J. Bruyas to -.

Copy of memoir on La Salle, attributed to Renaudot.

Memoir on the conduct of the Jesuits in Canada.

Copies of documents printed in Margry, I. and II.

[ff. 5-14

[ff. I8-37

[ff. $38-40$

[if. $49-70,73$, $76-87,97$, IO4-III, I 44, I 54-I 55, I64-I 75, I89-I 93 , 20I-204, 220, 228, 232, $233,236,248,26 \mathrm{I}, 266,279,283,287,29 \mathrm{I}-297,312,317-322,332,338-342$, $346,352,356,360,373,395,399,403,408,4 \mathrm{I} 4$

I872, Mar. Io. Autobiographical note by Margry, recounting the circumstances under which he assisted Brodhead in his mission for the state of New York, and thus became interested in the history of French colonization and exploration.

Letters from Colbert to Frontenac, printed by Clément.

$[$ f. $96 \mathrm{v}$

I683, Aug. 26. Original letter from Father Enjalran to La [ff. I 48 - I 53 in Margry, V. 3 .

9289. Henri Joutel and La Salle, I648-i 703.

[f. 339

Copy of Henri Joutel, Voyage de Monsieur de La Salle. Ptd. in Margry, III. 88 et seq.

[ff. I-I 49

Documents relating to Guillaume and Jean Joutel, I648, I666, I678. Marriage contract, receipts, etc. The originals are in MSS. Fr., nouv. acq., 9293.

[ff. I60-I62

I703. Correspondence of Claude Delisle, Henri Joutel, and De Beaumont. See Margry, III. 648-649. [ff. I63, I84-I87
[186)

"Remarques tirées du Livre intitulé, Les Dernières Découvertes dans l'Amérique Septentrionalle mises au jour par Mr. le Chevalier de Tonty... où l'autheur avance quantité de choses fausses et inventées par le Sr. Joustel.";

9290. Enterprises of La Salle.

[ff. I64-I 82

Memoirs and documents relating to Peñalosa and to projects for attacking the Spanish possessions in America, I682-1684. The most important of these are printed in Margry, III. 39-70.

Notes, extracts, and copies of documents reflat 7-68 f of I684-1686: memoirs and correspondence of Seignelay, La Salle, Beaujeu, Cabart de Villermont, Renaudot, Machault Rougemont, Denonville, St. Laurent, Bégon, Henri de Tonty, Abbé Tronson, Abbé Jean Cavelier, and others. The originals are chiefly in the Bib. Nat., Arch. Colonies, Arch, Marine, Arch. Service Hydrog., and in private papers loaned to Margry. Most of the documents have been printed in Margry, II.

[ff. $72-219$

Extracts from letters of Abbé Tronson, superior of St. Sulpice, Montreal, I680-1690. A few are printed in Margry, II. and III. [ff. 22I-227, 279-280

Notes, extracts, and copies relating to the death of La Salle, news of his expedition, his debts, claims against his estate, his heirs, patent of nobility, etc., I686-I756. A few of these are printed in Margry, II., III., and V.

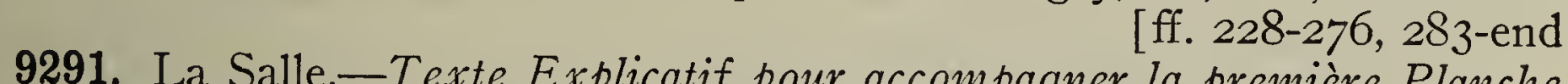
9291. La Salle.-Texte Explicatif pour accompagner la première Planche Historique relative à la Louisiane (Paris and New Orleans, I868, 44 pp., 8vo). Documents relating to La Salle, and his discovery of the mouth of the Mississippi. Printed in French and English, in parallel columns.

9292. La Salle, Henri de Tonty, and miscellaneous, I652-I752, I846-. Rough notes, lists of documents, extracts and copies, correspondence, and printed works. 
I856, Aug. 8, Boston. Francis Parkman to Margry, requesting use of material relating to La Salle, with notes of Margry's reply, refusing, and complaining of "disloyalty" of Poore.

[ff. 5-7

I846. Two letters from George Catlin, respecting a proposed series of pictures representing discoveries of La Salle, etc.

[ff. 7-I I

Rough notes on life of La Salle, extracts from printed works, and copies of memoirs on La Salle.

[ff. I 3-I 29

I698, Sept. 3, Toulon. Report by the Sieur de La Salle, écrivain in the marine, on La Salle's discoveries.

[ff. I $29 \mathrm{v}-\mathrm{I} 3 \mathrm{OV}$

Printed extract on La Salle, from R. Thomassy, Géologie Pratique de la Louisiane (Paris, 1859).

[ff. I $32-\mathrm{I} 47$

Notes, extracts, and copies, relating to Laurens Tonty and to Henri de Tonty, I652-1675.

Printed copy, with introduction by Margry, of Tonty's memoir of 1693 , Sur la Découverte du Mississipi (36 pp.).

[ff. $169-186$

A New Map of Louisiana and the River Mississippi (ca. I75o). [f. 20 I

List of Catholic dioceses in America.

[ff. $229-235$

List of Paris streets named for personages and events of French colonial history.

[f. 236 ica, etc.

Rough notes on English encroachments on French possessions in Amer-

9293. I a Salle, family papers, I648-I762. The oreater part of this volume ff. I-240, is composed of original documents or of 17 th-I8th-century copies, some of them certified. See Margry, III. 653, note.

I684, Mar. 23, Versailles. Seignelay to Dumont de Blaignat, directing him to fit out Le Joly for La Salle.

I683, Sept. 23, Quebec. Receipt by Fleutelot de Romprey.

I648, Mar. 8. Marriage contract of Guillaume Joutel.

[f. I

I648, Dec. I5; I666, Aug. 28; 1672, Nov. I. Receipts by Jean Joutel.

[ff. 8-1o

I692, Oct. I4, Fontainebleau. The king to the Marquis de Surville d'Hauttefort. Respecting a nephew of La Salle.

I7 I7, July 26, Paris. Registration of arms of Jean Baptiste Cavelier de La Salle.

I7I7, June, Paris. Confirmation to Jean Baptiste Cavelier de La Salle of letters of nobility to La Salle.

[f. I 5

I7I7 [I7I9?], Dec. I4, 16. Three letters from Madeleine Le Forestier, respecting La Salle, his property in America, the family of La Forest, etc.

[ff. I9-30 La Salle.

I756, Jan. 2I. Mme. Le Forestier to Lebaillif, respecting papers of

I756, Feb. Ia De Silhouette to Lebaillif, asking for papers of La $[1.31$ that may be of use in settlement of boundary questions.

[f. 33

1675, May I3. Letters of nobility, granted to La Salle, and concession of Fort Frontenac. (I 7 th-century copies.)

[ff. $36-4 \mathrm{I}$ 1675, Sept. 23-Dec. 23. Registration, by the Conseil Souverain of Quebec, of the concession of Fort Frontenac.

[ff. $42-56$

I675, Oct 12. Order of Frontenac. Ptd., Margry I. $292 . \quad$ [f. 44 296.

I677, Sept. 7. "Revue faite au fort de Frontenac." Ptd., Margry, I.

I684, Apr. I2. Commission to La Salle. Ptd., with date Apr. 46 Margry. II. 382 . [f. $48 \mathrm{v}$ 
1675-1684. List of concessions to La Salle in Canada.

I675, Oct. IO. Receipt by Duchesneau of I0,000 livres for [f. $5^{2}$ cation of Fort Frontenac. I678, May I2. Letters patent to La Salle. Pt], [f. 54

1678, May I2. Letters patent to La Salle. Ptd., Margry, I. 337.

I684, May 27, Rouen Religious powers granted to Jean Cavelier. 55 François Chefdeville. (Parchment.) Ptd., Margry, II. 475.
I694, Aug. 25, "Transaction 1694, Aug. 25, "Transaction entre la Dame Veuve Chefdeville . . . et D. Marie Fauvel Veuve du Sr. Nicolas Cavelier." [ff. $6 \mathrm{I}-98$
[ I7I9, Nov. I9. Marshal d'Estrées to Jean Cavelier, asking to see the papers of La Salle, with draft of reply. [ff. IOI-IO3, IO]
[ing

"Réponses aux articles du mémoire de Monsieur de La Forest." (Draft, in hand of Jean Cavelier.) Extracts ptd. in Margry, III. 548, $55^{\circ}$.

"Mémoire pour M. Cavelier." [ff. I04-106

Records of sales, memoirs, petitions, divi. [f. I08 marriage contracts, and other family papers division of property among heirs, to America. I653-1762.

[ff. I 1 2-233 Départemen notes, extracts, and modern copies of documents from Arch. Départementales, Seine-Inf., relating to Nicolas Getz, Jean Cavelier, Nicolas
Crevel, etc.

9294. Correspond $240-299$
[ff. by or for Correspondence and papers of Nicolas Thoynard.-Extracts made by or for Margry, apparently in I868, when the papers were offered for sale. Cf. Margry, III. 655 .

Extracts of letters to Nicolas Thoynard from La Salle, Renaudot, Iberville, Galinée, Sérigny, Abbé Dubos, Beauharnois, and Ste. Colombe, I684I705.

Voyages of La Salle. Ptd. in Margry, I. 545, II. 589.

[passim

Queries by Thoynard and replies by Iberville respecting his voyages.

I705. Aug 29 . I00
[fersilles. Conditions on command, Aug. 29 , Versailles. Conditions on which Iberville is placed in command of a squadron, with proposal by Iberville for an attack on Carolina.

Catalogue des Autographes de la Bibliothèque de feu $M$ [ [ff. II2-II8 (Paris, I868, 47 pp.). Includes correspondence of Thoynard. J.-Ch. Brunet

9295. Iberville the Mississippi, projects ance of Thoynard. [f. I78
[ 9295. Iberville, the Mississippi, projects against the English colonies, I686I739.-Copies, extracts, and rough notes. Most of the documents copied in this volume are printed in Margry, IV., V., and VI.; a few are printed in N. Y. Col. Docs., Mich. Hist. Coll., and French, Hist. Coll. of Louisiana.

Memorials respecting Carolina. (English.)

[ff. II 2 -I 39 I7OI.

Journals, correspondence, etc., relative to Iberville's voyages of I699I7fo4, June 26. "Projet I9, I 53, I62, I63, I79, I92, 224, 229, 257 "Projet sur la Flotte de Virginie et la Causte Engloise I706, Apr. 8. Iberville's narrative of his expedition against Nevis.

[f. 298
[739. Mar. 3. Memoir by Lafitau on Georgia N739, Mar. 3. Memoir by Lafitau on Georgia and English projects in North America.

Memoir on New England and the fisheries. [f. 3I2
[fol

Certificate of burial of Bienville: "Le dit jour, dimanche 8 mars I 767 , M. Jean Baptiste Le Moyne de Bienville . . . garçon agé de 87 ans, demeurant rue Vivienne, décédé du jour d’hier a été inhumé dans notre église [St. 
Eustache, Paris] . . " Extract from the register of St. Eustache, apparently copied before $187 \mathrm{I}$ from the municipal archives in the Hotel de Ville.

9296. Iberville and the Mississippi, I699-I706.

[f. $3^{\mathrm{I} 6}$ 395, 432 .

Journals of Iberville's voyages of I699-I700. Ptd., Margry, IV. 20I,

Extracts from the preceding documents.

[f. $1-36$

I700. Journal by Le Sueur, relating to the Mississippi.

[ff. $37-46$

I706, Jan. I9-May 30. Journal of the Chevalier de Maupeou, commanding the Phoenix in the squadron of Iberville.

[ff. 79-105

I705, Oct. 23, Madrid. Daubenton to the minister of marine. Ptd., Margry, IV. 575 .

9297. Iberville, Hudson Bay, Newfoundland, Acadia.

Transcript of part of the printed Mémoire succinct de la Naissance et des Services de defunt Pierre Lemoyne, Ecuyer, Seigneur d'Iberville (I716). [ff. 4-IO

Notes, and correspondence with Abbé Faillon, A. Morin of Dieppe, and the Comte de Sérigny, respecting family papers, documents, etc., relating to the family of Lemoyne and to Iberville.

[ff. I I-26

I686-1697. Notes, copies of memoirs, journals, letters of Iberville and others, relating to Hudson Bay, Newfoundland, and Acadia. Many of these are from Arch. Colonies, Ci I, A.

[ff. 33-end

9298. Transcript of "Relation par Pénicaut ... de ce qui s'est passé dans le Pais de la Louisiane . . . jusqu'en I72I". Ptd., Margry, V. $373 \mathrm{ff.}$ Cf. MSS. Fr. 14613.

9299. Antoine de La Mothe Cadillac, Michilimackinac, and Detroit, I694I704. - Notes on the family and biography of La Mothe Cadillac; copies and extracts of correspondence, memoirs, etc., of Cadillac, Champigny, Callières, Father Marest, the court, and others, relating to Michilimackinac and Detroit. The documents copied are chiefly in Arch. Colonies, Ci I, A, vols. 13-21, and CI I, E, vols. 14-16. Many are printed in Margry, V., VI., Mich. Hist. Coll., XXXIII., and N.Y. Col. Docs., IX.

9300. Families of La Salle and Le Moyne; censuses of Louisiana.

Notes, extracts, and copies, relating to genealogy and family of La Salle: marriage contracts, sales of property, death certificate of Jean Cavelier, brother of La Salle (Nov. 24, I722), extracts from parish registers and court records, correspondence of Margry with various persons, etc. [ff. I-78

Correspondence of the Comte de Sérigny, Château de Luret, with Margry, I862-I863, relating to papers and portraits of the family of Le Moyne.

[ff. 88-99

Rough notes, extracts from parish registers, copies of documents, etc., relating to the family of Le Moyne (Longueuil, Bienville, Chateauguay, Iberville); death certificate of Joseph Le Moyne de Sérigny (Sept. I2, I734), will of Bienville, etc.

[ff. IOI-I6I

"Notice Historique et Généalogique sur la Maison Le Moyne, originaire en Normandie. Fait au Château de Luret, près Tonnay-Boutonne, Charente inférieure, le I2 Xbre, I862. Cte. Emile de Sérigny." [ff. I63-I87

Censuses of New Orleans and Louisiana (1722, I724, I732), list of passengers embarking for Louisiana (I II9-I72I), and list of officers serving in Louisiana (I734).

[ff. 200-299

9301. Family of La Salle, Mississippi, Sea of the West, Louisiana, Detroit.

Copies of documents relating to family of La Salle. (Also in MSS. Fr., nouv. acq., 9293.)

[ff. I-I I 
Copy of article: "Découverte du Mississippy, par mon ami M. Jules Magne, I845, Abeille de Nouvelle Orleans."

[ff. I3-58

Copies and extracts of letters, memoirs, etc., of Jolliet, Bellin, Le Sueur, Bobé, Raudin, Riverin, and others, relating to the Mississippi, the Sea of the West, Detroit, the River St. Lawrence, etc., I685-I754. In part from Arch. Colonies, CI I, E, vols. 13, 15, 16.

[ff. 6o-237

Copies and extracts of documents relating to Louisiana, I7I3-I7I8. Chiefly from Arch. Colonies, Ci3.

[ 850 ca.] Copy of article: "Les Indiens Renards et la Nation du Feu au Détroit Pontchartrain des deux Lacs."

9302. Champlain, La Vérendrye, La Clède.

Biographical sketch of Samuel Champlain.

[ff. $35^{8-396}$

Copy of memoirs of Champlain of Feb., I6I8, addressed to the king, to the Chamber of Commerce, etc., from Bib. de la Ville de Carpentras, MS. I 777 , ff. $378-382$.

Mémoire en Requête de Champlain pour la Continuation du Paiement de sa Pension, ed. Gabriel Marcel (Paris, ı886, 29 pp.).

I852, May 30. Article by Margry: "Les Varenne de La Vérendrye et les Français aux Montagnes Rocheuses sous Louis XV." [ff. I85-2I4 Correspondence, rough notes, copies of documents, etc., relating to Pierre La Clède, his trade, family, estate, etc.

[ff. $245^{-295}$

9303. Louisiana.-Rough notes, extracts, lists of documents, etc., relating to the Mississippi Valley, Lake Ontario, and Louisiana, I654-I763, chiefly of I7 I5-I730, taken mostly from Arch. Colonies, CI3.

"Compilation historique sur les premières années de la Louisiane, faite par M. Margry à la demande de M. [James H.] Perkins qui en a fait hommage à l'état, Paris, 3 I mai, I849." List of documents relating to Louisiana, I698-I70I.

[ff. 328-359

I 844 , Dec. 30 , Cambridge. List of documents relating to Louisiana to be copied for J. Sparks.

[f. 368

9304. Canada, I 524-I727.- Notes, extracts, and copies, from Arch. Colonies, B, CI I, A, Ci I, E; Arch. Nat., M 242, K 1374, and elsewhere. Letters and memoirs of Verrazano, Lescarbot, Poutrincourt, J. F. Buisson, Montigny, La Source, Gabriel Marest, and others ; notes on La Salle, Raudot, father and son, land concessions in Canada, the Illinois country, etc.; list of documents relating to Jesuits ; extracts from registers of Detroit and Kaskaskia.

9305. Canada, I728-I755.- Notes, extracts, copies of letters and memoirs, of Dupuy, La Ronde Denys, the court, and of governors and other officials in Canada, taken in large part from Arch. Colonies, B, Ci I, A, and Arch. Guerre, Corr., 3404, 3417.

I723-I756. Extracts of letters of Mme. Duplessis de Ste. Hélène.

[ff. I-20

I732, Apr. 28-Aug. Io. Journal of voyage of Régis du Roulet from Mobile to the Choctaws and New Orleans.

[ff. $37-8 \mathrm{I}$

I750, Sept. I. Census of Detroit.

I753. Journal of George Washington. Probably copied from Arch. Colonies, CI I, E, vol. 10.

[ff. $25 \mathrm{I}-26 \mathrm{I}$

9306. Canada, I756-I757.-Notes, extracts, copies of correspondence, memoirs, etc., of Bigot, Vaudreuil, Dieskau, and others, taken mainly from Arch. Colonies, Ci I, A, and Arch. Guerre, Corr., 3417. Some are ptd. in $N . Y$. Col. Docs.

9307. Canada, I757-I 758.-Chiefly copies of documents from Arch. Guerre, Corr., 3457, 3498, 3499. 
9308. Lists of documents relating to America.

List of documents in I7 volumes of transcripts, apparently those made under Brodhead's direction for N.Y. Col. Docs., IX. and X.

[ff. I-44

"Recueil de documents inédits pour servir à l'histoire des origines françaises de l'Amérique." A classified calendar of documents, with résumés, relating to French activities in North America and the West Indies, chiefly before I740. The provenience of the documents is only occasionally indicated.

[ff. $50-266$

9309. Cessions of Louisiana, I762-1804.-Extracts and copies of correspondence and memoirs, chiefly from Arch. Affaires Etrangères, Corr. Pol., Etats-Unis, Espagne, and Mém. et Doc., États-Unis.

I769, Mar. Io, Versailles. "Idée sur l'opposition trouvée par les Espagnols à la Louisiane", by d'Estaing.

[f. II

I770. Documents relating to the shipwreck of the Père de Famille, returning from Louisiana, with Aubry, La Forest, Bobé, and others on board.

[ff. I2-I3

1789, Jan. Extract from a memoir on the question whether France should desire the retrocession of Louisiana.

[ff. $4 \mathrm{I}-53$

I85I, Nov. 27, Fauréal, près Pontoise. F. André Michaux to Margry, respecting the plans for the invasion of Louisiana in I792-I793, in which his father was concerned.

[f. I 5 I

9310-9311. Lists of documents relating to Louisiana, I682-I809.-A note by Margry states, "J'ai fait ce travail en I 849 pour M. Perkins. M. Martin m'y a aidé pour la dernière partie".

9310. Chronological calendar of documents relating to Louisiana, I697I733, chiefly in Arch. Colonies, $\mathrm{CI}_{13}$, but some in $\mathrm{C}_{\mathrm{I}} \mathrm{I}$ and $\mathrm{B}$, and a few in Bib. Nat.

9311.-Continuation of calendar in preceding volume, I733-I744. [ff. I-I 55

List of documents, I744-1809, in Arch. Colonies, CI3. [ff. I 56-222

List of documents, I7IO-I 737 , in $i d ., \mathrm{B}$.

List of undated documents.

List of documents, I698-1764, in id. [С $13, \mathrm{~B}, 1$ ?].

List of documents, I682-I802, in $i d$., $\mathrm{F} 3,241-243$.

[ff. $223-292$

[ff. $293-297$

[ff. $300-304$

[ff. $307-3$ I 2

List of documents relating to military and civilian personnel, I692-I 776 , in id. [D2 c?].

List of documents, I7IO-I73I, in id., B, 42bis, 43.

[f. 313

Extracts of memoirs on Louisiana [in id., $\mathrm{Cr}_{3}$ ?].

[ff. 3 I $5-342$

[ff. $343-356$

9312-9314. Lists of documents relating to Canada, I732-I763. - Lists of documents in Arch. Colonies, $\mathrm{CII}_{\mathrm{I}}$ and $\mathrm{F}_{3}$. The lists in the three volumes are respectively for the years I $732-1739, \mathrm{I} 740-\mathrm{I} 749$, and I750-I 763 .

9315-9316. Lists of documents relating to French origins in America.These volumes contain classified lists of documents similar to those in 9308 . The lists are rather roughly made, and the provenience of documents is never indicated. Vol. 9316 (which is the first of the two, chronologically) contains lists relating to the first settlements of Canada and Acadia, the West Indies and Guiana, the Mississippi, and Louisiana. Vol. 9315 contains lists relating to the Mississippi Valley, the chain of forts, Ile Royale and Labrador, the Northwest, the western sea, etc.

9317. Florida.

Reprint (Paris, I853) of L'Histoire Notable de la Floride ... par le Capitaine Laudonnière ... mise en Lumière par M. Basanier . . . [ff. I-I24 

of Rouen.

I 553, Feb. I7. Record of a sale by Jean Ribault, from the tabellionage

I566. Extracts of letters of de Forquevaux.

[ff. I25-I 26

[ff. I27-I 29

[Bordeaux.] N. de Gourgues to Margry. Sends him a MS. relation of the voyage to Florida; birthplace of Dominique de Gourgues; family papers, etc.

[ff. I $32-134$

Transcript of "La Reprinse de la Floride par le Cappitaine Gourgues". Cf. above, MSS. Fr. 2145.

9318. West Indies, I620-1648.

[ff. I $35-143$ lation.)

1620, June 9. Charter of Dutch West India Company. (French trans-

Memoir by the French Marchands français souffrent en Espagne sur le fait du Commerce".

[ff. 9-Io
[626.

1626. Memoir on "La différence qu'il y a du traittement que les françois reçoivent en Espagne et Flandres d' avec celuy que les Espagnols et flamans reçoivent en France".

1635, Feb. I2. Agreement between Richelieu and Capt.

the colonization of St. Christopher. [ff. I9-23
[fold

[ff. II-I $3 \mathrm{~V}$ 1635-1648. Extracts from the register of "Actes d'assemblées de la Compagnie des Isles de l'Amérique, pour ce qui concerne ses affaires particulières".

[ff. 25-I 57

9319. "Histoire de la Guadeloupe, par un missionnaire qui y sejourna de I640 à I642, avec une description, accompagnée de dessins des produits de l'île." (I7th-century MS.) Not examined.

9320. "Relation des PP. Carmes sur les Antilles, depuis leur embarquement avec M. de Waily à Paimboeuf jusqu'à leur établissement à la Guadeloupe et à la mort de trois de leurs religieux, I646-I650." (Not examined.)

9321. Transcript of Relation de l'Establissement d'une Colonie Française dans la Gardeloupe .. . par le Frère Mathias Du Puis (Caen, I652).

9322. Transcript of Relation de l'Establissement des Français depuis l'an I635 en l'ile de la Martinique... par le P. Jacques Bouton (Paris, I640).

9323. West Indies, I 597-I861.-Copies of documents relating to Belain d'Esnambuc (f. I6) ; instruction to the Sieur de Cahuzac, going to St. Christopher, Feb. I8, I629 (f. 27) ; taking possession of Guadeloupe, Martinique, and Dominica, I635 (f. 52 ); inventory of documents produced by the Sieur de Thoissy, I640-I648 (f. I05); sale of Martinique to Du Parquet, I650 (f. I87) ; instructions to the Marquis de Tracy, Nov. I9, I663 (f. 229); memoir on the present state of Martinique, I6g6 (f. 348).

9324. Letters, extracts from registers, etc., relating to families of persons connected with the history of the West Indies.

9325. West Indies, Florida, Darien, Mississippi.

Note on death of d'Ogeron, Jan. 21, I676, and his burial in St. Severin, Paris.

I669-I67I. Letters and memoirs of d'Ogeron, respecting the establishment of a colony in Florida.

[ff. I 25, I40-I 55, I 87

I699-I700. Letters to d'Harcourt, de Bonnac, Du Casse, de Tallard, Bonrepaus, La Boulaye, Galiffet, and others, relating to Darien. [ff. $353-363$

I699, July I. Ministerial letters relating to the expedition of Iberville to search for mouth of the Mississippi.

9326. Transcript of I8th century, "Histoire de Saint-Domingue par de Beauval-Ségur". 
9327. Martinique, Santo Domingo, Guadeloupe.-Population of Martinique, I660-I700; list of inhabitants of Santo Domingo returning to France, I776; letters relating to Generals Dugommier and Gobert in Guadeloupe.

9328. Colonies: emigration, indentured servants, women, volunteers, negroes, etc.

I7I7, Jan. 22, Paris. "Mémoire . . concernant les colonies de l'Amérique au sujet des marchands, des habitants, et des engagés", by La Boulaye.

Notation of melodies of Danse Canadienne, and Chanson des Sauvages
[f. $3^{8}$ du Canada.

Letters of Marie Madeleine de Verchères, Agathe de St. Pierre de Repentigny, and Mme. Drucour. [ff. 53, 56, 57

I658, Oct. 24, Quebec. D’Argenson to Mme. de La Peltrie. [f. 70 Hubert.

[I664?] Trial of Robert Hache, Indian, for assault upon Marthe

Notes on censuses and concessions in Louisiana, Village des Allemands, I7 I9-I722. soldiers.

I753, I754. Extracts from letters of Duquesne, respecting marriages of [f. 84

Notes from Recherches sur la Situation des Émigrants aux Etats-Unis (Brussels, I846), by Baron Ponthez, first secretary of the Belgian legation.

French translation of Longfellow's Evangeline, with notes.

[ff. I 23-I 37

[ff. I8o-end

9329-9333. Five boxes of cards or slips, containing lists of documents relating to America, notes, etc.-9329. Canada, I534-I7I7. 9330. Canada, I7 I7I729. 9331. Canada, I729-I8I2; Acadia, I604-I7 I4; New foundland, I6I II705. 9332. Newfoundland, I705-I7I6; Louisiana, Antilles. 9333. Colonization in general; places in France of interest for the history of the colonies. (9329 alone examined.)

9334. Antilles, Mexico, English colonies, California, and maps.

Memoirs of La Salle. Ptd. in Margry, II. 359-370. [ff. I55-I75 I684, Apr. Memoir on expedition against the West Indies proposed by the Comte de Peñalosa. Also in MSS. Fr., nouv. acq., $9290 . \quad$ [ff. I77-I90 Memoirs on Georgia and New England. Also in id., 9295. [ff. I9I-208 I702. "Projet sur la Caroline", by Iberville. [ff. 2I6-220 I7or. "Projet sur la Nouvelle Angleterre." [ff. 230-238 I7or. "Mémoire du Sr. d'Iberville sur Boston et ses dépendances."

Biographical sketch of Louis Hennepin.

[ff. 238-253

[ff. 300-309

Les États-Unis et le Mexique: l'Intérêt Européen dans l'Amérique du Nord (Paris, I852), by H. Du Pasquier de Dommartin. [f. 363 I706. Memoirs of Danycan, respecting gold in California. [ff. 507, $5^{\mathrm{I} 2}$ I727. Tracing of part of "Nouvelle Carte de la Louisiane par $f$. Lemaire".

Carte pour servir au Journal de Mr. le M'quis de Chastellux, redigée par Mr. Dezoteux . . . $\quad[\mathrm{f} .522$ I789, Aug. 25, New York. "Plan de la Communication des Lacs Erié et Ontario, vers le milieu de laquelle se trouve la Chute de Niagara . . . adressée à M. Ally St. John par son affectioné père, à dessein de faciliter la description de cette Cataracte qu'il lui envoye." (Original.)

[f. 523

Lists of maps in Dépôt des Cartes [Service Hydrog.], and the ministries of Foreign Affairs and of War.

[ff. 526-582 
9335. Copies of letters from Abbé Bernou to Abbé Renaudot.-See above, MSS. Fr., nouv. acq., 7497.

9336. Guiana, Pacific, Northwest Passage.

I85I-I853. Extracts and copies of letters of J. Bellot, Lady Jane Franklin, and E. Kane, U.S. N., relating to the search for Sir John Franklin.

[f. 35I

9339. Africa, Senegal.-Rough notes, copies of documents, and extracts, relating to the slave-trade; agreement of Mar. 21 , I679, between the directors of the domaine d'Occident and the Compagnie du Sénégal respecting the African trade in negroes and merchandise; relation of the voyage of Ducasse to the coast of Guinea, I687-I688.

9340. Algeria, Senegal, Guinea, Ile Bourbon.-Rough notes, extracts, and copies; copy of inventory of the Compagnie des Indes, I719-I724, showing vessels, cargoes, profits of voyages, etc., in the trade with Senegal, Santo Domingo, Martinique, Louisiana, etc. (ff. 74-87).

9341. Compagnie des Indes in the eighteenth century.

[ l 749 ca.] "Mémoire pour La France, servant à la découverte des Terres Australes ", by Bénard de La Harpe.

9353. Compagnie des Indes, I664-I7I4.-Notes, extracts, and copies, mostly relating to the East Indies.

I664-I774. Chronology of the Compagnie des Indes.

[ff. I-2

I664-I720. "Mémoire sur la compétence de la Compagnie des Indes au Département de la Marine."

[ff. $3-8$

I706. Documents relating to the proposal to send vessels of the Compagnie des Indes from the coast of Peru to the Philippine Islands. [ [ff. 330-34I

9354. Compagnie des Indes, I7 I4-I 742.- Notes, extracts, and copies.

I7I 5, Dec. I5. Memoir, containing references to the voyages of vessels from the Philippine Islands to China.

[ff. 3-10

I7I9. Extracts from correspondence of missionaries, containing references to the success of the Compagnie des Indes on the Mississippi. [f. 48 Indes.

I723. Note on the grant of the tobacco privilege to the Compagnie des

I723. "Mémoire au sujet des droits prétendus par les gouverneurs et intendants des îles sur les vaisseaux négriers." [ff. I4I-I43V

I725, June, Versailles. Edict confirming privileges and concessions of the Compagnie des Indes.

[ff. I $75-182$

I725. Memoir on the Compagnie des Indes and its future organization, containing references to the slave-trade, Louisiana, etc.

I726, July 17. Protest by the subdelegates of Marseilles against the concession to the Compagnie des Indes of the tobacco and coffee trade.

[f. 2 I I

I726. Memoir by the merchants of Nantes, respecting the trade carried on with the colonies of Martinique and Guadeloupe by the English and Dutch.

[f. 2 I 8

I 727, Mar. 20. Permission for English manufactory at Montreal; arrest of Radisson; construction of Fort Niagara.

[f. $224 \mathrm{~V}$

I723. Memoir by Duche on the condition of the Compagnie des Indes in Mar., I723, containing references to vessels in Louisiana. [ff. 237-239

I732, Apr. 3. Note on cultivation of tobacco, Jesuit missions, and slaves in Louisiana.

[f. $259 \mathrm{v}$

I734. Extracts from memoir on the relations of the inhabitants of Louisiana with the Compagnie des Indes.

[f. 268 
I736, Feb. I5. Note on the manufacture of beaver hats and woolens in Canada.

[f. 290 Islands.

I738. Memoirs on commerce in the Orient, including the Philippine

9381. Correspondence of Pierre Margry.-This volume includes scattered letters from E. B. Washburne, Charles Whittlesey, Henry Vignaud, the Bishop of Manitoba, and others, and especially a group of 4I letters from O. $\mathrm{H}$. Marshall of Buffalo, I872-I884, and a group of 79 letters from Francis Parkman, I867-I889. There are also a very few drafts of letters from Margry to Marshall and Parkman. The correspondence deals with historical questions, searches for documents, the progress of Parkman's work, etc., and particularly with the publication of Margry's Découvertes et Etablissements des Français dans ... l'Amérique and to matters connected therewith-appropriation by Congress for purchase of copies of the work, difficulties with A. R. Spofford, librarian of Congress, threatened interference by $\mathrm{H}$. Harrisse, contents of volumes, duplication of material already published, etc. Parkman's letters have been published by J. S. Bassett in Smith College Studies in History, VIII., nos. 3-4. Margry's letters to Parkman are preserved in the collections of the Massachusetts Historical Society.

9384. "Marins et Découvereurs avant le XVII Siècle."-Notes, copies, extracts from MSS. and printed works, relating to Columbus, de Gonneville, Ango, Verrazano, Parmentier, Jacques Cartier, the discovery of Newfoundland, etc. ; letters to Margry from librarians in Italy.

9385. Extracts from the works of Jean Alphonse and Enciso.

9386. Copies of documents in the Torre do Tombo, Lisbon, relating to the Angos and to expeditions to Brazil and the Indies, I500-1644.

9388. Maritime matters, sixteenth and seventeenth centuries.-Notes and extracts from MSS. Clairambault (ff. 35-6I, 79-92); information respecting documents at St. Malo relating to Jacques Cartier (f. 98); extracts from works of André Thevet (f. I03).

9389. Razilly.-Copies of documents relating to family and genealogy of Claude de Razilly, Charles de Razilly, Isaac de Razilly; memoir by [Isaac] de Razilly on the importance of navigation and the advantages of commerce, Nov. 26, I626 (f. 60) ; Grand Master of Malta to Richelieu, Sept. 6, I627, relating to Razilly (f. 80); correspondence of Richelieu and Razilly, I627, I629, and other documents relating to Africa.

9390. Marine, I643-I690.- Rough notes, extracts, and résumés from Arch. Marine. References to d'Estrées, Gulf of Mexico, the Antilles, etc.

9391. Marine and Colonies.-Rough notes, extracts, and copies. Letter of Paul Ragueneau, Paris, Nov. 7, I664 (f. 97v) ; note on annual relations of affairs in Montreal sent to the superior of the Seminary of St. Sulpice in Paris (f. 285) ; memoir on New England, I703 (f. 427) ; lists of docliments.

9392. Marine, 1690-1697.-Rough notes, extracts, etc., chiefly from Arch. Marine, containing occasional references to Canada.

9395. Marine under Louis XIV., Duguay-Trouin.-Rough notes, extracts, etc.

9399. "Mémoire sur la Marine."-This memoir is an original or contemporary copy and appears to have been composed before I749. A note by Margry indicates that he purchased it in 1860 . It is an exposition of the naval system of France, and includes a good account of the "soldats de la marine" and of the "soldats suisses". 
9400-9404. Marine of Louis XV., I733-I774.-Rough notes, extracts, etc., chiefly from Arch. Marine. Occasional references to the Mississippi, Louisiana, Louisbourg, Canada, etc.

9405. Bougainville.

"Journal de l'expédition de l'Amérique commencé en l'année I756, le I5 mars." The second part of this document deals with the campaign of Baron Dieskau of I 755. (Copy, incomplete.)

[ff. I-8

"Journal des Campagnes faites en Canada pendant trois années, I756, I 757 et I758, commencé le I 2 Mai I756, et fini le I I 9bre I758." By Louis Antoine, Comte de Bougainville. (Copy, ending June 22, I758.) Cf. R. de Kérallain, Les Français au Canada: la Jeunesse de Bougainville et la Guerre de Sept Ans ( I896).

Note on cost of the war in Canada, I750-I760.

9406. Bougainville.

[ff. 9-385

[f. $385 \mathrm{v}$

I729-18I3. Certificates, memoirs, notes, etc., relating to biography, services, and scientific works of Bougainville.

"Précis de ce qui s'est passé de plus considérable dans l'Amérique septentrionale pendant l'hiver de I756 à I757."

[f. 34

"Relation abrégée de la campagne du Canada jusqu'au I ${ }^{\text {er }} 7$ bre 1756 ", by Bougainville.

[ff. $38-40$

I 756-I759. Letters from Bougainville to his brother, and to his mother, Mme. Hérault de Séchelles. [ff. $42-45,55,61,77,79,83,87,93$, Io I, I05, I07, I I6, 235, 237, 239, 245, 294, 322

"Carte des environs du fort de Carillon en Canada, à Madame la Marquise de Pompadour."

Map of "Fort du Carillon et ses environs".

[f. 50

[f. 5 I

I757-I 758. Letters from Montcalm to Mme. Hérault de Séchelles, to the

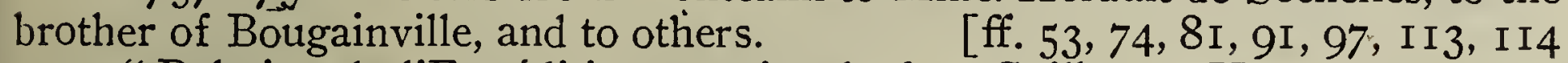

"Relation de l'Expédition et prise du fort Guillaume Henry, le 9 aoust I757." (Fragment.)

[f. 75

"Journal de la Campagne de 1758 commencé le 23 juin", ending with "Journal de Navigation de Québec en France", Nov. II.- A note by Margry states that this is the copy of a MS. loaned to him by M. de Bougainville.

[ff. I I8-219

"Mémoires depuis le I5 9bre I758." Two narratives by Bougainville commencing, respectively. "Je partis de Québec le I5 9bre I758 ..." and "Je partis de St. Malo le 22 7bre I763 ..."

[ff. 226-233

"Relation de la victoire remportée à Carillon par les troupes du Roy, le 8 juillet, I758."

[f. 24I

"Campagne de I759." Narrative commencing May 23, "La crainte où l'on était .

[ff. $250-260^{\circ}$

"Relation du Siège de Québec", commencing, "Depuis que les Anglais ont commencé les hostilités . .." and ending," secours de toutes espèces dans cette colonie".

[ff. $262-273$

"Relation de ce qui s'est passé à Québec en I759", commencing, "Dans la crainte où l'on était d'être prévenu ... .", and ending, "Plusieurs s'étaient même déjà évadés et auraient déserté".

[ff. 274-279v

"Journal fait par le Sr. Laforce, commandant les bâtiments sur le lac Ontario, du Siège de Niagara, du 6 Juillet jusqu'au I4 dud." [ [ff. $280-283 \mathrm{v}$ I758, Dec. 29, Versailles. “Mémoire. Graces que demande Mr: le M'is de Montcalm comme graces à lui personnelles pour des Officiers de la Colonne ou Canadiens qui ont bien servi sous ses ordres." By Bougainville. 
I759, Sept. 2, "du Camp de Lorette". Narrative by Bougainville of the campaign of I 759, commencing, "Voici mon histoire abrégé . . ."

[ff. 286-291

I759, Feb. 8. "Second Mémoire. Examen du projet de faire passer les habitans du Canada à la Louisiane."

Memoir proposing the transfer of the Canadians to Louisiana, and promising to develop the plan more fully in a later memoir. Louisiana. [ff. $305-305 \mathrm{v}$
Canada for [ff. $307-3$ I I I76I, Apr. "Mémoire pour la Transmigration proposée du Canada à la Louisiane." " [ff. 313-3I6v

I76I, June. "Moyen de peupler la Louisiane-encouragements à donner aux habitants du Canada pour passer au Mississippi."

[ff. 3 I $9-320$

I 76I, July I5. Memoir on the boundaries of Louisiana in the event of the cession of Canada to England.

[ff. 32I-32Iv

I763-I764. Extracts from Arch. Affaires Etrangères: letters of La Corne, d'Eon, de Guerchy, and Praslin.

[ff. 329

Notes on Canadian chronology.

[ff. 336-34I

I 743, May 5-Dec. 3I, I753. " Mémoire pour servir à l'histoire de ma vie", by the Marquis de Montcalm.

"Eloge historique du Marquis de Montcalm."

[ff. $342-353$

" Notice sur mon frère le Sauvage" par M. de Mun, secrétaire d" f. 354 sade au Brésil. Account of an Indian reputed to be the son of Bougainville.

9407. Bougainville-Copies, notes, etc., from Bougainville's journals $367-370$ voyages in the Pacific and around the world, I766-1769.

9408. Bougainville: original papers.

I758, Oct. 16, Carillon. "Observations Diverses sur Carillon, Fort Frédéric, et la frontière du Lac Champlain", by Desandrouins. [ff. 7-9

Note on the St. John River.

I759, Sept. I8. Duraurepay [?] to Bougainville.

[f. Io

[I760?] “ Etat général des offiers de trouppes de terre, de la Conie, [1760?] "Etat général des officiers de trouppes de terre, de la Colonie, de la Milice, et des soldats de chaque corps qui ont été tués ou Blessés à La Bataille du 28 avril " [Ste. Foy?].

I76I, June 27, Paris. H. Stanley to - Transmitting reply he has received from England, that the capitulation of Canada should not be "further frustrated".

9409. Bougainville, I76 I-I 8 I I.

I 776 , Dec. I2-I 777 , Nov. 30. Journal of Bougainville, in command of the Bien-Aimé. Mention of numerous American vessels; American powder much inferior to that manufactured in Europe.

[ff. $47-60$

Letter to Margry from the minister of war, to the effect that the archives of the ministry do not contain documents relating to the order of the Cincinnati.

[f. 69

I778, Mar. I 5-I779, Dec. 21. Journal of Bougainville, commanding Le Guerrier in the squadron of the Comte d'Estaing.

I78I, Mar. 22-I782, Jan. I2, "Relation de la campagne aux Comte de Grasse."
[ff I9I-208 ville.

I78I, Sept. 7, on board the Ville de Paris. Comte de Grasse to Bougain-

I782, Apr. 26-May I. Continuation of Bougainville's journal (see $\mathrm{ff}$ I9I-208).

[ff. $216-218$ 
Memoirs, correspondence, evidence, reports, etc., respecting the charges laid against Bougainville by the Comte de Grasse, with regard to his conduct in the naval action of Apr. I2, I782.

[ff. $22 \mathrm{I}-283$

I784, Jan. I9, Paris. Maj. P. L'Enfant to Bougainville, transmitting \begin{tabular}{l} 
to him the eagle of the order of the Cincinnati. [f. 247 \\
\hline
\end{tabular}

I789, Jan. I. Certificate of membership of Bougainville in the order of the Cincinnati.

9410. La Pérouse and the marine, I74I-I 763.

[f. 288

Biographical notes on La Jonquière Taffanel and Hocquart. [ff. 33-39

I757, June 29, Aug. 8, 25, Sept. I7, harbors of Louisbourg or Quebec. Capt. Montalais to the minister of marine. Sickness on the vessels. [ff. I45-I 48 I758. June 29, on board the Dragon. Capt. Du Chaffault de Besné to the minister of marine. Account of the attack on Louisbourg by the English.

[ff. I6o-I63

I 758, Aug. 30, Sept. 25. Lists of vessels in Canadian waters. [ff. I68-169

I 762, July 7, 9, I0, Oct. I 5, 25. Letters from the Chevalier de Ternay, respecting his expedition against Newfoundland. [ff. 275, 284

“Journal de ce qui s'est passé à St. Jean depuis le 87 bre jusqu'au I 5 du même mois, jour de mon départ." [By the Chevalier de Ternay.] [f. 282

9412. La Pérouse and the marine, I76I-I77I.-Contains a few translations of articles in English newspapers on the American colonies.

9414. La Pérouse and the marine, I77I-I 786.

I772, Aug. I8, Compiègne. Ordonnance du Roi, portant Création de Quartre Régimens pour le Service des Colonies de l'Amérique (Versailles, I772, I6 pp.).

[ff. $87-95$

I774, Dec. 26, Amsterdam. Maillet du Clairon to the minister of - . Effect produced in Amsterdam by the resolutions adopted by the American colonies.

9415. La Pérouse and the marine, I775-1776.

I776, Apr. 30, Fort Royal, Martinique. D'Argout to —. Lack of cattle caused by troubles in New England. [f. I79

I776, Nov. I5, Versailles. "Mémoire du Roi pour servir d'instruction particulière au Sr. Cte. Du Chaffault", commanding the squadron sailing for the West Indies.

[f. 234

I776, Dec. 30, Versailles. [Minister of marine] to the Comte Du Chaffault. Protection to American insurgent vessels must be accorded in such a way as to avoid appearance of so doing.

9416. La Pérouse and the marine, I776-1778.

[f. 255

Memoir by M. Parisot: "Exposition du Rôle de la Marine Française dans la Civilisation Européenne et la Liberté des Mers." [f. 5

I776, Oct. I7, Port au Prince, Santo Domingo. Comte d'Ennery, governor of Santo Domingo, to M. de Sartine, minister of marine. Proposals which he has received from the American colonies and the advantage of commercial relations with them. With the letter are enclosed letters of August, from a committee of the Continental Congress, from [Gen. Lee] at Savannah, and from Governor Bulloch of Georgia, to d'Ennery, and his replies of Oct. I6.

[ff. $23-25$

I776, Apr. 6. Mémoire sur les Colonies Américaines, sur leurs Relations Politiques avec leurs Métropoles, et sur la manière dont la France et l'Espagne ont dî̀ envisager les suites de l'Indépendance des Etats-Unis de l'Amérique, par feu M. Turgot (Paris, I79I, 75 pp.).

[f. 26 
I777, May-June. Extracts from the journal of M. de Foligné Deschalonge, commanding the Marquis de La Charlotais in American waters. Convoy of American vessels, Lafayette, etc.

I777, Apr.-Dec. Extracts from journal of cruise of Beaussier de Châteauvert in the West Indies.

[ff. $78-80$

I777, May 9, Philadelphia. Secret Committee of Congress to Franklin, Deane, and Lee. Purchase of a vessel for John Paul Jones.

[f. 82

I777, Sept. 23, "au soir, Feuilles au Roi". Respecting the American vessels Reprisal and Dauphin, which must not be permitted to remain in French ports longer than the customary time.

[f. 9 I

I777, June 27. "Remis à M. de Sartine. Mémoire sur les insultes des Anglais."

[f. I70

I778, Feb. Io, On board the Ranger, Nantes. John Paul Jones to Franklin, Deane, and Lee. (Ext.)

[f. 205

Extracts, notes, etc., mostly from Arch. Marine, relative in part to the American war of independence.

[ff. 206-end

9417. La Pérouse and the marine, I778-I779.-Copies, extracts, and notes, mainly from Arch. Marine, and relative chiefly to plans of operation against England in India, Africa, and elsewhere. A few documents only relate to naval operations in American waters.

9418. La Pérouse and the marine, I778-I $78 \mathrm{I}$.

Copies of letters of d'Estaing, La Pérouse, Ternay, La Luzerne, Breugnon, Albert de Rion, Major Galvan, Destouches, and others.

[passim

I 778, Nov. 5, On board the Languedoc, at sea. D'Estaing to the minister of marine.

[f. 6

I779, Dec. 5, On board the Languedoc, before Brest. Report of d'Estaing on his operations.

[f. I2I

I779, Oct. 31-I780, Feb. 27; I780, Apr. 5-18. Journal of La Pérouse on board the Amazone. Copied by Margry from the original, which was communicated by Dr. Daynac.

Instructions, no. 2, to Lafayette.

[ff. I 44-I 52, 240-24I

List of transports in the squadron of de Ternay. List of vessels in the English fleet off Block Island. List of vessels in convoy. [ff. 242, 258, 259

9419. La Pérouse and the marine, I780.

Copies of letters from La Touche, Des Hayes, Lafayette, La Luzerne, Destouches, Thévenard, Guignac, and others, relative to reception of Lafayette at Boston, the general situation in America, transportation of arms to America, fight between John Paul Jones and Mr. Blodget, purser of the Alliance, difficulty of Jones in enlisting crew of Ariel, etc. Chiefly from Arch. Marine.

[passim

I780, Mar. 23-May 22. Extract from the journal of the squadron of the Comte de Guichen.

[ff. 58-70

I779-I780. Observations by M. Le Ray de Chaumont on the plan submitted by $M$. de Mauléon for a service of packet-boats between France and the United States.

9420. La Pérouse and the marine, I $78 \mathrm{I}-\mathrm{I} 782$.

[f. IO9

Copies and extracts of letters from Destouches, Rochambeau, Comte de Grasse, Thévenard, Barras, de Monteil, Marquis de Kergariou, M. de La Villebrune, Marquis de Vaudreuil, Chevalier de Vallogne, and others, relating to naval operations in American waters, situation in the Southern States, expedition against Pensacola, etc. Chiefly from Arch. Marine.

[passim

I 783 , Mar. Io, Brest. Account by M. de La Grandière of the naval battle in the Chesapeake of Mar. I6, I78I.

[f. 73 
I78I, June 8. Minutes of council of war on board the Neptune. [f. I33 I78r, Aug. 25-Oct. 20. Summary of naval operations in the Chesapeake and of the siege of Yorktown.

I 78I. "Précis du Combat de Chesapeak tiré du Journal de M. [f. I53 de Vaugirard, major de l'armée aux ordres du Cte. de Grasse."

9421. La Pérouse and the marine, I78I-r784.

Letters of La Pérouse, Comte de Grasse, Caron de Beaumarchais, and others, relating to naval operations, surrender of Cornwallis, the West Indies, expedition against Hudson Bay, etc.
[ff. I-I I8

Portrait of Caron de Beaumarchais, "Gravé par Hopwood d'après un dessin original communiqué par la famille". [f. 26

[I78I-I782.] Copy of autograph letter of La Pérouse to the Comte de Creutz, minister of Sweden. Surrender of Cornwallis; naval engagement of July $2 \mathrm{I}, \mathrm{I} 780$.

[f. 78

I782, Sept. I, On board the Sceptre. Lal Pérouse to M. de Rostain. Bad condition of vessels. (Copy of original communicated by M. Dauquin.)

[1782.] "Précis de la Campagne de la division sous les ordres de M. De la Pérouse destinée contre les Etablissements Anglois dans la Baye d'Hudson." By the Marquis de La Jaille.

[r778?] "Réflexions sur la Guerre de l'Amérique Septent'ale." " First and last words: "On ne peut pas contester que les différens qui se sont élevés ... entre elles que par la gazette ne peut pas avoir." (Original or contemporary copy. "Donné par Mr. Charavay.")
[ff. I 57 -r68

I775, July 25, London. "Plan de la Position des Américains sur la Baye de Boston. On voit d'après ce plan que les troupes du Roi de la Grande Bretagne ne peuvent déboucher de Boston qu'en forçant le poste de Roxburgh, très respectable par sa situation qui ferme le passage de l'isthme, ou en attaquant les hauteurs entre Cambridge et Charlestown." (Colored MS. map, about $8^{\prime \prime} \times \mathrm{I} 2^{\prime \prime}$; original or contemporaneous copy.)
[f. 169

I829, July. An historical account of the naval combats engaged in by French vessels during the war of American independence. This article, written to refute assertions in an article by M. de Pradt in the Courrier Français of July I2, I829. may have been prepared in the Section Historique de la Marine, whose chief, Parisot, certifies it to be "conforme à l'original". [ff. I I I-209
[

1783. Memoir prepared for the king by the minister of marine, on the finances of the marine during the war of American independence, years $1780-$ 1783 .

I780. Copies and extracts of the correspondence, instructions, memoirs, etc., of the Comte de Rochambeau.
[ff. 256-277

"Tableau des avances faites par le Roy au Congrès des Etats-Unis de l'Amérique pendant la dernière guerre, et des époques auxquelles le Congrès s'est engagé d'en rembourser les capitaux et intérêts au Trésor royal de Sa

9422. Lá Pérouse and the marine, I774-r789. "Mémoire sur l'état des affaires politiques de l'Europe et sur le plan
d'après lequel la maison de Bourbon doit entamer une négociation, pour obtenir une paix honorable et avantageuse entre Elle, las Provinces unies de l'Amérique septentrionale et l'Angleterre." (Fair copy ; Margry suggests that original appears to be in hand of Beaumarchais.)
[ff. 87-II6

I783. Copies and extracts of correspondence relating to proposed monument to de Ternay, to be erected in Rhode Island. 
I783, Aug.-Oct. Copies of letters from Thévenard relating to transatlantic packet-boats.

9423. La Pérouse and the marine, I78I-I789.

I78I-I782. Copies and extracts of correspondence of naval officers in the ports and of Beaumarchais, respecting the use of certain vessels. [ ff. 2-3I

I78I, Oct. 6, On board the Ville de Paris. Instructions of the Comte de Grasse to La Pérouse.

[f. 34

9424. La Pérouse and the marine, I77I-I807.

Copies and extracts of letters, and other documents, relating chiefly to the voyage of discovery of La Pérouse in I 787. These include a few references of slight value to the intended exploration of the northwest coast of America.

[passim

Copies of I 5 letters of La Pérouse, loaned to Margry by the grand-nephew of the former, including letters to his mother of May I9 and Sept. IO, I782, written in American waters.

[ff. $280-285$

I78I, Oct. 20, Boston. La Pérouse to his mother. Combat of July 20.

[f. 324

I779, June 20. Copy of orders of La Motte-Piquet to La Pérouse, licutenant de vaisseau, commanding the frigate Amazone. [f. 35 I

9425. Original letters to La Pérouse and copies of letters from him or relating to him, I775-I833.

[I778], Apr. 30, Paris. Chevalier de Ternay to La Pérouse. References to d'Estaing, and to continual changes of plans for war.

I778, Mày I I, Paris; June I6, Toulon. —— to La Pérouse. News of d'Estaing's squadron.

$\left[3^{2-33 v}, 3^{6-37 v}\right.$

[ I778, May] I8, Paris. - to La Pérouse. Has reported to the minister the effect produced on French sailors by the arrival of the "capitaine insurgent" [John Paul Jones].

[ff. $34-35 \mathrm{v}$

$[\mathrm{I} 78 \mathrm{I}]$, Apr. I, Newport. —— to La Pérouse, commanding the frigate Astrée at Boston. Minor engagement with English squadron; must

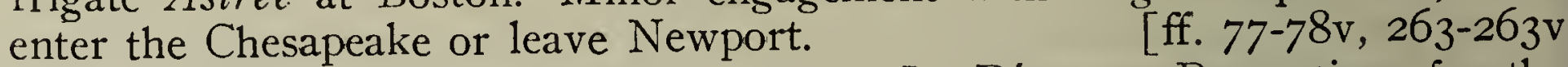

I78I, June I5, Providence. Barras to La Pérouse. Precautions for the convoy to Newport; English cruising off Boston ; movements of Arbuthnot's squadron. [I78I or I782.] to La Pérouse. Intention of English to burn
all their vessels; return of La Touche [Tréville]; agent left at Providence

[ff. 79-8ov, 265-266v should be dismissed ; provisions for the flûtes ; letters received for the Engageante and the Résolue; sailors sent to New York to serve on transports.

[ff. 83-84, 272-272v

[I783.] Chevalier de Langle to La Pérouse. Has received furs from Fort York [Hudson Bay]; asks that he take off the English whom he has on board.

[ff. I I 3-I I 4v, 277-277v

I828, Mar. I7 ; I833, Mar. I8, 29, Apr. 2. B. de La Pérouse, nephew of La Pérouse, to La Bouisse. Biographical details respecting his uncle and his participation in the war of American independence. [ff. I26-I33v, 3IO-3I3 Pérouse. I779, June 20, July I7. Orders of La Motte Piquet and d'Estaing to La

I78I, Jan. 2I, St. Malo. Surcouf, sr, to the minister of marine. Project respecting Hudson Bay.

[f. 262

I78I, Oct. 6, On board the Ville de Paris. Instructions of the Comte de Grasse to La Pérouse, to leave Boston for escort of merchant vessels to the Antilles.

[f. 269 
I78I, Oct. 20, Boston. La Pérouse to his mother. Expects capitulation of Cornwallis and establishment of American independence; siege of Yorktown; his station at Boston, and engagement with six English vessels. tions.

I 78I, Oct. 23, Versailles. Minister of marine to La Pérouse. Congratula-

I 82, Dec 2I Boston. Marquis de Vaudreuil to the [minister of mar: 273

[f. 273 Character of the French who should be sent to the United States; praise of La Pérouse; scandal caused by La Touche.

I783, Sept. I4. Note by d'Estaing. Praise of Dorré, his services America, especially in Hudson Bay.

[f. 283

[f. 290

I786, Sept. 22, Monterey, [California]. De Langle to the dowager Comtesse de Langle. His sojourn in California ; approaching departure for the Philippines.

9426. Chevalier de Ternay, I740-I780.

[ff. 340-34I

I780, Mar.-Dec. Copies and extracts of letters from the Chevalier de Ternay to the minister of marine.

[ff. I99-2 I9, 269-283 I780, May 2-I78I, Jan. 4. Journal by Des Hayes of the expedition under de Ternay.

[ff. 22I-267

9427. Marine of Louis XVI.: de Ternay and La Pérouse.

I762. Instructions from the king, and letter from the minister of marine, Apr. I2, to de Ternay, with regard to his expedition against Newfoundland.

[ff. $58,6 \mathrm{Iv}$

I780, Mar. 24. “Mémoire du Roi pour servir d'instruction particulière à Mr. le Ch'er de Ternay, chef d'escadre des armées navales." (Copy of draft, approved.)

[f. I 22

I780, Mar.-Apr. Copies of letters from de Ternay to the minister of marine, during fitting out of the fleet at Brest.

[ff. I34-I 5 I

I780, Mar.-Aug. Copies and extracts of correspondence of Rochambeau.

Plan for an expedition against Hudson Bay, proposed by M. de St. Aubin.
Platin

9428. Marine of Louis XVI. : d'Estaing.

[f. 3 I8

I769, May ro, Versailles. “Idée sur l'opposition trouvée par les Espagnols à La Louisiane ", by d'Estaing.

I778, Aug. 22, 24, ; I779, Mar. I4, 23, 26. Lafayette to d'Estaing.

[ff. I2O-I23v

\begin{tabular}{l} 
[ff. I85-203 \\
\hline
\end{tabular}

I778-I779. “Remarques sur ce qui s'est passé dans la Campagne de Mr. le Cte. d'Estaing depuis le I3 avril I778 . . jusqu'au 20 [Janvier?] I779."

[ff. $214-24 \mathrm{I}$

I780, Jan. I I, May 4. Three memoirs of instructions to the Comte de Guichen.

[ff. $255^{-269}$

I780, June 8. Instructions to the Comte de Grasse.

Numerous documents relating to naval operations in the West Indies.

[f. $28 \mathrm{I}$

9429. D’Estaing.

[passim

Engraving of "Charles Henri Cte. D'Estaing" and "Prise de la Grenade". Legend: “En I779, Mr. Le Comte d’Estaing témoin de la valeur de Mr. Horadon . . . en récompense de son courage l'embrasse et le fait Officier."

[f. I

I746, Apr. I4. Certificate of marriage of d'Estaing and Marie Sophie de Rousseles de Châteaurenault, in St. Sulpice, Paris. (Copied by Margry be- 
fore the destruction of the parish registers in the burning of the Hotel de Ville.)

I777-I779. Copies, extracts, rough notes, etc., of correspondence of d'Estaing with Washington, Lafayette, Bouillé, John Laurens, Sullivan, Gérard de Rayneval, La Neuville, de Borda, John Hancock, Nathanael Greene, St. César, J. Rutledge, Vergennes, Holker, Bretigny, and others.

[ff. 106-337

9430. D'Estaing.

I782, June I4. "Situation présumé des forces de Sa Majesté dans les colonies de l'Amérique."

I782, Aug. 20. "Etat des choses."

[f. 63

[f. 76

I782, Dec. Copies and extracts of correspondence of d'Estaing, Montmorin, Vergennes, and others.

[ff. I $47-152$

I777, Mar. I5-1783, May. "Mémoire détaillé de mon administration aux iles du Vent ", by Bouillé.

Rough notes relating to career of d'Estaing after I780.

[ff. 220-398

[passim

9431. Suffren and the marine, I648-I780.

I778, July-Sept. Copies and extracts of letters of Suffren, capitaine de vaisseau, commanding the Fantasque in the fleet of d'Estaing. [ff. 505-end

9434. Marine of Louis XVI.

[I778?] D'Estaing to [Franklin?]. Respecting a dinner party planned for Beaumarchais, Deane, Lee, Carmichael, and others. [f. I2 I78I, Feb. I7. "Réflexions sur les secours à donner à l'Amérique", by Caron de Beaumarchais.

[ff. $49-53$ I 782 , Nov. I6-20, Brest. Inventory of goods on prizes captured by the Astrée.

783, Feb. I9, On board the Triomphant, Porto Cabello. Marquis de Vaudreuil to Marquis de Castries. Left Boston Dec. 24. [f. 68 I785. Extract of instructions to Girardin, commanding the Newfoundland station, with respect to fisheries.

9435. Marine of Louis XVI., I777-I783.

I785. Extracts from notes of Georges d'Aristides Aubert Dupetit Thouars on the American war of independence.

Extracts from Arch. Nat., K 1364, papers of Broglie, de Kalb, etc.

[ff. $217-240$

[ff. 294-349, 44I-467, 474

Extracts from Arch. Guerre, Corr., vol. 3732, correspondence of de Kalb, I767-1769.

[ff. $35^{\mathrm{I}-440,468-473}$

"Tableau figuré de ce que l'alliance de la France avec les Etats-Unis de l'Amérique a pu valoir à chacun des alliés depuis I775 jusqu'en I795." [f. 570

9436. Extracts from the journal by M. de Monneron of the voyage of the St. Jean Baptiste, commanded by M. de Surville, Mar., I762-Apr. 9, I770.At f. IO4 is Bellin's Carte Réduite des Parties connues du Globe Terrestre ( 7755 ), on which the course of the vessel is traced in red ink.

9442. Marine during the Revolution and the Empire.

I8I5, June 26-Aug. I3. Copies of correspondence of Decrès, Duc d'Otranto, Bonnéfoux, Gen. Becker, and others, and extracts from journal of Ensign Luneau of the Amphitrite, respecting plans for embarking Napoleon on a vessel at Rochefort for transportation to Boston or Philadelphia.

9443. Marine of the Restoration, 1816-1827.

[ff. I 49-223, 285-300

Notes, extracts, etc., relating to the American wars of liberation, I82 II 825 , the slave-trade, etc.

[passim

1821, Feb. 26. Notes on a memoir respecting the Newfoundland fisheries. 
1826, May 24, Lima. Exposición que hace Benito Laso Diputado al Congreso por la Provincia de Puno (Lima, I826, 40 pp.). [f. 226

9447. Pacific.

I833, I837, I838, I841. Copies and extracts of letters of T. A. Moerenhout, consul of the United States at Tahiti, Richard Charlton and John Jones, English and United States consuls at Oahu, and others, relating to affairs of the Hawaiian Islands, French and American missionaires, Anglo-American rivalry, etc.

[ff. $47-84$

9455. Notes taken on board the Méléagre, in West Indian and Gulf waters, I853-1855.-Mention of American plans for establishment of a steamship line (p. 97), of the Darien expedition for locating a passage across the Isthmus (p. 224), etc.

9457. Journal of the Méléagre, I854-1860.-Mentions of American vessels, bombardment of Greytown, I854, American plans to take possession of the peninsula of Samaná in Santo Domingo, troubles between English and Americans, political situation in Cuba, I855, American filibusters, American projects for annexation of Cuba, etc.

9463. Log-books, etc., of Capt. Leps.

1855, May, on board the Méléagre, Havana harbor. Report [by Capt. Leps] on affairs of Cuba, American vessels and filibusters, etc.

[f. 253

9464. Log-books of the Cléopâtre and the Bayard, stationed in West Indian waters and the Gulf of Mexico, I858-I859.

9465.-1864, June 19, Cherbourg. Penhoat, commanding the Couronne, to the maritime prefect of Cherbourg. Account of the engagement between the Alabama and the Kearsarge. Ptd. in Amer. Hist. Rev., XXIII. II9-I 23.

9466. - Copy of document noted in $\mathbf{9 4 6 5}$.

[ff. $95-98$

9467-9469. Letter-books of Penhoat, commandant-cn-chef, on board the Belliqueuse, in South American Pacific waters, I866-I868.-O Occasional letters relate to American vessels, protest of American and other consuls to the president of Panama (May 26, 1867), mediation between Spain and the allied South American republics (I867), irritation against Americans in Peru (I868), disturbances in Colon in which Americans were involved (Mar., I868), etc.

9483. Sail and steam vessels.

I 788-1845. Extracts, copies, and translations of letters, memoirs, articles, etc., of St. Jean de Crèvecoeur, La Forest, L. de Valcourt, Oliver Evans, J. Doolittle, and others, relative to the inventions of John Fitch and Robert Fulton, the beginning of steam navigation, its application to the Ohio, etc. [passin

9487. Miscellany.

[ $7748 \mathrm{ca}$.] Instructions to Chabert. (Copy of draft in hand of La Galissonière.)

[f. 90

I748, Aug. 30. "Projet d'observation astronomique pour constater la position de l'entrée du golfe de St. Laurent . . .", by M. de Chabert, ensign.

[f. 92

I750, Dec. I2, Paris. La Galissonière to $M$. de Chabert, respecting the latter's observations.

[1783]. June 17. Memoir by the Marquis de Chabert, containing refer\begin{tabular}{l} 
ences to his services in the battle of Chesapeake Bay. [f. IO7 \\
\hline
\end{tabular}

9491. Personnel of the marine.

1754. "Mémoire circonstancié concernant MM. les Intendants de la Marine." Lists of intendants in the different ports and in the colonies, with records of service.

[ff. 4I-7IV 
9492. Officers of the marine.

Notes on the life and services of M. de La Galissonière. [f. 244

I875, July i8. "Le M'is de La Jonquière, chef d'escadre des armées navales, gouverneur et Lieutenant Général de la Nouvelle France." Article by the Marquis de La Jonquière.

[ff. $273^{-292}$

9493. Ports of Normandy.

I729-I730. Three memoirs by Sicard on the towns of Honfleur, Rouen, and Dieppe, respectively. Commerce, fisheries, relations with Canada, Newfoundland, West Indies, etc.

1825, Mar. 6-Oct. I9. Journal of the voyage of the French whaler Groënlandais, Capt. Louis-Antoine Guédon of Dieppe, to Baffin's Bay. By Nell de Bréauté.

[ff. $147-$ I 56

9494. Ports of Aunis and Saintonge.

"Etat des différentes manières dont les négociants traitent avec les gens de Mer sur leurs navires de commerce." Customs of different ports as to engagement and payment of seamen for coastwise or deep-sea voyages, fisheries, etc.

[ff. $236-301$

9495. Ports of Brittany, Navarre, and Provence.

Notes on La Hontan; extracts from archives of Bayonne relating to La Hontan, to Dominique Cabarrus, etc.

[ff. I 53-I 55, I79-I 80

I725, Mar. 7. Note by de Rostan on commerce of Bayonne. [f. I70

1760, Oct. 2. Representation by Solignac and Cabarrus, merchants of Louisbourg, ruined by the company of Bigot.

[f. 178

I 783-I857. Notes and documents relative to establishment of packet-boat and steamship services between the United States and France.

9496. Notes on the archives of the Marine and Colonies.

I749. June. “Mémoire sur l'ancienneté et le tems des établissements des Bureaux de la Marine existant actuellement tant à Versailles qu'à Paris, des Réunions et des unions des détails qui y ont été faites en différents tems, les noms des premiers commis et commis en ze qui ont été chargés . . ." [f. 7

9497. Archives of the Marine and Colonies.

Notes on the history of the archives of the marine. [ff. I-I6

Inventory of the archives of the administration of the colonies from the time of Richelieu to I789. Signed by Margry. [ff. 2I-34v Inventory of the archives of the marine, "Campagnes" [B4], vols. I-279.

9498. Dépôt Hydrographique.-Inventories, lists of log-books and of reports of voyages, and history of the Dépôt des Cartes et Plans.

9499. Reports by Margry on his publications of documents ; critical reviews of his work; documents relating to Louisiana, I7I9; proposal for a statue of Champlain, etc.

9500. Letters to Margry, I865-I868.

I866-I867. Letters from Daniel (Montreal), F. de Bellefeuille (Montreal), W. McDougall (Paris), Francis Parkman (Boston, July 7, Dec. I3, I867), N. Bourassa (Montebello), and Abbé Tanguay (Quebec), relating to historical and genealogical matters.

9501. France and foreign countries.

Notes on Parisian sites, streets, buildings, etc., of interest for the history of America.

[f. 30

I787. Extract from a memoir on New Hampshire by the French viceconsul at Portsmouth.

"Etat succinct de la Province de Quebec... Par M. Ogden pour l'instruction du Prince William Henry."

[f. I 4 I v 
Rough notes on history of Canada and Louisiana.

[ff. $162, \mathrm{I} 78$

I786, Dec. 20. "Arrêt . . . concernant l'Établissement des paquebots pour la correspondance avec les colonies françaises et les États-Unis d'Amérique."

[i786.] "Instruction pour la Direction et Régie des Paquebots établis pour communiquer du Hâvre et de Bordeaux aux colonies françaises, aux îles du Vent et sous le Vent, et les États-Unis de l'Amérique." By Marshal de Castries.

[f. 267

I787, Apr. 18, Nantes. "Mémoire des négocians de Nantes sur les Paquebots établis par les arrêts du Conseil des 14 et 20 décembre I786." [f. 274

I 283 , I 788 . Extracts from letters and memoir on packet-boat service between France and North America.

[ff. 288-291

I857, I862. Extracts and clippings from newspapers, relating to service of packet-boats between France and America, and the inauguration of the service between Hâvre and New York of the Compagnie Générale Transatlantique.

[ff. $301-320$

9502. Clippings from newspapers, corrected proof-sheets, and reprints, containing historical and genealogical articles by Margry, relating to Hector Garneau, emigration from French provinces to America, Champlain, Joliet, Fox Indians, La Vérendrye, French participation in war of American independence, navigation of the Mississippi, etc., 1852-1863.

9504.-Extracts from Arch. Colonies, B, vols. 2-8, I663-1677. [ff. 36-IOI

9510. Pamphlets and newspapers.

Moniteur de la Louisiana, no. 345, May 28, 1803, with Supplément : 346, June 4. I803, with Supplément; 347, June II, I803, with Supplément; 348, June I8, I803, with Supplément; 372, Dec. 3, I803; 373, Dec. I9, I803 (4 copies) ; 377, Jan. 7, I804, mutilated ; 382, Feb. 22, I804; 383, Feb. I8, I805, with Supplément.

[ff. I-30

Six. Indiens Rouges de la Tribu des Grands Osages, arrivés du Missouri au Havre, le 27 Juillet I827 . . . (Paris, 1827,36 pp.).

[f. 33

Histoire de la Tribu des Osages... écrite d'après les Six Osages actuellement à Paris. Par M. P. [de].V[alcourt] (Paris, I827, 92 pp.).

[f. $5^{1}$

Remarks on the Mining Region of Lake Superior ... and Report on Mining Locations claimed on the Canadian shores of the Lake . . . By W. E. Logan (Montreal, I847, 3I pp.).

[f. 104

Fragment of Col. Auguste Choutean's Narrative of the Settlement of St. Lonis (St. Louis, I858, Io pp.).

Mines de Cuivre du Comté d'Ontonagon (Paris, I86I, 30 pp.). [f. I29

Relation inédite du Naufrage de la Bourgogne . . . par le Chevalier de Coriolis (Paris, 1870, reprint from the Revue Militaire Française). The Bourgogne, with part of the regiment of Bourbonnais on board, was wrecked in 1783 en route from Boston to Porto Cabello.

[f. I 47

Manitoba et le Nord-Ouest du Canada. By Thomas Spence (second ed., Ottawa, 1875,39 pp.).

[f. 164

Article on "Le Centenaire du Dernier Siège de Québec", in Journal de l'Instruction Publique (Quebec, Jan., I876).

[f. I87

illustrated Guide cind Sonzenir of Detroit (Silas Farmer and Co.. Detroit, 68 pp.).

[f. I95

Address delivered before the Missouri Historical Society, July I9, I878; the Anniversdry of the Discovery of the Mississippi by Marquette and Joliet, by John Gilmary Shea (New York, I878, I8 pp.).

[f. 222 
Invitations, programmes, circulars, newspaper clippings, reprints, pamphlets, etc., relating to observation of historical anniversaries, La Salle, the American Indians at the Jardin d'Acclimatation, the Northwest Rebellion of I 885 , etc.

[ff. 244-472

9545, 9551. Correspondence and papers of Hippolyte Nectoux, botanist, director of the Royal Botanical Garden of Santo Domingo--Letters to Nectoux from Arthaud, La Luzerne, Thouin, Watson, [Barbé-] Marbois, Adet, and others, relating for the most part to the culture of indigo, cotton, and coffee, to the search for quinine, and to other scientific matters, with a few references to the sojourn of Nectoux in the United States, I 789-I797.

9801.-I720, Aug., Dec. Letters, contracts, and other documents relating to a plan for transporting Italian families to Louisiana ; memoir in refutation of discredit cast upon Louisiana.

[ff. $59-72$

10253. MS., with autograph corrections, of La Rochefoucauld Liancourt, Voyage dans les Etats d'Amérique fait en I795, I796 et I797 (Paris, l'an VIII).

10406. "De l'isle d'Oléron ... "-This MS. contains passages on the discovery of Newfoundland and the Gulf of St. Lawrence by Basques in the thirteenth century.

10421. Journal of voyages of Dumanoir, I689-I696.-Account of Santo Domingo.

10566-10585. Memoirs and other documents relating to the marine, copied from the admiralty archives of Brest, Morlaix, etc., by Dr. Corre. $C f$. below, 21075-21090.

10567. Extracts from the admiralty archives of Brest, I684-I 79I, made by Dr. Corre.-Extracts relating to contracts for beaver trade in Canada ( $\mathrm{f} .95 \mathrm{v}$ ), passports for Newfoundland (ff. II4v, II6), Newfoundland fisheries ( $\mathrm{f}$. I I9v), and capture of Pensacola, I7I9 (ff. I49v, I60, I74, I76v).

10570. Extracts from the admiralty archives at Brest.-Numerous extracts relating to vessels engaging in the Newfoundland fishery, the slave-trade, captures of vessels from the English colonies, etc.

10571. Extracts from the admiralty archives at Brest.-Extracts relating to the capture of the Cumberland, I757, from Carolina (p. 5), and to naval operations in the Antilles, I762 (p. IO9).

10572. Extracts from the admiralty archives of Brest.-Roll of crew of the St. Jean of Brest, bound for Martinique, I72I (p. 5).

10573. Extracts from the admiralty archives of Brest.-Extracts relating to vessels in the West Indies. Capture of vessels from or by the English, privateers, etc., I 777-I 779 .

1057\%. Extracts from the admiralty archives of Morlaix.-Notes relating to a ship's crew going to Placentia, I 7 Io (f. $6 \mathrm{v}$ ), to encouragement of the cod fishery, I 786 (f. I9v), and to prizes made by the Black Princess of Boston, I $78 \mathrm{o}(\mathrm{ff} .42,43 \mathrm{v})$.

10695.- [ [650 ca.] "Relation des isles de Sainct Christofle, Gardelouppe et la Martinique." Contains reference to New France.

10720.-I767. Memoir on the Philippine Islands.

Memoir on Guadeloupe and the sugar industry. [ff. I36-I39
I 766 , Aug. 9. Notes by Verdun on the commerce of Marseilles. Refer-

[ff. $275-294 \mathrm{v}$ ences to commerce with West Indies.

[ff. I49-I6Iv 
10737. - Notes on the bishopric and bishops of Quebec.

10996. "La vie du révérend Père Isaac Jogues, martyr chez et leurs premières missions." I 8 th century. Jogues, martyr chez les Iroquois,

11189, 11206-11207. Correspondence of Henry Harrisse, I863-I90I. In 11189 are autograph letters of George Sand, not relating to America in any way. In 11206 are letters to Harrisse from various European scholars, personalities, or book dealers, relating to history, geography, and bibliography, particularly with reference to Columbus (ff. $32,35,36,56,266,269,272,282$ ) and $\mathrm{La}$ Salle (f. 57). In 11207 are similar letters (ff. 92, 95, 97, 98). a letter from Parkman about the documentary publication of Margry (f. 80 ), and notes or letters by Harrisse relating to the siege of Paris in 1870 , the use of the U. S. diplomatic pouch for transmission of personal news, etc. (ff. $3 \mathrm{I} 7$, $34 \mathrm{I}, 343,345)$.

11220-11222. Collection of notes on current affairs, in the hand of Buvat, employe in the Bibliothèque du Roi, collected by Abbe Melani for the compilation of nouvelles à la main, I700-I721. - A few references to American affairs are to be noted: 11221, terms of preliminary articles of peace, I709, relating to Newfoundland and colonial conquests (f. I92) ; 11222, French proposals of peace at Utrecht, I 7I2, with respect to American possessions (ff. I 53, I55); assays of minerals from the Mississippi, I 720 (f. 3 IO) ; colonization of Louisiana, I720 (f. 3IIv).

11258. "Idées politiques et morales, par Louis Narcisse Baudry des Lozières, citoyen du Nouveau Monde." I780.-A volume devoted to Santo Domingo, with passages relating to Louisiana and the United States (ff. 23, $68 \mathrm{v})$.

11259. "Les entretiens d'un fils avec l'ombre de son père". [by Baudry des Lozières] " at Cottage near of Philadelphia . . .", I792.- Revolution of Santo Domingo.

11651. Narrative of the voyage of the Etoile, commanded by Chesnard de La Giraudais, and the Aigle, commanded by Duclos-Guyot, to the Falkland Islands and Straits of Magellan, I 765-1 766.

11700. Journal of travels in America, composed of extracts from the letters of Baron Salomon de Rothschild to his wife, Oct. I7, I859-June 23, I861.The letters are dated from New York, Jamestown, Montreal, Saratoga, Newport. Baltimore, Havana, and New Orleans; they include passages relating to John Brown's raid, secession. Henry Ward Beecher, firemen, thieves, society, business, accidents, politicians, Washington, slavery, Lincoln, Quakers, visit of the Prince of Wales, etc.

20078-20102. Papers of Comte Charles-Étienne Coquebert de Montbret, I755I83I. commissaire des relations extérieures at Hamburg and Amsterdam, and director of statistics of the Ministry of the Interior, and of his son, Eugène Coquebert de Montbret, I 785 -I 849 , interpreter secretary in the Ministry of Foreign Affairs.

20087. Military history.

Extracts from newspapers of $1819,1820,1828$, relating to events in South America.

20088. Marine and colonies.

[ff. $193-200$

I7I7, Apr. Extract from letters patent regulating commerce of the French colonie\$.

[f. II

I730. Extract from a memoir on external commerce, read to the king in council: whale fishery, Newfoundland fishery, commerce of Canada and Ile Royale. 
I757. Fragment of a relation of the sending of envoys of the Five Nations to Montreal.

[f. I8

[I759.] "Requeste des principaux habitans et négocians de Québec à Mrs. les Commandants et officiers majors de la ville de Québec." Lack of provisions, weakness of the garrison, and necessity of a capitulation. [f. I9

I759, Sept. I5, Quebec. Procès-verbal of council of war.

I759, Sept. I8. Capitulation of Quebec.

[f. $20 \mathrm{~V}$

[f. $22 \mathrm{v}$

I759, Sept. 2I, Quebec. Bernier, commissaire des guerres, to de Ramezay, respecting lack of provisions at the General Hospital, and his conversation on the subject with the English general.

I759, July 25. Second manifesto of Gen. Wolfe.

「f. 24

Map in colors of Fort Carillon and its environs.

[f. $26 \mathrm{v}$

[f. 27

Order from Montcalm to Bougainville, from camp at Point Lévis. 「f. 28

I763. Memoir of the inhabitants and merchants of Rochefort, desiring the establishment of an entrepôt and permission to trade directly with the French colonies of America and with the coast of Guinea.

[f. $3^{2}$

"Mémoire touchant la découverte, les établissemens, et les possessions de l'Isle de Terre Neuve par les sujets de Labour, fourni par les négocians de St. Jean de Luz et de Ciboure à M.PPlanthion, syndic général du pays de Labour en Mars I7 Io."

20102. Voyages.

Extract of a letter from M. Dupin, inhabitant of New Madrid, near the mouth of the Ohio.

Note on the native inhabitants of the region about Halifax.

[ff. $9 \mathrm{I}-9 \mathrm{IV}$

[f. 93

20277. Collection of original letters relating to Santo Domingo.

I789. Letters to Barbé-Marbois from Baussan (Léogane), St. Jean de Crèvecoeur (New York), and Marquis du Chilleau (Port au Prince), relating to sale of Louisiana, finances of Santo Domingo, American vessels, etc.

[ff. 26, I 3 I, 2 I 5

20500.-Reviews, by Adolphe de Circourt, of a volume of Lowell Lectures. Boston, I869 (f. 36), and of F. Geffcken, Die Alabama Frage, Stuttgart, I872 (f. 68).

20536-20542. Memoirs on French and foreign commerce, collected by D. C. Trudaine, intendant of finances (obiit I 769 ).

20536.-I745, Oct. "Mr. Fournier.-Réflexions sur les moyens de sauver les débris du commerce maritime de France ou même de le rétablir, autant que les circonstances peuvent le permettre."

[f. 27

I753, Sept. II. "Avis des députés du Commerce sur le mémoire de Mrs. les Fermiers généraux No. 32I4 au sujet de l'entrée dans les pais conquis des cuirs secs provenant des colonies françaises."

[f. I 32

Memoirs and other documents relative to the fisheries, duty on fish, etc.

[ff. $213,216,243,244$

"Mémoire pour faire connaitre la situation actuelle du commerce martime et le soutenir."

[f. 273

20539.-Mémoire de la Chambre de Commerce de Bayonne sur l'ancien Etat de cette Ville et les Révolutions arrivées à son Commerce (Bayonne, I738). [f. I5

I752. Memoirs and other documents dealing with trade in eau de vie to Canada, syrup from the West Indies, etc. [ff. 83, 86, I68, I94, I96, 426

20541. - Numerous memoirs and other documents relating to commerce with the Netherlands, commerce of the West Indies. fisheries, tobacco, etc.

[ff. I, I8, 32, 44, 66, 67, 74, 84, I08, I 26, I 27. I48, I60. I62, and passim 
20542.-I757. "Mémoire sur quelques articles relatifs au Canada et à son Commerce."

[ff. $64-88$

20556. "Etat au vrai des 70,875,950 livres de reconnaissances Nouette, fixées par arrêt du Conseil du I 3 avril I766." Account of certificates of indebtedness issued to the creditors of the colonies by Nouette, trésorier général des Invalides de la Marine.

20806. "Dossier Margry. H[enry] H[arrisse]."-A volume of correspondence of Henry Harrisse with Parkman, Barlow, Washburne, R. R. Hitt, Senator Howe, and others, I870-187I, respecting the publication of documents relating to American history by Pierre Margry, with an introductory note by Harrisse. The purpose of the "dossier" is to demonstrate that Harrisse himself had an important and unrecognized part in making the publication possible, expecting that he would be entrusted with it. There is much complaint of unfair treatment, and severe criticism of Margry.

20807.- " Mémoire touchant la découverte, les éstablissements et la possession de l'île Terreneuve et l'origine des pêcheries des baleine et des morues . . . par les négocians de Saint Jean de Luz et de Siboure... en mai I7ro." (Copy.)

[ff. I-IO

Notes on St. Jean de Luz by M. Heremboure. Discovery of Newfoundland, whale and cod fisheries, Canada, etc.

[f. 43

20956. Documents relating to dispute between the inhabitants of St. Christopher and the Compagnie des Iles de l'Amérique, I650-165I.

21075-21090. Memoirs, letters, and other documents collected by Dr. Corre of Brest. Cf. above, 10566-10585.

21076. - I884, I885. Letters of G. de La Landelle to Margry, relating to services of his grandfather at Louisburg in 1757 , and to Fulton and Joel Barlow.

[ff. $36,45,52,58$

21078. - I685, Mar., Versailles. Printed copy of the Code Noir.

[f. 92

I77I, Feb. 8, Metz. Father Dieudonné, provincial of the Capuchins of Champagne, to - Nine missionaries detained in Louisiana by the Spanish government complain of their treatment, and desire to go to Santo Domingo.

[f. I3o

21079. Journal of the travels of M. Jardin, commissaire de la marine, in the Antilles, Mexico, and North America, I858-I859.-French policy in Mexico (f. I) ; Newfoundland, St. Pierre, Miquelon, and the cod fishery (ff. I05, I59); Halifax, Nova Scotia (f. I6o); New York, Albany, and Niagara ( I9I).

21081.-I 778, Sept. 26, London. Photographic copy of a letter of marque against American vessels, issued to the English vessel Anna Gally. [f. 8o

I779, Apr. 5, Versailles. Photographic copy of letter of King of France to the Admiral of France, explaining the motives of the war against England. [f. 84

21089.-[ $1850 \mathrm{ca}$.] Journal of a voyage from Kamtchatka to the northwest coast of North America. Description of Monterey, state of California, whaling vessels, English settlements on the Columbia, etc.

[ff. 89-94

21261. "Principes des Ministres sur la Marine. Depuis i669 jusqu'en I723."-Exposition of policies of Colbert, Seignelay, the two Pontchartrains. the Conseil de Marine, and M. de Morville, especially with regard to commercial and colonial matters. 


\section{(COLLECTION ARNOUL.)}

21306-21444. Collection Arnoul.-This collection is composed of the correspondence, administrative memoirs, and other papers of Nicolas Arnoul (obiit 1674) and of his son Pierre Arnoul (obiit I7I9). The elder Arnoul was intendant of galleys at Marseilles from 1665 , and intendant of marine at Toulon from I673. His son succeeded him as intendant of galleys in 1673, and as intendant of marine in 1675 . In 1680 he was appointed intendant at Havre, and from 1683 to 1687 served in the important intendancy of Rochefort. Subsequently he became intendant des classes, and from I7 Io to I7 I9 served as intendant of galleys. The interest of the collection, for the purposes of this Guide, is chiefly in the correspondence of Pierre Arnoul with the secretary of state for the marine, especially during the Rochefort intendancy. While this correspondence is mainly administrative in character, it nevertheless often contains interesting information which the intendant at Rochefort received in his dealings with officers and officials in the various American services. The earliest part of the collection records certain of Colbert's activities in attempting to build up French commerce, particularly with the West Indies. A more detailed inventory of the collection than that included in the printed catalogue of the MSS. Fr., nouvelles acquisitions, is published by Robert Latouche in Revuc des Bibliothèques, XVIII. (Paris, I908) 244-263. It may be noted that most of the documents in the volumes that relate in any way to Canada, Acadia, Newfoundland, the cod fisheries, etc., have been copied for the Public Archives of Canada, and transcripts of them are available at Ottawa.

21309. General correspondence, I669.-A few references, in correspondence with Colbert and Seignelay, to fishermen of St. Malo (ff. 227, 332, 336), and to payment of officers and embarkation of soldiers destined for Canada (ff. 363 ).

21310: General correspondence, I670.

I670, Dec. 26, Paris. Colbert to Arnoul. Hopes that merchants of Marseilles will engage in commerce with the West Indies; it is desirable that inhabitants of Provence should engage in the cod fisheries. (L. S.) [ff. 480-490

21311. General correspondence, I671.

Numerous letters of Colbert and Arnoul contain references to efforts to interest the merchants of Marseilies in the commerce of the West Indies and in the cod fishery; Colbert sends Arnoul ro,ooo livres to enable him to take a half interest in a company for trading with the West Indies; lack of success of merchants of Marseilles in the cod fisheries, etc.

$$
\text { [ff. } 28,44,56,65,283,307,324,34 \mathrm{I}, 345,35 \mathrm{I}, 362,383
$$

21312. General correspondence, I672, Jan.-June I5.

Letters of Colbert and Arnoul contain references to encouragement of commerce with the West Indies, and conditions imposed by the merchants of \begin{tabular}{l} 
Provence for their participation in the cod fisheries. [ff. 70, II 3,144 \\
\hline
\end{tabular}

21329. General correspondence, I683.

Original letters from Seignelay and royal memoirs of instructions addressed to Pierre Arnoul at Rochefort contain references to despatch of vessels, munitions, supplies, and troops to Canada, and to encouragement of merchants to engage in Canadian and West India trade, etc. The record copies of most of these letters are in Arch. Marine, B2, vols. 48, 49.

21330. General correspondence, I684.

$$
[\mathrm{ff} .5,32,239,258,260,266,28 \mathrm{I}, 299,3 \mathrm{I} 7,447
$$

Original letters of Seignelay, royal memoirs of instructions to Arnoul at Rochefort, and copies of letters of Arnoul to Seignelay and others contain 
references to the following matters: Acadian timber for masts, preparation of the Joly for La Salle's expedition to the mouth of the Mississippi, inspection of vessels to be despatched to Canada, troops for Canada, return of the Entreprenant, disabled on the Grand Bank, investigation of naval contracts, abundance of flour in Canada and supply of flour to Cayenne and Martinique, supply of lead for Quebec, etc.

[ff. 44, 78, 84, I 36, I 5 I, I 56, 209, 21 3, 220, 240, 272, 280, 309 I684, Mar. 23 [sic], Versailles. Royal order appointing Pingault to command the Joly. (D. S.)
$[\mathrm{f} .64$ 1684, Mar. 27, Versailles. Seignelay to Arnoul. Instructions respecting the semi-annual assembly in each port of merchants trading by sea, for the preparation of memoirs respecting commerce, and for the selection of deputies to present the memoirs. (L.S.)

I684, Apr. Io, Versailles. "Règlement que le Roy veut estre observé pour le payement des officiers et soldats qui sont et seront destinés pour servir dans la Nouvelle France." (Copy ; also in Arch. Colonies, B, vol. 11, f. I4v.)

I684, Apr. I2, Versailles. Royal order naming the Sieur Du Mf. 70-70v
[ffnil Patte I684, Apr. I2, Versailles. Royal order naming the Sieur Du Mesnil Patté to command a company of marine troops in New France. (D. S.) [f. 84

21331. General correspondence, I685, Jan.-Aug. I4.

Copies of letters from Arnoul, at Rochefort, to Seignelay, containing references to arrival of the Emerillon from Canada and news from that colony, purchase of flour for Cayenne and Martinique and cheapness of Canadian wheat as compared with that of France, preparation of the Diligente for the Compagnie de la Pêche Sédentaire, recruiting of soldiers for the West Indies, departure of vessels for Canada, embarkation of Denonville, cost of clothing for soldiers in Canada, expenditures for Canada, supplies and soldiers for Canada and Acadia, return of the Joly, interviews with Beaujeu, captain of, the Joly, who thinks that La Salle is not at the mouth of the Mississippi, but is to the west of it (July 8, f. 307), departure of Perrot for Acadia, payment of the crew of the Joly, instructions to Beaujeu and his officers not to talk against the enterprise of La Salle, freight charges to Quebec and Chedabucto, etc.

[ff. I I, I 20, I4I, 205, 223, 226, 243, 245, 254, 265, 299, 303, 307, 31 3, 330, $348,370,402$

21332. General correspondence, I685, Aug. I5-Dec.

I683 [sic], Aug. 25, Fontainebleau. Royal memoir of instructions to Arnoul respecting supplies and soldiers for Canada. [ff. 30-3 I
[

Copies of letters from Arnoul to Seignelay, dealing with the following matters: payment of sums due to Beaujeu; balance of pay due the crew of $L a$ Belle, which remained with La Salle, should be paid to wives of crew who are in great need; deaths of M. de Rochefort and of soldiers and sailors on voyage to Canada due to overcrowding of vessels; prevention of private trading on the part of officers of vessels in Canadian and West India service.

21333. General correspondence, I686.

[ff. I 20, I 53, I69, 32 I, 379, 428, 457

Copies of letters from Arnoul, at Rochefort, to Seignelay, containing references to the following matters: receipt of draft for expenditures for Canada ( $f .22$ ) ; recommendation of the Sieur de St. Michel, native of Canada, the best pilot for the voyages to Canada, and his commission as ensign (ff. 47 , 96 , I23) ; cost of recruiting, equipping, and transporting soldiers to Canada, efforts to have this done by merchants vessels (ff. 72 , I23, I3 I, I73, 21 2, 257, 286) ; reprisal for capture of the Marie by the English of Boston (f. 83 ); Compagnie de la Pêche Sédentaire of Acadia (ff. I54, 316, 36I) ; munitions 
for Canada (f. 386) ; estimated cost of wheat for Canada (f. 4I3) ; reports of forbans on the Newfoundland Banks (ff. 452, 493).

21334. General correspondence, I687.

Copies of letters from Arnoul, at Rochefort, to Seignelay, containing references to the following matters : equipment of vessels for Canada, expenditures on account of Canada, troops and provisions for Canada (ff. 56, 75, 79, 84, 90, I02, I08, I4I, I89) ; reports of La Salle's colony from captured Spanish letters (ff. I I9, I83) ; attack on filibusters in Carolina, and French Protestants in that colony ( $f$. I 54); plans of the Sieur Riverin for establishment of a whale fishery in the St. Lawrence (ff. I65, I69, 2I2); proposed voyage of Beaujeu to Santo Domingo and Mexico by way of the Mississippi (f. 309). I687, June I4, La Rochelle. " Mémoire sur l'establissement de la pesche de la Baleine dans le fleuve St. Laurent . . . par le Sr. Riverin." (D. S.)

[ff. I70-I7Iv

I687, Aug. 22, On board the Arc-en-Ciel, harbor of Placentia. Croiset to Arnoul. Remarkably quick voyage of squadron from France in 34 days; much trade by officers on their own account ; unpopularity of Perrot. ( $\AA$. L. S.)

21337. General correspondence, I693, Apr.-1695.

[ff. 298-300

Correspondence of Arnoul and Pontchartrain, containing incidental references to sailors for Newfoundland fisheries, regulations for voyages to the West Indies, Canadian matters, etc.
[ff. 218, 260, 287, 327, 343 I693. Aug. 29, Versailles. Royal order permitting privateering in all parts of the world. (Ptd. broadside.)

I694, Oct. I2, Fontainebleau. "Ordonnance du Roi portant deffenses aux officiers de Sa Majesté commandant ses vaisseaux d'escorts, de n'abandonner ceux des marchands, et particulièrement ceux venans de l'Amérique." (Collated copy.)

21338. General correspondence, i696-i 70 I.

I606, Apr. 28, Paris. De Lagny to Observations on the

[f. $5 \mathrm{I} 3$ commerce of La Rochelle. (L. S.) [ff. 2I-22

[1696.] List of merchants of La Rochelle engaged in maritime commerce. Mention of Bions and Brians, Louis Massiot, Théodore Pagez, and Gatebois as having refineries and trading with the West Indies; Faneuil and Son, and Jacques Godefroy trade with Newfoundland for dried fish, and with Canada and the Iles du Vent.

[ff. $23-23 \mathrm{~V}$

[1696, June 2, Rochefort.] Memoir on the commerce of La Rochelle, by

Phélypeaux. Deals with trade with West Indies and Canada, and with trade in negroes, cotton, tobacco, sugar, beaver, etc.

[ff. 39-7I 1698, Jan. 24, Paris. Rémonville to [Pontchartrain]. Importance of Louisiana as a French establishment. (A. L. S.)

21340. General correspondence, I702, Aug.-Dec.

I702, Oct. I5, Cadiz. Arnoul to - News of English vessels off

Newfoundland and in the mouth of the St. Lawrence. [f. 330

21344. General correspondence, I703, Sept.-Dec.

Correspondence of Arnoul, at Cadiz, with Pontchartrain, containing a few references to the protection of Newfoundland fishing vessels entering the Mediterranean.

21346. General correspondence, I705-1706.

I706, Jan. II, I3, Versailles. Argoud and Pontchartrain to Arnoul. Disapproval of project of Iberville.

[ff. I74, I76

Correspondence of Arnoul and Pontchartrain, containing references to the Compagnie de l'Assiente, trade with Santo Domingo, price of tobacco. and purchase of negroes.

[ff. $227.245,259$ 
21347. General correspondence, I707-1708.

I708, Dec. I3, Les Sables d'Olonne. Alexander Honde, professor of hydrography, to [Pontchartrain], on the dangerous practice of allowing vessels to make the voyage to Newfoundland without pilots.

I 707, Nov. I. Estimates of expenses of maintaining 30 companies of 50 men each in the West Indies, 28 companies of 30 men in Canada, 4 companies of 50 men in Acadia, and 3 companies of 50 men at Placentia.

21348. General correspondence, I709-I 7ro, Apr.

Correspondence of Pontchartrain, Arnoul, Guilbaud, and Pointel, relating to necessity of having pilots on vessels going to Newfoundland, the difficulty of securing them, their training, etc. [ff. I, 3, 26, 30, 3I, 36, 38, 40, 43

21353. General correspondence, I 7 I I, Feb. I6-Mar.

Correspondence of Pontchartrain and Arnoul with Messrs. Le Vasseur and de Gartigny, and Blondel Jouvancourt, of Marseilles, respecting shipment of munitions to Canada from Marseilles.

21354. General correspondence, i 7 I I, Apr.-May.

$[$ ff. $200,296,327$

I 7 I I, May i I, Marseilles. Blondel Jouvancourt to Arnoul. Reasons for probable failure of project to trade wine with Canada for timber. (A. L. S.)

21359. General correspondence, I7ı2, Apr.-May.

Correspondence of Arnoul, at Marseilles, and Pontchartrain, referring to request by Martelly, lieutenant of infantry in Canada, for extension of leave.

21360. General correspondence, I7 I2, June-Aug.

$[\mathrm{ff} .42, \mathrm{I} 55,260,264$

Correspondence of Arnoul, at Marseilles, and Pontchartrain, relating to the following subjects: Martelly prevented by illness from joining the convoy for Canada (f. 49); information desired respecting vessels sailing to the American colonies (ff. I5I, 270, 277, 327).

21364. General correspondence, I7 i3, Apr.-May.

I7 I3, May 24, Marly. Pontchartrain to Arnoul. Transportation of discharged marines to the colonies on merchant vessels in place of engagés.

21365. General correspondence, I7 I8, June-July.

Correspondence of Arnoul and Pontchartrain, respecting transportation of soldiers to the colonies, and to requirement of passports for vessels bound for America.

[ff. I8I, 338, 39 I

I7I3, June 27. "Règlement touchant le nombre de soldats que chaque vaisseau allant dans les Colonies françoises de l'Amérique sera obligé d'y porter à l'avenir à la place des Engagés."

I7I3, July 5, Versailles. Ordonnance défendant aux Propriétaires d'expédier aucun Vaisseau ... pour les Colonies... sans avoir pris auparavant de Passeports de Sa Ma'té. (Ptd. broadside.)

21366. General correspondence, I7 I3, Aug.-Oct. I 5.

Correspondence of Pontchartrain and Arnoul, relating to the following matters: transportation of discharged soldiers to the colonies (ff. 88, I44); prohibited commerce in the South Sea (ff. I30, 2I I) ; fisheries of Ile Royale (ff. 304. 394).

21367. General correspondence, I7 I3, Oct. I6-Dec.

Orders to release convicts condemned to the galleys on condition that they serve for life in the detachments of marine maintained in the Islands of America.

[ff. I 5, I 94

Correspondence of Pontchartrain and Arnoul relating to fisheries at Ile Royale, disinclination of merchants of Provence to engage in them, etc.

[ff. I IO, 222 
Form of contract or agreement for engaging in the trade with Guinea and supplying negroes to the West Indies.

21375. General correspondence, I7 6 , Oct.-Dec.

I716, Nov. 21, 22, Dec. 9. Letters relating to the transfer of Pierre Bazin, faux saunier, to the troops serving in Louisiana.

[ff. 208, 210, 287

21381. "Personnel de la marine."

I684, July I 5, Rochefort. Articles of indenture of ten engagés for service of three years in Canada. Physical description of each.
[ff. I4I-I42 I69o, Mar. I2, Quebec. Commission to Duclos as captain on half-pay (réformé). (Signed, Frontenac, with seal.)

[f. 158

1696, Rochefort. "Écrivains extraordinaires entretenus au port de Rochefort." Signed, Phélypeaux. References to clerks on vessels in Canada, Acadia, Hudson Bay, and West Indies.

[ff. I62-166

I693, I694, I697. Letters of recommendation, commission, certificates of service, etc., of Jean Martelly, lieutenant in Canada.

21386. "Approvisionnements."

[ff. I69-1 73, I79, 187, I89

1685, July 4, Rochefort. Account of rations furnished for crews of vessels (including Canadian squadron).

[ff. $29-48$

21393.- I664-I70I. A printed pamphlet, without general title, containing letters patent, arrêts, and extracts from the registers of the Conseil d'Etat, relating to the Compagnie de Guinée, Compagnie du Sénégal, Compagnie des Indes Occidentales, Compagnie de l'Assiente, etc. (42 pp.). A few of the documents (nos. 4, 5, 6, 7, 9) are printed in Moreau de St. Méry, Loix et Constitutions, I. I 14, I34, I37, I44, I47.

"Estats des pertes que la Compagnie de Guinée a faites depuis son établissement."

[1705, Dec. I.] Table of "Emprunts faits par la Compagnie roialle de Guinée et traité de l'Assiente."

[f. 48

Memoir on trading companies with especial reference to the development of the slave-trade for the benefit of the French West Indies. "[f. 49-58

Memoir: "Motifs et moyens de traiter beaucoup de Nègres." Signed, de Gallifet.

[ff. $59-62 \mathrm{v}$

Memoir: "Du Com'ce libre des Nègres à la manière des Portugais."

"Sur les Anglois et hollandois." A series of questions relating to E3-64 lish and Dutch establishments and trade in the West Indies, Central America, Mexico, the South Sea, Manila, etc.

[ff. 206-207v

Memorandum of considerations to be borne in mind in planning and organizing an expedition to the Bay of St. Esprit, for the discovery of the mouth of the Mississippi.

[ff. 209-209v

Memorandum of possible naval enterprises against England and Holland. Attack on Boston, recapture of Placentia and Acadia, etc. [ff. 266-277v

Memorandum on the next naval campaign. References to Canada and the West Indies.

[3 copies, ff. 278-290v, 292-307, 308-323

I7 3 , Mar. I8, On board the Téméraire. "Relation de la Descente de Curassol faite par l'Escadre . . . commandée par M. Cassard, le I8 février. I7I3."

Memorandum on the utility of a navy.

21395. "Consulats, Colonies, Amérique."

[ff. $35 \mathrm{I}-355 \mathrm{v}$

I67 I, Dec. 26. Representation by the merchants of Marseilles respecting the conditions of the cod fishery.

[ff. $3-3 \mathrm{v}$ 
I70o, Apr. 4, Natchez. "Extrait d'une Lettre du Sieur Lesueur qui est allé faire un establissement sur des mines de cuivre à 5 à 600 lieues dans le Mississippi." Comprises a journal commencing at La Rochelle, Oct. I6, i699, of the writer's voyage to Santo Domingo on the Gironde, to the Louisiana coast, and up the Mississippi. (Copy.)

[ff. 5-I 3

[I687.] Difficulties in providing subsistence for the soldiers in the new levy for service in Canada.

[f. I 5 Virginia.

[I690-I697.] Memoir on means of interfering with English trade with

[r690-1697.] Memoir on Acadia and New England [ff. r7-I9v CI I, D, vol. 2, ff. I93-200.

Memoir on the discovery of mines in Canada. Proposal by DuplessyFabert to discover and develop copper mines in the region of Lake Superior.

[ff. $37-38$

"Ce qu'il Conviendroit faire pour garder et augmenter la colonie françoisse au lieu apellé terreneufve, coste de Plaizance, à continuer au cap de ray jusques à l'isle St. Georges."

[ff. 39-40

[ I696. June 26-r697, Apr. I 5.] "Journal Du Voiage que Jay fait avecq Monsieur D'Hyberville Capitaine de fregatte de france en lacadie et de lacadie en lisle de Terreneuve." By Abbé Beaudouin. (Copy.) Cf. Arch. Colonies, CI I, D. vol. 3, ff. 27-40. Ptd. by A. Gosselin, Les Normands au Canada: d'Iberville, Journal de l'Expédition de d'Iberville en Acadie et à Terre Neuve par l'Abbé Beaudouin (Évreux, I900). [ff. 4I-54V

[ I690-I700 ca.] "Mémoire de La ville de Baston et autre Lieux de nouvelle Engleterre." "[ff. 59-60v in Canada.

[I685.] Note in hand of Denonville on the cost of maintenance of troops

I677-I692. "Compte de L'armadille de Barlovento." Transmitited by the viceroy of New Mexico.

[ff. 62-65v

[I702.] Various memoirs and other documents relating to Buenos Aires, the Spanish Indies, Brazil, etc.

[ff. $68-85 \mathrm{v}$

Memorandum on slave-trade with Carácas, Cartagena, Havana, Portobello, etc.

[ff. $88-89$

I687. General census of French West Indies, 36,655 souls. [ff. 9ov-9I

Memorandum on defense of West Indies. $\quad$ [ff. IO9-I Io

r697, Dec. 22, Rochefort. Memoir on the commerce of La Rochelle, by La Boulaye.

[ff. I 2 I-I 35

Memoir on the commerce of Provence with the West Indies, and request of Maurellet et Cie. of Marseilles for privilege of engaging in the slave-trade in order to sustain theit sugar refinery at Marseilles and their commerce with the West Indies.

[ff. I $37-\mathrm{I} 38 \mathrm{v}$

r69I-r693. Memoirs on Santo Domingo and Martinique, by [Gallifet].

[ff. I 4 I-I $80 \mathrm{v}$

I607. Narratives of the expedition of the Baron de Pointis and the siege of Cartagena.

I702. Sept. I9. “Relation de l'Entreprise du Vice-amiral Benbow sur les rades de Léogane."

[ff. $247-248 \mathrm{v}$

I716. Nov. I6. Règlement au sujet des Engagez et Fusils qui doivent estre porte: par les Navires Marchands aux Colonies des Isles Francoises de l'Amérique, et de la Nouvelle France (Paris, I7 I6, i I pp.). Ptd. in Moreau de St. Méry, Loix et Constitutions, II. 53I.

[ff. 255-260

Memoirs on the French West Indies, their commerce and defense, on attacks against Spanish. Dutch, and English possessions, etc.

[ff. $26 \mathrm{r}-372$ 
21396. Memoirs relating to Spain.

[I690.] "Projet de ce qui se peut faire sur les nouvelles qu'on vient d'avoir que les Galions pourroient estre arrivés en Espagne, et sur les préparatifs que les Anglois et Holandois font pour envoyer deux escadres, l'une à Canada, et l'autre à l'Amérique."

[ff. I68-I7 I

21399.-[I703.] Nov. 30-I705, Mar 27. "Nouvelles." Items of news, e.g., Jan. 3, I704, return of the Seine and the Loire from Quebec and Mobile, Indian hostilities in Louisiana; Nov. 23, I704, return of Beauharnois from Canada, etc.

[ff. I-II $3 \mathrm{~V}$

MS. map: "Plan de la Coste de La Floride depuis le Cap St. Blanc iusques aux Isles St. Diegue." Shows soundings along the coast, Spanish settlement at Pensacola, and anchorage of Iberville.

21426. Correspondence of P. Arnoul.

1687, Aug. 2, Quebec. Champigny to Massiot. Clothing for soldiers, remarkable voyage of 35 days from La Rochelle to Quebec.

[ff. 206-207

I687, Aug. I, On board the Arc-en-Ciel, in the St. Lawrence. Charritte to [Arnoul]. Sends map of sand-bar seven leagues below Quebec, which should be marked by buoys.

21427. Correspondence of P. Arnoul.

[ff. $245^{-246}$

I687, Aug. 25, 27, Montreal. Denonville to Arnoul. War with Iroquois ; action of Iberville in Hudson Bay.

[ff. I 3, I 4

I683-I687. Martinique. Letters from Dumaitz de Goimpy to Arnoul. (A. L. S.)

21429. Correspondence of P. Arnoul.

[ff. 92-105

1694-I706. Letters from Joseph Martelly and his son Jean Martelly, lieutenant in Canada, relating to promotion of the latter.

21430. Correspondence of P. Arnoul.

1683, Nov. 5, io; I685, Sept. 24; 1684, Nov. 12, Quebec. Meulles, intendant of Canada, to Arnoul. Canadian news. Arrival of the Tempête. Complaints, need of money in Canada, lumber for masts. Need of money in Canada, abundance of flour, exportation of wheat. (L. S. or A. L. S.)

[ff. $350,352,364,378$

I684, Nov. Io, Quebec. Lefebvre de La Barre, governor of Canada, to Arnoul. Complains of inter ference at Rochefort in Canadian affairs. (A. L. S.)

[f. 354

I685. Aug. I9, Quebec. Lemaire to Arnoul. Losses from sickness during the voyage of the vessels from Rochefort to Canada. (A. L. S.) [f. 356

I685, Aug. 20, Sept. I, Nov. II, I I, I I, I2, I4, Quebec. Denonville, governor of Canada, to Arnoul. Death of Rochefort during the voyage-Losses from illness during voyage, cruelty of officers to soldiers.-Corrupt practices of de Meulles.-Thanks.-Sailors sent back to France.-On behalf of brother of St. Michel.-Returns defective gun, list of things received. (A. L. S.)

$[\mathrm{ff} .360,362,368,370,372,376,386$

I685, Oct. 22, Nov. 5, Quebec. M. de St. Vallier, vicar general of Quebec, to Arnoul. Personal matters, need of masons for work on the cathedral. death of two missionaries during voyage.-Masons and other workmen for the cathedral. (L. S., A. L. S.)

[ff. 366,384 i684, Nov. II, Quebec. De Montortié to Arnoul. Arrival of vessels. (A. L. S.) I684, Nov. I3, Quebec. Du Riva diring the voyage. (A. L. S.)

[f. 374 [f. 382 I686, Nov. I 3, Quebec. Champigny to Arnoul. News of a pirate off the St. Lawrence; need of soldiers for war with Iroquois. (L. S.) [f. 388
[ 
21440. Correspondence of P. Arnoul.

I694, I695. Letters from Joseph Martelly relating to his son, Jean. (A. L. S.)

[ff. 492, 526, 529,537

I694. Nov. 23, Bayonne. [Jean] Martelly to his father. Voyage to Placentia, illness, engagement with English. (A. L. S.)

21443. General correspondence. Supplement.

$[\mathrm{f} .5 \mathrm{I} 8$

[i684, Aug. 26, La Rochelle. Arnoul to Meulles.] Despatches the Emerillon and the Entreprenant to Canada. [f. II3

Minute by Arnoul recommending [Jean] Martelly, half-pay lieutenant in Canada, for promotion.

[f. I 30

[I70o ca.] Minute of memoir on the best season of the year for the sailing of vessels to the West Indies.

[f. I 43

[1685, June I2, Rochefort. Arnoul to Meulles.] Soldiers, munitions, and merchandise destined for Canada.

[I687.] Champigny to Arnoul. War with the Iroquois.

[I684.] "Le Sr. De la Salle." A memorandum in two columns containing (I) the requirements of La Salle for his expedition to the mouth of the Mississippi-vessels, personnel, equipment, supplies, etc., and (2) decisions as to meeting the requirements. The document appears to be an earlier version of that printed in Margry, II. 378-38o. [ff. 448-449

"Ordres laissés par Monsieur l'Intendant au sieur De Mauclerc pour agir pendant son absence." Instructions respecting troops, clothing, supplies, etc., for the West Indies.
[ff. 477-480

[1685.] Summary of passengers on board the Diligente, Fourgon, and Mulet, with names of members of Denonville's family.

[ff. 534-535, revised copy at ff. 536-537

Minute of a memoir on the commerce of the West Indies and Newfoundland.

[ff. $569-572$

[I69I.] Memoir as to whether it is desirable to equip a naval force for the present year. Defense of Canada and West Indies, loss of Acadia; attack on Quebec [by Sir William Phips] of previous year. [ff. 597-602

21476-21479. Correspondence of the Americanist scholar, Eugène BobanDuvergé, I869-I899.- This correspondence, arranged in alphabetical order, contains numerous letters from American scholars, booksellers, and dealers in antiquities. The letters relate to a variety of matters, such as American Indian languages, shipments of antiquities, exploration of Mexico, Peruvian figurines, U. S. exhibit of minerals and metals at the Paris Exposition of I889, Maya civilization, etc. Among the American correspondents are noted Charles Balliard, Metropolitan Museum, E. A. Barber, Philadelphia, August Belmont, New York, Daniel G. Brinton, Philadelphia, Father Domenech, missionary in Texas, George Ellis, New Orleans, H. W. Haynes, Boston, W. H. Holmes, Washington, George F. Kunz, Robert H. Lamborn, New York, Henry Phillips, jr., Philadelphia, James C. Pilling, and others.

21510. Collection B. Fillon, Miscellany.

I780, Oct. 5-I78I, Jan. 24, Newport [R. I.]. Six letters from the Vicomte de Tressan, relating to personal affairs, expenses, return of son of Rochambeau to France, general disgust of all except those who made their fortune in America, exaggerated consideration for the population, etc.

[ff. $5 \mathrm{I}-6 \mathrm{ov}$

I668, May 8, Paris. Confirmation by the Compagnie des Indes Occidentales of the concession in Acadia to M. de Cangé by the Compagnie de la Nouvelle France.

[f. 202 
I696, Oct., Quebec. Thierry to - War with the Iroquois ; cruise of La Bouffonne.

[ff. 2 I $3-2$ I $4 \mathrm{~V}$

21516. Letters and documents relating to Santo Domingo.

I786, June 28, Marseilles. J. F. Billon to Baron de Perier. Letter from a correspondent in Boston relating to paper money.

[f. I

I 786, Feb. 23, Charlestown [Charleston]. Antoine Terrasson to Messrs. $J$. Cottin et fils. Voyage of McQueen to Paris to seek lumber contracts and to present to d'Estaing the gift of 20,000 acres made by the state of Georgia.

[ff. $63-64$

I794, I803. Letters, memoirs, and other documents relating to Louis Chenu and his family, refugees from Santo Domingo, his residence in Bristol. R. I., and in Boston, aid rendered him by Free masons, etc.

[ff. I I9-I25, 229-234v

21562-21564. Autograph MS. of Mémoires de Larevellière-Lépeaux (Paris, I 895,3 vols.).

21565-21566. Correspondence and other papers of Larevellière-Lépeaux.In 21565 are letters of C. Volney to Larevellière-Lépeaux of 24 Mess., an III, I 2 Flor., an V, Jan. I4, 23, I797 (ff. 67-74), relating to his travels in America. American and French policy, etc. In 21566 is a letter from J. A. B. Rozier, New York, 7 Niv., an VII, accompanied by a "Note . . . sur la négociation entre la France et les États-Unis" (ff. I-8), and a memorandum of reply to Monroe's address on taking leave of the Directors: "Des Points pour etre présentés à l'Amérique, dans un discours du président à l'audience de congé de M. M." (ff. 9-Io).

22028-22036. Letters, MSS., and printed documents collected by Alphonse Pinart, relating to the history of printing and of newspapers in the nineteenth and twentieth centuries.

22036. America.

I892, I893, I905, I906, I908. Letters to Pinart from editors, officials, and others, in Saskatchewan, Oklahoma, Arkansas, St. Pierre and Miquelon, Bermuda, Bahamas, Barbados, Jamaica, Antigua, St. Lucia, St. Vincent, Trinidad, Tobago, Virgin Islands, Guadeloupe, and St. Bartholomew, relating to local history of printing and of newspapers.

[passim

List of newspapers published in Louisiana.

[ff. I8-20

I857, I877, I906, I907, I908. Copies of various newspapers published in the West India islands.

22065. Letter-book of Pierre-René Guiton, procureur dı roi in Santo Domingo, I $742-1756$.

22072. Papers and correspondence of Léon Angrand, relating to Mexico and Central America, I86I-I863.

I86I. Newspaper clippings relating to cultivation of cotton in Central America, Panama, Cuba, and the United States.

[ff. $24-28$

I86I-I862. Extracts of letters from Mexico, and notes on that country. German colonization in Mexico and the United States; European project for a Mexican monarchy; English activities in Central America directed against the United States; sentiment in favor of annexation of Mexico to the United States.

[ff. 29-I I $4 \mathrm{~V}$

I863. Notes on Mexico. French expedition, monarchists, activities of Slidell, Soulé, Benjamin, and others.

Notes on ancient and modern systems of colonization.

Letters to Angrand on Mexican affairs, the French expedition, etc.

[ff. I I 7 -I 40

[ff. I $42-\mathrm{I} 45_{\mathrm{V}}$

[ff. $147-196 \mathrm{v}$ 
Papers relating to Venezuela and plans of annexation to France.

[ff. 2I7-234v

22075. Biographical and bibliographical notes collected by A. A. Barbier.

Notes on Joel Barlow, Jacques Cartier, Lafitte of Barataria, John Law, Latouche Tréville, and La Luzerne.

Lists of works on history of America, works of Las Casas, etc.

[ff. I $27 \mathrm{v}, 3$ I I

22084-22088. Papers of Louis Narcisse Baudry des Lozières. Cf. above, 11261-11262.

22084. - Memoir, including an account of the misfortunes of the Milhet family in Louisiana. (Mlle. Milhet married Baudry des Lozières.) [ff. 47-52 5795 [I795], 9th day, 4th month, Philadelphia. Certificate delivered to Baudry des Lozières by the French Freemasons of Santo Domingo, refugees in Philadelphia.

22085.-I778. Essay by Baudry des Lozières on the island of Tahiti [f. 392 inhabitants.

"Conversation coloniale." Opposition to slavery.

Essay on sugar-making in France and the colonies.

I782-I 786. List of arrêts, edicts, déclarations, and ordinances. $57-\mathrm{fo} 2$ to the colonies.

[ff. IO3-IO7

I7II, Jan. I, Quebec. Commission of Baron de St. Castin as lieutenant, accorded by Marquis de Vaudreuil.

[ff. I I8-I I9

An VIII, Fruct. "Aperçus sur le nouveau système de politique et de colonisation qui convient au peuple français comme peuple modérateur." By Leyritz. Includes a chapter on the United States and on the means of arresting its prodigious growth of power.

[ff. I $20-126 \mathrm{v}$

An III, Frim. 5, I5, Philadelphia. Two memoirs by Donatien Rochambeau: "Sur les rapports à venir des Etats-Unis . . . avec la France." "Sur la situation de l'agriculture et du commerce des Etats Unis . . . sur celle de ses manufactures, et sur le degré de perfection qu’elles peuvent acquérir."

[ff. I $52-187 \mathrm{v}$

An IX, Fruct. I3. "Considérations sur les stipulations à insérer dans le traité de paix entre la France et l'Angleterre." Advice respecting Louisiana.

I785. "Dissertation ś les suites de la découverte de l'Amérique."

[ff. $274-28 \mathrm{I}$

[ff. $294-362 \mathrm{v}$

22086. - I784-I786. Prospectus, list of members, etc., of the Cercle des Philadelphes at Cap Français, Santo Domingo. [ff. I34-I 37
[

I 804, Nov. I, St. Augustine, Fla. Vermonnet to minister of marine. His services as engineer under Washington; asks for position of commissioner of commercial relations [i.e., consul] in the United States.

[ff. 229-232v

[I790-I805 ca.] Miscellaneous documents, notes, letters, etc., relating to Santo Domingo, Martinique, and Guadeloupe, regiments in the West Indies, service of Baudry des Lozières, etc. [ff. I 42-228, 240-248, 264-467

22088. - Study by Baudry des Lozières of language and customs of American Indians.

[ff. I $46-\mathrm{I} 47$

22101. Papers of M. d'Hermand, French consul at Lisbon, Madrid, and elsewhere, I763, I777-I 798 .

I 796. Letters to d'Hermand, from Philippe Rose Roume, agent of the French Republic to Santo Domingo.

[ff. I $54,184,185,205,233,234,256,263,266,267$ 
I763. Memoir on trade in Newfoundland codfish carried on at Alicante. [f. 28I

I797, Apr. 6, Lisbon. Edward Church to d'Hermand. Capture by a Spanish privateer of a vessel belonging to him.

[f. 294

I797, Sept. 9. Bourgoing to d'Hermand. Re-establishment of the Spanish colonial system.

22129. - I708, Dec., The Bastille. Koch to the Comte de Waldstein. Exchange of the Bishop of Quebec and of the Marquis de Lévy, captured at sea by the English.

[f. 664

22134. Papers of Victor Schoelcher, I870-1885.-Notes, memoirs, letters, etc., relating to slavery and its abolition, racial prejudice, the West Indies, insurrection in St. Pierre, Martinique, of 1848 , etc.

22135. Papers of Victor Schoelcher.

Notes, extracts from newspapers, and other documents, relating to abolition riots in Philadelphia, sales of negroes in the United States, etc. [ff. 58,76

"Intelligent Negroes." Copy of a MS. in English relating to negroes in the United States at end of eighteenth century.

[f. I 32

22144. Funeral orations and sermons.

[1698, Quebec.] Le Roy de La Potherie to Comte de Maurepas, on the death of Frontenac, with funeral oration by Father Olivier Goyer. [f. 269

22186. Miscellany relating to geography and voyages.

List of MSS. of d'Anville. [f. I I

Catalogue of maps engraved from the drawings of d'Anville. [f. 45

Notes on the United States. [ff. 403-4I4

Note on steam navigation in the United States. [f. 4I 5

Note on the galleons going to Portobello. [f. 4I9

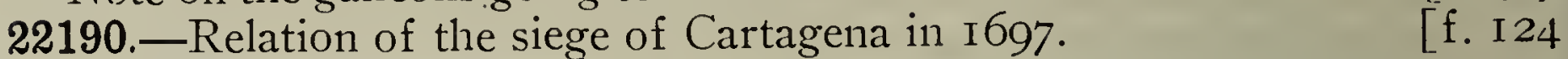

Memoir on the negotiations of Ryswick, I697. References to secret treaties concluded by England relating to America. [f. I35

22192. - I7 55-I759, Sept. "Almanack de la Guerre, qui contient un tableau général de la Guerre depuis les premières hostilités des Anglois jusqu'à présent." Much respecting the war in America. [ff. I67-200

22194.-Memoirs and other documents presented to the Conseil des Prises, relating to captured American vessels, I807-1810. [ff. I67, I75, I88, I95, 201

22213.-[Post I6Io.] Geographical description of parts of America: New Spain, Virginia, Florida, Cuba, Jamaica, etc.

[f. 98

22220.- [ I762.] Lists of Canadian officials tried and convicted, and their sentences.

[ff. $217-220$

22222.-Notes by Abbé Barthélemy: "Objets à traiter dans la nouvelle édition de mon ouvrage sur les anciennes colonies ou dans celui que je me propose de faire sur les colonies modernes." Mention of various American subjects.

22245. Finances.

I7I8-I722. Memoirs and other documents relating to the Compagnie des Indes and to the bank of John Law : quotations of stock of the company, I7 I8I72I; list of persons who have enriched themselves by speculating in the stock of the company, including Leblanc, Chaumont, Ducher, Kolly, and others who held concessions in Louisiana, etc.

[ff. $289-342$

I756-I762. "Etat actuel des affaires générales concernant les finances' du Royaume. . avec les affaires extraordinaires faites en France depuis et compris l'an I756 jusqu' à la fin de l'année I 762 au sujet de la guerre." [f. 392

I 786. "Aperçu de l'administration des finances de la France." Includes a census of the colonies and a table of their commerce. [f. 4I6 
22253.- I664-I668. List of letters patent, commissions, orders, etc., relating to colonies and companies of commerce.

I677, Feb. 28, La Rochelle. Inventof [ff. 7-7v for Newfoundland.

I730, Aug. Io "Plaintes de la Francesures les Anglais aux Colonies

I740, Apr. 21. Report on minerals in Canada [f. I34

"Précis pour M. de Vaudreuil, ancien gouverneur général du [f. 142

I 7 48-I762. Letters and other documents relating to commercial opera-
[forats tions of Bigot, Gradis, Bréard ${ }_{1}$ and others in Canada. [ff. I55-168bis
[ 5 -

[I763.] "Conditions générales de la paix." [f. 236
[for. trade.

Note on the various types of Spanish vessels engaged in the American

[Post I763.] Notes on colonial products, commerce of Canad, [f. 257 Indians, commerce of England, tobacc

22268. Documents relating to the marine
[ff. $37 \mathrm{I}-373$

7740. Letters, extracts from London newspapers, etc., relating to expedition of Adm. Vernon, bombardment of Cartagena, capture of Chagres, capture of St. Augustine by Oglethorpe, etc.

Letter relating to voyages west of New Orleans and the [ff. I25-I67

22288. Miscellany relating to history of England.
[f. $32 \mathrm{I}$

[Post I663.] "Raisons très puissantes pour prouver que le Roi d'Angleterre doit éviter de rompre avec la France." Possibility of English expansion in America; English war against Spain. [f. I66 I 709-I7I2. Register of accounts and correspondence in English, apparently forming a part of the records of an English commercial house trading with America; a section is entitled "Maryland letters". [f. I84 Some Remarks on a Pamphlet intitled, "Popular Prejudices against the Convention and Treaty with Spain", in a Letter to a Member of Parliament \begin{tabular}{l} 
(London, I739). Deals with colonies, prizes, etc. [f. 234 \\
\hline
\end{tabular} 1740. Manifesto dealing with hostilities of English against the Spaniards in America before the declaration of war; English preparations against the French colonies; pacific attitude of France; plan of English to capture commerce with the New World.

22289. News from England in letters from London to M. Leffilles " Bureau d'adresse aux galéries du Louvre à Paris ", I 742-I743.-Among subjects treated are the following: war between Spain and England; capture or loss of numerous vessels from the English colonies in America; Spanish prizes taken into ports of English colonies; Spanish invasion of Georgia ; reinforcements sent to Georgia; movements of squadrons in American waters; bills in Parliament relating to the colonies; 60o Palatines at Philadelphia; Spanish operations against the Indians at St. Augustine; departures of officials for the American colonies; despatch of criminals to the American plantations ; French preparations for war in Canada.

22335.-I68I-I698. "Mémoire instructif de tout ce qui s'est passé au Pérou depuis dix ans ...."

1830. Table of exports of Peru.
22367. Papers relating to Pantaléon Ogé and his family, of Santo [f. 4655 I722-I79I. 
22734-22741. Collection of autographs, drawings, and portraits, formed by Alexandre Bixio. A detailed inventory by $\mathrm{L}$. Dorez of this collection is published in the Bulletin d'Histoire du Comité des Travanx Historiques, I9I6, pp. $276-423$.

22735.-J. Fenimore Cooper to A. Bixio. (A. L. S.) [f. 198

22736.-Engraved portrait of Benjamin Franklin: "Né à Boston dans la nouvelle Angleterre le I 7 Janvier I706. Dessiné par C. N. Cochin .... en I777, et Gravé par Aug. de St. Aubin, Graveur de la Bibliothèque du Roi."

[f. 246

22737.- [ $1859 \mathrm{ca}$.$] A. de Humboldt to [A. Bixio]. Relating to the publi-$ cation of his works.

f. 187

Portrait of Alexander Humboldt. Engraved by S. A. Schoff. [f. I89

Portrait: "John Paul Jones, Commodore au service des Etats-Unis de l'Amérique. Dessiné par C. J. Notté. Gravé par Carl Guttenberg." [f. 214

I800-I838. Three letters of Joseph Bonaparte, with unsigned engraved portrait of him.

[ff. $220-224$

22738. - I779, Feb. I9, Paris. Lafayette to Louis XVI. Sets forth the reasons which decided him to espouse the American cause, and excuses his disobedience. The arrival of the king's fleet in America persuaded him that his duty was to remain there. (A. L. S.)

[f. 6

Two engraved portraits of Lafayette, not signed; one represents him in a costume of the period of Louis XVI., the other in a costume of the Restoration.

[ff. 8, 9

22741.-Two engraved portraits, sixteenth century, of Americus Vespucius.

Engraved portrait: "Geo. Washington Esqr. Late President of the United States of America. From an original picture in the possession of $I$. Sebn. De Franca Esqr. of Devonshire Place, to whom this Plate is dedicated by his obliged humble servt. Robt. Cribb. C. G. Stuart pinxt." London I798.

[f. 307

22755.- [ [ I700 ca.] “Mémoire sur le voyage depuis Nantes jusqu'à Dunquerque." Trade of Nantes with the West Indies; cod fishery. [f.66

I760, Aug. 27, Gerinsdor[r]f, near Breslau. King of Prussia to M. d'Argens. France will lose Canada and Pondicherry to please the Queen of Hungary and the Czarina; contempt for Choiseul.

[f. 2 I9

22757. "Histoire de l'Europe, contenant ce qui s'est passé de plus considérable, tant sur mer que sur terre, depuis la paix de Riswick jusqu'à présent." I697-I708.--References to American affairs : return of Coëtlogon and Châteaurenault from the West Indies in I7O2; surrender of St. Christopher to the English; voyage of Ducasse to Havana; capture of the Bishop of Quebec by the English; raid on Nevis by Iberville.

22762.- " Mémoire sur les avantages que le pacte de famille peut donner à la France et à l'Espagne pour le rétablissement de la Marine et du commerce maritime." By M. de Peysonnel.

"Mémoire sur le commerce de Cadix et les marchandises qu'on peut y envoyer."

[f. 42

I7I7, Sept. 20. "Mémoire sur le commerce en général et surtout sur celui qui a rapport à St. Domingue." Proposal to permit the sale of syrups to New England; trade between Canada and the West Indies.

$[\mathrm{f} .50$

I769, Mar. Io, Versailles. "Mémoire donné par M. d’Estaing dans le mois de Mars I 769 à l'instant qu'on apprit en France que les Français de la 
Louisiane avaient chassé les Espagnols." Example of New Orleans should aid the separation of North America from England.

I764. Documents relating to Martinique and St. Lucia.

[ff. $75-77 \mathrm{v}$

[ff. 78, I00, III, I 47

I763, Dec. 3, Martinique. Observations respecting commerce of the West Indies with New England, etc.

[f. I05 I764. "Essai sur la colonie de Ste. Lucie." Trade with English, salt beef and flour from Philadelphia, etc.

[f. II 7

I679, June, St. Germain-en-Laye. Edict confirming the regulations of the Conseil Souverain of Quebec of Nov. 7, I678, with some modifications. [f. I52

"Notice du plan que présentent les éclaircissemens déjà réunis sur la situation des pêches maritimes ..." By Lemoyne. References to Newfoundland fishery.

"Traité de la nicotine ou du tabac en poudre et en fumée."

22778. - "Histoire de Beaumarchais." Satirical verses.

[f. I 54

[f. I58

I790. Feb. 27-May II "Récit sommaire et véridique de ce qui. $5^{8}$ ti. "Récit sommaire et véridique de ce qui s'est passé dans la partie du nord de l'isle St. Domingue ..." [f. I82

22816-22819. Collection of autograph letters formed by Prosper Valton.

22816. - I826, Dec. 26, Paris. J. Fenimore Cooper to the prefect of the Seine. Letter of thanks. (A. L. S.)

22817. - I 768, Sept. 21, London. B. Franklin to M. Le Roy. Has introduced Abbé Taglieri to Sir John Pringle; recommends M. l'Espinasse, and. sends the "Pennsylvania Farmer's Letters", which have had a "prodigious effect" in the colonies. (A. L. S.) [f. 90

22818.-I791, I823, I824. Autographs of Lafayette, not relating to America.

[ff. $4,5,6$

N. d. Autograph note of Lafayette stating that he is installed with his family and his American friends.

[f. 8

I807, Aug. I3, Sept. I8, New York. Gen. V. Moreau to St. Paui, advocate in Paris. Prospect of war between United States and England; purchase of United States bonds; visit of Le Ray de Chaumont.

[ff. I78, I80

22820. Documents relating to Isaac Le Maire and Charles de L'Aubespine and the northeast passage, I609.-Cf. Charles de La Roncière, in Bibl. de l'École des Chartes, LXXVIII. I 54, I78.

22937. "Lettres et discours moraulx du sieur de Fourquevaux, ambassadeur en Espagne pour le Roy très Chrétien", I 566-1570.

I 569, Mar. 6, Madrid. Cardinal de Guise to King of France. Seven English vessels bound for the Indies have been sunk by the Spaniards. [ff. I Iv-I4

23021. Papers of Du Portal, director general of fortifications in Santo Domingo, I72I-1767.-Correspondence of Du Portal, Choiseul, d'Estaing, Frézier, Reynaud, Bongars, and others, relating to fortifications; engraved maps and plans of towns, harbors, forts, etc., and memoirs relating to the fortifications of Martinique.

I723, Mar. 27, Petit Goave. "Relation du soulèvement de la colonie française de l'isle St. Domingue pour expulser la Compagnie des Indes . . . " By Frézier.

[f. 105

I 763, Oct. "Réflexions sur les moyens de deffendre les colonies de l'Amérique et principalement celle de St. Domingue." Sent by M. de Fontanelle.

[f. I4I 
I764. " Mémoire sur le commerce de la colonie françoise de St. Domingue." By Foache. Foreign trade; purchase of vessels in the English colonies.

[f. 199

23022. Papers of Du Portal, I768-I770.--Correspondence, drawings, etc., relating to fortifications of Santo Domingo. Georgia.

[I768.] Notes on the commerce of Môle St. Nicolas; vessels from

Bill for masts.

[f. 265

Ther. 3 I, Môle St. Nicolas. "Etat des differentes denrê. portées et importées tant par les Français que par les Anglais."

[f. 272 [f. 290 I769, June 20, Môle St. Nicolas. D’Anctéville to Du Portal. Introduction by the English of light-weight money made at Boston and in Rhode Island. [p. 347

23043-23044 (I volume). Album of maps and plans of Santo Domingo. Papers of Du Portal. 


\section{COLLECTION BALCZE.}

The Collection Baluze, composed of copies of historical documents, original documents, and correspondence, was formed by the historian, Etienne Baluze ( $1630-17$ I8), who was for over thirty years, I667-I700, the librarian of the Colbert Library. An account of the composition and history of the collection will be found in the introduction of the very detailed catalogue that has been published by Lucien Auvray and René Poupardin, Catalogue des Manuscrits de la Collection Baluze (Paris, I92I). See also L. Delisle, Cabinet des Manuscrits, I. 364-367.

149. Seized papers of Nicolas Fouquet, superintendent of finance.

I660. "Pour Monseigneur le Surintendant des Finances. Responses aux prétendus moyens d'opposition à la concession que Sa Majesté à faite au Sr. Gargot et du gouvernement qu'elle luy a donné de l'isle de Terre Neufve en l'Amérique." Includes a list of concessions in America since I 562.

[ff. 5-IOV

I66o. "Commission du Roi à Nicolas Gargot, Comte de Plaisance, pour passer à Terre Neuve et y établir des habitations ..." [ff. I I-I2v I660, Dec. 2I, Paris. Nicolas de Gargot to [Fouquet]. Asks if he should see Colbert; conversation with d'Estrades about Acadia; asks to be paid balance of his pension. (Autograph.)

150. Papers of Fouquet.

I66I, Aug. 29. [Lacave, agent of Fouquet,] to Fouquet. Arrival at Bilbao of a cargo of dried fish from Newfoundland. [ff. 9-Iov
[ Memoir by [Lacave] on the vessels employed in the New foundland fishery and on the commerce in fish at Bordeaux. (Incomplete.) [f. I3 I66I, Apr. 7. - to Fouquet. Great number of persons desire to purchase islands, especially Martifique. Ptd. in Chéruel, Mémoire sur la Vie . . . de Nicolas Fouquet, II. 3I 5-3I6.

[ff. 6o-6I I66I, Sept. 3. - to Fouquet. Health of Cabar [sic], preparations for expedition, financial assistance to be lent him by Fouquet. (Same hand as f. 60.$)$

196.- - 667 , May I3/23, Madrid. Copy of treaty between England and Spain. Ptd. in Dumont, Corps Diplomatique, VII., pt. I., p. 27 . [ff. I9-36v I662, Sept. 4/I4, Whitehall. Copy of treaty between England and Holland. (Latin.) Ptd. id., VI., part II., p. 422.

"Descriptions de l'estat de la place de la Havana." Note in hand of Colbert: "Bibliothèque à garder soigneusement."

[ff. $5 \mathrm{O}-5 \mathrm{IV}$

I665, Dec. I3, Quebec. "Articles de paix demandés par six Ambassadeurs Iroquois . . . Et accordez ... par Messire Alexandre de Prouville, chevalier seigneur de Tracey ..." (Original, with signatures.) [ff. 72-77v I666, May 25, Quebec. Ratification of treaty with Iroquois of Dec. I3, I665, and request of Iroquois for French families and Jesuit missionaries.

I666, July I2, Quebec. Treaty of peace with Iroquois.

[ff. $78-79$

[ff. $80-82$

216. Papers of Mazarin and Colbert.

"Mémoire sur les offres faictes de la part des Espagnols pour composer une compagnie de commerce pour les Indes avec divers princes d'Allemagne." Spanish possessions in America and the Philippines; it is the place of France 
to propose to the German princes that they enter the Compagnie des Indes Occidentales; situation of the company, colonies which it might establish on the main land or in the West Indies. (In hand of Colbert.) [ff. I77-I 78 I653, Oct. 30, Paris. Memoir by Colbert for Mazarin. Next voyage of M. de Baas. [ff. 308-3I I 296.-1695. Memoir on Provence. Reference to trade with the West Indies.

Relation of the capture of the island of St. Catherine by the English. [ff. $2-60 \mathrm{v}$

354. Correspondence of Baluze.

[ff. IO7-IIIV

I690. [Jacques Joseph] de Gourgues, bishop of Bazas, to Baluze, with a memoir on the family of Capt. de Gourgues, "conquerant de la Floride".

[ff. $58-6$ I 


\section{COLLECTION CLAIRAMBAULT.}

The important group of manuscripts which bears the name of Clairambault is what remains of a much larger collection formed by Pierre Clairambault (I65I-I740), genealogist of the Ordres $d u$ Roi from I698 to his death. Clairambault spent his life largely in collecting material of all sorts relating to the history of France, the French nobility, etc. Under Colbert, Seignelay, Pontchartrain, and Maurepas he held positions which afforded him ample opportunity for securing valuable historical documents, including many relating to the marine, the colonies, voyages, explorations, etc. He was also employed in classifying the vast collection of Gaignières, from which his own collection profited to no small extent, as it also did, particularly in the matter of documents relating to America, from his administration of the estate of Abbé Bernou. After his appointment as genealogist in 1698 he formed an enormous collection of documents relating to the history of the order of Saint Esprit and of the families of those belonging to it. When he died in 1740 , his papers passed to his nephew, Nicholas-Pascal Clairambault ( $1678-1762$ ), who succeeded to the post of genealogist, but who added little to the collection, which he sold in I755 to the order of Saint Esprit. In I792 the collection passed into the hands of the government for deposit in the Bibliothèque Nationale, but it suffered a reduction of more than one half through the destruction, under the decree of May I2, I792, of all the genealogical documents, titles of nobility, etc.

In its present state the collection numbers 1350 volumes, which are inventoried, with carefully made summaries of their typical or more important contents, by M. Ph. Lauer, in his excellent Catalogue des Manuscrits de la Collection Clairambault ( 2 vols . Paris I923, I924). A third volume of the Catalogue (in MS., I930) contains an introduction with a history of the collection, and indexes. A brief account of the collection is given by L. Delisle in his Cabinet des Manuscrits de la Bibliothèque Nationale (Paris, I874), II. I8-25.

[In addition to the volumes of this collection reported on below, the following have been examined and found to contain nothing of sufficient interest for the purposes of this Guide to warrant their inclusion: vols. 296, 297, 376, $522,527,705,720,806,850,861,862,885,938,1027$.

284.-I7I2, Aug. I9. Traité de Suspension d'Armes entre la France et l'Angleterre (Paris, François Fournier, I7 I2, I4 pp., 4to). Includes proclamation of the treaty, Fontainebleau, Aug. $2 \mathrm{I}$; additional article, Fontainebleau, Aug. 24: continuation of the suspension of hostilities, Versailles, Dec. I4, London, Nov. 26/Dec. 7 ; proclamation of the suspension of hostilities, Versailles, Dec. I 5. Cf. Dumont, Corps Diplomatique, VIII., pt. I., p. 308.

[ff. 44-50

I7I2, Mar. 5. Demandes faites à Utrecht de la part des Puissances Alliées (Utrecht, I7 I 2, 42 pp., 4to). Includes demands of Great Britain respecting Newfoundland, Acadia, Hudson Bay, Canada, West Indies, etc. Cf. Actes, Mémoires . . concernant la Paix d'Utrecht, I. I56.

[ff. 54-75

Articles de Paix proposez à Utrecht par les Plénipotentiaires de France (4 pp.). In I 7 articles, including provisions respecting America. [ff. $76-77$ I7I3, July I I. "Mémoire sur les pays cédez aux Anglois dans le Canada." Cession of Acadia, Newfoundland fisheries, ambiguity of Treaty of 
Utrecht as to Sable Island, etc. $C f$. a memoir of Jan. I9 in the same hand [Bernou?] in MSS. Clairambault 286, f. I04. [ff. 90-9I

285.-I702, July 3. Ordonnance du Roy, portant Déclaration de Guerre contre l'Empereur, l'Angleterre, les États Généraux des Provinces Unies, et leurs Alliez (Paris, I702, 4to).

[ff. I-2v

Memoirs in Spanish relating to the "Comte de Peñalossa mort en I687 à Paris". Spanish possessions in America, revenue from the West Indies, history of Havana, etc. C f. a different document in Margry, III. 39, and below, MSS. Clairambault 286, f. I I .

[ff. $79-87 \mathrm{v}$

I693. Letters from the King of Spain and the viceroy of New Spain to the président of Santo Domingo, and from the latter to the governor of Jamaica, respecting joint action proposed to be taken by Spain and England for the expulsion of the French from the island of Santo Domingo. [ff. 97-I I6

286.-I7I3, Jan. I9. "Mémoire sur les pays de l’Amérique que la France doit céder aux Anglois par la paix prochaine." St. Christopher, Hudson Bay, Acadia, Newfoundland. In the same hand [Bernou?] as the document noted above, MSS. Clairambault 284, f. 90.

[ff. IO4-IO5

[I7I3.] Incomplete memoir, in same hand as preceding document, and on the same subject, but of slightly later date.

Outline of a memoir on Martinique [?] by Bernou [?]. [ff. I06- I06v

"Mémoire touchant le comte de Pegnalossa", I626-I669. Services in Havana and New Mexico, war against the Apaches, and his difficulties with the Inquisition. Cf. Margry, III. 39 .

[ff. I I I-I I I v

[1683?] "Fr. Louis Hen[ne]pin, pauvre esclave des barbares", to Abbé Renaudot. Recalls that Renaudot was first to be informed of his discovery ; complains of conduct of Abbé Bernou towards him. [ff. 244-244v

298.- I739. Carte Réduite de l'Océan Méridional compris entre l'Afrique et l'Amérique Méridionale . . . dressée au Dépôt des Cartes, Plans, et Journaux de la Marine. Engraved map accompanied by Observations sur la Construction de la Carte de l'Océan Méridional (Paris, I739, i 8 pp., 4to).

[pp. 453-472

299.-I738, Nov. I7. Clairambault, contrôleur de la Marine at Brest, to Wreck of the squadron of the Comte d'Estrées on its voyage to the West Indies.

[p. 3

I74I. Roll of troops embarked for the [English] expedition against Cartagena.

I74I, Feb. I5, Apr. 26, Brest. Clairambault, contrôleur, to his brother, Pierre Clairambault. Losses caused by sickness (the plague) in the squadron of the Marquis d'Antin, returned from the West Indies; death of d'Antin.

[pp. 655, 68I

I74I. Report of the naval action of Jan. I8-I9, off Cape Tiburon, Santo Domingo, between French and English vessels.

I740, Sept. 26, Fort Royal, Martinique. Nogarée de La Fillière to Clairambault. Account of his voyage.

[p. 685

I740, Nor I6, Fort St. Louis, Santo Domingo. D’Achéry de Serquigny to his brother. Combat with a vessel of the squadron of Adm. Vernon ; arrival of the squadron from Provence.

[p. 689

300.-Affair of Mme. de Sougé, of Santo Domingo; petition and memoir.

[pp. I99, 201

I735, June 4, Rochefort. Desgouttes to Maurepas. Passage of La Brosse for Louisiana.

[p. 373 
I736-1738. Lists of members attending meetings of the superior councils of Santo Domingo (1736, Sept. I5, July I8) and of Martinique ( I738, May 28).

$[$ pp. $445,629,587$

I739, Apr. I, Poitiers. Le Nain to _— Respecting the will of Duclos, intendant of Santo Domingo, former ordonnateur of Louisiana. [p. 699

I739, Apr. I2, May 24, July 27, Martinique. Lists of passengers on the Argonaute, the Gironde, and the Fée.

[pp. 701, 703, 727

I739. Sept. The widow Le Maire to Maurepas, asking for news of her grandson, de Marigny, in Louisiana.

[p. 729

I739, Sept. 24. Marquise de Rochechouart Du Bellay to Maurepas, with a memoir of the services of the Comte de Rochechouart, captain of a marine company in Martinique.

[p. 73I

I739. Request of the Sieur de La Plaigne for a company. in Santo Do-

mingo, with recommendation and certificate.
379.-1 - 628 , I657. Edict du Roy, pour l'Establissement de la Compagnie de la Nouvelle France, avec l'Arrest de Vérification de la Cour de Parlement de Paris (Paris, Sébastien Cramoisy, 1657, I6 pp., 4to). Cf. Isambert, Anciennes Lois Françaises, XVI. 216.

[f. 434

381.-I632, Nov. I5. Du lundy quinziesme novembre I632, au Bureau de la Compagnie de la Nouvelle France (4 pp., fo.). Proceedings of the Compagnie de la Nouvelle France (Cent Associés), organizing a private company to carry on the fur-trade in the Gulf of Saint Lawrence for five years ; indemnity for de Caen. C $f$. Salone, Colonisation de la Nouvelle France, p. 5I.

\begin{tabular}{l} 
[ff. IOI-IO2V \\
\hline
\end{tabular} 385.-I642, Mar., Narbonne. Privilèges concédés à Messieurs de la Compagnie des Isles de l'Amérique (4to).

[ff. 6o-65

Draft of an arrêt of the Council of State in behalf of the associates of the Compagnie des Isles de l'Amérique.

[f. 66

442.-1656, Dec. 28. Ordonnance du Parlement d'Angleterre, pour l'Encouragement du Commerce et de la Navigation (Paris I657). [pp. 383-385

I628, May. Edict. . . Same as above, MSS. Clairambault 379, f. 434.

[pp. 477-491

443.-i66r, Aug. I6, Fontainebleau. Arrest sur les Colonies et Concessions de l'Amérique. For the reporting of land grants in the colonies, and the formation of new colonies. (Broadside.).

I66I, Apr. IO [sic]. Arrest du Conseil d'Estat, pour le Restablissen. 31 Combr, Apr. Io [sic]. Arrest du Conseil d'Estat, pour le Restablissement du. Commerce tant au dedans qu'au dehors du Royaume (Paris, I66r, 7 pp., 4to).

[Pp. $77 \mathrm{I}-777$

444.-I664, Aug. 27. Vincennes. Déclarations du Roy, l'une Portant Établissement d'une Compagnie pour le Commerce des Indes Orientales, l'autre en faveur des Officiers de son Conseil et Cours Souveraines intéressées en ladite Compagnie, et en celle des Indes Occidentales (Paris, I664, 37 pp., 4to).

[ff. $434-45^{2}$

I664, Dec. 5. Arrest du Conseil de Commerce, donné en faveur des Marchands et de tous autres qui feront cy-après bastir des Vaisseaux, ou trafiqueront sur Mer (Paris, I664, 8 pp., fo.).

Iff. $453-456 \mathrm{v}$

445.- - 665, Jan. 24, Paris. Arrest du Conscil d'État sur la Police des Ports (5 pp., 4to).

[ff. I-3

I666, Jan. 26, St. Germain-en-Laye. Declaration of war against England.

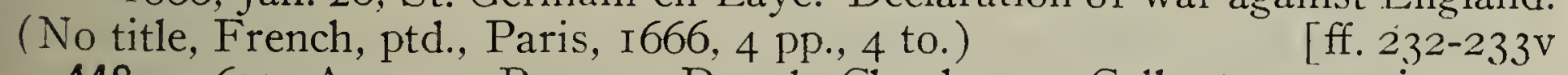

448.- I677, Aug. 23, Rennes. Duc de Chaulnes to Colbert, respecting captures of Dutch vessels made by vessels of St. Malo returning from the fisheries.

[ff. I $59-160 \mathrm{v}$ 
I678, Aug. Io. Traittez de Paix, et de Commerce, Navigation, et Marine. entre la France et les États Généraux des Provinces Unies des Pays-Bas, conclus à Nimègue (Paris, I678, 48 pp, 4to). [ff. 209-233v

I682, Nov. 8, Quebec. Lefebvre de La Barre, governor of Canada, to Clairambault. Imminence of war with the Iroquois; recommends d'Hombourg for command of vessel bringing reinforcements; claim of La Salle to have discovered the mouth of the Mississippi. (A. L. S.) Cf. Margry, II. 302, 303.

[ff. 3I 5-3 I6v

I684, Apr. Io. Arrêt of the Council of State, forbidding the inhabitants of Canada to assume the title of écuyer unless they are véritablement gentilshommes.

[f. 369

I685, Jan., Versailles. Déclaration du Roy: pour. . la Compagnie de Guinée, qui fera seule. . . le Commerce des Nègres, de la Poudre d'Or et de toutes autres Marchandises qu'elle pourra traiter ès Costes d'Afrique ... (Paris, r685, 7 pp., 4to).

[ff. 408-4I I

452.-1703, Apr. 28, May 26, Madrid. Abbé Legrand to Clairambault, respecting manuscript maps of America which have been shown to him, on which are marked the routes for the Philippines; affairs of California; voyage of a vessel from St. Malo to the Pacific; a manuscript relating to South America.

Extrait des Registres du Conseil d'État Privé du Roy (I 5 pp., fo.). Respecting suit brought against Jean Baptiste Nolin by Guillaume Delisle for plagiarism of the latter's maps.

[ff. $276-283$

Methods of assaying gold and silver ore in America employed by Du Clos and Borelli.

[ff. $54 \mathrm{I}-55^{2}$

484.-Journal du Siège de Carthagène en Amérique. Imprimé à Madrid dans le mois d'Août I'74I, par l'Ordre du Roy d'Espagne, et traduit de l'Espagnol en François par celui de son Excellence Monseigneur le Prince de CampoFlorido ... (Paris, I74I, I6 pp., 4to).

[ff. I78-I $85 \mathrm{v}$

492.-Extrait des principales Curiositez du Cabinet de feu Monsieur Begon, Intendant de la Rochelle et de la Marinè à Rochefort (4 pp., 4to). Various objects of American origin listed.

[f. 182

I725. Départemens de Messieurs les Secrétaires d'État (Paris, I725. broadside). Distribution of functions.

[f. $256 \mathrm{v}$

I725. Départemens pour Messieurs les Intendans du Commerce (Paris, I725, broadside). Attribution to Maurepas of affairs of America, and cod and whale fisheries.

[f. $258 \mathrm{v}$

I725. Commissions Extraordinaires du Conseil (Paris, I725, broadside). Attribution to the $14^{e}$ Bureau of disputes and cases arising out of concessions in Louisiana granted by the Compagnie des Indes.

[f. $262 \mathrm{~V}$

I722. Commissions Extraordinaires du Conseil (Paris, I722, broadside). Attribution to the $I 3^{e}$ Bureau of affairs relating to the Compagnie des Indes and concessions in Louisiana.

[f. $268 \mathrm{v}$

I722. Conseils de Régence, de Marine, et de Commerce, établis en Exécution de la Déclaration du Roy du I5 Septembre I7I5 (Paris, I722, broadside).

[f. $276 \mathrm{v}$

495.-Bulla de la Santa Cruzada concedida por la Santidad de Paulo Quinto de felice Recordacion, para todos los fieles Christianos, Vecinos, estantes, y habitãtes, en las Provincias del Peru, Terra-firme, y sus Partidos del de Lumana, sujetas al Rey nuestro Señor, con grandes Indulgencias para socorro de la Guerra contra Infieles que se ha de publicar, en acabandose la primera Predicacion, de la decima Concession. (Broadside, 2 copies.)

[p. Ig6 
Memoir on plan of campaign for the vessels which are being equipped in the ports of the Ponant [Western] division.

[p. 397

Memoir on means by which France can share in the slave-trade to the Spanish colonies, and the advantages of such participation.

[p. 429

Memoir on the "Partages de la Succession d'Espagne", including American possessions.

[p. 434

Memoir on the necessity of preserving the Spanish monarchy during the life of the king, and, upon his death, of asserting the rights of the dauphin therein. Especial reference to preventing American possessions of Spain from falling into the hands of the English.

"Projet pour la Louisiane." Memoir respecting proposal of Iberville to discover the mouth of the Mississippi, and to establish forts and a colony there.

[pp. 485-492

Extracts from various letters written by Spaniards in the American Indies, respecting the conduct of the Marquis de Castel dos Rios in the government of Peru.

Petitions of Léonard Chauney respecting the Straits of Magellan [P. 493 I671, Feb. I2, Valdivia. Letter from Don Carlos Henriques Clerque to the Count de Lemos, viceroy of Peru, respecting proposals made by the "Royalle Compagnie de Commerce d'Angleterre" prejudicial to the interests of the American possessions of Spain. (Copy.)

Spanish narratives relating to South America.

[p. 585

[p. 609

497.-I726, Jan. 27. Arrest du Conseil d'État du Roy, qui permet aux Négocians François de porter en Droiture des Isles Françoises de l'Amérique dans les Ports d'Espagne, les Sucres de toutes espèces, à l'exception des Sucres Bruts, ensemble toutes le autres Marchandises du Cru desdites Isles Francoises (Paris, I726, 4 pp., 4to).

[p. 33

I726. Départemens de Messieurs les Secrétaires d'État (Päris, I726, broadside). Attribution to Maurepas of maritime commerce and colonies.

[p. 292

I726. Commissions Extraordinaires du Conseil (Paris, I726, broadside). Attribution to $I 7^{e}$ Bureau of cases arising out of concessions in Louisiana granted by the Compagnie des Indes.

[p. 297

I726. Départemens de Messieurs les Intendans du Commerce. Attribution to Maurepas of affairs of the American islands, and the cod and whale fisheries. (Broadside.)

[p. 303

499.-I672, Oct. 23. "Harangue prononcée par Mgr. le Comte de Frontenac en l'assemblée tenue à' Quebec." . [pp. 89-93 [1673:] "Harangue pour l'assemblée généralle qui a esté faite par Mons. le Comte de Frontenac pour la Police de la ville de Québec." [pp. 97-99 I673, Mar. 23. "Ordonnance pour la police de Québec faite par M. le Comte de Frontenac."

[pp. IOI-I IO

1673. "Relation du voiage de Mr. le Comte de Frontenac au Lac Ontario et de l'establissement qu'il y fit en l'année I673." Ptd. in Margry, I. I95; N. Y.Col. Docs., IX. 95.

Proposal for an attack upon the American possessions of Spain.

[pp. I I 3 -I 48

Brief descriptions of Santo Domingo and Jamaica with reference $245^{-247}$ attack on them.

[pp. 249-25I

"Advis pour faire la guerre aux Anglois et ruiner leur commerce dans l'Amérique."

"Advis sur la nouvelle Espagne."

[pp. $253-256$

[pp. $26 \mathrm{I}-262$ 
503.-I683. "Table du Registre desi Dépesches de la Marine, Année I683." Table of contents of vol. 49, series $\mathrm{B} 2$, of the Archives of the Marine. A note describes this as a " minutte faite par Charpentier en I73I et transcrite ensuite par son fils". A number of such tables are to be found in the MSS. Clairambault.

[pp. 233-339

511.-I694. Table of contents of Arch. Marine, B2, vol. 95.

I695. Id., vols. 103, 104.

I706. Id., vol. 187.

[p. 231

I 728. Id., vol. 279.

[p. 243

[p. 363

529-I664-I738. "Collection générale . LP. 425 rêts et Règlemens rendus en faveur de la Companie des Indes, concernant les Exemptions et Modération de Droits à Elle accordées . . . I664-I738."

[pp. 567-6oI

530.- [I685-I7I 5 ca.] "Estat des Pensions et Gratiffications annuelles accordées aux officiers de la marine sur le Trésor Royal." This list indicates name of recipient, position or service, date and amount of pension, etc. Many names of persons living or serving in America are included: $e$ g., (I685) "Marquis du Quesne, gouverneur des Isles du Vent . . comme nouveau converty"; (I697) “Sr. Charité, gouverneur de la Martinique; (I700) "Dauteuil, cidevant procureur général du conseil supérieur", Canada; (I7OI) Merville and La Durantaye, captains in Canada; (I705) "au Sr. de Breslay, prestre chez les sauvages Algonquins, en considération des services qu'il rend pour leur conversion", widows of La Mallerie and Descayrac; (I707) St. Ours; (I7II) Lotbinière; (I7I2) "Damoiselle Catherine Daubusson, canadienne, pour subsister dans le couvent des Ursulines du Havre"; (I7I4) Ovide; (I7I 5) Baron de Longueuil, widow and children of Petit de Levilliers. [p. 289

[I7I5, Feb. I7.] Mémoire pour Jacques Belin, Paul Vallée, et Pierre Sibilet-Labrousse, Marchands de . . La Rochelle .. . conjointement Propriétaires du Navire le Saint-Dominque . . commandé par Jacques Robiou . . destiné pour les Colonies Françoises de l'Amérique.

[p. 547

531.- I730, Jan. 8, Moscow. Despatch from Villardeau. News from Kamtchatka respecting expedition of Capt. Bering to discover new lands.

[p. I3I

I7I4, Mar. I9. Extract from instruction to Vaudreuil and Bégon (Canada) respecting testimony of savages as to sale of brandy. [p. I63

I7 6, May 4. Extract from minutes of the Superior Council of Martinique respecting value of Spanish currency.

[p. I67

I716, May I5. Memoir by Marseiller, of the Superior Council of Martinique, on the specie of Santo Domingo and the American islands.

I7I6. Lists of procureurs and huissiers of St. Pierre, Martinique.

[P. I7I

[pp. I 81,183

I7I7, Oct. 20, Quebec. List of persons provided with passage to France on the frigate Astrée.

[p. 257

I7 I7, Nov. 26, Rochefort. Lists of officers and other passengers on the Astrée who ate at the captain's table or in his office, on the voyages from Rochefort to Quebec and from Quebec to Rochefort.

[p. 26I

I718, Apr. 30, Léogane. Lists of officers in Santo Domingo.

[pp. 269, 285, 297

I7I9, Feb. 4. Extract from register of the hotel de ville of Bordeaux, respecting the prevention of fralid in the exportation of wine to Martinique and elsewhere. (Printed broadside.)

[p. 323

I7I9, Apr. 6, Brest. Lists of passengers provided with passage to the American islands, on the Hercule, Mars, and Vémus.

[pp. 327, 329, 33I 
I719, Aug. I7, Fort Royal, Martinique. Table of marine companies in the Iles du Vent.

[p. 333

I7I9, Oct. I6, Quebec. Letter from Vaudreuil, governor of Canada, acknowledging receipt of cross of the order of St. Louis for Lhermite, Dejordy, de Gannes, and Bégon.

[p. 335

I719, Oct. 27, Quebec. List of passengers embarking on the Chameau. Signed, Bégon.

[p. 337

I720, June 24, Brest. François de Briqueville, comte de La Luzerne, to Conseil de Marine. Arrival of vessels from Louisiana under command of Saujon; death of Marolles, commander of the Mercure, on the Mississippi coast.

I7I9, I720. Judicial papers relating to the estate of Maillart Marting [p. 365
rtinique. [pp. 371, 379

I720. Replies of the intendant des Isles to charges against him by Desrieaux, respecting foreign trade.

[I72I.] Requests for the cross of the order of St Iouis : Santo Do.: 4OI Iles du Vent, Cayenne, Canada, and Ile Royale.

I722. Documents relating to a lawsuit between Dorillac and 5.95 of Guadeloupe.

I721, Oct. I6. La Chassaigne, lieutenant at Montreal, to Vaudreuil. 635 of brandy to savages. (Copy.)

I722, Dec. I2, Louisbourg. Table of officers serving in Ile Royale, with records of service and comments on merits or faults. Signed, Lenormant.

532.-[1663.] List of stockholders of the Compagnie des Indes Orientales who have the right to vote for its officers, with the amount of their respective holdings.

[p. 58

[1665 ?] "Estats des interessés dans la Compagnie des Indes Orientailes qui n'ont pas payés leur second tiers."

[p. 77

I667, Oct. 28, Quebec. "Liste des officiers servans en Canada qui meritent d'estre distingués . . ." Signed, Talon.

[p. I4I

I704-I708, I7I2-I7I4, I7I6-I7I9. Rough memoranda of letters sent, commissions, etc., to officers in the colonies: Iles du Vent, Santo Domingo, Cayenne, Canada, Acadia, Placentia, and Louisiana. Cf. Arch. Colonies, series B. [Pp. I89, 301, 487, 523, 549, 597, 629, 673, 689 I710, May 5, Marly. "Remplacement d'officiers en Canada." [p. 445 I 7 I I, Sept. I. Lists of marine officers serving in the colonies. [p. 475 I714, Mar. I4. Memorandum of letter from Champigny, intendant at Havre, respecting Catherine Daubusson, Canadian, and her sister, who are to go to Canada. $C f$. above, MSS. Clairambault 530.

I718. Lists of officers serving in Santo Domingo.

533 1756 [pp. 647, 68I, 683 (n) in Acadia and region since the preceding autumn. (A. L. S.)

I756. General account of events in Canada and Louisiana, Nov. 89-94 May, I756 [by the Chevalier de Ramesay?]

[ff. 95-106

I756, Mar. 27. "Relation de la prise du fort Bull." Details of military operations.

I756, July 29, Fort Frontenac [Kingston]. Report by Decombles on a reconnaissance made by him, July 25, of Fort Choüagen [Oswego], and on its defenses and the best mode of attacking it, with a plan in colors of the fort and its approaches.

I756 “Courier du Canad " A résumé of military events: [ff. I I 2-I I 8 Fort Duquesne, Lake St. Sacrement [Lake George], naval fores on Lourg, 
Ontario, Fort Frontenac [Kingston], and Fort Choüagen [Oswego]. [iff. I $47-\mathrm{I} 5 \mathrm{I}$ in Canada, chiefly capture of Fort Choüagen [Oswego]. [ff. I 47-I5 I 664-i667, May I I, St. Germain-en-Laye. "Règlement . . . pour les affaires de la Marine et du Commerce."

[p. 2I5

r669, Mar 7, Paris. "Règlement ... entre Mrs. Colbert et de Lionne . . . sur leurs Départements." J. B. Colbert, secretary of state for the marine, and Hugues de Lionne, minister of foreign affairs.

[p. 223

I669-1698. "Extrait des Registres des ordres du Roy pour la Marine concernant les dépesches de Sa Majesté pour les Pays Etrangers depuis I669 jusqu'en I698." List of despatches to various French diplomatic agents abroad. The minutes of the despatches are probably in the various series of Correspondance Politique, archives of the Ministry of Foreign Affairs, especially Espagne, Rome, Angleterre, etc.

[p. 293

I669-I698. "Mémoire des Lettres Escrites de la part du Roy aux Ambassadeurs et Envoyés de Sa Majesté dans les Pays Estrangers par Mrs. Colbert, Seignelay, et de Pontchartrain, secrétaires d'Estat ayant le départment de la Marine." A list of despatches, the minutes of which are probably in the archives of the Ministry of Foreign Affairs; from I669 to July, I683, résumés of the individual despatches are given.

[p. 32I

I699, Sept. I3, Fontainebleau; I70I, Dec. I2, Versailles. "Règlement entre le Secrétaire d'Etat de la Marine et le Controlleur-général des Finances." Attributes to former all affairs of Canada and the American islands in matters of religion, justice, police, concessions, agriculture, hunting, permits to coureurs de bois, labor, negroes, commerce, etc., "ensemble le soutien, la discipline et la conduite des colonies à la reserve des droits de la ferme du Domaine d'Occident "; to the latter are attributed all affairs connected with the domaine d'Occident.

707.-I67I-I673, I680, I684-I685. Tables of contents; made by Charpentier in I730-I732, of Arch. Marine, B2, vols. 14, 15, 18, 23, 24, 43, 51, 53, 54. [pp., respectively, I 25, I 57, I89, 45 I, 235, 343, 49 I, 64I, 6I 3

709. Inventories of State Papers.

Tables of contents of the ten volumes of expéditions (arrêts, brevets, commissions, déclarations, lettres, ordinances, provisions, règlements, etc.), from about I6Io to I669, which Colbert caused to be collected when he was appointed secretary of state in the latter year. These tables are of service in tracing documents relating to America prior to I666-I669, the period at which the series of expeditions in the archives of the colonies (series B) commences.

[ff. I-399

I673, Feb. 26. Inventory of papers in the armoires of Colbert, and an. notated in his hand.

I686, July 25. Inventory of the registers in the offices of Seignelay.

[ff. $417-426$ [ff. $429-435$

I69I, Mar. Memoir by Clairambault on the registers and papers of Colbert and Seignelay.

[ff. $437-439$

I692, Mar. 2. General inventory of the registers, folders, and papers of the ministries of the late Messeigneurs Colbert and Seignelay. [ff. $447-587$

I702, June 26. Inventories of the folders of useless papers in the dépôt since 1672 .

[ff. $607-655$

Table of folders of papers relating to commerce and naval affairs, which are in the hands of M. d'Argenson.

「ff. $667-692$ 
847. Documents relating to the marine, chiefly from the papers of Abbé Bernou, of whose will Clairambault was executor.

I 706, Nov. I7, Versailles. Royal ordinance permitting merchants who send vessels to America to compound their obligation to transport indentured servants (engagés) at the rate of 60 livres per servant, during the continuance of the present war. (Broadside.) Cf. Isambert, Anciennes Lois Françaises, XX. 49I, and Moreau de St. Méry, Loix et Constitutions des Colonies, Françaises, II. 83.

[f. 96

I 7 I4, Mar. 20, Versailles. Royal ordinance requiring vessels to New France to carry a number of indentured servants proportional to their tonnage, or two recruits in place of each such servant.

[f. I I I

848. "Pièces sur le flux et le reflux, mouvement et courans de la mer, avec des extraits de voyages ... . provenant de la succession de M. l'abbé Bernou et presque tous écrits de sa main. J'ay été son exécuteur testamentaire et ses héritiers m'en firent présent." 1636).

Extracts from Gabriel Sagard-Théodat, Histoire du Canada (Paris,

Extracts from Les Voyages de la Nouvelle France Occidentale dite Canada faits par le Sieur de Champlain (Paris, 1632).

[p. I3

Series of extracts, in hand of Bernou, from various volumes of voyages, geography, etc.

[pp. $29-278$

Notes on region of Lake Superior, on "tides" in the Baie des Puants [Green Bay], etc.

[p. 333

Extracts relating to geography of North America.

[p. 339

Extracts from Denys, Description Géographique et Historique des Côtes de l'Amérique Septentrionale (Paris, I67I), and Rochefort, Histoire des Isles Antilles (Lyons, I66I. [sic]).

[p. 347

Memorandum of queries presented by Abbé Bernou, " bachelier en théologie de la faculté de Paris, dans la place du Palais Royal, rue St. Honoré, chez le Sr. Audiger, limonadier ", to M. Dalera, respecting tides in the Great Lakes and other matters of geographical interest.

[p. 363

"Mémoire pour les mers et costes du nord": Hudson Bay, Labrador. Acadia, and the St. Lawrence.

[p. 387

Memorandum of information desired respecting winds and currents on the coasts of South, Central, and North America.

[p. 4I7

"Estendue des Costes des Amériques selon Gomera en son Histoire des Indes" [F. Lopez de Gomara, Historia General de las Indias ( 1532 )].

[p. 639

Memorandum of information desired respecting currents, tides, etc., in Canada.

[p. 695

849.-I683, Dec. 3I. List of officers of the marine asking for promotion, pensions, etc., with statements of services, names of those endorsing their requests, comments, etc. Some services in America are noted. [ff. 50-53

List of petitions by officers of the marine or relating to them, with comments.

[ff. 6I-63

I688, Feb. Reasons for sending the former Bishop of Quebec back to Canada; petition of Champigny, intendant in Canala ; petition of Mme. Voquet, wife of an inhabitant of Canada.

[ff. $65-66$

I687-I689. "Canada. Diverses demandes sur lesquelles il reste à prononcer." Frontenac, Vaudreuil, La Mothe Cadillac, Villiers, Poncourt, Montigny, Dame de La Vallière, Castel Du Fouché.

[ff. 70-7I 
Petition signed by five gardes marines in Canada: Boishébert de Beau\begin{tabular}{l} 
court, Quatrebarbes, La Gémerais, Forsans, and Lespinay. [ff. I05-Io6 \\
\hline
\end{tabular} I691, Oct. I5, Quebec. Memoir signed by Frontenac, recommending various officers and others.

[ff. 107-108

I693, Nov. 2, Quebec. Memoir signed by Frontenac, respecting certain

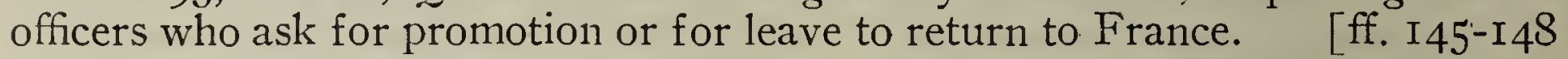
I693, Nov. 4, Quebec. "Estat des emplois vacans ausquels Monsieur le comte de Frontenac a pourvu en l'année I693 en attendant la commission de Sa Majesté."

[f. I 55

Note requesting that certain officers be placed on the list of those who are to return to Canada. [f. I 85 I694, Apr. List of " officiers des troupes de Canada qui sont présentement en France".

[f. 187

I695, Mar. 27, Apr. 20. List of "Capitaines en pied en Canada qui ont des certificats de gardes de la marine, qui supplient S. M. de leur accorder des brevets d'enseignes de vaisseaux sans appointements".

[ff. 208-209

I697, Feb. "Mémoire sur les places d'officiers d'infanterie à remplir dans les troupes qui servent en Canada."

[ff. $335-336$

I697, Oct. I8, Quebec. Memoir signed by Frontenac, respecting officers who ask for promotion.

[f. 337

I697, Oct. 20, Quebec. List of concessions of land granted by the governor and intendant of Canada, confirmation of which by the king is asked for. Signed, Champigny.

[ff. $340-343$

I697, Oct. I9. List of concessions of land in Acadia, granted by the governor and intendant of Canada between Nov. 14, I696, and Apr. 23, I697, confirmation of which is asked for. Signed, Champigny.

[ff. $345-347$

I697, Oct. I8, Quebec. "Relation de ce qui s'est passé de plus remarquable en Canada depuis le départ des vaisseaux en 1696 jusques au I 5 octobre I697." Cf. N. Y. Col. Docs., IX. 664

851. I647-I 7I8. "Extraits d'Ordonnances, Règlemens, et Arrests du Conseil d'Etat du Roy, concernant la Marine." A list of titles of documents.

852.-169o, Dec. I6. "Règlement pour la levée, solde, et discipline de 80 compagnies franches d'infanterie pour les vaisseaux de guerre." [f. Igv I692, Mar. 29, Nov. 8. "Ordonnances pour l'entrée du port de Plaisance", Newfoundland.
[ff. 8Iv, I 2 IV I692, Apr. I2. "Règlement du rang entre les officiers commandant les soldats des colonies."

[f. $82 \mathrm{~V}$

853. "Tables alphabétiques des Ordonnances de la Marine." Rough lists of ordinances, some of which relate to such matters as Canadian card money, colonial commerce, the Compagnie d'Occident, etc. Of negligible value.

854.-[1660.] Mémoire ou Discours Politique Concernant la Conduite de la Marine ... par le sieur Gravier. . . Commissaire Général de la Marine (2I pp., fo., "présenté au Roy en I660"). Also in Bib. Nat., Imprimés, Lf, 69 , I I.

I647-167I. Tables of contents of Arch. Marine, B2, vols. 4, 7, 8, 9, 10, $11,12,13$.

[ff. $25,3 \mathrm{I}, 53,69,76$, I $29, \mathrm{I} 49$, I 57 A list.

"Ordonnances sur le commerce qui sont dans le recueil imprimé de I675."

1675, I686. Inventories of papers of Colbert, relating to the marine.

[f. 183

[ff. I86, I93, 252

I678, July-Dec. Abstracts of letters received from the various ports. Cf. Arch. Marine, B3, vols. 28, 30.

[f. 224 
"Mémoire sur la fonction des officiers de la Marine dans un Port et à la Mer." Interesting account of duties of various officers, especially of those in the ports ; intendant, contrôleur, garde magasin, écrivain, etc.

Dictionary of nautical terms.

[ff. $344-370$ "Tables Ordres du Roy pour la Marine", I68I, I682.-A roughly made alphabetical index to subjects; a few American items under the word Amérique. Cf. Arch. Marine, B2, vols. 44,46 .

856. I673, 1674, 1684-1686. Tables of contents of various volumes of orders of the king and of despatches relating to the Marine. Cf. Arch. Marine, $\mathrm{B} 2$, vols. 20, 25, 50, 52, 53, 54, 55, 56.

[ff. 36, 54, I36, I99, 233

I682, July I-1686, Aug. Tables of contents of certain volumes of orders on the treasurer of the marine. $C f$. Arch. Marine. E, vols. 2, 3. Numerous documents relating to America are listed, e. g.: I683, May 24, order to pay 600 livres to the sisters de La Boissière and Des Rosiers, as a bonus for their services in conducting 50 girls to America; 1683, May 26, order for payment of salary to Frontenac; " estat de fonds pour diverses dépenses pour Canada pendant 1683 "; order to pay the Jesuits 219 livres for their mission at Lorette and for the support of several Iroquois in 1674; 1684, Apr. I2, " estat de la solde de 4 compagnies d'infanterie destinées pour la Nouvelle France pendant 4 mois de I684"; 1685, Apr. 3, "gratification extraordinaire aux Recollets du Canada"; 1686, Apr. 5, expenses of the château of Quebec.

[ff. 99, I $78, .243$

I685, I686. Tables of contents of certain volumes of orders for the Islands of America and for Canada ; 1685, Aug. 5-Sept. 25 ; I686, Jan. 26-June 5.-Cf. Arch. Colonies, B, vols. 11, 12.
[21 7, 218v., 230

858-859. 1680-1686. "Ordres, dépesches et autres expéditions concernant la Marine." I680, May 2-1683, Dec. 3I ; I684, Jan. I-I686, Aug. I 5.-Cf. Arch. Marine, B2, vols. 42-58. The letters here copied, addressed to officers in the ports, concern chiefly appointments, finances, supplies, leaves of absence, etc. Many of them relate to the West Indies, but there are relatively few that relate to Canada.

863.-I 728. List of marriages in Canada, e. g.: Baron de Longueuil and Mme. de St. Ours; Chevalier de Longueuil and Mlle. de Soulanges; Chevalier de La Corne and Mme. de Coüagne, M. de Largentière and Mlle. Basset; M. Pommeroy and Mlle. de Catalogne, ainée, etc.

[p. 289

1732, Aug. I5. List of officials of the two councils of Santo Domingo and of their dependent jurisdictions.

[p. 639

864. Log-books, a ship's letter-book, ship's accounts, etc.-This volume, which appears to be homogeneous, is in two parts: ff. I-5I, and ff. I-end. According to Lauer, Catalogue de la Collection Clairambault, the log-books were kept by' Henry. Brunet.

I655. Record of sales of fish.

[f. B

I672. July-Oct. I2. Log-book of voyage from La Rochelle to Newfoundland.

[ff. I-I $8 \mathrm{v}$

"Compte des frais que j'ay faict pour la décharge de nostre Cargaison."

\begin{tabular}{ll} 
"Compte de la disposition de nostre cargaison." & [f. I9 \\
\hline f. 20
\end{tabular}

I673, June $\mathrm{I}$. "Compte de victuaille que j'ay avancé pour le vaisseau du Roy le Call[a]isien quy ont commencé le premier juin, I673." [f. 23

"Mémoire du Vin qu j'ay embarqué tant pour mes victuaille que pour mon compte."

[f. 24 
1673, June I5-Dec. 25. "Journal de mon voyage que j'espère faire moyenant la grace de mon Dieu en le navire Le Callaisien par les ordres de Monsieur l'intendant Colbert de Terron, pour Plaisance et la coste de la Cadie et les lieux que j'estimeray pour le bien des Interessés, après que M. de la Tour aura delivré les provisions et autres choses dont il est chargé." Details of navigation, fisheries, sale of cargo, etc. The vessel arrived at Placentia, Newfoundland, on Sept. 5 .

[ff. 25-5I

I674, Apr. 22-July 30. "Journal de mon voyage que j'espère faire moyenant l'assistance du Seigneur, lequel je prie de toutes les forces de mon ame à me voulloir bénir et prospérer et réussir en mes entreprise. Sans quoy on a beau bastir sa maison si Dieu n'y met la main." This journal is incomplete. Placentia was reached on June I8; fishing operations occupy a large part of the journal.

[second foliation, ff. I-I 8

"Mémoire des hardes que j'emporte pour mon voyage."

[f. 2 I

I672-I676. Letter-book. Minutes of letters, chiefly I674-I675, written from La Rochelle, New foundland, St. Pierre, Acadia, Kennebec, and Boston, to various correspondents (Jacques Godefroy, Duportault, Dupont, Faneuil, etc.), relative to fishing trade, and various matters of ship's business, and to personal affairs of the writer. Over twenty letters written from Boston in Feb., I675, and Jan., I676, contain interesting observations on religious, social, and economic matters.

I676-I678. Various accounts.

[ff. $22-88 \mathrm{v}$

[ff. 89-1 29

865. I689, June 7-I690, Jan. 2I. Log-book of the frigate La Gaillarde, on a voyage from Rochefort to the Azores and the West Indies.-Capture of the Blessing, of New England, Capt. Samuel "Schoots", on Dec. 24.

866.-I740. Mémoire pour Marie-Catherine Moussu, Veuve de Guillaume Lautier. . . et sa Fille, Veuve de Jean-Baptiste Potel... contre Dame Françoise Castaing, Veuve du Sieur Pierre Cassaigne . . . (Io pp., fo.). This brief by Mtre. Delambon bears on law of succession in the French colonies.

I74I, Feb. I. List of officers of the Superior Council of Martinique. [p. 27

[p. 37

I740-I 74I. Letters, certificates, etc., relating to Joseph Dutertre, sent to Louisiana in I735, after imprisonment for 5 years at Charenton, who seeks a commission as ensign in the marine troops. Signatures of Bienville, Loubois, Noyan, Salmon, and other officers of Louisiana.

I 746. Summary of the cruise of the squadron commanded by the Chevalier de Conflans, to Santo Domingo and Acadia. Addressed to Clairambault.

[p. 237

1746. List of those who have received the order of St. Louis from its creation to I 746 , including a list of chevaliers named from the colonial service, I694-I 746.

[pp. $343-475$

867.-I670, Mar. I3, Dieppe. David Asseline, "pilote, pescheur et bon habitant du Canada", to Talon. Asks for passage to Canada for himself and four children; favorable endorsement by Talon.

[pp. 5-Io

Robineau de Bécancourt represents to Colbert that he is ready to leave for New France with his wife and seven children, and asks for an indemnity.

[p. II

Dodier represents to Talon that he went to Canada in 1632 and lived there more than 20 years, clearing much land, especially at Three Rivers, and he now asks for passage to Canada for himself, wife, two children, and two men. 
Request for passage to Canada, addressed to the directors of the Compagniie des Indes, by Jean Marc Noël, Nicolas Robetaille, François Levesque, Anthony Godet, " et plusieurs autres ", of Auchy and neighboring villages near Hesdin [Pas-de-Calais].

[P. I7

Memoir for the heirs of Emanuel Le Borgne, who acquired from the heirs of Menou d'Aulnay [Charnisay] all their rights to Acadia, setting forth the expenditures made by Le Borgne for the colony, which have left them ruined, protesting against the assertions of the Compagnie de la Pêche Sédentaire that they have done nothing for the colony, and asking that they may be reimbursed for sums spent by Le Borgne.

[p. I8I

I68I, Oct. "Liste des 32 jeunes gentils-hommes que Mr. de Denonville a créez pour servir de sous-lieutenants et d'enseignes dans les i6 Compagnies qui sont anciennement arrivées en Canada." [p. 260 I68I, May 2. "Mémoire des charges demandées en Canada." [p. 274 I686-1687. Charges against M. de Ste. Marthe, governor of Cayenne, and depositions and other documents relating thereto. [pp. 514, 526, 528, 602 islands.

I687, Jan. IO. List of officers commanding the troops in the American

List of officers in forts Cataraqui and Niagara.

I687, Dec. Lists of officers in Canada.

[p. 554

[p. 598

[pp. 698, 700

I687, Dec. 28, St. Malo. "Estat des principaux et des plus riches négotiants de St. Malo qui n'ont pas voulu entrer dans aucune des sociétiés faites pour la pesche de la baleine."

[p. 704

Lists of applicants for governorship of Martinique, and of vacancies in the companies maintained in the islands of America. [pp. 706, 708 I688, Mar. I. Lists of officers selected to command the detachments of soldiers on the vessels to be sent to Canada in 1688 .

[p. 878

"Mémoire sur le choix des officiers qui doivent mener les troupes en Canada."

[p. 880

List of officers, for whom commissions are requested, who have been appointed by M. de Denonville to the vacancies in the troops in Canada. [p. 886 I689. Petition of Emanuel Le Borgne to be reimbursed for his expenditures on behalf of Acadia.

[f. 890

868. - [169I, Aug. I5?] List of vacancies filled by Frontenac in I69I. (Duplicate.) Cf. Arch. Colonies, Ci I, A, vol. 11, f. 22I. [pp. 259-265 1692, Oct. 6, Quebec. List by Champigny of officers serving in Canada, with length of service. (Duplicate.)

[pp. 297-303

869.-I603-1703. Rough list of ordinances, letters patent, déclarations, arrêts, and other documents, relating to Acadia. [Pp. I 59-I69 I700, June 27, Chalons. Letter from Pomereu respecting taxes paid by Soulanges, captain in Canada.

[pp. 24I-243 I70I, Mar. 5, Angoulême. Father Bonnault, S. J., to Pontchartrain, in behalf of his nephew, deserter from a company stationed at Placentia, Newfoundland. (A. L. S.)

I702, Aug. I4, Porto Rico. Joseph Menendes de Valdes to asking for a company of infantry in Porto Rico, and enclosing certificates of service. (Spanish.)

[pp. 287-289; enclosures at pp. 277-286

I702, Dec. I9, Rochefort. [Claude Charles] de Villieu to [Pontchartrain], asking for commission of ensign in Acadia, and enclosing certificates of service signed by Chacornacle and Brouillan. [pp. 306B-309

[I702.] Documents relating to the counts de Fernanuñez, father and son, and the vice-royalty of the Indies. (Spanish and French.) [pp. 3I I-32 I 
I700. Memorial of the Marquis de La Mina, governor of Panama, addressed to the Conde de La Monclova, governor of Peru. (Printed.)

[pp. 355-374

I703, May 16, Bayonne. Statement of munitions loaded on vessels for Placentia, Newfoundland.

[p. 479

I703, July I9-Aug. 5. "Journal fait par moy [François] Amariton, lieutenant d'un détachement au Fort Louis de Plaisance." Expedition against Forillon [Ferryland], Newfoundland. Cf. Garneau, Histoire du Canada, I. 463.

871.- I740, Sept. I6, Rochefort. Lists of passengers on the Charente for Louisiana, and from New Orleans to Brest and Rochefort.

872.-I7IO, Jan. 3, Paris. Montholon to [Pontchartrain]. Supplies of food for the West Indies, and of flour for Acadia and Placentia. [f. 26

873.-1689. Request of Bourbon, procureur of the Seminary of St. Sulpice at Montreal, addressed to Seignelay, respecting the payment of subvention for instruction of Indian children.

$[\mathrm{p} .275$

[1689?]. Memoir by Denonville addressed to Pontchartrain, respecting the granting of trade permits (congés) as a means of repaying to the merchants of Canada the 20,000 livres advanced by them for subsidizing the Ottawa and Illinois Indians in the war against the Iroquois.

[I696.] Anonymous letter [to Pontchartrain] respecting war against the Iroquois, war with the English on the coast, trade permits, fortifications of the St. John River, etc.

[p. 356
I608, Dec, 26, Ouebec Vaudreuil to [Pontchartrain] tenac. The Iroquois. (A. L. S.)

I698, Oct. Frontenac to de Lagny. (L. S.)

I698, Nov. 22, Quebec. Will of Frontenac.

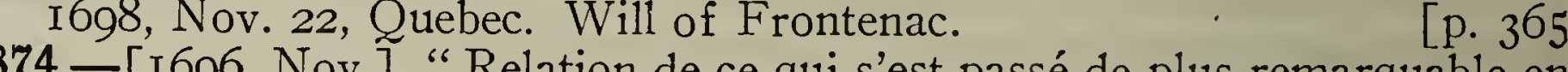

[p. 359

[p. 36r

874.- [1696, Nov.] "Relation de ce qui s'est passé de plus remarquable en Canada depuis le départ des vaisseaux de l'année dernière, I695, jusqu'en commencement de Novembre, I696." Cf. Arch. Colonies, Ci I, A, vol. 14, f. I5, and $N . Y$. Col. Docs., IX. 640.

1696, Oct. 25, Quebec. Frontenac to de Lagny. (L. S., duplicate.)

[ff. $2-23$

[ff. $26-30$

[1693.] Note on dispute between the Bishop of Quebec, Jean Baptiste de St. Vallier, and the seminary, with the request that the king direct MM. [Louis Anges] de Maizerets and Glandelet to return to France with St. Vallier.

- June 6, [La Rochelle?]. St. Vallier to [Pontchartrain], He is 37 on board his vessel ready to sail ; causes of delay. [f. 38 [1695.] Paris. St. Vallier, Bishop of Quebec, to de Lagny. His visit to Versailles and interviews with the king and the controller general. (A. L. S.) [f. $4 \mathrm{I}$

"Raisons pour faire retourner en France l'ancien Évêque de Québec." Two versions, slightly variant.

I693, Oct. I (last paragraph dated Oct. 26). Bishop of Quebec, St. Vallier, to de Lagny. (L. S.)

「Sheets are bound out of order, ff. $32,33,5$ I, 52, 34, 35

I693, Oct. I5. Duplicate of preceding document.

[ff. $44,46,47,48,49,50,45$

[j692.] "Relation de ce qui s'est passé de plus Considérable en Canada depuis le départ des Navires au mois de Novembre, I69I."

I692, Oct. 5, Quebec. "Proiet des dépenses à faire pour la guerre en Canada, l'année r693." Signed, Champigny. (Duplicate.)

[ff. $65-66$ 
1674. Letters from Father Raymond Carbonnières, missionary in Martinique.

[ff. $70,74,76$

1690. Memoir on the Antilles, and letters from Castaigne, at Martinique.

[ff. I 59, I73

[r703.] "Mémoire pour Vincent de St. Castin . . . sur le procès qu'il a au Parlement de Navarre contre le sieur Labaig, juge d'Oloron, son beaufrère."

[f. I67

I703, Sept. 29, Paris. St. Castin to [Pontchartrain]. Wishes to have his suit against Labaig decided as early as possible, in order to present a memoir on Acadia and to depart for that country. (A. L. S.)

[f. I7 I

I720, Apr. 23. " Mémoire des services rendus par les Sieurs de St. Castin, père et fils, dans le pays du Canada, en la Nouvelle France", by the Baron de St. Castin. Two copies, the first of which is signed.

[ff. $38 \mathrm{I}-383$

875.-1696, Oct. 29, Ile d'Aix. Sérigny to [Pontchartrain]. Account of his voyage to Hudson Bay under the orders of Iberville. (L. S., duplicate.)

I740-I764. Memorandum of services of M. de Chabert.

[ff. $2-3 \mathrm{v}$

I69r, Sept. I, Quebec. Champigny to [Pontchartrain]. (L. S.) [f. I6

1693. Barbe Denis, widow of M. de Contrecoeur, of the Carignan regiment, to Pontchartrain. Asks that pension of her late husband be continued to her.

[f. 2I 5

I7I7, Memoir by [Philippe de] Costebelle, governor of Ile Royale, recalling his services and asking for increased salary.

[f. 245

r699, Apr. 25. Placentia, [Newfoundland]. M. de Costebelle, governor, to M. de Piedmarin, directing him to prepare the procès-verbal of a shipwreck. (A. D. S.)

[f. 248

876.-I697. Letter from the Chevalier de Coëtlogon, respecting the death of the Vicomte de Coëtlogon before Cartagena. [f. I47 I689. May.-Sept., Martinique. Letters from the Comte de Blénac, respecting his operations in the West Indies, capture of St. Christopher, etc.

[ff. $247-299$

I689, July I9-Aug. 21, St. Christopher. "Journal de ce qui s'est passé à la prise du fort anglois de St Christophe", and "Mémoire pour le Roy", dealing with operations of Blénac.

[ff. $272-280$

I689, Dec. 20. "Mémoire pour faire connoistre à Monsieur le marquis de Seignelay la conduite qu'on a tenue avec le sr. Du Casse depuis le 23 aoust, qu'on est party de St. Christophe, jusqu'à cet heure 20 décembre r689." Signed, Blénac.

[ff. $296-299$

877.-1696, Mar. 7. Extract of a letter from the Sieur de Gastinez, respecting Danican, Sieur de Lespine, who awaits orders for his vessels, the Dia. mant and the Harcourt, bound for Newfoundland, and who will despatch the Pelican, the Espérance, and the Ville de Bayonne from La Rochelle, with supplies and munitions for Placentia.

[f. I 53

[1696?] Factum pour Nö̈l Danican Sieur de Lespine, Armateur de la Frégate la Providence, et Demandeur en Partage dans les Prises de l'Espérance de Flessingue, et celle de Lespine-Galère, contre Gilles de la Ruë et autres Armateurs de la Frégate le Dauphin, Déffendeurs (7 pp. fo.). The Providence, out of Brest. was bound for Newfoundland.

r696, July 24, Cap [Français], Santo Domingo. De Gallifet to [Pontchartrain]. General news of the West Indies.

†ff. $258-262$

I694, Oct. 3. Martinique. Dubois and Co. to [Pontchartrain], respecting commerce in the West Indies.

[f. 286 
878. - I69I-I697. Letters from Jean Baptiste Du Casse, governor of Martinique, relating to general affairs of the West Indies, operations of the English and Spaniards, expedition against Cartagena, etc.

[ff. I4-IO3

Memoir presented [to Pontchartrain] by Dumont, respecting his services, and referring to a map and to memoirs which he has brought from Canada.

I69I, July 28, on board the Hazardeux, before Quebec "Récit que I98 sieur Dutast est obligé de faire pour sa deffense et pour sa justification", respecting dispute with Frontenac over question of saluting a royal vessel, followed by testimony of various witnesses taken by order of Frontenac on July $27-28$.

[ff. 288-30I

879.-I691, Oct. 4, Martinique. "Mémoire pour le Roy", by the Chevaliers de Guitaud and Dumaitz. Matters of religion, commerce, defense, etc.

[ff. $33-64$

“Relation de la prise de l'Isle et forts de Cayenne et de l'ataque de celle de Tabago, contre les Hollandois en I677 par les vaisseaux du Roy." [By the Comte d'Estrées?] (Incomplete.)

[ff. I $32-139$

Certificates of various dates, respecting services of Charles Fézeret and wounds received by him in the campaign on the Chambly against the English and Iroquois in the winter of I688-I689. (Certified copies.) [ff. 21 8-223
[

"Mémoire de Jean Baptiste Louis Franquelin, hydrographe pour le Roy à Québec en Canada." Addressed to Pontchartrain, presenting maps and plans of the New England coast, and proposing to sail along it in a small armed vessel. making charts and securing information.

[f. 278

I688, Nov. 5. Instructions of Denonville and Champigny to Franquelin to make a map of the Ottawa country, with permission to trade. (Copy.)

[f. 280

Memoir, signed by Frontenac, respecting the insufficiency of Franquelin's salary of 400 livres as hydrographer.

[f. $28 \mathrm{I}$

"Mémoire [by Franquelin] pour informer Monseigneur de l'importance qu'il y a de tirer les lignes justes sur les limites des terres qui appartiennent au Roy dans la Nouvelle France." [f. 282 ; a copy, with additions, is at f. 290

Petition of Franquelin to Seignelay. [f. 283
[ I686, Nov. I5, Quebec. Franquelin to [Seignelay], thanking him for his appointment as royal hydrographer at Quebec, with a salary of 400 livres.

"Mémoire touchant les voyages que Franquelin, hydrographe [f. 285 "Mémoire touchant les voyages que Franquelin, hydrographe du Roy en
Canada, a faits de Québec à Paris pour le service de Sa Majesté." Addressed to Pontchartrain.

I698, Jan. 27, Paris. "Mémoire concernant la concession de Mirami 294 accordée au Sr. Denis de Fronsac."
[f. 3I2 I689, Dec. 27, La Rochelle. Marquis de Denonville [to Seignelay], announcing his arrival.

[f. 319

I693, Oct. 25, Quebec. Frontenac to M. de Lagny. Fort at Naxouat, English fort at Pemaquid, operations of Iberville in the north, Tonty in the \begin{tabular}{l} 
Illinois country, etc. (A. L. S., with postscript of Nov. 4.) [ [f. 32O-337 \\
\hline
\end{tabular} I693. Aug. I7, Quebec. "Relation de ce qui s'est passé en Canada au sujet de la guerre contre les Anglois et Iroquois depuis le mois de Novembre I692." By Champigny. (Duplicate, signed.) Cf. Arch. Colonies, Ci i, a, vol. 12 , f. 256 .

"Mémoire pour servir à la justification de la conduite que la comte de Frontenac a eue en Canada." (Incomplete, in hand of Frontenac.) [f. 34.5 
1696, Oct. 25, Quebec. Frontenac to the king. (A. L. S.) Cf. N. Y. Col. Docs., IX. 639. signed.)

1696, Oct. 25, Quebec. Frontenac to [Pontchartrain]. (Duplicate,

880- - 692 , I693. Letters from M de Gallon, at Martinique, [tf. 350-363 train].

I7 6, Feb. I5, La Rochelle. Armand Gallut to the regent, complai. 19 [f. I9 of action of M. Crozat with respect to a shipment of money from Mexico.

[f. 42

I688-1693. Letters from M. de Gémoset, governor of Grenada, relating to affairs of the West Indies.

「ff. IOO-I I I

I726. Memoirs and letters of Jean Baptiste Gourdon, respecting his application to be appointed intendant of Canada, Martinique, or Santo Domingo.

[ff. $213-237$

[1690?] "Mémoire pour L'accadie", by Mathieu de Goutin, [judge in Acadia].

[f. 301

I693, Oct. I6. Statement of Abraham Bondot respecting neutrality of the Sieur de St. Castin.

[f. 302

[Mathieu] de Goutin to Pontchartrain, requesting assignment to a vessel bound for Acadia.

[f. 303

881.-I692-I694. Letters, memoirs, etc., of Dumaitz de Goimpy, intendant, and d'Harbourville, commissaire ordonnateur, relating to Martinique.

1696, Sept. 24, Placentia. Iberville to [Pontchartrain]. Account of his voyage, June-Sept., engagement with vessels from Boston, capture of the Newport. (L. S.) Cf. Arch. Colonies, Ci I, A, vol. 14, f. 238.

[ff. I 35-I 43: another copy (L. S.) on ff. I74-I77

I694. May Io, La Rochelle. Iberville to - Plans for expedition against Hudson Bay. (A. L. S.)

[ff. I $45-146 \mathrm{v}$ seal.)

1694, Apr. 25, La Rochelle. Iberville to M. de Lagny. (A. L. S., with

I696, Feb. 24, La Rochelle. Iberville to -

I693, Aug. I5, Quebec. Iberville to - (A. L. S.)

[ff. I $47-\mathrm{I} 48$

[ff. I $49^{-1} 5^{\mathrm{IV}}$

I694, Apr., La Rochelle. Iberville to M. de Lagny. (A.L. S., with seal.)

I697, Nov. 30, Rochefort. Iberville to [Pontchartrain]. Wishes to be appointed governor of Placentia and capitaine de vaisseau. (A. L. S.)

I694, Apr. 8, Rochefort. Iberville to - (A. L. S.) [ff. I $57-$ I 58 I694, May I8, Paris. M. de Lagny to — , respecting Iberville's plan for an expedition against Hudson Bay. [f. I6I I694, Aug. 8, Quebec. Iberville to [Pontchartrain]. Capture of vessel from Virginia loaded with tobacco; he is about to start on expedition against Hudson Bay. (L. S.)

[ff. $162-163$ I697, Jan. 5, Rochefort. De Gabaret to [Pontchartrain]. Vessels for Canada; arrival of the Newport, captured by Iberville.

[f. I64 I696, Oct. 28 ; with P. S. of Oct. 29, Placentia. Iberville to [Pontchartrain].

[ff. I66-169; $c f$. below, f. I78 I695, Oct. I3, La Rochelle. Iberville to [Pontchartrain]. Capture of English fort on Hudson Bay. (L. S.)

[ff. I 70-I73 I696, Oct. 8, 28, Placentia. Iberville to - The main part of the letter, Oct. 8 , is the same'as the letter of Oct. 28 , at f. I66; the P. S. of Oct. 
28 (A. L. S.) differs from the P. S. of Oct. 29 (also A. L. S.), at f. I69.

[ff. I $78-\mathrm{I} 8 \mathrm{I}$

I696, Oct. Io, Placentia. Iberville to M. de Lagny. War with the English on the coast of Acadia. (A. L. S.)

[ff. I $85, \mathrm{I} 86, \mathrm{I} 82$

I696, Sept. 24. Placentia. Iberville to [ [ff. I83-I84

Representation addressed to Pontchartrain by Jesuit missionaries in America, respecting a concession in Martinique.

[f. I95

[I696.] "Requeste, à Monseigneur de Pontchartrain au nom des Jesuites qui sont en Canada." Dispute with Frontenac respecting trade with the Indians ; desire to be permitted to take servants with them to their missions and that their servants may bring supplies to them.

[ff. I97-I98

882.-Memoir on consuls in America, addressed to Seignelay by M. de Lagny.

I765, Dec. Io, Paris. Lacorne, vicar general of Quebec, to the pope. \begin{tabular}{l} 
Asks that Briand be accepted as Bishop of Quebec. (L. S.) [f. 20 \\
\hline
\end{tabular} I766, Jan. 22, Rome. Cardinal Costelli to Lacorne. The pope accepts Briand as Bishop of Quebec. (Italian, L. S., with seal.)

[f. 24 ; a French translation is at f. 26

I763, June 28. Duc de Praslin to the Chevalier de la Houze, at Rome. \begin{tabular}{l} 
Matters of religion in Canada. (Extract, with reply of July I3.) [f. 27 \\
\hline
\end{tabular}

[I724?] Memoir on the services of the Sieur La Marre, of Caen. Voyages in the Pacific and to the coast of California, I689-1692.

Engraved portrait of Antoine La Marre.

Lamothe Cadillac to (A. L. S.)

[f. 123

[f. I 25

L [ff. 137-I38v 1695, Mar. 29, Fort Buade. Depositions by Lamothe Cadillac and others, respecting a sermon preached by Father Pinet, at Michilimackinac, on Mar. $25, \mathrm{I} 695$.

I689, Dec. 29. Rochefort. Lamothe Cadillac to [Seignelay].

[ff. I39-I4I

Lamothe Cadillac to [minister of marine]. (A. L. S.) [ff. I43-I44
[ff. I45-I46

[ff. I43-I 44

[ $1730 \mathrm{ca}$.] Memoirs and other documents relating to the services of Gabriel de La Vigne, former captain of militia in Martinique.

[ff. $20 \mathrm{I}-2 \mathrm{I} 7$

883.-I693, Nov. 4, Quebec. "Projet pour la fortification du Port Royal dans l'Acadie, à faire examiner à Monsieur de Vauban ... " By Duplessy Fabert.

[ff. 206-207v

I687 [I689?] Memorandum of disbursements for the fortification of Chambly [Fort St. Louis], by Duplessy [Fabert]. [f. 208

I693, Nov. 4, 8, 9, Quebec. Three letters from Duplessy Fabert, the first and last being addressed to "Monseigneur". [ff. 210, 2I2, 225

I693, Oct. Io, Montreal. Certificate by Callières, governor of Montreal, respecting the services rendered in Canada by Duplessy Fabert, captain of the marine detachment.

[f. 214

884.- I695-1696. Papers in the proceedings against Macharis-Bègue, lieutenant in Martinique. Details relating to commerce, the islands of St. Croix, St. Thomas, etc.

I693. Martinique. Letters from de Molé and Dumaitz de Goimpy.

[ff. I-9I

[ff. 99-II7

I683-I738. "Liste générale des Gardes de la Marine du Port de Roche-

fort."
[ff. I38-I69

I688, May 2-Oct. 5. Journal of a voyage from La Rochelle to Acadia.

[ff. I89-I97

I694, Feb. I. Extract from the registers of the Sovereign Council, Quebec, relating to charges against the Sieur de Mareuil. Cf. Jugements et Délib- 
crations du Conseil Souverain de la Nouvelle France, and Parkman, Frontenac and New France, ch. XV.

[f. 270

I7 18, Nov. 8, Quebec. Louis de Monseignat to the Comte de Toulouse, requesting appointment to position held by his father, Charles de Monseignat, deceased in Oct., who was clerk of the Superior Council, and director of the fermes du roi.

[ I693 ca.] Memoirs by Charles de Monseignat, secretary of [f. 456bis respecting his salary, etc.

886.-I732, Apr. 7. Pechon dff. 458, 459 886.-I732, Apr. 7. Pechon de Conté, captain of militia, Mobile, [to Maurepas], asking for appointment as capitaine réformé.

I69o, Jan. I, St. Malo. Extract of a letter from Arthur $[$ f. 76 [Seignelay], respecting supplies for Placentia.

I687. Documents relating to the case of Ler. 83

[f. 83

Request from M. de Pontual that his s@ may be sent to Louisiana because of his unworthy conduct in France.

[f. 194

I684, I692, I693. Letters, memoirs, and extracts from Frontenac, Provost, Gallifet, and others, relating to dispute between Provost and Gallifet respecting the post of major of Quebec. Cf. Arch. Colonies, CI I, A, vol. 12, passim.

888.-Engraving by P. Brissart, entitled, Assaut des Hollandais, repoussés $d u$ Fort Royal de la Martinique . . . July I9, I674.

[f. I65

I74I, July I, Niagara. Orders of Saint-Michel Gourville, commanding at Niagara, to M. de "Baujeu", to proceed with 3I men to Fort Frontenac to obtain news respecting provisions for Fort Niagara.

[f. I66

I687. Letters, memoirs, and other documents, relating to accusations against A. de Sainte-Marthe, governor of Cayenne, in the affair of the filibustering vessel Hirondelle.

[ff. I69-I 74,185 I684-I 685. Documents relating to charges against Tarin de Cussy, governor of Santo Domingo. 1696, July 30, "Nennagoesche, au bas de la rivière St. J.208-23I Tibierge to 1 . Account of events since Oct. I, I695. (A. L. S.)

889. 687 . Dec. I/I Whitehall. Copy of provisional treaty. 232-237v the neutrality of the American possessions of provisional treaty for assuring Arch Affaires the Ameat Britain. Cf. Arch. Affaires Etrangères, Corr. pol., Angleterre, vol. 163, f. 222v. [f. 82 I687, May 5, Versailles. Copy of full powers to MM. Barillon and de Bonrepaus to conclude what remains to be settled with respect to the treaty of neutrality. $C f$. Arch. Affaires Etrangères, ibid., f. 6. I687, May 5, Versailles. Copy of letters of credence of MM $[1.84$ and de Bonrepaus.

I687, Dec. 7. Whitehall. The King of England to the King of [f. 85 respecting return of $M$. de Bonrepaus to France to report on the state of negce, tiation of the treaty of neutrality. (Copy.) in Canada. I687, Jan. 3I, Brest. De Varlet to [Seignelay], asking for a lieutenancy

890.-I696, Sept. 24. Plan by Villebon, governor of Acadia, for the destruction of all English settlements beyond Pemaquid, and for the capture of Boston and of important towns beyond Cape Cod. Cf. Arch. Colonies, Ci I, B, vol. 3, and Parkman, Frontenac and New France, ch. XVII. [ff. 308-309v

Copy of a memoir addressed to the Marquis de Chevry [director of the Compagnie de la Pêche Sédentaire de 1'Acadie]. Commercial relations between Villebon and Dubreuil; wheat carried from Port Royal to Boston by Dubreuil; 
de Louvière asks for goods on credit; trade of the Recollects with the Indians ; cannon of the company lent to Guyon by Villebon; presents by Villebon to the chief of the Pentagouet Indians.
[ff. 3IO-3 I Iv

1696, Sept. 24, Naxouat. Villebon to [Pontchartrain]. Capture of Pemaquid; expedition preparing at Boston; need of naval protection in order to rebuild the fort at the mouth of the St. John; sends a memoir (see above, f. $308)$; troops lack provisions. Cf. Arch. Colonies, Ci I, B, vol. 3, f. I9.

I694, June Io, La Rochelle. [Michel] Bégon, intendant, to [Pontchartrain]. Capture by the Lière of an English vessel laden with provisions for the English colonies.

[f. 482

951.-1644, Fontainebleau. "Minutte de déclaration de provision à M. le comte de Brion de viceroy de l'Amérique." Title taken from note on first page of document ; the text, however, leaves a blank space for the name of the appointee.

[pp. I I-I 4

I647, Feb. 25, Paris. Extraict des Registres du Conseil d'Estat (ptd., 8 pp.). Ordinance regulating the claims of de Poincy and de Thoisy Patrocle to post of lieutenant general of the Islands of America. [pp. I 5-22

[1657.] "Charge de Gouverneur Lieutenant général pour le Roi dans toutte l'estendue du fleuve St. Laurent pour le Sr. Dailleboust." (Copy.)

[pp. $23-25$

I523-1660. "Mémoire de la découverte des Terres neuves nommées nouvelle france, et des gouverneurs qui y ont été pourveus." (From a MS. belonging to the Comte d'Exelmont.)

Rough notes on appointments of viceroys in America.

[ff. C-Ev

[pagination recommences: p. I

1638. Copy of appointment (Feb. 27) and commission (Sept. 15) of the Chevalier de Poincy as lieutenant general of the Islands of America, with certificate of receipt of originals, signed by de Poincy, Dieppe, Nov. 6.

[p. 3

[1650.] Memoir in favor of continuing the Sieur de Poix in his functions as lieutenant of the late Sieur [Charles de Menou d'Aulnay] Charnisay for the administration of Acadia during the minority of the latter's son.

[p. 27

I647, Nov. "Convention [with Dolu?] pour l'abitation en l'Amérique." (Copy.)

I651, Jan. I7, Paris. Commission of Jean de Lauzon as governor of New France. (Copy on parchment, not signed.) Ptd. in Édits et Ordonnances, III. I6.

[p. 39

I65 I, Jan. I7. Copy of preceding document, but with name of Du Plessis Kerbode substituted for that of Lauzon in the first part of the document, though the latter name is retained in the subsequent part.

[pp. 4I-42

1655. July, Lafère. Lettres de Provision de la Charge de Viceroy et Lieutenant général pour le Roy . . . dans tous les Ports, Havres, Isles, Costes, Rivières et Terres Fermes de l'Amérique, données à Monsieur le Duc Dampville. Verifées en Parlement le 2 I Janvier I658. (I 4 pp.)

[pp. $43-56$

I660. "Mémoire de la Compagnie de la Nouvelle France contre la prétention de M. de Feuquières à estendre l'autorité de sa Charge de Viceroy de l'Amérique sur la Nouvelle France parceque la Nouvelle France est dans l'Amérique." " [pp. 57-58

1662. "Provisions de Viceroy des Isles de l'Amérique pour M. le Maréchal d'Estrades, après la demission du Marquis de Feuquières." (Certified copy by Clairambault.)

[pp. 59-6 I 
I663, Nov. Io, Paris. "Pouvoir de Lieutenant général en l’Amérique en l'absence du vice-Roy pour le sieur [Alexandre de] Prouville, [Marquis de] Tracy." (Copy.) Cf. Arch. Colonies, B, vol. I., f. 64 . [pp. 65-72

I665, Mar. 23, Paris. "Provision de gouverneur et lieutenant général en Canada, Acadie et Isle de Terreneuve pour le sr. de Courcelles." (Copy.) Ptd. in Edits et Ordonnances, III. 3I.

[pp. 75-80

Memoranda of appointments of La Barre (I683) and Denonville (I685), as governors of Canada.

[pp. 83-84

I685, Jan. I, Versailles. Copy of commission of Denonville as governor of Canada. Ptd. in Edits et Ordonnances, III. $48 . \quad$ [pp. 85-88 1687, Aug. I, Versailles. Copy of commission of Marshal d'Estrées as viceroy of America.

I669-I7 12. Copies of commissions of governors in the West Indies.

[pp. 99-I4I

I707, May I, Versailles. Copy of commission of de Muy as governor of Louisiana.

I69I-I7I 5. Lists of commissions of governors.

[pp. I I9-I 20

[pp. I 43 -I 47

Copy of oath taken by the governor and lieutenant general of the Islands of America.

[p. I49

995.-[Post I7I I.] Documents relating to the dispute between the seminary of the Missions Etrangères of Paris and the bishop and chapter of Quebec on the one side, and on the other the nuns of the priory of La Colombe, united to the abbey of Lestrées, respecting the revenues of the priory and the transfer of the services of the abbey to Quebec: petition of Sister Anne-Marie-Hiacinthe, prioress of La Colombe (ptd., f. 326) ; petition of the superior and directors of the seminary of the Missions Etrangères (f. 338 ) ; report on the two petitions (f. 339); petition of the seminary of the Missions Etrangères ( $f$. $347)$; memoir on the creation of the bishopric of Quebec, and the presentation to it of the abbeys of Maubec, Bénevent, and Lestrées (f. 35I) ; extracts from documents relating to the suppression of the abbeys of Maubec, Bénevent, and Lestrées, and the assignment of their revenues to the bishopric and chapter of Quebec (f. 355) ; note on the members of the commission which the bishop and chapter of Quebec desire to have appointed (f. 359) ; memoir on the dispute between the bishop and chapter of Quebec and the nuns of La Colombe ( $f$. $360)$.

[ff. 326-397

996. Inventory of titles and papers of the abbey of Lestrées, drawn up in execution of the decision of Aug. 24, I7I4, rendered by the commission appointed by the king to judge in last resort the case of the bishopric of Quebec. Inventory by Raudot, a member of the commission, Dec., I7 I7.

1015. [I650 ca.] Collection of notes and extracts, all in the same hand, relating to geography and history.

"Abrégé des choses les plus remarquables que se sont passées à la descouverte des Indes occidentales."

[ff. I02-II $6 \mathrm{v}$

Notes and extracts relating to the Incas, and to the history and geography of South America.

「ff. I I6v-167

Notes and extracts relating to the rivers and Indians of North America: the St. Lawrence, description of Anticosti, Quebec, Montreal; beaver; the Hurons and Iroquois.

[ff. $168-176 \mathrm{v}$

Notes and extracts relating to the West Indies : first voyage of Columbus; native canoes of Hispaniola; island of Jamaica; Spanish avarice in the West Indies.

[ff. I $777-187 \mathrm{v}$ 
1016. Documents relating to the French colonies in America, etc., I673-1702. - This volume is from the papers of Abbé Bernou, and many of the documents are in his hand. Margry made much use of this material and printed a number of the documents. The following list accounts for all the documents in the volume that relate to the American continents or islands.

[1677. Frontenac to Colbert.] (Draft in hand of Abbé Bernou.) Ptd., Margry, I. $301-325$.

[I677.] "Mémoire sur le projet du sieur de La Salle . . . " (Draft in hand of Bernou.) Ptd., Margry, I. 329-336.

[ff. $49-50 \mathrm{v}$

"Relation des descouvertes et des voyages du Sieur de La Salle seigneur et gouverneur du Fort Frontenac au sudouest du Canada par l'ordre de Monseigneur Colbert." (Draft, with many erasures and corrections, in the hand of Bernou, of the first four pages of the Relation printed by Margry from the complete fair copy in the archives of the Service Hydrographique. This fragment corresponds to Margry, I. 435-44I, ending with the words et sa cheute est composée.)

[ff. $5 \mathrm{I}-52 \mathrm{~V}$

[168I.] La Salle to - (A. L. S., fragment, first pages lacking.) Ptd. in Margry, II. II 5-I 59, under the title, "Relation du voyage de Cavelier de La Salle du 22 août I680 à l'automne de I68I".

[ff. $53-64 \mathrm{v}$

La Salle to - (A. L. S., first pages lacking.) Ptd. in Margry, II, 32-93, with dates "I679-29 septembre, I680", and with title "Lettre du Découvreur à un de ses associés". [ff. 65-84v

"Extrait de la Relation des voyages et des découvertes du Sr. de la Salle, seigneur et gouverneur du fort Frontenac." (In the hand of a copyist ; end of document missing.) This is the first part of an abridgment of the Relation printed by Margry, I. $435 \mathrm{ff}$; ; it covers pp. $435-437$ of the printed text.

[ff. 85-9Iv

Relation of La Salle. (In the same copyist's hand as the preceding document ; a fragment, the first and last parts being missing.) . Practically identical, except for slight verbal variations, with Margry, I. 467-540, commencing with the words que forme la rivière, and ending with the words durant une année. [ff. $92-\mathrm{I} 47 \mathrm{v}$

[1682, Oct., Michilimackinac.] La Salle to Monsieur-_ (A.L. S.) Ptd., with place and date supplied as here indicated, in Margry, II. 288-30I.

Copy of preceding document. [ff. I 48 -I 5 ov [ff. I 5 I-I $56 \mathrm{v}$

[I68I, Dec.-I682, Jan.] Fragment of autograph narrative by La Salle. Ptd. in Margry, I1. I64-I80, under title "De La Salle arrive aux Illinois. Description du pays jusqu'à la rencontre du Missouri ..." [ff. I57-I62v I682, June 3, Mississippi River. Father Zenobe [Membré] to [superior of the Recollects]. (Copy.) Ptd., Margry, II. 206-2 I2. [ff. I63-I65v

I682, July 23, Michilimackinac. Tonty to - Account of his voyage with La Salle to the mouth of the Mississippi. (Copy, in same hand as preceding document, and forming with it a single transcript of I2 pp.)

[ff. I $65 \mathrm{v}-\mathrm{I} 68 \mathrm{v}$

I682, Aug. I4, Ile St. Bonaventure. Letter from a Recollect missionary

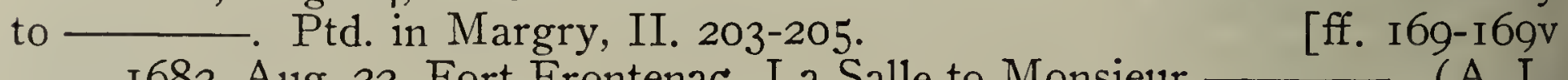
1682, Aug. 22, Fort Frontenac. La Salle to Monsieur _ _. (A. L. S., except that ff. I83v-I84v appear to be an inserted copy, in hand of Bernou, of the erased portions of $\mathrm{ff}$. I82v, I85, and 185v. Cf. note in Margry, III. 629.) Ptd., Margry, II. 21 2-262.

[ff. I7O-I $87 \mathrm{v}$

Fragment of letter of narrative in hand of La Salle. Ptd., Margry, II. 196-203.

[ff. I $88-$ I $89 \mathrm{v}$ 
"Mémoire pour Monseigneur le Marquis de Seignelay sur les découvertes du Sr. de La Salle au Sud et à l'ouest des grands lacs de la Nouvelle France." (In hand of Bernou.) Ptd., Margry, II. 277-288.

[ff. I90-193v

"Discours sur la question s'il est avantageux à la France de s'emparer des pays que les Espagnols possèdent en Amérique." (Draft, in hand of Bernou, with erasures, additions, etc.) $C f$. below, f. 653 .

[ff. I94-I98v

"Proposition pour établir une colonie dans la Floride à l'embouchure du fleuve appellé Rio-bravo. Et les avantages qui en reviendront au Roy et à ses Sujets." (Copy.)

[ff. $199-205 \mathrm{v}$

I682, Jan. I8. “Mémoire pour Monseigneur le Marquis de Seignelay. Touchant l'établissement d'une nouvelle Colonnie dans la Floride, dans l'ambouchure de la Rivière appellée Rio-bravo. Et les avantages qui en peuvent revenir au Roy et à ses sujet." (Copy, based on preceding documents.) Ptd., Margry, III. 44-48.

[ff. 206-207

"Projet pour attaquer les Espagnols dans la Nouvelle Espagne." (Draft, in hand of Bernou.)

[ff. 208-209v

Memorandum respecting the Peruvian creole [Conde de Peñalosa] proposed as leader of the expedition against New Spain. Cf. Margry, III. 50-5I.

"Mémoire pour la découverte et la conquête des pays de Quivira et de Theguayo dans l'Amérique Septentrionale." (Draft in hand of Bernou, with erasures and insertions.)

[ff. 2I I-2I5

Memorandum suggesting the conquest of New Biscay as an alternative to the plan presented in the preceding document. (In hand of Bernou.)

[ff. $216-217$

Rough draft of preceding memorandum, with memorandum on the mines of New Biscay.

[ff. $218-219 \mathrm{v}$

I684, Nov. I4. "Relation de Monsieur de Tonty. Commencée en L'année I678, Et finie En i683. Ecritte à Quebecq le I4 ${ }^{\mathrm{e}}$ Novembre, I684." Ptd., Margry, I. 573-6I6.

[Two copies : ff. 220-266, 267-279

I686, Apr. I3, "Fait à l'isle Saint Henry." "Second voyage de Mr. de Tonty à l'embouchure du fleuve Colbert en l'année i686." (Two copies of the procès-verbal, which Margry, III. 554-558, prints from a different source, Service Hydrographique. The second of these copies includes the "Liste des françois qui ont accompagné M. de Tonty", which is lacking in the first copy. Both copies lack the signatures, except that of Tonty, which are printed by Margry.)

[ff. $279-28 \mathrm{o}, 28 \mathrm{I}-285 \mathrm{v}$

I686, Aug. 24, Montreal. Tonty to [Cabart de Villermont?]. (Copy in hand of Bernou.) Ptd., with a final paragraph lacking in this copy, in Margry, III. $559-562$.

[ff. $286-286 \mathrm{v}$

Copy, in hand of Bernou, of the procès-verbal on ff. $28 \mathrm{I}-285 \mathrm{v}$, above.

I689, Mar. 28. Fort St. Louis de la Louisiane. Tonty to [Cabart de Villermont?7. (A. L. S.) Ptd., Margry, III. 564. I689, Oct. 28, Montreal. Tonty to Monsieur [ff. $288-289$ in Canada. (A. L. S.) Indian hostilities [ff. 290-292v I689, Nov. 6, Montreal. Tonty to Monsieur [same as preceding letter]. Asks for his influence in procuring him command of a company in Canada. (A. L. S.)

[ff, 293-294 I676-1689. A group of 22 documents relating to Ile Percée and the fisheries there. A complete and substantially correct list of these documents is printed in J. E. Roy, Rapport sur les Archives de France relatives à l'Histoire du Canada, pp. 750-75I. They include memoirs on the establishment of the 
pêche sédentaire, inventories of supplies and equipment, petition of the inhabitants of Ile Percée, etc.

[ff. 295-337

Memoir on the French colony in the bay of Rio de Janeiro, I 555-I 560, founded by Villegagnon.

[ff. $338-339 \mathrm{v}$

Draft of a French translation of the Descripção do Estado do Maranhão, Pará, Corupá e Rio das Amazonas, of Mauricio de Heriarte (Vienna, I874).

"Mémoire sur le différent touchant [ff. 340-373 Bernou.) Jan. 2, Grenada. P. E. Radisson to Account of his voyage from Brest. (A. L. S.)

[ff. $376-377 \mathrm{v}$

I678, Oct. Io. "Procès-verbal de M. du Chesneau de l'Assemblée tenue au Conseil ou vin [g]t des principaux habitans ont été appellez pour avoir leur avis sur la permission ou les défenses des boissons." (Copy.) Ptd., from another source, in Margry, I. 405-420.

I684, Nov. I4, Petit Goave, Santo Domingo. [Joutel] to count of the voyage of the Joly from La Rochelle to Petit Goave, and of preparations in Santo Domingo for the next stage of La Salle's expedition to locate the mouth of the Mississippi. (Copy, unsigned, with conclusion lacking.) Ptd. in Margry, II. 492-499. Margry does not attribute this letter to Joutel, and Parkman attributes it to "another" than Joutel (La Salle, ed. Igo6, p. 346 , n. 3), but a comparison of the letter with the first section of Joutel's Relation as printed in Margry, III. 92-I06, makes it clear that the two documents had the same author.

[ff. $387-388 \mathrm{v}$

Fragments of memoirs and notes on New France, in the hand of Bernou. "La Nouvelle france est un pays d'une si grande estendue, si beau, si fertile et si bien scitué qu'il semble que Dieu l'ait reservé pour la France." This phrase and other parts of these fragments are repeated in the draft of a memoir by Radisson, also in the hand of Bernou, to be found below, f. 649. [ [ff. 389-39I

[1689?] "Mémoire pour le Canada." Necessity of attacking and capturing New York; plan for an expedition against that colony. $C f$. memoirs by Callières, governor of Montreal, in Arch. Colonies, Ci I, A, vol. 10.

[r689?] “Interrogations faittes au Maistre de la quesche [ff. 392-393 [ff. $392-393$
angloise prise au Cap Breton le I8 juin dernier, par le sieur de Bonnaventure." The ketch was from Boston; the questions and answers related to affairs of Boston and New York, and especially to their state of defense. [ff. 394-395v
[

[I677?] "Mémoire pour le Canada." In two columns: on the left, a series of questions on Canada, chiefly relating to winds, tides, etc., addressed by Bernou to Barrois, superior of the Missions Etrangères ; on the right, replies to some of the questions by the Sieur de St. Martin, secular professor of mathematics chez les Jésuites at Quebec.

[ff. 396-397v

Summary of the census of Canada of I685, with comments and explanatory notes, in the hand of Bernou.

[ff. 398-399

I685, July 9, Island of Dominica. Dom Claude Philippe, missionary, to M. de Châteaudubois, Guadeloupe. Conversion of natives. [ff. 400-40 I
[fopt. ] I685, June 6-Aug. I. Journal of the vessel La Diligente, Capt. Jean Duran[d], La Rochelle to Quebec. [ff. 402-408
[ull I686, Mar. "Relation et journal du voiage du Nort par un détachement de cent hommes commandés par le Sr. de Troyes." Expedition against the English on Hudson Bay. Cf. Garneau, Histoire du Canada (I920), I. 4IO4I 2.

[ff. $409-45^{2 \mathrm{~V}}$ 
I686, Jan. 2, St. Malo. Report on information gathered at St. Malo respecting the commerce of all countries with Cadiz and Spanish America. (Copy in hand of Bernou.)

I686, Apr., Madrid. Additional report on subject of preceding document. (Incomplete copy in hand of Bernou.)

I686, Mar., Versailles. Letters patent conceding to islands of Cape Breton, St. John, and Magdelening to Gabriel Gautier the with all rights of hunting and fishing. (Copy.)
[ff. 463-463v I686, Oct. 30, Montreal. Fragment of a letter relating to Indian affairs, designs of the English, and Tonty's plan for assembling friendly Indians.

[ff. 465-466
60 General census of Newfoundland, lowed by notes on taken by Governor Parat, followed by notes on population extracted from a letter of Parat, Aug. I4, I685. (In hand of Bernou.)
[ff. 467-468 nique."

I687, Jan. 9. "Extrait des Registres du Greffe civil de 1'Isle de Marti-

[ff. 469-470
I687, Aug. I I. Account of the attack on Petit Goave, Santo Domingo, by Spaniards, and their capture and execution, with a transcript of the examination of certain of them.

I687, June I3-Aug. I3, Montreal. “Mémoire du voyage de Mr. le Marquis de Denonville pour l'entreprise contre les Sonontouans [Senecas] . . ", (Copy in hand of Bernou.) Cf. N.Y. Col. Docs., IX. 358.

I687, Aug. 22, Montreal. [Denonville] to - 1 [ff. 474-48I expedition against the Senecas. (Incomplete copy.)

I687, Oct. I2 "Copie de la lettre de [f. 482 Chasteau Vilain." Departure of a lettre de $M$. de Cailleres. [Callières] de Chin win over the Illinois; capture of two parties of them by Tonty, La Forest, Du Lhut, and La Durantaye; escape of Father Lamberville from the Iroquois. (In hand of Bernou.)

[ff. $483-483 \mathrm{v}$

I687, Oct. 30. Quebec. Du Comporté to [Cabart] de Villermont. Hudson Bay campaign. (Copy in hand of Bernou.)

I687, Nov. 3, Quebec. Riverin to [Cabart] de Villermont. America. (Copy in Hostilities in

[Iff. 485-485v [I687?] Letter to John Bridger, governor of Hudson Bay, from the governor and directors of the Hudson's Bay Company. (French translation, in hand of Bernou.)

[ff. $486-488 \mathrm{v}$

I687, Sept. I9, Quebec. Father Beschefer to [Cabart] de Villermont. (Copy in hand of Bernou.) Ptd. in Thwaites, Jcsuit Rclations, LXIII. 268. I687, Oct. 22, Quebec. Father Beschefer to [Cabart] de Villermont.
(Copy.) Ptd., ibid., p. 286.

I658-I685. "Estat du temps que nous advons entretenu des religieux et prêtres à nos despents autant que ma mémoire me faict scavoir."

[1689 ca.] Memorandum of amounts paid to the king by [ff. 493-494 ses fermes for the ferme du Canada.

[6f. 495-495v to the to the King of Spain, respecting French in the island, defenses, etc., depositions of Spaniards who had been prisoners of the French. (French translation.)

I694. Oct. I2, Placentia, Newfoundland. [ff. 496-500v surances of esteem. (A. L. S.)

[ff. 5OI-5OIV 
I695, Dec. 24, Fort Naxouat. Villebon to - Information re\begin{tabular}{l} 
specting the English colonies. (A. L. S.) [ff. 503-507 \\
\hline
\end{tabular}

1697. "Relation de Mon Voyage des Amazones." By Ferrolle.

[ff. 508-5 I I

1698, June 20, Cayenne. "Mémoire concernant la Possession de la Guyanne par les François." By Ferrolle. [ff. 5I2-5I3

I699, June 30. La Rochelle. Iberville to Monsieur - "Petit mémoire de tout ce que j'ay fait dans mon voyage de la coste de la Floride depuis mon depart de St. Domingue, qui fust le premier de Janvier." (Last few lines and signatures are autograph.) $C f$. Iberville to Pontchartrain, June 29, in Margry, IV. II6-I28. [ff. 514-5I7 I702, Apr. I2, Paris. "Mémoire sur l'établissement d'une colonie dans \begin{tabular}{l} 
l'Isle du Cap Breton." By Riverin. [ff. $5^{18-520}$ \\
\hline
\end{tabular} "Mémoire des Indes." Description of provinces, cities, etc., of Spanish America, with proposals for their capture. [ff. $5^{22-54 I}$ I684-1688. "Relation d'un voyage faict à la mer du sud." [ff. 542-6i 2 [1697?] July I2 . "Journal du P. Silvy depuis Bell'isle jusqu'à Portnelson." Ptd. in Relation par Lettres de l'Amérique Septentrionale, ed. \begin{tabular}{l} 
Rochemonteix, pp. xxxiii-lxiii. [ff. 6I 3-622 \\
\hline
\end{tabular}

Request by Daniel Masson and Richard Denys, Sieur de Fronsac, associates, to Seignelay for permission to engage in the salmon fishing. Signed, Denys.

Petition of Richard Denys to Seignelay against being disturbed in his concession of the Gulf of St. Lawrence. (Copy.) [ff. 624-625

"Mémoire contenant les droits de la France sur les pays situez entre la rivière des Amazones et la rivière d'Orénoc." [ff. 626-627v

Jurisdiction of the bishopric of Quebec. A document in three columns: I. “ Mémoire envoyé par M. l'Abbé de St. Vallier nommé à l'évêché de Québec." (This memoir is also at ff. 630 and 646.) 2. "Reflexions sur le mémoire de M. l'Abbé de Saint Vallier." (The same, excepting slight verbal variations, as on $\mathrm{ff} .630-630 v$.$) 3. "Clause extraite et traduite des Bulles de l'érection de$ l'évêché de Québec."

[f. 629

"Mémoire pour faire connaitre à Mgr. le Cardinal d’Estrées que tous les Missionnaires de la Nouvelle France y doivent travailler sous la dépendance de l'Evesque de Québec jusqu'à ce qu'on y érige d'autre Eveschez." Document in three parts: the first two parts, in parallel columns, consist of (I) the memoir itself, which is identical with the memoir above, f. 629, and below, f. 646 ; and (2) reflections on the memoir, nearly identical with the "Reflexions" above, f. 629; the third part, ff. 63I-63Iv, consists of additional comments not found on f. 629 . [ff. 630-63Iv
[

Gaudais to Bernou. Note asking for copy of the "déclaration du Roy touchant les esclaves étrangers que les habitants de Cayenne peuvent traiter le long de la coste". [f. 632

"Mémoire pour l'érection d'un Evesché dans les isles françoises de l'Amérique." (In hand of Bernou.) Cf. below, f. 669. [ff. 633-634

"Mémoire contenant les droits de la France sur les pays situez à l'ouest de la Rivière des Amazones." (In hand of Bernou, with marginal references to

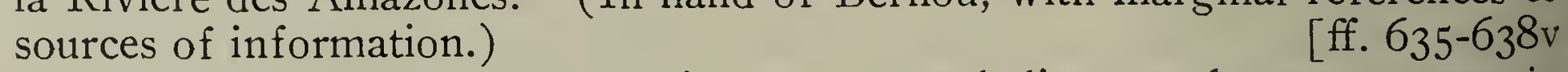

Notes on Peru and on various towns and distances between towns in South America. [ff. 639-64I
[fol

Notes on distances between the principal points of the route from Quebec to the mouth of the River Divine [Illinois].

[ff. 642-643 
"Proposition pour établir une colonie en terre ferme à 60 lieues au Nord de Panuco ou de Tampico, qui est la ville la plus septentrionale habitée par les Espagnols sur cette coste." (In hand of Bernou.)

"Mémoire pour faire connoitre à Mgr. le Cardinal D'Estrées 444-64, Same as on ff. 629 and 630, above, but without comments or reflections. "Mémoire sur les découvertes et commerce de l'Amérique [ff. 646-646v ale." (In hand of Bernou.) [ff. 647-648v Memoir of Radisson. In part identical with the rough notes above, $f$. 389. (Draft in hand of Bernou, with erasures, etc.) [ff. 649-650v
[ Draft of note by Bernou to "Votre Altesse Sérénissime", complaining that his compensation for services in Rome in the interest of the claim of Portugal to the colony of St. Sacrament has not been as promised.

[Df. $65 \mathrm{I}-65 \mathrm{Iv}$
"Discours sur la question si les sujets du Roy peuvent avec justice faire la guerre aux Espagnols en Amérique." (In hand of Bernou.) Cf. above, f. I94.

[ff. $653-654$

"Relation de la plus belle découverte que l'on ayt faite depuis plus de mil ans, par le Sieur Sagean, du Royaume de Caaniba . . . "Cf. the longer relation in Margry, VI. 93-162.

"Mémoire pour la Guyane ou France Equinoctiale."

[ff. $655-656 \mathrm{v}$

[ff. $657-667 \mathrm{v}$

" Mémoire pour l'érection d'un Evêché aux Isles françoises de l'Amérique Equinoctiale." $C f$. above, f. 633 .

"Mémoire sur l'afaire des Missionnaires Capucins du Brézil."

[ff. 669-67Iv

[ff. 672-673

Rough notes on the settlement of the northern coast of South America.

Rough notes on early history of Canada.

[ff. $674-674 \mathrm{v}$

"Suitte des Voyages de la Compagnie du Cap de Nord en terre ferme des Indes occidentales." [f. 676

"Mémoire sur les pays situez entre l'Isle de Cayene et la rivière des Amazones." (Draft in hand of Bernou.)

[ff. $677-678$

"Replique à la réponse faite au Mémoire présenté par l'Ambassade de France en Portugal touchant les droits du Roy Très Chrestien sur les terres situées au nord de la rivière des Amazones." (Draft in hand of Bernou.)

[ff. $679-683$

1017. - " Mémoires, letters et autres pièces sur la Colonie du St. Sacrement à La Plata, sur la Chine et la Turquie ... " (From the papers of Abbé Bernou.)

Memoir on the dispute between the Prince Regent of Portugal and the King of Spain respecting the colony of St. Sacrament on the River La Plata. (Draft in the hand of Bernou, followed by a fair copy.) [ff. 2I-24, 25-30
[

Series of sketch maps or tracings by Bernou. These appear to have been copied or traced from some general map of North America. They include Labrador and Hudson Strait; Canada from Lake St. John to Lake Huron; English colonies from Florida to Boston, with part of Lake Erie and of the Ohio ; Lake of the Sioux [Lake of the Woods], Lake Superior, part of the Lake of the Illinois [Michigan], and part of the Mississippi; Lakes Assiniboine and Christino; parts of the Mississippi, the Ohio, the Wabash, and the Missouri ; Florida (this sketch bears a reference to a map by J. B. L. Franquelin, Quebec, I686, "Amérique Septentrionale depuis environ 27 jusqu'à 62 degrez de latitude") ; Gulf of Mexico ; Arkansas river ; rivers of the "Outantes, Parouké et Chepoussea ".

[ff. I $33 \mathrm{v}-\mathrm{I} 43$ 
I455-I 506. Copies of seven papal bulls relating to the Portuguese colonies. These are all printed in Davenport, European Treaties, I., Docs. I, 2, 4, $7,6,8$, I I.

[ff. I $50-175 \mathrm{v}$

Letter relating to the mission in the affair of the colony of St. Sacrament. (Italian, n. d., n. s.)

[f. I9I

1053.-I686, May, Versailles. Edit du Roy portant Création et Règlement d'une Compagnie Générale pour les Assurances et Grosses Aventures de France en la Ville de Paris . . . ensemble l'Acte de Société fait en conséquénce par les Personnes nommées par Sa Majesté: Avec l'Arrest du Conseil d'Estat du 6 jour de Juin au dit $A n$ (Paris, Cramoisy, I686, I6 pp.).

[f. 18

1057. - A. M. le comte de Vergennes, à l'Occasion de la Paix. A poem. (Broadside, 4to.)

[f. 6

I698. Mar. I6, Paris. Renaudot to [Pontchartrain]. Hears that the English are planning settlements on the Mississippi and that 800 families of refugees expect to settle there. (A. L., n. s.)

"Je ne crois pas que . . . vous souffriez qu'on entre en hostilité ouverte comme serait celle de se saisir de la Louisiane découverte par des Français .. Car vous n'ignorez pas que si le Prince d'Orange a un titre pour ce pays lá, il est fondé sur l'épitre dedicatoire du livre du P. Hennepin, qui est un séraphique forfante s'il en fut jamais ..." [f. I8

1103.-Factum pour Philippe de Rigand, Marquis de Vaudreuil, Gouverneur Général du Canada, contre Armand de Rigaud, Sr. de Vaudreuil . . . ( 2 pp., fo.). Family matters. [f. I45

1306.-I694-I 703. Commissions as chevaliers of the order of St. Louis to the following: Frontenac, Feb. I 5, I697 (p. I 59) ; Beaujeu, Apr. I, I697 (p. I 7 I) ; Brouillan, May I, I698 (p. 218 bis); Vaudreuil, May I, I698 (p. 219); Marquis de Grimaldy, May 27, I698 (p. 221) ; Iberville, Aug. 24, I699 (p. 28I ) ; Surgères, Aug. 24, I699 (p. 283) ; de Ramezay, June I, I703 (p.602); Baron de Longueuil, July 3, I Z03) (p. 620).

I699-I703. Lists of pensions of chevaliers of the order of St. Louis.

[pp. 309, 335, 373, 45 I, 457, 493, 523, 647

1307.-I704-I705. Commissions as chevaliers of the order of St. Louis for the following: St. Ours, June I, I704 (f. 2) ; Levasseur de Néré, June I, I 704 (f. 4) ; Marquis d'Alongny, and de Langloiserie, June I5, I705 (f. I5); Galiffet, June I 5, I705 (f. I6v) ; Subercaze, Aug. 9, I705 (f. 48).

I702-I707. Lists of officers proposed for the order of St. Louis; lists of chevaliers, etc., in which appear names of those serving in America.

$[$ ff. I $6,136,267,28$ I 


\section{MÉLANGES DE COLBERT.}

The collection of 454 volumes and cartons, numbered I-416, which comprise the Mélanges de Colbert, was acquired in part in I732, when the library of Colbert was purchased for the Bibliothèque du Roi, and in part by confiscation at the time of the Revolution. The collection iswin four principal parts, as follows: (I) The first part, nos. I-IOO, in I05 volumes, is composed of originals and transcripts mostly of the seventeenth century; the documents are of the greatest variety and relate to religious, diplomatic, administrative, and judicial history. They include the minutes of the letters of Mazarin, I646-I660, the memoirs of Colbert and his son Seignelay, and documents relating to England, Spain, America, and other countries. (2) The second part, acquired in the Revolution, is the correspondence of Colbert, I66I-I674, in I I volumes, numbered IOI-I76 bis. These volumes contain chiefly the letters addressed to Colbert, but they also include a considerable number of minutes or drafts of letters by Colbert and Seignelay. They were originally bound in green and were long known and referred to as the volumes verts. They have been exploited by Pierre Clément, in Lettres, Mémoires, et Instructions de Colbert (Paris, 8 vols., I862-I882), and by G. B. Depping, in Correspondance Administrative sous le Règne de Louis XIV. (Paris, 4 vols., I850-I855). (3) The third part, I 66 volumes, nos. I $77-343$, is composed chiefly of administrative and financial documents, while (4) the fourth part, 76 cartons, nos. 344-4I6, known as the Chartes de Colbert, is composed of charters and diplomas. An excellent and detailed catalogue of the collection has been published by the Bibliothèque Nationale: Catalogue des Manuscrits de la Collection des Mélanges de Colbert, by Charles de La Roncière and Paul M. Bondois (Paris, 2 vols., I920, I922). The first volume contains a brief history and general description of the collection (pp. I-xvi), upon which this paragraph is based, while a very complete index is in vol. II. See also L. Delisle, Cabinet des Manuscrits, I. 439-486.

31.-I606. "Relatione di Spagna ... " Includes, ff. 6ov-6iv, an account of the Spanish Council of the Indies, its organization, officers, salaries, etc. French translation by the "sieur de Beaulieu, Heües O'Neil" [Adrien Baillet], of G. Gardyner, Description of the New World (London, I65I). Cf. below, 38, and above, MSS. Fr. 19032.

"Proposition pour faire une Compagnie en France pour les Indes Occidentales", by Blaeu. An engraved map accompanies this memoir: Insulae Americanae in Oceano Septentrionali, cum Terris adiacentibus. Amplmo Prud ${ }^{m o}$ Doctmoq'e Viro D. Alberto Conradi vander Burch . . . Amsterdamensis Senatori ... Tabulam hanc inscribit Guiljelmus Blaeu.
[ff. 424-429 dans l'Amérique et sur leur-retour en Europe." Account of routes and ordinary practice followed by the Spanish treasure fleet. [ff. 434-440
[

"Discours sur les Entreprises qu'on peut former sur les places de La Terre ferme et sur les Isles du Golphe Mexique."
[ff. 442-45 Iv I669. "Relation de la prise"des forts de Portebelles et le pillage de la ville par les flibustiers anglois." [ $456-465$
[ff. 456 la 
I624, Aug. 31, The Hague. The States General to the Sieur de Caron. Account of the capture of [Bahia de] Todos Santos in Brazil. (Translation.) [ff. $466-468 \mathrm{v}$

1658. "Relation des voyages du Sr. d'Accarette dans la Rivière de la Platte..." Cf. An Account of a Voyage up the River of Plata, and thence over land to Peru, by "Mons. Acarete" (London, r698). [ff. 470-498v [Post I658,] "Proposition du sr. d'Accarette pour la conqueste de Bon-
nes-Ayres. . 500-506 Aires.

Alternative proposal by the Sieur d'Accarette for the pillage of Buenos

I666, Nov. 5, Madrid. News of disturbances in Peru and Chile.

[ff. 5 I6-5 I9

[ff. $522-524$

I665. "Relation des Indes occidentales, par Balthazar Pardo de Figueroa."

I67I, June 5, Nov. 22, Guadeloupe. Gov. Du Lion to [Archbishop of Rouen]. Conduct of the Compagnie des Indes, etc.

[ff. 593-620v

Description and historical notes on the Caymans, Trinidad, and Jamaica.

[ff. $622-626$

1669. “Mémoire des choses qu'a Raporté l'homme de Mons'r Du Bois, Gouverneur de Ste. Croix, à son Retour de Porterique la fin du mois d'avril dernier, I669."

[ff. $632 \mathrm{v}-633$

1668. French translation of commissions from the governor [Sir Thomas Modyford] of Jamaica to English filibusters, and to Benjamin Sergent (Oct. 28).

r668, Sept. I8. Copy of commission from Gov. Ogeron of Tortuga, to Capt. Grifin.

[1668.] "Le Commandant du fort de La pointe d'Araya au Sieur de Beaulieu Capitaine du Vaisseau du Roy L'Infante destaché de L'Escadre avec ordre de S'approcher de la Terre Ferme et particulièrement de Comane pour y faire de L'Eau." (Copy, Spanish.) "f. $635 \mathrm{v}$ I668, Nov. 19-1669, Jan. I3. "Extraict du Journal du Sieur Beaulieu . " " “Mémoire d'un homme qui venait de Corassal [Curaçao]

[ff. $638 \mathrm{v}-639$

38.-Duplicate of 31, ff. 3 I4-422.

[f. 548

48.-Transcripts of English documents, authenticated by S. Killingworth: commission to Edward D'Oyley, governor of Jamaica; r66o, Dec. I, commission and instructions to "Council for Foreign Plantations" (Cal. St. Pap., Colonial, I 574-I660, p.492) ; I626, Mar. I, commission to George Yeardley, governor of Virginia, and to members of the council (ibid., p. 77) ; 1660, Nov. 7 , commission and instructions to Council of Trade (ibid., p. 490); r66o, Aug. r7, commission to John Dawes, secretary of Barbados; I660, Aug. 2, commission to Francis Cradock, provost marshal general in Barbados (ibid., p. 487) ; r667, Jan. 3, commission to Lord Willoughby, captain general and governor in chief of the Caribbee Islands (id., I66I-1668, no. I372); I661, Sept. 27, commission of Thomas Breedon, governor of Acadia and Nova Scotia ( $c f$. ibid., no. 189).

[ff. $232-403$

51-52c. Minutes of the correspondence of Cardinal Mazarin, I654-166r, 6 vols.-Ptd. by A. Chéruel and G. d'Avenel, Lettres du Cardinal Mazarin pendant son Ministère, in Documents Inédits.

53. Transcripts of English or Latin documents, authenticated by S. Killingworth.-I669, May 8, grant to Earl of St. Albans et al., Virginia (Cal. St. Pap., Colonial, I669-1674, no. 63) ; 1670, Nov. I, grant to Duke of Albemarle, Ba- 
hama Islands (ibid., no. 3I I) ; I665, June 30, second charter to Lords Proprietors of Carolina (id., I66I-I668, no. IoI I) ; I664, Mar. I2, Duke of York's patent (ibid., 110. 685); 1630 , Dec. 4, patent of incorporation of Company of Adventurers for the Plantation of the Islands of Providence, etc. (Cal. St. Pap., Colonial, I574-1660, p. I23); I620, Nov. 3, patent incorporating the council at Plymouth (ibid., p. 24) ; I637, Nov. I3, grant of Newfoundland (ibid., p. 260) ; I666, Dec. 20, patent to Sir James Modyford, lieutenant governor of Island of Providence (id., I66I-I668, no. I358) ; I632, June 20, patent of Maryland (id., I 574-I660, p. I 52) ; I627, Jûly 2, first grant to Earl of Carlisle, of Caribbee Islands (ibid., p. 85) ; 1628 , Feb. 20 [?], grant of Trinidad to Earl of Montgomery (ibid., p. 87).

84. Collection of memoirs drawn up by Jean Baptiste Colbert, Marquis de Seignelay, and addressed to Colbert, during the former's sojourns at La Rochelle and Rochefort, I670, and at Toulon and Marseilles, I67I, and during his travels in Italy, England, and Holland, I671.-While the memoirs in this volume are not of direct interest for the purposes of this Guide, they have a considerable indirect interest, especially the description of the arsenal at Rochefort, and the very detailed report on the English navy. A few lists of vessels are also to be noted (ff. I I5, I84, I90), and especially (f. II7v) a description of Le Jolly (La Salle's vessel?), under construction in I670 (200 tons, length of keel, I I $8 \frac{1}{4} \mathrm{ft}$., length over all, I $43 \mathrm{ft}$., depth, I9 ft., beam, $39 \frac{1}{3} \mathrm{ft}$; ; pierced for Io guns). Finally should be noted a document by Colbert which contains interesting details respecting the administration of the marine: "Instruction pour mon fils [Seignelay] pour bien faire la première commission de ma charge" ( ff. 216-233).

101. Letters to Colbert, I649, I656-1660.

1656, Jan. 19, 23, Feb. 9, 27, Mar. I, 30; 1658, Dec. I8, Brouage or La Rochelle. [Charles] Colbert de Terron [intendant général de la Marine et des Ports du Ponant] to Colbert. References to vesssels engaged in the Newfoundland fisheries.

105. Letters to Colbert, Nov.-Dec., I66r.

$[$ ff. 4,8, I $5,19,22,39,328$

I661, Oct. 27, La Rochelle. Paul Thévinin [merchant] to Bilbaud. English encroachments on Newfoundland fisheries, Acadia, mouth of the St. Lawrence. (Ext., enclosed with Bilbaud to Colbert, Nov. 4, f. 24.) [f. 26 I66I, Nov. I8, Brest. [Abraham] Du Quesne to [Colbert]. Relating to two vessels from Newfoundland at Belle Isle. (A. L. S.) Ptd. in Jal, Du Quesne et la Marine de son Temps (Paris, I873), I. 243. . [f. I28

106. Letters to Colbert, Sept., I66I-1666.

I66I, Nov. 24, Dec. 8, I 2, 19, 26; I662, Feb. 28, Mar. 8, I5, 23, Apr. 2, May I4, I7 ; 1663, Mar. 9, Nov. I I, La Rochelle or Brouage. Colbert de Terron to Colbert. English prisoners sent to La Rochelle by Le Borgne for trading with Indians in Acadia ; New foundland fisheries ; Acadia ; interest of local commerce in fisheries; recommending despatch of vessels to Newfoundland and Acadia to carry instructions to La Tour and Le Borgne, and to regulate boundaries with the English; recommendations of various officers and commanders of vessels; troops and supplies for Canada, etc. (All A. L. S. or L. S.)

[ff. $328,348,352,358,372,4$ I I, 4I 7,42 I, 425, 430, 436, 482, 537, 556

I665, Sept. 7, Collège de Clermont. Father Paul Ragueneau to News from Quebec; reception of de Tracy, troops, expenditures, heavy snows of previous winter, solar and lunar phenomena. (A. L. S.) [ff. 6I7-6I8

"Liste des prisonniers Anglois qui sont en France." Havre, Calais, Honfleur, and Dunkirk.

[f. 762 
107. Letters to Colbert, Jan.-Mar., I662.

I662, Mar. 20, London. Comte d'Estrades to Colbert. Negotiations over fisheries, price of slaves, etc. (A.L.S.)

[ff. I8-I8v

I662, Mar. I I, Harbor of La Pallice; Feb. 6, Brouage. Duc de Beaufort [François de Vendôme] to Colbert. References to vessels going to Newfoundland, and recommendation that Newfoundland sailors be detained for service on the king's vessels.

108. Letters to Colbert, Apr.-May, I662.

[ff. $277,43 \mathrm{I}$

I662, Apr. 9, Brouage. Colbert de Terron to Colbert. Opposition of the "maison de Vendosme" to the king's plans for Newfoundland. (A. L. S.)

C $[\mathrm{ff} .87-88 \mathrm{v}$

Comte d'Estrades to Colbert. Desires to give him a map of Canada "fort bien faite". (A. L. S.)

109bis. Letters to Colbert, July, I662.

[f. 178

Letters from [Antoine] Lefebvre de La Barre (ff. 684, 966), not relating to American affairs.

I662, July I7, Brouage. [Pierre Chertemps] de Seuil [commissaire général de la marine] to Colbert. Sends accounts of expenditures for vessels leaving for Quebec and Placentia, and of the cargo of each vessel. (A. L. S.)

[f. 845

r662, July i7, On board the Aigle d'Or, Ile de Ré. Capt. de La Rochette Gargot to Colbert. Claims for subsistence of passengers fed at his table on voyage to Placentia and Quebec. (A. L. S.)

111. Letters to Colbert, Sept., I662.

I662, Sept. I8, Placentia. Du Perron Talour, commandant, to M. Picon. Advantages of the port of Placentia, situation of the country, etc. [ ff. $322-323 \mathrm{~V}$ I662, Sept. 28, London. Comte d'Estrades to Colbert. Conduct of governors of Martinique and Guadeloupe; administration of the islands.

112. Letters to Colbert, Oct., I662.

[ff. $478-48$ I

I662, Oct. 6, St. Jean de Luz. De [Sauba] Haristéguy, capitaine entretenu de la marine, to Colbert. Learns that the port of Placentia has been burned "par l'intelligence et motif secret qu'il ont eu, par leur patron basques, que de bretons, par leurs bourgeois". (A. L. S.)

I662, Oct. I2, London. Comte d'Estrades to Colbert. Has secured various memoirs relating to the Antilles; complaints against the governor of Martinique.

[ff. I08-I08v

I662, Oct. I6, 30, Brouage. De Seuil to Colbert. No news of arrival of Gargot. Low state of commerce, advantages of La Rochelle as commercial port; supplies for Newfoundland.

112 bis. Letters to Colbert, Nov., 1662.

[ff. 4IO-4II

I662, Nov. 3, La Rochelle. Paul Thévinin to Colbert. Commerce, reference to Canada.

[ff. $544-545$

I662, Nov. 6, London; Nov. 21, Gravelines. Comte d'Estrades to Colbert. Asks that commission as viceroy of America be delivered to him in order that he may take the oath of office; reports of ill success of Gov. d'Avaugour in Canada, who should be replaced: "Je vous supplie de continuer à protéger ce pauvre pays."-It is so easy to be deceived that he prefers not to propose anyone for Canada.

113. Letters to Colbert, Dec., I662.

[ff. 57 I $-573,873-873 \mathrm{v}$

I662, Dec. 23. Alexandre de Prouville, Marquis de Tracy, to Colbert. Personal financial difficulties.

[ff. 642-643 
I662, Dec. 29, on board the Aigle d'Or, harbor of La Rochelle. La Rochette Gargot to Colbert. Asks reimbursement for subsistence furnished on return voyage from Canada.

114. Letters to Colbert, Jan.-Feb., I663.

[1663], Feb., Placentia. Du Perron Talour to Colbert. Unfortified state of Placentia, excellence of harbor, and proximity of English settlers.

115. Letters to Colbert, Mar.-Apr., I663.

[ff. 566-567

I663, Mar. 8, The Hague. Comte d'Estrades to Colbert. If Canada and the islands were out of the hands of their governors, of whom the inhabitants greatly complain, it would be possible to induce wealthy persons to engage in commerce with these colonies.

115bis. Letters to Colbert, Apr.-May, I663.

I663, Apr. 23, Rouen. H. de Rassent to Colbert. Can furnish men for the American colonies to any number desired, without violence and at a moderate price; also arms, tools, equipment, etc.

[ff. $652-653$

1663, May Io, Brouage. De Seuil to Colbert. The two vessels for New France are ready to sail, but are detained by bad weather.

[ff. 923-924 I663. May I7, La Rochelle. Gaudais Dupont [commissaire in Canada] to Colbert. Has delivered letters to the Bishop of Petraea [Laval] and M. de Mézy; passengers are to embark on Saturday and vessels will sail early next week.

[ff. IO32-I033

I663, May 18, Rouen. Chevalier de Clerville to Colbert. Results of his investigations respecting the commerce of the various ports. Ptd. in G. B. Depping, Correspondance Administrative sous le Règne de Louis XIV., III. 335 .

[ff. IO 34-I035

I663, May 25, 30, La Rochelle. François [de Laval], Bishop of Petraea, to Colbert. Thanks for support of religion in Canada.-Letter of farewell on point of sailing; obliged to leave horses behind. (A. L. S.) [ff. I I60, I 200

116. Letters to Colbert, June-Aug., I663.

i663, June 4, 6, I I, Brouage. De Seuil to Colbert. Sailing of vessels for Canada with 300 passengers ; transmits accounts and inventories of supplies.

[ff. 80, 91, I 56

I663, Mar. I [4?], Martinique. La Paÿre to Dolu. Suspects the Aigle d'Or, which has arrived, to have been freighted for the account of [Nicolas] Fouquet.

[ff. I I 4- I I 5

I663, Aug., Dieppe. Échevins of Dieppe to Colbert. Difficulties of commerce; reasons for control of West India trade by the Dutch. [ff. 428-430

116bis. Letters to Colbert, June-Aug., I663.

I663, Aug. I8. [Louis de] Bechameil to Colbert. Relating to an enterprise in Terre Ferme [Central America].

[f. 764

I663, Aug. 23, The Hague. Conte d'Estrades to Colbert, with letters of Dumesnil and Du Coudray relating to Guadeloupe.

117. Letters to Colbert, Sept.-Oct., I663.

I663, Sept. 27, Oct. 4, The Hague. Comte d'Estrades to Colbert. West: India affairs; privilege of establishing [sugar] mills in the islands for the Sieur François de Martin, a merchant of Amsterdan.

117 bis. Letters to Colbert, Oct., I663.

I663, Oct. 24, Brouage. Colbert de Terron to Colbert. American affairs. measures for assuring possession of Islands of America, preparations for voyage of Marquis de Tracy.

iff. 885-886v fairs.

I663, Oct. 25, The Hague. Comte d'Estrades to Colbert. American af- 
I663, Oct. 28, La Rochelle. Le Borgne to Colbert. Complains of capture and imprisonment at Boston of his son, Alexandre Le Borgne; English taken prisoners by his son Joseph Le Borgne.

118. Letters to Colbert, Nov., I663.

[ff. $997-998$

I663, Nov. Hubert to Colbert. D'Estrades has asked for orders relating to request of Newfoundland fishermen of Havre and Dieppe for passports.

[ff. $23-24$

I663, Nov. 3, Dieppe. [J. de] Champigny to Colbert. Affairs of Guadeloupe; calumnies circulated by his brother-in-law, Houel. [ff. 94-95

I663, Nov. 6, Bayonne. Michel Dantèz [host of Colbert at Bayonne] to Colbert. His voyage to America; compelled to put in on the New England coast; news of death of M. de La Tour ; destruction of Fort Royal and seizure of Acadian coast by English.

[ff. I 5.3-I 54

I663, Nov. 8, The Hague. Comte d'Estrades to Colbert. Receipt of brevet for sugar-mills (see above, 117), which he has forwarded to the burgomaster of Amsterdam; approves choice of Marquis de Tracy as lieutenant general of America.

[ff. I 89-Igo

I663, Nov. 9, Dunkirk. [N.] Nacquart to Colbert. His secret mission to Holland to gather information respecting the East and West Indies.

118bis. Letters to Colbert, Nov.-Dec., I663.

[ff. 205-207

I663, Nov. 25, Brouage. Colbert de Terron to Colbert. Canadian ship timber; troops to accompany de Tracy to America.

[ff. 605-608

I663, Nov. 29, The Hague. Comte d'Estrades to Colbert. Will give all possible information to Nacquart ; Canadian affairs ; d'Avaugour has spent two days with him; need of strong men to carry on war against Indians and to govern inhabitants.

[ff. 689-692

I663, Dec. 2, Honfleur. [J. de] Champigny to Colbert. Calumnies and misdeeds of Houel in Guadeloupe.

[ff. $775-776$

I663, Dec. 3I, La Rochelle. Marquis de Tracy to Colbert. Will expedite his departure [for America].

119. Letters to Colbert, Jan.-Feb., I664.

[f. 1076

I664, Jan. 7, La Rochelle. G. d'Alméras [chcf d'cscadre] to Colbert. Résumé of instructions to Marquis de Tracy for his tour of duty in America, and preparations for the accompanying expedition.

[ff. 33-34

I664, Jan. 7, Feb. 4, 8, I 2, I 7, 28, La Rochelle or Brouage. Colbert de Terron to Colbert. Preparations for expedition of de Tracy and La Barre.Troops.-Precautions to be taken in sending troops to America, and in choice of their commander, who must be able to maintain discipline and who must not arouse opposition of the Jesuits; suspicions of Dutch and English must not be aroused; qualifications for position of intendant in Canada.- Small hope of interesting merchants in East India trade; fleet for Cayenne to sail shortly.Fleet for America ready to sail, but is delayed by contrary winds.-Fleet still delayed.

[ff. 4I, I 28, I 80, 273, 370, 508

I664. Feb. 7, I7, I8, La Rochelle. Du Lion to Colbert. Expects to embark with de Tracy; asks for reimbursement of expenditures.-Letter of farewell.-Review of the four companies of soldiers on the Brèze; vessel has 540 on board; soldiers having infectious diseases have been placed ashore.

[ff. I68, 368, 393

[I664] Feb. I I, On board the Brèze, [La Rochelle]. [Antoine Lefebvre] de La Barre to Colbert. Letter of farewell; praise of Colbert de Terron; "Nous avons... toutes les choses nécessaires pour commencer une des plus grandes affaires que les français ayent jamais embrassées." [f. 275 
119bis. Letters to Colbert, Mar., I664.

I664, Mar. 2, Xaintes; Mar. 5, I6, 30, Brouage. Colbert de Terron to Colbert. The fleet left at noon, on Mardi gras.-Introducing the Sieur Dumesnil Perronne, who has long been the general agent of the Compagnie du Canada, in Quebec.-Summary of vessels, men, supplies, etc., composing the American expedition; opinion of La Barre; need for a commander in America who is "choisy et donné par le Roi"; greater need of women and provisions than of men.- Refusal of the Sieur Le Gaigneur to take a horse and a mare to Quebec.

[ff. $640,732,917$, I2I 5

I664, Mar. I2, 14, Dunkirk. Nacquart to Colbert. Respecting project of a "Compagnie des Isles de l'Amérique et costes de Guinée.".-Sends charter of Dutch West India Company.

[ff. 842,872

I664, Mar. I8, 20, Funchal, Maderia. M. de La Barre to Colbert. Praise of French consul at Funchal.-Agreeable voyage of 18 days to Madeira; English captain reports that 4 months ago there were not 40 Flemings at Cayenne.

120. Letters to Colbert, Apr., I664.

[ff. 974, 1022

I664, Apr. I6, Dieppe. Echevins of Dieppe to Colbert. “. . plusieurs de nos négociants s'efforceront d'augmenter le commerce dans l'Amérique s'il y a lieu à la diminution des droicts qui est leur plus grand obstacle."

[ff. 200-20I

1664, Apr. I6, Rouen. [L.] Fermanel [d'Épinay] to Colbert. "Je crois que l'on ne vous a pas donné bon advis lorsque l'on vous a conseillé de joindre le Cap de Vert et Senégal et Canada à la compagnie de Cayenne." [ [ff. 204-205 1664, Apr. I6, Bayonne. Echevins of Bayonne to Colbert. Protection and extension of cod and whale fisheries.

[ff. 2IO-2II

121 bis. Letters to Colbert, June, I664.

1664, June 16, Martinique. Du Lion to Colbert. News of the expedition in the West Indies.

[ff. $582-583$

1664, June 21, Dieppe. Échevins of Dieppe to Colbert. Difficulty of securing subscriptions to the Compagnie des Indes Orientales; merchants of Dieppe are chiefly interested in American commerce, and would subscribe heavily to a West India company.

[ff. $777-778$ I664, June 26. Anonymous letter. Harmful effects of separate commercial companies of Senegal, Canada, etc.; need of general companies. [f. 940 I664, June 28, 30, Paris. [L. de] Bechameil to Colbert. Affairs of the Compagnie des Indes Occidentales; purchase of goods to send to the islands; reimbursement of proprietors of islands; affair of St. Christopher.

[ff. IOIO, 1077

I664, June 30, Paris. J. Bellettes to Colbert. Information relating to the Dutch East and West India companies.

122. Letters to Colbert, July, I664.

I664, July 3, 21, 22, Paris. [L. de] Bechameil to Colbert. West Indies, arrival of de Tracy at Martinique, interruption of Dutch commerce by fear of

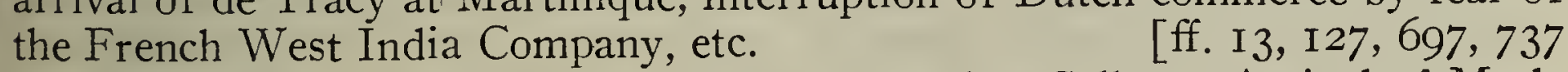
1664, July 22, Paris. [Louis de] Matharel to Colbert. Arrival of M. de La Barre at Cayenne and of de Tracy at Martinique; interruption of Dutch commerce in the islands.

123. Letters to Colbert, Aug., I664.

I664, Aug. I 5, Cayenne. M. de La Barre to Colbert. State of the country; English claims to Surinam.

[ff. $349-359 \mathrm{v}$ 
I664, Aug. I6, Bayonne. [P.] de Cheverry to Colbert. Prejudice to the sugar industry of the West Indies caused by the severe orders of the King of Spain against contraband commerce.

I664, Aug. 25. Rousseau to Colbert. Having lent his name 365-366v for the creation of the Compagnie name to Mazan West India Company.

123bis. Letters to Colbert Aug. Colbert from the éching Colbert from the échevins of Rouen (f. 667), Lagarde de Belin, Amsterdam (ff. 693, 697, 700, 965), Du Fresne, Würzburg (ff. 894, I033), and the Comte d'Estrades, the Hague (f. IO2I), relating to the organization of the Compagnie des Indes Occidentales, trade with the West Indies, etc.

124. Letters to Colbert, Oct., I664.

I664, Oct. I4, I8, Paris. Father Paul Ragueneau to Colbert. News from Canada; war with Iroquois.

[ff. $28 \mathrm{I}, 356$

I664, Oct. I7, Honfleur. Thierry to Colbert, with memoir. Repairs to port necessary for equipment of the vessels of the Compagnie des Indes Occidentales; exactions of the admiralty of Normandy with respect to registrations of permits.

[ff. $34 \mathrm{I}-343 \mathrm{~V}$

I664, Oct. I I, La Rochelle. [Louis Rouer] de Villeray [member of the Conseil Souverain of Canada] to Father Paul Ragueneau. Disputes between Gov. de Mézy and the council.

125. Letters to Colbert, Nov., I664.

[ff. $357-358 \mathrm{v}$

I664, Nov., Nov. 6, The Hague. Comte d'Estrades to Colbert. Question of restitution of Acadia; sends Le Borgne to furnish information to Colbert. - Merchants of Zeeland make proposals for supply of slaves to the islands.

I664, Nov 7 Paris. Father Paul Ragueneau to Colbert. Capture [ff. I43 Netherland by the English. advice of for the destruction of the Iroquois. Groseilliers in New Eotiate with the English I664, Nov. 9, Rouen. [J. B.] Voisin de La Noiraye to Colbert. Newfoundland and Acadian fisheries carried on by the inhabitants of Dieppe.

I664, Nov., Middelburg. Health certificates of [ff. 258-259v going to the West Indies.

I664, Nov. 22, Saumur. Colbert de Croissy to Colber. 370,754 America by an agent of the Colbert de Croissy to Colbert. Recruiting for sauniers there.

126. Letters to Colbert, Dec., I664.

I664, Dec. I, St. Malo; Dec. I9, Port Louis. Colbert de Terron to Colbert. References to Canadian affairs, supplies for de Tracy, etc. [ff. 39, 455
[ I664, Dec. 4, I I, The Hague. Comte d'Estrades to Colbert. Vessels loaded at Amsterdam by Lagarde de Belin for the Compagnie des Indes.-The new company must have I2O vessels for the service of the Islands of America.

I664 Dec 9, Bordeaux. Delachèze to Colbert. Participation iff. I 29, 266 Compagnie des Indes Occidentales.

I664 Dec Du Fresne [diplomation. 228-229v projects of the Elector of Mainz; despatch of emissaries to America.

I664 Dec 25. Amsterdam. 368-370 vessels for the West India Company; facilities secured from the Stauipment of 
127. Letters to Colbert, Jan.-Feb., I665.

I665, Jan. I, II, 25, Feb. I, La Rochelle, Brouage, or Tonnay-Charente. Colbert de Terron to Colbert. Funds for troops in Canada.-News from Placentia ; prosperity due to the Compagnie des Indes Occidentales.-Canadian squadron.-Supplies and munitions for Canada.

[ff. 2I, I I 2, 297, 476 1665, Feb. Gaudais Dupont to Colbert. Favors requested for himself and for his son in Canada.

127bis. Letters to Colbert, Feb., I665.

[ff. $445-446$ I665, Feb. I 5, Poitiers. Colbert de Croissy to Colbert. Seeks an intendant for the troops in Canada. I665, Feb. 26, Bordeaux. [Cl.] Pellot to Colbert. Visit from [ff. 818-8I9 de Sertière [Salières?], colonel, who goes to Canada. [ff. 847-848v I665, Feb. Proposals of Ponthon, Rémy and Co. of Dunkirk, and letters from Nacquart and [Bivel] de Montpezat, respecting cod fisheries to be carried on from Dunkirk.

128. Letters to Colbert, Mar., I665.

[ff. 1047, 1067-1073 I665, Mar. 4, Bordeaux. [J.] Lombard to Colbert. Vessels equipped for Newfoundland.

[ff. I 22-I $23 \mathrm{~V}$ I665, Mar. I6, I9, Tonnay-Charente. Colbert de Terron to Colbert. Preparations of the fleet for Canada. I664, Feb. 22, Whitehall, London, Royal Proclamation respe ous insults and injuries inflict, London. Royal Proclamation respecting various insults and injuries inflicted by the Dutch East and West India companies, and by other subjects of the United Provinces.

[f. 387 I665, Mar. I 5, Würzburg. Du Fresne to Colbert. Plans of collaboration in colonial enterprises between France and the German electors. [ff. 39I-394v 1665, Mar. 22, La Rochelle. Delaroche St. André to Colbert. La Gigaudière commands the St. Sébastien; other vessels for Canada.

128bis. Letters to Colbert, Mar.-Apr., I665.

[f. 5 I 8 1665, Apr. I3, I9, 27, La Rochelle or Tonnay-Charente. Colbert de Terron to Colbert. Equipment of vessels for Canada. [ff. 850, 938, I I 23 1665, Apr. I4, 24. Du Fresne to Colbert. Plans of the Elector of Bavaria for a colony in America.

[ff. 858-1054 1665, Apr. I7, 24, Middelburg. Janot to Colbert. Vessels of the [Dutch $\rceil$ West India Company.

[ff. 898, I048 1665, Apr. 24, Guadeloupe. Du Lion to Colbert. Establishment at Dominica, de Tracy, vessels of the company, etc.

129. Letters to Colbert, May, I665.

[f. 1070 I665, May. Letters from Vincent and Hubert. West India affairs.

[ff. I 3,57 [1665, May.] Petition addressed to the king by the widow of Jean de Lespiné respecting the concession to her late husband in Guadeloupe. [f. 44 I665, May 3, Io, Du Fresne and Elector of Mainz to Colbert. Colonial projects of the later.

[ff. I06, 3І 3

I665, May 4, Io. La Rochelle. Colbert de Terron to Colbert. Embarkation of troops for Canada; arrival of fleet in the West Indies.-Equipment of vessels for Canada; requests of Compagnie des Indes Occidentales and of "les bourgeois de Québec", respecting cargoes.

1665. May 7, Amsterdam Claude Blot to Colbert, with specting seizure by the English of his vessels fitted out for the

665. May I Paris [Guillaume] [ff. 226-228v Zeeland vessel coming from the West Indies and seeking refuge in the Garonne. 
129 bis. Letters to Colbert, May, 1665.

1665, May I8, La Rochelle. Micheau to Colbert. His arrival from America; advice respecting Guinea. [ff. $530-53$ I

1665, May 18, 28, 31, La Rochelle or Tonnay-Charente. Colbert de Terron to Colbert. Departure of vessels for Canada; recommends Capt. Micheau; equipment of vessels for Canada and for the Compagnie des Indes Occidentales. [ff. $536,784,857$

130. I.etters to Colbert, June, I665.

1665, June 7, Rouen. [Charles de Ste. Maure, Marquis de] Montausier to Colbert. Plans for participation of merchants of Dieppe in the Compagnie des Indes Occidentales; whale and cod fisheries.

[ff. II 3 -I I $4 \mathrm{v}$ 1665, June I5, I8, Tonnay-Charente. Colbert de Terron to Colbert. The Canadians there present are not in accord as to the purchase of a vessel.Equipment of vessels for Canada; prizes.

[ff. 202,233 Boston. 1665, June I8. Id. to de Lionne. Capture of an English flute bound for

\section{0bis. Letters to Colbert, July, 1665.}

[f. 234

I665, July 2, Madrid. Archbishop of Embrun to Colbert. Mines in New Spain; quicksilver on captured Spanish vessels.

[ff. $574-575 \mathrm{v}$ I665, July 3, St. Germain. [P.] De Cheverry to Colbert. Cod and whale fisheries carried on by the Basques.

[ff. $588-589 \mathrm{v}$ I665, July 10, Bordeaux. [François d'Épinay] de St. Luc to Colbert. French vessels returning from Newfoundland fisheries captured by English.

[ff. $669-670 \mathrm{v}$

I665, July I7, 3I, Bordeaux. [J.] Lombard to Colbert. Departure for America of vessel belonging to the Compagnie des Indes Occidentales.Return of the vessels from New foundland. I665, July 25. [L.] Bechameil to Colbert. Revolt in Martinique.

[ff. 799, 1089

[ff. $905-906 \mathrm{v}$

I665, July 26, Tonnay-Charente. Colbert de Terron to Colbert. Newfoundland fishermen from Nantes at Bayonne.

131. Letters to Colbert, Aug., I665.

1665, Aug. 8, Paris. [Nicolas] Le Camus to Colbert. Establishment of manufacture of beaver cloth.

[f. 266 1665, Aug. 16, Tonnay-Charente. Colbert de Terron to Colbert. Arrival of de Tracy in Canada; death of Mézy; flutes for the Canadian service. [f. 437 131 bis. Letters to Colbert, Aug.-Sept., I665.

I665, Aug. 25, Dieppe. Echevins of Dieppe to Colbert. Refusal of the Compagnie des Indes Occidentales to pay duties.

[f. 616 I665, Aug. 3I, Quebec. Officers of the troops in Canada to Colbert. Appreciation of good offices of M. de Villepars, commanding the vessel on which they have come to Canada.

[ff. 814-815v

1665, Aug. 31, Sept. I4, 21, 27, La Rochelle or Tonnay-Charente. Colbert de Terron to Colbert. News from de Tracy, Courcelles, and Talon. Arrival of vessels in Canada; supplies to be sent them.-Return of Le Gaigneur, who transported the troops to Canada; arrival of vessels at Tadoussac.-Culture of flax, and shipbuilding in Canada. [ff. 820, I063, II 29, II 78 I665, Sept. I7. Father Paul Ragueneau to Colbert. Return of vessels from Canada; boats for the expedition against the Iroquois; fort constructed by de Tracy on the Richelieu; siege of Three Rivers by the Iroquois.

[ff. I093-I084v 
133. Letters to Colbert, Nov., I665.

1665, Nov. 6, Middelburg. Janot to Colbert. Recommendation of Ogeron; establishment of Santo Domingo.

I665, Nov. 8 , I6, 22, 30, Tonnay-Charente or La Rochelle. Terte Terron to Colbert. Return of the Aigle d'Or from Quebec; praise of Villepars.-Passage of the officers of the regiment of Carignan to Quebec.-Return of the St. Sébastien from Quebec; bad quality of provisions sent to Talon. - Expenditures to be incurred for Canada.

[ff. I8I, 364, 51 I, 751 1665, Sept. 20, Quebec. Marquis de Tracy to Colbert de Terron. Praise of Villepars and Chamot.

[f. I 82

1665, Sept. I8, Quebec. Talon, intendant, to Colbert de Terron. Praise of Villepars and Guillon; Denis sent to the lead mine at Gaspé. [ff. I84-I85 1665, Nov. 28. Father Paul Ragueneau to Colbert. News from Canada: wreck of La Paix; militia and boats for the expedition against the Iroquois; forts; crops ; Indian raids west of Quebec; missionaries in the west; Acadian mission. (A. L. S.)

134. Letters to Colbert, Dec., 1665.

[ff. 699-700v I665, Dec. 4. Father Paul Ragueneau to Colbert. News of Canada by the Jardin de Hollande.

[f. Iog 1665, Dec. 7, La Rochelle. Colbert de Terron to Colbert. Memoir submitted by Le Borgne du Coudray, commandant in Acadia.

134 bis. Letters to Colbert, Dec., I665.

[ff. $230-234 \mathrm{v}$

I664 [sic], Dec. I3, La Rochelle. De Chambré to Colbert. His departure for America as general agent of the Compagnie des Indes Occidentales; vessels of the company leaving for the West Indies and Canada. I665, Dec. 22. Petition of the inhabitants of St. Jean de [ff. 454-455v boure to the Abbé de St. Martin-[Barès], praying that they may Luz and Sito continue their cod fishing in Canada as usual, etc.

135. Letters to Colbert, I678-i683; drafts of letters from [ff." $683-684$ Mar., I 666.

List of "cartes qui ne sont point comprises dans les précédents inventaires", including several maps of America.

[ff. I9-20 I666, Jan. I I, I 5, Mar. 4, I5, Paris. Colbert to Colbert de Terron. Cod fishery; purchase of vessel built in Brazil ; vessels of the Compagnie des Indes Occidentales; brewery workers requested for Canada, etc.

[ff. $565,568,586,643,663$

[I666.] Colbert to de Logerie. Assembling of men, women, and boys to be sent to Tortuga.

136. Letters to Colbert, Jan.-Mar., I666.

[f. 685

I666, June [?] I7, Feb. I I, La Rochelle. Colbert de Terron to Colbert. Departure of M. de La Barre; passage of eight companies with M. de St. Léon.-The St. Sébastien and the Aigle d'Or to go to Canada. [ff. 30, I95 I666, Mar. 30, Guadeloupe. Du Lion to Colbert. Defense of the island: attack by English on Dominica.

137. Letters to Colbert, i666.

[f. 630

I666, Apr. 8, La Rochelle. [A.] Lefebvre de La Barre to Colbert. Preparations for his departure; troops and vessels; the English are fortifying themselves in St. Christopher.

[f. I02 I666, Apr. 8, La Rochelle. Hubert to Colbert. Capture of a vessel of the Compagnie des Indes Occidentales; fortifications of English in St. Christopher; embarkation of M. de La Barre. I666, Apr. I7, St. Malo. De Guynant to Colbert. The bourgeois of St. Malo desire permission to take part in the cod fisheries.

[f. 298 
137bis. Letters to Colbert, May, 1666.

I666, May Io, I3, 20, 24, 30, La Rochelle or Tonnay-Charente. Colbert de Terron to Colbert. Departure of La Barre; his plans for Cayenne.-Embarkation of four companies for the West Indies.-Respecting M. Du Mont, charged with the affairs of Canada.-Objections of La Barre to the embarkation of St. Léon.-Projects of La Barre respecting his route to the West Indies.

[ff. 649, 72I, 85I, 9I I, 933 I666, May I4, Caen. G. Chamillart to Colbert. The inhabitants of Granville desire to go to the Newfoundland fisheries.

[f. 765

138. Letters to Colbert, June, I666.

I666, June, June Io, St. Christopher. Chevalier de St. Laurens to Colbert. War with England.

[ff. 61, 406 I666, June. Hubert to Colbert. St. Christopher; departure of La Barre.

[ff. 69, 7I

1666, June 3, La Rochelle. La Barre to Colbert. Danger to other islands if English capture St. Christopher; reinforcements despatched to Canada; insufficient force which he is taking to the West Indies.

[ff. I $52-\mathrm{I} 53^{\mathrm{v}}$ I666, June 9. L. Bechameil to Colbert. Proposal to send Dutch privateers to the West Indies with privilege of trade.

138bis. Letters to Colbert, June-July, 1666.

[ff. $343-345 \mathrm{v}$

I666, June I4, 21, 24, July I, 5, 8, I2, I 5, I9, 22, 26, 29, La Rochelle, Rochefort, or Tonnay-Charente. Colbert de Terron to Colbert. Defense of West Indies; departure of vessels for West Indies and Canada, etc.

[ff. $588,736,757,799,8$ 10, 839, 849, 864, 879, 920, 936, 961 I666, June I7, May 23, Martinique. [Capt. Robert Le Frichet] de Clodoré to Colbert. Hostilities in the West Indies.

139. Letters to Colbert, Aug., I666.

I666, Aug. 2, II, I9, Charente or La Rochelle. Colbert de Terron to Colbert. Ogeron, St. Laurent, and St. Léon; sends account of expenditures for Canada; hostilities in the West Indies.

$[\mathrm{ff} .26,187,280$ 1666, Aug. 26, Madrid. Note on the arrival of the fleet from New Spain.

140. Letters to Colbert, Sept., I666.

[ff. $359-360 \mathrm{v}$

I666, Sept. 2, I3, La Rochelle. Colbert de Terron to Colbert. Despatch of supplies and munitions to the West Indies and Canada.-Ogeron and Tortuga.

[ff. 82,374

I666, June II. "Estat de la dépense faite pour la levée, armement, habitz et subsistance des troupes embarquées pour l'Amérique." By Colbert de Terron.

[ff. I6I-I $62 \mathrm{v}$

I666, Aug. 3I, Middelburg. Copy of instructions of the States of Zeeland to their deputies in the States General, respecting commerce with the French West Indies.

141 bis. Letters to Colbert, Oct., I666.

I666, Oct. 2I, Paris. The king to Colbert. Examination of the accounts of the former Company of Canada; meeting held by Boucherat.

[f. 585

I665 [sic], Oct. 30, Quebec. Bourdon, procureur général, to Colbert. Reinstatement of himself and the Sieur de Villeray by de Tracy; troops in camp; provisions; marriages; desire for freedom of commerce for Canada; grievances against the Compagnie des Indes Occidentales.

142. Letters to Colbert, Nov.-Dec., I666.

I666, Nov. Ogeron to Colbert. Awaits aid sent by the Compagnie des Indes Occidentales; capture of a vessel at Jamaica.

[ff. $59-60 \mathrm{v}$ 
1666, Nov., Nov. 27, La Rochelle. [H.] Hubert to Colbert. Provisions for the West Indies.-Arrival of cargo of furs from Canada. [ff. 6I, 220 I665, [sic], Nov. 2, Quebec. Father [François] Le Mercier to Colbert. Urges that name of New France be substituted for that of Canada; praise of de Tracy and Talon; the Canadian mission.

[ff. $72-73 \mathrm{v}$ I666, Nov. 5, Rouen. [L.] Fermanel to Colbert. Prospects of commerce with the West Indies.
[ff. $74-75 \mathrm{v}$ I666, Nov I2, Milhau. Mme. de Maty to Colbert. Asks for payment of pension accorded to her husband, M. de Salière[s?], who has gone to Canada.

[ff. $84-85 \mathrm{v}$ I666, Dec. 2, Paris. The profits from the Senegal and Canada vessels will enable the company to send aid to the islands.

[ff. $35^{2-353 \mathrm{v}}$ I666, Dec. 3, Brest. Colbert de Terron to Colbert. Sends an account of affairs in Canada.

142bis. Letters to Colbert, Dec., I666.

I666, Dec. 7, 14, La Rochelle. [P.] de Seuil to Colbert. Equipment of merchant vessels for Newfoundland.-D Despatch of troops to the West Indies. [ff. $5^{16}, 7^{22}$ I666, Dec. 9, Paris. Lauson de Charny to Colbert. Sends him a letter from the Bishop of Petraea, and desires to talk with him about Canada. [f. 565 . I666, Dec. Io, Brest. Colbert de Terron to Colbert. Arrival of cargo of fish oil; project of instructions respecting Placentia.

1666, Dec. 16, Middelburg. Janot to Colbert. Sale of Canadian furs; \begin{tabular}{l} 
proposal of Conrad Tradel. [f. 766 \\
\hline
\end{tabular} 1666, Dec. 16, Amsterdam. Extracts from letters relating to English naval forces in the West Indies.

[ff. 877,879 I660, Dec. 21, Paris. Father Paul Ragueneau to Colbert. Success of de Tracy's expedition against the Iroquois; Lauson de Charny can give him information relating to Canada.

[ff. $88 \mathrm{I}-882 \mathrm{v}$ I666, Dec. 24, Bayeux. Chamillart to Colbert, with petition of inhabitants of Granville for permission to take part in the Newfoundland fisheries at Chapeau-Rouge, and list of 14 vessels ready to leave for Newfoundland.

143. Letters to Colbert, Jan.-Apr., r667.

[ff. 919-922v

I667, Jan. 3, 27, Feb. 7, I7, La Rochelle or Charente. P. de Seuil to Colbert. Sends a memorandum of the expenditures to be incurred for Canada. -Provisions, clothing, and munitions for the West Indies, Canada, and Newfoundland.-Secret equipment of expedition for the West Indies.-English expedition against the French West Indies.

[ff. I, I66, 228, 304 "Conditions auxquelles l'on offre de livrer à Toulon ou à Marseille partie de nègres."

[ff. $259^{-259 \mathrm{v}}$ I667, Apr. 22, 26. Bechameil to Colbert. Shipment of provisions to the West Indies.-La Barre's attack on the English at Montserrat.

144. Letters to Colbert, May-Aug., I667.

[ff. 488,497 I667, May I, Cadiz. Guillaume Eon to Colbert. Recapture of the island of St. Catherine from the English by the president of Panama.

[f. 42 Letters relating to the West Indies. [ff. 210, 237, 320, 447 1667, Aug 15, Placentia. De Palme to Colbert. Arrival at Placentia; complaints against La Fontaine-Belot.

[ff. $523-524 \mathrm{v}$ 
145. Letters to Colbert, Sept.-Oct., 1667.

I667, Sept. I2, La Rochelle. Le Borgne to Colbert. Asks that the king demand restitution by the English of the munitions and stores captured in Acadia.

[ff. II $6-$ II $7 \mathrm{~V}$

I667, Sept. Letters from [M. J.] Gauntheliard (Funchal), Hubert (Paris), and Janot (Middelburg), relating to the West Indies.

I667 Sept Ifters from [J]. I24, 235, 4I7 (Paris), Chamillart (Caen), La Ferrière (Granville), Duc D. de Cheverry Rochelle), and François (Havre), containing references to Newfoundland \begin{tabular}{l} 
fisheries, or to vessels engaged therein. [ff. I $28,144,263,264,332,37 \mathrm{I}$ \\
\hline
\end{tabular} Quebec.

I667, Sept. 29, La Rochelle. De Tracy to Colbert. Has returned from

146. Letters to Colbert, Nov.-Dec., I667.

[ff. $304-305 \mathrm{v}$

I667, Nov. 3, London. H. de Ruvigny to Colbert. Restoration of St. Christopher.

[ff. $53-55 \mathrm{v}$

I667, Dec. I, La Rochelle. H. Hubert to Colbert. Hurricane at St. Christopher.

[ff. $285-286 \mathrm{v}$

I667, Dec. 28, Toulon. L. d'Infreville to Colbert. Assembly of vessels of St. Malo in the ports of Provence to sail for the cod fisheries. [ff. 569-57 Iv

147. Letters to Colbert, Jan.-Mar., I668.

Petition addressed to Colbert by the children of the late Sieur d'Aulnay Charnisay, governor of Acadia, together with a memoir of the services of the latter and of the exactions of Le Borgne.

[ff. I-5v

Letters of Colbert de Terron, Brodart (Dunkirk), and Chamillart (Bayeux), containing references to supplies for Canada and to the cod fisheries.

"Rolle des marchandises que l'on demande de déclarer n'estre sujettes à l'augmentation du nouveau tarif." References to beaver, whale oil, etc., with annotations by Colbert.

149. Letters to Colbert, Oct.-Dec., I668.

[ff. $373-373 \mathrm{v}$

Letters from Colbert de Croissy (London), Louis de Matharel, Comte Jean d'Estrées, and L. de Logerie, containing references to the West Indies and to the despatch of vessels there.

150. Letters to Colbert, Jan.-Feb., r669.

[ff. $33,248,340,5$ I 2,58 I

I669, Jan. De Mignarde to Colbert. Disbanding of two companies returning from Canada.

I669, Feb. 18, Bordeaux. Letters from [Cl.] Pellot and [J.] Lombard to Colbert, relating to interest among the merchants of Bordeaux in the organization of the Compagnie du Nord.

150bis. Letters to Colbert, Feb.-Mar., 1669.

I669, Feb. 2I, Caen; Mar. 29, Coutances. [G.] Chamillart to Colbert. Construction of vessels at Granville for the Newfoundland fisheries.

I669, Mar. 30, [Cadiz]. [Guillaume] Éon to Colbert. Commerce of the French established in Spain with the Spanish Indies. [ff. 669-672v

151. Letters to Colbert, Apr., I669.

1669, Apr. Letters from Cl. Pellot (Bordeaux), de Lagny (La Rochelle), $\mathrm{H}$. Tersmitte and Louis Pagez (Bordeaux), and Colbert de Terron (La Rochelle), relating to the organization of the Compagnie du Nord.

[ff. 83, I8I, I9I, 240, 298, 306, 399, 406, 4I8, 429 
I669, Apr. 8, I I, La Rochelle. Colbert de Terron to Colbert. Despatch of infantry companies to Canada.-Affairs of Canada; flute needed by Talon.

I669, Apr. Io, St. Malo. Coëtlogon to Colbert. Crews of vessels engaged in the cod fishery. [f. 342 r669, Apr. Io, Rennes. [Fr.] d'Argouges to Colbert. Newfoundland fishing fleet.

151bis. Letters to Colbert, Apr., I669.

[f. 358

Letters from Pellot (Bordeaux), Colbert de Terron (La Rochelle), and R. Durribaud (Bordeaux), and letter from Colbert to Pellot (Mar. I I, f. 795), relating to the organization of the Compagnie du Nord.

[ff. $531,633,639,765,792,795,841,946$

1669, Apr. 2I, 24, Rennes. Fr. d'Argouges to Colbert. Recruiting of sailors and departure of fleet for Newfoundland. [ff. 722-820
[ I669, Apr. 22, 25, 28, La Rochelle. Colbert de Terron to Colbert. Equipment of the St. Charles of Bayonne for Canada; memorandum respecting munitions to be sent to Canada; receipt of memoir from Colbert on Canada; troops and munitions.

152. Letters to Colbert, May, I669.

I669, May 4, I3, I6, I9, 22, 26, 30, Oléron, Rochefort, or La Rochelle. Colbert de Terron to Colbert. Transportation of goods to Canada ; Compagnie du Nord; capture of slave-ship by Algerian pirates ; Canadian timber ; shipbuilding in Canada.

$[\mathrm{ff} .46, \mathrm{I} 42, \mathrm{I} 84,22 \mathrm{I}, 252,306,365$ I669, May I2, St. Christopher. Comte d'Estrées to the king [?]. Restitution of the island.

[f. I33 I669, May I3, La Rochelle. H. Tersmitte and Louis Pagez to Colbert. Organization of the Compagnie du Nord.

153. Letters to Colbert, June, I669.

Archangel. Jean Goossen to . Commerce of Russia with Virginia and Canada; trade in Canadian beaver carried on at Archangel by the Dutch.

[ff. I-7

"Projet de ce qui se peut tirer tous les ans de la France pour être vendu à Archangel et aussi des retours qui se peuvent tirer d'Archangel." Furs, whale oil, etc.

[ff. $5 \mathrm{v}-6$

I669, June 2, 6, Io, I3, Rochefort. Colbert de Terron to Colbert. Conference with Ste. Colombe respecting the South American coast.-Engagement of carpenters and smiths for shipbuilding in Canada; entrepôt to be established at the mouth of the St. Lawrence or in Acadia.-Compagnie du Nord; construction of a vessel; Talon not yet arrived.-La Barre leaves the \begin{tabular}{l} 
West Indies. [ff. 6I, I89, 298, 39I \\
\hline
\end{tabular} I669, June 3, 5, La Rochelle. Letters of [Capt.] de Gorris [de La Guerche] and Ste. Colombe to Colbert. Project for an expedition to South America and establishment of a colony there.

[ff. 84, I47 1669, June 6, r2, La Rochelle. De Lagny, Tersmitte, and Pagez to Colbert, relating to the Compagnie du Nord.

[ff. I 79,387 I669, June Io, I3, Bordeaux. Pellot to Colbert. Compagnie du Nord.

[ff. $286,4 \mathrm{I} 4$

I669, June I2, Montreuil. Du Lion to Colbert. His government of Guadeloupe; relations with de Baas and the Compagnie des Indes Occidentales.

153bis. Letters to Colbert, June, I669.

[ff. $37 \mathrm{I}-372 \mathrm{v}$

r669, June I6, 20, 24, 27, Rochefort or La Rochelle. Colbert de Terron to Colbert. Proposals for a colony in South America; Talon expected daily; 
Compagnie du Nord; foreign commerce in the West Indies.-Arrival of Talon; negotiations with directors of the Compagnie du Nord; Comte d'Estrées in the West Indies.- Sends a memoir drawn up by himself and Talon on Canada; material for shipbuilding in Canada.-Contract for tar in Canada ; Compagnie du Nord.

[ff. $482,625,745,839$ I669, June I6, Havre. Dumas to Colbert. Local importance of the New foundland fisheries.

I669, June 20, 24, Bordeaux. Pellot to Colbert. Compagnie du Nord.

154. Letters to Colbert, July-Dec., I669.

$[\mathrm{ff} .607 .772$

The provincial of the Recollects to Colbert. Arrival at La Rochelle of the Recollects who are going to Canada.

[ff. $7-8 \mathrm{v}$

I669, July 4, 25, i6, La Rochelle. [J.] Talon to Colbert. Departure of his secretary for Canada; he remains for the embarkation of the troops.Embarkation of six companies for Canada; has received orders of King of England for the restoration of Acadia.-Six carpenters who will go to Canada with him; will send an account of the goods sent to Canada, and of expenditure of funds.

155. Letters to Colbert, Jan.-Dec., I670.

[ff. 6I, I69, I7 I

I670, Aug. 2, Paris. Memoir of the king for Ralph Montagu, ambassador of Great Britain, respecting the prohibition against the entry of foreign vessels in the ports of the French West Indies.

I670, Dec. 3, Dieppe. Berryer to Colbert. Construction of vessels for the West Indies and Newfoundland.

156. Letters to Colbert, Jan.-Mar., I67 I.

[ff. $446-449 \mathrm{v}$

I67 I, Jan. I, 8, 22, Feb. I6, 25, Mar. I6, Rochefort or La Rochelle. Colbert de Terron to Colbert. News from St. Christopher; building timber of the "Compagnie d'Occident"; capture in the West Indies of vessels from La Rochelle; expenditures for Placentia and Acadia; proposals of merchants of La Rochelle with regard to trade with Placentia and Acadia; naval matters.

[ff. 9, 19, 57, I26, 190, 299

I67I, Feb. I 5. Memoir by Bellinzani respecting the prisoners sent from Santo Domingo by Ogeron.

[ff. I $24-125 \mathrm{v}$

I671, Mar. "Billet que je prie Monseigneur Colbert d'examiner." Memoir of a plan to assign the Iroquois missions to the Jesuits and those of the Ottawa to the Sulpicians.

156bis. Letters to Colbert, Apr.-June, I67I.

[ff. 226-227v

I67 I, Apr. 20, 30, May 7, 4, June I, 4, 8, 25, Rochefort or La Rochelle. Colbert de Terron to Colbert. Departure of squadron of Châteaurenault; arrival of Gabaret and Sourdis; repression of buccaneers in Santo Domingo: diseases contracted in the West Indies : requests of Patoulet, secretary of Talon, and certificates given to him for transportation of various goods.

$[\mathrm{ff} .421,442,460,483,592,61 \mathrm{I}, 633,722$

I67I, June 22, La Rochelle. Comte d'Estrées to Colbert. Capture of a vessel from La Rochelle on the coast of Campeche.

157. Letters to Colbert, July-Sept., I67 I.

[f. 709

I67I, July 24, Rochefort. Memoir on the affairs of the department of Rochefort, by Colbert de Terron. Expenditures for the squadron of Gabaret.

[ff. 96-97v

i671, June 4. Arrest . . . qui décharge de tous Droits les Marchandises qui seront chargées en France pour estre portées dans les Isles de l'Amérique (Paris, I67I).

[ff. $265-266 \mathrm{v}$ 
I67I, Feb. 9. Arrest par lequel Sa Majesté descharge les Marchands et Pescheurs de son Royaume du Droit d'Abord dans les Ports et Havres de son Obćissance, de tout le Poisson frais, sec, ct sallé de leurs Pesches ... .

157bis. Letters to Colbert, Sept.-Dec., I67I.

[ff. $267-268$

I67I, Sept. 7, I4, 24, 27, Rochefort. Colbert de Terron to Colbert. Vessels of the Compagnie des Indes Occidentales, West Indies. Capture of vessel of La Rochelle by Spaniards in Mexican waters. [ff. 448, 480, 546, 572

158. Letters to Colbert, Jan.-Mar., I672.

Talon to Bellinzani. Requests his return; sends his secretary, Patoulet, with new memoirs on beaver, fisheries, and manufactures. (Ext.) [ff. I-2v

I672, Jan. "Mémoire pour la Bretagne", by the Duc de Chaulnes. Requests by merchants with respect to Newfoundland fisheries. [ff. $7-8 \mathrm{v}$

I672, Jan. 5, Nantes. S. de Molac to Colbert. Complaints by merchants with respect to enrolment of merchant captains in the "classes" ( $i . e$., for naval service), followed by "Noms des capitaines et commandants des vaisseaux qui doivent aller aux Terres Neuves à la pesche des morues".

[ff. $52-55 \mathrm{v}$

I672, Jan. 5, Mar. 29, Paris. [Fr.] Bellinzani to Colbert. Plan of Zeelanders to send a squadron to the West Indies to molest French vessels; vessels ready to depart for Senegal and the West Indies.

[ff. 61,432

I672, Jan. 7, I8, 25, 28, La Rochelle or Rochefort. Colbert de Terron to Colbert. News from the West Indies; illness and death of Villepars at Guadeloupe ; voyage of Guillot to the Bay of Tous les Saints; aid for Placentia and Acadia; carpenters sent to Canada; munitions for the Compagnie des Indes Occidentales.

[ff. $66, \mathrm{I} 24, \mathrm{I} 58, \mathrm{I} 82$

I672, Jan. II, Feb. 4, I 5, I8, 22, 29, Mar. 3, 2I, Rochefort. Memoirs for the king on the affairs of the department of Rochefort, by Colbert de Terron. Vessels for the West Indies; munitions for Acadia and Placentia; crew of Villepars at Antigua; supplies for West Indies, etc.

159. Letters to Colbert, Apr.-May, 1672.

$$
[\text { ff. } 88,227,283,297,307,337,343,384
$$

N. d., I672, Apr. I 5, 23, 26, May I. Bishop of St. Malo to Colbert.

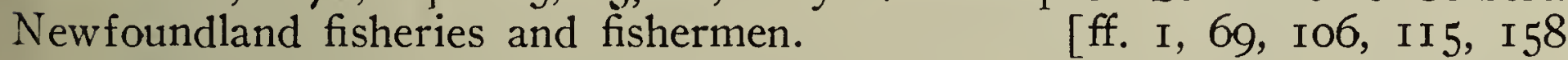
I672, Apr. I4, La Rochelle. Memoir on the affairs of the department of Rochefort, by Colbert de Terron. Funds for payment of officers and laborers in Canada, Placentia, and Acadia.

I672, Apr. 30, May 8. Notes [by Bellinzani] on goods of Guenet for

Canada, and on equipment of squadron of La Barre.

[ff. I 50, I93 I672, May 8, St. Malo; May 20, Brest. Duc de Chaulnes to Colbert. Newfoundland fishing fleet; squadron of La Barre.

[ff. I85, 29I I672, May 9, I6, I9, 26, La Rochelle or Rochefort. Colbert de Terron to Colbert. Vessels for the West Indies; troops arrive at La Rochelle for the West Indies; passage of Frontenac to America, and return of Courcelles and Talon to France.

[ff. 197, 249, 278, 323 I672, May 2I, Cologne. [Louis de ] Verjus [Comte de Crécy] to Colbert. Debt of Frontenac to him.

160. Letters to Colbert, June-July, I672.

I672, June 2, 23, July 3, I8, 21, 25, Rochefort or La Rochelle. Memoirs for the king on the affairs of the department of Rochefort, by Colbert de Terron. Departure of Frontenac for Canada; vessels for the West Indies.

[ff. 6I, 5'I 9, 706, 9I I , 943, 988 
I672, June 6, 9, I0, I2, I6, 20, 20, 23, 27, 30, July 7, I I, I4, 21, 25, Rochefort or La Rochelle. Colbert de Terron to Colbert. Preparations and departure of Frontenac and Escort; vessels and troops for the West Indies.

[ff. 196, 254, 262, 266, 429, 467, 492, 523, 581, 605, 774, 810, 860, 939, 992

I672, July 22, Paris. Bellinzani to Colbert. Liquidation of the Compagnie d'Occident.

I672, July 22, On board La Grande Espérance. Frontenac to Colbert. Return of Bourdet, commanding his escort; details of the voyage.

161. Letters to Colbert, Aug.-Sept., I672.

[ff. $95^{8-960}$

I672, Aug. I, 8, I I, Rochefort. Colbert de Terron to Colbert. Vessels for the West Indies, capture of the vessel of La Chesnaye, La Plume d'Or, bound for Quebec.
$[\mathrm{ff} .27,55,87$ I672, Aug. 3, Madrid. [Marquis P.] de Villars to Colbert. Capture by a Dutch vessel of a French bark with cargo for Canada. [f. 39 I672, Aug. 9, Au Conquêt. Capt. Bourdet to Bellinzani. Return from escorting Frontenac. (Ext.) [f. 66
[fourdet.

I672, July 22. Certificate given by Frontenac to Capt. Bourdet of the Aigle Noir, who escorted him. Annotation by Colbert. [ff. 67-69v

1672, Aug. 15, I8, Sept. I, Rochefort. Memoirs for the king on the affairs of the department of Rochefort, by Colbert de Terron. Vessels and troops for the West Indies; return of Bourdet from escorting Frontenac; return of sailors from the West Indies. [ff. I I9, I6I, 310
[

1672, Aug. I6, 20, 23, Sept. 4, I8, 25, 28, Nantes or St. Malo. Duc de Chaulnes to Colbert. Protection of vessels returning from Newfoundland.

[ff. I 35, I $88,239,317,385,402,444$

I672, Aug I7, Rouen. Pellot to Colbert. Danger to New foundland and whaling vessels from the pirates of Holland and Zeeland. [f. I43

I672, Aug. 26. L. Verjus to Colbert. Debt of Frontenac to him. [f. 262

162. Letters to Colbert, Oct.-Dec., I672.

I672, Oct. I3, London. Colbert de Croissy to Colbert. Dutch vessels cruising off Cadiz to capture French and English vessels returning from Newfoundland.

[f. 105

I671, Nov. I2; 1672, Dec. 5, I2, La Rochelle or Rochefort. Colbert de Terron to Colbert. Capture of an English vessel by the American squadron; Patoulet; arrival of three vessels from Canada with Courcelles and Talon.

[ff. $286,436,5^{15}$

I671, Nov. 20, Guadeloupe. Du Lion to Colbert. Charges against him.

[f. 335

I672, Nov. 25. Petition of the Compagnie des Indes Occidentales to Colbert, praying that the inhabitants of the West Indies may be informed of the continued existence of the company in spite of rumors of its dissolution.

[ff. $375-376$

I671, Nov. 3, Paris. Colbert to directors of the Compagnie des Indes Occidentales. It is the will of the king that the commerce of the company shall be restricted to the slave-trade in the countries within its concession.

[f. 424

I671, Nov. I3, Paris. Colbert to officers of admiralty. Restriction of commerce of the Compagnie des Indes Occidentales to that of negroes. (Circular.)

163. Letters to Colbert, Jan.-Apr., I673.

I673, Jan. 2, Rochefort. Colbert de Terron to Bellinzani. Escort of merchant vessels. (Ext., with annotations by Colbert.) [ff. I5-I6v 
I673, Jan. 2, I9, 30, Feb. I6, Apr. I3, 24, 27, Rochefort. Colbert de Terron to Colbert. Merchants wish to know if they have freedom of the fisheries: provisioning of vessels for the Wes Indies; recommendation of Chamot; transmits account of expenditures for Placentia and Acadia; superiority of Chambly, on service in Canada, over Grandfontaine; praise of La Poipe ; expansion of the English on the French coast of Newfoundland ; sending of girls to Canada; will arrange with the merchants of La Rochelle respecting the use of funds for Acadia and Placentia; is having a small vessel for Acadia and Placentia overhauled. Cf. Arch. Marine, B2, vol. 24, ff. I8Iv, $250 v$. [ff. 21, I I7, I63, 247, 556, 583, 593

1673, Jan. 9, Feb. 6, I3, 20, Rochefort. Memoirs for the king on affairs of the department of Rochefort, by Colbert de Terron. Escort of fishing vessels; merchants of La Rochelle preparing to send aid to the West Indies; provisions for the West Indies; departure of Newfoundland vessels not to be permitted until quota of sailors for the royal navy has been filled; sends memoirs on Acadia and Placentia. [ff. 72, 217, 227, 269
[

I673, Feb. I, St. Malo. [Philibert] de Narp to Colbert. Crews of vessels going to New foundland.

[f. 182

I673, Feb. I, St. Malo. Julien Éon to Colbert. Thanks for permission received from the king to send vessels to Newfoundland, and for exemption of three "classes" of sailors from naval service.

[f. I85

I673, Feb. I6, London. Colbert de Croissy to Colbert. Restitution of a \begin{tabular}{l} 
vessel captured in American waters. [f. 255 \\
\hline
\end{tabular}

I673, Mar. 6, Rochefort. Memoir for Seignelay by Desclouzeaux. Expenditures for Acadia and Placentia.

164. Letters to Colbert, May-June, I673.

[ff. $358-362 \mathrm{v}$

I673, May I I, I5, I8, 22, 25, 29, June I, 5, I2, I5, Rochefort or La Rochelle. Colbert de Terron to Colbert. Lack of provisions for vessels going to the West Indies; recommends Chambly for governor of Acadia; despatch of vessels to Newfoundland; escort of Newfoundland vessels ; expedition of de Baas; Canadian timber; construction of a vessel in Canada.

[ff. 70, I03, I44, I82, 21 3, 239, 305, 365, 449, 500

I673, May 12, Paris. Bishop of Petraea [Laval] to Colbert. Funds obtained from the king for the publication of bulls; is taking ecclesiastics from the Missions Etrangères to Quebec with him. [ff. 77-78v
[ I673, May 22, Courtrai. Seignelay to Colbert de Terron. Departure of vessels from Havre and Brest for America; Chambly appointed governor of Acadia; despatch of a vessel to Acadia.

[ff. I89-I9I V

I673, June I7. Memoir respecting the captains in the service of the Compagnie des Indes Occidentales.

[ff. $524-526 \mathrm{v}$

I673, June I7, 22 (2), 23, 24, 26, Havre. Duc de St. Aignan to Colbert. Newfoundland vessels and sailors.

165. Letters to Colbert, July-Aug., I673.

I673, July I5. Patoulet to Colbert. Will endeavor, with Desclouzeaux, to establish commerce in Canada; Canadian timber and flax. Annotations by Colbert.

165bis. Letters to Colbert, Aug.-Sept., I673.

1673, Aug. 26, Paris. Colbert de Terron to Colbert. Voyage of the Belliqueux in the West Indies.

$[\mathrm{ff} .435-436 \mathrm{v}$

I673, Sept. 21. Louis de Bourbon, Prince de Condé, to Colbert. Recommends the Englishman [Col. John] Scott, who has been in the West Indies. 
166. Letters to Colbert, Oct.-Nov., I673.

1673, Oct. 3, Rome. Duc d'Estrées to Colbert. Respecting bulls on the bishopric of Quebec.

[f. 38

1673, Oct. 16, London. Colbert de Croissy to Colbert. Opposition of the English commissioners to the union of the English forces with the squadron of Valbelle in the West Indies.

[f. I 28

I673, Oct. 21, Havre. L. Berryer to Colbert. Lack of sailors for the New foundland vessels.

167. Letters to Colbert, Jan.-Mar., I674.

I674, Jan. 4, Feb. 5, 8, Mar. 6, Rochefort or La Rochelle. Memoirs for the king on affairs of the department of Rochefort, by Colbert de Terron. Return of vessel which carries provisions to Newfoundland and Acadia; Chambly must have arrived in Acadia, whence Grandfontaine has returned; contract with merchants of La Rochelle for supplying the West Indies; arrival of Courcelles; orders to de Baas to aid Ogeron. [ff. 92, 300, 31 2, 40I 1674, Jan. 19, Feb. 15, 19, 19, Rochefort. Colbert de Terron to Colbert. Claims presented by Grandfontaine for provisions supplied to Acadia; sale of sugar and tobacco from cargo of the Amitié; arrival of Courcelles; specie on the Amitié.

[ff. I86, 325, 343, 347

I674, Jan. 26, Falmouth. Chevalier [Fr. L.] de Châteaurenault to Colbert. Escort to La Rochelle requested by captain of a French vessel at Falmouth, coming from Quebec.

[f. 326 I674, Feb. I 5. [J.] de Fita, lieutenant criminel, to Colbert. Thanks for entrusting to him the affair of M. de Courcelles.

[f. 329

I674, Feb. 20, Berlin. [Louis] Verjus to Colbert. Brosseau will speak to him of his affair with Frontenac.

[f. 353

1674, Mar. 5. Memoir of vessels loaded with provisions for the West Indies, which are in the river of Bordeaux.

168. Letters to Colbert, Apr.-June, I674.

[ff. $395-396 \mathrm{v}$

I674, Apr. I, 5, 26, 30, May 8, I4, 27, June 5, I4, I5, Rochefort or La Rochelle. Colbert de Terron to Colbert. Vessels for the West Indies; praise of Courcelles; case of the Amitié of Curaçao; troops for the West Indies; Grandfontaine placed in command of a battery.

$[\mathrm{ff} . \mathrm{I}, \mathrm{I} 4,85, \mathrm{IOI}, \mathrm{I} 24, \mathrm{I} 4 \mathrm{I}, \mathrm{I} 75,209,25 \mathrm{I}, 253$

1674, Apr. 6, I8. Inventories of papers of Colbert relating to the marine, Canada, and the West Indies.

[ff. $37-40 \mathrm{v}, 52-53 \mathrm{v}$

1674, Apr. 17, Paris. Bellinzani to Colbert. Relating to Dupont de Neuville, proposed for the position of maitre des eaux et forêts in Canada.

[f. 50

I674, Apr. 23, May I3, I7, 24, Rochefort. Memoirs to the king on affairs of the department of Rochefort, by Colbert de Terron. Troops, vessels, and priests for the West Indies.

168bis. Letters to Colbert, June-Aug., I674.

1674, June 28, July 10, 19, 30, Aug. 6, Rochefort. Memoirs for the king on affairs of the department of Rochefort, by Colbert de Terron. Vessels for the West Indies; departure of a fly-boat with despatches for de Baas. [ff. $322,379,428,489,5^{1} 5$

I674, July 7. List of royal vessels at sea and in the ports. [ff. 359-363

I674, July 18, 23, 23, 25, Rochefort. Colbert de Terron to Colbert. Case of the Amitie of Curaçao; protection of vessels returning from the fisheries; arrival of vessels from Cayenne; fear that De Ruyter may threaten the West Indies.

$[$ ff. $419,466,467,476$ 
I674, July 22, Dover. Abraham Stora to - Passage of Dutch fleet bound for the West Indies.

I674, Aug. 7, Rochefort. Observations on the recruiting of sailors.

[ff. $458-458 \mathrm{v}$

[ff. $526-527 \mathrm{v}$

1674, Aug. 20, 27. Brest. Duc de Chaulnes to Seignelay. Dutch vessels despatched to New Netherlands and the West Indies to join De Ruyter; arrival of merchant fleet from the West Indies.

[ff. 560,575

I674, Aug. 30, harbor of Camaret. "Billet que les capitaines marchands venant de l'Amérique sous l'escorte de $M$. de la Rocque luy ont donné pour ne point faire la routte du Havre où ils doivent descharger." (Copy.) [f. 589

169. Letters to Colbert, Sept.-Dec., I674.

Letters from de Seuil, Comte d'Estrées, Duc de St. Aignan, Duc de Chaulnes, Bellinzani, and Colbert de Terron, containing references to defense of the West Indies, Dutch attack on Martinique, etc.

I674, Oct. 2. List of royal vessels.

[ff. $76,82,96$, I39, 187, 191, 21 2,5 I4

1674. Dec. 25. Memoir on troops in the West Tndies. 200

170. Letters to Colbert, Jan.-Feb., I675.

[Perrot] de Fercourt to Colbert. Intrigues of Mme. de Frontenac.

I675. Jan 20, St Malo. De Sachez-[Séjourné] to Colbert [ff. 3I-32v [f. 5 I 5 sailors for a successful season at Newfoundland; vessel for the West Indies.

171. Letters to Colbert, Mar.-May, I675.

[ff. I $89-200 \mathrm{v}$

I675, Mar. 4, St. Germain-en-Laye, Mar. 9, Paris, Apr. 5, Versailles. Father Hyacinthe Le Febvre, provincial of the Recollects, of Paris, to Colbert. Enquires as to number of priests he wishes to send to Canada.-Transmits letters from the superior of the Canadian Recollects and from Frontenac.Respecting the conduct of the Recollects in Canada.

I674, Nov. Io, Quebec. Frontenac to "Père Germain". Religious situation in Canada; asks for more priests; location of various missions. [f. 54

1674, Nov. 12, Quebec. Father Eustache Maupassant, superior of the Recollects of Canada, to - Recollects and aid sent by the king have not yet arrived; building constructed by Frontenac for the priests; refuses to join cabal against Frontenac.

[f. 57

1675, Mar. 21, harbor of Martinique. Beaujeu to Colbert. Sojourn of the Galant at Martinique.

[f. IOO

References to Newfoundland' fishers and fishing vessels. Of slight value.

1675, May 2. Report on funds for the fortification of Martinique and other islands.

171bis. Letters to Colbert, June, I675.

Letters from Pérou (Port Louis), Pellot (Rouen), Chappellain (Port Louis), Duc de La Vieuville (Poitiers), and Duc de Chaulnes (Rennes), containing slight references to sugar from Surinam, commerce in tobacco, vessels from the West Indies, annoyances to Newfoundland vessels, etc.

172. Letters to Colbert, July-Aug., I675.

[ff. $362,438,5$ I $7,586,686$

1675, July 2, La Rochelle. De Mirande and Du Bouchet to Colbert. Vessels leaving for New France without passports. [ff. I I-I2V

172bis. Letters to Colbert, Aug.-Dec., I675.

Letters from Duc de Charost (Calais), Bellinzani, and Marquis de Grancé, containing references to the West Indies, operations of Dutch vessels, etc.

[ff. $367,469,492$ 
Letters from Dusault (Paris), de Lavardin (Nantes), de Logeric (Belle-Ile), Duc de Chaulnes (Rennes), de Seuil, de Muyn, and de Vauvré, containing references to Newfoundland fishing vessels.

$$
\text { [ff. } 5^{\text {I I }, 514,515,520,522,553,580, ~ 588, ~ 632, ~} 644
$$

I675, Dec. 23. "Mémoire sur ce qui est à faire par les vaisseaux de guerre que le Roy fait armer pour envoyer en Terre Neuve." By Seignelay, with annotations by Colbert.

[ff. 626-627v

173. Letters to Colbert, Jan.-July, I676.

I676, May I. "Liste générale des vaisseaux dı Roy en I676."

[ff. I-I4 I676, Aug. 4. "Mémoire des lieux où sont les Vaisseaux du Roy armez
[f. I5

Memoir by Bellinzani respecting the domaine d'Occident. [ff. 47-49v

Notes on letters from de Muyn and de Seuil, containing references to escort of Newfoundland and Canadian vessels, provisions and sailors for Newfoundland vessels, despatch of vessels to Canada, the West Indies, etc.

173bis. Letters to Colbert, July-Dec., I676.

[ff. I I o- 376

Notes on letters from de Muyn and de Seuil, as in preceding volume.

[passim

I676, Aug. I9, 21, 24, 28, Sept. 7, 2I, Brest. Memoir and letters from the Comte d'Estrées to Colbert, containing references to Cayenne and the West Indies.

[ff. $423-459$

1676 , Oct. 20, Versailles. Notes by Colbert on letters received from the ports. West India squadron; capture of a Newfoundland vessel.

[ff. $530-53 \mathrm{Iv}$

I676, Oct. 24, Nantes. Guillet to Colbert. His voyage to Quebec; Canadian timber, voyage of the Trompeur; meeting with de Sourdis. [ff. $588 \mathrm{v}-559$ I676, Oct. 24, Versailles. "Résultat des dépêches de marine." By Colbert and Seignelay. Arrival of vessels from Newfoundland and Canada; cargoes of Newfoundland vessels; capturel of fishermen off the Acadian coast: voyage of de Sourdis; bad condition of Placentia.

[ff. $572-573 \mathrm{v}$

1676, Nov. I3, Fort Royal [Martinique]. De Baas to Colbert. Defense of Grenada.

174. Letters to Colbert, Jan.-Apr., I677.

"Liste générale des vaisseaux du Roy en 1677." [ff. I-6v "Vaisseaux qui iront en Terre Neuve." "Escadre des îles d’Amérique." [ff. I $5 \mathrm{v}-\mathrm{I} 7$

Petition from the Jesuits in Canada to Colbert, requesting the settlement of their lands and a concession for the Iroquois mission at Prairie de la Madeleine.

[ff. 8o-8Iv

I677, Apr. 26. Request by Dupont de Neuville to Colbert, that his commission as grand maitre des eaux et forêts of Canada be forwarded to him.

174bis. Letters to Colbert, May-Aug., I677.

[f. 296

Notes on letters from P. de Seuil, L. de Muyn, Comte Jean d'Estrées, and Desclouzeaux, containing references to vessels for the West Indies or engaged in the Newfoundland fisheries, Dutch plans to send a squadron to America, provisions for vessels in the West Indies, escort of Newfoundland vessels, etc. $\quad[\mathrm{ff} .353,355,365,393,508,546,592,636,646,68 \mathrm{I}, 683$ 
1677, June I8. La Chesnaye to Bellinzani. Convoy of the Espérance and the Mouton, ready to sail for Canada. (Ext.)

[f. 395

1677, Aug. Memorandum of a letter from Gombauld to Colbert, relating to the reported discovery of a gold mine in Canada by St. Aubin. [f. 607v

175. Letters to Colbert, Sept.-Dec., I677.

Notes and memoranda on letters from Desclouzeaux (Havre), Méricourt, Berger (La Rochelle), La Lande (Bayonne), P. de Seuil (Brest), Chevalier de Réals (La Rochelle), Herpin, L. de Muyn (Rochefort), and Gallon, containing references to return of the Bouffomne and the Gaillarde from Newfoundland, loss sustained at Tobago by Méricourt, capture of vessels by the Dutch in the West Indies and off Newfoundland, departure of vessels for the West Indies, provisioning of Tobago, goods and expenditures for Cayenne and Canada, commerce of Gallon in the West Indies, departure of squadron of the Comte Jean d'Estrées, revocation of freedom of fisheries, arrival of vessels from Canada, etc. Cf. Arch. Marine, B3, vol. 24.

[ff. $7,72 \mathrm{v}, 80, \mathrm{I} 28, \mathrm{I} 32, \mathrm{I} 34, \mathrm{I} 49,206,257,27 \mathrm{I}, 332,390,402,432,436$, $480,486,494,5$ OI, $578,622,637$

1677, Sept. 9, Havre. Procès-verbal of the declaration made before the procureur du roi of the admiralty of Havre, by David Descultot, master of the St. Michel, respecting his voyage to Newfoundland and the attack on his vessel by a Dutch frigate.

1677. Sept 24 Paris. [Franço] Bellinani to Collert. Captu-230v inçois] Bellinzani to Colbert. Captures of vessels by the Dutch in violation of the fisheries treaty. [f. 236 I6z7, Sept. 20-Očt. 9. "Mémoire des ordres généraux donnés par mon père" [Colbert]. By [Seignelay].

[f. 316

I677, Oct. I3. "Points principaux des lettres cy-jointes sur lesquelles il faut consulter mon père." By Seignelay.

[f. 342

I677, Oct. [27ך. Bellinzani to Colbert. Despatches sent to Comte d'Estrées; voyage of the Dutch squadron to Tobago ; arrival of negroes at Lyons.

176. Letters to Colbert, I667-1670.

[ff. 386-387

I667, Oct. I5, Quebec. Bishop of Petraea [Laval] to Colbert. Peace in Canada; the intendant is endeavoring to establish a local commercial company.

I670, Apr. 3, I0, 21 28, May I, 5, 8, I I, I4, La Rochelle or Rochefort. Memoirs for the king on affairs of the department of Rochefort, by Colbert de Terron. Claims by Talon respecting a vessel freighted by him; approaching departure of vessels for Plaćentia, Acadia, and Canada; Grandfontaine in command in Acadia ; arrival of Talon expected; complaints against Gabaret in the West Indies; departure of the Hirondelle with troops for Canada; conferences with Jacquin and Pellimier on West India affairs; arrival of Talon; departure of the Nouvelle France for Canada; girls, cattle, and sailors for Canada; burning of a vessel destined for Canada; the St. Sébastien, bound for Acadia, puts in at Belle-Île. [ff. 65, 85, I03, I I 7, I 27, I4I, I 45, I 53, I 55 I670, Apr. I4, I7, 24, June 4, I4 (Reims), Sept. I5, I8, 22, 22, Oct. 6. I3, 20, 27, 30, Nov. 6, I3, La Rochelle or Rochefort. Colbert de Terron to Colbert. Embarkation of merchandise of Talon and of the troops; despatches from Gabaret in the West Indies; attempted revolt by the blacks in Barbados; departure of the Gédéon, with Talon, and of the Ville de Rouen for Canada; return of the St. Sébastien from Acadia; carpenters needed by the Compagnie "d'Occident"; respecting the voyage of Brunet, director of the Compagnie "d'Occident", expenditures for Canada and Acadia; voyage of Brunet; advances by the Compagnie "d'Occident" for Canada; conferences with the 
directors of the Compagnie du Nord and of the Compagnie "d'Occident"; notes received from Talon and Courcelles; return of the Hirondelle from Canada; rumor that Talon sends his secretary to France. 427 .

[ff. 9I, 97, I09, I85, I95, 3I 5, 319, 333, 335, 37 I, 383, 39 I, 404, 4I 5, 42 I,

I670, June I, Rochefort. Desclouzeaux to Colbert. Provisions for the vessels going to the West Indies; departure of Talon.

[f. 193

[I670.] “ Mémoire tant sur l'arrivée des vaisseaux du Roy au Cap-Vert et leur séjour à ces rades, que sur le commerce qu'on peut faire à ces costes jusques à là rivière de Gambie." Slave-trade with the West Indies.

[ff. $224-235 \mathrm{v}$

I670, Sept. 24, St. Germain-en-Laye. Colbert to Colbert de Terron. Cargo of the Ville de Rouen; Guinea slave-trade; despatch of provisions to the West Indies. (Copy.)

[ff. 369-370v

I670, Sept. I9, Quebec. Courcelles to Colbert de Terron. Shipbuilding; recommends Lamothe; men sent to obtain news of Grandfontaine in Acadia.

176bis. Letters to Colbert, I670-1675.

[ff. 4I6-4I7

I670, Dec. 7, I I, I 5, 22, 25 ; I67 I, Oct. 4, Rochefort. Colbert de Terron to Colbert. Publication of "classes" to be made for the engagement of sailors for Newfoundland; Talon wishes to drive Le Gaigneur from Canada; return of Gabaret's squadron from the West Indies; letters for Canada, Placentia, and Acadia ; voyage of Forant to Brazil.

[ff. $453,456,460,464,466,494$

I670, Dec. I I, Rochefort. Colbert de Terron to de Sachy. Complaints by merchants of Nantes of the difficulties of making up crews for Newfoundland.

[f. $45^{8}$

I67 I, Nov. 9, Dec. 7, I4, Rochefort. Memoirs for the king on affairs of the department of Rochefort, by Colbert de Terron. Capture of an English vessel by Villepars at Petit Goave; Mme. de Villepars requests that her husband remain in the West Indies; memoir by Grandfontaine; provisions for Acadia and Placentia.

[ff. $549,568,58 \mathrm{I}$

I675, Nov. I4, Versailles. Memoir by Seignelay on the memoir by the Comte d'Estrées, respecting the service of vessels of the Ponant division in I676. Proposals of attacks on vessels from New Spain and on the Guinea coast.
[f. 875

270. "Trésor Royal", Jan.-June, I665.- " Roole de plusieurs parties et sommes de deniers que le Roy a commandé et ordonné à Me. Estienne Jehannot, Sr. de Bartillat ... garde de son trésor royal, de bailler, payer et delivrer comptant ou assigner par ses mandemens . . . aux personnes pour les causes selon et ainsi qu'il en suit." Orders for payment from the royal treasury for the first semester of 1665 , as follows: troops in America (f. 38) ; Sieur de Salières, colonel of the Regiment de Carignan (f. 83v): salaries of Talon and Courcelles (f. I I9) ; troops going to Canada (f. I2I) ; salary of de Tracy (f. I 22); vessels for Canada (f. IOO); Compagnie des Indes Occidentales (f. 200); Bourdon ànd Villeray (f. 4I6).

271. "Trésor Royal ", July-Dec., I665.-Orders for payments from the royal treasury during the second semester of 1665 , as follows : letters of change drawn by de Tracy at Guadeloupe (f. 48v) ; duties on merchandise embarked on vessels of the Compagnie des Indes Occidentales (f. 5 Iv) ; voyage to Canada (f. 56) ; establishment of the Compagnie des Indes Occidentales (f. 93 ) ; troops serving in America (f. 235).

273. "Trésor royal", Jan.-June, I666.-Orders for payments from the royal treasury during the first semester of I666, as follows: infantry to be 
sent to America (f. I 5I) ; voyage of Forant to America (f. 232) ; salaries of Talon (f. 249v), de Tracy, Courcelles, and Du Lion (ff. 25I-25Iv), of Chaumont, aide-de-camp of de Tracy, and Patoulet, secretary of Talon (f. 259); wreck in the St. Lawrence of a bark loaded with provisions for de Tracy (f. 26Iv); expenditures in the West Indies, and vessels to be equipped and sent thither (f. $265 \mathrm{v}$ ).

274. "Trésor royal", July-Dec., I666.-Orders for payments from the royal treasury during the second semester of $\mathrm{I} 666$, as follows : eight companies of troops sent to America (f. 304).

287. "Trésor royal", Jan.-June, I67I.-Orders for payments from the royal treasury during the first semester of 1671 , as follows: crews of vessels equipped at Rochefort for the West Indies (f. I 24) ; passage of engagés and girls to Canada (f. I $32 \mathrm{v}$ ) ; maintenance of Acadia (f. I36v) ; voyage of Patoulet from Quebec to St. Germain and return (f. I 79) ; to Patoulet for troops, fathers of large families, the bishop, hospital nuns of Quebec and Montreal, mines, and other expenses for Canada and Acadia (ff. 281-283).

288. "Trésor royal", Oct.-Dec., I67I.-Orders for payments from the royal treasury during the last quarter of $167 \mathrm{I}$, as follows: salaries of Ogeron and de Baas (ff. I77v-I 78) ; public works in the West Indies (ff. I80-I80v).

289. "Trésor royal", Jan.-June, I672.-Orders for payments from the royal treasury for the first semester of 1672 , as follows: equipment of infantry companies for America (f. I 58) ; equipment of vessels for the West Indies (ff. I89v-I92) ; salary and voyage of Frontenac, salary of Talon, officers and workmen in Acadia (ff. Ig6-I97); journey of Frontenac to La Rochelle (f. 25Iv). 


\section{CINQ CENTS DE COLBERT.}

The group of five hundred volumes known as the Cinq Cents de Colbert, or more usually the 500 Colbert, is of miscellaneous character, containing some correspondence of Colbert. Among the documents relating to America are a number bearing on commercial and naval matters. An inventory of the collection has been printed, Catalogue des Manuscrits de la Collection des Cinq Cents de Colbert, by Charles de La Roncière (Paris, I908).

17.- I609, Feb. Protest by de Bretignières, syndic of the Etats de Normandie, against the imposition of a tax of one écu per ton on commerce beyond the line [of demarcation].

[ff. I-2

I626, May I9, Limours. "Articles et contract de la Compagnye de la nasselle de St. pierre fleur-delizée pr. le commerce. Pour l'établissement de la Marine en faveur de Mr. le Card'al de Richelieu." [ff. 35I-362v

45.- I640, St. Christopher. De Poincy to the directors of the Compagnie des Iles de l'Amérique (Nov. I5), and to Richelieu (Dec. 2), with "Relation de ce qui s'est passé en l'isle de Saint Christophe depuis... le 27 aout I639".

88.-I6I I, Oct. I2, Fontainebleau.

[ff. $459 \mathrm{v}-483 \mathrm{v}$

[Marie de Médicis] to M. de La Ravadière. None but the Catholic religion must be tolerated in the countries which he and M. de Razilly may conquer in the Indies.

[ff. 23 I v-232

89.-I6I2, Aug. 7, Paris. [Marie de Médicis] to M. de Biencourt, commanding at Fort Royal in New France. Recommends certain Jesuit priests.

[ff?. $67-67 \mathrm{v}$

I6I3, Jan. 4, Paris. $[I d$.$] to i d$. Respecting Jesuits who are to make the voyage to New France with the Sieur René Le Cocq.

[ff. I I $8 \mathrm{v}-$ I I9

126.-I666, Jan. 24; I667, Feb. I5, St. Germain. Colbert to Colbert de Terron. The St. Sébastien is destined for Canada.-Pay of infantry troops in Canada and the West Indies.

[ff. 27,245

[I667.] Memorandum of matters to be included in the instructions to the lieutenant general of the Islands of America. Supply of timber from Canada, etc.

[ff. 26 I v-266

199. "Inventaire général et descriptive de tous les vaisseaux appartenans aux sujets du Roy de l'année I664, en conséquence d'un arrest du Conseil royal des finances donné au rapport de Monsieur Colbert."-Original inventories, drawn up in each port by the lieutenant and greffier of the admiralty, of Frenchowned vessels, with notes as to their condition. The inventories for Rouen, Dieppe, Honfleur, Nantes, St. Malo, Bordeaux, etc., all include vessels engaged in the Newfoundland fisheries. Cf. Mims, Colbert's West India Policy, p. 2.

203. Memoirs on marine and commerce.

Mémoires concernant la Marine, by Gravier. Cod fisheries, West India and African trade, etc. (n. d.).

[ff. I-I 5

Apr. I-Nov. I 5. Journal of the Chevalier de Razilly: inspection of vessels intended for Canada.

"Mémoires et advis donnés au Roy sur le fait de la navigation et commerce de l'Amérique et les ordres des armées d'Espagne." [ff. I62-I70v

I620. "Sommation adressée à Montmorency amiral de France, par les marchands de Rouen et St. Malo associés au commerce de la Nouvelle France." 
I620, Nov. 8, Paris. “Articles accordés par le Duc le Montmorency viceroy au pays de la N'elle France au Sr.—— et ses associés." [ff. I93-I96v I626, Mar. 3I, Charonne. Contract between Richelieu and the Compagnie des Cent Associés [Morbihan].

[ff. I $197-202 \mathrm{~V}$ 1626, May 19, Limours. Contract between Richelieu and the Compagnie de la Nacelle de St. Pierre Fleur-de-Lysée, with royal ratification of July, I626, at Nantes. Cf. above, 17.

[ff. $214-228$ I608, Feb., Mar. Letters of Sully and Jeannin relative to the "advis de Isaac Le Maire pour l'establissement d'une compagnie en France."

[ff. $236-242$

"Propositions pour faire une compagnie en France pour les Indes Occidentales." Plan of attack on the Spanish colonies in America. [244-255v [1656-1659 ca.] "Plan véritable de l'estat présent des affaires de l'Europe." [ff. $257-286 \mathrm{v}$
[ Mémoire pour les Marchands de Paris, Rouen, S. Malo, Nantes, Morlaiz, le Havre et Dieppe, trafiquans en Mer.

I629. Edict du Roy" pour l'Establissement de la Compagnie Royed-288 Voyages de Long Cours

I664, Dec. 5. Arrest du Conseil de Commerce, donné en faveur des Marchands, et de tous autres qui feront cy-après bastir des Vaisseaux, ou trafiqueront sur Mer. Bonus for transportation of colonists to Canada, Newfoundland, the West Indies, etc.

[ff. $347-350 \mathrm{v}$ I664, Jan, 21. Extract from petition of the [Dutch] West India Company. Conference at Boston between representatives of New England and New Netherland.

[f. 400

204.-1667, Mar. 20, 27, 27, Apr. I3, May I3, 25, June I4, July 3, I6, Aug. 2, I0. Colbert to Colbert de Croissy, French ambassador in England. Restitution of Acadia and St. Christopher.

[ff. 9v, I8v, 50v, 54v, I00v, I I8v, I 39v, I67v, I85, 209v, 219

I662, Mar. 27. Louis XIV. to Colbert de Croissy. Restitution of Acadia and St. Christopher.

[f. 18

I669, May 3, July 5, Aug. 2. Colbert to M. de Pomponne. Impossibility of making use of the Englishman [John] Scott in America. A vessel of the Dutch West India Company maltreats a French vessel on the Guinea coast.

[ff. 7Iv, I7I, 2IOv

I669, June Io, Dec. 7. Colbert to M. de St. Romain, ambassador in Portugal. Commerce of Guinea and Brazil._-Arrival of the St. Charles at Lisbon, illness of Talon, delay of vessel prejudicial to interests of New France.

[ff.. I 3 I, I 30

I669, June 28, Aug. i6, Nov. I, 8, I5, Dec. 27. Colbert to Abbé de \begin{tabular}{l} 
Bourlemont. Bishopric of Quebec. [ff. I 59, 223, 286v, 300, 305, 348v \\
\hline
\end{tabular} I669, June, St. Germain. "Édit portant établissement d'une compagnie de commerce pour le Nord."

[ff. I $94 \mathrm{v}-200 \mathrm{v}$

I669, [Aug. I0]. Circular letter to the mayors and échevins of maritime towns, relative to freedom of trade with the West Indies.

I669, Nov. I. Colbert to the Archbishop of Rouen. Bishopric of Quebec.

[ff. $288-289$

1669, Nov. 20, St. Germain. Memoir of instructions to the Bishop of Béziers, appointed ambassador in Spain. Commerce with the West Indies.

I669, Dec. 20. Colbert to Talon, intendant in Canada. [ff. $322 \mathrm{v}-328$
$[$ ff. $34 \mathrm{IV}-342$ 251.- I664, May, Paris. Edit du Roy, pour l'Establissement de la Compagnie des Indes Occidentalles (Paris, I664, 28 pp.). [ff. 279-292 
I664, Aug. 27. Déclaration du Roy en faveur des Officiers de son Conseil et de ses Cours Souveraines interéssés ès Compagnies des Indes Orientales et Occidentales.

[ff. 333v-335

291. "Procès-verbal de visite des costes et éveschés de Bretagne fait par le Sieur Colbert..." I665.-Commerce of St. Malo with the Spanish Indies, and the Newfoundland fishery.

[ff. 42-43v

323. Treaties and diplomatic negotiations between France and England, I606-т664.

1632, Mar. 29. Copy of treaty of St. Germain-en-Laye. Ptd. in Davenport, European Treaties, I., Doc. 36.

[ff. 46-50

"Responces sur les prétentions des Srs. Kerkes en conséquences du traité entre la France et l'Angleterre, I632." Cf. Cal. of St. Pap., Colonial, I66I-I668, no. 210.

[ff. $5^{2-53}$

"Mémoire touchant la restitution à faire de la part des Anglois du pays de l'Acadie en la Nouvelle France."

[ff. 54-55

I662. "Remonstrance faicte par M. le Comte d'Estrades au Roy d'Angleterre au sujet de la Nouvelle France."

[ff. 56-56v, 59

I 499-I655. "Abrégé des voyages, descouvertures, et habitations faictes en l'Amérique Septentrionale par les François et ensuite celles faictes par les Anglois."

[ff. $57-58 \mathrm{v}$

"Escrit de l'Ambassadeur d'Angleterre touchant l'Acadie." (Latin.)

[ff. 6o-75

"Véritable fondement des droicts du Roy sur la Nouvelle France par ou l'on peut respondre aux raisons ou aux subtilitez de l'autheur de l'escrit d'Angleterre." Restitution of Port Royal, St. Jean, and Pentagouet; annotations in hand of Colbert.

[ff. 76-79

"Mémoire de M. l'Abbé Bourzeix sur la restitution du port Royal occupé par Anglois." Annotations in hand of Colbert.

[ff. 8I-8Iv

I665, Nov. 3, Westminster. Traicté de Paix entre le Royaume de France et la République d'Angleterre, d'Ecosse et d'Irlande (Paris, Sébastien Cramoisy, I655).

[ff. I 25-I $5^{2 \mathrm{~V}}$

Scriptum Dom. Protectoris Reipublicae Angliae, Scotiae, Hiberniae etc., ex Consensu atque Sententia Concilii sui editum; in quo hujus Reipublicae Causa contra Hispanos justa esse demonstratur (Londini, Henricus Hill et Johannes Field, I655, 42 pp.).

[ff. I60-I8Iv

[1664.] Remarks on a project of a treaty between France and England. Art. relates to Pentagouet, St. Jean, and Port Royal. [I664.] Draft of a treaty between France and England. (In hand of
Colbert.)

[1664.] Draft of a treaty between France and England. (In hand of

I664, Sept. 29, Vincennes. “ Response à la réplique de M. l'ambassadeur d'Angleterre sur le traitté proposé entre le Roy et le Roy son M'e." (In hand of Colbert.)

[ff. $369-37$ I

I666, July, The Hague. Letter relating to English colonies, commerce, and cultivation of tobacco.

324. Treaties between France and Holland, I 596-I664.

"Discours présenté au Roy par l'envoyé de Messieurs les EstatsGénéraux des provinces-unies des paîs bas en suite de la harangue par luy faite à Sa Majesté touchant les différens d'entre les dits Sieurs Estats Généraux et le Roy d'Angleterre pour le Commerce le 29 Décembre i664." English attack on New Netherland. $C f$. below, 341, f. 500 .

[ff. $248-267 \mathrm{v}$

334.- - 66I, May 23. Instructions to the Comte d'Estrades, ambassador in England. Restitution of Acadia.

[ff. $249-263 \mathrm{v}$ 
337.- I 577, Oct. 9, London. Two despatches from Castelnau de La Mauvissière, ambassador in England, to Henry II. and to Catherine de Médicis, respectively. Return of Frobisher. (Originals.) Ptd. in Amer. Hist. Review, XXXI. (Jan., I926) 286-287. Cf. MSS. Fr. 15973.

577, Oct. I3, London. Castelnau to Henry

[ff. $673-678$ turning from a voyage of I4 months.

338. - [ I750 ca.], July Io. Memoir presented by the French ambassador to the King of Spain. Seeks release of two Frenchmen, former inhabitants of Florida, who are imprisoned in Seville.

339. - "Condiciones del Pliego que a dado en la J Salas a de armadas el Licenciado Don Francisco de Salas .. . para la compañia y armada de corso que pretende se forme en estos Reynos de la corona de Castilla a semejança de las compañias orientales y occidentales que tienen formadas los olandeses."

[ff. II6-II9

341.-I654. "Manifesto degl'Inglesi contro li Spagnuoli." Anglo-Spanish relations in the West Indies. (Italian.)

I664. Oct. 9. The Hague. Réponse des Etats Generaun des Provinces

. Unies des Pays Bas à Réponse du Roi de la Gde. Bretagne remise par son Ambassadeur. English attack on New Netherland.

[f. 500

441-454. Copies of the negotations of President Jeannin for the truce of Antwerp, I607-I609.- See above, MSS. Fr. 7086-7090.

466.-I609, Dec. I4; I6ro, Jan. I 5, Apr. 26, London. Letters from [J. de] Beaulieu to [Jean de] Villiers-Hotman, at Dusseldorf. News of the colonization of Virginia.

467.-I632, Mar. 25 [29]. Copy of treaty of St. Germain-en-Laye.

[ff. 4I 5, 4I9, 425

[ff. $427-435 \mathrm{v}$

470-473. Collection of correspondence addressed to Michel de Casteinau de La Mauvissière, ambassador in England, I $575^{-1} 585$.

470.- I 585, July 2, Paris. The king to Castelnau. Reference to Drake's expedition to the Indies.

[ff. I $33^{-1} 34$

473. - $5^{82}$. Letters patent, declaring the will of the king that his fleet, sailing to the West Indies, shall do nothing to the prejudice of neighboring kings or princes or of the Queen of England.

[ff. 3 II -3 I 4

474-476. Copies of the diplomatic correspondence of Antoine Lefèvre de La Boderie, I606-I6Io.--i609, Mar. 3, London. La Boderie to Villeroy, referring to the preparation of an expedition to Virginia in spite of the protests of the Spanish ambassador (476, f. 205).

478. "Relation d'Angleterre" [by a French diplomat, I665].-References to New Netherland and New England.

[ff. I32V-I33

483. - "Des Places fortes ès Indes Orientales, en l'Amérique et en Africque tenues par les Compagnies des Indes Orientales et Occidentales soubs la souveraineté des Estats des Provinces Unies des Pays Bas." [ff. 443-444v

I6I 5, July I 5, Quebec. Father Denis Jémes [Jamay], Récollect missionary, to the Cardinal de Joyeuse. Fertility of the country, the St. Lawrence. description of the Indians, difficulties of their conversion, and libertinage of the French.

[ff. $58 \mathrm{I}-582 \mathrm{v}$

I653, Mar. Confirmation of the concession of St. Christopher to the order of Malta.

"Relation de Brésil."

[ff. $583-586$

[ff. $587-589$

497. - I654. “Plan véritable de l'estat présent des affaires de 1'Europe

"References to discovery of America, the Florida colony, Drake, the West Indies, etc.

「ff. I84-2I6 


\section{COLLECTION DUPUY.}

The Collection Dupuy was formed by the brothers Pierre Dupuy (obiit I65I) and Jacques Dupuy (obiit I656). It is composed of various elements, such as MSS. bequeathed by their father, Claude Dupuy (obiit I 594), MSS. bequeathed by Lullier, counselor of the Parlement de Metz, portfolios of Peiresc, papers of Théodore Godefroy, etc. An inventory of the collection has been made by Léon Dorez, Catalogue de la Collection Dupuy (Paris, I899, 2 vols.) ; brief accounts of its formation and its accession by the Bibliothèque Nationale are in Léopold Delisle, Cabinet des Manuscrits, I. 263, 422.

39. Miscellany relating to the history of the Netherlands, I295-I63I. (Copies.)

I608, Jan. I6, Brussels. Instructions of the archdukes to Spinola, Richardot, and Verreycken, respecting trade in the West Indies, etc. [ff. 56-59 I609. "Mémoire des plus importantes raisons pour lesquelles les Seigneurs Estats ne doivent aucunement quiter le trafficq et navigation des Indes." Dutch trade with the West Indies.

[ff. $67-70$

I6o9, June I7. "Promesse de garantie de la tresve des paÿs bas par les Roys très Crestien et de la Grande Bretagne, à ce intervenans les Ambassadeurs des Archiducs." Assistance to be furnished the Netherlands by France and England if their trade with the West Indies is disturbed. [ff. 85-86v I609. "Déclaration des Ambassadeurs qui sont intéressés à la tresve sur la navigation de Messieurs les Etats aux Indes." [ff. 86v-88. I6r4. "Les raisons que les Ambassadeurs de Hollande ont apportées pour la conservation et maintenue des droits de pescherie. . . " [ff. I I6-I I8 1624, June 10. Treaty of Compiègne between France and the United Netherlands. See Davenport, European Treaties, I., Doc. 32. [ff. 219-219v 1625, Sept. 17. Extract from the treaty of Southampton between the United Netherlands and Great Britain. See ibid., Doc. 33. [ff. 230-23 I

198-202. Negotiations of President Jeannin for the truce of Antwerp, I607-I6o9. See above, MSS. Fr. 7086-7090.

273. Register of a secretary of state, reigns of Francis I. and Henry II.

[ I542?] "Pouvoir g'nal à monsieur de Roberval pour aller decouvrir les terres de Canada, Ochelaga, et Saguenay." Followed by "Ampliation du pouvoir au dit sieur de Roberval". This commission, omitted from the Catalogue des Actes de François I., and apparently ignored by writers on the voyages of Cartier and Roberval, seems, because of the inclusion of the term Saguenay, to apply to Roberval's voyage of I542-I543. The document was communicated by Léon Dorez to the Académie des Inscriptions et Belles Lettres in 1908.

318.- - r6o3, Jan. [sic] 8, Fontainebleau. "Lettres par lesquelles le Roy de France nomme pour son Lieutenant général le sieur de Montz au pays confins de la terre de la Cadie aux Indes."

[ff. IOO-IO3 I603, Dec. 18, Paris. "Lettres patentes en faveur dud. Sr. de Monts pr. le faict de son entreprise des Indes."

[ff. I05-106 I603, Dec. I8, Paris. "Remontrances faites au Roy par le Sieur de Montz sur les articles par lui proposés à Sa Majesté au mois de novembre pour la descouverte et habitation des terres de la Cadye." [ff. ro7-I08 
I603, Nov. 6, Fontainebleau. "Articles proposez au Roy par le sieur de Montz pour la descouverte et habitaõn des costes et Terres de La Cadie."

[ff. IO9- I I I

I626, Mar. I9, Paris. "Contrat fait par M. Le Cardinal de Richelieu comme surintendant général du commerce de France et pays Etrangers, avec la compagnie de Flandres et associés, lui accordant le privilège du commerce général dans le Royaume et hors de France, toutes colonies, Canada, Nouvelle France, etc."

[ff. I $23-\mathrm{I} 34$

I626, May I9, Chateau de Limours. "Traité fait par le Roy de France (M. le Cardinal de Richelieu traitant pour les seigneurs) qui permet à cette compagnie [de la Nacelle de St. Pierre Fleur-de-lysée] d'entreprendre dans son royaume et dans tous autres pays hors de France, Canada, etc . . . un établissement général du commerce." [ff. I37-I 54 N. d. "Causes du désistement par les Français de toutes longues navigations par suite de la rivalité et de la jalousie des Espagnols." [ff. I 57 -I 58

462. Diplomatic miscellany, I428-1633.

[1632, Mar. 29, St. Germain-en-Laye.] "Articles arrestez entre les plénipotentiaires françois et anglois pour la restitution des choses qui ont été prises depuis le traicté de paix faict entre les deux couronnes le 24 avril I629." Ptd., Davenport, European Treaties, I., Doc. $3^{6 .}$

464. Miscellany relating to admiralty and commercial companies, I 584I632.

"Avis donné au Roy de France sur le fait de la navigation et du commerce de L'Amérique et des ordres des armées d'Espagne." [ff. I3-32

Très humbles Remontrances en Forme d'Avertissement que font au Roy et aux Seigneurs de son Conseil, les Capitaines de la Marine de France, contre les Inhumanités commises envers eux par les Portugais et les Espagnols (I6 pp.). References to French discoveries, to the destruction of the French colony in Florida, etc.

[ff. $48-55$

Ordonnances, Privilèges, Franchises et Assistances octroyez et concedez par les Très Hauts et Puissants Seigneurs, des États Généraux des Provinces Unies des Pays-Bas, à la Compagnie des Indes Occidentales par leurs Édits du 9 Juin I62I, Io Juin I622, et l'Ampliation du 21 Juin I623 (Paris, Jean Anthoine Joallin, $1623,36 \mathrm{pp}$.$) .$

[ff. I06-125

1626, [June I4, Stockholm.] "Etablissement d'une Compagnie pour le commerce du Royaume de Suède, pour les Pays d'Afrique, de l'Asie, de I'Amérique, et de la Magellanique, ou Terre Australe, et des Iles qui sont entre eux deux... avec les Privilèges octroyés à la dite Compagnie par le Roy Gustave II." Also in Bib. Députés, MSS. $1354 . \quad$ [ff. I 40-I 52

523. Diplomatic despatches, I 563 - I 573 .

I564. "Sommaire de ce que le Roy Catholicque a faict respondre et remonstrer à Monsieur de Sainct Sulpice, Ambassadeur de son frère le Roy Très Chrestien." Complaint against the "portugalois pirate" who "s'apprestoit et esquippoit ja pour faire aultre navigation et emprise sur la Florida et aultres conquestes de Sa Majesté Catholicque".

[ff. $93 \mathrm{v}-98 \mathrm{v}$

I 565, June 20. Articles presented to the King of Spain by M. de Fourquevaulx, respecting the massacre perpetrated by Menéndez and his men, in Florida (à la Terre aux Bretons), in violation of the capitulation of Jean Ribaut.

[ff. 200-206

I566, Dec. 4. Fourquevaux to the King of France. Massacre of Ribaut and his followers by Menéndez.

[ff. 207v-208v 
1566. Reply of the King of Spain to the articles presented by Fourquevaux. Menéndez has punished Ribaut and his followers not as subjects of the King of France but as pirates; liberation of the women and children of Ribaut's expedition, imprisoned in Spain ; judgment passed on the men [of the expedition] in Seville; Frenchmen arrested at Havana.

[ff. 2I 5-22I

661.-I6I3, June. Description of the city of Mexico as recounted to Guillaume du Var by a Spanish half-breed.

[ff. I85-186 


\section{COLLECTION JOLY DE FLEURY.}

The Collection Joly de Fleury, in 256I volumes, is composed chiefly of the archives of the office of the procureur genéral before the Parlement of Paris, an office held by members of the family of Joly de Fleury from I7I 7 to the Revolution. The papers which make up the collection, judicial and administrative documents, are mostly of the eighteenth century, but there are also numerous documents, chiefly copies, of the seventeenth century, which were brought together for historical or administrative purposes. Material relating to America is scanty and scattered, and for the most part of small importance. It is of interest, however, as showing to a certain extent what American affairs came before the Parlement of Paris through the office of the procureur général.

A rather summary catalogue of the collection has been printed: Inventaire Sommaire de la Collection Joly de Fleury, by A. Molinier (Paris, 1891), which contains an excellent account, in the introduction, of the history of the collection and of the nature and interest of the various sections. Vols. 2553-2554 of the collection contain an inventory of vols. I-562, and vols. 2557-2561 an inventory or tables of other parts of the collection. See also manuscript additions in copy of Molinier in the Département des Manuscrits.

5. "Avis et mémoires sur les affaires publiques."

I7I7, June. "Observations sur le projet de déclaration qui deffend à tous vaisseaux et batimens particuliers de faire commerce dans les pays et terres concédées à des Compagnies ", followed by copy of the draft déclaration of Dec., I7I6, on which the opinion was rendered.
[ff. 206-222

14. "Avis et mémoires sur les affaires publiques."

I719, May, June. Letters and opinions relating to the union of the companies of the Indies, Occident, China, and Senegal, with copies of the edict of May, and of the arrêt of Parlement of June I7, I7I9.

20. "Avis et mémoires sur les affaires publiques."

[ff. 79-94

[I72I ca.] M̀́moire signifié pour le nommé Francisque, Indien . . . de Pondichéry ... contre le Sieur. . . Breignon ... Appellant. Legal distinction between American and East India Indians.

27. "Avis et mémoires sur les affaires publiques."

[ff. $239-257 \mathrm{v}$

I723, Feb., Versailles. Letters of recall granted to Jean François Gruet, banished to Louisiana in I7I9, with notes and draft by Joly de Fleury.

220. "Avis et mémoires sur les affaires publiques."

[ff. I 47-I $50 \mathrm{~V}$

I74I-I742. Drafts, letters, opinions of Joly de Fleury, etc., respecting selection of guardians for minors who are possessed of property in France or in the colonies.

253. "Avis et mémoires sur les affaires publiques."

[ff. 383-402v

[1747.] Autograph draft of a memoir by Joly de Fleury on the attitude of the Parlement of Paris towards the Compagnie des Indes. History of the company, with especial reference to its privileges.

273. "Avis et mémoires sur les affaires publiques."

[ff. 200-208v

I749, Nov., Fontainebleau. Édit .. . portant Suppression des deux Offices de Trésoriers Généraux des Galères, et Création de deux Offices de Trésoriers Généraux des Colonies Françaises de l'Amérique. [ff. 544-544v 
283. "Avis et mémoires sur les affaires publiques."

I750, Sept. IO, 26, Versailles. Rouillé [minister of marine] to Joly de Fleury. Appointment of La Galissonière and de Silhouette to settle with the British commissioners disputes of the two countries with respect to their American possessions.-Acknowledges copies of documents relating to Acadia found in the archives of the Parlement, with list of documents. [ff. 93-95
[

392. "Avis et mémoires sur les affaires publiques."

I764. Proposal to the administrators of the General Hospital to furnish children for populating the colonies, and correspondence of Joly de Fleury and the Chevalier Turgot relating thereto.

393. "Avis et mémoires sur les affaires publiques."

[ff. $279-282$

I763-I764. Commission to the Châtelet to judge as a court of last resort the accusations brought against the Sieur Bigot with respect to abuses practised in Canada, accompanied by letters to Joly de Fleury relating to the sentence rendered in the "affaire du Canada".

396. "Avis et mémoires sur les affaires publiques."

[ff. $70-74 \mathrm{v}$

I76I, Aug. I, Compiègne. Lettres Patentes du Roi, portant Règlement pour les Biens des Jésuites, situés dans les Colonies.

398. "Avis et mémoires sur les affaires publiques."

I765. Draft of a déclaration conferring upon the members and officers of the superior councils of: Canada and Ile Royale the same honors, privileges, and prerogatives as those enjoyed by the corresponding magistrates and officers within the kingdom, accompanied by correspondence of the Duc de Choiseul and Joly de Fleury relating to the proposed déclaration. [ff. 333-34 I

422. "Avis et mémoires sur les affaires publiques."

I745. "Mémoire présenté à M. le Comte de Maurepas ... sur le commerce maritime et celui des colonies."

Printed manifesto: "Depuis le départ des escadres de Brest et de Toulon ... la Cour de Londres, qui ne se cache plus du projet qu'elle a formé d'envahir à force ouverte tout le Commerce du Nouveau Monde . . ."

[f. 390

I745. "Mémoire pour faire connoitre la situation du commerce maritime, la nécessité de le protéger par la Marine du Roy, ... " State of commerce, at the time of the declaration of war, cod fisheries, Canadian commerce, English clandestine commerce in America, necessity of aiding the Compagnie des Indes, and of indemnifying it for the retrocession of Louisiana, etc.

430. "Avis et mémoires sur les affaires publiques." [ff. $392-445 \mathrm{v}$

I768, Feb. I4, Versailles. Lettres Patentes du Roi, concernant la Vente et Discussion des Biens de la Compagnie et Société des Jésuites dans les Colonies.

503. "Avis et mémoires sur les affaires publiques."

[f. 276

I 778. Printed copies of treaty of alliance between France and the United States, Feb. 6, 1778 , and of arrêts, ordinances, and regulations relating to privateering, prizes, neutral vessels, etc., and manuscript correspondence of Joly de Fleury, Sartine, and others.

1307. "Mendiants, I724-I74I."

[ff. $363-389$

[I729.] Memoir on the necessity of sending French subjects to the West Indies and to Canada.

1467. "Affaires financières: Mélanges, I643-I 776."

Memoir on the edict relating to finance and commerce. Art. II deals with Louisiana, Crozat, the Compagnie d'Occident, and Canadian beaver.

[ff. I IO-I 29 
1720. "Papiers de Des Haguais: Commerce maritime."

[1699.] Memoir on the respective functions of the secretary of state for the marine and of the controller general, as regards commercial matters.

[ff. 90-I IOV

I703, June I3, Madrid. Memoir on the Philippine Islands, by Daubenton de Villebois.

I493, May 4, Rome. Copy of the bull Inter Caetera.

[ff. II 3 -I $29 \mathrm{v}$

[ff. I3O-I35

Memoir on the question of permitting French subjects to engage in trade with the Spanish Indies.

1721. "Papiers de Des Haguais : Commerce maritime."

[ff. $136-169$

Contract for supply of provisions to crews of vessels. Transport of supplies to the West Indies.

I699, Sept. I3, Fontainebleau. "Règlement du Roi déterminant les attributions du Contrôleur général des Finances et celles du Secrétaire d'Etat ayant le département de la Marine ", followed by correspondence and memoirs on the subject, and by copies of the regulations of I667 and of Mar. 7, I669.

1722. "Commerce et colonies."

[ff. I $34-185$

I742. Notes and correspondence relating to the déclaration of Jan. 6 , I742, respecting the cod fisheries of Cape Breton.

[ff. 37-4I

I 783-I 784, I787-I788. Memoirs, letters patent, and correspondence of Joly de Fleury, Baron de Breteuil, de Blossac, d'Escar de Perusse, and Nanteuil, relating to the establishment of Acadian families in Poitou. [ff. I79-206

1723. "Commerce et colonies."

I787. Notes, memoirs, and correspondence, relating to the establishment of a service of packet-boats between France and the United States and the French colonies.

[ff. I $5 \mathrm{I}-\mathrm{I} 85$

[I750 ca.] Draft of a contract proposed to Rouillé, minister of marine, for the importation of negroes into Louisiana, and the exportation of tobacco therefrom.

[ff. 207-210

"Précis pour servir de mémoire sur les avantages que pourrait tirer l'établissement $\mathrm{d}$ el'assiente française en cette ville, de la Havane, Cartagenne, Portobello, Vera Crux et autres lieux où se tenoit l'assiente angloise avant la présente guerre."

[ff. $2 \mathrm{II}-2 \mathrm{I} 2 \mathrm{~V}$ Louisiane."

[I750 ca.] "Précis d'un mémoire pour l'établissement de tabac à la

1726. Memoir on Louision memoir in 263 pp., dealing with the situation of Louisiana, its native population, posts, troops, defense, administration, products, plantations, inhabitants, justice, police, commerce, etc. The memoir is preceded by the following note: "Je n’ay dressé ces mémoires au surplus que d'après les ordres de la Marine lorsque j'ay été envoyé à la Louisiane pour y remédier aux abus et surtout à l'agiotage ; mais le ministre en qui on devait avoir confiance ne se trouvant en place en I749 que je revins en France je n'ay pu lui rendre compte de ce que contenaient ces mémoires ..."

1985. "Evocations" [cases called before the Parlement de Paris].

I727, Jan. 2I, Marly. Extract from the registers of the Conseil d'État, respecting exclusive right of the Compagnie des Indes to the sale of tobacco, including that from Virginia.

2118. "Parlement, Mélanges et histoire, I763-1776."

[f. 95

I776, June, Versailles. Edit du Roi, portant Etablissement à Versailles, d'un Dépôt des Papiers Publics des Colonies (Paris, I777).

[ff. $275-279 \mathrm{v}$ 
2206. "Mariages."

I757, Apr. 7. Original letter from curé of St. Sulpice, respecting the marriage of Mlle. Herbert of Martinique to M. de Villeneuve, without parental consent.

โf. I77

Draft of an ordinance regulating marriages of French subjects. [f. 253

$\left[\begin{array}{lll} & 750 & \mathrm{ca}\end{array}\right]$ Memorandum respecting a draft of a déclaration on the subject of marriages of residents of America.

[f. 267

2376-2392. Judicial decisions.-The last three volumes of this group constitute an index to the material in the other volumes, but although this index indicates the existence of documents that should be of interest for American history, an examination of the volumes referred to shows all such material to be lacking.

2437. "Recueil de lettres, documents historiques, et nouvelles à la main, I687-I 789."

Exposé des Motifs de la Conduite du Roi relativement à l'Angleterre (Paris, I779). Statement of French policy with respect to American colonies and England.

2453. "Guerre d'Amérique; nouvelles à la main, I755-1756."

[f. 195

I 755, July 28, news of French vessels in the St. Lawrence, reasons for expecting preservation of peace (f. 3 ); news of naval combat in Acadian waters, capture of Beauséjour by English (f. 5) ; Sept. 2I, news of capture of Nova Scotia and New England by French and Indians (f. I6) ; Sept. 25, confirmation of news of capture of Boston (ff. 18, 23).

1756. Translation of English declaration of war on France. [f. 30

I756, June 9. Ordonnance du Roi portant Déclaration de Guerre contre le Roi d'Angleterre.

[f. 32

I756, Aug. I, Calais. Dagieu to Joly de Fleury. Blockade of Louisbourg; defeat of Johnson.

2510. "Papiers de La Reynie."

[f. 38

"Mémoire et réflexions générales sur le commerce, manufactures et navigation de France." Efforts of Santo Domingo to compete with Virginia in tobacco trade; beaver trade in Canada. [ff. 2-16 I660, Dec. "Advis . . . pour le commerce pour monstrer la nécessité d'avoir la protection spéciale du Roy ... " Discoveries, colonies, and fisheries.

"Plainte publique sur l'interruption du Commerce." Commerce of the English, whale and cod fisheries, commerce of American colonies. (Copy of printed work by Vibaud?)

[ff. I I $7-124 \mathrm{v}$

I655. Tariff of import and export duties in Holland. American products, beaver, etc.

2511. "Papiers de La Reynie."

"Mémoires et advis donnez au Roy sur le fait de la navigation et commerce de l'Amérique ..." " [ff. 4-16
[

English and French commerce in America. [ff. $58 \mathrm{v}, 59$

I620, Nov. 8, Paris. "Articles accordés par le duc de Montmorency, Viceroy ... . de la Nouvelle France . . . aux Srs. Guillaume . . . et Ezechiel de Caen ... pour les voyages, commerce, traite et trafficqz au dit païs ..."

[ff. $83-88 \mathrm{v}$

Extract from Discours d'un Grand Capitaine Français de Dieppe. [ [f. 107 I685. July I7. Versailles. Le Tellier to La Reynie. Revival of herring and cod fishery at Dunkirk.

"Projet pour l'établissement d'une pescherie sélentaire â. $115-115 \mathrm{~V}$ cotte de Coccade au Poisson secq." Signed, Le Roux.
[ff. I 42 -I 49 
2512. "Papiers de La Reynie."

1667. "Mémoire des Asseurances faicttes à Paris par l'entremise de Mre. Jean Le Roux." Mention of vessels going to Newfoundland.

1672. "Estat de navires assurés à Paris pendant le mois [ff. IO2-IO3v Id., Feb., Mar.

2514. "Papiers de La Reynie."

[ff. I09, I I 2 , I 18

1632, Mar. 29. Treaty of St. Germain-en-Laye; substance of articles relating to Canada and Acadia.

[f. I2Iv I667, July 31. Articles de Traité de Paix et de Commerce entre le Roy d'Angleterre et les Estats Généraux des Provinces Unies, conclus à Bréda . . . (Paris, I667).

2516. "Papiers de La Reynie."

[ff. $33^{\mathrm{I}-348}$

Address to the King of France by the ambassador of the Netherlands, respecting the dispute between the English and Dutch over islands captured by the latter in the East and West Indies.

[ff. 91-106 I667, Feb. Speech from the throne at the opening of Parliament (England). Rebellion in Virginia.

[ff. I 29-I 3OV 


\section{COLLECTION MOREAU.}

The Collection Moreau, I834 volumes, comprises the manuscript part of the Cabinet des Chartes, or library of historical documents, formed under the direction of Jacob Nicolas Moreau, avocat des finances and historiographer of France, between I759 and the Revolution. The purpose of the collection was to facilitate research and reference in all matters pertaining to legislation and administration; it may indeed be regarded as a prototype of the modern legislative reference library. The collection is composed, for the larger part, of transcripts of documents in foreign, provincial, and, to a less extent, Parisian archives, which were gathered in the course of numerous historical missions. It also includes groups of documents, original and transcribed, that were collected by others than Moreau. It is in one of these groups, the collection of Fevret de Fontette (vols. 734-861), relating mainly to the history of Burgundy, that are found the few important documents of interest for American history; other documents, in the group known as Collection d'Ordonnances (vols. 1282-1421), are ordinances and edicts which are for the most part accessible in print or in other depositories.

A catalogue of the Collection Moreau, containing a brief account of its formation and history, has been published: Inventaire des Manuscrits de la Collection Moreau, by $\mathrm{H}$. Omont (Paris, I89I). See also Le Comité des Travanx historiques, by X. Charmes (Paris, I886), I. iv et seq., in the collection of Documents Inédits, and L. Delisle, Le Cabinet des Manuscrits, I. 557 et seq.

726. "Collection Brequigny. Pièces historiques, I657-I702."

I657, Sept. 2. Sourdeval de Mendre to Chancellor Séguier. Mentions services of members of his family in founding of Canada. [ff. 28-3Iv

I702, Sept., Vigo. De Gatines, intendant, to - Operations of the squadron of Chateaurenault in American waters, I7OI-I702, with list of vessels.

[ff. 3I I-3I9

734-861. These volumes constitute the group known as the collection de Fevret de Fontette.

781.- [ [ 600 ca.] "Mémoire de M. de Ste. Catherine, résident pour le Roy à Heidelberg, pour faire des Colonies françoises ès terres neufves." [ff. I-7

833.-I598, Dec. 2I, St. Germain. Henri IV. to the Parlement of Burgundy. In favor of the enterprise of La Roche in Canada, and directing the transportation thither of persons sentenced to be banished. If. I9

I 599, Apr. 3, Fontainebleau. Id. to $i d$. Same subject.

[f. 22

834.- I7 I9, Feb.-I720, Jan. Letters from d'Argenson, John Law, and Dupleix to the presidents of the parlements of Dijon and Bordeaux, and to the director of the bureau de l'aumône, relating to the despatch of prisoners and vagabonds to Louisiana.

[ff. I 3 I-I 46

841. - [ I600 ca.] "Mémoire de M. de Ste. Catherine, Résident pour le Roy à Heidelberg, pour la carte de l'Amérique."

I67I, Jan I7 Cayenne. I etter from Father Jacques

“ “ff. 36-45v

I534. "Le Voyage de Jacques Cartier." Ptd. in Biggar, Voyages of Jacques Cartier (Ottawa, I924), pp. 3-81. According to Biggar, ibid., p. x, this 
MS. is "a unique MS. copy of the original French text", and has been reproduced in facsimile by James Phinney Baxter in A Memoir of Jacques Cartier (New York, I906), pp. 26I-296.

[ff. $5 \mathrm{I}-68 \mathrm{v}$ I646. "Journal du voyage fait au Brésil par Mr. le général Van Goch."

“Voyage projeté par Jean Dennebault au Brésil."

[f. 128 I67I. Relation of Guiana by Father Jean Grillet, S. J.

[f. 132 1657. Relation of Martinique and St. Christopher, by Father Jean Halley, S. J.

[f. I 58 I660, Jan. 29. " Copie d'une lettre escrite du Village de St. Joseph sur la Rivière du St. Esprit que les Indiens appellent Tacobagai ... par le R. P. Claude Galiet, Minime Missionnaire apostolique au Sr. Galiet son frère à Beaumont sur Vigenne." Description of Florida. (Incomplete.) [ff. 246-246v 1644, Sept. 2, Richelieu, New France. Father Georges Eudemare to Father François de La Vie, at Dijon. Indians, travels of missionaries, etc. (A. L. S.)

[ff. $25 \mathrm{I}-25^{2}$

842.-166I-1665. Relations of New France, by Father Chaumonot.

[ff. 3-30 1674, Aug. I. "Relation par le P. d'Ablon de la Découverte de la Mer du Sud faicte par les Rivières de la Nouvelle France."

[ff. $3 \mathrm{I}-32 \mathrm{v}$ I666, Oct. I, 4; I667, Aug. 25, Quebec. Extracts from letters of Father Thierry Beschefer.

[ff. $35-37$ I667, Aug. 4, "au cap de la Magdelaine". Extract of a letter from Father Marquette to Father Dupin.

[f. $37 \mathrm{v}$ I668, June I4; I67I, Feb. 3, Cayenne. Letters from Father Jean Grillet. 1667, Aug. 12, Lake Champlain. Letter from Father Jean Pierron.

[ff. 62,80

[ff. $72-75 \mathrm{v}$

1282-1421. "Collection d'Ordonnances."

1311. - [ I $720-1725 c a$.$] "Instruction sommaire pour achever en peu de$ temps un solide Etablissement dans la Loüisianne, dirigée par le Sr. Droüot de Valdeterre, Ecquyer Capitaine réformé au régiment de Pons et cy-devant commandant l'isle Daufine et les Biloxy dans la Louisianne." General description of Louisiana, government, reform of abuses, posts, etc.

[ff. $3-20$

"Taxes faites sur les Mississipiens en actions." A list of IO2 persons or companies, apparently holders of shares, with indications as to the amounts of their respective assessments.

[ff. $21-23$ 1626-1721. "Chronologie des Compagnies de Commerce établies en France depuis I626."

[ff. $3 \mathrm{I}-33$ I648-I732. Lists of documents in the "volumes de la Cie. des Indes", vols. 2-10, which are not included in the tables.

[ff. $34,52,65,79,88,89,93,94$, I I I 1665, Oct. 26, Paris. Arrêt confirming the contract made by the directors of the domaine d'Occident for the slave-trade in the West Indies. [ff. 54-55

1336. - "Projet des articles pour l'establissement d'une Compagnie des assurances et grosses aventures de France", followed by lists of thirty associates with amounts of their respective subscriptions.

[ff. $254-263$

1338-1339. The admiralties of France.-Outlines of a treatise indicating the jurisdiction of each admiralty. Those of Dieppe, St. Valéry-en-Caux, Havre, Fécamp, Honfleur, La Rochelle, etc., had jurisdiction over certain fisheries. 
1340.-I248-I703. "Inventaire des édits, ordonnances, déclarations, règlemens, arrests, jugments, sentences, provisions, commissions, et autres actes concernant la Marine."

1341.-I697, Feb. 6. "Ordonnance du Roy, Qui permet aux vaisseaux armés en course pour l'Amérique d'y faire des rançons jusques à 30,000 livres."

[f. I05

r684, Mar. 3, Versailles. "Arrêt . . . qui ordonne la confiscation des bâtiments étrangers qui font la pêche de la morue sédentaire ou le commerce des pelleteries en Acadie dans l'étendue de la concession des Srs. Bergier et Cie."

[ff. I96-I97v

I684, Mar. 3, Versailles. "Arrêt ... Qui augmente l'étendue de la concession accordée aux Srs. Bergier et Cie. à la côte d'Acadie." [ff. I98-I99v I697, Oct. 25, Fontainebleau. Judgment of the admiral respecting the prizes taken by de Pointis at Cartagena.

[ff. $325-332 \mathrm{v}$

1342.-I703, Dec. I7. Judgment of the admiral with respect to the prize La Nouvelle Espérance, laden with cod.

I704, Sept. 9. Arrêt relating to the Newfoundland fisheries.

[ff. I I $7-$ I I $8 \mathrm{v}$

Pontchartrain to Beauharnais, intend

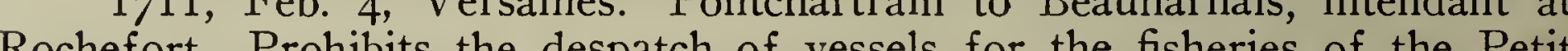
Nord, and along the Newfoundland coast.

[ff. $216-216 \mathrm{r}$

1343. of engagés and guns to the West Indies and New France.

ff

I730, June, Fontainebleau. Arrêt uniting to the royal domain the 2 lov of St. Jean, granted to the Comte de St. Pierre in Aug., I7I9. [ff. 249-250v

1382.- I709, May 28, The Hague. Copy of preliminary articles for the general treaty of peace.

[ff. I $45^{-1} 5 \mathrm{OV}$

I680, Oct. 29, Versailles. Extension for three years, commencing July I, I682, of the lease to Jean Oudiette of the taxes of the domaine d'Occident.

[ff. 3I4-3I $5 \mathrm{v}$

$1396,1407,1408,1417,1419$. I600-I 778. These volumes contain lists of ordinances, arrêts, letters patent, edicts, regulations, treaties, etc., relating, inter alia, to Canada, Acadia, Louisiana, the West Indies, fisheries, the domaine d'Occident, commerce, and related matters. 


\section{MANUSCRITS LATINS.}

No attempt has been made at an examination of the large and important collection of Latin MSS. A single item, noted by Biggar, Early Trading Companies, has been seen and is described.

17059. Charters, I $400-1789$.

I 538, Sept. 22, St. Germain. Royal warrant to the treasurer general to pay to "Jaques Cartier ñre pillote en la marine de ponant demeurant à Sainct Malo", the sum of fifty écus for salary, food, and maintenance of savages. (In French.)

[no. 202

\section{MANUSCRITS ANGLAIS.}

The small collection of English manuscripts, about Ioo volumes, was formed in I86o by bringing together in a single group the MSS. in the English language that had previously been scattered in various other collections. A brief catalogue of the collection has been published by Gaston Raynaud, Catalogue des Manuscrits Anglais de la Bibliothèque Nationale (Paris, I884).

51. Memoranda of navigation.-These consist of bluewash drawings or paintings of the profiles of various points of land in the West Indies, Cuba, and Central America, as they appear from on board a vessel approaching them, and of memoranda of bearings, variations of the compass, color of water, etc.

68. Ship signals. - A list of signals for use in day time, at night, and in time of fog, and by private vessels. On fly-leaf: " The Gift of Sir Peter Parker to Toby Caulfield, Nov. 27th, on board of the Chatham off the Town of New York, N. America." (Parchment.)

69-70. Journals of the House of Commons. - "Commons Journals from Nov. I8, I606, to Feb. 9, I609/10", and "Commons Journals from Mar. I7, I627/28 to Mar. Io, I628/29".

98. Penn family papers.

I747, Sept. I. " Deed of Covenant upon an intended marriage Act. Mr. John Haydon and Miss Mary Penn." (Parchment, seals, stamps.) ment.)

Probate of the will of Sarah Penn. Will is dated May 22, I777. (Parch-

100. Inventory of the despatches of the diplomatic agents of the United States in France, I789-1816.-A carefully prepared calendar in 370 pages, evidently compiled from the archives of the Department of State in Washington. 


\section{DEPARTEMENT DES IMPRIMES, CARTES, ET PLANS.}

\section{SECTION DES IMPRIMÉS.}

\section{COLLECTION ANGRAND.}

The collections of printed works administered by the Section des Imprimés include exceptionally a few groups of manuscripts. One of these relates to Mexico, Central America, and South America, and is known as the Collection Angrand, having been bequeathed to the Bibliothèque Nationale in 1885 by Léonce Angrand, the Americanist.

1-3. Two volumes of letters, notes, memoirs, etc., by Col. Galindo, I83II838, relating to the languages, antiquities, and geography of Central America, accompanied by a volume of illustrations.

4. Letters and memoirs of Brasseur de Bourbourg, I859-I865, accompanied by photographs.

5. "Idée générale d'une exploration archéologique au Mexique et dans l'Amérique tropicale", by Angrand. (Incomplete.)

6-7. "Bibliotheca americana. Catalogo de los autores que han escrito de la America en differentes idiomas ... compuesto por el coronel D. Antonio de Alcedo..." I79I. Two volumes.

8. "Libro de sermones predicables sobre los misterios que en la quaresma se celebran desde la Septuagessima hasta el tercer dia de Pascua . . compuesto en langua cakchiquel por el padre fray Antonio del Sal ... " I643.

9. "Vocabulario en langua kiche y castellana." (Incomplete.)

10. "Vocabulario de la lengua general de los indigenas de la provincia de Quito." I834.

11. "Discurso en que se prueba el derecho que el rey tiene como soberano de valerse del oro y plata de las iglesias de sus reynos y estados, para subvenir a los gastos de la presente guerra...."

12. "Atlas guatemalteco en ocho cartas formadas y grabadas en Guatemala de orden del gefe del Estado C. Dr. Mariano Galvez, año de 1832." By Miguel Rivera-Maestre. Printed, with addition of MS. maps and notes.

13. "Notas geograficas, topograficas . . . sobre la isla de Pinos."

14. "Note sur les antiquités de Kiché et de Tepam-Guatemala par Miguel Rivera-Maestre." I834. Nine plates.

15. Carton of miscellaneous notes on the Plata.

16. Letter of Angrand on the Gardens of Lima. I866.

17. "Noticias de Nutka", by D. José Mariano Moziño; "Estado del reino de Santa Fe", by Sr. Cavallero; "Lo importante que es la poblacion y medios que se proponen para conseguirlo en este nuevo reyno de Granada", attributed to Dr. Pedreros.

Pictorial. Annexed to the MSS. of the Angrand collection are 24 portfolios or albums of photographs, lithographs, pencil sketches, wash drawings, tracings, etc., representing scenes, towns, sites, ruins, remains, costumes, and various objects in Mexico, Central America, South America, and Cuba. 


\section{SECTION DES CARTES ET PLANS.}

The collections of the Section des Cartes et Plans consist of maps, plans, atlases, geographical reviews, works on geography and cartography, instruments, etc. The maps and plans, engraved, printed, or in manuscript, number over 200,000 . The collection has been formed from a variety of sources, and in it have been incorporated important smaller collections such as those bearing the names of Angrand, Barbier du Bocage (I844), Gosselin (I842), Klaproth (1832), Moreau, Archives Nationales (1873-1876), and especially, in I924, the great collection of $J$. B. d'Anville, very rich in American maps, which was formerly in the archives of the Ministry of Foreign Affairs.

The maps acquired before 1886 constitute the Ancien Fonds, those acquired since that date the Nouveau Fonds, but a general reclassification is in progress which will bring all the maps together into a single general classification.

In the following list there have been included all the manuscript maps of North America and the West Indies that have been revealed by a painstaking search of the card catalogues, followed by an examination of the maps themselves. For convenience in consultation the list has been given a geographical classification, which does not in any way correspond to the classification of the maps themselves. The call-numbers of the maps are indicated in open brackets. Those numbers that include the letters "Ge" are of the new classification; those that include the letters "DD" refer to maps in the d'Anville collection.

There is no published catalogue of the maps, but the section possesses card catalogues of both the Ancien Fonds and the Nouveau Fonds. The following lists are mentioned because they contain detailed descriptions of a number of important American maps in the collection.

Henry Harrisse, Notes pour servir à l'histoire à la Bibliographie et à la Cartographie de la Nouvelle France et des Pays Adjacents, 1546-I7oo (Paris, I872).

Gabriel Marcel, Cartographie de la Nouvelle France: Supplément à l'Ouvrage de M. Harrisse (Paris, I885).

Gabriel Marcel, Quatrième Centenaire de la Découverte de l'Amérique: Catalogue des Documents Géographiques exposés à la. Section des Cartes et Plans de la Bibliothèque Nationale (Paris, I892).

Albert Isnard, Joseph-Nicolas Delisle, sa Biographie et sa Collection de Cartes Géographiques à la Bibliothèque Nationale (Paris, I9I 5).

Léon Vallée, Notice sur les Documents esposés à la Section des Cartes, Bibliothèque Nationale.

"Inventaire de la Collection de Cartes de M. d'Anville." An eighteenthcentury MS. in the Library of Congress, containing a list of 8793 maps.

\section{CLASSIFIED LIST OF MS. MAPS RELATING TO NORTH AMERICA} AND THE WEST INDIES.

\section{GENERAL.}

[I450-I492.] Mappemonde, published by Ch. de La Roncière: La Carte de Christophe Colomb (Paris, I924). (Parchment, I200 $\times 720 \mathrm{~mm}$.)

[Ge. AA. 562
[

[I6th century.] Portolano of Europe, Africa, and America. (Parchment, I030 $\times 890 \mathrm{~mm}$.)

[Rés. Ge. B. I204 
[r6th century.] Portuguese portolano. Coasts of North America and West Indies $(830 \times 590 \mathrm{~mm}$.). Gulf of Mexico and parts of North and South America. (570 $\times 790 \mathrm{~mm}$.

[Rés. Ge. C. 5086

[I6th century.] Portuguese atlas. Includes: map of the world; map of Canada, Newfoundland, and Labrador; maps of Santo Domingo and the Antilles: map of Gulf of Mexico and Florida. Formerly in the possession of the Duchesse de Berry. See Vallée, Notice, no. 49. (Parchment, $385 \times 270$ mim.)

[Rés. Ge. FF. I 4409 mm.)

[I6th century.] Portuguese map of the world. (Parchment, $420 \times 370$

[Rés. Ge. D. 7824 [I6th century.] Portuguese portolano of the Atlantic Ocean. (Parchment,
[Ge. B. I I 48
[I 5 I 3 ca. $]$ Globe on a pedestal, school of J. Schöner.
[Ante I 527.$]$ "Nova et integra universi orbs [sic] descriptio." See Vallée, Notice, no. 29I. (Globe of gilded copper.)

[Ge. A. 333

r534. Portolano showing western Europe and Africa, with the Atlantic Ocean and part of the east coast of Brazil. Signed, Gaspar Viegas. See Winsor, Kohl Collection, no. I5I ; Vallée, Notice, no 3I7. (Parchment, 680 X $940 \mathrm{~mm}$.

[Rés. Ge. B. I I 32 [ I535 ca.] Globe of wood showing America and Asia united. See Vallée, Notice, no. 286.

[Ge. A. 338

I 543. Atlas of Baptista Agnese, Venice. Includes: map of North America; map of Atlantic Ocean, with Gulf of Mexico and coasts of North America; map of the world. See Lowery, List of Maps of Spanish Possessions, I502I820, no. 40 ; Vallée, Notice, no. 42. (Parchment, $350 \times 250 \mathrm{~mm}$.)

I 543. Copy of preceding, with slight variations. [Rés. Ge. FF. I 44I I
[Ret

[I 550-1600.] "Lectori S. Quando-quidem quotidiana diversarum nationum .. Auctore Arnoldo Florentio a Langren Reg. cat. Maj'tis cosmographo et pensionario ..." See Vallée, Notice, no. 63. (Globe of wood.) [Ge. A. 275 I566. Map of the world, by Nicolas Desliens, Dieppe. See Winsor, Kohl Collection, no. 69; Vallée, Notice, no. I98. (Parchment, $470 \times 290 \mathrm{~mm}$.)

[Rés. Ge. D. 7895

I 570. Map of the world, by Jehan Cossin of Dieppe. See Vallée, Notice, no. I88. (Parchment, $450 \times 260 \mathrm{~mm}$.)

[Rés. Ge. D. 7896

I584. "Terres Neufves, la Floride, les Neufves Espaignes, le Péru, le Brésil." "Ceste carte a esté faicte par Jaques de Vaulx, pilote entretenu pour le Roy en la Maryne au Havre." See Vallée, Notice, no. 222. (Parchment, $565 \times 8$ Io mm.)

[Rés. Ge. C. $405^{2}$

I604. "Americæ sive novi orbis nova descriptio, Florentiae, Per Mattheum Neronium Pecciolen, Cosmogr." [Matteo Nerone Peccioli.] See Lowery, List of Maps, no. $97 .(2570 \times 2550 \mathrm{~mm}$. $)$

[Rouleau I2

I6ro. "Nova orbis terrarum geographica ac hydrogr. tabula . . . By Harmën Ianss ende Marten Ianss caert schryvers in den Pascaerte. Tot Edam." ( $1970 \times$ I $390 \mathrm{~mm}$.)

[Rouleau 548

I6r8. Portolano showing America with part of Europe and Africa. "Domingo Sanches a fes em Lisboa." See Vallée, Notice, no. 195. (Parchment, $920 \times 820 \mathrm{~mm}$.)

[Ge. AA. 568

[ I8th century.] " Ière Mappemonde ou représentation du globe terrestre dont les extrémités sont développées selon les règles des projections géographiques ..." [By P. Buache.] (490 × $335 \mathrm{~mm}$.)

[I8th century.] "Hemisphères austral et Boréal." ( 8 sheets.)

[Ge. D. 7832

[Ge. A. 29 and 30 
[I700-I750.] "Carte (mappemonde) faite par les Japonais, apportée en Europe par Kaempfer, et déposée dans le cabinet de M. Hans Sloane président de la Société Royale de Londres." ( I 2 Io $\times 635 \mathrm{~mm}$.)

[Ge. C. 5029

1706. "Carte et journal de la route qu'a tenue l'escadre des vaisseaux du Roy armée à Brest et au Port Louis . . . commandée par Mr. le chevalier des Augiers." Parts of Newfoundland, Canada, and the Antilles. (790 ×545 mm.)

[Portef. 35. No. 44ter

1737. Hydrographic map of the Atlantic Ocean, with manuscript corrections, by Bellin and Buache. $(650 \times 500 \mathrm{~mm}$.

[Ge. C. I 220

I768. "Nuevo mapa geographico de la America Septentrional, perteneciente al virreynato de Mexico . . . por . . . don Joseph Antonio de Alzatey Ramirez." "Copie exécutée sous les yeux de M. Buache pour estre remise à M. l'Abbé Chappe d'Auteroche qui doit passer incessamment dans cette partie de l'Amérique ..." See Lowery, List of Maps, no. 515. (870 $6990 \mathrm{~mm}$.

[Ge. B. I I87

I768, I792. “Nuevo Mapa geographico de la America Septentrional, perteneciente al virreynato de Mexico, dedicado a los sabios miembros de la Academia real de las ciencias de Paris . . . por Joseph Antonio de Alzate y Ramirez." With note on position of towns according to the observations of Chappe d'Auteroche during his journey in California in I769. Cf. ibid., no. 516. (680 $\times 550 \mathrm{~mm}$.

[Ge. C. 4643

[I77I-I774.] Map of the world, with coat of arms of De Boynes, minister of marine. (730 $\times 530 \mathrm{~mm}$.

[K1. I 59

I789. "Carta reduzida, que contem os dous Oceanos Atlantico e Oriental, por Jose Fernandes Portugal na Bahia de todos os Santos . . ." (Parchment, I380 $\times 790$.

[Ge. A. 32

[Igth century.] Map of the world, without legends. (Pencil, $660 \times 500$ mm.)

[R. C. 67 I 5 (5)

Planisphere, by Barbier du Bocage, showing the Pacific Ocean with the coasts of America and Asia. (Tracing, 755 $\times 5$ I 5 mm.) [R. C.67I3 (3)

Parts of Asia and America, showing northwest coast of America. (Two tracings on one sheet, $330 \times 440 \mathrm{~mm}$.)

Maps of the Atlantic Ocean. (Tracing, $390 \times 280 \mathrm{~mm}$. ) [K1. 938
[Ke

GULF OF ST. LAWRENCE, NOVA SCOTIA, AND ILE ROYALE.

I697. "Carte dans laquelle est marquée la route des vaisseaux du Roy commandés par Mr. le Marquis de Nesmond." From France to Newfoundland. By Demari. $(850 \times 355 \mathrm{~mm}$. $)$

[Portef. 35. No. 44 bis

[I700-I750.] Coasts of the Gulf of St. Lawrence. $(760 \times 540 \mathrm{~mm}$.

[1700-I750.] Coasts of the Gulf of St. Lawrence. (I $300 \times 450 \mathrm{~mm}$.)

[Ge. C. $4.64 \mathrm{I}$

[Ge. C. 4642

[Ante I763.] "Carte du golphe de St. Laurent et islle Royalle. Carte du détroit de Bellisle." Copy by Deslongchamps, senior. ( 2 sheets, $600 \times 450 \mathrm{~mm}$. and $580 \times 450 \mathrm{~mm}$.)

[Ge. AA. 487

I765. Map of the island and bay of Corke, Newfoundland. "Joint à la lettre de M. le Duc de Choiseul du 3I Mars I765." (450×550 mm.)

"Baye des Chaleurs." (8ro $\times 990$ mm.) [Ge. DD. 2987. No. 8614

[Ge. DD. 2987 . No. 8656

[I8th century.] "Carte de l'Isle St. Jean et d'une partie de l'Isle Royale et de l'Accadie." (570 $\times 470 \mathrm{~mm}$.)

[Ge. D. 8056

[I th century.] "Ile St. Jean." $(570 \times 450$ mm. $)$ [Ge. DD. 2987. No. 8636 
[18th century.] "Carte de la grande anse des Trois Rivières et des côtes adjacentes." (Tracing, $470 \times 250 \mathrm{~mm}$.)

[Ge. D. 7943

I746. "Island of St. John . . . in the bay of St. Lawrence, subject to King George by the capitulation of Lewisburg I7th June 1746." $(320 \times 200 \mathrm{~mm}$.) "Plan des Trois Rivières en l'Isle St. Jean." $(470 \times 340$ mm. $)$ [Ge. D. $735^{8}$ [Ge. D. 807 I "Vue des Saintes, prise des hauteurs du Quartier des Trois Rivières." $(580 \times 300 \mathrm{~mm}$.

[Ge. D. 8048

"Le Port de la Joye dans l'isle St. Jean." (530×530 mm.) [R. C. I3522 (5).

[I8th century.] "Plan du Port-Royal dans l'Acadie appelée aujourd'hui par les Anglais Annapolis royale." (3I0 $\times 200$ mm.) [Ge. D. 8069
[

[ r8th century.] " Plan de la rade, baye et Port de Chibouctou ou d'Halifax en la Nouvelle Ecosse ou Acadie." $(625 \times 345$ mm. $)$ [Ge. D. 8052

[18th century.] "Isle Royalle." ( $840 \times 560 \mathrm{~mm}$.) [Ge. DD. 2987 . No. 8626 [18th century.] "Port de Louisbourg." $(670 \times 560 \mathrm{~mm}$.)

[r8th century] "Plan du port et DD. 2987. No. 8630 [I8th century.] "Plan du port et de la ville de Louisbourg avec ses batteries." By Ste. Marie. $(900 \times 480 \mathrm{~mm}$.)
[Ge. C. 5II7

[I8th century.] "Rade de Louisbourg." (I I $90 \times 890$ mm.) [Ge. AA. 494

[18th century.] "Port de Louisbourg avec figure des fortifications projetées par l'ingénieur en chef." $(600 \times 450 \mathrm{~mm}$. $)$

[r8th century.] "Plan de la ville de Louisbourg avec les fortifications du

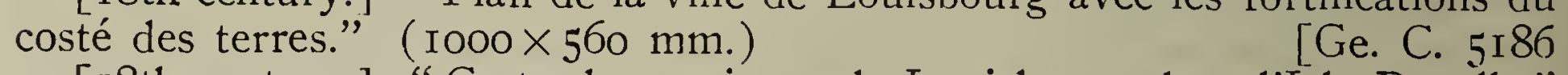

[I8th century.] "Carte des environs de Louisbourg dans 1'Isle Royalle." $(420 \times 290 \mathrm{~mm}$.) $[$ [R. G. 7485 ; without legends, R. C. 7486

[Post I 7I3.] "Isle St. Jean, isles de Miscou, isles de la Madelaine, coste d'Acadie, isle Royale." ( $1080 \times 920 \mathrm{~mm}$.) [Ge. C. 505I
[P.

[Post I725.] "Plan d'une partie de l'Isle Royale." Vicinity of Louisbourg. $(680 \times 5$ I $10 \mathrm{~mm}$.

[R. C. I $259 \mathrm{I}$

I727. "Carte de l'isle Royale et des principaux caps de l'isle de Terre Neuve. Verrier fils fecit." ( $800 \times 440 \mathrm{~mm}$. $)$

[Ge. C. $507 \mathrm{I}$

I73I. "Veüe de la ville de Louisbourg prise en dedans du port. Verrier fils fecit." ( $1000 \times 360 \mathrm{~mm}$.) [Rés. Ge. C. 5019

I 732. "Plan de Louisbourg où est marqué en rouge la ville, les forteresses et les fortifications, qui sont bastie et finie, et en jaune celles qui restent à faire, après lesquelles on travailloit au mois d'Aoust $1732 . "(730 \times 725 \mathrm{~mm}$.)

[ 1750 ca.] Plan of Louisbourg. $(520 \times 450 \mathrm{~mm}$.)

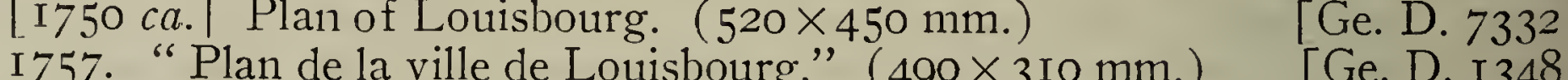

"Carte de l'Isle Royale, de l'Isle Saint Jean et d'une partie de la D. I348 la Cadie par Dubois." $(720 \times 515 \mathrm{~mm}$. $)$ [Ge C. $5 \mathrm{I}^{82}$
[G

"Suivant le sentiment de Mr. Soldricq l'Isle de Sable est à 2.3 lieues de la

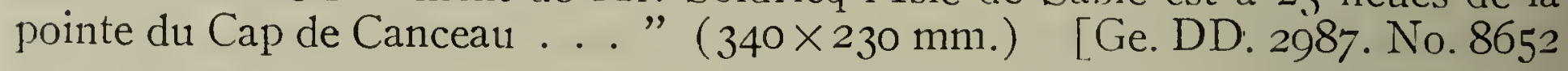

\section{CANADA.}

[164I ca.] Map of the St. Lawrence from the Saguenay to Montreal. By Jean Bourdon. ( $500 \times 700 \mathrm{~mm}$.)

I64 I "Carte depuis Kebec jusqu' don." ( $585 \times 430 \mathrm{~mm}$ )

[Rés. Ge. D. 8070 Laurens en Canada, contenant dix sept lieuxe de la Coste au sud du fleuve St. tion des isles de St. Bernabé et du Biq, qui sont proche de la d. coste. lad'c demonstration faite accause de l'Isle du Biq par le sieur Chamot escrivin du 
Roy en la marine envoyé audit lieu par Monsieur Colbert de Terron ..." $(580 \times 4$ I $\mathrm{mm}$.

[Ge. DD. 2987. No. 8664

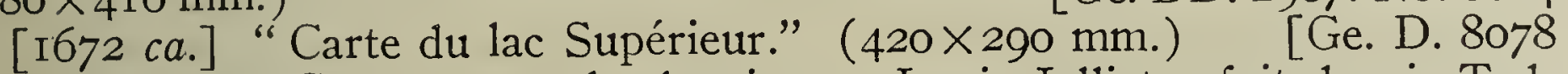
1679. "Cete Carte montre le chemin que Louis Jolliet a fait depuis Tadoussac jusqu'à la Mer du Nord, dans la Baye d'Hudson; et marque la vraye situation de la Baye et du Detroit ... Fait à Québec en Canada le 8 novembre I679 . . " "Signed, L. Jolliet. Cf. Harrisse, Notes, no. 207. $(560 \times 345 \mathrm{~mm}$.)

[Ge. C. C. I 275 ; tracing, Ge. DD. 2987. No. 8665

1680. Map of the St. Lawrence river, with the Great Lakes. "Ce que j'ay, marqué avec un trait dessous est tiré d'une carte faite par un sauvage et envoyé par Mr. de Belmont." (I $8 \times 450 \mathrm{~mm}$.) [Ge. DD. 2987. No. 8662

1688. "Le Lac Ontario avec les lieux circonvoisins et particuliêrement les Cinq Nations Iroquoises. Par le Père Raffeix." ( $500 \times 380 \mathrm{~mm}$.

[Portef. 40. No. 37

1690. "Plan de Quebec Et de ses environs, En la Nouvelle France Assiégée par les Ang̣lois le I6 d'Octobre I6go jusqu'au 22 dud. mois qu'ils s'en allèrent, apprès avoir esté bien battus, Par M. le Comte de Frontenac, gouverneur général du Pays. Par le Sr. de Villeneuve, Ingénieur du Roy." ( $580 \times 300 \mathrm{~mm}$.)

[Ge. D. 8053

[I8th century.] "Nouvelle France ", from Newfoundland to Long Island. $(590 \times 485 \mathrm{~mm}$.

[I8th century.] "Le fleuve Saint-Laurent." $(620 \times 530 \mathrm{~mm}$. $)$

[Ge. D. 10639

[Ge. D. 10640 [I8th century.] Course of the St. Lawrence river from Quebec to the Gulf
of St. Lawrence. (Parchment, $720 \times 490 \mathrm{~mm}$.)
[Ge. D. 733I

[I8th century.] "Plan du lac Champlain." $(750 \times 230 \mathrm{~mm}$.

[Ge. D. 4444

I729. “ Carte figurative du promt secours envoyé par l'Ordre de Monseigneur le Marquis de Beauharnois ... au Vaisseau du Roy l'Eléphant le 2e Septembre I 729. Designé par Mahier à Québec le I 5 Ocbre. I729." Environs of Quebec with view of Quebec. See Vallée, Notices, no. 237. $(550 \times 390$ $\mathrm{mm}$.)

[Rés. Ge. D. 7825

[I73I.] "Carte du Domaine du Roy en Canada dediée à Monseigneur le Dauphin par le Père Laure, jesuite missionaire de ces endroits." (900 ×795 mm.)

[Ge. DD. 2987. No. 8666

I732. "Carte du domaine du Roy en Canada Dressé par le P. Laure miss. jes. I73I, augmentée de nouveau ... en attendant un exemplaire complet l'automne I732." ( $555 \times 430 \mathrm{~mm}$. $)$

[Ge. D. 8016

[Post I732.] Map of Canada from the St. Lawrence River to Hudson Bay. No title. By d'Anville, from the map by Father Laure. ( $490 \times 420 \mathrm{~mm}$.)

[Ge. DD. 2987. No. 8667

[ I733 ca.] "Carte du fleuve Saint Laurent depuis Gaspé et Mingan juqu'à Québec ... prise ... sur les observations ... que M. des Herbiers de Létanduère capitaine de vaisseau, a faites dans ses campagnes de I730 et I732 . . . Copiée sur celle donnée par M. de Létanduère en I733, par Bellin." $(2160 \times 790 \mathrm{~mm}$.

[1750 ca.] "Plan de la rivière de Québec." (940×440 mm.) [Ge. C. 4640

[ I750 ca.] "Carte de la rivière du Canada depuis l'isle d'Anticostie jusqu'à Québec les isles, rochers, battures et sondés marquées comme elles parroissent ã base mer." ( ( $020 \times \overline{4} 65 \mathrm{~mm}$.)

[Ge. B. 1025

I758. "Plan du fort Carillon et du camp retranché pour s'opposer à l'attaque des Anglais avec l'ordre des colonnes à l'action du 8 juillet I758." (Tracing, $5 \mathrm{IO} \times 320 \mathrm{~mm}$.)

[R. C. I4799 (63) 
"Carte du Fleuve et du golfe de St. Laurens." (790 $\times 490 \mathrm{~mm}$.

"Ge. DD. 2987. No. 8585
"Car "Carte générale des Paroisses et missions établies des deux cotéz du Fleuve St. Laurent depuis Rimousky en montant jusqu'au côteau des Cèdres." (Tracing, $335 \times 3460 \mathrm{~mm}$.)

[Ge. DD. 2987. No. 8663

Map of the St. Lawrence towards the Thousand Islands, and of the vicinity

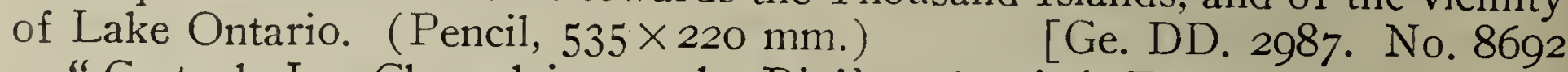

"Carte du Lac Champlain avec les Rivières depuis le Fort de Chambly dans la Nouvelle france jusques à Orange ville de la nouvelle Angleterre dressée sur divers mémoires." $(470 \times 335 \mathrm{~mm}$. $)$

"Carte du Lac Huron." (420 290 mm.)

"Cartographie du pays des Hurons." (I $90 \times 270 \mathrm{~mm}$.)

[Ge. DD. 2987. No. 8682

[Ge. F. 2470 "Carte du Lac Ontario et du fleuve St. Laurens depuis le lac Erié jusqu' au

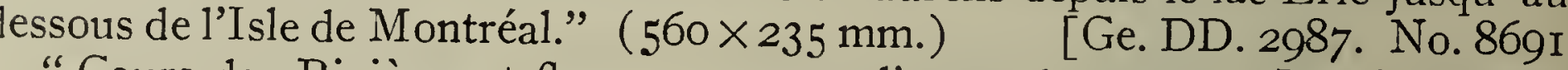

"Cours des Rivières et fleuve courant a l'ouest du nord du Lac Supérieur suivant la carte faite par le sauvage Ochagac et autres ... Il est certain que la Rivière ou plutôct fleuve d'Ouest, doit se décharger dans la mer du Sud ... il paroist aussi par le carte des Sauvages que le fleuve Missisipi prend sa source à la hauteur des Terres au sud du Lac Ouinipigon, de mesme que la Rivière marquée dans la carte de Mr. de l'Isle Rio Colarado qui se décharge dans le fond ou le nord de la mer Vermeille." (IoIo $\times 360 \mathrm{~mm}$.)

[Ge. DD. 2987 . No. 8696

\section{MISSISSIPPI AND OHIO VALLEYS.}

1673. "Carte de la nouvelle découverte que les RR. Pères Jésuites ont faite en l'année I672, et continuée par le R. Père Jacques Marquette de la mesme compagnie ... en l'année I673, qu'on pourra nommer la Manitounie à cause de la statue . . que les Sauvages ... appellent Manitou." See Vallée, Notice, no. 227 . (755 $\times 430 \mathrm{~mm}$. $)$

[Rés. Ge. C. 5014

[1682 ca.] "Carte de la Louisiane en l'Amérique septentrionale, depuis la Nouvelle France jusqu'au golfe de Mexique, où sont décris les Pays que le sieur de la Salle a découverts ... les années 1679,80 , 8I et 82." See Lowery, List of Maps, p. 167 . (Tracing, $530 \times 390 \mathrm{~mm}$.)

[Ge. DD. 2987 . No. 8782

[1685?] "Plan de la côte de la Floride la plus occidentale, depuis le $27 \mathrm{e}$ d. de latitude nort jusqu'au 29e deg.", showing "l'endroit où nous trouvâmes Mr. de la Salle avec ses 2 vaisseaux ...." [By Minet.] See Lowery, List of Maps, no. $184 .(440 \times 300 \mathrm{~mm}$. [Ge. DD. 2987. No. 8839 [I688,] "Parties les plus occidentales du Canada." By "Pierre Raffeix Jésuitte". Lakes, Ohio, and Mississippi above the Ohio, with notes on voyages of Marquette, Jolliet, Dulhut, and La Salle. See Winsor, Cartier to Frontenac, p. $347 .(620 \times 380 \mathrm{~mm}$.

[Portef. 40. No. 36

[1689.] Map showing the routes followed by the Sieur des Coutures in his journeys from Lake Michigan to the mouth of the Mississippi. $(500 \times 350$ mm.)

1699. "Environs de la rivière de Misisipi découvertes par M. de la Salle en 1683 et reconnues par M. le chevalier d'Iberville en I698 et 1699:" By Father Gentil. See Winsor, Mississippi Basin: the Struggle in America betreen England and France, p. 55. $(290 \times 200 \mathrm{~mm}$. $)$

[18th century.] Map of Louisiana. (Tracing, $240 \times 230 \mathrm{~mm}$.)

[Ge. DD. 2987. No. 8798 
[I8th century.] "Carte de la Côte de la Louisiane depuis la Côte du Oüest de la Floride jusqu' à l'oüest de la Rivière du Mississipy; par Soupart." (I $50 \times 420 \mathrm{~mm}$.)

[Ge. DD. 2987. No.880I

[I8th century.] "Carte de la côte de la Louisiane depuis l'embouchure de la Rivière de Micissipy jusques à la Rivière de St. Martin.” ( $840 \times 430 \mathrm{~mm}$.)

[Ge. DD. 2987 . No. 8804

[I8th century.] "Le cours de la Rivière des Alibamons." (560 $\times 450 \mathrm{~mm}$.)

[Ge. DD. 2987. No. 88I6

[I8th century.] "Carte de la Coste du Nouveau Biloxy avec les Isles des Environs pour faire voir la situa'on de la Rade de l'Isle aux Vaisseaux et celle de'Isle de la Chandeleur." $(490 \times 370 \mathrm{~mm}$. $)$

[Ge. DD. 2987. No. 88I mm.)

[18th century.] Map of the Mississippi River up to the Illinois. $(300 \times 820$ [Ge. DD. 2987. No.8819
[18.) [18th century.] Map of the Mississippi from New Orleans to Grand Gouffre above Natchez, showing "concessions Ste. Reine et Desmarets". $(420 \times 545 \mathrm{~mm}$.)

[Ge. DD. 2987. No. 883 I

[I8th century.] Map of the Mississippi between Natchez and Bienville

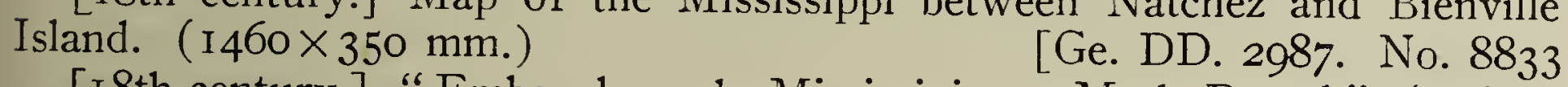
[I 8th century.] "Embouchure du Mississipi, par M. de Rossel." ( I I60X $420 \mathrm{~mm}$.)

[I 8th century.] "Plan de la Nouvelle Orleans." (480 $\times 5$ Io mm.)

[Ge. C. 614

[Ge. DD. 2987 . No. 8826 bis

1716. "Carte nouvelle de la Louisiane et pays circonvoisins dressée sur les lieux pour estre présentée à $S$. M. très chrétienne par $F$. Le Maire, prestre parisien et missionnaire apostolique." $(580 \times 470 \mathrm{~mm}$. $)$

[Ge. D. 7883

I717. "Ydée ou plan du chenal par lequel est sorty le navire la Paix et le vaisseau du Roy le Pan [sic] du port de lile Dauphine le I5e may I7 I7." $\left(585^{\prime} \times 450 \mathrm{~mm}\right.$.)

[Ge. DD. 2987. No. 8815

I 7 7. "Carte de 1'Isle Dauphine. Avec la grande terre de l'O. et celle de la Mobille ... Par le Sr. Du Sault Lieutt. Commandt. Le Vaisseau du Roy le Paon en I7 I7." (Colored, $765 \times 490 \mathrm{~mm}$.) [Ge. DD. 2987. No. 88I 5 bis

I7I8. "Carte de 1'Isle Daufine, ses Environs. Envoyée par le Sr. Bajot le 23 juin I7 I $8 . "$ ( ( $540 \times 400 \mathrm{~mm}$.)

I7I8. "Plan de la Baye de St. Joseph tiré par Jean Beranger ce Ier May I718." Shows Fort Crèvecoeur. (400×310 mm.) [Ge. DD. 2987. No. 8809

[I7I9 ca.] Map of Louisiana, showing the post established by Bénard de La Harpe on the Red River. (Tracing, $350 \times 465 \mathrm{~mm}$.)

[Ge. DD. 2987. No. 8796

I720. "Carte nouvelle de la partie de l'Ouest de la Province de la Louisiane sur les observations et découvertes du Sieur Benard de la Harpe Commandant sur la Riviere Rouge, et où paroissent ses routes colorées de jaune et établissement relatif à son journal dressé par le Sr. de Beauvilliers . . à Paris en No'bre I720." See Lowery, List of Maps, no. 30I. $(530 \times 700 \mathrm{~mm}$. $)$

I720. "Carte de La coste de la Louisiane depuis La bayés. Ge. C. 5I I 5 de St. "Carte de La coste de la Louisiane depuis La baye de St. Louis ou de St. Bernard jusqu'a celle de St. Joseph . . . levée aux années I7I9 et I720 par Devin." See Lowery, List of Maps, no. 302. (970 $\times 330 \mathrm{~mm}$.)

[Ge. C. 5072 and G. DD. 2987 . No. 8802

[I720 ca?] "Carte de la côte de la Louisiane depuis l'embouchure de la grande rivière de Micissipy jusques à la côte occidentale de la Floride." (920 $\times 630 \mathrm{~mm}$.)

[Ge. C. II 27 
I720. "Carte de l'entrée de la Baye de St. Louis nommée par les Espagnols St. Bernard. . . levée au mois d'Octobre 1720 par Devin." (6oo $\times 420$ $\mathrm{mm}$.)

[Ge. DD. 2987. No. 884I

I722. "Plan de la Baye du St. Esprit nommée par les François de St. Bernard . . . les Espagnols s'i sont établis en I 7 I 8 et l'ont fortifiée en I722." $(520 \times 380 \mathrm{~mm}$.

[Ge. DD. 2987. No. 8840

[Post I 722.] Map showing part of Lake Pontchartrain, with the land of M. de Bienville. (Tracing, $490 \times 290 \mathrm{~mm}$.) [Ge. DD. 2987. No. 882I

[Post I722.] "Carte particulière de l'Embouchure du fleuve St. Louis." (Tracing, 4I0 $\times 290 \mathrm{~mm}$. )

[Ge. DD. 2987. No. 8823

I725. "Plan de la ville de La Nouvelle Orléans en l'état qu'elle étoit le 30 may I725." $(640 \times 450 \mathrm{~mm}$. $\quad$ [Ge. DD. 2987. No. 8826 ter I726. "Carte de La Rivière des Pascagoula, où l'on voit la situation des isles, lacs et terrain des habitans avec vue de l'habitation du Sr. de la Pointe. Venu avec la lettre de M. de la Chaise du 30 Octobre I 726." (720 $\times 500 \mathrm{~mm}$.

[Ge. DD. 2987. No. 8818

1727. "Carte des environs du fort Rosalie aux Natches. Levée par Broutin, janvier, I723. Dessinée par Gonichon, en Mai I727." (I800 × I080 mm.)

[Ge. DD. 2987 . No. 8834

I731. " Carte particulière du cours du fleuve Missisipy ou St. Louis, à la Louisiane, depuis la Nouvelle Orléans jusqu' aux Natchez, levée par estime en I72I, I726, I73I et dressée au mois d'aoust I73I, par Broutin." (770 2020 mm.)

[Ge. C. 5015

I732. "Carte de la Louisiane par le Sr. d'Anville, dressée en mai I732." See Lowery, List of Maps, no. 333. (930 $\times 530$ mm.) [Ge. DD. 2987. No. 8800

I746. "Carte de la Coste et Province de La Louissianne dans l'Amérique septentrionale, du Fleuve Saint Louis ou Misisipy, de la Baye et rivière de la Mobille et Plusieurs autres rivières avec les sondes le long de la ditte Coste, L'intérieur du pays et tout Bois de Haute Futaye . . . A la N'lle Orléans le cinq gbre M. D. CC. XXXXVI." (Parcliment, i i io $\times 440 \mathrm{~mm}$.)

[Ge. B. I 169

I75I. "Nouvelle Carte Platte Pour le Missisipy Dédié a Monsieur de Silhouette Chancelier de S. A. R. Monseigneur le Duc Dorléans Faitte l'an I75I Par le Sr. Curatteau Cap'ne de Navire." ( $440 \times 650 \mathrm{~mm}$.)

[I754 ca.] "Plan du Fort Duquesne." (360 $\times 5$ I 8 mm.)

[Ge. DD. 2987 . No. 8944

[R. C. I 3522 (I4)

I755. "Carte de la partie occidentale du Canada contenant les lacs Ontario, Erié, Huron, Michigan et Supérieur avec partie du cours des rivieres d'Ohio Ouabache et fleuve Mississipi par le Sr. Bellin ingénieur de la Marine." (640 $\times 440 \mathrm{~mm}$.)

[Ge. D. 8050

I755. "Carte du Cours de l'Ohyo ou la Belle Riviere, depuis sa source jusqu'à sa jonction avec celle d'Ouabache, avec les pais les plus voisins. Par le Sr. Bellin." (720 $\times 5$ 10 mm.)

[Ge. C. $5^{\mathrm{I} 83}$

[1796 ca.] "Carte physique et politique de l'Amérique Septentrionale Dressée au Dépôt Général de le Marine et des Colonies pour l'intelligence des voyages du Gl. Collot." $(865 \times 600 \mathrm{~mm}$. $)$

[Rouleau $5^{\text {I } 8}$

I796. "Carte générale du cours de la rivière de l'Ohio depuis ses sources jusqu'à ses bouches ... . le tout dessiné sur les lieux par Joseph Warin Adjudt. Gl. des Armées de la République, Pour servir à l'Intelligence des voyages du Général Collot ...." "G. Bois St. Lys et J. J. Boudier, Fc." With plans and views. (3070 $\times$ I 5 IO mm.)

[Rouleau I64 
I796. "Carte particulière du Cours du Mississipi depuis le Missouri et le Pays des Illinois jusqu'à l'embouchure de ce Fleuve, I796." With plans of Forts Natchez, Baton Rouge, Nogales, Écores à Margot, New Madrid and Cape Girardeau, and St. Louis. By Gen. Collot. $(3460 \times 940 \mathrm{~mm}$.)

[Rouleau 486

I796. "Carte du Missouri, des hauts du Mississipi et du Plateau où se fait la division des eaux ... à laquelle on a joint la route parcourue par McKenzie en I789, lorsqu'il a trouvé la Mer Glaciale, dressée pour donner une idée de la charpente du Pays et servir à la Reconnoissance faite par le Gl. Collot, des Etats de l'Ouest, du Nord Ouest et de la Haute et Basse Louisiane en I796." "G. Bois St. Lys fecit." (I000 × 910 mm.)

[Rouleau 486

I796. "Carte du pays des Illinois dressée pour l'intelligence des voyages du Gl. Collot dans l'Amérique Septentrionale en 1796." With plan of St. Louis. (I $60 \times 735 \mathrm{~mm}$.)

[Rouleau 520

I796. "Carte des sources de la Mobile et de la rivière du Yasou comprenant une partie du cours du fleuve du Mississipi depuis la Rivière à Margot jusqu'aux Natchez. Pour servir à l'intelligence des Voyages du Gl. Collot dans cette partie en I796." ( I I00 $\times 730 \mathrm{~mm}$.)

[Rouleau $5^{\text {I9 }}$

I796. "Carte du Territoire N. O. des Etats-Unis. Dressée pour l'intelligence des voyages du Gnl. Collot dans cette partie du continent en I796." "J. Mouchet fecit." With plans of Forts Erie and Niagara. (I 5 Io $\times 960 \mathrm{~mm}$.)

Map of the mouth of the River St. Louis. (Tracing, $520 \times 290 \mathrm{~mm}$.)

[Rouleau 477

"Embouchure du fleuve St. Louis." $(370 \times 320 \mathrm{~mm}$. $)$

[Ge. DD. 2987. No. 8822

[Ge. DD. 2987. No. 8824

FLORIDA AND NEW MEXICO.

[I7th century.] "La Floride par P. Du Val d'Abbeville. A Paris ches l'Autheur." Cf. Lowery, List of Maps, nos. I 53, I 54. (580 $4430 \mathrm{~mm}$.)

[Portef. 9. No. 75

[I7th century.] "Le Mexique Nouveau avecque l'Isle de Californie par P. Du Val d'Abbeville. A Paris ches l'Autheur . .." $(550 \times 360 \mathrm{~mm}$. $)$

[Portef. 9. No. 76

I710. "Nuevo Reyno de la Nueva Navara con sus confinantes otros Reynos I7IO." "Copié sur l'original mst. le $9^{\circ}$ de Septembre I $724 . "(400 \times 330 \mathrm{~mm}$. $)$

[Ge. DD. 2987. No. 888

I7I9. Map of the Rio Bravo and neighboring countries, showing the " nations avec lesquelles le Sr. de La Harpe a fait alliance en I 7 I9 qui font la guerre aux Cannecis". (Tracing, $350 \times 470 \mathrm{~mm}$.)

[Ge. DD. 2987. No. 8797

I779. "Plano de la provincia interna de el Nuevo Mexico que hizo ... Dn. Bernardo de Miera y Pacheco . . Santa-Fé, I779." (Photograph, $270 \times 275 \mathrm{~mm}$.)

"East Florida." (Tracing, 270 $210 \mathrm{~mm}$.)

"Plan du port et rade de pensacole." $(490 \times 320 \mathrm{~mm}$.)

"Plan de la rade de Pensacole." (7 $10 \times 530$ mm.)

[Ge. DD. 2987. No. 8812

[Ge. DD. 2987. No. 88ז3 
ENGLISH COLONIES, WAR OF AMERICAN INDEPENDENCE, UNITED STATES.

[I754-I757.] "To the Honourable Mr. Machaute [Machault] ... this plan of the bay, fortifications and part of the Province of New York and New Jersey . . are most humbly inscribed." (655×1970 mm.)

[R. C. I3522 (2)

I776. Carte du Port et Havre de Boston avec les Chotes adjacentes dans laquelle on a tracé les camps et les Retranchemens occupés, tant par les Anglois que par les Américains. Dediéc et présentée au Roy par... le Ch'r de Beaurain ...en I776. With MS. legend. $(740 \times 590 \mathrm{~mm}$.

[Portef. 40. No. I8

I776. "Plan de Crown Point ou Grande Pointe, aussi Fort Frédéric." "Les Rebelles comme ils ont quités le I3me d'Octobre I776 l'endroit de Crown Point ... Son Excellence Mr. le Général Carleton a occupé le I 4me d'Octobre le camp ..." $(265 \times 3 \mathrm{I} 5 \mathrm{~mm}$. $)$

[R. C. I3522 (4)

I777. "Plan of Carillon or Ticonderoga, which was quitted by the Americans in the night from the 5 th to the 6 th of July I777." $(720 \times 520 \mathrm{~mm}$.)

[R. C. 8022

I777. "Plan de l'action de Glocester entre un parti amériquain d'environ 350 hommes sous le Gen'al Lafayette et un parti des troupes de Lord Cornwalis commandé par ce Lieutt. G'al après son fourage dans le Jersey le 25 9bre I 777." (500 $\times 445 \mathrm{~mm}$.

I778. "Plan de la Retraite de Barren-hill en Pensilvanie où un dètachement de deux milles deux cens hommes sous le Gen'al Lafayette étoit entouré par l'armée angloise sous les Généraux Howe, Clinton et Grant le 28 May I778." (520×370 mm.) [R. C. 8024

I778. "Carte de l'affaire de Montmouth oì le Gen'al Washington commandoit l'armée amériquaine. et le Gen'al Clinton l'armée angloise le 28 juin I778." (790 ×365 mm.)

[R. C. 8025

I 778. "Plan de Rhodes Island, les différents opérations de la flotte francoise et des trouppes amériquaines commandées par le major Sullivan contre les forces de terre et de mer des Anglois depuis le 9 Août jusqu'à la nuit du 30 au 3 I du même mois que les Amériquains ont fait leur retraite." $(780 \times 470$ mm.)

[R. C. 8026

I778. "Carte des positions occupées par les trouppes amériquaines après leur retraite de Rhode Island le 30 Août i 778." (530×375 mm.) [R. C. 8027

I779. "Siège de Savannah Septembre I779. Commandé par M. le Comte d'Estaing." (630 $\times 430 \mathrm{~mm}$.

[R. C. 8604

I779. "Siège de Savannah fait par les troupes du Roi aux ordres de Monsieur le Comte d'Estaing, vice-amiral de France en Septembre et Octobre I779." Signed, "Nicolas". $(620 \times 450 \mathrm{~mm}$.$) \quad [Portef. 40. No. I72$

I 781. "Siège d’Yorck." $(720 \times 480 \mathrm{~mm}$. $)$ [R. C. I904

I78I. "Carte réduite des routes qu'a parcourues l'armée française commandée par M. le Cte. de Guichen sortie de Brest le io décembre I78I convoyant une flotte de 52 voiles . . . par Dolivet de Rouen, L'ant de frégate." $(6 \mathrm{Io} \times 490 \mathrm{~mm}$.

[Ge. D. 4296

I 782. "Carte réduite et démonstration des routes qu'a parcourues l'armée navale française commandée par M. le Cte. de Guichen, sortie de la baÿe de Brest le I I et I 2 février I 782 allant à Cadix et convoyant une flotte appartenant au Roy, destinée pour l'Amérique et l'Inde . . . Dressée et présentée à Mr. B. J. C. par Delivet, lieutenant de frégate à bord du vaisseau le Majestueu.r." $(590 \times 430 \mathrm{~mm}$.

[Ge. D. 6274

[I800-I825.] Baltimore: plan of the Seminary of St. Sulpice and the neighboring district. $(655 \times 6$ I $\mathrm{mm}$.)

[Ge. FF. 12346 


\section{GULF OF MEXICO AND THE WEST INDIES.}

I7I4. "Golfo de Mexico. Berthou C. I. F. I7 I4." (4 tracings, $330 \times 560$ mm. each.) [Ge. DD. 2987. Nos. 8940, 8941, 8942, 8943

I742. Map of Gulf of Mexico. "Por el Teniente de Fragata y Piloto de la Real Armada D. Antonio de Matos. Año de I742." (3 tracings, $340 \times 520$ $340 \times 6$ Io, $340 \times 460$ mm.) [Ge. DD. 2987, Nos. 8937, 8938, 8939

I746. "Carte de toutes les côtes de terre ferme des Isles du Vent, golphe de Mexique, Ressifs, sondes, ances, caneaux et rivières nouvellement corrigée de quelques erreurs par l'expérience de différents pilotes pratiques. I746." See Vallée, Notice, no. I20. (Parchment, $820 \times 490$ mm.) [Rés. Ge. C. 5I io

Maps, without legends, of the coasts of the Gulf of Mexico and of the Antilles. ( 2 sheets, $520 \times 320 \mathrm{~mm}$.)

[Ge. DD. 277 I

\section{CUBA.}

[I8th century.] Plan of Havana. ( $485 \times 342 \mathrm{~mm}$.)

[I8th century.] "Plan de la Havane." ( $375 \times 255 \mathrm{~mm}$.

[R. C. $7600 e$

[Ge. D. 7347 [I775-r799.] " Plan de la rade et du port de la Havane dans l'isle de Cuba." $(430 \times 420 \mathrm{~mm}$.

[Ge. D. 906

I806. "Plan d'une partie du territoire de Ste. Catherine, situé entre la baye de Watanamo [Guantánamo] et la paroisse Tygoabo, dépendance de Santiago de Cuba, copie conforme à l'original levé par nous soussigné . . . P. Audier, \begin{tabular}{l} 
Santiago de Cuba, 24 Septembre I806." $(560 \times 580 \mathrm{~mm}$. $)$ [Ge. C. 5002 \\
\hline
\end{tabular} $\mathrm{mm}$.

"L'ile de Cuba et celle de la Jamaïque . . . (Hérisson del.)." $(350 \times 250$
"St. Yago de Cuba." (300 $\times 5^{\mathrm{I}} 3 \mathrm{~mm}$.)
"Mouillage de la Havanne dans l'Isle de Cuba." (400×290 mm.)
[Ge. D. 376
[R. C. 7577

[R. C. $7600 d$

\section{JAMAICA}

I639. Map of Jamaica and neighboring islands, by Joan Vingboons. (7 Io $\times 500 \mathrm{~mm}$.

[Ge. C. I 445

[I8th century.] "Carte des havres de Kingston et Port Royal sur le plan d'un ingénieur anglais." (300 × I90 mm.)

[Ge. D. 7348

[I8th century.] Map of the eastern part of Jamaica. ( $460 \times 340 \mathrm{~mm}$.)

[Ge. D. 806I

I756. "Plan l'une partie de l'isle de la Jamaique, dans la bande du Sud . . levé par Alexandre Dubrocq, capitaine de Bayone, prisonnier onze mois à la Jamaique en 1755 et I756." (930 ×575 mm.)

I767. "Island of Jamaica with exact plans of Port Royal and Kingston." (Tracing, $530 \times 320 \mathrm{~mm}$.)

[Ge. D. 3763

\section{SANTO DOMINGO.}

[I7th century.] "Ile de St. Domingue ou l'Espagnole." (4Io $\times 250 \mathrm{~mm}$.) [r8th century.] "StD. 8082
[Ge. [18th century.] "Sto. Domingo et environs." (Tracing, $500 \times 440 \mathrm{~mm}$.) [I8th century.] "Ville de St. Domingue." ( $480 \times 360 \mathrm{~mm}$.$) [Ge. D. 8087$ [I8th century.] "Plan de la Plaine du Cul de Sac, Port au Prince, Isle St. Domingue. Levé sur les lieux par Mr. de Hesse . . ." (I950 × I270 mm.) [I8th century.] "Rade du Port-au-Prince et environs." (400 $\quad$ [Ge. A. 55' 
[ 18 th century.] Hydrographic map of part of northern coast of Santo Domingo in the vicinity of Port Margot. $(580 \times 430 \mathrm{~mm}$.)

[Ge. C. 1426

[18th century.] "Plan du fort St. Louis dans l'ile de St. Domingue." ( 675 $\times 470 \mathrm{~mm}$.)

[ I8th century.] "Plan de la ville de Léogane dans l'ile de St. Domingue."

$(220 \times 340 \mathrm{~mm}$. $)$
[Ge. D. 8062

[i8th century.] "Carte de la plaine de Léogane et de ses environs." (770 $\times 670 \mathrm{~mm}$.)

[Ge. C. 5 I80

[i8th century.] "Carte des concessions avec les noms des propriétaires dans les environs de Léogane." ( $380 \times 480 \mathrm{~mm}$. $)$

[ 18 th century.] "Plan de la ville de St. Marc dans l'ile de Saint-Domingue." $(550 \times 370 \mathrm{~mm}$.

[i8th century.] "Partie de la baye de St. Marc." (500 $\times 385$ mm. $)$

[I8th century.] "Vue de la baie de St. Marc." (240× I 50 mm.)

[Ge. D. 7373

[Ge. F. I I 34

[I8th century.] "Plan de la baye de la ville et des redoutes du Fort Dauphin." Signed, Rabié. $(330 \times 220 \mathrm{~mm}$. $)$

[Ge. D. 7378

I 748. "Plan de l'entrée de la baye du Fort Dauphin." Signed, "Meinat, Juillet I $748 " .(2$ I $5 \times 470 \mathrm{~mm}$. $)$

[Ge. D. 7368

[ 1750 ca.] "Carte de la côte [de St. Domingue] depuis et comprise la rade du Cap jusqu'au Borgne, levée par le Sr. Rabié, ing'r ord're du Roy et augmentée sur les plans des différents arpenteurs de la colonie." (990×670 mm.)

[I750-I799.] Northern coast of Santo Domingo. (8Io $\times 630 \mathrm{~mm}$.

[Ge. AA. 500

[I750-I799.] The channels of Santo Domingo. (I370 $\times 9$ ro mm.)

[Ge. C. 4672

[I750-I799.] "Plan de la Baie, de la ville et des fortifications du Môle." $(670 \times 500 \mathrm{~mm}$.

[I750-I799.] "Plan de la ville du Môle St. Nicolas avec la position des blockhouses et autres postes qui couvrent la place." (770 $\times 495 \mathrm{~mm}$.

[I8th century.] Plan of Fort Dauphin. $(820 \times 620 \mathrm{~mm}$.

[R. C. 4288

[Ge. DD. 2987. No. 8633

[I8th century.] "Plan de la Crête à Pierrot et de ses environs." (770X $560 \mathrm{~mm}$.)

I7I7. "Veüe et perspective du Cap François faite et levée par le Che'r Du Sault, lieutenant des vaisseaux du Roy." (I030 ×485 mm.)

[Rés. Ge. B. I I97

I734. "Plan de la ville et du Fort-Douphin, juin I 734." ( $475 \times 375$ mm.)

[Ge. D. 7370

I734. "Vue du Cap Français à St. Domingue." Fire of Dec. 20-2I, I734. ( I $530 \times 450 \mathrm{~mm}$.)
[Ge. C. 5 I I6

I740. "Plan de la baie et du port du Fort Saint-Louis . . . St. Domingue, I740." (470 $\times 360 \mathrm{~mm}$.)
[R. C. 7555

I740. "Plan de la baye et du port St. Louis, située sur la coste du sud de l'isle de St. Domingue, levé par ordre de M. le Marquis d'Antin ... en I 740." (540 × $400 \mathrm{~mm}$. mm.)

[I750-I799.] "Môle St. Nicolas à Saint-Dumingue." (Tracing, 635×525

[R. C
[Post $\mathrm{I} 750$.$] "Plan de la plaine du cul de Sac." ( 890 \times 900 \mathrm{~mm}$.)

[R. C. 4290

[Ge. B. I I 78 
I753. "Plan du Moule [sic] Saint Nicolas." (I90 $\times$ I40 mm.)

[Ge. F. II 36

I756. " Réparations du fort ou port de Paix dans les parties du front de la mer et de la rade, faites par ordres de Mr. le Marquis de Vaudreuil, général, et Mr. Laporte-Lalanne, intendant, par le Sr. Devillers, ingénieur ordinaire du Roy ayant de département du gouvernement du Cap et dépendance en I756." $(790 \times 525 \mathrm{~mm}$. $)$
[Ge. C. 4674

I760. "Relevé général de la juridiction de l'amirauté du Cap depuis I75I jusqu'en I 760." $(860 \times 940 \mathrm{~mm}$.) [Ge. AA. 50 I

I76I. "Plan' de la partie du cours de la rivière de l'Artibonite aux environs des restes d'une écluse qui étoit construite sur sa rive nord . . . levé et dressé .. . par Peyrottes, arpenteur général, 28 novembre i76ı." $(500 \times 750 \mathrm{~mm}$.)

[Ge. D. 7374

[ 1762 ca.] "Plan de la baye du Cap de St. Domingue." (470 $\times 380 \mathrm{~mm}$.)

[Ge. D. 7372

[ 1762 ca.] Neighborhood of Port-au-Prince. Two copies. ( $355 \times 240 \mathrm{~mm}$.) $(390 \times 320 \mathrm{~mm}$.
$[\mathrm{Ge} . \mathrm{D} .7375,7376$

[I762 ca.] Roads of Port Dauphin. $(530 \times 320 \mathrm{~mm}$.) [Ge. D. 7377

[ 1762 ca.] Plan of the plain of Artibonite. ( $1200 \times 900 \mathrm{~mm}$.)

[Ge. AA. 502

I762. "Carte topographique du Sud et d'une grande partie de l'Ouest de Saint-Domingue, y joint la sciographie des chemins . . signé : Rolland, capitaine d'artillerie et géographe du Roy. I5 novembre I762." (I $480 \times 620$ $\mathrm{nm}$.)

[Ge. AA. 503

I762. "Plan de la ville du Cap Français . . . avec les divers projets proposez à nos seigneurs les général et intendons par Deforges [l'aîné], voyer de la ville." (700 $\times 5$ Io $\mathrm{mm}$.

I762. "Plan de l'ancien fort du Port-de-Paix." Signed, "Rabié; I6 mars I762". (390×280 mm.) [Ge. D. 7342

I762. Coast of Limonade. With a memoir, signed, "d'Anctéville, I762". $(4 \mathrm{IO} \times 320 \mathrm{~mm}$.
[Ge. D. 7366

I762. Plan of part of Fort Dauphin. Signed, " Joubert, arpenteur du Roy, I3 décembre I762". (405 $\times 265 \mathrm{~mm}$.) [Ge. D. 7369 I763. "Nouvelle batterie de canon" [à la Pointe Tapion]. Signed, "Rolland, capitaine d'artillerie et géographe du Roi, Jacmel, Ier janvier I763". $(305 \times 270 \mathrm{~mm}$. $)$
[Ge. D. 7387

I767. "Plan de la ville du Môle Saint-Nicolas, côte S. Domingue, par nous arpenteur du Roi . . . I I juillet I767." Signed, Le Royer. [Ge. C. 3I60 [1769.] "Carte particulière des côtes de l'ile de St. Domingue à commencer de Mont-Christ jusques et y compris la baie de Samana dressée par ordre de S. A. le Prince de Rohan par l'abbé L. Dumenil." (930×670 mm.)

[Ge. C. 2958

I773. "Plan de la ville et baye du Môle St. Nicolas, par de Moulceau, Portau-Prince, I773, Sept. I I." (61 $5 \times 560 \mathrm{~mm}$.)

[I775-I799] "Môle Saint-Nicolas." (I820 $\times 600 \mathrm{~mm}$ ) [Ge. C 3801

I775. "Plan du port du Môle Saint Nicolas dans l'ile de St. Domingue." Signed, "J. J. J." [Drawn during the cruise of La Flore.] $(650 \times 445 \mathrm{~mm}$.)

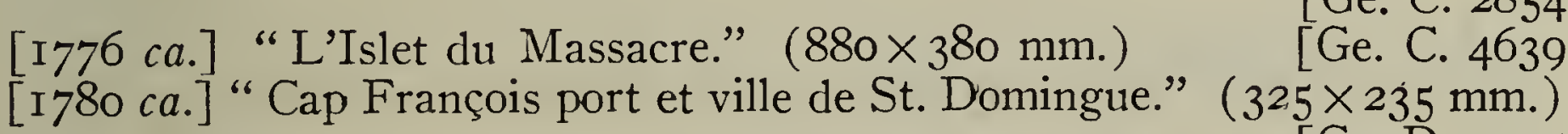

[Ge. C. 2854

[Ge. D. 4025

I782. "Plan de l'habitation de mesdames la V'esse de Scapeaux et C'tesse d'Autichamp, située au quartier de Bellevue, dépendance de Port-au-Prince, 
île de Saint-Domingue, levé par le Sieur Petit . . . ce 20 juillet I782." (850 $\times 580 \mathrm{~mm}$.)

[Ge. C. I I 3 I

I782. "Plan de l'habitation de Montalembert, située au quartier de BelleVue, dépendance de Port-au Prince, île de Saint-Domingue, levé par le Sr. Petit . . le 20 juillet I782." (750 $500 \mathrm{~mm}$.

[Ge. C. I I 33 I783. "Colonie française de Saint-Domingue; plan du cap et de la baie de Tiburon. A Saint Louis, côte du Sud, le 20 décembre I783." Signed, de Boisforêt. $(530 \times 390 \mathrm{~mm}$. $)$

[Ge. D. 908

[I793-I803.] "Plan de la ville du Port Républicain et ses environs." (950 $\times 765 \mathrm{~mm}$.

[R. C. 4329

I793. "Plan de la ville du Cap français sur lequel sont marqués en teinte noire les ravages du premier incendie et en rouge les îles, parties d'îlets, édifices etc. qui existent encore le $2 \mathrm{I}$ juin I793. A M. Berard Verzel, par son ami Ch. Jos. S. Warin." See Vallée, Notice, no. I83. (360 ×250 mm.)

[Rés. Ge. D. 9I3

I794. "Carte générale de la partie française de Saint-Domingue, par Fallize, ingénr." (890 $\times 780 \mathrm{~mm}$. $)$ [Ge. C. 2986
[Gan I794. "Plan des villes du Cap et du Port-au-Prince, île de Saint-Domingue, fait et réduit par G. J. de Bois St-Lys, officier du génie." (I95 × I40 mm.)

[Ge. D. 3753

[ 1800 ca.] "Plan de la ville et de la baie du Fort Dauphin dans 1'île St. Domingue." (66o $\times 440 \mathrm{~mm}$.

[Ge. C. 1465

[ I80o ca.] "Plan de la baye et de la ville du môle St. Nicolas avec la position des blockhouses et autres postes qui couvrent la Place." By S. Bte. Augin. Grosier. (900 $\times 525 \mathrm{~mm}$.)

[R. C. 4292 [I802-I803.] "Plan de la ville du Môle Saint-Nicolas, dans l'île de St. Domingue, avec les forts, redoutes et batteries, ans XI et XIIe." $(675 \times 480$ mm.)

[Ge. C. 1463

I802. "Plan de la ville de Jacmel et de ses environs, ainsi que les positions des rebelles pendant le blocus commencé le I 5 fructidor an Io et terminé par l'évacuation le 2 I fructidor an i Ie." ( $685 \times 470 \mathrm{~mm}$. $)$

[Ge. C. I 466

[I803.] "Port à l'Écu dans l'isle de St. Domingue." (240× I30 mm.)

I803. "Cartes de 1'Isthme du Môle St. Nicolas, Ventose en Onze." 4286 $\times 120 \mathrm{~mm}$.)

[R. C. 4287

I803. "Plan de la Place du Môle St. Nicolas et de ses environs. I 5 germinal an XI." By Gillet. $(675 \times 495 \mathrm{~mm}$.)

[R. C. 429I

I809. "Plan de Santo-Domingo pour servir aux sièges de I805 et I809 par

L. Delafosse, I809." (400 × 240 mm.)

"La Espanhola ou la St. Domingue." $(370 \times 250 \mathrm{~mm}$.

"Plan de l'isle et golfe de Samana." ( ( $040 \times 720 \mathrm{~mm}$.)

[Ge. D. I9I "Lisle de St Domingue par le Sr. de Cussy, ci-devant commandant pr. le Roy dans l'isle de la Tortue." (520×390 mm.) [Ge. CC. I 275 "Partie de St. Domingue, de Port-au-Prince à la rivière de l'Artibonite." $(360 \times 250 \mathrm{~mm}$.)

"Plan de la rade du Cap François en l'île de Saint-Domingue." (470 ×360 mm.)

"Plan d'une partie de la plaine du Cul de Sac pour servir à Ge. D. 7367 situation des différentes possessions de M. Marinière." (340× $160 \mathrm{~mm}$.)

"Coste de l'Ouest D. 3550
[Gepuis Portau-Prince jusqu'au Grand Goave" 755

"Coste de 1'Ouest depuis Port-au-Prince jusqu'au Grand Goave." (75.5 $\times 503 \mathrm{~mm}$.)

[R. C. 12465 
“Le Petit Gouave en la coste du Nord de St. Domingue.” ( 5 I $8 \times 305$ mm.)

[R. C. 7577 bis

"Plan général de la rivière de l'Artibonite depuis la montagne de la Tranquilité jusques au delà du bourg de la Petite-Rivière et des différents projets de prise d'eau et canaux pour l'arrosement de la plaine de l'Artibonite." ( I I 20 $\times 480 \mathrm{~mm}$.

[Ge. AA. 227

"Baia aen cabo de Tyburon aen't west eyndt van't eylandt Hispaniola." $(580 \times 420 \mathrm{~mm}$.

[Ge. C. I 423

"Caerte van de bay Savana en't eylant Vaca, met omgelegen eylandskens aen de zuid kust van Spagnola." $(580 \times 430 \mathrm{~mm}$. $)$ [Ge. C. I424
"Pland

"Plan du fort du Morne-Garnier avec les limites du terrain de l'habitation appartenant au Roi." (610 $\times 405 \mathrm{~mm}$.)

[Ge. D. $5^{108}$

BARBADOS.

[1775-1785.] "Carte de l'Isle de la Barbade avec plan de Bridge Town." By Nicolas. $(570 \times 440 \mathrm{~mm}$.)

[I775-1785.] "Plan de la Baye de Carlisle de la Barbade." By Nicolas. $(540 \times 350 \mathrm{~mm}$.

[Portef. I06. No. 87

\section{DOMINICA.}

[I775-1785.] "Plan de l'Isle de la Dominique, par Nicolas." (650 $\times 400$ nim.)

[Portef. I06. No. 78

[I778.] "Plan du morne Bruce, île de la Dominique." (670 $\times 490 \mathrm{~mm}$.)

[Ge. C. I I 40

I778. " Plan de la conquête de l'île de la Dominique par M. le M'is de Bouillé en I778." $(520 \times 320 \mathrm{~mm}$.)

I778. "Plan du fort de la Reine au Roseau, île de la Dominique, avec les augmentations qui y ont été faites depuis la prise de l'île I $778 . "$ ( (710 $\times 500$ $\mathrm{mm}$.

[Ge. C. I I39

I778. "Plan de la batterie de la Cheze, située en l'île de la Dominique au sud du Roseau, sur la rive droite de la rivière Canary . . . " $(680 \times 490 \mathrm{~mm}$.)

[Ge. C. I I 4 I

GRENADA.

I667. "L'Ile de la Grenade.” By Blondel. (690×430 mm.)

[I8th century.] Map of coasts of Grenada in the vicinity of Fort Royal. $(765 \times 485 \mathrm{~mm}$.

[Post I 748.] Hydrographic map of the environs of Fort Royal. C. 3583 $(770 \times 480 \mathrm{~mm}$.)

[Post I748.] “Plan du port, de la ville et du Fort Royal [Ge. C. 3580 Grenade ..." (720 $\times 460 \mathrm{~mm}$. $)$

[ 7550 ca] "Plan du port de Caliveni, du Culdu chemin et de la presqu'ile du fort Jeudi situés dans la partie méridionale de l'île de la Grenade." (770 $\times 495 \mathrm{~mm}$.)

[Ge. C. 3582

[I775-1785.] "Plan de l'Isle de la Grenade.” By Nicolas. $(600 \times 450 \mathrm{~mm}$.

I779. "Vue du Fort et ville de St. George dans 1'Isle de la Grenade, et du Morne de l'Hôpital emporté d'assaut par les troupes du Roy aux ordres de M. le Cte. d'Estain [sic], le 4 juillet I779." By Nicolas. $(540 \times 380 \mathrm{~mm}$.)

[Ge. D. 8063 


\section{GU'ADELOUPE.}

[I8th century.] "Plan du Nouveau Chemin de la Rivière Salée qui sert de communication de la Guadeloupe à la Grande Terre. Par Thévenet." (Tracing, $930 \times 505 \mathrm{~mm}$. )

[Ge. C. 5187

I 755. "Plan général du quartier nouvellement étably qui contient les quartiers dits: la ravine à mulâtre, les Ténèbres, ravine du Boucau neuf, grande rivière, Trou villain, Bas Auragans et Nouvelle Gascogne . . . fait par moy arpanteur soussigné le 3I aoust I755. Delpuech.” (990 ×640 mm.)

[Ge. C. 467 I

I765. "Plan de la rade de la Pointe-à-Pitre, levé ... par MM. de SaintMartin, capitaine de port du lieu, et de Charnières, enseigne de vaisseau, Septembre I765." ( I050 $\times 830 \mathrm{~mm}$.)

[Ge. C. 5052

I769. "Plan du Fort St. Charles et d'une partie de la Basse-Terre relatif aux projets de l'année I 769." (Tracing, 620 ×480 mm.) [Ge. D. 8044 I776. "Plan de la ville de la Pointe à Pitre située en l'île Grande-Terre, Guadeloupe, par C. F. Nassau, I776." (Tracing, 560 ×410 mm.)

[R. C. I4799 (50)

I784. "Plan de la ville Pointe à Pitre en l'isle grande terre Guadeloupe - . par Nassau . . En I783-I784." (990×695 mm.) [Ge. C. 5176 "Plan du fort St. Charles de la Basse Terre de la Guadeloupe." ( I ooo $\times 750$ nm.)

[Ge. D. 7840

\section{MARTINIQUE.}

[I8th century.] "Plan du cul de sac Marin." (Martinique.) (520 $\times 4$ I 5 mm.)

I734. "Ville et rade du fort St. Pierre de la Martinique levés en I734, par M. Romain." (4Io $\times 270 \mathrm{~mm}$.)

I774. "Plan de la ville et citadelle de Fort-Royal de la Martiniqu. D. 7938 I 774." (625 ×365 mm.)

I776. "Plan du fort Bourbon de la Martinique, pour désigner [Ge. D. 7532 faits au mois de juillet I 776 et ceux qui restent encore désigner les ouvrages faits au mois de juillet I776 et ceux qui restent encore à faire." $(530 \times 420$
mm.)
[Ge. D. I 859

[Ge. D. I 859

NEVIS.

[I8th century.] "Ile de Nièves." (520 $\times 400 \mathrm{~mm}$.

[Ge. D. I 54I

\section{ST. EUSTATIUS.}

[I775-I785.] "Plan de l'isle de St. Eustache." By Nicolas. (580 $\times 420$ mn.)

[Portef. I06: No. 83

ST. KITTS.

I766. "Plan de la rade de la Basse Terre de l’île St. Christophe, levé . . . au mois de janvier I 666 par M. de Charnières." (740 $\times 580 \mathrm{~mm}$.)

[I775-I785.] "Carte de l'Isle de St. Christophe." By Nicolas. ( $560 \times 350$
[Ge. C. 5059 mm.)

[I 782.] "Plan du siège de Brimston hill dans l'île St. Christophe." (540 $\times 435 \mathrm{~mm}$.)
[Ge. D. 3656

I 782. "Plan du siège de Brimston-Hill investie le I2 janvier et rendu le I3 fevrier I 782 a Monsieur le Marquis de Bouillé ... "By Nicolas. (5 Io $\times 360 \mathrm{~mm}$.)

[Portef. I06. No. 85 
ST. LUCIA.

[1778.] "Plan d'une partie de Ste. Lucie avec la position des deux escadres française et anglaise." $(695 \times 225 \mathrm{~mm}$. $)$

I778. "Attaque de Sainte-Lucie, I778. . . projet d'attaque de la flotte anglaise mouillée dans le Cul-de-Sac." (Tracing, $670 \times 610 \mathrm{~mm}$.)

「Ge. C. 2815

I778. “Attaque de l'isle Ste. Lucie par l'escadre et les troupes du Roy aux ordres de Mr. le Comte d'Estaing le I 5 et I7 décembre I778." Legends without plan. $(450 \times 275 \mathrm{~mm}$.)

[Ge. D. 8064 (2)

[1779.] "Carte de la partie de l'Isle de Ste. Lucie depuis l'ance du Choc jusqu'au Marigot des Roseaux." By Nicolas. Operations of d'Estaing and Bouillé. $(580 \times 390 \mathrm{~mm}$.)

I77. "Plan du Morne Fortef. I06. No. 79 I779. "Plan du Morne Fortuné en l'Isle Ste. Lucie." By Nicolas. English fortifications. $(560 \times 520 \mathrm{~mm}$.) [Portef. I06. No. 80 [ 1784.$]$ "Plan de la rade et de la ville du Carenage, à la Ste. Lucie." By de Peyre. $(450 \times 400 \mathrm{~mm}$.) [Ge. D. 80I0 I784. "Carte d'une partie de la côte de l'isle Ste. Lucie depuis la pointe du Cap jusques au Marigaut des Rozeaux. Par le Sr. de Peyre." (I $340 \times 555$ mm.)

[Ge. C. 60I 4

ST. MARTIN.

I775. "Plan de l'île St. Martin appartenant aux Français et aux Hollandois." ( $650 \times 490 \mathrm{~mm}$.

[Ge. D. 8020

TOBAGO.

I677. “Plan du fort et des environs de Tobago avec le port où s'est donné le combat qui montre par lettres cù étoient nos vaisseaux et ceux des Hollandois." $(450 \times 320 \mathrm{~mm}$.)

[Ge. D. 8079

$\left[\mathrm{I} 775^{-1785 .]}\right.$ Plan of the island of Tobago. By Nicolas. ( $560 \times 420 \mathrm{~mm}$.)

[Portef. Io6. No. 82

I780. "A Map of the island of Tobago by Thos. Bowen, I779. L. Bertram f. . . . I780." $(240 \times 190 \mathrm{~mm}$.

[Ge. D. 366I 


\section{ACADÉMIE DE MÉDECINE.}

The library of the Académie de Médecine, I6, Rue Bonaparte, has a collection of 55'r volumes of manuscripts, an excellent inventory of which is printed in Catalogue Général des Manuscrits des Bibliothèques Publiques de France: Paris, II. 349-428 (Paris, 1909).

33. Autograph memoirs and letters.

1783 , Feb. 28, Paris. John Adams to "Vicy d'Assis " [Vicq d'Azyr], perpetual secretary of the Société Royale de Médecine. Acknowledges receipt of the society's diploma, and of the second volume of the Journal de Médecine Militaire, which he will transmit to the medical college of Boston. (A. L. S.)

[f. I

I780, Sept. I I, Passy. Benjamin Franklin to Vicq d'Azyr. Will transmit the packets confided to him by the Société Royale de Médecine; sends, by a young American, Mr. Foulk, objects received from a surgeon in Minorca. (L. S., French.)

[f. $6 \mathrm{I}$

I784, Mar. I, Passy. Benjamin Franklin to Vicq d'Azyr. His indisposition, "stone", prevents him from being present at the reading of his eulogies on Sanchez and Hunter. (A. L. S.)

35. Letters from foreign associates and correspondents of the Acall Royale de Médecine foren associates and correspondents of the Academie the following: Edward N. Bancroft, Kingston, Jamaica, Aug. 24. I835 (f. I) ; John B. Beck, New York, June 20, I836 (f. 2) ; Halphen, New Orleans, Aug. 2, I805 (f. 26) ; Thomas, New Orleans, Aug. 3, I835 (f. 72 ).

94. "La fièvre jaune à la Havane, sa nature, son traitement et sa prophylactique: suivi d'un rapport sur l'épydemie actuelle par le Docteur Charles E. Belot, Propriétaire, Directeur de la maison de santé qui porte son nom à la Havanne." I862 (I I7 pages).-Communicated by the Ministry of War to the Committee on Yellow Fever. 


\section{BIBLIOTHĖQUE DE L'ARSENAL.}

\section{MANUSCRIPTS.}

The Bibliothèque de l'Arsenal ( I, Rue de Sully), so named because of its location in the surviving building of the Arsenal of Paris, was founded by Antoine-René de Voyer d'Argenson, Marquis de Paulmy (I722-1787), who sold it to the Comte d'Artois in I785. Confiscated during the Revolution, it was made a public library and is now one of the richest of the Parisian libraries in point of importance of its collections. These include some Io,ooo volumes of manuscripts and also the archives of the Bastille, described below. The manuscripts include papers of the Comte d'Argenson, most of which, however, were deposited in the library of the Louvre and destroyed in the Commune of I87I, papers of Gabriel Brizard, of Abbé Henri Grégoire, of Joseph Dreux, secretary of Vergennes, of Gudin de La Brenellerie, of the family of LézayMarnésia, involved in the Scioto colony, of Mirabeau, and of many others. The American material while not abundant contains a number of valuable documents, especially memoirs on eighteenth-century explorations.

An exceedingly detailed inventory of the manuscripts has been published: Catalogue des Manuscrits de la Bibliothèque de l'Arsenal, by Henry Martin (vols. I.-VIII., Paris, I885-I899). Of this work vols. I.-VII. contain the inventory, with index, while vol. VIII. is devoted to the history of the library and to an elaborate account of the formation of its collections. Supplements to the inventory are published in the Catalogue Général des Manuscrits des Bibliothèques Publiques de France: Supplement, IV. (Paris, I904) I-I26; Départements, XLV. (Paris, I9I5) I-34.

676.- "Mémoire touchant le commerce des Indes Occidentales par Cadix."

[f. 2 I 4

"Description des isles de Curassol, de Bonaires et Saint-Eustache. Leur commerce particulier."

[f. 244
"Mémoire touchant les colonies que les Hollandais ont aux Indes occidentales, en Afrique, et le commerce qu'ils y font à présent."

"Mémoire concernant le commerce des isles françoises de [f. 255 meridionale, appellées Antilles."

I688 May 26. “ Mém. [f. 26I ies Provinces-Unies des Pays-Bas font dans les divers endroits du Monde." Presented to the States of Holland by Daniel Braems.

[f. 310

2481.-I726, Dec. 3I. Arrêt freeing raw products from the West Indies imported into Ile Royale from the duty of I per cent. for a period of ten years, and freeing those imported into Canada from the duties of the domaine d'Occident.

2786. "Traité abrégé de tout le Commerce de la Terre", I725.- Sections devoted to Newfoundland (f. 4), California (f. I73v), Louisiana (f. 2I4), Florida (f. 2I 4v), English colonies (f. 2I 5), Acadia (f. 2I9), Canada (f.' 22I), and Labrador (f. 224).

2875. Description of plants of the Antilles, with plates, by Plumier.

3221. Relation of the voyage of Capt. Paulmier de Gonneville and his companions, in the Espoir, to the coast of Africa and to Brazil [?], in I 504. Extract from the register of the admiralty (Table de Marbre) of Rouen. 
3459. "Poème en vers touchant l'Etablissement de la Louisianne, connue sous le nom du Missisipy, avec tout ce qui s'est passé depuis I 7 I 6 jusqu'en I74I. Le Massacre des François au Poste des Natchez, les Moeurs des Sauvages, leurs Danses, leurs Religions, enfin ce qui concerne le pays en le Général." By Dumont [de Montigny], I744, dedicated to the Comte d'Argenson, minister of war.-A versified history of Louisiana, I7I6-I74I, in I70 pages. Baron Marc de Villiers du Terrage publishes a study of this document, with extracts, in Journal de la Société des Americanistes de Paris, n. s. XI., fasc. I, pp. 35-56 (Paris, I9I4). M. de Villiers identifies the author of the poem as Dumont de Montigny, who served as an officer in Louisiana from I7I9 to I738, and who was the author of the Mémoires Historiques sur la Louisiane . . composés sur les Mémoires de M. Dumont, published by Abbé Le Mascrier (Paris, I753, 2 vols.).

3724.-I724, Nov. I2. "Relation des Complimens que les quatre Sauvages de Missisipi arrivés à Paris le 20 septembre dernier ont fait au Roy, aux Princes du Sang, à la Compagnie des Indes, etc."-Addresses by Indians and by Father de Beaubois, with replies of the controller general and the Duc de Bourbon, followed by "Traduction en vers de la Harangue des trois Nations Sauvages amenées en France par ordre du Roy par le Chevalier de Bourgmont". Cf. Bib. Nat., MSS. Fr., nouv. acq., 2551, f. 8I. [ff. 77-8Iv

3812-3818. "Description géographique et historique du monde et de ses principalles parties."

3817. "De 1'Amérique Septentrionale", I749.-History and geography of North America: discovery of Louisiana, habits of the Americans, Canada, Louisiana, government, New England and English colonies, the Appalachians, California, Newfoundland, Cape Breton, etc. (539 pages.)

3818. "De l'Amérique méridionale", I749. (534 pages.)

3857.- " Mémoire pour examiner quels sont les contradicteurs de la Compagnie des Indes ; pourquoy ils en demandent la supression, et de quelle utilité cette Compagnie est à l'Etat." A section is devoted to the colony of Louisiana.

[ff. $35 \mathrm{I}-380$

4069. "Extrait ou.Abrégé des Mémoires touchant le Commerce de France et les Moiens. de le Restablir", by Jean Le Pottier. See below, 4561.

4258. - I673. "Voyage de M. le Comte de Frontenac au lac Ontario." Cf. Arch. Colonies, Ci I; A, vol. 4, f. I2. Ptd., Margry, I. I95.

[f. 8

1673, Mar. 12. "Harangue prononcée par Mgr. le comte de Frontenae en l'assemblée tenue à Québec dans l'église des R. P. Jesuites." On the necessity of establishing a police.

I673, Mar. 23. Police ordinance for Quebec, by Frontenac. [f. 23

4392-4394. Memoirs relating to commerce from the memoirs of the généralités of I699.- References to the cod fisheries and the commerce with Canada and the West Indies are contained in the memoirs for Rouen and Granville (4392, ff. 2I 5, 227), Nantes and St. Malo (4393, ff. I74, 243), and for La Rochelle and Bayonne (4394, ff. 22, I6I).

4496. Memoirs on the present state of commerce, the causes of its decline, and the means of reviving it, drawn up by the deputies of the provinces and sent to the Chamber of Commerce established in Paris, I70I.-The memoirs of the deputies of Nantes, La Rochelle, Bordeaux, and other ports contain numerous references to American, especially Canadian, commerce, beaver, fisheries, etc. Cf. Bib. Nat., MSS. Fr., nouv. acq., 885.

$$
\text { [ff. } 27 \mathrm{v}, 44.48 \mathrm{v}, 56,64 \mathrm{v}, 65,68,73 \mathrm{v}, 75,77,84 \mathrm{v}, 88
$$


4497. Fugitive documents relating to commerce.

I628, May. Articles accorded by the king to the Compagnie de la Nouvelle France. (Ptd.)

I7I7, May 23, 24. Letters from inhabitants of Martinique.

[ff. $37-48$

I720, Aug. I [?]. The Sieur Pellerin to M. Foret, his cousin. His arrival in Louisiana, Mar. I5, I7I9, dealings of the Compagnie des Indes with the concessionnaires, application for a concession at Natchez, description of Natchez, measures which should be taken in France by a concessionnaire to assure his success in Louisiana, etc.

I720, Aug. 29, Oct. I6. Biloxi.

[ff. $5^{2-58}$ letters by the a letters by the agent of a syndicate for establishing a plantation in Louisiana.

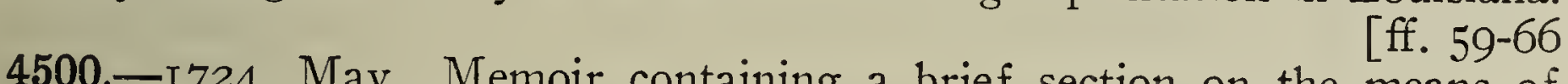
4500.-I724, May. Memoir containing a brief section on the means of developing the colony of Louisiana.

I726, Dec. "Mémoire pour la Compagnie des Indes" Contain [p. I37 section on the maintenance of Louisiana.

"Mémoire pour examiner quels sont les contradicteurs de Co. I67 des Indes ". "Duplicate of 3857 ,

[p. 269
4518. - I778, Duplicate of 3857, f. 35I. 4518. - I778, Oct. 28, Boston harbor. Proclamation by d'Estaing to the former French subjects of Canada.

[f. 210

I779. Relation of the capture of Grenada (ptd., French), followed by letters on the same subject.

[ff. 2 I8 et seq.

4561. "Mémoires touchant le commerce de la France et les moiens de le restablir", by Jean Le Pottier, chevalier, Seigneur de La Hestroy, lieutenant general of the admiralty of Flanders. - A study of the memoirs presented by the députés du commerce in I YoI (see 4496), containing short sections (ff. 34I345 ) on Canada and Acadia. An abridged version of this document is in 4069 .

4565. "Plan de guerre contre l'Angleterre, rédigé par les ordres du feu Roi, dans les années I763, I764, I765, et I766, par M. le comte de Broglie, et refondu et adapté aux circonstances actuelles pour être mis sous les yeux de Sa Majesté, à qui il a été envoyé le I7 décembre I778." (269 pages.)

4788. "Nouveaux Mémoires touchant la Nouvelle-Espagne", by a captain in the service of Spain, I707.-Description of Mexico and of the principal Spanish posts and provincés of North America: Pensacola (f. I 53), California (f. $154 \mathrm{v})$, etc. (I62 pages.)

4789. "Extrait de l'Histoire de l'Origine du Commencement et du Progrès de la Guerre en Amérique entre l'Angleterre et ses Colonies depuis l'année I763", to I779. (216 pages.)

4817.-Memoir on Cayenne and Guiana, by the Sieur Desmontis.

[pp. I I6-I 44 Atlas 39. "Voyage à la Louisianne." Narrative by the [commander?] of the Atlas, transporting troops and munitions to Louisiana, of his voyage thither, with reflections on the present state of the colony, and unfavorable criticisms of its inhabitants, of Bienville, etc.

5301. Extracts relating to the slave-trade and to the history of Santo Domingo, in hand of Abbé Grégoire.

"Carta apologetica de Casas contra la falsa imputacion de haber solicitado el commericio de esclavos."

Extracts from the MS. of M. Mauriel, bishop of Santo Domingo.

5768. Papers of the Comte d'Argenson.

I760, June 24, Montreal. Chevalier de Lévis to d'Argenson. Siege of Quebec; arrival of the English squadron. (A. L.S.) [ff. 3-4
[ 
I762, June I9, Rochefort. Letter or memoir containing reference to despatch of five vessels from Bordeaux to Louisiana, of which only one escaped capture ; inevitable loss of Louisiana to English.

I756, Dec. 25. Journal Maritime de Bayonne. News of vessels from Quebec and Louisbourg.

[f. 235

I755. Memoir by d'Estaing: "Examen des différentes idées que l'on avoit eues sur les occurences présentes et de celles que l'on pourrait encore y joindre." Political situation as regards Canada and Louisiana ; basis of peace without session of Canada.

I755. Memoir by d'Estaing. "Extraits des conjectures [ff. 272-287 leurs ministères et leurs ministères et sur nos différents. On y a joint un exposé, distingué par province, de ce qu'ils appellent nos usurpations ", $i$. e., Canada and Louisiana.

「ff. 30I-3IO

I755, Apr. I6, London. D'Estaing to d'Argenson. Sends the two preceding memoirs. (A. L. S.)

[f. 3 I 2

I755. Memoir by d'Estaing: "Extraits des Livres Anglais qui paraissent actuellement sur les Affaires des Colonies du continent de l'Amérique Septentrionale."

I755, Dec. "Lettre d'un Hollandais à un Suédois", followed by " Réponse d'un Suédois à un Hollandais". Necessity of preventing England from becoming too powerful; English views as to Canada and Louisiana; commerce, etc.

5769. Papers of the Comte d'Argenson.

[ff. $341-364$

I757, Jan. 22, Aug. 23. Journal Maritime de Bayonne. Items respecting captures of vessels from Virginia and Rhode Island.

[ff. 2,22

Dialogue in the Elysian Fields between Marshal Saxe and Baron Dieskau. Ptd. in N. Y. Col. Docs., X. 340.

Relation de la Prise de Chouaguen [Oswego].

[ff. $288-295 \mathrm{v}$

[ff. 298-299v

I757. Extracts from letters, etc., containing news relating to Canada: names of vessels bound for Quebec from Bordeaux; vessels at Quebec; news from Fort St. George.

I757, June 30; I759, Apr. I3; I760, June 29, Montreal. Chevalier de Lévis to d'Argenson. News of engagements. - State of the colony ; prospects of coming campaign; his understanding with Montcalm and Bourlamaque; marine troops held in higher esteem than the regulars.-Failure of his attack on Quebec.

1757, July I, 30, Aug. I 5, Oct. I 5 ; I758, Apr. 20, July I7, 8; I759, Sept. I 3 ; I760, June 23, July 5, Montreal, Quebec, or in various camps. Montreuil to d'Argenson. News of actions in various parts of Canada; understanding between Montcalm and Vaudreuil.-Courageous conduct of the Indian allies. - Surrender of Fort William Henry.-Distress in the colony ; arrival of English fleet off Louisbourg.-Indians.- Narrative of events.-Defenses erected by French and English at Carillon.-Battle of Plains of Abraham.-French attack on Quebec.-Asks for promotion.

[ff. 308, 310, 316, 3I 7, 322, 332, 334, 369, 37 I, 375

I757, Aug. 9. Articles of capitulation accorded by Montcalm to the garrison of Fort William Henry.

I757. News from Ile Royale.

I757, June 26. News of effects of war in the English colonies.

[f. 3 I4

1758. Relation of the French victories at Ticonderoga of July 5 and 6 , and printed copy of the letter of Montcalm relating to them. [ff. 326-33Iv I758. Relation of the French victory at Ticonderoga of July 8 , with lists of killed and wounded on July 6 and 8 .

[ff. 338-34I 
I758, Aug. I, Quebec. Doreil to d'Argenson. Praise of Montcalm.

I758, Nov. 2I, Montreal. Montcalm to d'Argenson. (Dupliche) 342-343V

[ff. 354-355

[I758.] Memorandum on Indian neutrality and English plans for attack on Canada.

[f. 356

I760. Account of the victory won by the French under Quebec [Ste. Foy], with list of Canadian officers arriving [in France] on Nov. 27, I 760.

6056-6103. Papers of Gabriel Brizard-An examination of 6098, 6100, and 6101 reveals only a few notes made in 1783 , on French and English rivalry, with mentions of Washington, Franklin, and Lafayette (6100, ff. 379-38I).

6113.- "Mémoire sur l'étendue et les bornes des loix prohibitives du commerce dans nos colonies."

[f. 8I

6193. "Mémoire sur le Commerce de l'Amérique, par M. [Jean Roland] Mal[1] et ..." Feb., I732.-Deals with commerce of France and England with the Spanish possessions in America. Engraved maps by d'Anville are at pp. 1xi, 1xv, 630, 632. (1xvi, 633 pages.)

6339. Papers of Abbé Henri Grégoire, former bishop of Blois.-Reports, speeches, fragments, and letters to Grégoire from various persons, relating to slavery, especially in Haiti, to its abolition, etc., I797-I820.

[18I8.] Fragment of a MS. by [P. N. Clary] relating to the exclusion of colored persons from the distribution of relief to refugees from Santo Domingo in Louisiana. [ff. 62-62v I820. Letters to Grégoire from Zachary Macaulay and Thomas Clarkson, relating to slave-trade carried on by French vessels.

$[\mathrm{ff} .67-76 \mathrm{v}$

"Notes of information relative to the island of St. Domingo, communicated by a Partner of the house of Williams and Miercker, American merchants, many years established at Cape François."

6364. French-Iroquois dictionary. ( I8th century, I64 ff.)

6402-6403. Papers of Pierre Lucien Joseph Dreux, secretary of the Comte de Vergennes.-In 6402 the following documents are noted: résumé of the clauses of the Treaty of Utrecht relating to the cession of Hudson Bay, Acadia, and Newfoundland to England (f. 94) ; notes on the geography of North America, the West Indies, etc. (ff. I77-I84v) ; poem “ à Mad'e $* * *$ revenant d'Amérique, I775-I78I " (ff. 288-288v) ; "Vers faits pendant la guerre d'Amérique, I779" (ff. 295-295v). 6403 contains nothing of interest for American history.

6432-6465. Collection of maps, plans, and memoirs relating to fortified places, formed by the Marquis de Paulmy.

6432.-I75I, Jan. "Mémoire sur les limites de la Nouvelle France par un ami de M. de la Condamine." Boundaries of Louisiana, Acadia, Hudson Bay, etc. ( 8 pp.)

[no. I

I755. Two memoirs, with letter of transmittal of Comte de Raymond, Mar. IO: (a) "Mémoire concernant l'Isle Royale et réflexions sur cette colonie dans les circonstances présentes"; (b) “Mémoire concernant la défense de Louisbourg et des moiens à prendre pour l'assurer à la France à jamais, autant qu'il est possible."

[no. 2

I755. Two memoirs transmitted with letter of Mar. Io, as above: (a) "Mémoire par lequel il est prouvé que l'on peut assurer pour toujours la subsistance en grains des colonies de l'Isle Royale et Isle St. Jean"; (b) similar memoir respecting supply of fresh meat. 
[Post r763.] "Réflexions générales sur le gouvernement des îles du Vent de l'Amérique."

I732. " Plan de l'Isle Roialle." (680 ×5 10 mm.)

[no. 4

"Plan du port et de la ville de Louisbourg." (990×600 mm.) [no. I8

"Partie du port de Louisbourg", showing works of Dubois de Lamotte $(660 \times 500 \mathrm{~mm}$.$) ; and "Plan de la ville de Louisbourg" (830 \times 510 \mathrm{~mm}$.

[no. I9 mm.)

Plan of Louisbourg, with the works constructed in 1757 . (ro6o $\times 530$

Plan and views of Louisbourg. (I $40 \times 5$ Io mm.) [no. 21

Plan of Louisbourg, showing the guard-house constructed by the English. $(700 \times 410 \mathrm{~mm}$.

6433.- "Carte des environs de Louisbourg." (ro3o $\times 720 \mathrm{~mm}$.) [no. 23

I700. "Plan de la ville et château de Québec." $(560 \times 400 \mathrm{~mm}$.

[no. 24

I757, Aug. 3-I6. "Journal du siège du fort Georges, apellé par les Anglois William Henry, scitué au fond du lac St. Sacrement, avec la description de ce fort et du camp retranché des ennemis. Par M. Des Androuins."

[no. 24

I757. "Plan de fort George apellé par les Anglois William Henri, et de ses attaques par M. le Marquis de Montcalm." By J. Crèvecoeur. ( $580 \times 540$ $\mathrm{mm}$.)

"Carte de la partie de la Guiane occupée par les Hollandais formant la Société de Surinam." $(680 \times 495 \mathrm{~mm}$.)
[no. 25

6650.-[I7I7.] Project of a déclaration confirming the privileges of the Compagnie des Indes, in 32 articles.

[ff. I $7-52$

[Post I7 I8.] "Relation contenant l'étendue des isles de Missisipi et de leurs proprietez, avec une explication des villes que les François y ont bâties."

[ff. $54-55$

I540/4I, Feb. 26. Order of Parlement for the delivery of prisoners to Roberval for his expedition to Canada. (Parchment.)

[f. 56

6771.-I 540/4I, Feb. 7. Authorization by Francis I. to Roberval to take prisoners for his expedition to Canada. Vidimus of Jean d'Estouteville, Feb. r8. (Parchment.) Cf. H. Harrisse, Notes sur la Nouvelle France, pp. 258-264.

[f. 30

r 540/4r, Jan. I5. Authorization by Francis I. to Roberval to enroll men and provide himself with arms and munitions for his expedition to Canada. Vidimus as in preceding document. (Parchment.) Cf. ibid., pp. 265-268.

[f. 3I

I8r6, Apr.-June. Correspondence between the customs service and merchants of Rouen respecting entry of American cotton.

[ff. $176-190$

6798. “Le Français chez les Hurons, ou La Vertu de la Baguette. Comédie en 2 actes, mêlée d'ariettes. Par le Chevalier de Launay." I780.

6871-6881. Papers of Paul Ph. Gudin de la Brenellerie, I738-1812.

6880. " Histoire Politique et Philosophie."-Fragments, notes, etc., containing frequent references to American history as follows: note on article in the Journal de Paris of May I3, I784 or I785, on the Philadelphia balloon (f. I 56), French participation in the war of American independence (ff. $195 \mathrm{v}$ $205 \mathrm{v}$ ), preliminaries of the treaty of $\mathrm{r} 783$ (f. $2 \mathrm{r} 6$ ), description of a medal presented by Franklin to Fleury (f. 2I7), summary of the history of the American war, population of the thirteen States, treason of Benedict Arnold, American Indians, etc. (ff. 264-286). 
7053-7055. Collection of autographs, chiefly from the collection of Victor Luzarche.-In these three cartons a small number of American letters, mostly without interest, are to be noted: 7053, Henry Clay, Ashland, Oct. 27, I835, asking that a sum of money be sent to him ; J. Cox Barnet, U. S. consul, Paris, Jan. 25, I831. 7054, Andrew Jackson; John Jay, Philadelphia, Jan. Io, I779; Albert Gallatin to Samuel M. Hopkins, Treasury Dept., Nov. 27, I807. 7055, William C. Rives, U. S. minister, Paris, Jan. 26, I83I ; Vergennes to Gerault, Mar. 28, I 763 , on the treaty of peace; William Ducoudray, New Orleans, Oct. I7, I8I3, on his travels in the United States; Daniel Webster to Justice [James M.] Wayne, Mar. 8; Justice James M. Wayne to _— Taft, June I8, I840 ; D. B. Warden, U. S. consul, to M. Coulier, Aug. I8, I833, Mar. 2, I837; W. West to W. H. Crawford, Washington, July 7 , I8I8.

7169-7183. Catalogue of maps and plans included in the "atlas historique militaire du Dépôt de la guerre", I635-1871.-A considerable number of American maps are listed in $7180,7181,7183$.

7184. “Résumé historique des guerres", I7 I9-I768.-References to hostilities in America during this period.

7193-7339. Archives of Lezay-Marnesia.-Because of the part taken by the Marquis de Lezay-Marnesia in the Scioto Company, and of his interest in America, an examination was made of 7320-7326, and 7338-7339. One document only was found: (carton 7326) I792, Apr. I8, Fort Pitt, letter from Pierre Audrain to Lezay-Marnesia, relating to consideration of their affairs by a committee of Congress, to letter from Tardiveau in Illinois, to Lezay-Marnesia's plans for trade in Illinois, to activities of the Des Pintraux, to proposed fort to prevent contraband trade of the English, to accounts with O'Hara, Wilkins, Ormsby, Probst, etc.

7581-7589. A collection of notes of slight value, bearing the general title Diversité. The first volume is dated, Evreux, I774. A few references to American matters have been noted, as follows: 7586. Emigration to America (p. I 52) ; hieroglyphic representation of the arrival of white men, by Virginia Indians (p. I88). 7587. Reasons for refusal of Spain to join France in aid of American insurgents (p. 264) ; Spanish views of slaughter of natives in West Indies (p. 3I 7). 7588. Indian remedies (p. I3); Canadian beaver trade (p. 38) ; revolt of American colonies (pp. 282-29o).

7592-7594. Autograph note-books of Mirabeau.-The first and last of these contain nothing bearing on American affairs; the second, 7593, is entitled by Mirabeau, "Pensées diverses et anecdotes sur l'administration", while a note signed by Lucas de Montigny states that the contents are "fragments historiques insérés dans les mémoires du Duc d'Aiguillon", and refers to the Mémoires of Mirabeau, IV. 84 et seq. The following points of interest for American matters are to be noted: Beaumarchais and the insurgents, his connection with Le Ray de Chaumont for supplying them; criticism of the first operations of the war, of French attitude toward England, and of joint action with Spain; financial disorder; criticism of d'Estaing; attitude of Vergennes, d'Aiguillon, Maurepas, Turgot, Necker, Sartine, and Gérard; influence of Gérard on Vergennes; ministerial intrigues; it was the king who willed the war, etc.

9026-9041. Papers of the Chevalier d'Eon.

9026. - I793, Jan. I8, London. Capt. O'Gorman to his " aunt, M'lle " d'Eon. His experiences in Santo Domingo; campaign against the negroes in revolt. 
9027.-I769, Sept. I5; I775, Sept. 8. Gazette d'Utrecht. News from New England.

[nos. 7,13

I776, June 28; I787, Oct. I2. Courrier de l'Europe. American news.

[nos. 9, 2 I Canada.

I796, Aug. 30. Courrier de Londres. List of prizes; United States and

9039-1786, Feb. Note from Capt. John Collet, relating to the sums pended by him for. Carolina. subject.

I786, Jan. I4, London. Memoir by Capt. Collet on the same subject.

I787, Aug. I7. G. Rose, secretary of the treasury, to Capt. Collet. Same

\section{ARCHIVES DE LA BASTILLE.}

When the Bastille was stormed on July I4, I789, its archives were subjected for two days to general pillaging, after which what was left of them was placed under guard and later deposited in the Hotel de Ville, the Abbey of St. Germain-des-Prés, and the convent of St. Louis-la-Culture. It was probably in 1798 that they were finally removed to the Bibliothèque de 1'Arsenal. They are now preserved in some 2725 cartons, numbered IOOOI-I 2725 , constituting a continuation of the series of manuscripts described above. They are in three groups or divisions: ( I) administration of the lieutenant general of police, nos. IOOOI-IO329; (2) dossiers of individual prisoners and biographical documents, nos. I0330-I247 I ; (3) administration of the Bastille, of the prison of Vincennes, and of other prisons, nos. I 2472-I 2725. The second and third of these groups contain the American material, the most important of which consists of the documents relating to the trial of the Canadian officials after the fall of Quebec, the trial of Kerlérec, governor of Louisiana, and the lists of prisoners in the chain-gangs sent out to Louisiana. Vol. IX. of the Catalogue des Manuscrits de la Bibliothèque de l'Arsenal (Paris, I892-I894) contains a history and inventory of the archives of the Bastille, with an index to the fifty or sixty thousand names of persons to be found in them, by Frantz Funck-Brentano.

10028. Papers of Levié, commissaire, police inspector of ports.

I755, Nov. 5; I759, Aug. 20, Havre. Levié to [the lieutenant of police]. Effect on the Bourse of the engagement at Fort Frederic; news from Canada.

10496. Dossiers of prisoners, A-Z. I693.-Dossier of Martin De Lino (merchant at Quebec) : order of arrest; examination of De Lino for information respecting English designs on Canada, news from and trade with Boston, Nelson, the English interpreter of Frontenac, etc.; passport for Frontenac to return to France.

10501. Dossiers of prisoners, D-Z. I694.-Dossier of Nelson, the English subject mentioned in the preceding item. He was released at the close of 1695 on his promise to go to England via Flanders without stopping in Paris.

10597. Dossiers of prisoners, A-E. I7 I I.-Dossier of Alexandre Bellefond. According to the examination this officer of marine was the son of a notary at Quebec, and at this time (June, I7II) was forty-five years of age. He had fought the Iroquois in Canada, had served under Villebon in Acadia, and afterward had been with Iberville until I703. The cause of his imprisonment was a proposal to the King of Spain to assassinate the archduke. He was sent to the Spanish frontier, and thence to the Bastille. 
10631. Dossiers of prisoners, I-L. I7 I7.-Dossier of Antoine de La Mothe Cadillac and his son. There is no record of examination, the cause of imprisonment being given as "discours peu convenable". The period of their joint incarceration is Sept. 27, I7I7-Feb. 8, I7I8.

11374. Dossiers of prisoners, Th-U. I737.-Dossier of Thiersant: memoir of Mme. de Thiersant to Cardinal de Fleury, touching upon beaver trade by the English, and their manufacture of hats at Montreal in I725, Fort Niagara, contraband trade by the English, etc.

11970. Dossiers of prisoners, Me-Mi. I757.-Dossier of Pierre Charles Mesnil : papers dealing with his relations with La Salle at the Hague, and La Salle's plots against Canada.

12110-12136. The dossiers of prisoners included in these cartons contain only brief notes indicating the cause of arrest, the punishment if any, and the period of detention. All are dated I76I : 12110, Barbel ; 12111, François Bigot; 12112, Deschamps de Boishébert ; 12114, Cadet ; 12115, Jean Corpron ; 12119 , Claude Nicolas Fayolle; 12124, Joncaire dit Chabert; 12125, Jean Pierre La Barthe; 12128, Le Mercier; 12130, Jean Baptiste Martel, de Villers, and François Maurin ; 12133, Michel Jean Péan and Louis André Joachim Pénissault; 12136, François Paul Duvergé de St. Blin.

12142-12148. “Aftaire du Canada." I76I-I772.- These papers relate to Bigot, Péan, Cadet, and their numerous accomplices. For the most part they represent the work of the commission charged with the investigation of frauds in Canada. Among them are found orders of various kinds relating to the prisoners, papers seized, correspondence of the prisoners at the Bastille, lists, notes on procedure, memoirs, information respecting witnesses, notes on sentences and terms of imprisonment, etc. Occasional documents of a wider historical interest are found, e.g., one relating to La Friponnel of Quebec (12142, no. 359), and a memoir for Péan, I762, dealing with military affairs in the western country in I753-I754 (12145, ff. 7-55).

Names of the accused are as follows: Bigot, Billeau, Boishébert, Bréard; Cadet, Chabert, Corpron, Curot, Dartigny, Dauterive, Desmeloises, Deschenaux, Douville, Dumoulin, Estèbe, Fayolle, Ferrand, Ferrières, Gamelin, Garreau, Hauteraye, Héguy, La Barthe, La Chauvignerie, Landriève, Laplace, Le Gras, Le Mercier, Lemoine-Despins, L'Espervanche, Lorimier, Martel (3), Maurin, Noyan, Papin, Péan, Pénissault, Perrault, Poisset, Roustan, Rouville, Sacquespée, St. Blin, St. Germain, St. Sauveur, Sermet, Varin, Vassan, Vaudreuil, Villebon, and Villefranche.

12148 contains documents seized for the purposes of the examination, including commercial papers of the firm of David Gradis of Bordeaux, I752I754, relating to Canadian supplies.

12151-12166. Certain dossiers in these cartons consist merely of notes or fiches on certain persons concerned in the "Affaire du Canada", and deal with length of imprisonment and punishment. The list is as follows: 12151, Bréard; 12154, Desmeloises ; 12156, Estèbe; 12159, La Potherie ; 12162 , Noyan; 12163, Perrault; 12166, Villebon, Vassan, and Vaudreuil.

12200. "Affaire de l'Ile Royale." I758-I764.-This carton of 5I8 folios relates to charges of embezzlement brought against Jean de La Borde, treasurer general of Ile Royale and procureur général of the Superior Council, and Jacques Prévost, conseiller général de marine and ordonnateur of the same colony. Decarette, son-in-law of La Borde, and Fabres, Prévost's uncle, were 
also arrested. The papers consist of memoirs, correspondence of the prisoners, examinations and other documents relating to the trial, orders, etc. La Borde alone was judged guilty.

12249. Dossiers of prisoners, Mar.-May, I765.-A note on the imprisonment of Philippe de Marigny de Mandeville, Apr. 30-May 24, for his writings on Kerlérec and Louisiana.

12262. "Affaire de la Louisiane." I765-1770.-This case grew out of disputes in Louisiana between Gov. Kerlérec and certain officers and officials there. The controversy continued after their return to France, and was accentuated by the publication of alleged libels against Kerlérec. A commission was appointed to examine the case, and finally issued its report in 1769 . It was unfavorable to Kerlérec, who was exiled from Paris and the court. He died in 1770 .

The dossiers in this volume of 280 folios are of Louis Billouart de Kerlérec, Jean Philippe Gougon de Grondel, Antoine Philippe de Marigny, Paul de Rastel, Chevalier de Rocheblave, and Jean Baptiste Le Bossu. There is a certain amount of memoirs, procès-verbaux, orders, and other routine documents, but the major part of the volume consists of correspondence of the individuals noted above, and also of the lieutenant of police, the governor of the Bastille, the Duc de Choiseul, Duval, Mme. Rochemore, Chevalier, Huart Du Parc, Abbé de Rocheblave, Delfau, and various others.

In addition to this material, among the sequestrated papers of Le Bossu are the following of wider historical interest:

N. d. Memoir by Le Bossu, on the vexation of officers in Louisiana by Kerlérec. (Draft.)

N. d. Le Bossu to —. Kerlérec's despotism. (Draft.)

[ff. $240-24 \mathrm{IV}$

[ff. $243-244 \mathrm{v}$

N. d. [Le Bossu] to Dubiq, chief clerk of the Bureau des Colonies. Summary of Le Bossu's memoir against Kerlérec. (Draft.) [ff. 246-250
[

N. d. Baron de Portneuf, commandant at Fort Orleans, among the Missouri, to [Le Bossu]. Census of Missouri tribes seems forged by Le Bossu. (Draft.)

[f. 257

Information compiled in 1756 among the Illinois in order to learn from them the western tribes known and attached to the French, and on whom in case of need the Missouri post can rely for aid. (Census.) a [f. $257 \mathrm{~V}$

12324. "Affaire des colonies de la Guyane." I767-I774.-Documents relating to the trial of Thibault de Chanvallon, intendant of Cayenne and Guiana, for misappropriation of funds.

12383. Dossier of Denis Nicolas Foucault. I770.-Foucault was arrested at the request of O'Reilly, who laid charges against his conduct as ordonnateur in Louisiana. He was forgotten at the Bastille for a year, and finally obtained his release in I77I. Examinations and memoirs relate in part to the revolt in Louisiana against Spanish rule; there are also letters of Foucault, Sartine, Abbé de Beaujeu, Abbé de Carlier, Duc de Praslin, Macarty, Duc d’Aiguillon, and others.

12453. Dossier of Chevalier de Lannay, I782.-Brief document, indicating his connection with a Franco-Anglo-American gazette published at Maestricht, and his correspondence with Swanton.

12472-12478. Ordres du Roi. I666-I779.-Letters of the king and of the minister to the governor of the Bastille. For the most part they are lettres de cachet, signed by the king and countersigned by the minister, ordering imprison- 
ment in or release from the Bastille. The above dates are not complete, as the entire collection of twenty-two volumes has been widely dispersed.

12473.-Orders for the release of La Salle (Mar. 7, 1675) and Perrot (May 7, I675).

12478.-Orders for imprisonment (Aug. Io, 1777) and release (Sept. 24, I777) of William Hodge, Philadelphia merchant.

12479-12481. Registres de la Salle du Conseil: Registres d'Écrou.-These registers contain the date of entry of prisoners, their names, list of articles found on them at their arrival, name of the minister who countersigned the lettre de cachet, etc.

12479. I 7 I I-I728.-Bellefond, La Mothe Cadillac and son.

12480. I762-I771.-La Borde (Mar. I6, I763), Prévost (Apr. 28, I763), Grondel (May 9, I765), Mandeville (May 13, I765), Rocheblave (May II, I765), Cadet.

12481. I773-1787.-Brissot de Warville (no. 364), Baudard de St. James (no. $\left.35^{2}\right)$.

12482-12484. Feuilles d'Écrou. I709-I750.- Signed by prisoners on arrival and departure. Vol. 12482 contains the feuilles of La Mothe Cadillac and his son.

12486-12517. Correspondence of the lieutenant general of police with the governor and the major of the Bastille, I723-1789.-There are also letters of secretaries of the lieutenant of police and of commissaries at the Bastille, petitions, etc. The correspondence deals with the life of prisoners at the Bastille, the rigor of their confinement, any privileges granted them, their petitions, complaints, and requests.

12501. Letters of the lieutenant of police. I 762, Jan.-Apr.-Correspondence relating to Cadet, Martel, Corpron, Boishébert, Péan, Pénissault, Joncaire, Bigot, Varin, Vaudreuil, Le Mercier, Villers, and Noyan.

12502. Letters of the lieutenant of police. I762, Sept.-Dec-Correspondence relating to Varin, Péan, Le Mercier, Estèbe, Martel, Noyan, Fayolle, Bréard, Pénissault, Bigot, Maurin, Chabert, Cadet, Vassan, Corpron, and St. Blin.

12503. Letters of the governor and the major of the Bastille to the lieutenant of police. I760, Jan.-I762, Dec.-Correspondence relating to Péan, Le Mercier, Bigot, Cadet, Noyan, Estèbe, Vassan, Bréard, Pénissault, Martel, Corpron, Chabert, La Barthe, Fayolle, Maurin, Perrault, and Varin.

12504. Letters of the lieutenant of police. I763, Jan.-May.-Correspondence relating to Péan, Pénissault, Chabert, Noyan, Varin, Martel, Estèbe, Vassan, Bréard, Le Mercier, Maurin, Corpron, La Barthe, Cadet, St. Blin, Fayolle, Bigot, and La Borde.

12505. Letters of the lieutenant of police. I764, June-Sept.-Correspondence relating to Péan, Fabres, La Borde, Corpron, Pénissault, and Maurin.

12506. Letters of the major of the Bastille to the lieutenant of police. I763, Jan.-I764, Dec.-Correspondence relating to Bigot, Bréard, Cadet, La Borde, and Prévost.

12507. Correspondence of the lieutenant of police with the governor and major of the Bastille. I765, Jan.-I766, Dec.-A small amount of routine material relates to the Canadian prisoners.

12519. Correspondence on supplies for prisoners. I759: Jan.-1767, Dec.Various routine items relate to Cadet and to St. Blin. 
12581-12582. Registers of declarations signed by prisoners on their departure from the Bastille, in which they promised not to speak of certain matters in connection with their imprisonment, and acknowledged the receipt of personal effects.

12582. I763-I770, I786-I789.-Fayolle, Perrault, Vassan, Le Mercier, Noyan, Joncaire, St. Blin, La Barthe, Bigot, Varin, Estèbe, Dec. 15, I763; Martel, Cadet, Bréard, Jan. 27, r764; La Borde, Aug. 23, 1764; Corpron, Maurin, Pénissault, Dec. 25, I764; Grondel, Rocheblave, Mandeville, May 24, I764; Cadet, Mar. 25, I766; Fabres, Aug. 2, I766.

12708. Correspondence and other documents on transportation of prisoners to Louisiana and Cayenne, I7 I9-I720.-For Louisiana there are eight lists of prisoners, which cover forty-two pages and doubtless contain many duplicate names, six letters or notes, and three petitions. Most of these prisoners came from Bicetre. The material relating to Cayenne is of a similar nature, and deals mainly with the chain-gang. 


\section{BIBLIOTHĖQUE DE LA CHAMBRE DES DÉPUTÉS.}

The library of the Chamber of Deputies, in the Palais Bourbon, contains I 546 volumes of manuscripts, which constitute a miscellaneous collection acquired by various means, in considerable part by purchase. Among the few documents of American interest are items of administrative correspondence, extracts from English and American laws, edicts and letters patent, memoirs on commerce, narrations of voyages, etc. An extended inventory of the collection by Ernest Coyecque and $\mathrm{H}$. Debraye has been published: Catalogue Général des Manuscrits des Bibliothèques Publiques de France: Chambre des Députés (Paris, I907, pp. 1xxi, 663).

285-289. Despatches of C. de Harlay, Comte de Beaumont, ambassador in England, to the king and Villeroy, with their replies, I602-I605. Cf. Bib. Nat., MSS. Fr. 3499-3513.

292. Expenditures for the marine, I66I-I668.

I66I-I668. "Fonds pour les dépenses générales de la Marine." Items relating to America have been noted as follows : voyages to Canada, payment of captains and crews, etc., of the Aigle-d'Or, Flûte Royale, Brezé, Jardin de Hollande, and vessels of the Compagnie des Indes Occidentales; recruitment and transportation of emigrants to Canada; maintenance of troops; salaries of Tracy, Chevalier de Chaumont, Courcelles, Bouteroue, and Talon; payments to Dubois, former commandant of artillery in Canada, to Chamilly, La Poterie, and the Bishop of Petraea ; expenses of New France, etc. [ff. 3-3 I I662-I668. "Dépenses générales de la Marine." Items similar to those above.

293. "Recueil des Mémoires établissant les inconvéniens du Commerce
[ff. 40-228 des Fraudeurs Anglois pendant les hostilitiés ; ensemble la nécessité de rendre les armateurs français armant sous pavillion américain justiciables des juges de leur domicile. Par M'e Poirier, Avocat en Parlement à Dunkerque, I779 à I782."

IZ80, Mar. 20. Case of the privateer Prince Noir. Memoir presented to Sartine, on question whether a French subject fitting out a privateer under American flag is justiciable in French or American courts.
[pp. 70-74 I780, Aug. Io. Letter from the king to the admiral. Adjudication of prizes brought into French ports by American privateers.
[pp. 76-78 I780, Aug. I I. Sartine to admiralty officers of Dunkirk. French courts to exercise jurisdiction in the cases of the Prince Noir and the Princesse Noire since the letters of marque granted to them by the Congress of the United States have been withdrawn.

[pp. 78-80

325. Collection of extracts from English and American laws (New York and Massachusetts) relating to corrupt practices in elections. Compiled and translated in 1844 for the questors of the Chambre des Députés.

338-353. Collection of ordinances, edicts, letters patent, etc., presented to Parlement for registration, I645-1675.

345. - I669, June, St. Germain-en-Laye. "Edit portant établissement d'une Compagnie de commerce pour le Nord." "
[ff. 275-278 I669, Apr., Paris. Letters patent confirming the establishment of the Hospital Nuns of St. Joseph at Montreal. Ptd. in Edits et Ordonnances, I. 55. 
350.- - 67 I, May, Dunkirk. Letters patent confirming the establishment of the Congrégation de Notre Dame in Montreal.

[f. 204

352.-I673, Apr., St. Germain-en-Laye. Letters patent uniting the abbey of Meaubec to the bishopric and seminary of Quebec.

[ff. 355-357

436.-I637, Nov. I9, St. Germain-en-Laye. Déclaration du Roy, pour le Restablissement du Commerce par Terre et par Mer ... (Paris, I639).

[ff. I $96-$ I 99

I627, Sept. 7, St. Germain-en-Laye. "Lettres patentes portant rupture de la paix avec l'Angleterre."

[ff. $489 \mathrm{v}-492$

1047. Commerce.-This volume appears to be a duplicate of Bib. Nat., MSS. Fr., nouv. acq., 7287, q.

1048. [I7OI.] "Extrait ou abrégé des Mémoires touchant le Commerce de la France et les Moiens de le rétablir, par Messire Jean le Pottier ... seigneur de La Histroy." $C f$. Arsenal, MSS. 4561.

1091. Mémoires, ordonnances, instructions pour la Marine, expediẻes par M. Colbert et par M'is de Seignelay."

r667. "Règlement que le Roy veut être observé pour les affaires de la Marine et du Commerce."

[ff. I6v-Igv

I675, Mar. 26, St. Germain-en-Laye. Instruction for the Comte de Blénac, commanding the vessels which are to protect the French vessels engaged in the Newfoundland fisheries.

[ff. $205 \mathrm{v}-207$

I675, May I3, Condé. Instructions for the Comte de Blénac, governor and lieutenant general in the Islands of America. Commerce between Canada and the West Indies; maintenance of correspondence with Frontenac.

[ff. 244v-254v

1139. "Mémoires des Députés à la Chambre du Commerce."-Memoirs on the commerce of Bayonne (ff. I7-20v, 30-32v); and by "M. de Fénélon député de la ville de Bordeaux" (ff. 36-86v), and "M. Descasaux du Hallay -député de la ville de Nantes" (ff. I74-206v) contain references to American commerce, beaver, slave-trade, fisheries, etc. Cf. Bib. Nat., MSS. Fr., nouv. acq., 885.

1246. Voyages.

I 703, Dec. 26-I706, Jan. 4. Narrative of the voyage to the South Sea by the Sieur du Coudray, commanding the St. Charles of St. Malo.

[ff. I69-I8ov I698-I70I. Extract from the journal of the voyage to the South Sea by M. de Beauchêne.

[ff. I $8 \mathrm{I}-\mathrm{I} 95 \mathrm{v}$

I707-I708. "Mémoire de mon voyage à Mexique et de tout ce que j'ay négotié pour le départ de la flotte de la Nouvelle Espagne", by M. de Catigny.

[ff. I96-208 Magellan.

[ff. 209-220

I703. "Journal du voyage de Marseille au Pérou avec le vaisseau le Grand St. Pierre, commandé par Mons. de Carman."

[ff. $22 \mathrm{I}-264$

1249. Relation du Voyage de la Mer du Sud fait pendant les Années I7I2, I I 3 et I7 I4 par le Sr. Frazier, Ingénieur Ordinaire du Roy, I7I 5.-Contains MS. maps and drawings.

1354.-I626, June I4, Stockholm. "Etablissement d'une compagnie pour le commerce du royaume de Suède ès pays de l'Afrique, de l'Asie, de l'Amérique, et de la Magellanique ou terre Australe . . . Avec les privilèges octroyès à la dite Compagnie par le Roi Gustave II." Also in Bib. Nat., Dupuy, 523. [ff. I $73-187 \mathrm{v}$ 
I632, Oct. I6, Nuremberg. "Déclaration et ampliation des privilèges octroyés par le Roi de Suède à la nouvelle Compagnie Australe." [ff. I89-I95 I634, July I, St. Germain-en-Laye. "Déclaration du Roi portant défenses à ses sujets d'entreprendre sur les Espagnols et Portugais au deça du premier méridien."

[ff. $234-236$

1487. "Commerce général et étranger de la France dans le 4 parties du monde pendant l'année I753." (I73 pages.)-A few references to the commerce of the principal towns of France with America, and a brief history of the Compagnie des Indes.

1488. "Etablissement de la Cie. des Indes. Son progrès. Son commerce, sa régie, ses revenus particuliers, ses dépenses particulières sur les dits revenus, dettes ... troupes ... employés ..." I754.-References to the commerce of the company in America, pp. 24-26, 49-52.

1537.-La Science du Bonhomme Richard. Signed, Richard Saunders. (Broadside.)

[f. 382 


\section{BIBLIOTHÈQUE DE L'INSTITUT DE FRANCE.}

The library of the Institut de France (23, Quai Conti) possesses a considerable number of manuscripts, consisting of a principal collection and two special collections, Cuvier and Godefroy. The principal collection of manuscripts has not been completely catalogued. A summary and very inadequate catalogue was published in 1890 by Fernand Bournon, Catalogue des Manuscrits de la Bibliothèque de l'Institut.

\section{MANUSCRIPTS.}

309. "Recoeuil Du Voyage au Tour Du monde Par Desbois." I7 I I, Jan. I5-I7I3, July 28.-Details respecting the slave trade, Chile, Peru, and other South American countries.

487. Collection of MS. and printed documents from the library of M. Bonamy.

I72I, Mar. 5. Memoir on Louisiana, by Charles Legac, former director in Louisiana for the Compagnie des Indes. State of the colony at the time of his arrival, Aug. 25, I7 I8; account of events to the time of his departure, Mar. 5 , I72I, and state of the colony on this latter date, with recommendations as to the measures necessary for its solid establishment. Also in Arch. Affaires Etrangères, Mém. et Doc., Amérique, 6, ff. 8I-129. [ff. 508-558v I740, Jan. 4, Fort Assumption. Fontaine Mervé to the minister. Relations with Indians; gratitude of Broutin; construction of fort; troops. \begin{tabular}{l} 
(A. L. S.) [ff. $560-56 \mathrm{r}$ \\
\hline
\end{tabular}

[I739.] List of troops on the Mississippi. By Fontaine Mervé.

[f. $562 \mathrm{v}$

I739, Dec. 20, "Rivière à Margot". Fontaine Mervé to the minister.

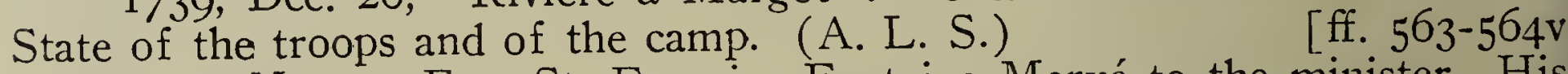

I739, Nov. 4, Fort St. Francis. Fontaine Mervé to the minister. His voyage; preparations against the Chickasaw. (A. L. S.) [ff. 565-566

488. - I697. Memoir on the commerce of West Flanders, containing references to the trade of Dunkirk with the West Indies, sugar refineries, cod fisheries, etc.

[f. 2 I 5

[i716.] Memoir on the importance of Mobile for navigation and commerce, with an account of the expedition of St. Denis to New Mexico. (Copy.) Also in Arch. Colonies, Ci3, A, 4, p. IOOI. [ff. 4I4-426 I7I7, Sept. 20, Santo Domingo. Memoir on commerce in general and especially on the commerce of Santo Domingo. Prepared by M. Mithon, by order of the council. Commerce with New England and Canada. ]f. 427

[I730.] Narrative of the defeat of the Natchez Indians. By Perier, commandant general of Louisiana. Cf. Arch. Colonies, Ci3, A, 12, f. 37.

[ff. $457-463 \mathrm{v}$
7730. Narrative of the defeat of the Fox Indians by the French Louisiana and Canada. [ff. $465-468$
[ Rossel.

I729. Memoir on the commerce of Cayenne, transmitted by $\mathbf{M}$. de

I714, Sept. Memoir on Guinea. Slave trade.

[f. 477

f. 483

I716, July. Memoir on Santo Domingo, Guinea, and the Mississippi. Slave trade; opposition to monopoly of Crozat. [ff. 493-509
[ 
I7I7, Mar. 3. [Author of preceding document] to Duc de Noailles. Recommendations respecting the settlement of Louisiana. (Copy.)

[ff. 509v-5IIv

I7I7, Mar. I7. "Mémoire sur la Louisiane." Difference between the savages of the Spanish colonies and those of Louisiana; Pensacola; communication with Canada; funds necessary for the establishment and support of Louisiana; beaver; relief for the "Compagnie du Mississipi". (Copy.)

[ff. 5 I I v-52I

I7I7, Apr. 3. "Mémoire sur le Mississipi." Mission of investigation to be sent to the Mississippi should be composed of men of affairs rather than of soldiers; indentured servants and faux sauniers to be sent there ; Boisbriant; the Wabash; Indians; the Illinois country, etc. (Copy.) [ff. $5^{2 \mathrm{IV}-5^{28 \mathrm{v}}}$

I7I7, May 14. "Mémoire sur le Mississipi." History of the discovery of Louisiana; productions ; colonists ; trade with Spaniards ; Indians ; mines ; transportation of Canadians to Louisiana; the Illinois country ; tobacco ; composition of the "Compagnie du Mississipi". (Copy.) [ff. 528v-543v

I7I8. "Mémoire pour faire connaitre les raisons qui combattent la vue qu'on a de supprimer la ferme du tabac et le préjudice que causerait aux revenus du Roi le commerce libre de cette marchandise." Refers to competition between Virginia and Santo Domingo.

[f. 544

489.- [1728?] "Mémoire du Conseil de Commerce sur le commerce d'Espagne." Consequences of the cession to England of the Assiento ; transportation of French manufactured products to the West Indies.

[f. 278

651. "Stato della Religione cattolica in tutto il Mondo . . D.'Urbano Cerri . . . MDCLXXVII." Cf. Urbano Cerri, État Présent de l'Église Romaine dans toutes les Parties du Monde (Amsterdam, I7r6).

838. - French translation of an essay, by Francis Wharton, on the negotiations for peace in 1782 and 1783 , revising Jay's treatments (1871, infra) in the light of the Stevens collection of Franklin papers in the Department of State, and printed in vol. III. of Wharton's Digest of International Law, app., sect. I 50.

857. Papers of Condorcet. Dossier, " Esclavage": papers relating to the Société des Amis des Noirs, addresses and letters of Condorcet, fragments relating to the slave-trade in America and the attitude of the United States, etc. Dossier, "Oeuvres et fragments politiques antérieurs à I789": draft of essay, "De l'influence de la Révolution d'Amérique sur les opinions et la législation de l'Europe" (I804).

979-982. "Historica Plantarum per Americanas Insulas annis I689-I697 observatarum a R. P. Car. Plumier, inedita . . ." 979 contains the descriptive notes, in Latin, of the plants, the drawings of which fill 980-982.

1057. - Plan of the harbor and fort of Cayenne.

1288. Marine maps, I 7 th century.

"Carte géographique des Costes et bords de la mer jusques à present descouvert en la Zone Frigide Boréale. Faict par Ressel G [erritz] avec privilège des Haults et Puissants Seigneurs les Etats Généraux des Provinces Unies des Paï-bas." (MS.)

[No. I

MS. chart of the northern shores of the ocean, showing Newfoundland.

MS. chart of the coasts of China, Cochin China, and the Philippine Islands.

[No. I 5

Engraved chart by "Jacob Aertz Colom", showing the coasts of Newfoundland, New France, New Netherland, Virginia, Florida, and South America.

[No. I 8 
MS. chart of the northern coasts of Europe and America, showing Newfoundland and Greenland.

1659. West Indische Paskaert, Amsterdam, by Hendrick Donker. Engraved chart showing the coasts of Newfoundland, New France, New Netherland, Virginia, Florida, and South America.

No. 20 America.

MS. chart of west coast of North America, and of the coasts of South

1646. MS chat showing Newfoundland, New France, New INo. 21 Vir 1646. MS. Cow Helland, Virginia, Florida, West Indies, and Central America. "Feita em Lixboa o Anno de 1646 por Ioaõ Teixeira Cosmographo de Sua Mg'de." [No. 22
[No

I673. Engraved chart of Brazil. Signed, "B. Sloet". [No. 23
[No

1299. "Etat des importations et des exportations en Bretagne depuis et compris I749 jusques et compris I759, avec l'Etat général du Commerce de France avec l'Étranger pour l'entrée et la sortie des marchandises pendant l'année I758." Includes importations from the West Indies, and exportations to the West Indies and Newfoundland.

1352. "Segunda parte de las noticias historiales de las conquistas de Tierra Firme, I50I-I605." By Fr. P. Pedro Simon. [I627.]

1356.-Letters from Bolivar to various persons, of the following dates: I812, Oct. 2; I816, May 8, I8, 20; I826, Nov. I5; I828, Feb. 29, Oct. 23 , Dec. $20 ;$ I829, Nov. Io; I8-. Sept. 2 I.

1583. "Journal des observations météorologiques faites à la Guadeloupe . . pendant les ans V à IX . . p par le Citoyen Hapel-Lachenaye."-Monthly tables of meteorological observations made in the commune of Sainte-Rose, canton of Basseterre.

1610. Essay on the "Grammatical character of the Lenni, Lenape, Mohegan and Chippewa Languages”, by Edwin James, Albany, July 22, I834. (36 pages.)

1619. MSS. Labène. "Histoire ancienne et moderne jusqu'à la chute de Napoléon I." Contains numerous references (ff. 339-567) to American history.

1620. MSS. Labène. "Sciences." Notes on westward movement in the United States (ff. I8-I8v).

1689. Correspondence of $\mathrm{H}$. Doniol relating to his Histoire de la Participation de la France à l'Établissement des Etats-Unis d'Amérique.-Report by Doniol to the garde des sceaux , June 8, I884; letters to Doniol from Henry Vignaud, Francis Wharton, Worthington C. Ford, John Bigelow, and Charlemagne Tower, I888-I895.

1871. French translation of John Jay's essay on the negotiations for peace in 1782 and 1783 , printed by the New York Hist. Soc. in 1884 (Griffin, Bibliog. of Hist. Socs., no. 533I). See also 838, supra.

2043. Correspondence of François Arago (I786-1853). - A few letters of slight importance, mostly letters of introduction from A. D. Bache, W. Davies, James P. Espey, Lewis Cass, and others.

2050. Papers of the Duc d'Orléans, in the Collection Beugnot.-Letters from Sartine, minister of marine, to Louis Philippe, duc d'Orléans, on board the St. Esprit, I776-I 778, relating to naval affairs, John Paul Jones, etc.

2098. Papers of Antoine Th. d'Abbadie.-Correspondence with chief signal officer, U. S. Army, I884-I886, relative to a co-operative bibliography of meteorology.

2117-2119. Papers of Jules A. B. Maillard de La Gournerie (I8I4-I893). -These consist largely of notes, correspondence, and copies of contemporary documents, relating to the scientific expedition of C. M. de La Condamine, Pierre Bouger, and Louis Godin to Peru, in I735-I745. 
2167. Collection of autographs of Henri Delaborde.-I8I3, Apr. 29, Benjamin West to Mr. Taylor, accepting an invitation.

2170. Letters from correspondents of the Académie des Beaux Arts.-A group of letters from Charles C. Perkins, of Boston, I866-I885, relating to personal matters, American collections of art, various matters of art and erudition, etc.

2222. Papers of Abbé P. L. Lefebvre de la Roche.

"Au C. Pierre Didot Imprimeur du Sénat, Sur Franklin." Biographical fragment, containing personal recollections of Franklin's sojourns in France and England.

Benjamin Franklin to Mme. Five letters in vein of gallantry. See Bernard Faÿ, in Forum (New York), March, I928.

Codicil of Franklin's will; translation of a letter from Franklin to Le Sou $\longrightarrow$, Passy, Sept. 22, I782, relating to the terrestrial globe; "Note sur la fluide dont les vibrations sont appelées lumière", Passy, June, I784.

2302-2326. Papers of Delisle and Buache.

2306. Manuscript maps.-Tracings of maps of Trinidad and Guadeloupe; sketches of Guiana.

2310. Engraved maps.-Amérique, I774; Mer de l'Ouest, I752; Barbade; Martinique; Canada, I754; Maris Pacifici, G. Tattonus, I6oo.

2311. Communications made by Buache to the Académie des Sciences: Northwest coast of America; Antillia; etc.

2314-2319. Miscellaneous memoirs on geography by Buache and others.Among these, some of which appear to have been communicated to the Académie des Sciences, may be noted memoirs on the Northwest Coast of America, on Antillia, on the capture of Buenos Aires by the British in I806, on the latitude and longitude of various American cities, on Newfoundland; on naval operations of I778, English policy in American affairs, I807, etc.

2378.-Notes on D. B. Warden's Chorographical and Statistical Description of the District of Columbia.

2387. Register of memoirs of the Compagnie des Indes and of its addresses to the controller general of finance.

"Mémoire pour fair connaitre la situation du commerce maritime ...." Situation of French commerce before the war with England [I745]; colonial commerce, the cod fisheries, Canadian trade, Guinea trade, losses in war, Spanish-American commerce.

[Pp. I-I9

"Réflexions sur les moyens de sauver les débris du commerce de France ...."

[pp. 20-40

Memoirs on the Compagnie des Indes by M. de Montaran, I745-1747. Beaver trade, negro trade, needs of the company, history of the company, etc.

"Etat des pertes sur le commerce de la Louisiane ... depuis I7I7 jusques... I746."

[pp. 259-263

"Etat des demandes et représentations faites au Roy par les syndics et directeurs de la Cie. des Indes." Retrocession of Louisiana to the Company ; slave-trade.

[pp. 345-352

2396. Correspondence of Lacroix.--Letters from H. I. Bowditch, Boston, 1839, Marie Aglaée Brown, Carlisle, Pa., 1839.

2467. Papers of Jean Le Rond d'Alembert.-Verses for a portrait of Franklin. 
2489. Papers of Armand Baschet.-Notes and documents relating to affairs of Buenos Aires, I840-1847, to Gérard de Rayneval and his memoirs, negotiations, and functions in French-British-American relations, etc.

2504. Papers of Dr. Jean-Louis Guyon.-Notes on creoles of Martinique.

2556-2561. Works of A. Fournier.-MSS. of his life of Columbus, and of his histories of the conquest of New Grenada, Peru, and Mexico.

2721. MS. maps.

"Carte du golfe du Mexique et des Isles de l'Amérique Dressée sur celle qui a été faite en I 723 par Phil. Buache au Dépôt des Cartes de la Marine comparée avec la Carte d'Amérique de Pieter Goos, Janv. I730." $65 \times 48 \mathrm{~cm}$.

"Carte dNo. 4I
[Notes “Carte des Costes de Terre Ferme de l'Amérique Septentrionale, depuis la Riviere Orinoque jusqu'au Golphe du Mexique et Canal de Baham avec les Isles du Vent et sous le Vent." (I 8 th century.) I I I $\times 66 \mathrm{~cm}$.
[No. 42

"Carte des Isles de l'Amérique, des Cotes de la nouvelle Espagne et du Golfe du Mexique dressée par le P. Feuillés, Mathématician et Botaniste de Sa Majesté." 9I $\times 66 \mathrm{~cm}$.

"Carte de partie des cotes de la Floride et de la Louisiane, de $[N 0.43$ lemb "Carte de partisiane, de Muspa à

"Co. 44
"Co dussissipi." (I8th century.) $93 \times 64 \mathrm{~cm}$.

"Carte du Détroit de Magellan." (I8th century.) $53 \times 37 \mathrm{~cm}$. [No. 45

"Detroit de Magellan." (I8th century). $69 \times 45 \mathrm{~cm}$. [No. 46
"No

"Nuevo mapa geographico de la America Septentrional, perteniente al virreynato de Mexico dedicado a los sabios miembros de la Academia real de las ciencias de Paris, por su muy rendido servidor y capellan Don Joseph

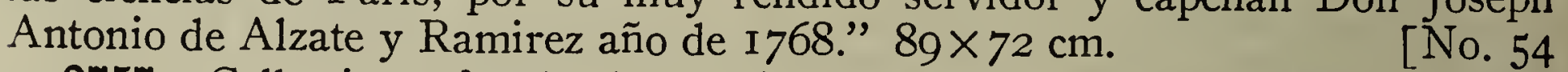

2757. Collection of school exercises from the United States.-Pupils' papers and examinations. 1876 .

2952. "Visite des couleurs en Europe et en Amérique."-Memoir by Dr. A. Favre. Measures adopted in the United States relating to use of colors in navigation, railroading, etc.

3710-3714. Correspondence of Le Verrier, director of the Paris observatory. -Letters from J. M. Gilliss, James Ferguson, Asaph Hall, B. A. Gould, M. F. Maury, Asa Gray, O. M. Mitche1, Horace P. Tuttle, James C. Warner, and others, I848-I868.

\section{FONDS CUVIER.}

The collection known as the Fonds Cuvier comprises the scientific papers and correspondence of Baron G. Cuvier ( I 769-1832), perpetual secretary of the Académie des Sciences. A catalogue of the collection has been published by Henri Dehérain in the Revue des Bibliothèques (Paris, 1907, 1908): "Catalogue des Manuscrits du Fonds Cuvier." garten.

194.- [1815.] Eulogies of Count Rumford, by Cuvier and Anton Baum-

200. - I820. Eulogy of Palisot de Beauvois, by Cuvier, with letters relating to Palisot de Beauvois, by P. A. Adet and others.

222. Letters to Cuvier, I800.- J. A. H. Reimarus, relating to tooth of large animal found on the banks of the Ohio (nos. 28, 29).

223. Letters to Cuvier, I801.-Felix Pascalis, Philadelphia, announcing the first issue of Philosophical Correspondence, "for the diffusion of knowledge in the western world" (no. I3). 
225. Letters to Cuvier, I802.-Extracts from letters of Alexander von Humboldt, from South America (no. I7) ; J. A. H. Reimarus, Hamburg, on the Ohio elephant and a large animal of Paraguay (no. 29).

238. Letters to Cuvier, 1816.-Samuel L. Mitchill, New York, on geology of New York City (no. 4).

239. Letters to Cuvier, 1817.- Lamoureux, Caen, on crustaceans and marine growths from the Newfoundland banks (no. I3) ; note by Samuel L. Mitchill on an experiment with hen's eggs (no. I8bis).

240. Letters to Cuvier, I8I8.-C. S. Rafinesque, on discoveries of Dr. Mitchill and himself and his scientific expedition in the Ohio valley; expedition of Maj. Long (nos. I6, I7).

241. Letters to Cuvier, I8I9.-C. A. Lesueur, Philadelphia, relating to Albany and the Hudson valley; geology of the region ; American ploughs, with sketches of Indians of the Sandusky River, and of the hills above the Hudson near Albany (no. 5). Samuel L. Mitchill, New York: sends geological map; praise of Hyde de Neuville; Milbert's work and collections (nos. 8, 9). C. S. Rafinesque, Philadelphia, on his work; annoyances by Milbert ; John D. Clifford, of Lexington, $\mathrm{Ky}$., desires to enter into relations with the Natural History Museum in Paris; his appointment to the chair of botany and natural history at Lexington, Ky. (nos. II, I2).

242. Letters to Cuvier, I820.-List of animals observed at St. Pierre and Miquelon, by B. de La Pylaie, from Aug. I, I8I9, to June I5, I820. [no. 9bis I820, June Io, Ghent, Ky. Lakanal to Geoffroy-Saint-Hilaire. Is sending boxes of natural history specimens to Cuvier ; note on his personal situation and on the aid which he seeks from the French government. [nos. 23, 24 I820, June I2, Ghent, Ky. Lakanal to Cuvier. His sojourn of 4 years in Kentucky and his acquisition of an estate; his collections; criticism of Catesby, Palisot, and others; description of objects sent to the museum. (A. L. S., 8 pp.)

[no. 25

243. Letters to Cuvier, 1821.- - Letters from N. Corsini and J. Fabbroni, relating to the travels in Italy of Mr. Ritchie of Boston (nos. 2, 6), and from R. S. Redman, Halifax, relating to a geological collection of the, West Indies and his projected visit to western Canada and the United States (no. 27).

244. Letters to Cuvier, 1822.--Descourtils, relating to his ruin caused by the revolution in Santo Domingo, and to a proposed work on the flora of the Antilles (no. 20) ; André de Luc, relating to the North American musk-ox and elephant (no. 24); Edward Everett, announcing election of Cuvier as member of the American Academy of Arts and Sciences (no. 28) ; Montgéry, relating to the dredge used by Commodore Decatur in securing deep-sea shell fish (no. 45) ; Samuel L. Mitchill, introducing Mr. Tibbits, and relating to various scientific works (no. 57) ; Camillo Ranzani, relating to Mr. Ritchie, of Boston (no. 6o) ; F. A. Zea, desire of Colombian government to receive the visit of a French scientific mission (nos. 74, 74bis).

245. Letters to Cuvier, 1823.-Prof. John C. Warren, Boston, sends a work on the crania of American savages (no. 29).

247. Letters to Cuvier, I825.- William Cooper, New York, on fossil bones found in the southern part of the United States (no. 8) ; Guyon, Martinique, relating to yellow fever in the Antilles (no. I6) ; Richard Harlan, Philadelphia, sending scientific works and fossil shells (nos. 23, 24); W. de Mandeville, Buenos Aires, sending a bird taken on the banks of the Rio de la Plata (no. 47).

248. Letters to Cuvier, I826.-Baron de Damas, transmitting a proposal relating to prehistoric objects found in a tomb in Colombia (nos. IO, II); Evries Bros., Havre, recommending M. Taincturier of New Orleans (no. I9); 
minister of marine, respecting proposed researches of M. Ricord in Haiti, and suspicions aroused by naturalists in the new Spanish-American states (no. I4); Grandsire, Rio de Janeiro, sending the jawbone of an unknown fish and a MS. in the language of the Guarany Indians (no. 23); Isaac Hays, Philadelphia, transmitting a volume (no. 27); F. Lherminier, relating to incrusted human skeletons found in Guadeloupe (no. 33) ; B. de La Pylaie, relating to proposed gift of objects collected in Newfoundland (no. 30) ; C. Rostan, Martinique, relating to studies of tropical vegetation (no. 4I).

249. Letters to Cuvier, I827.- Joseph Delafield, New York, sending a specimen of fish known as "Proteus of the Lakes" (no. 9) ; Edward Everett, reminding Cuvier of his election in I82I to the Academy of Arts and Sciences of Boston (no. I3) ; R. Harlan, Philadelphia, relating to fossil human skeleton obtained in South America by Capt. Elliot, U. S. N. (no. 2I) ; Samuel L. Mitchill, introducing John C. Cheeseman (no. 32).

250. Letters to Cuvier, r828.- James Deville, London, sends casts of Indian skulls from South America (no. I2) ; W. Buckland, Oxford, and Dr. Fitton, London, introducing Capt. Franklin, the explorer (nos. 5, I6) ; Louis Thoré, New Orleans, relating to bone remains and sending negro skulls and a Cuban tortoise; learns that Lesueur has already sent specimens of fish from the Mississippi (no. 36).

251. Letters to Cuvier, I829.- - Louis Agassiz, relating to his study of Brazilian fishes (no. 3) ; de Blosseville, specimens of fish obtained in expedition to Baffin's Bay (no. 8) ; Jacob Green, Philadelphia, was first to discover and describe the American animals of the genus Salamandra (no. 27) ; S. G. Morton, Philadelphia, relating to his essays on American geology (no. 45); D. B. Warden, presenting publications on civilization of the Cherokee Indians and on the American colony of Liberia (no. 68) ; Jean P. Yosy, London, offering his services for the exploration of the Missouri and California (no. $7 \mathrm{I}$ ).

252. Letters to Cuvier, I830.-Max Franck, Paris, on pre-Columbian relations between eastern and western hemispheres (no. 30); Jacob Porter, Plainfield, Mass., asks for Cuvier's works for the American Antiquarian Society (no. 64).

253. Letters to Cuvier, I831.-Pierre de Angelis, Buenos Aires, relating to his visit in America, and to news of M. de Bonpland (no. 2) ; Audubon, presenting a copy of his work, his interest in American birds (no. 3) ; J. C. Beltrami, discovery of source of the Mississippi (no. 5) ; R. Harlan, Philadelphia, describing specimens he is sending, and giving his opinion of C. S. Rafinesque (no. 20).

254. Letters to Cuvier, I832.-John George Children, introducing Dr. Macaulay of Baltimore (no. 8) ; W. Cooper, New York, offering plaster casts of bone remains, and his memoir on Big Stone Lick (no. 9) ; Griscom, New York, introducing Isaac Lea of Philadelphia (no. I4).

\section{COLLECTION GODEFROY.}

The Collection Godefroy was formed in the seventeenth century by Théodore Godefroy (I580-I649), royal historiographer, and his son Denis Godefroy, the second. It includes original papers of Villeroy, Puisieux, Sillery, Richelieu, de Harlay, and others. A detailed catalogue of the collection, with an historical introduction, is published by François Gébelin in Catalogue Général des Manuscrits des Bibliothèques Publiques de France: Paris, Bibliothèque de l'Institut, Collection Godefroy' (Paris, I9I4). 
14.-I653, Mar., Paris. "Lettres patentes confirmant la concession des droits de la Cie. des Iles de l'Amérique sur l'île de St. Christophe et autres iles en faveur du grand maitre de l'ordre de St. Jean de Jérusalem." [f. I29

29.-La Defaite Navale de Trois Mil, tant Espagnols que Portugais, mis et taillez en pièces par les Hollandois à la Baye de Todos los Sanctos. Traduite de Flamand en François. A Paris, MDCXXV. ( I6 pp.) [f. 53

No. 32. Extraordinaire, du XIII Mars, MDCXXXV, contenant la Prise de Philippia, dans Paraiba, sur les Espangnols par les Holandois . . a Paris le I3 Mars I635.

[f. I 25

No. I39. Extraordinaire, du XV Decemb. MDCXXXIV, contenant, $I^{0}$ le Rapport de l'Estat des Indes Occidentales, fait par les Directeurs Holandois qui en sont naguères venus.

[f. 127

40.-I626, June I4, Stockholm. "Etablissement d'une Compagnie pour le Commerce au royaume de Suède, ès Pays de l'Afrique, de l'Asie, de l'Amérique et de la Magellanique ou Terre Australe et Iles qui sont entre d'eux, à commencer par delà le détroit de Gibraltar du côté du Midi. Avec les privilèges octroyés à ladite Compagnie par le Roi Gustave II." (Also in 65, f. Ioo.)

[f. I34

1632, Oct. 16, Nuremberg. "Déclaration et ampliation des privilèges octroyés par le Roi de Suède à la Nouvelle Compagnie Australe ou devers le Midi, établie au royaume du Suède et en Allemagne." (Also in 66, f. 213.)

[f. 142

I634, July I, St. Germain-en-Laye. “Déclaration du Roi portant défenses à ses sujets d'entreprendre sur les Espagnols et Portugais au deça du premier méridien."

[f. 186

61.-I600, Dec. 3I, Westminster. "Priviledge for fifteene yeares granted by her Majestie to certaine Adventurers for the discoverie of the trade for the East Indies." (Also in 66, ff. 60, 78.)

[f. 2

62._- "Advis de Isaac le Maire pour l'établissement d'une Compagnie en France." Includes correspondence of President Jeannin with Sully, de Villeroy, and Henri IV., I608-I6o9, printed in the Négociations of Jeannin. [f. 8 r62I, June 3, Amsterdam. Charter of the Dutch West India Company.

63. English settlements in North America.

[f. 28

Copies in English, with French translations, of the following documents : part of first Virginia patent, Apr. Io, I606 (f. 4) ; the king to the Virginia Company, respecting silk works and the planting of vines in Virginia, July 9, I624 (f. I 2) ; the Virginia Company to the governor and council of Virginia (f. I2v) ; the "Mayflower Compact", Nov. I I, I620 (f. 20).

"The beginning of the Patent for New-found-land and the Plantation there made by the English, I6ro, delivered in a letter dated thence from $\mathrm{Mr}$. Guy to M. Slany; also of the weather the three first winters and of Captain Weston, with other remarkable Occurrents."

「f. 24

I62I, Sept. Io, Windsor. "The King's Patent to Sir William Alexander, Knight, for the Plantation of New Scotland in America, and his proceedings, therein, with a description of Marrooshen for better knowledge of those parts." (Also in 66, f. 237.)

64. Miscellany relating to commerce and navigation.

"Routes et cours de la navigation d'Espagne ès Indes Ocidentales et Orientales et desdites Indes en Espagne."

I6I7, July I5, The Hague. "Mémoire du voyage de Speelberghen aux Indes Orientales par le destroit de Magellan et la mer de Zur . . ." [f. 3 
"Mémoire du traictement que font les Espagnols à ceux qui ont esté aux Indes ou sont rencontrés sur la route et des remèdes à y apporter, ensemble de la coustume receue qu'au delà des Açores nulle plainte n'est receue." [f. I5

"Bref et important advis touchant la négoce des Indes et Isles St. Christophe et autres."

[f. I6

I626, Mar. 31, Charonne. Agreement for the organization of the Compagnie des Cent Associés.

[f. 2I

I626, June 8, I2, I3. Acts of subscription to or of resignation from the Compagnie des Cent Associés.

[f. 26

I626, July, Nantes. "Édit . . . pour l'établissement du commerce général en France... contenant les privilèges et avantages accordés par Sa Majesté à la Compagnie des Cent Associés." (Also in 66, f. 23.) [f. 29

Notes, extracts, etc., on the following subjects: establishments of the Dutch West India Company in America (f. 37 ) ; discovery of Newfoundland by John Cabot (f. 39); the Treaty of Vaucelles of I 555 [I 556 ] did not forbid the discovery and conquest of lands in the Indies by the French without the consent of the Emperor and the King of Spain (f. 40); observations by Michael Locke on the route towards the west and the circumnavigation of the world (f. 47); the Northwest passage (f. 50); English encroachments on the French in North America, I6I I-I625 (f. 54); discovery of New France and Newfoundland by the French in I504 (f. 55).

I642, Mar., Narbonne. "Lettres patentes . . en faveur de la Conpagnie des Indes Occidentales pour faire peupler l'Isle de St. Christophe et autres de l'Amérique ..." [f. 43

65.- "De la pesche et commerce des François en Amérique et devers la rivière de Canada ou de Sainct Laurent et devers 1'Isle de Terre Neuve ou Neu-Fondlande, et comment les Anglois les y peuvent empescher." [f. Iro

66. Miscellany.

Notes and extracts relating to the Dutch East and West India companies, and containing references to the West Indies and South America.

$[\mathrm{ff} . \mathrm{I} 3, \mathrm{I} 8,23,40,48,66$

I627, Nov., Lubeck. Proposal for the organization of a company in the Hanseatic towns for trading with the Spanish Indies, etc.

[f. 147

68. Miscellany relating to voyages, navigation, and commerce. 17 th century. I66I, July 20. "De l'advis des Marchands de Nantes présenté par Estienne Grilleau et Pierre Lory, députés de la dite ville." [ff. 27v, 37Iv I66I, July I4, La Rochelle. Memoir by Colbert de Terron on commerce, including passages relative to foreign commerce in America. [ff. $28 \mathrm{v}, 374$ 1680. "Relation d'un voyage fait aux isles de l'Amérique et indes occidentales en l'année i680 sur les vaisseaux du Roy commandés par Mr. le Comte d'Estrées, vice-admiral."

[f. I37

I 588, May 5, Paris. Arrêt of the Conseil d'Etat revoking the exclusive privilege of commerce and fishery in the "Isles du Canada, Conjugon et autres terres neuves", granted to Estienne Chatton, Sieur de la Jannaye, and Jacques Noël, of St. Malo, on Jan. I 4 last.

[f. 299

I66I, June I, The Hague. M. de Thou, ambassador in Holland, to the "Surintendant". France will exclude the Dutch from commerce with its islands in America unless the articles respecting commerce in the East Indies are accepted. (See below, f. 360.)

[f. 301

I66i, June. Project of an arrêt for the revocation of colonial concessions which have not been utilized.

[f. 303 
I629, Feb. I8, Grenoble. Instructions to the Sieur de Cahusac, going to St. Kitts.

[f. 306

List of documents relating to commerce, Canada, St. Kitts, and South America.

[f. 308

I66I, May. "Mémoire touchant le commerce par mer et des moyens dont se servent toutes les nations de l'Europe pour se l'attirer." [f. 338 I66I, June I. "Articles touchant la navigation et le commerce des Indes Orientales dont il est faict mention dans le cinquiesme article du traité faict à Compiègne en I624." Reciprocity of commerce in the East and West Indies. These are the articles referred to above, f. 3OI. See Davenport, European Treaties, I., Doc. 32.

[f. 360 I662. "Discours sur le misérable estat du commerce et navigation de France et les moyens de le restablir, par le Sieur Menu, Advocat du Conseil." Proposed creation of a trading company for the West and East Indies. [f. 473

"Des usurpations des anglois sur les françois en la Nouvelle France en l'Amérique, depuis l'an I6I I."

[f. 444

I623, Sept. 2. "Audition de Pierre Guérard devant le lieutenant de l'amirauté de Dieppe par laquelle il déclare qu'il s'est retiré du service de Robert Gourdon [Sir Robert Gordon], Seig'r Escossois parcequ'il se vouloit emparer du Cap Breton qui est à l'embouchure de la rivière de la Nouvelle France."

[f. 473

I66o, May, St. Jean de Luz. Letters patent granting the port of Placentia to Nicolas de Gargote.

[f. 487

79.-i625, Sept. $5[7 / \mathrm{I} 7]$, Southampton. Treaty of alliance between the United Netherlands and Great Britain. In Davenport, European Treaties, I., Doc. 33 .

[f. I3

84.-I667, July 3I [2I]. Treaty of Breda, and "Projet de la convention réciproque arrestée entre les Anglois et Holandois pour la détention ou resti-, tution des lieux occupez de part et autre . . . soit avant ou durant la guerre."

[ff. 59,69

86. - 1665 . Treaty of commerce between England and Denmark. Art. 2 relates to British colonies.

[f. 350

90.-1646, Dec. "Demandes des Pays-Bas pour le traité de paix avec l'Espagne, avec les réponses." Relating to articles 5 and 6 of the Treaty of Münster, dealing with commerce and navigation in the East and West Indies. See Davenport, European Treaties, I., Doc. 40.

[f. I74 206. - I63.4. "Discours de la trêve des Pays-Bas avec le Roy d'Espagne; par le duc de Rohan." Refers to West Indies.

[f. $60 \mathrm{v}$

207-208. Draft of a dictionary of marine terms, largely in the hand of Théodore Godefroy.-Occasional terms or subjects of interest for America, e. g., cod, Campeachy wood, Santo Domingo, Havana, etc.

210. Eulogies and biographies.-Fernando Cortez (f. I33); Christopher Columbus (f. I36); Magellan (f. I4I); Amerigo Vespucci (f. I45).

256. Correspondence, reign of Charles IX.

I 573, Jan. I9, La Guerche. Duc d'Anjou to Charles IX. Approval of plan of conquest in "l'Yndie" submitted to the king; profits drawn from Peru by the Spaniards.

269. Original correspondence.

I622, May 2, Pointoise. Charles des Boves, grand vicar of Pointoise and syndic of the Recollect seminary near Quebec, to Louis XIII. Requests permission to send to Canada a vessel loaded with provisions, laborers, artisans, and munitions. 
270. Original correspondence.

1627, July 25, Port Loméron in New France. [Charles] de La Tour to Louis XIII. Efforts of French and English to drive him out; means of defense against them ; holds governorship since death of Poutrincourt. [f. 4I

273. Original correspondence, I643-I648.

I644, Apr. I9, "Gardeloupe". Mme. de La Fayolle to M. de La Marquerie. Gov. Houel has asked her to remain in Guadeloupe to found a house of St. Joseph for the reception of the young girls who may be sent from Paris.

[f. I 49

I648, Apr. 25, St. Kitts. Chevalier de Poincy to Seguier. Conquest of St. Martin and St. Bartholomew.

[f. 494

291.- "Escrit envoyé par le Marquis de La Roche . . . au Roy Henri IV. environ l'année ... I 598 ou I 599 lors de la Paix avec le Duc de Mercoeur sur le subject principalement de la traverse qui luy estoit faite dans l'Isle de Bourbon à vingt-cinq lieues de distance du Cap Breton vers la Nouvelle France . . ."
[f. I4I 495.- “Les defauts et manquemens du comte d'Olivarès ..." [f. 228

"Les généraux et particuliers motifs de la disgrace de D. Gaspard de Guzman, comte [d'Olivarès], duc de San Lucas ... arrivée en janvier, I643." Loss of Pernambuco and Brazil.

[f. 243

496. -List of Spanish possessions in the various parts of the world. [f. I8 I643. Memoir on the causes of the disgrace of the Conde d'Olivares. Loss of Pernambuco and Brazil.

[f. 94

I656, Dec. Letter to Mazarin, proposing an alliance with Portugal against Spain. American possessions, recapture of Pernambuco from the Dutch, etc.

I57I. "Relatione di Portogalle de Constantino Garzoni" A [f. I27 commerce and possessions.
[f. I 52

512.-I595. "Estat des vaisseaux, capitaines, gens de guerre, vivres et munitions qui sont en l'armée que Drack, Anglois, a mené aux Indes." [f. Io9 


\section{BIBLIOTHÈQUE MAZARINE.}

The Bibliothèque Mazarine (23, Quai Conti) no longer possessed in I789 the manuscripts that had been collected by its founder, Cardinal Mazarin. Given the status of a state library during the Revolution, it was enabled to replenish its collections from the contents of the confiscated private and religious libraries. It now has about 5000 volumes of manuscripts, largely drawn from the collections of Parisian convents. An inventory has been published by Auguste Molinier, Catalogue des Mamuscrits de la Bibliothèque Mazarine (4 vols., Paris, I885-I892). In vol. I. is a brief history of the library. A supplementary inventory is in Catalogue Général des Manuscrits des Bibliothèques Publiques de France, XLV. (Paris, I9I5) 35-55.

1533. "Orbis terrarum descriptio." Tome III.-Anonymous MS. of I7th century. At pp. 392-4I3 are descriptions of North America: Nova Francia, Nova Terra, Norumbega, Virginia, Florida, Hispania Nova, Quivira, Iles de l'Amérique du Nord. Engraved maps by Sanson, inserted in the MS., are to be noted as follows:

\section{Les Isles Philippines, I652.}

[ff. $25 \mathrm{I}-252$

Amérique Septentrionale, par N. Sanson d'Abbeville, Géog. du Roy. A Paris ... I650.

[ff. 392-393

1616. "Archeveschez et éveschez des Indes Occidentales au NouveauMonde. Tome Premier."-Cf. Bib. Nat., MSS. Latins 16945-16976. Not examined.

1833. History of France, England, and the United States.-Courses of lectures by Prof. Koch, Strasbourg [?]. The section relating to England contains a few pages on the American colonies (pp. 72, I06, I IO); the section on the United States (pp. I-8I) presents a general view of their history from I607 to I783.

1850.-1755. Discussion Sommaire sur les Anciennes Limites de l'Acadie, et sur les Stipulations du. Traité d'Utrecht qui y sont relatives. [By Pidausat de Mairobert, according to Barbier.] (68 pp.) -French and German texts on opposite pages.

"Mémoire contenant les matières essentielles du commerce ..." The third section is devoted to complaints against the abuse by the English of the treaty of assiento and of the permission they have received to send a vessel of 500 tons to the West Indies.

1912. Memoir on the commerce of Spain with America, with the draft of regulations for its promotion and for reserving the monopoly of it to the subjects of the Catholic king. By a commission created by Philip V., Madrid, Feb. I7, I706.

1913. Reglamento y Aranceles Reales para el Comercio libre de España a Indias de Iz de Octubre de I778. Madrid, on la Imprenta de Pedro-Marin. (262 pp.) - Followed by French translation in MS. Passages relating to the commerce of Louisiana are at pp. 53-6o.

1963._-I643, Aug. 3-I645, Nov. I. "La véritable relation de tout ce qui s'est fait et passé durant le voyage que M. de Brétigny fit en Amérique." Cayenne.

"Histoire de Montréal", I640-1672, [by Dollier de Casson]. Corrected draft, 207 pp. Ptd. in Soc. Hist. de Montréal, Mémoires (I868). 
1964. [ I700 ca.] "Abrégé des vies et moeurs et autres particularitez de la Nation Iroquoise laquelle est divisée en cinq villages, sçavoir Agnez, Onneywt, Nontagué, Goyogwan et Sonnontwani."-Villages, lands, animals, religion, councils, character, superstitions, mourning. (29 pp.)

2006.-I7I5, Apr. "Mémoire pour la découverte de la Mer de l’Ouest, dressé et présenté en Avril, I7ı8, par Bobé, prêtre de la Congrégation de la Mission ", followed by supplementary memoir on the discovery of the Gulf of California. (Copy, with autograph corrections, 86 pp.) Cf. another copy of this memoir in Arch. Colonies, Ci I, E, 16, ff. 48-73, and Bobé to Claude Delisle, May 27, I7 I8, in Arch. Service Hydrog., I I 5, x., no. 26.

2107-2111. Negotiations for the truce of Antwerp, by Jeannin, I607-I609. - See Bib. Nat., MSS. Fr. 7086-7090.

2219-2229. Documents and correspondence relating to the negotiations of Münster and Osnabrück, I646-I648.

2404. List of vessels, officers, troops, etc., composing the expedition against Great Britain, under the command of the Comte de Vaux, at St. Malo, I779. ( 128 pp.)

2626. - "Mémoire sur une levée de compagnies suisses . . . pour servir de pepinière aux colonies." Means of securing two or three hundred men annually for the Mississippi.

"Mémoire sur la balance du commerce." Loss of Newfoundland ; preparations of English to drive the French from Canada; overtures to Indians for purpose of taking Louisiana from the French.

[f. 192

Memoir on French commerce, dealing in part with English contraband trade in the West Indies.

[ff. 202-206

I730. Memoir on the necessity of preventing foreign commerce in the American colonies. By Desrivaux.

[ff. 284-3I 5 America.

Memoir and reflections on American commerce. Slight interest for North

2764. "Mémoire sur la situation politique et financière de la France à la fin de l'année I739, avec les moyens d'y porter prompt remède."-References to conflict with English in America ; in part text is identical with 2626, ff. I92-208.

2778-2779. Projet de Tarif pour servir à la Perception des Droits des Traites, à l'Importation des Marchandises de l'Étranger et à l'Exportation a'es Marchandises du Royaume à l'Étranger.-At the end of each of these two printed volumes is a MS. section of observations, apparently by the chamber of commerce of Rouen, about or after I749. The MS. section in 2779 deals, inter alia, with the Newfoundland fisheries, colonial commerce, etc.

2882. “Principes de la Marine."-See Bib. Nat., MSS. Fr. 11325-11329.

2884. "Etat abrégé de la Marine du Roy", I757.-Lists of colonial officials (intendants, commissaires, contrôleurs, écrivains, etc.) are included.

3192.-Memoirs on Anjou and Brittany, by their respective intendants, Miroménil and Nointel, I698. Not examined, but doubtless contain references to commerce with America.

3205. Memoir on the généralité of La Rochelle, by Michel Bégon, I698.Same comment as for 3192.

3292. "Mémoire sur le Commerce de Bordeaux", Aug., I730.-_References to commerce with North America and the West Indies, fisheries, shipbuilding, etc.

3446. Duplicate of part of 3447 .

3447. "Compte ou résultat de la vérification des faits imputés à M. de Chauvallon faite par M. le Chev. Turgot, gouverneur, le procureur, et le doyen 
du Conseil Supérieur de Cayenne en conséquence des instructions données par S. M. le 3I Août I764." Cf. Bib. Nat., MSS. Fr. 6233-6256, and MSS. Fr., nouv, acq., 3605-3606.

3448. Register of letters written to Choiseul by the Chevalier de Turgot, governor of Cayenne, I762-I769. Cf. Bib. Nat., MSS. Fr. 6233-6256.

3449. Autograph MS. of parts of the Nouvean Voyage aux Isles de l'Amérique, by Father Jean Baptiste Labat (Paris, I 722, 6 vols.).

3450. " Mémoire abrégé de l'isle Guadeloupe . . . par le sieur de MuyssartDesobeaux." Feb. I, I768. (92 pages.)

3451. "Objets des batteries de la Basse-Terre et Grande-Terre, Guadeloupe." Wash drawings by Muyssart-Desobeaux, June 23, I768.

3452. Extracts from the chancery registers of Tobago, I $787-1789$.

3453. "Remarques sur la colonie de St. Domingue, par Mr. Desdorides, lieut. colonel du Régiment provincial d'Artillerie de Besançon." (I779.) (337 pages.)

3455. “Mémoire de l'Intendant de Québec, Dupuy, sur les troubles arrivés en Canada en I727 et I728 après la mort de M. de Saint-Vallier, évêque de Québec."-Accompanied by an engraved map by M. de Fer: Le Canada ou Nouvelle France . . . La Loüisiane, Paris, 1705. (86 pages, with table of contents.)

3749.- “Réflexions sur la guerre des Anglais, envoyées à M. de Choiseul en I767."

[pp. I-4

I775, July I3. "Observations sur l'armement de 1'Espagne." Fortification of Pensacola by the English ; revolt of the English colonies; inadvisability of Spanish aid to the insurgents.

I 775, July 30. "Mémoire sur la formation et le recrutement des troupes des colonies."

[pp. 2I 4-2I8

3783. - [Ante I7I3.] Small and summary MS. plan of Quebec and environs [by Gentil]. 


\section{SÉMINAIRE DES MISSIONS ÉTRANGĖRES.}

The Séminaire des Missions Etrangères ( I 28, Rue du Bac) dates from I663. In principle its archives are not accessible for purposes of research. As a special act of courtesy the information was furnished that only three volumes in the archives, 344,345 , and 346 , relate to America, and permission was given to examine and list the contents of the first two of these.

344. "Amérique, Canada . . . I687-I849."

I687. Mgr. de St. Vallier to the pope. Excellent state of the diocese of Quebec; praise of Mgr. de Laval.

[Pp. I-3

“Eclaircissement sur l'Institution de la Dévotion . . . et office de la Ste. Famille establie dans le pays de la N'lle France. Présenté à Mgr. l'Illustrissime et Révérendissime Evesque de Québec l'an I689, par. C. G."

[pp. 5-45

I702, Nov. 3. Callières, Beauharnois, and Champigny to the court. Religious affairs and expenses of New France in I703.

[pp. $47-50$

I682. Extract from the "Registre du Séminaire de Québec", relating to the finances of the seminary.

[pp. 5I-52

I7oI, Mar. 20, Paris. St. Vallier to Charmot, at Rome. Asks that a jubilee be proclaimed for Canada. (A. L. S.) [pp. $53-56$

I702, Dec. I2, Mobile. Father Davion to Murder of Father Foucault; details relating to the Choctaw and Chickasaw; the Indian allies of the English killed two Spanish missionaries and 200 Indian allies of the Spaniards; journey of Tonty to Pensacola. (A. L. S.)

[pp. $57-62$

I 703, Feb. 13, Mobile. Father Davion to St. Vallier. Destitution of the colony; murder of Father Foucault and two soldiers from the Illinois country; relations of the Yazou with the English. (A. L., incomplete.) [pp. 65-68

I703, Sept. 23, Mobile. Father Davion to St. Vallier. Endeavors to establish liturgical uniformity; wretched condition of the missions; missionaries are murdered on all sides; will remain at Mobile until the arrival of Iberville. (A. L. S.)

[Pp. 69-7I

I7 Io, Jan. I6, I8, 23, Mar. I3. Four letters from Glandelet to Father Silvy. Discussion between the Jesuits and the Missions Etrangères over rites. [Pp. 73-96, 101-102

I7ro, Jan. 24. Glandelet to the superior of the college of Quebec, with the reply of the latter. Rites.

I70I-I705. Correspondence relating to rites, between Abbé Brisacier and Father Bouvart, superior of the Jesuit missions in Canada. [pp. I03-106

I726, Oct. 24-I735, Oct. 29. Correspondence between the nuns of the Hôtel Dieu of Quebec and M. de Montigny. [pp. Iog-229, 235-237, 27I-304

I732, Oct. 25, " aux Tamarois". Father Mercier to Abbé de Montigny. Poverty of the mission; necessity of establishing it solidly in order that it may support the missions that might be established on the Missouri ; hostile attitude of the Indians; hopes that families will come out to Canada. (A. L. S.)

[pp. $23 \mathrm{I}-234$

I732, I735. Receipts, accounts, etc., of the Hospital Nuns of Quebec. [pp. 239-244, 247-267, 307-310

Biography of Jean Louis Le Loutre, missionary in Acadia. [Pp. 3 I I-334 268 
I763, Sept. 21. Bishop of Quebec [?] to Abbé Le Noir. Discussions between the missionaries and the superior of the seminary.

[pp. $335-338$

I793-I82I. Correspondence, chiefly of the directors of the seminary of Quebec, and of Mgr. Plessis, relating to the affairs of the seminary, its property in France, etc.

1821, Nov. 5, Quebec. Mgr. Plessis to Breluque, superior of the Missions Etrangères, relating to the despatch of missionaries to New York. [pp. 649-652 1820, June 6, near New Orleans. [Evremond] to Langlois, superior of the Missions Etrangères. The College of St. Louis, near New Orleans ; progress of religion in Louisiana.

I820, June I7, New Orleans. Louis, to Langlois. State of the college ; need of aid.
[pp. 633-635

345. MS. of the Historie du Seminaire de Québec, by Mgr. Taschereau, Archbishop of Quebec.-Appendices contain: "Plan général des missions du Missouri et du Mississipi", and a history of the "Missions du Seminaire de Québec chez les Tamarois ou Illinois sur les bords du Mississipi de I6g8 à $\mathrm{I} 789$ ".

346. "Album-Canada."-Examination not permitted.

Note.-Since the above list was compiled the Public Archives of Canada have inventoried and transcribed additional material. 


\section{MUSÉUM D'HISTOIRE NATURELLE.}

The library of the Muséum d'Histoire Naturelle (8, Rue de Buffon) contains 2009 volumes of manuscripts, an inventory of which, by A. Boinet, is published in Catalogue Général des Manuscrits des Bibliothèques Publiques de France: Paris, II., pp. iii-vi, I-357.

The American material includes memoranda and correspondence of Auguste Plée, Ch. A. Lesueur, F. A. Michaux, La Pylaie, and other scientists, relating to American fauna, flora, minerals, etc., as well as letters written by American naturalists and others to French correspondents.

71-73. Manuscripts relating to the travels of Auguste Plée in America and the West Indies, I819-1825.-73 is an atlas of pencil-sketches of scenes in Martinique, Guadeloupe, Marie Galante, St. Lucia, St. Kitts, St. Eustatius, St. Bartholomew, Porto Rico, the United States, and Canada. The sketches made in the United States and Canada, I821, include the following: St. Lawrence River, Quebec, Lake Champlain, Buffalo, Fort Niagara, Hudson River, New York, "Jersey River", Philadelphia, Brandywine, Potomac River, Mount Vernon, Richmond, Williamsburg, Jamestown, Yorktown, Norfolk, and Portsmouth.

177. Miscellany.

I848, Mar. 25, Washington. Lieut. J. W. Abert, U. S. Top. Eng., to A. Vattemare. Description of the ortyx squamosa, inhabiting the region of Santa $\mathrm{Fe}$, with colored drawing.

293. Geographical miscellany.

"Procès verbal de la visite des mines de la Baye de Saint Paul faite en I749 ¿... M. le Marquis de La Galissonière étant présent."

"Réflexions et preuves qu'on peut ajouter au mémoire de M. Guettard sur les minéraux du Canada." Mineral wealth of Canada.

I752, Oct. 2, Quebec. Gaultier to [Guettard]. Praise of La Galissonière and Duquesne; mines in Canada ; seeds and shrubs sent to the king.

"Mémoire des morceaux de pierres et des mines que j'envoye à $\mathrm{Mr}$. Guettard de l'Académie Royale des Sciences." Minerals from the Illinois country.

I755, Nov. 2. “Catalogue des minéraux que j'envoye à M. Guettard ... " Copper from Illinois and Lake Superior.

I755', Nov. 2, Quebec. Gaultier to Guettard. Collection of minerals which he is sending him; burning of the hospital of Quebec; defeat of the English on the Ohio; defeat of Dieskau on Lake George.

328. Original drawings ( I 47 water-colors) by P. J. Redouté and P. Bessa, for F. A. Michaux, Arbres Forestiers de l'Amérique Septentrionale (1810I8I3).

335. Volume of 129 colored drawings, with explanatory texts, of mushrooms collected in the vicinity of Columbus, O.

357.-Extracts or notes on American trees, by L. G. Lemonnier and F. A. Michaux.

371-395. Notes, drawings, etc., used by S. B. J. Noël de La Morinière for his uncompleted Histoire Générale des Pêches (vol. I., Paris, I815). 
380.- Fragmentary notes on the ice about Newfoundland and on navigation in North American waters.

[ff. 93,262

Dictionary of ports, lakes, and rivers where fishing is carried on. [f. I 52

\begin{tabular}{l} 
1778. Prospectus relating to fisheries in Canadian waters. [f. 296 \\
\hline
\end{tabular}

Memoir on the islands Newfoundland, Anticosti, St. Jean [Prince Edward], and Cape Breton.

[f. 308

[ I 8 I4 ca.] "Pêche de la baleine, de la morue et autres." Historical and statistical memoir on fisheries of the United States, with an appendix entitled, "Voyage à la côte Nord Ouest, Nootka Sound", addressed to Noël de La Morinière.

Notes on codfish.

[ff. 3 I2-332

[f. 348

"Vues générales sur les pêches françaises." [By Noël de La Morinière.] Whale and cod fisheries.

382.- - Notes on the seal fishery of Hudson Bay.

[f. 373 Europe Europe et en Amérique dans la préparation des poissons." [f. 209

Notes on frozen fish of Hudson Bay.

List of arrêts relating to the cod fisheries.

383.- Notes on American and English whale fisheries.

Dictionary of fishing ports, towns, and rivers.

f. 216

[f. 24I

[ff. 34, I 34

[f. I 57

384. Cod fisheries.- Notes and memoirs on the cod fisheries : general introduction; Dutch fisheries of Newfoundland and Greenland; regulations of June 20, I 743, respecting the fishery of Ile Royale; memoir on the advantages of nets in the cod fisheries; use of deep-sea lines; fisheries of Dieppe, Honfleur, St. Malo, St. Valery, Sables d'Olonne, Granville, Cherbourg, and Ile Royale; American fisheries; English fisheries; Newfoundland fishing vessels; consumption of cod in the West Indies; the Placentia fishery; memoir on the fishery at Petit Nord, Newfoundland, I8I8.

385. Cod fisheries.-Notes and memoirs: cod fisheries carried on by the Americans; the French cod fishery of Newfoundland; French and English rivalry; English fishery at Newfoundland; different kinds of codfish; the Nova Scotia fishery.

395.-Lists of fishes of Martinique and Santo Domingo. Comparative influence of fisheries and agriculture upon population. Benefits accruing to the arts and industry from the fisheries. Bonusesl accorded to British fisheries.

417.-A Memoir concerning the Fascinating Faculty which has been ascribed to various Species of Serpents. By Professor [Benjamin S.] Barton. (New edition, Philadelphia, I8I4, 76 pages.)

444-445. "Essai sur la flore de Terre-Neuve et des îles Saint-Pierre et Miclon.” By Bachelot de La Pylaie. I8I6-1820.

691. Catalogues of seeds planted at the Museum of Natural History, I790I80I.-Include seeds from Louisiana, Florida, Manila, etc.

763. " Description de plusieurs espèces de poissons des rivières de l'Amérique du Nord, par C. A. Lesueur, envoyée au Muséum national de Paris, de la Nouvelle Orléans." June 23, I831. Accompanied by five engraved plates.

841. "Notes and observations on the drawings of the spiders of Georgia", by Abbot, followed by “ Mémoire sur les araignés d'Amérique”, by Bosc.

940-943. Works of Gen. Le Vavasseur.-940 contains "Observations botaniques [taken at Cap Français, Santo Domingo], présentées à M. Jussieu par le général Le V [avasseur], intendant du jardin de Philadelphie."

944.-Catalogue of plants sent from Canada in I704 by "Mr. Sarrazin, conseiller du Conseil suprême et médecin du Roy en Canada". 
948. "Relation de La Louisiane par Le Maire" [I7I4].-Extract from the memoir by Le Maire ( $c f$. Arch. Colonies, CI3C, 2, f. I09), incorporated in a letter from Bobé, " prêtre de la Congrégation de la Mission", relating to timber, trees, wine, medicinal plants, snakes, climate, Indians, etc., of Louisiana.

1072. "Plantarum americanarum nomina vernacula a D. L. C. Richard communicata." I8th century.

1081. "Catalogus plantarum americanarum." By Thiéry de Menonville. I8th century.

1082. "Praenotiones in coccum Mexicanum cacti." By Thiéry de Menonville, Mar. 9, I778.

1113-1161. Papers of Antoine de Jussieu (I686-I758).

1140. - Note on a plant from Louisiana.

1151. "Histoire du gin-sen et ses qualités." [Post I7 I3.]

1181-1240. Papers of Antoine Laurent de Jussieu (I748-1836).

1194. " Mémoire sur les diverses espèces de quinquina découvertes à Santa Fé." Ptd., Mém. Soc. Royale de Médicinc, I779.

1225. Articles communicated to Abbé Raynal for his Histoire Philosophique des Établissements . . . des Européens dans les Indes. - Notes on the pitahaya tree of California, on the Mexican beverage pulque, on the sugar cane, on Indian beverages, etc.

1261. "Livre des simples de l'Amérique, servans au corps humain, découverts par le sieur André Minguet, tant en médecine que onguents, à la coste de Saint-Domingue." I7I3.

1262. Mémoire sur quatre nouveaux genres de plantes trouvés dans les Etats-Unis de l'Amérique." By Palisot-Beauvois.

1267. Two memoirs on the manufacture of sugar, with especial reference to Cayenne. I8th century.

1314. Voyage of the Venus to Newfoundland and Iceland, $1835-1836$.Thirty-nine colored plates of birds, fishes, etc.

1406-1443. Collection of catalogues of botanical gardens.

1443. Catalogues of botanical gardens in Africa and America. Marbois."

"Catalogue [of] seeds of American trees, shrubs, etc. For M. Barbé de

"Catalogue of American seeds of trees, flowering shrubs, and plants."

"Catalogue des graines des arbres arbuisseaux et plantes de l'Amérique septentrionale selon le sistème de Lineus."

"Catalogue des végétaux cultivés à la Jamaïque dans le jardin dirigé par M. Clarcke, I789."

1715-1749. Papers of Charles-Alexandre Lesueur (I778-1846).-See article on C. A. Lesueur and his drawings in the museum of Havre, by W. G. Leland, in Mississippi Valley Historical Review, X. 53-78.

1743. Mammifères d'Amérique.

I836. "Notice relative à la mâchoire du mastodonte trouvée dans la White River et déposée dans la bibliothèque de Vincennes." Addressed to C. A. Lesueur at New Harmony, Indiana; accompanied by two plates and by newspaper clippings.

"Notes relatives au dauphin, à la baleine, au phoque, à l'ursus, à l'écureuil, à la taupe, etc." Accompanied by pencil and colored drawings. 
I834, Dec. I. Letter addressed to Lesueur containing news of events in New Harmony since his departure.

1744-1745. "Perche d'Amérique."-Notes on the various kinds of American perch. Accompanied by drawings in pencil and in color. The notes are variously dated between 1825 and I832, and from the Wabash, Lake Erie, the Ohio, the St. Francis, New Orleans, and Jackson.

1746. "Chéloniens."-Notes, accompanied by drawings, on various kinds of salamanders, tortoises, etc., found on the Wabash, on Lake Erie, at New Harmony, Vincennes, Pensacola, New Orleans, and elsewhere, I8I I-I845.

1747. "Ophidiens d'Amérique."-Notes on serpents, New Harmony, Louisville, and elsewhere, I8I8, and memoir on the sea-serpent.

1748. "Crustacés d'Amérique."-Notes and drawings in pencil and colors, I8I 5 - I 837 .

1749. "Batraciens d'Amérique."-Notes and drawings in pencil or in colors. Philadelphia, Ohio, Wabash, New Harmony, Nashville, Missouri, New Orleans, and elsewhere, I827-1837.

1797-1806. MSS. of Aug. J. M. Bachelot de La Pylaie (I786-I856).

1797. "Essai sur la Flore de Terre-Neuve et des îles St. Pierre et Miclon par A. B. de La Pylaie." Continued in 1806.

1798. New foundland.

Notes on various plants and birds, with pencil sketches, I8I6-I820.

Pencil-sketches of the coasts of Labrador and Newfoundland.

I8I6, Oct. 25, Brest. Letter from La Pylaie to Lespinasse, relating to his voyage to Newfoundland on the $\dot{C} y b e ̀ l e$, the colony of St. Pierre, the preparation of codfish, etc.

1799. "Essai sur la flore de Terre Neuve et des îles St. Pierre et Miquelon, commencé le I er Août I8rg et dédié à Mr. de Jussieu. Par B. De La Pylaie. Ce travail doit être réuni à celui de $\mathrm{r} 8 \mathrm{I} 6$...

1800-1801. Note-books containing descriptions of plants and animals, made during the second voyage of La Pylaie to Newfoundland, St. Pierre, and Miquelon, I8I9-1820.

1802. Journal of La Pylaie's voyage to Newfoundland, June 3-Oct. 2 I, I8I6.-Descriptions of the country, and of the flora and fauna.

1803. "Table méthodique des plantes que j'ai observées à Terre Neuve et aux îles voisines en 1816, I8I9, et $1820 \ldots$...-An index to the note-books of La Pylaie.

1804. "Observations faites au havre du Croc", Newfoundland, Sept.-Oct., 1820.- Notes on plants and animals.

1805. Notes on plants of Newfoundland.

1806. Notes on plants of Newfoundland.-Continuation of 1797.

1896-1898. "Journal de navigation pour servir à moi, Charles-Félix Pierre Fesche, volontaire sur la frégatte du Roy La Boudeuse, commandée par Mr. le chevalier de Bougainville . . . armée en partie à Nantes, en partie à Brest . . pour faire le tour du monde, commencé le 4 octobre, i766." I766I768.

1935. Papers of André Thoüin.

Lists of plants and trees sent from Martinique, Santo Domingo, Guadeloupe, and other islands.

I 788. List of objects collected at Manila and in Java by M. Norona.

Names of dried plants and seeds sent to the Jardin du Roi by the Chevalier de Villars, from New Orleans in Aug., I788. 
Note of seeds sent from Louisiana in $\mathrm{I} 788$.

I789, Mar. 24, New Orleans. “ Notice sur les plantes dont j'envoie les semences à M. Thouin ..." [By de Villars.] (40 pp.)

"Observations sur les plantes envoyées par Hingston à Mrs. ses suscripteurs en France, l'année I790." From the United States.

List of plants and trees which grow in Canada, and which are rare or lacking in Europe.

List of things sent from New Orleans by M. de Lassise, Oct. I 5, I788.

"Etat des graines d'arbres, arbustes, plantes médicamentales curieuses et utiles venues de la Louisiane. Dbnnées par M. Trenonay, Receveur général des finances." Received Mar. 24, I790.

"Liste des graines envoyées de la Caroline par M. Marhal, I790."

"Liste des graines de l'envoi du Sr. Hingston, I79I."

"Catalogue des plantes vivantes apportées d'Amérique en fructidor, an VI, par le capitaine Baudin ..."

"Liste des graines et plantes arrivées d'Amérique en I 788 et semées dans less différents jardins de Mgr. le Duc d'Orléans."

"Liste d'arbres et de plantes de l'Amérique Septentrionale qui manquent dans les jardins de l'Europe et qu'on pourra se procurer chez le Sr. Young, botaniste à Boston." I 784 .

"Liste d'un certain nombre de plantes qui croissent dans la Nouvelle Angleterre, selon Mr. Young." I784."

"Extrait du catalogue de John Bartram, fleuriste, près Philadelphie,

"Catalogue of American seeds of trees and flowering shrubs ... Those marked $\mathrm{x}$ are such as Mr. Gerard has particularly desired in his catalogue given to me [de Malesherbes?] by Mr. Marbois." [I78I.]

1961. Copy of a letter from Auguste Plée to his family, written from on board the frigate Junon, at Norfolk, Va., July I 5, I82I, and containing an abridged account of his journey from Norfolk, through the northern part of the United States, to Quebec, and return by way of Lake Champlain.-Plants collected by the writer; journey through Philadelphia, New York, Albany, Buffalo, Montreal, Three Rivers, Quebec, etc.

1964-1968. Correspondence of Alexandre Brongniart (I770-1847).

1965. Letters to Alexandre Brongniart.-Letters from correspondents in America as follows: Peter A. Browne, Philadelphia, I83I, sends specimens of anthracite coal. A. Bruce, New York, I8I4, sends box of American minerals. John D. Clifford, Lexington, Ky., I820, sends specimens of organic fossils, information relating to Transylvania University and to Prof. Rafinesque. E. I. Du Pont, I80I, sends a box of insects by Letombe, who will give, him news of his sister at Georgetown; I802, has purchased an estate near Wilmington; sends a box of birds. Amos Eaton, Troy, N. Y., I830, sends specimens of "antediluvian" plants from the Erie Canal; 1833 , geological investigations in America. Fréminville, Brest, I823, voyage to West Indies, revolt in Martinique ; I824, return from the United States ; insects of Virginia ; I825, voyage to the West Indies, collection of crustaceans of the Gulf of Mexico; I84I, sends a box of fishes, reptiles, molluscs, etc., from the Gulf of Mexico and the coasts of Florida and Louisiana.

1966. Letters to Alexandre Brongniart.-Letter from Wm. H. Keating, Philadelphia, Mar. I8, I837, relating to manuafctures near Philadelphia. 
1967. Letters to Alexandre Brongniart.-Letters from Samuel G. Morton, Philadelphia, I832, James Pierce, Catskill, N. Y., I822, C. S. Rafinesque, Philadelphia, 1832 (relative to his work and his geological expedition in Maryland), and Jer. Van Rensselaer, New York, I824. Chiefly letters of transmittal.

1968. Letters to Alexandre Brongniart.-Letters from Lardner Vanuxem, Columbia, S. C., I825, and "Bristol, U. S. A.", I832, and J. W. Webster, Boston, I82I.

1969-1970. Correspondence of Adolphe Brongniart (I80I-1876).

1969. Letters to Adolphe Brongniart from the following: Jacob Cist, Wilkesbarre, $\mathrm{Pa}$., I823-1824, sending drawings, and information relating to geology of Pennsylvania; J. E. Dekay, New York, I823; E. L. Dixwell, Boston, 1840; George Engelman, St. Louis, I86I ; Asa Gray, Cambridge, I857-I865, twelve letters, mostly transmitting books and packages.

1970. Letters to Adolphe Brongniart from the following: William $\mathrm{H}$. Keating, Philadelphia, I82I-I826, twelve letters, relative to sending of instruments, books, animals, chemical prodicts, etc. ; Isaac Hays, Philadelphia, I823, on expedition of Maj. Long to the western territory of the United States, with Keating, Say, and James; Louis de Schweinitz, Bethlehem, Pa., I824; B. Silliman, New Haven, Conn., I824, information respecting mines in Louisiana and on the Missouri; Charles Whittlesey, Cleveland, O., I846.

1980. Autographs.

I8I 5-I824, Philadelphia. Letters and notes from James Mease to Prof. Thouiin of the Muséum d'Histoire Naturelle, relative to agriculture in America, seeds sent from France, fort at the mouth of the Yellowstone, etc. fever, etc.

I 796, Mar. I4, New York. Samuel Mitchill to Dr. Valentin: Yellow

1997. Autographs.

I845, Jan. 7, Mar. 7, June 30, Neuchâtel. Louis Agassiz to the Prince de Canino [Charles Lucien Bonaparte]. Relating to his proposed voyage to the United States.

I847, Feb. 8, Boston: Agassiz to the Prince de Canino. Preparations for his lectures on glaciers.

N. d. The mother of Louis Agassiz to the Prince de Canino. Aid of which her son is in need before leaving for America.

I769, Mar. 4. Dubourg to Rush, of the faculty [of medicine of Edinburgh], a friend of Franklin.

1998. Autographs.

I834, May 24, Albany. James Eights to Alexandre Brongniart.

I845, Dec. I3, Washington City. Charles Lyell to Dr. Benjamin Silliman, of Yale College. His visit to Philadelphia. 


\section{BIBLIOTHĖQUE SAINTE-GENEVIÈVE.}

The Bibliothèque Sainte-Geneviève ( 8 , Place du Panthéon) possesses a collection of about $35^{\text {lo }}$ volumes of manuscripts, all of which, with the exception of some 100 yolumes of purchases or gifts, formed the cabinet of manuscripts of the Abbey of St. Genevieve, in Paris, at the time of the Revolution. The American material includes the papers and journals of A. G. Pingré, relating to the scientific expeditions in American, chiefly West Indian, waters in which he took part, and also the papers and correspondence of Ferdinand Denis relating to Brazil. An inventory of the manuscripts, accompanied by an historical introduction, has been published by Charles Kohler, Catalogue des Manuscrits de la Bibliothèque Sainte-Geneviève (2 vols., Paris, I893, I896), with a Supplément (Paris, I9I3); also in Catalogue Général des Manuscrits des Bibliothèques Publiques de France, XLV. 57-I 26.:

529. Description of the seacoasts of various countries.-The coasts of the Antilles, Santo Domingo, Bermuda, Newfoundland, and Labrador, and the Atlantic coast of North America are described at ff. I30-347. The MS. is ascribed to Father Alexandre G. Pingré.

530-533. Journals, log-books, observations, calculations, maps, etc., of the scientific expedition of the Flore, under Verdun de La Crenne, J. C. Borda, and A. G. Pingré, in I77I-I772, in the waters of the West Indies and South America.

534. "Journal de Mr. le Marquis de Courtanvaux, sur la frégate l'Aurore pour essayer . . plusieurs instruments relatifs à la longitude, mis en ordre par Mr. Pingré . . . r768." (240 ff.)

539-540. Autograph journal in German, by the Russian artist Louis Choris, of his voyage around the world, I8I5-I8I8, with documents relating to his assassination near Vera Cruz in I829. See Louis 'Choris, Voyage Pittoresque autour $d u$ Monde (Paris, 1822).

543. Pencil outlines of the coasts of Iceland, of St. Pierre and Miquelon, and of small islands in the Gulf of St. Lawrence., (I8th century.)

710.- I73I. Map with elevation: "L'abbaye du Cap François, Côte St. Domingue, fait par moy Jean Bap'te Roubaud Pilote."

[ff. I-2

1798. Bills of goods loaded on vessels bound for South America, I7I I, and journal of the voyage to South America, If 6 -I7I8, of the squadron commanded by M. de Martinet.

1805. Journals by A. G. Pingré of the voyages of the Aurore and the Ambition, in the West Indies and elsewhere, I $767-1772$, for the purpose of testing the marine clocks and watches of Le Roy and Ferdinand Berthoud.

1806-1809. Casernet des heures of the voyage of the Flore in the West Indies, I77I-I772 (scientific expedition of Verdun de La Crenne, Borda, and Pingré), with journals of navigation, observations, etc. $C f$. above, 530-533.

2036. "Mémoire présenté en I626 au Cardinal de Richelieu pour rétablir le commerce sur mer et autres choses très utiles, par le Chevalier de Rassily." Nov. 26, I626.-Plan for a royal company; necessity of colonization; division of America; bad conduct of colonists in Canada, etc. See L. Deschamps, Isaac de Razilly (Paris, I887), pp. I5-35. 
2088. "Mémoires sur l'état actuel du Canada”, ca. I777.-These memoirs, by a missionary who went to Canada in I754, serving at first in the Iroquois mission and later as chaplain of troops, are in chapters as follows: I. Situation du Canada; II. Étendue et commerce; III. Moeurs des Canadiens, leur attachment à la France; IV. Climat; V. Extrémité où l'on a trouvé la religion en Canada ; VI. Raisonnements politiques sur tout le continent septentrional, que le Canada s'unisse aux Insurgents, reste à l'Angleterre, ou revienne à la France. (20 pp.)

2127. "Voyages de Jean Mocquet en Barbarie, Afrique, Indes orientales et occidentales, Syrie et Palestine. En l'année I60I et suivantes."-Passages dealing with West Indies, Cayenne, Mexico, Brazil, etc., are on ff. Iov-24, $73 \mathrm{v}-77$.

2342. Astronomical and geographical observations of A. G. PingréLongitudes and latitudes of St. Pierre, Miquelon, Martinique, ascertained on board the Flore, I77I-I772 (ff. 4-I3v, 26-29v); summary of astronomical and geographical observations taken during a voyage in American waters on the Isis, I 768 (ff. $59-65 \mathrm{v}$ ) ; essay on the position of certain islands and other places in the Atlantic ocean, I768 (ff. 72-I05).

2551. Letters to A. G. Pingré.

I770-I775. Letters and observations: latitude and channels of Santo Domingo.

I773, Mar. 25-Apr. I8. Extracts from the journal of Capt. Mourand: Antilles, Bermuda, Atlantic.

[f. 3 I I788, Jan.-June, Bordeaux. Letters from O. Lourde Martignac, relating \begin{tabular}{l} 
to freemasonry in Santo Domingo. [ff. I $48-$ I $55 \mathrm{v}$ \\
\hline
\end{tabular} 3002. Geographical treatise, I7th century.-A section on North and South America (ff. 69 et seq.) contains lists of towns.

3417-3436. Collection of papers bequeathed by Ferdinand Denis.

3417. Letters from $F$. Denis to relatives and friends, written during his residence in Brazil, I8I6-I8I9, and containing information on a great variety of Brazilian matters. 3418. Chiefly letters to F. Denis, ca. I830-1852, relative in part to the works of Denis on Portugual and Brazil. 3419. Letters to F. Denis, $c a$. 1853-1886, relative to Brazilian affairs, American antiquities, voyage of C. Wiener in Peru ( 1876 ), Brazilian ethnography, etc. ; letters from Henry Stanley (Mar. I8, I869) and Henry Harrisse (July 7, I879) relate respectively to the MS. of Pigafetta and to Ortez Calzadilha and Columbus; five letters from Emperor Dom Pedro II., I874-I88I, relative to history of Brazil. 3420. Notes on Brazilian history and geography; "Souvenirs du Brazil, Oct., I818Jan., I819. 3421. "Mes sottises quotidiennes"; fragments of a journal kept by F. Denis in Brazil, Oct., I8I8-Jan., I8I9. 3426. Miscellany relating to bibliography, literature, geography, and history ; itinerary of Désiré Charnay from Boston to Mexico via Quebec, Chicago, and the Mississippi, I857-I86o (f. 60); description of the Amazon region by Nuno Alves do Coutto, I843 (ff. 64-86v); account of Brazilian geography, by Baron von Langsdorff (ff. $164-205 \mathrm{v}$ ); memoir by the Comte de Merle, French ambassador at Lisbon, on the exchange of the colony of St. Sacrement for the Spanish colonies, post I758 (ff. 2082IOv); history of Ecuador, by Bucher Martigny, I834 (ff. 216-239). 3427. Lists of principal explorers and voyagers in the South Sea, I5I9-I775, and of early French explorers and voyagers (ff. I-7v) ; notes on Brazilian geography, on the Amazon and its affluents, and on steam navigation on the Amazon (ff. 9-66) ; Brazilian statistics, I834, I843 (ff. 69-76v) ; account of the coronation of Dom Pedro II., I84I (ff. 77-98v); " Tableau des moeurs et coutumes des 
habitants de la Plata, du Paraguay, de la Magellanie ... " (ff. I06-I63). 3428. Fragments of a history of Quito (ff. 40-7 Iv). 3430. Portuguese commerce and navigation in 1838 (ff. 68-9Iv). 3431. Copies of documents relating to the Portuguese occupation of Cayenne in I8IO, and to the boundaries between French and Portuguese Guiana and Brazil. 3434. "Notes dominicales prises pendant un voyage en Portugal et au Brésil en I8I6-I8I8 par L. F. de Tollenare", with drawings and maps. 3435. Memoirs on the Portuguese colonies, by Baron Bois-le-Comte, French minister in Portugal, I838. 3436. "Villa Rica, poema en X cantos, de Claudio Manoel da Costa, Arca de ultramarino."

3504, 3505. Notes by F. Denis on the history, literature, geography, and biography of Portugal and Spain and of Portuguese and Spanish America.

3507. Travels of J. B. Douville in I833-I835 among the Indians of Brazil.

3508. Extracts from Francisco de Burgoa, Geographica Descripción de la Parte Septentrional del Polo Arctico de la America . . . (Mexico, I67 I).

\section{BIBLIOTHĖQUE MUNICIPALE DU XVI' ARRONDISSE- MENT DE PARIS.}

The Municipal Library of the Sixteenth Arrondissement, located in the mairie of that arrondissement on the Avenue Henri Martin, has been the recipient of several important gifts of books and manuscripts. A few letters relating to America have been found in the collection of manuscripts bequeathed by Parent de Rosan (I798-I890). An inventory of the manuscripts in the library is published in Catalogue Général des Manuscrits des Bibliothèques Publiques de France: Paris, I. (Paris, Igog) I-I09.

10.-Facsimile of fragment of a letter from Lapérouse relating to naval affairs of the American war of independence, with annotations by the Marshal de Castries and Fleurieu.

[f. 49

I78I, Oct. 20, Boston. Facsimile of letter from Lapérouse to his mother, relative to the surrender of Cornwallis.

[f. 50

13.-I724, Mar. 2I, Versailles. Maurepas to Clairambault. Raudot will take the minutes of letters written in Canada and at Placentia in I709-I 7 I for preservation in the Bureau des Colonies.

I772, Jan. I7, Versailles. Duc d'Aiguillon, minister of foreign affairs, to M. de Boynes, minister of marine. Relating to claims of the Chevalier de Noyan and the Sieur Jeury des Tours in Louisiana.

[ff. 46-46v

I 780, July I4, Paris. Necker to Sartine. Relating to flour intended for the colonies and held at Cadiz following the declaration of war. 


\section{BIBLIOTHĖQUE DU SÉNAT.}

The library of the Senate is located in the Luxembourg Palace; it is open daily from Io to 12 and from 2 to 5 , except those afternoons when the Senate is in session. For permission to work in the library application should be made to M. le Secrétaire Général de la Questure du Sénat.

The library contains I 343 volumes of manuscripts, of which 34I, known as the "Collection Boissy-d'Anglas", are registers of the Parlement de Paris, ranging in date from the twelfth to the eighteenth centuries. The miscellaneous manuscripts include a few documents relating to America, mostly memoirs on commerce.

A catalogue of the MSS. in the library with a brief account of the history of the collection has been compiled by Louis Engerand, Catalogue des Mamuscrits des Bibliothèques Publiques de France: Bibliothèque du Sénat (Paris, I908, xiii, 597.).

The following list of documents is based on an examination of such MSS. as seem likely, from the indications in the catalogue, to be of interest for American history. The number in heavy type is the number given in the printed catalogue, the number in parenthesis is the call number of the MS.

152 (90.I I). "Finance et commerce de France, avec explication de tout ce qui a rapport à ces deux objets."-A volume of 282 unnumbered pages, compiled in the latter half of the eighteenth century. Contents of interest for America include: historical account of the ferme $d u$ tabac, its adjudication to the Compagnie d'Occident, failure of tobacco growing in Louisiana, excellence of Virginia tobacco, etc. (4 pp.) ; historical account of the domaine d'Occident (I p.) ; slave-trade ; cod and whale fisheries ; administration and commerce of French colonies in America (3 pp.) ; histories of the Compagnie des Indes Occidentales of I664, the Compagnie d'Occident of I7I7, etc.

158 (9017). [ [ 752 ca.] Free translation of The British Merchant (London, I7I4), with translation of a discourse by [Charles] Davenant, on "l'usage de l'arithmétique politique dans le commerce des finances ".

174 (9033). "Etat général de la monarchie d'Espagne dans les quatres parties du monde", under Philip V., by La Croix, former secretary of the French embassy at Constantinople. I 8 th century. Contents relating to America and dependencies: Philippine Islands ( $\mathrm{p} .546$ ) ; discovery of America ( $\mathrm{p}$. 563 ) ; North and South America (p. 568); Norumbega, Florida, Gulf of Mexico (p. 572) ; Mexico, Central and South America (pp. 576-615), colored printed maps entitled Iucatana Regio et Fondura (p. 587), Castilia Aurifera cum vicinis Provinciis (p. 59I), Granata Nova et California (p. 595).

287 ( $\left.9 I_{3} 6\right)$. Collection of documents relating to the reign of Louis XIII., I610- I629.

I626, Mar. 3I, Charonne. "Traicté entre le Cardinal de Richelieu pour le Roy et quelques habitans de Paris, pour le commerce à establir à Morbian en Bretaigne."

[p. 695

I627, Apr. 29, Paris. "Articles de ratification du Roy de la Compagnie de la Nouvelle-France, Québec et Canada."

[p. 74I

1627, May 7, Paris. "Articles et conventions de Société faits pour l'exécution des articles accordés par le Cardinal de Richelieu à la Compagnie des Cent Associés."

[p. 745 
1628, May 6, Camp before La Rochelle. "Ratification par le Roi des articles accordés à la Compagnie de la Nouvelle France."

[p. 749

953-954 (9349). Memoirs on Normandy by Nicolas and Joseph Foucault, on Brittany by Louis Bechameil, on Poitou by Giles de Maupeou, and on La Rochelle by Michel Bégon. I698-1700. 2 vols. - Names of fishermen of Granville going to Newfoundland $(953$, f. $233 \mathrm{v})$; cod fisheries in Canada and Newfoundland, carried on by vessels of Honfleur, Le Havre, and St. Valeryen-Caux (954, f. 48v); commerce between Nantes and Newfoundland and the West Indies (f. 79); commerce of St. Malo with the Spanish West Indies and Newfoundland (f. I43) ; commerce of La Rochelle with the West Indies, Canada, Acadia, and Hudson Bay (f. 4v, at end of vol.).

1143-1144 (9468, C2-9468, C3). Two volumes of a collection of judicial memoirs, mostly printed:

Mémoire pour Messire François Bigot, cidevant Intendant ... en Canada, Accusé: contre Monsieur le Procureur-Général du Roi en la Commission, Accusateur. Première Partie, contenant l'Histoire de l'Administration du Sieur Bigot dans la Colonie, et des Réflexions Générales sur cette Administration (Paris, I763, 303 pp.).

$[1143$, p. 42 I

Mémoire pour Messire François Bigot . . . Seconde Partie, contenant la Discussion et le Détail des Chefs d'Accusation (Paris, I763, 55I pp.).

[1144, p. 7

Mémoire pour Messire François Bigot . . . Suite de la Seconde Partie. Contenant $\mathrm{I}^{\circ}$. La cinquième Classe . . Réponse au Mémoire du Marquis de Vaudreuil et à celui du Sieur du Verger de Saint Blin. $2^{\circ}$. La sixième Classe. $3^{\circ}$. La Réponse à la Requête des Dames de Montcalm (n. d., pp. 553-780).

$[1143$, p. 189

1192 (9468, R4). Mémoire signifié par Jean-Joseph Maximin, ci-devant Capitaine du Brigantin le S. Jean de la Martinique, Intimé, contre Jean Audouin, Négociant à la Rochelle, Propriétaire du même Brigantin, Appellant de Sentence de l'Amiranté Générale du Palais, à Paris, du 3 mars I752. [p. 365

1211 (9473). Collection of documents relating to commerce.

[I8th century.] Memoir respecting request of the town of Libourne to trade directly with the American colonies.

[p. 59

I756, Apr. I, Paris. Memoir respecting permission to neutrals to provision the French colonies.

[p. 63

[I8th century.] Memoir on domestic commerce. Aid furnished to England through purchase by France of tobacco from English colonies; danger to Canada and Louisiana. onies. [P. 7I
[I8th century.] Memoirs on cultivation of tobacco. References to col-

[pp. 91, 99, I03, I07, I I 5, 492 1349. (9489). Memoirs relating to England and Russia.

I728, Jan. Memoir on the present state of England. English commerce with the West Indies, slave-trade, Newfoundland fisheries, and English establishments in America.

[p. I

I74I. Addition to a memoir on Russia. English vessel sent to the South Sea; English contraband trade in the West Indies; plans of Cromwell after conquest of Jamaica; English mastery of Gulf of Mexico; danger to French.

[p. 55

I74I, July. Supplementary memoir. War of England against Spain directed especially against France; ruin of French commerce in the Gulf of Mexico.

[p. 79 


\section{BIBLIOTHĖQUE DE L'UNIVERSITÉ DE PARIS.}

The library of the University of Paris (Faculties of Sciences and Letters), commonly known as the library of the Sorbonne, possesses I590 volumes of manuscripts, many of which came, at the time of the Revolution, from suppressed colleges and religious communities, or from émigrés. The American material in this collection is all but negligible. A detailed inventory of the manuscripts, by Charles Beaulieu, is published in Catalogue Général des Manuscrits des Bibliothèques Publiques de France: Université de Paris et Universités des Départements, pp. iii-x, I-368 (Paris, I9I8).

86.-Investigation by the Chevalier Turgot, and the dean and procureurgénéral of the Superior Council of Cayenne, of the charges against M. de Chanvallon, intendant of Guiana.

91. "Traitté du commerce de mer." I 8 th century. (4I 5 ff.) -Deals with officers and sailors, partners and creditors, charters and charter parties, damages to vessels or freight, consuls in the Levant, sale of cargoes and letters of exchange, consular and admiralty jurisdictions, pirates and prizes, whale-oil and whalebone, etc.

671. "Miscellanea di storia." I8th century.-Includes a succinct account of the geography of America (ff. I2I-I27).

1318-1324. "Introduction a la Géographie." I 8 th century.-1324. "De l'Afrique." "De 1'Amèrique."-History and geography of America (ff. I85$297 \mathrm{v})$.

1325. Miscellany.-Extracts from Champlain's voyages (ff. I-5v.).

\section{BIBLIOTHÈQUE VICTOR COUSIN À LA SORBONNE.}

The Victor Cousin library, bequeathed to the University of Paris by Victor Cousin, constitutes an annex to the university library, but, under the terms of the legacy, it may "never, under any pretext", be united to it or to any other library. The library contains 26I volumes of manuscripts consisting of autographs of historic personages, papers relating to philosophy and education, the papers of Barthélemy-Saint-Hilaire and of Paul Janet, and the correspondence and papers of Victor Cousin. Practically all the American material is to be found among the papers of Victor Cousin and consists of letters from American educators, philosophers, and others. An inventory of the collection by Paul Deschamps is published in Catalogue Général des Manuscrits des Bibliothèques Publiques de France: Université de Paris et Universités des Départements, pp. 369-465 (Paris, 1918).

62. Miscellany. Philosophy and teaching of philosophy;

Translation of an article, "Cousin's Philosophy", published in the Christian Examiner, Boston, Sept., I836.

[ff. I-2IV

"De la Philosophie dans l'Amérique du Nord. Importation et critique des écrits de M. Cousin."

"Some remarks on the state of Philosophy in the United States." By

C. S. Henry, 84 Chambers Street, New York, Dec. 6, I837.

215. Correspondence.

Letter from A. D. Bache, president of Girard College, Philadelphia, to Victor Cousin, containing a list of schools seen by him in Great Britain.

[no. 183 
I838, Dec. 21, Philadelphia. A. D. Bache to Victor Cousin. His visits to schools in Europe; new school system in Massachusetts. [no. I84 I838, Mar. 2, Boston; I848, Jan. 23; I85'I, June I3, New York. Letters from George Bancroft to Victor Cousin. Sends his works; introduction of Mr. Tappan of New York. affairs.

I834-1835. Letters from Barbé-Marbois, not relating to American

220. Correspondence.

I837-I839, I864. Letters from Charles Brooks to Cousin, written from Hingham and Medford, Mass., and from New York, relating to schools and education in Massachusetts and other states; state normal schools, etc.

[nos. 954-96o

I832, I838, I844, I858. Letters from Orestes A. Brownson to Cousin, written from Boston or New York. Relating to his writings, to George Ripley, George Bancroft, James F. Clarke, and others, to his philosophical opinions, etc.

223. Correspondence. book.

I860, Sept. 9, New Orleans. S. Wharton Collens to Cousin, sending a [nos. 972-977
sin, sending a
[no. 1365

I837, Oct. 20, I839, Feb. 28, Boston. Thomas Cushing to Cousin. Activities of the American Institute of Instruction.

225. Correspondence.

I850, Mar. I8, New York. Henriette Deluzy des Portes to Cousin. Details of her departure for the United States; requests a testimonial from him that will enable her to marry. [The writer was the governess of the children of the Duc de Praslin, murderer of his wife, and had been charged with complicity in the crime.]

[no. 1607

227. Correspondence. a volume.

I838, Nov. 5, Brown University. Romeo Elton to Cousin, presenting

I833, Sept. 29, I834, Apr. I7, Boston; n. d., Paris. A. H. Everett to Cousin. State of education in Massachusetts, etc.

232. Correspondence.

I837, Mar. 6, Edinburgh. Sir William Hamilton to Cousin, introducing A. D. Bache of Philadelphia.

[no. 242I

I855, Dec. 24, Chapel Hill, N. C. Henry Harrisse to Cousin, asking him to write a preface for his English translation of the works of Descartes.

235. Correspondence.

[no. 2453 allusions.

N. d. Two letters from the Marquis de Lafayette to Cousin. Political

I828, Nov. 28, Washington. Lannes de Montebello to Cousin. Is going to Mexico via the Mississippi and New Orleans; his visit to the United States; progress of that country; condition of the French population of Canada; description of Washington; election and character of Andrew Jackson; customs tariff of Adams. (A. L. S., 6 pages.)

[no. 2937

237. Correspondence.

I834, Jan. I7, Philadelphia. Francis Lieber to Cousin. Educational matters and the school systems of Pennsylvania.

[no 3182

I834, Jan. I, June 30, Dec. 29, Paris. Edward Livingston to Cousin, transmitting documents relating to education in the state of New York.

[nos. 3190, 3I9I, 3I93 
I834, May 30, Col[umbia] Coll[ege]. W. A. Duer to Edward Livingston. System of education in the state of New York.

238. Correspondence.

[no. 3192

I860, July 2I, Lafayette College, Easton, Penn. Francis A. March to Cousin, relating to articles on the philosophy of Sir William Hamilton.

245. Correspondence.

[no. 3308

I837-I844, Boston. George Ripley to Cousin. Seven letters relating to their writings, to the new review started by Brownson, etc. "French eclecticism is to be the guiding light of American democracy." Introductions of Frederic Huidekoper, Theodore Parker, Albert Brisbane, and others. [nos 431 5-432I

246. Correspondence.

I838, Aug. I6, Boston. Eliza Robbins to Cousin. Sends her works; education in the United States; W. C. Bryant and Horace Mann. [no. 4328

248. Correspondence.

I833, Oct. 29, Paris. Theodore Sedgwick, jr., to Cousin. Information as to the state of education in the Unitedl States.

249. Correspondence.

[10. 4727

I835, July I I, Hartford, Conn. L. H. Sigourney to Cousin. Presenting a number of volumes.

[no. 4753

I837, May 27, Paris; I839, Sept. I5, Florence. Charles Sumner to Cousin. Relating to [O. A.] Brownson, and Joseph Story. [nos. 4866, 4867
[

250. Correspondence.

I840-I859, New York, Paris, Ann Arbor. Letters from Henry P. Tappan to Cousin. Sends works ; influence of Cousin in America. [nos. 4869-4872
[

I857, Nov. 20, Boston. George Ticknor to Cousin. Sends his work on Spanish literature.

[no. 4962

I853, Mar. 21, Middletown, Conn.; I86I, Feb. 23, New York. Charles $\mathrm{K}$. True to Cousin. Cousin's work on Locke is used as text-book in Wesleyan University; sends copy of his Elements of Logic.

252. Correspondence.

[nos. 5030, 503I

I852-I858. Three letters from O. W. Wight to Cousin. Campaign against sensualism by Emerson, Brownson, and Henry James.

[nos. 5261-5263

I838, July I3. Wm. C. Woodbridge to Cousin. Relating to the Annals of Education, recently edited by him.

[no. $530 \mathrm{I}$

I844, Aug. I, Berlin ; I845, Jan. 8, Paris. Henry Wheaton, U. S. minister at Berlin, to Cousin. Sends his historical works; recommends his son.

253. Correspondence.

[nos. 525I, 5252

I850, June I9, New York. J. D. L. Zender to Cousin. His residence in America; French Almanac for the United States; desires to publish in English a résumé of the doctrine of eclecticism.

260. Letters to Barthélémy Saint-Hilaire.

[no. 5318

I876, Aug. I I. Houghton to St. Hilaire, respecting his visit to Canada and the United States.

I867, Feb. I6. C. S. Henry to St. Hilaire. Influence of Cousin in America.

[no. 160

I891, Mar. I4, Apr. I 5, Osceola, Mo. Thomas M. Johnson to St. Hilaire. Asks for letters from Thomas Taylor to Cousin. [nos. I65, I66
[ 6 .

I867, Apr. I5, Frederick, Md. Samuel Tyler to St. Hilaire. Relating to his philosophical works; effect of Civil War on civilization in the United States.

[no. 345 



\section{INDEX}

Ibbadie, Antoine Thomas d', papers, 256

lbbot, John, on spiders, $27 \mathrm{I}$

1beille de Nouvelle Orleans, I I3

tbert, J. W., letter, 270

1bigail, 2I, 39

tblon, see Dablon

tcaanibas, Sagean's relation, 25, 67 69, I08, I77 Icadémie de Médecine, MSS., 238

lcadémie des Beaux Arts, correspondents, 257 lcadémie des Sciences, Description des Arts et Métiers, 25

Icadia, affairs, information, 84, I 57, I62, I69, I70, I8I ; aid, munitions, I95; attacks, captures, 48, 52, 87, I38, I4I, I68, I 84; Aulnay-La Tour affairs, 46, 53, I03, I07, I63, I92, 264; Bergier concession, 218; boundaries, claims, I07, I8I, 243, 265; Brissonier, 69; Brouillan, 67; Cangé concession, I4I; Chambly, I 97, I98; coasts, I 59; commerce, 6,74 , I34, I8I, I93, I94, 239, 24I, 280 ; Dumas, 45 ; expenditures, funds, I6, I37, I94, I95, I97, 20I, 203; fisheries, St. Pierre concessions, $8,33,34,78,82$, I07, I 35, I69, I86, 218; Gargot, I 49; Grandfontaine, 20I 202; Indians, 98, I8I ; jurisdiction, 64 ; land grants, I60; Le Borgne, I63, I89; maps, I02, 223, 224; memoirs, 28, I 39, I67; minerals, 68; missions, 27, I 89, 268; notes, 107, I I6; papers, list, I07, I I2, I I4, I 57, I63, 21 2 ; Poix, I70; restitution, Breda, Ryswick, I6, 28, 47, 49, 5I, I86, I92, I94, 205, 206, 21 5 ; St. Castin, I65; settling, I6; ships and supplies for, $63,65,67,68$, 1 35, I 38, 162, 164 I68, I97, I98, 20I, 202; ship timber, I35; troops, I35, I37, I63; Utrecht negotiations, I06, I5I, I52, 243; see also Monts; Nova Scotia; Port Royal

Icadians, and Guiana, 8; in France, 213

Iccarette, Sieur d', and Buenos Aires, I8o

iccarias de Serionne, see Serionne

Iccounts, see Chambre des Comptes; Finances Ichéry de Serquigny, —_ d', letter, fight, I80 1ctes des Negociations de Ryszrick, 47

Icts (arrêts, déclarations, edicts, lettres patents, ordonnances), amnesty to freebooters, 33; astronomical expedition, 26 ; beaver trade, 62,82 ; Canadian products, 57 ; catalogues, lists, tables, I4, 33, 44, 76, I05, I 43, I56, I60, 218, 27I ; colonial: bills of exchange, 36; cadets, 8I ; councils, 7 , I0, 88, I47; debts, 57; finances, revenue, farming, I4, $32,36,60,89$; gentry, I54; land grants, I53; money, cards, 9, I0, 83, 89; passports, I37; port dues, 8I; public records, 213; taxation, 89; troops, 27, I 21 ;-colonizing, 262 ; commerce, colonial, regulation ( I62698), 4I, 42, 89, 96, I45, I53, I94, I 95 ; (I7I5-
35), 33, 57, 58, 83, 89, I3I ; commercial companies, concessions (I 548-I642), 6, I 5, 50-52, 96 , I 53, 205, 262, 279, 280; (I655-98), 10, I $4,42,44,46,49,59,89$, I 53 , I 54, I 56 , I 78 , 205, 218; ( I7 17-38), 33, 59, 60, 78, 80, 83, I I7, I 56, 2I I ; convoys, I 36 ; coureurs de bois, Io ; declaration of war (I702), I52 ; departmental duties, 49, 77, 213; domicile, Io; fisheries, 78, 218; foreign goods for colonies, 56-58; foreign money in colonies, 89; Ile Royale, 77,78 ; naturalization, Io; negroes, I9, 42 ; nobles in trade, Io; officials and plantations, 57; packet-boats, I 29; police of ports, I53; privateering, I 36 ; registration, 25I ; retrocession of Louisiana (I73I), 80; Santo Domingo octroi, 89; seigniorage, Io; slaves in France, 77,78 ; slaves of minors, 58 ; slave trade, 56,58 , I54, 2I7; SpanishAmerican trade regulations, 265; sugar trade, I55; tobacco trade, 59; transportation of arms and engagés, I39, I 59, 21 8 ; treasurer general of colonies, 2II; vagabonds for colonies, 83

Acts of Trade, English, I 53

Adam, François, see Karrer

Adams, John, address, 36; arrival in Paris, 4I ; letters, 4I, 238

Adams, John Quincy, tariff, 282

Adet, Pierre Auguste, letters, 38, 39, I 30, 258 ; letter to, 22

Administration, colonial, 36, 37, 279; departmental functions, 49,77 , I54, I55, 21 3 ; see also Officials

Admiralty, colonial, 33, 37, 7I ; extracts, archives, I30; jurisdictions, 217, 28I ; Normandy, I05

Africa, botanical gardens, 272; description, 5I ; Dutch colonies and trade, 72, 85, 239; geography, 28I ; memoirs on trade, 204; papers, II 8; Paulmier de Gonerville's voyage, 239; piratical log-book, 3; portolanos, 22I, 222; see also Slave trade

Agassiz, Louis, letters, 260, 275

Agnese, Baptista, atlas, 222

Agriculture, and fisheries compared, 27I ; Canadian crops (I665), I89; control over colonial, I58; Guiana, 93; plows, 259; United States, 275; see also Land; Plants; Products; Wheat

Aigle, I3I

Aigle d'Or, I82, I83, I89, 25 I

Aigle Noir, I96

Aiguillon, Armand, $d u c$ d', attitude on American Revolution, 245 ; letters, 248,278 ; memoirs, 245

Ailleboust de Coulonge, Louis d', 69, I70

Akakia, Roger, see Du Fresne 
Alabama, C. S. S., Kearsarge fight, I27

Alabama claims, I32

Alabama Indians, and Louisiana, 25

Alabama River, map, 227

A la Claire Fontaine, song, I02

Albany, N. Y., Canadian Indian trade (I7I6), 7I ; geology, 259; map, 226; travel, I 33, 274

Albemarle, George Monck, duke of, grant, I80

Albert, —, letter ( I798), 93

Albert, Charles d', see Chaulnes

Albert de Rions, François Hector, comte d', campaign, 36 ; letters, I 22

Alcedo, Antonio de, 220

Alcide, 75

Alembert, Jean le Rond d'. see Le Rond

Alexander, Benjamin McTosh, I2

Alexander, Sir William, patent, 6, 26I

Alexandria, Va., port, 39

Alfred, 22

Algeria, pirates, I93

Algonquin Indians, dictionary, 75; missionary, I 56

Alicante, codfish trade, I 44

Aliens, domicile, Io; Franco-Spanish private international relations, II5; imprisonment and expulsion, I3, I6, 22, 48; naturalization, Io

Alliance, $\mathrm{I} 22$

Alliance, Franco-American, I26, 212

Allouez, Claude Jean, on mission, 72

All Saints Bay, I80, I95, 223, 26 I

Ally St. John, — , I I 6

Almanacs, "Calendrier de Boston i777", 61

Alméras, G. d', letter, I 84

Alongny, Marquis d', I 78

Alphonse, Jean, extracts, II 8

Alvensleben, Philip Charles, baron von, despatches, 95

Alves do Coutto, Nuno, 277

Alzate y Ramirez, Joseph Antonio de, maps, 223, 258

Amariton, François, journal, I64

Amazone, 122, I24

Amazon River, region, 277

Ambassades de la Bodeire, I3

Ambassadors, correspondence, Austrian, 94, 95; English, I94; French : to England, 5, I3, I7, $28,48,70,95,96,205-207,25 \mathrm{I}$; to Netherlands, I4, 47, 262; to Portugal, I 77, 205 ; to Rome, I3, I4; to Spain, I3, 28, 48, I 47, 205 ; Prussian, 95; see also Treaties

Ambition, 276

Ambulances, improvement, 90

America, censored works on settlement, 62 ; commerce, 3 ; cosmography, maps, 4, 5, 25, $26,42, \mathrm{I} 54, \mathrm{I} 8 \mathrm{I}, 2 \mathrm{I} 6,22 \mathrm{I}-223,257$; descriptions, coasts, I 5, 25, 5I, 53; discovery, effect, $28,6 \mathrm{I}, 73$, I43, 207; division (I626), 276; exploration, 43 ; history, bibliography, references, I 43, 256, 28I ; natural history, 40, 86, 272, 274; papers, I05, I79; project of treaty on expeditions, 47 ; state (I740), 43 ; treaty of Vaucelles and French conquests, 262 ; see also divisions by name

Americain aux Anglais, $6 \mathrm{I}$
American Academy of Arts and Sciences, 259, 260

American Antiquarian Society, 260

American Historical Review, 4I, 48, I27, 207

American Institute of Instruction, 282

American International Committee, 90

American Revolution, and home relations of European colonies, I2I ; and West India trade, I 2I ; Anglo-French relations, 3I, 45, I22, 243, 267 ; Boston, I23; Bougainville's journals and papers, I20, I2I ; Canada, I29 24I, 277; censorship reports on French books, 60, 6I ; conditions ( 1777 ), 88; correspondence of Austrian ambassador, 94, 95: description by French traveller (I777), 45: Dickinson's Letters, I47; Doniol's papers 9I-93; effect in Amsterdam (I774), I2I ; ex ample in Louisiana revolt, I 46 ; foreseen, 30 Franco-American communication, I22, I24 Franco-Spanish peace suggestions, I 23 French aid, supplies, 87, 9I, I 20, I22, I23 I26, 245; French alliance, value, I26, 2 12 French attitude, policy, 75, I23, 2I 4, 24I 244, 245; French colonial supplies, 278 French declaration of war, reasons, I I, I33 French expedition against England, 266 French forces (I779-80), 76; French letters I22, I 23; history, 24I, 244; influence ir Europe, 255; Kalb's correspondence ( 1767 . 69), I26; Lafayette, I22, I46; La Pérouse': journal, 36; maps, 230; Margry's article I 29; news in Europe, II, 246 ; notes, obser. vations, I 22, I $26,245,267$; Rochambeau' army, 9I, I23, I25, I26, I29, I4I ; rumorec truce negotiations, II ; South and Santc Domingo, I2I ; Spanish attitude, 245, 267 Spanish operations, I22; Talleyrand's mem oirs, 9I ; verses, 243; Virginia, Yorktown 44, 75, I22-I25, I27, 287; see also next title Commissicners at Paris; Paris, treaty of

American Revolution, naval affairs, 257, 278 changes in English and French navies, 76 English fleet, I22; Estaing, 122, I24-126 245; French correspondence, I24-I 26 French plans, finances, I22, I 23, 256; Frencl warships and American ships ( I 776-77), I2I I 22 ; Grasse, I I, I20, I2I, I23-I 25 ; Guichen 122, I25; Hudson Bay, 36, I23-I25; Jones I22, I24; privateers, I30, 25 I ; Ternay, I22 I 25; West Indies, I I, 45, 76, I2 I, I 22, I25 I 30, 235-237, 24I

Amériquain, play, 85

Amiens, treaty of, Louisiana, I 43

Amiol, Philippe, inventory, I06

Amitié, 198

Ammunition, see Arms

Amnesty, coureurs de bois, Io; Martinique, 78 pirates, 33,78

Amphitrite, I 26

Amsterdam, and American crisis ( I774), I2I

Anctéville, d', letter I 48; memoir, 233

Andros, Sir Edmund, letters, I04

Angelis, Pierre de, letter, 260

Angelus, - $\longrightarrow$, portolano, 26

Angeville, — d', letter, 68

Anglo-Dutch War of 1665,28 
Inglo-French War of 1627 , declaration, 252 inglo-French War of I666, Acadia, I92; declaration, I53; West Indies, I89-I9I ; see also Breda

Anglo-Spanish War of 1656, causes, 206, 207

inglo-Spanish War of I665, I 45

inglo-Spanish War of I739 (Jenkins's Ear), American preliminaries, I45; Cartagena, I 45, I 52, I 54; Florida-Georgia, I 45; French interest, 280 ; naval affairs, I 45 ; news, I 45, prizes, I45; references, 245 ; see also King George's War

Ango, Jean, I I 8

ingrand, Léonce, collection, 220, 22I ; on Gardens of Lima, 220 ; papers, I42

inimals, American mammals, 272; American prehistoric, 258-260; Canadian, drawings, 75; Newfoundland, 259, 273; see also Natural history; animals by class and name

Anisson (?), - memoir, 49

tnisson-Duperron, Etienne Alexander Jacques, collection, 6I; letter to, 88

Anjou, Duc d', see Henry III. of France

Anjou, France, memoir, 266

Inna Gally, I33

Annales de Bretagne, I7

Annals of Education, 283

Annapolis Royal, see Port Royal

Anne Marie Hiacinthe, Sister, I7 I

Anticosti, description, I7 I ; map, 225; memoir, $27 \mathrm{I}$

Antietam, battle, hospital, 90

Antigua, French capture, 63 ; printing in, I42; Villepars, I95; see also West Indies

Antilles, see West Indies

Antilles Anglaises, 62

Antin, Marquis d', I 52, 232

Antoine de Sainte Marie, voyage, 26

Antwerp, truce, negotiations, I3, 28, 47, 52, 54, $70,73,96,207,208,266$

Anville, Christophe, duc d', see Damville

Anville, Jean Baptiste Bourguignon d', maps, catalogues, I 44, 22 I, 225, 223, 243; list of MSS., I 44

Anville, Nicolas de la Rochefoucault, duc d', squadron, 32

Apache Indians, Peñalosa, I 52

Apalache, Spanish fort, 25

Apologie du Commerce, censured, 62

Apologie pour... Sainct Christophe, 53

Appalachian Mountains, 44, 240

Arago, François, correspondence, 256

Arbuthnot, Marriot, squadron, I24

Arc-cn-Ciel, I36, I40

Archaeology, Angrand's Spanish-American plan, 220; Boban-Duvergé correspondence, I4I ; Central American notes, 220 ; Colombian, 259

Archangel, trade, 193

Archives du Service Hydrographique, "Grande portefeuille", 3

Archives Nationales, map collection, 22 I

Arctic Ocean (North Sea), description, 5I ; Franklin, II7; Mackenzie, 229; maps, 69, 255; trade, 69; see also Polar exploration Ardent, 22
Argall, Sir Samuel, Acadia, 48

Argens, — d', letter to, I46

Argenson, — d', papers, I58

Argenson, Marc Antoine René de Voyer d', see Paulmy d'Argenson

Argenson, Marc Pierre de Voyer de Paulmy, comte d', dedication to, 240; letters to, papers, 24I-243

Argenson, Marc René de Voyer, marquis d', letters, 2 I 6

Argenson, Pierre Voyer, vicomte d', letter, I I6; papers, I03

Argentina, see Buenos Aires

Argentré, Bertrand d', Bretaigne, 6

Argonaute, I 53

Argoud, Pierre Joseph, letters, I 36

Argouges, François d', letters, I93

Argout, Comte Antoine Maurice Apolinaire d', letter, I2I

Ariel, I22

Aristides Aubert Dupetit Thoars, George d', see Thoars

Ark, 22

Arkansas, printing, I42

Arkansas Indians, English traders, 98

Arkansas River, map, I77

Arlington, Henry Bennet, earl of, complaint, I7

Arms and munitions, Acadia, I95; Canada ( I665-I7I I ), I35, I37, I4I, I 87, I90, I9I, I93; Compagnie des Indes Occidentalis, I95; defective, I40; French, for American army, I 22; Placentia, I64, I65, I9I, I95; required freight, I39, 218; West Indies, I9I ; see also Army; Supplies

Army (troops), French. Acadia, I35, I63; cadets, 80, 8I ; Canada ( I66I-97), Io, I 06, 134-136, I39-I4I, I60, I63, I 81, I 84, I 87-190, I92-I94, 20I ; clothing, I05, I 35, I 40, I 4I ; convicts for colonial, I 38 ; cost of company of fifty, I05; cruel officers, I40; deserters, I63; discharged soldiers as settlers, I37; expenditures, funds ( I66 I-I707), I37, I39, I87, 202, 203, 25I ; half-pay commission, I38; Ile Royale, I I ; leaves of absence, I37; lieutenant-general's guard, 27; Louisiana, $40,83,84$; marriage of soldiers, I I6; Martinique revolt, 80 ; Newfoundland, I6I; officers in colonies, lists, commissions, promotions, I0, 73, I 40, I4 I, I 53, I60, I62, I63, I69; pay in colonies, I6I, 204; rank in colonies, I60; regulation of colonial ( I77275), I $2 \mathrm{I}, 267$; transportation, I37, I40, I84; West Indies ( $1663-85)$, I35, I4I, I84, I85, I 89-I9I, I95, I96, I98, I99; ( I790-I 805), I 43 ; see also Arms; Impressment; Indians; Marines; Military; Supplies; Swiss; wars by name

Army, Spanish, colonial commission, I63

Arnauld de Pomponne, Simon, see Pomponne

Arnault, François A., Mines de Cuivre, Io8

Arneth, Alfred, ritter von, Correspondance Secrète de Mercy-Argenteau, 94

Arnold, Benedict, treason, 244

Arnold of Florence, globe, 222

Arnoul, Nicolas, collection, correspondence, I 34 
Arnoul, Pierre, collection, correspondence, I34- Auteuil, François Madeleine Fortuné Ruette, I4 I

Arouba, description, 72

Arsac, Charles Louis d', see Ternay

Artaguette, Diron d', 59

Arthaud, Charles, letters, I30

Artibonite River, plans, 233-235

Artigny, - d', papers, I05

Artois, Comte d', see Charles X.

Artur, Dr. - on Guiana, 83,84 ; translation, 84

Artur, Julien, 52

Asia, commerce, 51, 209, 252, 26I ; maps, 222, 223

Assaying method, I3I, I54

Asseline, David, letter, 162

Assiento, English, treaty, 82, 255, 265; FrancoSpanish, with Guinea Company, 20, 82; French, proposals, treaty, 34, 8I, 82, I36, I 38,213 ; see also Slave trade

Astrée, I24, I26, I 56

Astronomy, observations, 26, 34, 45, I27, 276, 277; phenomena, I8I

Atlantic Ocean, description, 5I; discoveries in southern, 67; journal, 277; maps, 3, 222, 223,255 ; positions, 277

Atlas, 24I

Atlases, see Maps

Aubenton, see Daubenton

Aubert, Claude, notary, 106

Aubert de la Chesnaye, Charles, see La Chesnaye

Aubertin, Charles, "Bourgeois de Paris", II

Aubery, Joseph, letters, I04

Aubeterre, Joseph Henri d' Esparbès de Lussan-Bouchard, marquis d', letters, 32 ; "Projet sur la Jamaique", 3I

Aubin, Joseph, collection, 2

Aubry, Charles Philippe, letter to, 31 ; lost at sea, II4

Aubusson, see Daubusson

Auch, France, colonial trade, 57

Auchy, France, I 63

Audier, P., map, 23I

Audiger, Sieur, I 59

Audouin, Jean, suit, 280

Audrain, Pierre, letter, 245

Audubon, John James, letter, 260

Auger de Subercase, Daniel d', see Subercase

Aulnay Charnisay, Charles de Menou, sieur d', and $\mathrm{La}$ Tour and English, 46, 53, 264; Le Borgne's rights, I63; letters, I03; papers on, I07; petition of children, services, I92; successor, I70

Aumont, Maréchal Jean d', letter, I03

Aumont, Louis, duc d', despatches, 28

Aunis, France, port, I 28

Aunoy, - d', Louisiana plantation, 30

Aurore, 276

Auroy, Amable, I02

Austria, despatches from Paris (I7I5-92), 94, 95 ; truce of Antwerp, 13

Austrian Succession, War of, see Anglo-Spanish War; King George's War

Auterive, see Dauterive

Auteroche, see Chappe de Auteroche

Auteuil, $-\mathrm{d}$ ', pension, I56

Auteuil, Denis Joseph Ruette d', papers, Io4 sicur d', on state of Canada, I05; restoration, I 2,7 I

Auteuil de Monceaux, _- letter, 8o

Autichamp, Comtesse d', 233

Autographs, Canadian officials, 102

Auvergne, Marie d', papers on, Io7

Auvray, Lucien, Cat. des MSS., 3, I 49

Auxillion, Paul d', papers on, IO3

Avaugour, Pierre Dubois, baron d', governor, I82, I84; papers, 104

Avaux, Claude de Mesmes, comte d', 76

Avenant, see Davenant

Avenant, 67

Avenel, Georges, vicomte d', Lettres de Ma arin, I 80

Avesac, Armand d', Bref Récit, 7

Azores, 262; voyage, I62

Azyr, Vicomte d', letters to, 238

B., J. C., "Voyage au Canada", 87

Baas, - - de, and Du Lion, I93; expedition, I 50, I97, I 98; letter, 200 ; letters to, I6, I7; salary, 203

Bache, Alexander D., letters, 256, 28I, 282

Bache, Franklin, 9o

Bachelot de la Pylaie, Auguste J. W., see La Pylaie

Bacon's Rebellion, 2I 5

Bacqueville de la Potherie, Claude Charles le Roy, sicur de, letter, I 44

Badine, 24

Baffin's Bay, fish, 260; whaling, I28

Bahama Channel, 258

Bahama (Providence) Islands, grant, I80, I8r ; pirates, 78 ; printing, I 42

Bahia de Todos Santos, see All Saints

Baie des Puants, see Green Bay

Baillet, Heües O'Neil Adrien, see Beaulieu

Bajot, Sieur, 227

Balliard, Charles, correspondence, I4I

Balloon, Philadelphia ( I784), 244

Baltic region, sugar and tobacco trade, 77

Baltimore, George Calvert, baron, charter, I8I

Baltimore, letters from, I3I; plan of portion, 230

Baluze, Etienne, collection, correspondence, I49, I 50

Bancroft, Edward N., letter, 238

Bancroft, George, Brownson on, 282 ; extracts, I08; letters, 282

Bank, Capt. John, 98

Banking, Law's, 83, I44

Bank-notes, Louisiana fund, 59

Banks, fisheries, see Newfoundland fisheries

Baptism, Montreal records, Io6

Barataria Bay, Lafitte, I 43

Barbados, commerce, 3 ; maps, 235, 257 ; printing, I42; secretary, I80; slave revolt, $20 \mathrm{I}$; see also West Indies; Windward Islands

Barbary, voyage, 277

Barbel, - Bastille papers, 247

Barbé-Marbois, François, marquis de, American seeds, 272, 274; Journal d'un Deporté, MS., 44 ; letters, I30, 282 ; letters to, 4I, I32

Barber, E. A., letters, 4I

Barber surgeon, Quebec, I04 
3arbier, Alfred, attributions by, 60, 61, 265

3arbier, Antoine Alexandre, notes, I43

3arbier du Bocage, Jean Denis, map collection, 22 ; planisphere, 223

3arbin, Claude, I02

3arillon d'Amoncourt, Paul (marquis de Branges), letter, I04; negotiations, I69

3arlovento, $\longrightarrow$, fleet, I 39

3arlow, Joel, correspondence, I33; notes on, I43

3arnes, Joseph K., letters, 90

3arnet, J. Cox, letter, 245

3arney, Joshua, letter to, 20

3aron, Hyacinthe Théodore (?), research commission, 34

3arrailh, Capt. —_ de, voyage, I 2

3arras, Louis, comte de, letters, I22, I24

3arren Hill, action, map, 230

3arrère de Vieuzac, Bertrand, translation, 87

3arrin, Rolland Michel, sce La Galissonière

3arringer, George A., Cat. de l'Histoire de l'Amćrique, I

3arrois, - , Missions Etrangères, I74

3art, François Cornil, letter, 88

3arthélemy, Abbé Jean Jacques, notes, I 44

3arthès, $-\frac{}{-}$, on Family Compact, 30

3artillat, Etienne Jehannot, sieur de, 202

3arton, Benjamin S., Memoir concerning Serpents, $27 \mathrm{I}$

3artram, John, botanical catalogue, 274

3asamier, Martin, Floride, 4, I I 4

3aschet, Armand, papers, 258

3asques, I 30, I 82, I 88

3asset, Mlle. —, I6I

3assett, John S., Parkman's letters, I I 8

3astille archives, American material, 239, 246250

Baton Rouge, plan of fort, 229

3audard de St. James - , in Bastille, 249

Baudin, Capt. Nicolas, 274

Baudrand, Michaelis Antonius, geographical remarks, 46

Baudry des Lozières, Louis Narcisse, papers, I3I, I 43

Baumgarten, Anton, eulogy on Rumford, 258

Baussan, - letters ( I789), I32

Bavaria, elector of, and colonization, 84, I87

Baxter, James P., Cartier, 217

Bayard, I27

Baye de St. Joseph, map, 227

Baye de St. Louis (Bernard), maps, 227, 228

Baye de St. Paul, mines, 270

Baye du St. Esprit, map, 228; proposed expedition, I38

Bayonne, commerce, 3I, 56, 57, 74, I 28, I32, 240, 252; fisheries, I85, I88; whaling, 81, 82

Bazin, Pierre, I 38

Bears, notes, 272

Beaubois, Nicolas I. de, 240

Beauchamp, Alphonse de, Voyage, 87

Beauchesne-Gouin, - de, voyage, 25, 67, 84, 252

Beaucourt, sec Boishébert de Beaucourt

Beaudouin, Abbé, journal, I39

Beaufort, François de Vendôme, duc de, letters, I 82, I 92
Beauharnois, Charles de la Boische, marquis de, and Eléphant, 225; and Foxes, letter, 8I ; and La Vérendrye, letter, 82; Iroquois speech, 79; letters to, 8I

Beauharnois, François, chevalier de, family, notes, I06; letters, I06, I I I, 268; letter to, 218 ; to and from Canada, 67,140

Beaujeu, —, and La Salle, I00, I09, I35, I36; decoration, I78; letters, 64, 66, 67, I99

Beaujeu, Abbé de, letters, 248

Beaujeu-Villemonde, Louis Liénard, sieur de, I69

Beaujour, Félix, Apperçu des Etats Unis, 87.

Beaulieu, Charles, Cat. des MSS. . . Universités, 28I

Beaulieu, Heües O'Neil Adrien Baillet, sieur de, journal, I8o; letter to, I80; translation, 53,179

Beaulieu, J. de, letters, 207

Beaumarchais, Pierre Augustin Caron de, American affairs, 95, I 26, 245; dinner for, 126 ; letters, I23, I24; peace suggestions, I23; portrait, I23; satirical verses on, 77, I47; $V$ oeu de toutes des Nations, 60

Beaumont, Christophe de Harley, comte de, correspondence, 95, 109, 25I

Beaumont sur Vigenne, 217

Beaurain, Chevalier de, map, 230

Beauséjour, capture, 2I4

Beausoleil, tomb, 79

Beaussier de Châteauvert, - cruise, I22

Beauvais, Samuel de, translation by, 26

Beauvais le Fer, — de, letter to, 82

Beauval-Ségur, _- "Saint Domingue ", I I 5

Beauvillier, Paul de, see St. Aignan

Beauvilliers, Sieur de, map, 227.

Beauvois, see Palisot de Beauvois

Beaver trade, Canadian, 214, 245; cloth, I88; Compagnie des Indes, 59, 60; contracts, I30; discount, I2; duties, Dutch, French, Spanish, 100, I92, 214; English, 247; freedom, I9, 20, 82 ; hats, Canadian, French, 85 , I I 8 ; history, 257; Hudson Bay, 36, 84; La Rochelle, I 36 ; Louisiana, 255; memoirs, 53, 195, 212, 240 ; notes, 72, 78, I7I ; prices, 9 ; references, 47 , 252; regulations, 57, 76; Russians, I93; see also Fur trade

Bécancourt, René Robineau de, I62; papers, I06

Bechameil, Louis de, letters, I83, I85, I88, I90, I9I; memoir, 280

Beck, John B., letter, 238

Becker, Léonard Nicolas, correspondence, 126

Bédos, - , letters to, 2I

Beecher, Henry Ward, I3I

Bégon, Michel [I], La Rochelle memoirs, 266, 280 ; letters, $24,63-69$, I70; Martinque memoir, 98 ; natural history collection, I54; papers, La Salle, I09

Bégon, Michel [2], and card money, 89 ; decoration, 157 ; instructions, 12 , 156 ; list of passengers, I 57 ; papers, I08

Belain, Pierre, see Esnambuc

Beletrus, $-\frac{}{A b b}$, Louisiana memoir, 2I3

Beliardi, Abbé Augustin de, career, papers, 2932,43

Belin, Jacques, suit, 156 
Bellard, Christophe, 20

Belle, I 35

Bellefeuille, F. de, letters, I28

Bellefond, Alexandre, in Bastille, career, 246, 249

Belle-Ile, France, I76, I8I, 20I

Bellestre, Anne Picoté de, letter, 66

Bellettes, J., letter, I85

Bellièvre, Pomponne II. de, see Grignon

Bellin, Jacques Nicolas, Antilles Anglaises, 62; error, 42; maps, I26, 225, 228; papers, II 3

Bellinzani, Père François, letters, I95, I96, I98, I99, 201 ; letters to, I95, I 96, 201 ; memoirs, I94, 200 ; notes, I95; return, I95

Belliqueuse, 127

Belliqueux, I97

Bellot, Joseph René, letters, I I 7

Belmont, - de, 225

Belmont, August, correspondence, I4 I

Belmont, Abbé François Vachon de, Canada, MS., 43, I05; Canadian papers, 43; Laval funeral oration, 40

Belot, Charles E., memoir, 238

Beltrami, J. C., letter, 260

Benbow, John, West Indies, I39

Benedictines, 23, 54

Benevent, abbey of, suppression, I7I

Benjamin, Judah P., I42

Bennet, Henry, sce Arlington

Beranger, Jean, map, 227

Berger, - letters, 20I

Bergier et Cie, monopoly, 21 8

Bering, Vitus, 40, I56

Bering Strait, Iberville's queries, 65

Berjon, Jean, I02

Bermudas, coasts, 276; French trade, 8; Mourand's journal, 277 ; printing, 142

Bernier, —, letter, I32

Bernis, François Joachim de Pierre, cardinal de, letter, 73

Bernou, $A b b \dot{e}$, and Renaudot, letters, 97, II7; and St. Sacrament, I77; Clairambault and papers, I5I ; Hennepin's complaint, I52 ; letters from Rome, American affairs, 98-IoI; letter to, I72; maps, 98, I77; Martinique memoir, I 52 ; on bishopric, I76; on Guiana claim, I76; papers: on American colonies, I72-I77; on Marine, I59; Villermont correspondence, 64

Berruyer, Capt. $\longrightarrow$, St. Christopher, I I5

Berry, Duchesse de, 222

Berryer, L., letters, I94, I98

Berryer, Nicolas René, correspondence, 35, 36, 62

Berthelot, — Compagnie des Indes, 59, 60

Berthou, —- map, 23I

Berthoud, Ferdinand, 276

Bertius, P., map, 25

Bertram, L., 237

Besançon, artillery regiment, 267

Beschefer, Père Thierry, letters, I75, 217

Bessa, P., drawings, 270

Bessière, Jean Baptiste, letters to, 2I

Béthune, - see Charost

Béthune, Maximilien de, see Sully

Betou, - letter to, 75

Betoulat de la Petitière, André, sce La Vauguyon
Betsey, 38

Betsy, two ships, 22

Beugnot Collection, 256

Béziers, bishop of, see Bonzy, Pierre de

Biard, Pierre, I07

Bibaud, Maximilien, Bibliothèque Canadienne. I04

Bibliothèque de l'Arsenal, origin, 239

Bibliothèque de l'École des Chartes, 3

Bibliothèque Nationale, American material in imprints, I ; departments, I, 2 ; fonds of Dept. of MSS., guides, 2 ; history, I ; location and use, I ; MSS. Français, series, catalogues, 2,3

Bicêtre, prisoners from, 250

Bic Island, map, 224

Bicn Aimé, I 20

Biencourt, Marquis de, letter (1847), I07

Biencourt de Poutrincourt, Charles de, letter, I07; notes, I07

Biencourt de Poutrincourt, Jean de, correspondence, papers, 107, 204; family, I07; suit, 107

Bienville, Jean Baptiste le Moyne, sicur de, burial certificate, III ; criticized, $24 \mathrm{I}$; illness, 56; Louisiana affairs (1700), 24, 25, 98; map of grant, 228; Natchez expeditions, 78; papers on, I08; signature, I62; will, II 2 Bienville Island, 227

Biët, Antoine, Voyage, 9

Bigelow, John, letters, 256

Biggar, Henry P., Early Trading Companies, 4; Voyages of Cartier, 25

Bigot, François, case against, Bastille, 35, 49, I28, I 45, 212, 247, 249, 250, 280 ; papers, 36 , I 3

Bigot, Père Jacques, 65 ; letters, I04

Big Stone Lick, 260

Bilbao, fish from Newfoundland, I49

Bilbaud, - , letter to, I8I

Billeau, _ , trial, 247

Billiard, Auguste, on abolition, 93

Billiet, $\longrightarrow$ letter to, 22

Billings, John S., 90

Billon, J. F., letter, I42

Billouart de Kerlérec, Louis, see Kerlérec

Bills of exchange, and card money, 70 ; colonial, rate, I4, 36, 202; treatise, $28 \mathrm{I}$

Biloxi, old and new, 25, 67, 78, 88, 97, 98; map, 227

Binneteau, Père Julien, 97

Biography, French-Canadian notes, I06

Bions et Brians, La Rochelle merchants, I36

Birch bark, letters on, 93

Birds, Newfoundland and Iceland, 272

Bishopric, proposed colonial, 84, I00, I76, I77; see also Quebec, bishopric of

Bixio, Alexandre, collection, letters to, I 46

Bizard, Jacques (?), papers, Io6

Black Princess, I 30

Blaeu, Guillaume, on commercial company, I79

Blanchard, Guillaume, Compilation Chronologique, MS. additions, I4

Blénac, Charles de Courbon, comte de, instructions, 252 ; letters, operations, I65 
Blodget, Nathan, Paul Jones fight, I 22

Blondel, —, map, 235

Blondel Jouvancourt, -

Blossac, - correspondence, 2I 3

Blosseville, Jules Alphonse René Poret, baron de, letter, 260

Blot, Claude, letter, I 87

Board of Trade, Spanish memoir on, 30

Boban-Duvergé, Eugène, correspondence, I4I ; Documents ... du Mexique, 2

Bobé, Père —, letters, 266, 272; on South Sea, 266 ; papers, I08, I I3; wrecked, I I 4

Bochart, Jean, see Champigny

Boinet, A., catalogue of MSS., 270

Boisbriant, Pierre Dugué, sieur de, 25, 255

Boisforêt, — de, map, 234

Boishébert, Charles Deschamps, sieur de, charges against, defense, 88, 247, 249; letters, 8I, I 57 ; papers on, I 06

Boishébert de Beaucourt, —, petition, I60

Bois-le-Comte, Charles Joseph Edmond, Comte de, on Portuguese colonies, 278

Boisnard Brothers, 85

Bois St. Lys, G. J., maps, 228, 229, 234

Boissise, Jean de Thumery, sieur de, correspondence, 5

Boissy, Clément de, collection, 32, 76; Juridiction de la Chambre des Comptes, 32, 76

Boissy d'Anglas, François Antoine de, collection, 279

Bolivar, Simon, letters, 256

Bonaire Island, description, trade, 72, 239

Bonamy, —- collection, 254

Bonaparte, Charles Lucien, letters to, 275

Bonaparte, Joseph, letters, portrait, I 46

Bonaventure, Simon Denys de, I74

Bondois, Paul M., Cat. des MSS. de Colbert, I79

Bondot, Abraham, on St. Castin, I67

Bongars, — , correspondence, I47

Bonnac, Jean Louis d'Usson, marquis de, letters to, I I 5

Bonnaissieux, Pierre, Grandes Compagnies de Commerce, I7

Bonnard, - , letter to, $2 \mathrm{I}$

Bonnault, Pèré André (?), letter, I63

Bonne, Rigobert, memoir, 8

Bonneau, Simon, I3

Bonnécamps, Père Joseph Pierre cie, papers, 42, I08

Bonnéfoux, - $\longrightarrow$, correspondence, I26

Bonnet, - on Toussaint, 94

Bonnevie, _- papers, I08

Bonnot de Mably, Gabriel, see Mably

Bonpland, Aimé de, 260

Bonrepaus, François d'Usson, marquis de, letters to, I I 5 ; negotiations, I 69

Bonzy, Pierre de, bishop of Béziers, instructions, I3, 205

Bool, Capt.

Boppe, Auguste, 76

Borda, Jean Charles, chevalier de, correspondence, I26; expedition, 276

Bordeaux, Antoine de, see Neufville

Bordeaux, and Compagnie du Nord, I92; commerce, 53, 56, 74, I 56, I 98, 240, 252, 266; fishing, 53, I49, 204; packet-boats, I29; slave trade, 53, 56; wartime navigation, 29, 242; see also Parlement

Boreel, Guillaume, letter, I87

Borelli, Giovanni Alfonso, assaying, I 54

Borne, Edme Étienne, see Desfourneaux

Bory, Gabriel de, letter to, 88 ; papers, 8

Bosc, Louis Augustin Guillaume, on spiders, 27 I

Boscawen, Edward, 75

Boston, Acadian wartime trade, I69; almanac, 6I ; astronomical determination, 8; correspondence from, I62; fire ( 1872 ), 90 ; French plans against, I 6 , I38, I39, I69, I74; Lafayette, I22; Lowell Lectures, Agassiz, I32, 275 ; military preparation (I696), I70; reported French capture, 214; St. Castin on, 98 ; siege, maps, I23, 230; social observations, 162

Boston, 22

Botta, Carlo, Guerre de l'Indépendance, 87

Bouchard, see Aubeterre

Boucher, Pierre, Histoire Veritable, I02; notes on, 106

Boucherat, - , I 90

Boucher de Niverville, —-, notes on, I 08

Boucherville, Sieur de, see Boucher, Pierre

Boudeuse, 273

Boudier, J. J., map, 228

Bouffonne, I 42, 201

Bougainville, Louis Antoine, comte de, American Revolution, journals and papers, I20, I2I ; Cincinnati, I2I ; circumnavigation, journal, I20, 273; French and Indian War, journal and papers, I05, II9, I20, I32; papers on, I 19 ; reputed Indian son, I20

Bouger, Pierre, expedition, 256

Bouguier, -

Bouillé, François Claude Amour, marquis de, West Indies, correspondence, I 26, 235-237 Boundaries, Acadia, I07, I8I, 265 ; censured work on American claims, 62; English encroachments, I I0; Guiana, 78, 79, 278; Hudson Bay, 23; Louisiana, I 20; New France, 243; proposed Anglo-French commission ( 750 ), 2I2; Santo Domingo division, 31 ; Silhouette and American, 73

Bourassa, N., letters, I 28

Bourbon, - , request (I689), I64

Bourbon, Henri de, see Condé

Bourbon, Louis de, see Condé

Bourbon, Louis Alexandre de, see Toulouse

Bourbon, Louis Henri, duc de, 240

Bourbonnais regiment, I 29

Bourdet, $C a p t, \longrightarrow$, and Frontenac, letter, I96

Bourdon, Jean, I90, 202; maps, 224; notes on, I08; voyages, 107

Bourgeois de Boynes, see Boynes

Bourgmont, Etienne Venyard de, 80, I08, 240

Bourgogne, I29

Bourgoing, Jean François, baron de, letter, I 44

Bourlamaque, François Charles, chevalier de, 242

Bourlemont, Abbé de, I7, 205

Bournon, Fernand, Cat. des MSS. de l'Institut, 254

Boursier, - , suit, I 57

Bourzeix, Abbé, memoir, 206 
Boutard, Abbé François, 68

Bouteille, —, letter to, 20

Bouteroue, Claude de, I6, 25 I

Bouton, Père Jacques, Relation, I I5

Bouvart, Père Martin, correspondence, I04, 268

Bowditch, Henry I., letters, 257

Bowen, Thomas, map, 237

Boynes, Bourgeois de, coat of arms, 223; letter to, 278

Boze, Claude Gros de, see Gros

Braddock, Edward, defeat, 270

Braems, Daniel, memoir, 239

Brainard, D., letters, 90

Bralle, - , censorship reports, 6I

Brandy, see Liquor

Brandywine Creek, sketches, 270

Branges, Marquis de, see Barillon d'Amoncourt

Brasseur de Bourbourg, Charles Etienne, letters and memoirs, 220

Brazil, boundaries, 79, 278; Capuchins, I77; commerce, 5, 77, 205; Denis papers, 276278; Douville's travels, 278; Dutch, 69, 77, 96, I80, I95, 223, 261, 264; expeditions, 6, II8; fish, 260; Forant, 202, 203; gold, 23; governors, list, 54; Huguenots, I74; Jesuit martyrs, 75; languages, 74; maps, 222, 256, 278; memoirs, relations, 26, I39, 207 ; news (I734), 82; precious stones, 8I ; shipbuilding, I89; sugar, 85 ; voyages, 87 , $217,239,277$

Bréard, Jacques Michel, charges against, Bastille, I45, 247, 249, 250

Bréauté, Nell de, see Nell

Breboeuf, Jean de, 54

Breda, Zébédée de, 82

Breda, treaty of, Acadia, I6; Anglo-Dutch territory, 263 ; extract, 47 ; text, 48,215 ; West Indies, I92

Breedon, Gov. Thomas, i 80

Brehaut de Galinée, see Galinée

Breignon, - - suit, 2I I

Breluque, - , letter to, 269

Brequigny, Louis G. O. F. de, collection, 216

Breslay, Père - 78 , 156

Bressani, Francisco Giuseppe, Breve Relatione, 72 ; captivity, 72

Brest, admiralty archives, I30; American Revolution, 4I, I25; as port, 56, I64, I97 ; fleets, 63, 212

Breteuil, Louis Charles Auguste le Tonnelier, baron de, correspondence, 213

Bretignières, — de, protest, 204

Bretigny, - , correspondence, 126

Bretigny, Charles Poncet de, voyage, 265

Breton de la Martinière, Jean Baptiste Joseph, translation, 87

Breugnon, - $\longrightarrow$ letters, I22

Brewing, Talon, 72 ; workers for Canada, 189

Breze, I84, 251

Briand, Jean Olivier, bishopric, I68

Brians, see Bions et Brians

Bridger, John, letter to, 175

Bridgetown, Barbados, plan, 235

Brienne, Henri Auguste de Loménie, conte de, collection, 3, 95-97; correspondence, papers, 48,69
Brienne, Hubert de, see Conflans

Brigham, Charles B., letters, 90

Brimstone Hill, St. Christopher, siege, plans, 236

Brinton, Daniel G., correspondence, I4I

Brion, Comte de, see Damville

Brion Island, concession, 78

Briqueville, François de, see La Luzerne

Brisacier, Abbé —, I3; 70, 268

Brisay, Jacques René de, see Denonville

Brisbane, Albert, 283

Brison, Claude de Roquemont, sieur de, see Roquemont

Brisonnier, - - Acadian commission, 69

Brissart, P., engraving, I69

Brissot de Warville, Jacques Pierre, De la France et des Etats Unis, 6r ; in Bastille, 249

British Merchant, French translation, 279

Brittany, Colbert's visit, 206; commerce and manufactures, ports, $15,17,18,56,128,256$; fishing, I5, 195; memoirs, I7, 266, 280 ; proceedings of estates, I7-I9; see also Brest; St. Malo

Brizard, Gabriel, papers, 239, 243

Brodart, Jean Baptiste, letters, I92

Brodhead, John R., I0I, I09, II4

Broglie, Charles François, comte de, papers, I26; plan for English war, 24I

Broglie, Jacques Victor Albert, duc de, Talleyrand's Mémoires, 9I

Broglie, Victor Claude, prince de, Journal du Voyage, 45 ; "Relation", 45

Brongniart, Alexandre, letters to, 274, 275

Brooks, Charles, letters, 282

Brooks, Walter, I2

Brosseau, —, 198

Brothers, 22

Brothers of Charity, see Pères de la Charité

Brou, $\longrightarrow$, letter to, 86

Brouillan, Jacques François de, Acadia, 67; decoration, 178 ; letter, 175 ; signature, 163

Broutin, J. F., 228, 254

Brown, John, raid, I3I

Brown, Marie Aglaée, letters, 257

Browne, Peter A., letter, 274

Brownson, Orestes A., 283; letters, 282

Bruce, Archibald, letter, 274

Brulard, Pierre, see Puisieux

Brulart, Nicolas, see Sillery

Brun, Père Jacques, letter, 216

Brunet, Henri, voyages, log-books, I61, I62, 20 I

Brunet, Jacques Charles, autograph collection, catalogue, II I

Brunetière, Ferdinand, "Direction de la Librairie", 86

Brutus, 39

Bruyas, Jacques, letter, I09

Bruys des Gardes, $\longrightarrow$; censorship reports, $6 \mathrm{I}$

Bryant, William C., 283

Bryon, Philippe de Chabot, sieur de, see Chabot

Buache, Philippe, maps, 222, 258; papers, 223, 257

Buade, Louis de, see Frontenac

Bucaneers, see Filibusters

Bucher Martigny, - on Ecuador, 277

Buckland, William, letter, 260 
Buenos Aires, affairs (I840-47), 258; capture, 257 ; commerce, 3I ; memoirs, I39; plan against, I80; voyage, 33 ; see also La Plata Buffalo, N. Y., Plée's visit, 274 ; sketches, 270

Buisseaux, Samuel Spifame, sieur de, despatches, 48

Buisson, J. F., papers, I I3

Bullarium Romanum, 27

Bulloch, Archibald, correspondence, I2 I

Burch, Conrad van der, map, I79

Burgoa, Francisco de, Geographica Descripción, 278

Burgoyne, John, I I, 45

Burgundy, documents, 216

Burials, Santo Domingo register, 8I

Buron, Edward J., "Chateaubriand en Amérique ", 4I

Butel du Mont, — , censor, 62

Buteux, Père Jacques, on Jogues, 54

Buvat, $\longrightarrow$, notes, I3 I

Buzenval, Paul Choart, sieur de, Antwerp truce, I3, 73, 96; letters, I4; Lettres, I4

Byron Island, see Brion

Caanibas, Sagean's relation, 25, 67, 69, 108, I77 Cabarrus, Dominque, I 28

Cabart de Villermont, Esprit, and Bernou and LaSalle, I 00, I0I, I09; correspondence, 24, 63-69, 98, I09, I73, I75; health, I49; memoir, I4; papers on, I08

Cabeça de Vaca, see Nuñez

Cabinet des Titres, MSS. from, 3

Cabot, John, 28, 97, 262

Cabot, Sebastian, 97

Cacao, cultivation, 79, 82

Cacti, Mexican, 272

Cadet, Joseph Michel, charges against, Bastille, $247,249,250$

Cadet de Saineville, — , censorship reports, 6o, $6 \mathrm{I}$

Cadets, for colonies, 8o, 8I

Cadillac, Antoine de la Mothe, sieur de, and commissions, 70; Bastille, 247, 249; demand, I 59; deposition on Pinet, I68; Detroit, 67; instructions, I05; letters, I68; papers on, I06, I I 2 ; recommended (?), 202

Cadiz, trade, I $7,30,72,85,146,175,239,278$

Caën family, company, 6 , I 5, 33, 49-5 I, I03, I 53 , 214

Cahideuc, Emmanuel Auguste de, see Dubois de la Motte

Cahusac, Sicur de, instructions, I I 5, 263

Cakchiquel, language, 220

Calais, English prisoners, I8I ; trade, 56

Calderon, José, letter to, 9I

Calendar of State Papers, Colonial, I80

California, affairs (I703), I 54 ; coast, I68 ; commerce, 239; Delisle's MSS., 26; description, 24I ; gold (I706), II6; history and geography, 42, 240 ; Langle, I25 ; maps, 229, 279 ; memoir, 72; piratical log-book, 3 ; trees, 272 ; voyages, $6 \mathrm{I}, \mathrm{I} 33, \mathrm{I} 68$

Caliveni, Grenada, plan, 235

Callaisien, $\mathrm{I} 6 \mathrm{I}, \mathrm{I} 62$

Callières, Louis Hector de, and plan against New York, I74; and Récollets, 23; and
Tonty, 66; certificate, I68; correspondence, 47 , I04, I I2, I75, 268; 'funeral oration, 77 ; memoirs, I04

Calvert, George, see Baltimore

Cambridge, Mass., position, 8

Camp de Lorette (I759), I20

Campeche, coast, I94; filibusters, 33; French wreck, I3

Campeche wood, 30, 263

Campet, Louis César, see Saujon

Campo-Florida, Prince de, I 54

Canada, administrative correspondence, I03; advantages ( 1630 ), 5 ; affairs, conditions, relations, events (1634-69), 46, 72, I05, I30, I85I87, I 89, I 91, I93, 217; ( I690-97), I60, I64, 166, I69; ( เ 702-56), 68, 105, I 57, 267, 268; and certain commercial companies, 96, I03, I85, I87, 20I, 202; and ports of Normandy, I28; Auteuil and procureur général, I2; boundaries, I66, 243; brewing, I89; cadets, 80 ; census, I04, I05, I74; changes, I63; commission to consider affairs (I643), 52; crops (I665), I89; customs of inhabitants, 87, I02 ; Delisle's MSS., 26; descriptions, 72, 265 ; discovery, exploration, 7, I $5,43,84$, 87, I 70,262 ; drawings of animals, $75 ; \mathrm{Du}$ Mont, I90; ecclesiastical memoirs, 72; engagés, I38, I59, 203, 218; English relations, $6,15,28,3 \mathrm{I}, 40,48,49,206,263,266$; established, 5I ; Estaing's proclamation, $24 \mathrm{I}$; etymology of word, 23 ; finances, I 4, I 5, 32, 33,35 , I6I, 20I, 25I, 268; fisheries, 5, 82, 27 ; flax, I88, I97; fortifications (I7I7), I 2 ; gentry, I 54 ; geography, 42 ; girls, I97, 20I, 203; governors, viceroys, intendants, instructions, I4, I6, 27, 69, I70, I7 I hats and woolens, I I8; history, papers, lists, 43, 67, I05, I 3 , I 14, I34, I 57, I6 I, I 77, I98, 240 ; hydrography, I74; interference from France, I40; Kirke, 48, 49, 206; land concessions, II3; large families, I6; Lauzon, 27 ; lead for, I35; loss, 45 ; Louisiana communication, 255 ; maps, 39 , I66, I77, I82, 224226, 255-257, 267; Marine orders, I61 ; marriages, list, I6I ; master of waters and forests, I98, 200 ; memoirs ( I667-97), I6, I04, I66, I93; ( I736-77), I04, I33, 277; militia, I6; minerals and mines, $80,83,145,201$, 270 ; money, cards, need, 5, 9, 70, 7I, 78, 89, I40; naval stores, I94; New France as name, I9I ; Northwest Rebellion, I30; notes, 46, I I6, I 18, I I9, I29, I33, I74; officials, autographs, conduct, decorations, instructions, lists, I2, 63, 67, I02, I57, I63; plague, 23; plants, 27I, 274; Plée's travels, scenes, 270 ; Poulet controversy, 54, 55; products, I02; proposed Lafayette expedition, I I ; protection and governor (I662), I82-I84; restitution (I632), 49; Ryswick negotiations, 49; settlers, 25I, 276; ships to and from, passage, $8,33,63,65-68,79$, I $35,136,140$, I4I, I62, I63, I74, I82, I83, I87-I90, I93, I96, 200-202, 204, 25I, 263 ; sovereign coun-

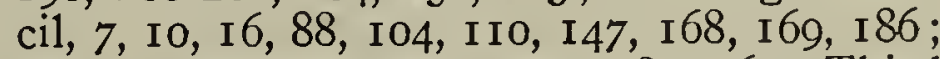
supplies, 55, I91, 201 ; taxes, 89, I63; Third Estate and trade, 52; timber, ship-building, 
I6, I84, I88, I93, I94, I97, 200, 204; Tracy, I88; Utrecht negotiations, I5I ; wartime navigation, convoys, $65,200,20 \mathrm{I}$; wheat and flour, I35, I36, I40; see also Army; Commerce; Governors; Indians; Intendants; Quebec; Roman Catholic Church; wars by name

Cangé, — de, concession, I 4I

Canino, Prince de, see Bonaparte, Charies Lucien Canoes, West Indies, I 7

Cap de Tourmente, map, 224

Cape Breton Island (Ile Royale), cadets, 8I ; commerce, 80, I3I; committee on claims ( I758-6I ), 35; Costebelle, I65; court, 7 I ; documents, papers, lists, I06-I08, I 4 ; embezzlement affair, 247; finances, 32 ; fisheries, 82, I37, 21 3, 27 I ; garrison, I I ; Gautier concession, I75; Gordon's designs, 263 ; history and geography, 240; hospital, Brothers of Charity, 70, 77 ; judiciary, 7I ; maps, 223, 224, 244; memoirs, I76, 271 ; notes, 46; officials, list, character, decorations, 63, I 57 ; oils, I8, I9; port dues, 8I ; Récollets, 7I, 77 ; ships in service ( 1727 ), 79; Sisters of the Congregation, 79 ; superior council, honors, bailiwicks, 78, 21 2 ; Utrecht negotiations, 28; voyage to, I2; wartime memoirs and news, 242, 243; West Indies trade, duties, 58, 239; see also Louisbourg

Cape Girardeau, plan of fort, 229

Cape Verde, and Cayenne Company, I85; French ships, 202

Cap Français, Cercle des Philadelphes, I 43; fires, 232, 234; maps, plans, views, 232-234, 276

Cap Haitien, see Cap Français

Capitation, colonial, 89

Capotilles, war, 8I

Cap St. Blanc, Fla., I40

Captain Anderson, $2 \mathrm{I}$

Cap Tiburon, maps, 234, 235; naval action, I52

Capuchins, Brazil, I 77; Louisiana, 33, 34, 79, 86; Port Royal, English confiscation, 5 I

Carácas, company, 35, 82; description, 40; slave trade, I39; voyage, 87

Carayon, Auguste, Documents inédits, 54

Carbonnières, Père Raymond, letters, I 65

Card money, Canadian, 5, 9, 89; decisions on, 7I ; Louisiana, 83 ; reduction and bills of exchange, 70

Cardon, $\longrightarrow$, pamphlet, 27

Carenage, plan, 237

Carib Indians, treaty, 79,82

Carignan-Salières regiment, 5, I65, I 89, 202

Caritat, Marie A. J. N., see Condorcet

Carleton, Sir Guy, 230

Carlier, Abbé de, letters, 248

Carlier, Pierre, 59

Carlisle, James Hay, earl of, grant, I8I

Carlisle Bay, Barbados, plan, 235

Carman, — de, voyage, 252

Carmelites, Guadeloupe, I I 5

Carmichael, William, dinner, I26

Carolina, charter, I8I; description, 88; filibusters, I36; Iberville's plan against, I I I,
I I6； memoirs, II I ; rice, 30； seeds, 274; see also Huguenots

Caron, Sieur de, letter to, I 80

Caron de Beaumarchais, see Beaumarchais

Carpenters, for colonies, I 94, I95, 20 I

Carpentras, Champlain MSS., I I 3

Carré, Père Jean Baptiste, letter to, 46

Cartagena, described, 40; English expedition, I45, I52, I 54; French expeditions, 6, 23-25, 68, I39, I44, I65, I66, 218; slave trade, I39, $2 \mathrm{I} 3$

Carte Réduite de l'Ocean Méridional, I52

Cartier, Jacques, ignored by Delisle, 26 ; instructions, 6 ; papers and notes on, 43, I03, II 8 , I 43; payment, warrants, 47, 219; Renaudot on, 97 ; voyages, versions of second, 7,28 , 84,216

Casas, Bartolomé de las, 24I ; bibliography, I43

Cass, Lewis, biography, I08 ; letters, I02, 256

Cassaigne, Pierre, widow, I62

Cassard, Jacques, actions, I2, I38; prizes, 70

Cassini, - , letter to, 24

Cassius, 38, 39

Castaign, Françoise, suit, I62

Castaigne, —, letters ( I690), I65

Castaignière, - director, 59

Castel, Père Louis Bertrand, geographical letters, maps, 43 ; on Northwest Passage, 42 ; papers, 108

Castel dos Rios, Marquis de, 155

Castel du Fouché, —, request, I 59

Castelnau, Michel de, see La Mauvissière

Castililia Aurifera, map, 279

Castillon, Louis de Pineau, sieur de, correspondence, 5

Castor, 8

Castries, Eugène Gabriel de le Croix, marquis de, annotations, 278; instruction on packets, I 29 ; letters to, 73 , I 26

Catalogne, Mlle. $\longrightarrow$ de, I6I

Catalogne, Gedéon de (?), on seigniories, 105

Catalogue de l'Histoire de France, I

Catalogue des Actes de François I., 208

Catalogue des MSS. Américains de la Bibl. Nat., 2

Catalogue des MSS. Français Ancien Fonds, 3

Catalogue Général des MSS. des Bibliothèques Publiques: Départements, 239; Paris, 238; Supplement, 239

Catesby, Mark, 259

Catherine de Médicis, letter to, 207

Catigny, - de, on his voyage, 252

Catlin, George, letters, La Salle pictures, Iro; North American Indians, 108

Cattle, for Canada, 201 ; New England-West Indies trade, 3I, I2I

Caulfield, Toby, 2I 9

Cavallero, - on Santa Fé, 220

Cavelier, Abbé Jean, 84, I I I ; correspondence, papers, I09, I I I ; death, I I 2

Cavelier, Nicolas, widow, I I I

Cavelier, Robert, see La Salle

Cayenne, plan, 255; see also Guiana

Caymans, notes on, I80

Cazenave, —- letter to, 2 I

Cedar Hill, Canada, 226 


\section{Ceisia, 2 I}

Censorship, Collection Anisson-Duperron, 6I, 62 ; correspondence and documents, 85-87; reports, American items (1767-88), 60

Census, Canadian, I04, I05, I74; Detroit, I I3; Indian, I05; Louisiana, 8r, II2, I 6 ; Martinique, 80; Newfoundland, 175 ; New Orleans, I I2; Quebec, I02; West Indies, I39

Cent-Associés, see Compagnie de la Nourelle France

"Centenaire du Dernier Siège de Québec", I 29

Central America (Terre Firme), Angrand's papers, affairs (I86I-63), I42; discovery, 26; Dutch and English, I38; French, I79, 183; Galindo's material, 220; La Croix's relation, 279; maps, 85 , 23I, 256, 258; memoirs, 72; navigation, I59, 219; see also Compagnie de la France Equinoctiale; Guatemala; New Spain; Spanish America Cercle des Philadelphes of Cap Français, I 43.

Cerri, Urbano, État Présent de l'Église Romaine, 255; "Stato della Religione cattolica", 255

Cette, trade, 56

Chabanel, Père Noël, death, 54

Chabaud, — de, letter (I688), 84

Chabert, Daniel, see Joncaire

Chabert, Joseph Bernard, marquis de, astronomical observations, I27 ; Yorktown campaign, I 27

Chabot, Philippe de, sieur de Bryon, papers on, 103

Chacornacle, $\longrightarrow$, signature, I63

Chagres, capture, I 45

Chaleur Bay, map, 223

Chambly, Gov. Pierre de, 197, I98

Chambly, Quebec, see Fort St. Louis

Chambon, - Commerce de l'Amérique, 6I

Chambré, — de, letter ( I665), r89

Chambre de Commerce, Paris, 53, 74

Chambre des Comptes, MSS. from, 3, 32, 76

( Chambre Syndicale de la Librairie et Imprimerie, archives, 60, 6I

\section{Chameau, I 57}

Chamillart, G., letters, fisheries, I90-I92

Chamilly, - $25 \mathrm{I}$

Chamot, — , in Acadia (c. 1668), I89, 197, 224

Champigny, Jean Bochart, marquis de, expense project, I64; instructions by, I66; letters, I 04, I I2, I 40, I4I, I 57, I65, I84, 268 ; military list, I 63 ; petition, I 59 ; record of events, I 66 ; return to France with wife, 68 ; signature, r60

Champlain, Samuel de, biographical sketch, II3; Documents inédits, I02; Margry, 102, I29; Mémoire en Requeste, 23; memoirs, 6, I I3; notes on, will, 43, I03; pension, II 3 ; portrait, 102; proposed statue, 128; published works, extracts, transcripts, 49, I02, I59, 281 ; Renaudot on, 97

Champmeslin, —, Desnos, comte de, 34,83

Champy, Hubert, see Desclouzeaux

Chancery, Tobago records, 267

Chandeleur Island, 227

Chanson des Sauvages, melody, I I6.

"Chanson sur la Reine de St. Domingue", 78
Chanvallon, Jean Baptiste Thibault de, Guiana affair, 8, 86, 248, 266, 28I

Chapais, Thomas, Jean Talon, ro

Chapeau-Rouge, Newfoundland, I9I

Chapelas, Henri de, see Salières

Chappe d'Auteroche, Abbé Jean, 223; Voyage en Californie, 61

Chappellain, _-, letter, I99

Charavay, Etienne, 123; Documents inédits sur Champlain, 102

Charente, 12,164

Charité, Gov.

Charles IX. of France, letter to, 263

Charles X. of France (Comte d'Artois), library, 239

Charleston, S. C., French traveller (1777), 45

Charlevoix, Pierre François Xavier de, Isle Espagnole, 23; papers on, 108

Charlotte, 22

Charlton, Richard, letters, I27

Charmes, Xavier, Comité des Travaux historiques, $2 \mathrm{r} 6$

Charmot, $\longrightarrow$, letter to, 268

Charnay, Désiré, itinerary, 277

Charnières, - de, map, 236

Charnisay, see Aulnay Charnisay

Charon, $\longrightarrow$, papers, I06

Charost, _- Béthune, duc de, letter, I99

Charpentier, - , tables, I 56, I 58

Charpentier, Victor Thérèse, see Ennery

Charritte, $\longrightarrow$ letter (I687), I40

Charters, English, 6, I80; see also Commercial companies

Chartier de Lotbinière, see Lotbinière

Chase, Capt. Bailey, 22

Chasseboeuf, Constantin, see Volney

Chasteau, see Château

Chastellux, François Jean, marquis de, map, Ir6

Chastillon, $A d m$. - de, voyage, 28

Châteaubriand, François René, vicomte de, letters and fragments, $4 \mathrm{I}$

Château de Luret, France, I 12

Château de Marly, France, 42

Châteaudubois, - de, 64; letter to, I74

Châteauguay, Antoine le Moyne, sieur de, notes on, II 2

Châteaumorand, Chevalier de, 24, 77

Châteaurenault, François Louis de Rousselet, marquis de, letter, convoy, I98; operations, $63,146,194,216$

Chatham, 219

Chatou, Etienne, sieur de la Jannaye, concession, $15,103,262$

Chaulnes, Charles d'Albert, duc de, letters, I 53, 195, I96, I99, 200; memoir, I95.

Chaumonot, Père Pierre Joseph Marie, death, 9; letters, I 04 ; relation, 2 I 7

Chaumont, Chevalier de, Tracy's aide, 203, $25 \mathrm{I}$

Chaumont, - , speculation (I720), I 44

Chaumont, Donatien le Ray de, see Le Ray

Chaumont, François de, Anglo-French memoir, 28

Chauney, Léonard, petition, I 55

Chauvallon, see Chanvallon

Chauvet, Jacques, 4, 54

Chauvin, Etienne, papers on, 103 
Chavigny, - de, letter to, Io6

Chavois, Sieur de, see Noyan

Chedabucto, freight charges, I35

Cheeseman, John C., 260

Chefdeville, François, I I I

Chefdhôtel, - papers, I03

Cheffaut, Antoine (?), 50

Chenu, Louis, papers, I 42

Chepoussea (Kaskaskia) River, I 77

Cherbourg, fisheries, 27 I

Cherisey, Chevalier de, papers, I08

Cherni, _ , letters, 38, 39

Cherokee Indians, civilization, 260; snake-bite remedy, 75

Chertemps, Pierre, see Seuil

Cheruel, Pierre Adolphe, Lettres de Masarin, I 80; Memoire sur Fouquet, I 49

Chesapeake Bay, battle (I 78 I), I 22

Chesnard de la Giraudais, _-, voyage, I3I

Chessieux, La Grange de, see La Grange

Chevalier, —-, Compagnie des Indes, 59

Chevalier, _ Kerlérec affair, 248

Cheverry, D. de, letter, I 92

Cheverry, P. de, letters, I86, I 88

Chevry, Marquis de, I69

Chickasaw Indians, campaign, 80, 254 ; information, 268

Child, D. Lee, Texan article, 75

Children, John George, letter, 260

Chile, coast, 56; Delisle's MS., 26; description (I7I3), 254; disturbances (I666), I80; voyages, 25,56

China, Compagnie des Indes, II7; Frondad's voyage, 88 ; map of coast, 255 ; missionary documents, 26; papers, I77; see also Compagnie de la Chine

Chinese, disease, 86

Chippewa Indians, language, 256

Choart, Paul, see Buzenval

Choctaw Indians, information, 268; Régis du Roulet, I I 3

Choiseul, Etienne François, duc de, correspondence, register, 3I, I 47, 212, 223, 267 ; Frederick the Great on, I 46 ; Kerlérec affair, 248 ; memoirs for, 3I, 74, 88, 267

Choiseul-Praslin, César, duc de, Guiana, 8 ; letters, I 20, I68, 248

Choiseul-Praslin, Charles Laure Hugues Théobald, duc de, 282

Chomedy, Paul de, see Maisonneuve

Choris, Louis, assassination, journal, 276; Voyage Pittoresque, 276

Chouart, Médard, see Groseilliers

Chouteau, Auguste, St. Louis narrative, I29

Christian Examiner, 28I

Christophe Colomb, play, 85

Church, Edward, letter, I 44

Ciboure, France, and Newfoundland, I 32

Cinchona, I30, 272

Cincinnati, Society of the, French papers, I20, I 21

Cinq grosses fermes, I75

Cinq-Mars, Henri, marquis de, letters, I03

Circourt, Adolphe de, review, I32

Circumnavigation, Locke on, 262 ; see also Voyages
Cist, Jacob, letters, 275

Civil code for colonies, 37

Civilization, and conquest, 73

Civil War, Alabama, I27, I32; and Mexico, I42; effect on American civilization, 283 ; surgical letters, 90

Clairambault, Charles, fils, letters, I 52

Clairambault, Nicolas Pascal, collection, I 5 ; letters to (?), I57, I58, I62

Clairambault, Pierre, certificate (?), I 70 ; collection, I5I; letters to, I 52, I 54, 278; on Colbert papers, I 58

Clairanville, A, de, Français Prisonniers de Guerre, 87

Clarck, Dr. A., letter, 90

Clarcke, - Jamaica garden, 272

Clarke, James Freeman, 282

Clarkson, Thomas, letter, 243

Clary, P. N., on Santo Domingo relief, 243

Clavière, Etienne, De la France et des EtatsUnis, 6r

Clay, Henry, letter, 245

Clement X., pope, brief, 27

Clement XIII, pope, I68

Clément, Pierre, Lettres de Colbert, I 5

Cléopâtre, I27

Clerque, see Henriques Clerque

Clerville, Louis Nicolas, chevalier de, letter, 183

Clifford, John D, letters, 259, 274

Climate, Louisiana, 272

Clinton, Sir Henry, Monmouth, 230

Clodoré, Robert la Frichet de, letter, I90

Clothing, colonial troops, I05, I35, I40, I4I

Coal, American production (I $844-52), 4 I$

Coates, Dr. B. H., letter, 89

Coccade au Poisson, Newfoundland, 214

Coche, $V$ euve, suit, 88

Cochin, Charles Nicolas, Franklin portrait, I 46

Cochinchina, map of coast, 255 ; missionary documents, 26; nineteenth-century documents, 87

Code Noir, copy, I 33

Cod fisheries, see Fisheries; Newfoundland

Coëtlogon, Vicomte de, death, I65; letter, I93

Coëtlogon, Alain Emmanuel, chevalier de, letter, I 65 ; squadron, 63 , I 46

Coffee, Compagnie des Indes, 34, II7; French trade, I 8, I9; Santo Domingo, I 30

Coffier, Antoine, see Effiat

Coffin, Mark, I 2

Coffin, Thaddeus, I2

Colbert, Jean Baptiste [I], and Gargot, I49; collections: Arnoul commercial, I34; Cinq Cents, 204; Mélanges, I79; correspondence (i66I-74), I79; countersignature, I4; foreign despatches, I58; guides to Marine papers, I 58, I60, I 98; letters, I9, I04, I09, I 89, I 93, I 96, 202, 204, 205; letters to, I 53, I62, I72, I8I-202; Marine administration, 33, I03, I33, I 8I, 201, 252; memoir for, 84; memoirs, 43, I04, I49, I79, I93, 200; minutes, I5-17; on Acadia, 206; tobacco, I9, 74; visit to Brittany, 206

Colbert, Jean Baptiste [2], see Seignelay

Colbert, Jean Baptiste [3], see Torcy

Colbert de Croissy, Charles, see Croissy 
Colbert de Terron, Charles, see Terron Colbert River, I 73

Colds, Franklin's remedy, 43

Coligny, Gaspard de, Florida, 55, 56

Collas, Capt. Vincent, 55

College at Quebec, 55, 268

Collens, S. Wharton, letter, 282

Collet, Claude, 102

Collet, John, 246

Collinet, $\longrightarrow$, letters, 68

Collom, Jacob Aertz, map, 255

Collot, Georges Henri Victor, voyages, 228, 229

Colombia (New Granada, Santa Fé), cinchona, 272 ; conditions, 220; Fournier's MS., 258; map, 279; prehistoric objects, 259; see also Spanish America

Colon, disturbances, 127

Colonies, French, estimates (1716-17), I2; importance, defense, 6 ; policy, 133

Colonization, comparative Anglo-Franco-Spanish laws, 6r; German project, 186, I87; necessity, 276; notes on systems, II6, I42; Petit on, 36; Roissy's memoir, 46; Sully's policy, 44

Colorado River, statement, 226

Colors, use in transportation, 258

Columbia River, English settlement, 79, I33, 226

Columbus, Christopher, biography, 263; Fournier's MS., 258; map, 22I ; papers on, II 8, I 31,277 ; play on discoveries, 85 ; Renaudot on, 97 ; voyages, $7, \mathrm{I} 7 \mathrm{I}$

Columbus, O., mushrooms, 270

Comane, Central America (?), I8o

Combenio d'Eminente, 30

Cominges, Gaston Jean Baptiste, comte de, despatches, 28 ; memoirs, 47

Comité des Travaux Historiques, Bulletin, 146 Commayagua, $3 \mathbf{I}$

Commerce, acts, list, 96, 153, I60, 252; American, relation (157I), 264; and Family Compact, 39, I46; Anglo-French and Franco-Spanish treaties on seaborne, 15,30 ; balance of French (1788), 8; Bayonne, I32; Canadian: control, 6, 77; foreign, 57 ; freedom, I8, 19; La Rochelle, I36, 280; local, 20I ; memoirs, conditions (I662-73), I82, I97; ( I70I-62), I $7,20,53,74,77,80$, I 31, I 33, 239, 240; (after I763), 8, I 45; regulations, own products, 57 ; Third Estate and, 52 ; with West Indies, $32,58,82,146,239,252,254$; - cargo accounts, I6I; censorship of books on, 86; Colbert's efforts, I34; colonial : conditions, $56,57,88$; control, freedom, regulations, I 8-20, 56, I31, I 58; documents, 263; French merchants and (1664), I 85; history, 279; importance, 7 ; Maurepas on, 212; memoirs, 204; Montmorency on, 204; petitions for, 280;-commission, I8, I9; condition of French, decline, rehabilitation (I662-1700), 49,263 ; (i70I-70) $6,20,37,53,57,74,132$, $240,24 \mathrm{I}, 252,257,266$; declaration of reestablishment (I637), 25I ; departmental control, 49, 77, 21 3 ; documents, list 49, 263; Dutch: and English relations, I3; seaborne, 96, 239; with France, 132; with West Indies and Africa, 72, I83, 208, 262 ;-
English: after I763, I45; and Indies (I657) , 28; menace to New France, 212, 2I4, 262; plans against English-American, I 55;-former French colonies, 45; FrancoAmerican (1784), 7 ; French, and demarcation line, 209, 253, 26I ; French merchants and Spanish, II 5; general history, treatise, 3; Guiana, 254; Gulf of Mexico, Anglo-French (I74I ), 280; La Rochelle, I36, I39; Levant, Oriental, 9, I I8; Louisiana : memoirs, 40, 85 ; promotion, 40 ; royal merchandise, payment, 83 ; with Spanish possessions, 40, 255 ;Marseilles, I30; Mediterranean, 9; memoirs on French and general, 5, 1 5, 17, 47, 69, 77, 85, 96, 131, 132, 214, 239, 252, 266, 276; Nantes, I46; Newfoundland, 9I, I4I, I45; nobility and, 10,18 ; notes, 46,47 ; Portuguese ( 1838$), 278$; private, by ship officers, I6, I35, I36; protection from officials, 70 ; Provence, I50; royal control, protection, regulation, 6 , 214, 252; Russian, with American colonies, 193; Ryswick negotiations, 49; St. Germain-en-Laye negotiations, 6; seaborne, promotion, 6, 7, 4I, 42, 80, I35, I53, 205, 253, 256, 263; South Seas, prohibition, I37; Spain and French colonial products, 30; Spanish-American: conditions, I3, 3I, 85, $208,255,276$; foreign, $96,175,243,262$; monopoly, 265; regulation, 31 , 265 ;-through Cadiz, 30, 72, 146, 192, 239, 281; West Indies: and American Revolution, I2I ; and Antwerp Truce, I3; conditions of French (1606-1700), 3, 5, I3, 73, 98, I36, I4I, I 50, I65, I68, I9I, I94, 201, 205, 240, 254, 262, 280: ( I70I-70), I 7 , 53, 56, 72,74, 77, 79, 83, I 28, I 30, I 32, I 36, I 46, I 48, I 55, 239, 254 , 256, 266; control, 77; Dutch, 85, 183, I85, I90, 196, 200, 201 ; freedom, 205; in treaty of Compiègne, 263; regulation, 89 ; subvention, 79 ; syrup, 132 ; wartime, 56 ; with Canada, 32, 58, 82, 1 46, 239, 252, 254; with English, '3I, I 47, 266, 280; with Mediterranean, 9; with West Flanders, 254; see also next title; Duties; Fur trade; Grants ; Mercantile system; Navigation; Neutral trade; Slave trade; articles by name, especially Liquor; Lumber; Sugar; Tobacco

Commercial companies, chronology (I626-I72I), 217; consolidation, I 85 ; Dutch participation in foreign, 83 ; general (I686), 46; harmful privileges; 74 ; history of French ( $1626-$ I724), I7; Le Maire's plan, 26I ; notes (1584-1632), 209; officials as members, I4; papers (I664-68), I 45 ; projects, 7I, 72, 205, 217, 263, 276; Roissy on, 46; Spanish, 82, 83, 267; Swedish, 209, 252, 253, 261; see also Charters; Commerce; Concessions; and "Compagnie", "Company", "Danish", "Dutch", and "English" titles

Commissary, 'French American-Revolution accounts, 9 I

Commissioners at Paris, American, arrival, presentation, I I, 36; dinner, I26; letters to, 122 Compagnie de Caëns, see Caën

Compagnie de Cayenne, see Compagnie des Indes Occidentales 
Compagnie de Flandres, see Compagnie de la Nacelle

Compagnie de Guinée, acts, 76 ; assiento, 20, 82; control, 77 ; harmful privileges, 74 ; memoir, 56; monopoly, I54; papers, I38; see also Slave trade

Compagnie de la Chine, 59, 2 II

Compagnie de la France Equinoctiale, and Cayenne, documents, 9, 27, I70

Compagnie de la Mer Pacifique, 66

Compagnie de la Nacelle de St. Pierre Fleur-deLysée, contract, 204, 205, 209

Compagnie de la Nouvelle France (Cent-Associés, Morbihan), Acadian concession, I4I ; colonization, 26, 27, 50; consolidation, 185 ; contract, articles, 6, 26, 27, 52, 96, 205, 25I, 279 ; de Caën, 50; documents, ro3; establishment, I8, 50, 52, 53, 96, I 53, 262, 279, 280 ; Feuquières, I70; general assembly, liquidation, 50 , r9o; members, 52 ; on fur trade, 5I, 73; proceedings, 69, I53; special company, 49, 50

Compagnie de la Pêche Sédentaire, affairs, r69; Le Borgne, r63; remarks, I35; ship, r35

Compagnie de l'Assiente, papers, I36, I38

Compagnie de Montmorency, see Montmorency

Compagnie de Morbihan, 18, 53, 96, 205, 279; see also Compagnie de la Nouvelle France

Compagnie de St. Domingue, 49, 60

Compagnie des Cent-Associés, see Compagnie de la Nouvelle France

Compagnie des Douez Seigneurs, see Compagnie de la France Equinoctiale

Compagnie des Indes, acts and documents, lists, $32,83,156,217$; agent in West Indies, 10; aid (r745) and indemnity, 212; and Bavarian Company, 84; and Department of Marine, II7; and Iberville expedition, 20; and Parlement of Paris, 2I I ; Chambre des Comptes papers, 76; China, Ir7; chronology, II7; coffee, 34 , II7; colonial currency, 83 ; colonial duties, 60 ; concessionaires, 24I ; condition, utility, I 5, II 7,240 , 24I; consolidation, 59, 2II ; departments, 59; East Indies, II7; finance, I9, 83, I 44; fur trade, I6, I9, 60, 83; future (I725), II7; Guadeloupe, I80; histories, 2 II, 253, 257; Indians in Paris, 240; Louisiana: Biloxi, 88; commerce, 83, II7; concessions, I 54 , I 55 ; defenses, royal grant, 83 ; expenditures, I5; fund, 59 ; losses, 257 ; maintenance, 24I ; memoir, I9; missionaries, 33, $34,79,86$; retention, retrocession, 20,60 , 80, 212, 257; settlers, 59, II7; subsidy, 33; success, I 77 ;-meetings, 59 ; needs, 257 ; passages to Canada, I63; Philippines, II7; prices, 9 ; privileges, 60 , II7, $2 \mathrm{II}, 244$; programme, 20; register of memoirs, 257; regulations, 60; Santo Domingo, revolt, 34, $60,78,83$, I47; slave trade, $59,60,79,83$, II 7, 257; tobacco, 34, II7, 213; warehouses, 82 ; see also Law, John

Compagnie des Indes Occidentales (Cayenne), Acadian concession, I4I; acts, 76 ; aid by, I90, I9I, 20I ; affairs (1664), I85; and prosperity, I87 ; Canadian complaints, I90; cap- tains, 197; cargoes, I87; carpenters, 20I; Chambré, I 89 ; colonization, I 86,262 ; consolidation, 59, I85; Dieppe, r88; Du Lion, I 93 ; establishments, 59, I85, I86, 205; history, 279; Honfleur, r86; liquidation, 89, I96; munitions, I95; officials interested, I4, I 53, 206; papers, I04, I38; port duties, 18, r88; Port Louis, I8; position in, r86; royal payment, 202 ; ships, I86-189, I95, 25I; slave trade, 33, r96; timber, 194 ; voyage of director, $20 \mathrm{I}$

Compagnie des Indes Orientales, acts, 76 ; establishment, 153 ; members, I57; officials interested, $14,153,206$; position in, 186 ; subscriptions, I 85

Compagnie des Isles de 1'Amérique, affairs, Ir 5 ; establishment, 52 ; Jesuits, 52; Knights of Malta, 26I; letter to, 204; privileges, I53; St. Christopher, I33

Compagnie des Voyages de Longs Cours, 51, 52, 96,205

Compagnie de Terre Ferme, see Compagnie de la France Equinoctiale

Compagnie d'Occident, consolidation, $2 \mathrm{II}$; formation, 59; history, 279; tobacco, 279

Compagnie du Cap de Nord, I77

Compagnie du Mississippi, composition, 255; relief, 255

Compagnie du Nord, conference, 202; establishment, I92-I94, 205, 25I ; harmful privileges, 74; Rousseau, I86

Compagnie du Sénégal, acts, 76 ; and domaine d'Occident, II7; consolidation, $76, \mathrm{I} 85,2 \mathrm{Ir}$; control, 77; infringement, I2; papers, I38; privileges, 46, 74; see also Slave trade

Compagnie Françoise pour faire le Commerce Générale, 52

Compagnie Générale pour les Assurances et Grosses Aventures de France, I78

Compagnie Générale Transatlantique, I 29

Compagnie pour l'Amérique, I9

Company of Bavaria, and Compagnie des Indes, 84

Company of Carácas, establishment, 35,82

Company of Merchant Adventurers (Muscovy), charter, Russian privileges, 97

Company of the Philippines, establishment, 83

Compiègne, treaty of, 208, 263

Concessions, Chatou-Noël, r 5, 103, 262; control, I 58; Cottard, 83; Guiana, 84 ; inactive, 262; La Porte's, I06; list in America, I 49; Louisiana, I2, I I6, 227, 228, 24I ; Placentia, I07, 149, 263; Prince Edward Island, 78, 83, I75, 218; Roberval, 6; West Indies, 33, 37, 38, 78, 187, 232; see also Acadia; Commercial companies ; Crozat

Condé, Henri de Bourbon, prince de, 50, ro3

Condé, Louis de Bourbon, prince de, letter, 197

Condorcet, Marie A. J. N. Caritat, marquis de, papers, 255

Confederation, paper money, I42

Conflans, Hubert de Brienne, chevalier de, cruise, I62; letter, 82

Congrégation de Notre Dame, Montreal, 252

Congrégation des Filles, Montreal, ro

Conjugon, 262 
mquest, and civilization, 73

inseil de Commerce, 34-36, 4I, 255; established, I54

onseil de Marine, I2, 39, 70, I57; established, I54; policy and practices, 33, I33

mseil de Régence, I2, I5; established, I54; minutes, $70,7 \mathrm{I}$

mseil des Prises, I44

onseil d'Etat, and New France (1643), 52; arrêts, registers, I2, I4, I5, 43, 52, I 38 , I 53 , 154, I70, I78, 213, 262; see also Acts

msidérations sur Canada, 104

mstitutions, French translation of state ( 1778$), 6 \mathrm{I}$

onsulates, documents ( $\mathrm{I}$ th cent.), 50 ; in America. I68: treatise, 28I

ontinental Congress, French imprint on Yorktown, 44 ; letter, ship for Jones, I22; "Lettres d'un membre", 6I

ontraband, Franco-Spanish negotiations ( 1765 ), 30

ontrec I65

introller general, commercial functions, 49,77 , 2I 3

onvicts, see Prisoners

Invoys, during various wars, 29, 65, 69, I37, I96-201, 230; French, of American ships (1777), 122; regulations, I36; slave trade, I7; tax for Newfoundland, I8

oper, J. Fenimore, letters, I46, I47

oper, William, letters, 259, 260

pper, mines, exploitation, I6, 83, I08, I29, I39; specimens, 270

squart, Père Claude Godefroy, letters, 42; papers on, 108

squebert de Montbret, Comte Charles Etienne, papers, I3I, I32

quebert de Montbret, Eugène, papers, I3I, I32 orda, Augustin, Cat. des Factums, 8

riolis, Chevalier de, Relation inédite de la Bourgogne, I 29

rke, Newfoundland, map, 223

rneau, __ Compagnie des Indes, 59

rnwallis, Charles, earl of, rumors on (1777), II ; Yorktown, map, I23, 230, 278

ronado, Francisco Vasquez de, 7 ronelli, Père Vincent, globe, 42 ; map, 98

rpron, Jean, Bastille papers, 247, 249, 250

rre, Dr. - , papers, I30, I33

orsette, see Ornano

rsini, N., letter, 259

orte Real, Gaspar, 7, 97

rtez, Hernando, 97, 263

rupá, description, I74

smography, Chauvet's 4; extracts, 5; Fonteneau's, 3,4 ; Thevet's, 5 I

ssin, Jehan, map, 222

sta, Claudio Manoel da, poem, 278

stebelle, Gov. Philippe de, correspondence, ro6, I07, I65; dispute, $7 \mathrm{I}$; services, I65; will, 107 stelli, Cardinal, letter, I68

ittard, Claude, concession, 83

tte, $-\mathrm{de}$, memoir, 35

ttin, J., et fils, letter to, I42

tton, Père Pièrre, letters, I07
Cotton, culture, I30, I42; French customs (I8I6), 244; La Rochelle trade, I36

Coüagne, Mme. de, marriage, I6I

Couderc, Camille, "Bibliothèque Nationale", I n.; Cat. Gen. des MSS. Français, 3; "Inventaire de la Collection Boissy", 32

Coulier, - letters to (1833), 245

Coulon, Louis, Voyages de Leblanc, 4

Council for Foreign Plantations, commission, I 80

Council for New England, charter, I8I

Council of the Indies, relation, I79

Councils, see Conseil; Sovereign; Superior

Courbon, Charles de, see Blénac

Courcelles, Daniel de Rémy, sieur de, commission, I7I ; letters, 64, 202; militia, I6; news, I 88 ; notes, 202 ; Ontario voyage, 44 ; praised, I98; return, I95, I98; salary, I96, 202, 203, $25 \mathrm{I}$

Courcillon, Louis de, see Dangeau

Cour des Aides, registered edicts, I4

Cour des Monnaies, Io

Coureurs de bois, amnesty, I0; papers on, I08; permits, 158 ; punishment, Io

Couronne, I27

Courrier de l'Europe, 246

Courrier de Londres, 246

Courrier Français, I23

Courtanvaux, François César Letellier, marquis de, journal, 276

Courtemanche, Mme. de, 78

Courtemanche, Augustin le Gardeur, sieur de, I05, 108

Courts, see Judiciary

Cousin, Victor, influence in United States, 282, 283 ; letters to, 28I-283; library, 28I

Coutto, see Alves do Coutto

Couture, Guillaume, notes on, I08

Couture, Jean, notes on, 108

Couvent, Anne, inventory, Io6

Coyecque, Ernest, Cat. des MSS. de la Chambre des Deputés, 25I; Inventaire de la Coll. Anisson, 6I

Cradock, Francis, commission, I80

Cramoisy, Sébastien, I 53

Crane, Surg.-Gen. Charles H., letter, 90

Crane, Dr. Edward A., letter, 90

Crane, Dr. John J., letters, 90

Crania, Indian, 259, 260; negro, 260

Crawford, William Henry, letter to, 245

Crécy, Louis de Verjus, comte de, letters, Frontenac, 195, 196, 198

Creek Indians, Milfort, 4I

Creoles, Martinique, 258

Crepon Pechon, Ecuier, see Pechon le Conte

Crête à Pierrot, Santo Domingo, plan, 232

Creutz, Gustave Philip, comte de, letter to, I 23

Crèvecoeur, Hector St. Jean de, see St. Jean

Crevel, Nicolas, papers on, I I I

Cribb, Robert, I 46

Crime, colonial code, 37; see also Amnesty; Punishment

Croc, havre $d u, 273$

Croiset, —, letter (I687), I36

Croisic, France, Newfoundland trade, I 45 
Croissy, Charles Colbert, marquis de, letters, I86, I87, I92, I96-I98; letters to, I7, 205

Cromwell, Oliver, Acadia, 52; Canada, 48; West Indies, 280

Crops, see Agriculture

Crown Point (Ft. Frédéric), attack, 246 ; observations (1758), 120; plan, 230

Crozat, Antoine, appeal from Louisiana council, I2; infringement, 7I ; letters patent, 73; memoirs on, 39, 212; opposition, 167,254 ; prospects, 88; retrocession, I2, 57, 7I

Crustacea, American, 273, 274

Cuba, American affairs, filibusters, I27; cotton, I42 ; description, I44 ; disease, 86 ; governor, 67; Louisiana supplies, 30, 31 ; maps, 23I ; memoir, 72; navigation, 219 ; pictorial collection, 220; tobacco, 29; tortoise, 260 ; see also Havana; Spanish America

Cul-de-Sac, Santo Domingo, plans, 23I, 232, 234

Cumberland, prize, I 30

Curaçao, commerce of Oruba, 72; descriptions, trade, 72, 198, 239; French attack (I713), I38; memoir, I80

Curatteau, Capt. - , map, 228

Curot —-, trial, 247

Cushing, Thomas, letters (1837), 282

Cushman, Capt. - 38,39

Cussy, - de, map, 234

Customs, see Duties; Tonnage

Cuvier, Baron Georges L. C. F. D., collection, 254; eulogies by, 258; papers, letters to, $258-260$

Cybèle, 273

Dablon, Pèrc Claude, letter, 9; relation, 217

Dablon, Claude Camille François, comte, Discours, 60

Dablon, Louis, journey, I07

Dagieu, —- letter, 2I 4

Dailleboust, see Ailleboust

Dalera, —, I 59

Daligre,

Dalmas, Pire Antoine, death, 9

Damas, Baron Ange H. M., letter, 259

Dames de la Sainte Famille, Montreal, I04

Dames de Montcalm, 280

Dames de Montreal, 280

Damien Strait, see Bering

Dampierre, Jacques de, Sources des Antilles Françaises, 23

Damville (Anville), Christophe de Levis-Ventatour, duc de (comte de Brion), viceroy, grant, 84, I 70

Daneaux, Nicolas, see Muy

Dangeau, Louis de Courcillon, abbé de, collection, 63 ; globe, 8 ; letter to, 69

Danican, _ - on gold in California, I 6 ; papers, I08

Danican, Noë1, see Lespine

Daniel, - letters (1866), I28

Daniel, Pc̀re Antoine, death, 54

Daniel, Capt. Charles, Voyage, Io3

Danish West India Company, St. Croix, 82; slave revolt, 82

Danse Canadienne, melody, I 6

Dantèz, Michel, letter, I 84
Danville, sce Anville; Damville

Danycan, sec Danican

Danzig, trade, 96

Daré —, émigré, 39

Darien, French expedition, 127; Scottish at tempt, 24,98 , I I 5

Dartigny, -

Dartmouth, William Legge, earl of, queries, 9

Daubenton de Villebois, Amboise, letter, II 2 ; o Philippines, 213

Daubigny, Eugène Théodore, Choiseul et l France d'Outremer, 8

Daubusson, Catherine, I56, I57

Daudigny, Hector, see Grandfontaine

Daulnay, sce Aulnay

Dauphin, 165

Dauphin, American ship, I22

Dauphine Island, see Isle Dauphine

Dauquin, —, I23

Dauterive, $\longrightarrow$, trial, 247

Dauteuil, sce Auteuil

Dauxion la Vaysse, Jean François, Voyagc, cer sured, 87

Davenant, Charles, French translation, 279

Davenport, Frances G., European Treaties, I

Davies, William, letters, 256

Davion, Pìre Antoine, letter, 268; mission, 97

Davis, - 39

Dawes, John, I 80

Daynac, Dr. $\longrightarrow$, 122

Deane, Silas, dinner, I26; letter to, I22; pri sented, I I

Debraye, Henry, Cat. des MSS. de la Chambr des Deputés, $25 \mathrm{I}$

Debts, in colonies, 37; see also Public debts

Decamps MSS., 3

Decarette, - , charges against, 247

Decatur, Stephen, dredge, 259

Declaration of Independence, English respons 60

Declaration of Rights, American, 43

Decombles, Lombart, Oswego, I57

Decrès, Denis, correspondence, I 26

Deer, report on enormous, 66

Defenses, Acadia, I68; Canada, I2, 105, I88, I8c collection of papers, 243; English, at S Christopher, I89; Louisiana, 40, 83; Mo1 treal, 7I ; Pensacola (1775), 267 ; St. Joh River, I64, I70; West Indies, I47, I48, I9. 267 ; see also "Fort" titles

Defiance, 22

Deforges, - map, 233

De Franca, I. Sebastian, I 46

Dehérain, Henri, "Cat. des Fonds Cuvier", 2

Dejordy, - - decoration, I 57

Dekay, James E., letter, 275

Delaborde, Henri, collection, 257

Delachèze, —-, letter (I664), I 86

Delafield, Joseph, letter, 260

Delafosse, L., map, 234

Delambon, Maitre - , brief, 162

Delandes, Capt. — 75

Delaroche St. André, - , letter, I87

Delauney, - , letters, 38, 39

Delaware (Lenape, Lenni) Indians, languag 256 
'elfau, ——, Kerlérec affair, 248

ieliette, $\longrightarrow$, scanda1, 65

lelisle, Claude, correspondence, 24, I09, 266; MSS., 26

lelisle, Guillaume, charges against Nolin, 8, 62, I54; MSS., 26, 257

ielisle, Joseph Nicolas, MSS., 26 ; notes on, 26

ielisle, Léopold Victor, Cabinet des MSS., 2; on Collection Clairambault, I5I ; Résumé de l'Hist. du Dépt. des MSS., 2

De l'isle d'Oléron", I30

'elivet (Dolivet), Lt.

ielpeuch, Maurice, "Glorieux Episode", 4

lelpuech, - map (I755), 236

leluzy des Portes, Henriette, letter, 282

'emandes faites à Utrecht, I5 I

emarcation line, and French commerce and duties, I37, 204, 253, 26I

lemari, _- map, 223

'enis, see also Denys

'enis, $\longrightarrow$, for Gaspé, I 89

'enis, Barbe, petition, 165

Ienis, Ferdinand, papers, 276-278

'enmark, English trade treaty, 263; neutral trade, 39

ennebault, Jean, voyage, 2I7

'enonville, Jacques René de Brisay, marquis de, appointment, commission, I $7 \mathrm{I}$; family, I4I ; instructions by, I66; Iroquois expedition, 98 , I40, I75; letters, I04, I40, I66, I75; military appointments by, 163 ; on cost of troops, I39; on La Salle, I09; on trade permits and Indian subvention, I64; return, I35, I 66

'enys, see also Denis

enys, Jehan, Newfoundland haven, 72

enys, Louis, see La Ronde

enys, Nicolas, Description Géographique,. extracts, transcripts, I02, I59

enys, Richard, see Fronsac

enys, Simon, see Bonaventure

'éon, 22

épartements de la Compagnie des Indes, 59

épôt des Cartes et Plans, history, I28; inventory, I04; list, I 6

epping, Georg Bernard, Correspondance Administrative, 179

erbanne, - , papers on, 108

ernières Découvertes dans l'Amérique Septentrionalle, 109

ernis, "Compagnies de Commerce" ( I742), I7

ernis, - Recueil des Arrêts, 80

e Ruyter, see Ruyter

esandrouins, — , journal, 244; observations, I 20

es Angiers, Chevalier, cruise, map, 223

esarnold, $\longrightarrow$, stove, 6I

esbillettes, -, Description de l'Art de l'Imprimerie, 25

esbois, —, voyage, 254

es Boves, Charles, letter, 263

escartes, René, Harrisse's translation, 282

escasaux, - , sieur du Hallay, memoir on commerce, 53, 74, 252

escayrac, $\longrightarrow$, pension for widow, 156
Deschamps, Charles, see Boishébert

Deschamps, Jérémie, commission, 27

Deschamps, Léon, Isaac de Razilly, 276; Question coloniale, 52

Deschamps, Paul, inventory of Cousin MSS., 28I

Deschenaux, - trial, 247

Desclouzeaux, Hubert Champy, chevalier, and Canadian commerce, I97; letters, 200-202; memoir, 197

Descourtils, - letter, 259

Des Coutures, Sieur, journeys, map, 226

Description de l'Art de l'Imprimerie, 25

Descultot, David, declaration, 201

Desdorides, Lt. Col. —, on Santo Domingo, 267

Deserters, Placentia, I6 3

Desfourneaux; Edme Etienne Borne, comte, memoir, 93

Desgouttes, - letter (I 735), I52

Des Groseilliers, see Groseilliers

Des Haguais, -

Des Hayes, Sieur Robert, journal, I25; letters, I 22

Des Herbiers de Letanduère, Henri François, marquis, observations, 225

Desjardins, $\longrightarrow$, papers, I07

Desjardins de Fontvanne, - , translation, 87

Desjean, Jean Bernard Louis, see Pointis

Deslandes, - - extract by, 33

Desliens, Nicolas, map, 222

Deslongchamps, Jacques Amand Eudes (?), 223

Des Maizerets, Louis Ango, letters, 55

Desmarets, Nicolas (?), Louisiana grant, 227

Desmeloises, Nicolas, trial, dossier, 247.

Desmontis, Sieur, memoir, 24I

Desnos, _-, see Champmeslin

Desnoyelles, see Noyelle

Des Pintraux, —. Scioto Company, 245

Despont, Antoinette, see Guercheville

Des Portes, see Deluzy des Portes

Des Rosiers, Soeur, I6I

Desrueaux, - , charges (1720), 266

Destouches, - letters, I22

Des Tours, see Jeury des Tours

Desvieux, - Compagnie des Indes, 59, 60

Detmold, $D r$. William, letter, 90

Detroit, census, II 3 ; extracts from registers, I I3; Guide, I29; Indians, II3; information on region (I7OI), 23 ; papers, II2, II 3 ; settlement, 67: see also commandants by name, especially Boishébert; Cadillac; Dubuisson; Sabrevois; Tonty

Devaulx, Jacques, pilot, MSS., 3

Devaulx, Pierre, map, 3

Deville, James, letter, 260

Devillers, Sieur, map, 233

Devin, —, maps, 227, 228

Dezoteux, - map, I 6

Diamant, 165

Diane, 7

Dias de Castro, - , petition, 38

Dickinson, John, Farmer's Letters, I 47

Dictionaries, see Languages

Didot C. Pierre, 257 
Diel du Parquet, see Du Parquet

Dieppe, admiralty, I07, 217, 263 ; commerce, 56, I83, I85, 205; Compagnie des Indes Occidentales, I88; fisheries, I86, I88, 204, 217, 27I; memoir, I 28

Dieskau, Ludwig August, baron de, campaign, I I 9, 242, 270; papers, I I3

Dieudonné, Pc̀re —, letter, I33

Dijon, see Parlement

Diligente, I35, I4I, I74

Dionne, Narcisse Eutrope, Samuel Champlain, 23

Diplomatic agents, American, despatches (I789I8I6), 219: see also Ambassadors; Commissioners

Diron d'Artaguette, see Artaguette

Disasters, see Earthquakes ; Fires ; Floods; Hurricanes

Discours d'un Grand Capitaine de Dieppe, 214

Discoveries, Renaudot's memoir, 25, 4I, 97

Discovery of America, results, I 43

District of Columbia, Warden's Description, 257

Divine River, name for Illinois, I76

Dixwell, E. L., letter, 275

Documents Inédits sur l'Histoire de France, 94

Documents relative to the Colonial History of Nere York, IOI

Dodge, Gorham, and Co., 2I

Dodier, Sébastien, I 62

Dolivet, Lt. —, see Delivet

Dollier de Casson, Abbé François, "Montreal ", I03, 265; Montreal, I06; on Courcelles' Ontario voyage, 44 ; voyage, 97

Dolphin, notes, 272

Dolu, F., company, 9, 27, I70; letter to, I83

Domaine d'Occident, acts, 76, 89; control, I 58; ferme, finances, $\mathrm{I} 4,57-60,76,8 \mathrm{I}, 2 \mathrm{I} 8$; history, 279; increased tax to subvent trade, 70; letters patent, 83; memoirs, 85, 200: separation, 36, 83; slave trade, II7, 217

Domenech, Père Emmanuel Henri, correspondence, I $4 \mathrm{I}$

Domergue, Pierre, I4

Domicile, French foreign, Io

Dominica, documents, 87; English attack, I89; establishment, I87; maps, 235; missionary, I74; possession, I I 5 ; see also West Indies; Windward Islands

Dominicans, Guadeloupe relation, 72

Dommengé, —- letters, 32

Dongan, Gov. Thomas, letters, 104

Doniol, Henri, Participation de la France, collection, correspondence, 9I-93, 256

Donker, Hendrick, West Indische Paskaert, 256

Doolittle, J., on steam navigation, 127

Doreil - , letter (I758), 243

Dorez, Léon, Cat. de la Collection Dupuy, 208; on Bixio collection, I46; on Roberval's commission, 208

Dorillac, —, suit, I 57

Dorré, - - services, I 25

Dosquet, Bishop Herman, Indian liquor trade, $80,8 \mathrm{I}$; revenues, $8 \mathrm{I}$

Douais, Célestin, 48; Depêches de Fourquevaux, 28 ; Lettres de Charles IX., 28

Donin, —- on marking negroes, I 9
Douville, —, trial, 247

Douville, J. B., travels, 278

Dowries, nuns, I0, 7 I

D'Oyley, Gov. Edward, commission, I80

Dragon, I2I

Drake, Sir Francis, expeditions, 4, 47, 207 264; French despatches, 48; Portobello, I79 Renaudot on, 97

Dreux, Pierre Lucien, papers, 239, 243

Droüot de Valdeterre, $\longrightarrow$, Biloxi, 88 ; relation 217

Drucour, Mme._, letters, I I6

Dubiq, - letter to, 248

Du Bocage, —, memoir, 74

Dubois, - governor of St. Croix, I8o

Dubois, —- Canadian artillery, 25I ; map, 22 .

Dubois, - $\longrightarrow$, on Toussaint, 94

Dubois, Pierre, see Avaugour

Dubois and Co., letter, 165

Dubois de la Motte, Emmanuel Auguste dr Cahideuc, comte, 244

Dubos, $A b b \dot{e}$, letters, II I

Du Bouchet, —, letter, I 99

Du Bouexic, Luc Urbain de, see Guichen

Dubourg, —, letter (I769), 275

Dubreuil, Claude Joseph (?), Boston trade, IOr

Dubrocq, Alexandre, map, 23I

Ducasse, Gov. Jean Baptiste, Cartagena, 6, 25 letters, I66; letter to, I I5; St. Christopher I65; squadron, voyage, 68 , I I7, I46

Ducéré, E., on log-book, 3

Du Chaffault de Besné, Louis Charles, comte cruise, I2I ; letter, I2I

Du Chastelet, Paul Hay, Politique de France MS., 44

Duché (Ducher), ——, Compagnie des Indes 59, I I7 ; speculation, I44

Duchesneau, Jacques, liquor trade, I74; offices Io ; papers, I04; receipt, I I I

Du Chilleau, Marquis de, I32

Duclos, Capt. —- half-pay (I690), I38

Duclos, - ordonnateur, assaying, I54; will I 53

Duclos-Guyot, Capt. — , voyage, I 3 I

Du Comporté, —, letter, I75

Du Coudray, Capt. - , and Begon, 69; fo Louisiana, 68, 69; South Sea voyage, 252

Du Coudray, - letter ( 1663 ), I 83

Du Coudray, Emmanuel le Borgne, sce Le Borgn

Du Coudray, J. A., "Armées en I779", 76

Du Coudray, William, letter, 245

Duer, William A., letter, 283

Du Fouché, see Castel du Fouché

Dufresne, G. T., "Considerations sur Saint Domingue ", 87

Du Fresne, Roger Akakia, sicur, letters, 84, I8t I 87

Dugommier, Gcn. Jean François Coquille, I 6

Du Guast, Pierre, see Monts

Du Guay, Comte, 75

Duguay-'Trouin, René, notes, I I 8

Dugué, Pierre, sce Boisbriant

Duguet, Pierre, notary, I 06

Duhail, - letter, 39

Du Halley, Sicur, see Descasaux 
1u Lhut, Daniel Greysolon, sieur, capture of English, I75; papers, I08; voyage, notes, 226

lu Lion, Gov. — charges against, I96; Dominica, I87; Guadeloupe, recognized, I6, I89, I93; letters, I80, I84, I 85, I87, I89, I93, I96; salary, 203

u Magnon, Capt. _ cruise, 63

lumaitz de Goimpé, Chevalier, letters, 64, I40, I68; memoir, I66; papers, I67

Jumanoir, _- voyages, I30

)umas, $\longrightarrow$, letter ( I609), I94

Jumas, C., autobiography, 45 ; on colonies, 44 , 45

Jumenil, Abbé L., map, 233

Ju Mesgouez, Trolius, see La Roche

Jumesnil, - Guadeloupe letter, I83

Jumesnil, _ Peronne, agent, 185 ; papers, 106

u Mesnil Patté, Sieur, command, I 35

Ju Mont, $\longrightarrow$, services, I66, I90

Jumont, Henry, research, 86

Jumont, Jean, Corps Diplomatique, 5

Jumont de Blaignat, - , letter to, Iro

Jumont de Montigny, - Memoires Historiques, 240 ; versified history of Louisiana, 240

Ju Motier, Marie, see Lafayette

)umoulin, $\longrightarrow$, trial, 247

Junglison, $D r$. Robley, letters, 90

Junkirk, commerce, 53, 85, 254; English prisoners, I8I ; fisheries, 85, I87, 214; whaling, I2 u Noyer, François, see St. Martin

) u Parquet, Gov. Jacques Diel, Martinique, I I 5

)u Pasquier de Dommartin, Hippolyte, EtatsUnis et le Mexique, II6

) u Perron Talour, - , letters, I 82, I83

u Petit Pré, Sicur de, see Hoüel

Jupetit Thouars, see Thouars

Jupin, - , letter, I32

Jupin, Père - letter to, 217

upleix, $\longrightarrow$, letter, 216

u Plessis, Armand Jean, see Richelieu

Duplessis de Ste. Hélène, Mère André, letters, I 3

Ju Plessis Kerbode, $\longrightarrow$, I 70

Juplessy Fabert, - Chambly, I68; letters, I68; mines, I39; services, I68

Ju Pont, _- see Poulet

Jupont, - letters to (I672), I62

Jupont, Eluthère Irénée, letters, 274

Ju Pont de Courtelay, Marquis, letter to ( I635), $9 \mathrm{I}$

Jupont de la Motte, Mme. —_, correspondence, 93

Jupont de Nemours, Pierre Samuel, letter, travels, $4 \mathrm{I}$

Jupont de Neuville, —, office (I674), I98, 200

Ju Portal, —, papers, I 47, I 48

Juportault, $\longrightarrow$, letters to, I 62

Ju Puis, Frère Mathias, Relation, I 5

Jupuy, $D r$.

Jupuy, Claude, MSS., 208

Jupuy, Claude Thomas, memoir, 267; papers, II 3

Jupuy, Jacques, collection, 208

Jupuy, Pierre, collection, 208
Du Quesne, Marquis de, pension ( I697), I56

Du Quesne, Jacob, suit, 52

Du Quesne de Menneville, Michel Ange, marquis de, administration, praised, 87, 270; foreign traders, 37 ; letter, I I6

Du Quesne-Monnier, Abraham, letter, I8I

Durand, Jean, printer, $5 \mathrm{I}$

Durand, Jean, voyage, I 74

Durand, Nicolas, see Villegagnon

Duraurepay, - letter (I759), I20

Du Rivau Huët, Capt. - letter (1684), I40

Durribaud, R., letter, I 93

Du Ru, Père Paul, 25

Du Ruau, Bertrand Pallu, sicur, agency, Io

Dusault, —, letter ( I675), 200

Du Sault, _- maps, 227, 232; soundings, 78

Dutast, - Frontenac dispute, I 66

Dutch East India Company, English complaints, I 87 ; formation, I4; information, I 85 ; notes, 262 ; posts, 207

Dutch Guiana, see Guiana, Dutch

Dutch West India Company, and New England, 205; charter, I4, 50, I I 5, I 85, 209, 26I ; English complaint, I87; Guinea privileges, 82; information, 185; maltreats French ship, 205 ; memoirs, 50,64 ; notes, 262 ; posts, 207 ; report, 26I ; ships, 187 ; see also Netherlands

Dutertre, Joseph, transporté, commission, I 62

Duties, American tariff of I828, 282; and American cotton, 244 ; beaver, 60 ; drawback, 85; Dutch, 214; farming, colonial, 59, 60; fish, free trade, I 32 , I 95 ; free trade goods for colonies, I94; in West Indies, 70; new ( I668), I92; on colonial products, I8, I9, $32,57-59$; project (c. I750), 266; SpanishAmerican products, 8I; sugar, 74; trade beyond demarcation line, 204; West Indies products for Canada, 58, 239; see also Commerce; Excise; Fermes; Tonnage

Duval, Jean Pierre, Kerlérec affair, 6I, 248

Du Val d'Abbeville, P., map, 229

Du Var, Guillaume, 210

Duverger de St. Blin, see St. Blin

Dyes, see Camneche wood

Eagle, 22

Earthquakes, Martinique, 79; Montreal, 8I

East Florida, map, 229; see also Florida

East Indies, Compagnie des Indes papers, I I7; French indifference, I84; Portuguese expedition, II8; Ryswick negotiations, 49; Spanish routes, 26I; treaty of Compiegne on trade, 262, 263; treaty of Münster, 263; see also Compagnie des Indes Orientales; Dutch East India Company; English East India Company; Indies; regions by name

Eaton, Amos, letter, 274

Ebbard, Jean, see St. Sulpice

Echénée, Bishop of, and Missions Etrangères, 27 Eclipse, moon ( 1700 ), 56

Ecole des Chartes, Bibliography, I 47

Economic conditions, Boston, I62; see also Agriculture; Commerce; Finances; Fisheries; Labor; Land; Lumber; Mines; Natural history; Property

Ecores à Margot, fort, 229 
Ecuador, history, 277; see also Quito

Edits et Ordonnances, 7

Education, European schools (1838), 282; Indian, I64; in United States, examination papers, 258; see also College; Seminary

Edward VII. of England, American visit, I3I

Edwards, Bryan, Saint-Doningue, 87

Effiat, Antoine Coffier, marquis d', 6

Eights, James, letter, 275

Eisenman, - 93

Elections, American corrupt practices, 25I

Eléphant, royal ship, wreck, 62, 80, 225

Eliza (2 ships), 22

Elizabeth of England, letter to, 7 .

Elizabeth of Russia, and France, 146

Elliott, Capt. Jesse D., 260

Ellis, George, letters, I4I

Elton, Romeo, letter, 282

Embrun, Archbishop of, letter, I88

Emerillon, I35, I4I

Emerson, Ralph Waldo, 283

Emigration, Acadians, to Guiana, 8 ; notes, $4 \mathrm{I}$; to United States, I16, I29, 245; see also Settlers

Enciso, Martin Fernández de, extracts, I I8

Enflammé, 67, 68

Engageante, 124

Engagés, see Servants

Engelman, George, letter, 275

Engerand, Louis, Cat. des MSS. . . . Bibl. du Sénat, 279

England, American policy ( I807), 257; and neglect of Spanish America (I669), I3; Colbert's documents, I79; commerce, 9, 28, 77, I45, 280; Cromwell and Canada, 48; Dutch relations, trade, I3, I87, 208; excise, 82; fisheries, 271; Indies, 28, I47; Isthmian transit, I43; Levant, 9 ; questions on colonies and trade, 138; Rupert's prizes in France, 48; Santo Domingo, I52; trade with French and Spanish colonies, 30, I45, 243; usurpations in America, 6, I5, 30, 3I, 40, 206, 263; whaling, 27I; Windward Islands claim (1730), 80; see also Ambassadors; Assiento; "English" titles; Neutral trade; Treaties; wars by name

English American colonies, commerce, 239; compared with French, 3I; complaints against French (I670), I7; conditions (1728), 280; Dartmouth's queries, 9 ; expansion ( $c$. I663), I45; Guiana trade, 8; history and geography, 240; information (I695), I76; Koch's lectures, 265; map, I77; news (I76I-7I), I2I ; notes, 46; plans against, 30, 3I, II I, I 55 ; regulations (c. I765), 3I; relation (I666), 206; to 1655,206 ; trade letters (1709-12). I45; see also England; Mercantile system; colonies and wars by name

English Channel, description, 5I

English East India Company, establishment, 26r

English manuscripts of Bibliothèque Nationale, 219

Enjalran, Père Jean, letter, I09

Ennery, Victor Thérèse Charpentier (?), comte d', correspondence, I $2 \mathrm{I}$

Entreprenant, I35, I4I
Eon, Chevalier d', see Eon de Beaumont

Eon, Guillaume, letters, I9I, I92

Eon, Julien, letter, 197

Eon de Beaumont, Charles d' (chevalier d'Eon), letters, I20; papers, letter to, 245

Épinay, L Fermanel d', see Fermanel

Epinay St. Luc, François de, see St. Luc

Erie (Presqu'ile), Pa., description, 87; plan of fort (1796), 229

Erie Canal, prehistoric plants, 274

Escar de Pérusse, see Pérusse

Escort, see Convoys

Eskimos, Courtemanche, I05; Joliet, I05; language, 75 ; relations, 78 , I05

Esmerillon, 55

Esnambuc, Pierre Belain, sieur d', papers on, 115

Esparbès de Lussan-Bourchard, Joseph Henri d', see Aubeterre

Espérance, 165, 201

Espey, James P., letters, 256

Espoir, 239

Estaing, Charles Hector, comte d', American papers, I22; career after I780, 126; correspondence, I22, I25, 126, I47, 242; criticism, 245 ; expedition, II, I20, I24-I26, 230; Georgia land grant, I42; marriage certificate, I 25 ; memoirs on English colonial relations (I755), 242 ; on Dorré, I25; on Louisiana, I I 4 , I25, I46 ; portrait, I25; proclamation to Canadians, 24I; Savannah, 230; Ternay on, 124; West Indies, I25, 235, 237, $24 \mathrm{I}$

Estates, Martinique papers, I57; of minors, slaves, 58,2 I I ; settlement, 37 ; succession in colonies, I62; unclaimed, reversion, I0, 7 I ; wills, 5, I 53

Estèbe, Guillaume, Bastille papers, 247, 249, 250

Estimates, colonial forces (I707), I 37 ; marine and colonial ( I7I6-I7), I2; see also Finances

Estoutéville, Jean d', 244

Estrades, Godefroi, comte d', and Gargot, I49; English negotiations, 206; letters, I \&2-I84, I86; viceroy, commission, 27, I70, 182

Estrador, Juan de, 74

Estrées, César, cardinal d', and Marly Globe, 42; memoir to, I76, I77; Roman embassy, correspondence, I4

Estrées, François Annibal, duc d', letter, I98

Estrées, Jean, duc (comte, maréchal) d', despatches for, 201 ; letters, West Indies, r92I94, 200; letters to, I6, 66, 67; memoirs, 200, 202 ; notes, I I8; squadron, West Indies, I 52, I66, I94, 20I, 262; viceroy, commission, I7I

Estrées, Victor Marie, duc (maréchal) d', letter, I I ; Marine affairs before regency, 70; St. Lucia concession, 33,78

Etoile, I3I

Etudes Critique sur l'Histoire, 86

Eudemare, Pére Georges, letter, 21 7

Eudes de Mézeray, François, see Mézeray

Europe, affairs (1657), 28; conditions ( 1654$56), 205,207$; history (I697-I708), I46; maps, 3, 22I, 222, 256; schools, 282

Evans, Oliver, I27

Evans, Dr. Thomas W., letter, 90

Eve, Dr. Paul F.. letter, 90 
verett, Alexander H., letters, 282 verett, Edward, letters, 259, 260 vremond, - - letter, 269; praised, 269 vries Bros., letter, 259 xchange, see Bills xcise, English tobacco and wine, 82 xelmont, Comte d', r7o xpenditures, Acadia and Placentia ( I670-73), I94, I97, 201, 203; American ( I632-34), 33; Canada (I665-87), I 35, I 36, I89-I91, I94, I95, 20I, 203; colonial military, estimate, I37, I90; Guiana (1677), 20I ; King William's War, I64; Louisiana, I5, 40; marine and colonial, royal, table of contents, i2, 89, I6I, 202, 203, 25I ; religious, in New France ( I703), 268; see also Finances xploration, Spanish jealousy of French, 209 'xposé des Motifs relativement à l'Angleterre, $2 \mathrm{I} 4$

abbroni, J., letters, 259

abres, — Bastille papers, 247, 249, 250 abri de Peiresc, Nicolas Claude, see Peiresc abry de la Bruyerre, - Louisiana memoir, 40; papers, 108

actum du Procès . . . Biencourt . . . et Biard, I07

aillon, $A b b e ́$, I07, I I2

alkiand Islands, voyage, I3I

allize, _- map, 234

'almouth, Eng., French ships, 67, I 98

amilies, royal bounty for large, 203

amily Compact, commercial aspect, I46; negotiations, 29, 30 ; opportunity, 30

aneuil, —, letter to ( I673), I 36

aneuil and Son, La Rochelle, I36

anny, 2I

antasque, 126

ar West, maps, 229; river to South Sea, 226; see also La Vérendrye; South Sea

aubourg St. Antoine, Paris, riots, 83

auchet, Jean Antoine Joseph, 39

auvel, Marie, veuve Cavelier, I I I

aux sauniers, as colonial troops, I38; transportation, 64, 70, I86, 255

avier, Jean Louis, memoir, 74

avre, Dr. Antoine, memoir, 258

ä̈, Bernard, Bibliographie Critique, 6I; on Franklin, 257

iayolle, Claude Nicolas, Bastille papers, 247 , 249,250

'écamp, France, admiralty, 217

iederal Constitution, Mably on, 43; translation of draft, 40

iée, I53

'énélon, —, Bordeaux memoir, 252

'er, Nicolas de, Description de le Découverte des Missisipi, 24; maps, 24, 267

iercourt, see Perrot de Fercourt

'erdinand II. of Holy Roman Empire, 96

erdinand VI. of Spain, 207

ieret, A., IO2

"erguson, James, letters, 258

ierland, Abbe, communication, notes, 106

'ermanel d'Épinay, L., letters, I85
Fermes, Canada, I05, I75; see also Domaine d'Occident; Finances; Tobacco

Fernandes, Jose, map, 223

Fernandez de Oviedo, see Oviedo

Fernanuñez, Condes de, and vice-royalty, I63

Ferrand, $\longrightarrow$, trial, 247

Ferrières, —, trial, 247

Ferrolle, — , voyage, memoir, I76

Ferryland, Newfoundland, expedition, I64

Fesche, Charles Félix Pierre, journal, 273

Feuillés, P., map, 258

Feuquières, Isaac de Pas, marquis de, viceroy, I70

Fevret de Fontette, —, collection, 216

Fézeret, Charles, services, I66

Field, John, printer, 206

Figueroa, Balthazar Pardo de, see Pardo

Filibusters, affair (1687), I69; amnesty, 33; and de Pointis, 23, Carolina, I36; Cuba, I 27; English, I79, I90; Martinique, 98; Santo Domingo, 97

Fillion, Michel, notary, Io6

Finances, Compagnie des Indes, I9, 83; declaration on Marine accounts (I744), 36; French colonial, I4, I5, I44; French, due to American Revolution, I23; regulation of departmental, I58; see also Accounts; Banking; Bills of exchange; Debts; Estimates; Expenditures; Fermes; Letters of credit; Money; Taxation

Finé, Oronce, on longitude, 45

Fire Indians, see Mascouten

Fires, Boston, 90; Cap Français, 232, 234

Fisheries, Acadian, Io7; acts, list, 76, 27I ; Admiralty jurisdictions, 2I7; Anglo-French negotiations ( I662), I82; Basques, I88; Bayonne, 3I ; Bordeaux, 266; Canada, 27I ; Cape Breton (Ile Royale), 82, r37, 21 3 ; Colbert's promotion, 28, I34, I89; compared with agriculture, 27I; concessions, I 5, 33, 34, 78, I06, I75, I76, 21 8; conditions, 262; control, 6; dictionaries of places, 27I; Dieppe, I86, I88; Dunkirk, I87, 214; Dutch rights (I6I4), 208; duty, I9; free trade, revocation, I95, I97, 20I ; French cod (I745), 257 ; Granville, I90-I92, 27 I, 280 ; history of cod, 279; Iceland, 272; Ile Percée, I73; impediments, 74; importance, 7 ; Labrador, $7 \mathrm{I}$; Marine policy and practices, 33; Marseilles, I38; Maurepas, I 54, I 55; Mediterranean cod trade, 77 ; memoirs, 5, 3I, II I, I 32, I95, 204, 2I4, 240, 27I ; Nantes, I46, I88; Normandy, 74, I 28 ; notes, 43 ; observations, 40; oil cargo, I9I ; permits, 44; preparation of cod, 273 ; prizes, I 53, 200, 20I, 218; Queen Anne's War, I36, 218; Raudot's work, II ; record of sales ( I655), I6I ; references, 47, 252, 254, 263; St. Lawrence River, 6; salmon, I76; ships, 82; Spain and cod, 30; treaty of Utrecht, I5I ; United States, 27I; West Indies and cod, 27I ; see also Concessions; Newfoundland; Whaling

Fishes, cod, 27 I f freshwater, of America, 27I ; Noël de la Morinière on, 270; perch, 273; West Indies, 27I 
Fita, J. de, letter, 198

Fitch, John, steamboat, I 27

Fitton, William Henry, letter, 260

Five Nations, sce Iroquois

Flag, abuse, I I

Flammermont, Jules, collection, 94; Correspondances des Agents Diplomatiques, 94

Flanders, private French relations, I I 5

Flax, Canadian, I88, I 97

Flemings, Cayenne, I 85

Fleuriau, Charles Jean Baptiste, sec Morville

Fleurieu, Charles Pierre Claret, comte de, annotation, 278

Fleurimont, Sieur de, see Noyelle

Fleuriot de Langle, sec Langle

Fleury, Abraham Joseph Bénard (?), 244.

Fleury, André Hercule, cardinal de, memoir to, 247

Fleutelot de Romprey, - I I

Floods, Santo Domingo, I2

Flora, see Plants

Flore, 233, 276, 277

Florida, Apalache fort, 25; commerce, 8, 239; Delisle's MSS., 26; descriptions, I44, 217, 265 ; French inhabitants (I750), 207 ; geographical relation, 42; Georgia operations, I45; histories, 65 ; Huguenots, Gourgues, 4, 5, 26, 29, 48, 54-56, I I 4 , I I 5 , I 50, 207, 209, 210; Iberville, I76; Indian attack, 268; Jesuit martyrs, 47, 75; La Croix's relation, 279; maps, 39, I 40, I $77,222,226$, 229, 255, 256, 258; Ogeron's papers, II 5 ; seeds, 27I; specimens, 274; Tonty, 268; Verrazano, 28

Flour, Canadian, I35, I40; for Acadia, I64

Flûte Royale, 25I

Foache, 1 , memoir, 148

Foligné Deschalonge, - , journal (I777), I2I

Fonspertius, - French consul at Charleston, letter, 38 ; relieved, 39

Fontaine Mervé, - letter, 254

Fontanelle, - , on colonial defenses, I 47

Fontanieu, —-, I05; MSS., 3

Fonteneau, Jean Alphonse, "Cosmographie", 3; Cosmographie, 4; Voyages Aventureux, 4

Food, see Agriculture; Fisheries; Provisions

Forant, Job, voyage, 202, 203

Forbonnais, François Véron Duverger de, communication, 40; Finances de France, 32

Ford, Worthington C., letter, 256

Foreign Affairs, department of, list of despatches (I669-98), I58; list of maps, II6; regulations, I 58

Forests, waste for Canadian, 198, 200; see also Lumber; Trees; Naval stores

Foret, —, letters to, 24I

Forillon, see Ferryland

Formidable, 75

Fornel, Joachim, letter, 55

Fornel, Louis, journey, journal, I05, 108

Forsans, - petition, I6o

Fort Assumption, 254

Fort Bourbon, Martinique, 236

Fort Buade, I68

Fort Bull, I 57

Fort Carillon, see Ticonderoga
Fort Cataraqui, I63

Fort Choüagen, see Oswego

Fort Crèvecoeur, Texas (?), 227

Fort Dauphin, Santo Domingo, sce Port Dauphin

Fort de Joux, 94

Fort de la Reine, Dominica, 235

Fort de Paix, Santo Domingo, see Port de Paix

Fort Duquesne, affairs (I756), I57; Braddock, 270 ; plan, 228

Fortescuyère, - letter ( 1635 ), 9I

Fort Frédéric, see Crown Point

Fort Frontenac, affairs, 98, I I0, I57, I68, I69, I 72 ; concession, I I 0 ; fund, I I I

Fort George, sce Fort William Henry

Fortifications, sce Defenses, "Fort" titles

Fort Jeudi, Grenada, 235

Fort Johnston, Cape Fear, 246

Fort Liberté, Santo Domingo, 22

Fort Louis, La., 25, 39

Fort Louis, Placentia, 26, I64

Fort Maurepas, 97, 98

Fort Mississippi, 56

Fort Naxouat, I70, I76

Fort Niagara, see Niagara

Fort Orleans, Mo., 248

Fort Rosalie (Natchez), 78 ; map and plan, 228, 229

Fort Royal, Grenada, 235

Fort Royal, Martinique, Dutch attack, I69; plan, 236

Fort St. Charles, Guadeloupe, 236

Fort St. Francis, La., 254

Fort St. George, Canada, 242

Fort St. George, Grenada, 235

Fort St. John, 7 I

Fort St. Louis (Chambly), I66, I68, 226

Fort St. Louis, I1l., 65, I73.

Fort St. Louis, Santo Domingo, I 52, 232

Fort William Henry, capture, I I9, 242, 244 ; plan, 244

Fort York, Hudson Bay, I 24

Forum, 257

Foucault, _- père, I 5

Foucault, Denis Nicolas, Louisiana revolt, Bastille papers, 248

Foucault, Joseph, Normandy memoirs, 280

Foucault, Père Nicolas, murdered, 268

Foucault, Nicolas, Normandy memoirs, 280

Fouché, Joseph, see Otranto

Foulke, Dr. John, in Paris, 4I, 238

Fouquet, Nicolas, 46, I83; papers, I49

Fourgon, I 4I

Fournier, - on commerce, I32

Fournier, A., works, 258

Fourquevaux, Raymond de Pavie, sicur de, correspondence and discourses, 28,48 , II5, I $47,209,210$

Foxes, notes, 72

Fox Indians, articles on, I I3, I29; defeats, 79-81, 254

Fragment of Chouteau's Narrative, 129

France, situation (I739), 266

Francis I. of France, and Havre, 74 ; and Roberval, 244 ; instructions to Cartier, 6

Francisque, East Indian, suit, 2I I

Franck. Max, letter. 26o 
Franco-American War, West Indies seizures (I796-97), 20-22

Franco-Dutch War (1672-78), Anglo-French naval operations, I98; convoys, I96-20I ; fisheries, Newfoundland, I96, 200; French naval plans, 202 ; peace, I 54; prizes, I96, I97, 200, 201 ; West Indies, Tobago, 54, I66, I69, 195, I96, I98-201, 237

François, - , letter (I667), I92

Franklin, Alfred, Précis, In.

Franklin, Benjamin, 243 ; arrival, I I ; biographical notes, 93; Didot's recollections, 257; dinner, I26; illness, 238; letters, 4I, 88, I 47, 238; letters of gallantry, 257; letters to, I22, I 26; medal for Fleury, 244; mission, 94; portrait, I 46 ; presented, I ; remedy for colds, 43; Science du Bonhomme Richard, 6I, 253; scientific notes, 257; stove, 61; verses on, 93, 257; will, codicil, 257

Franklin, Lady Jane, letters, I I 7

Franklin, Sir John, I I7, 260

Franklin, W. T., letter, 4I

Franklin, 22

Franquelin, Jean Baptiste Louis, and Ottawa country, I66; correspondence, I66; maps, 84 , I77.

Frederick II. of Prussia, and Gérard, I i ; letter, I 46

Freemasonry, Santo Domingo, I 43, 277

Fréminville, Christophe Paulin de la Poix, chevalier de, letters, voyages, 274

French, Benjamin F., Historical Collections of Louisiana, 97

French Alliance, value ( I775-95), I 26

French and Indian War, Acadian refugees, 8, 2I3; affairs, news, 29, 30, I44, I57, 214, 246; Anglo-Spanish rupture, 3I ; anticipation, 266; Bougainville's journal and papers, II9, I20; campaign (I756), I57; (1760), I20; Canadian officers in France (I760), 243; claims, commission, 35,42 ; convoys, 29; cost in Canada, I I9; Crown Point, I20, 230, 243; declaration, 88, 214; descriptions, 87; discussion of policies and peace terms, 242 ; effect on English colonies, 242 ; English plans (I758), 243; État Présent du Canada (I758), I04; finances, I44; Fort Duquesne, Braddock, I57, 228, 270; Fort Niagara, I I9; French consolation, 74; French victories, Te Deum, I4; graft, Bigot, 49, I44, I45, $212,246,247,280$; Indian neutrality, 242; Iroquois, I32; Lagrange's work, 86; Lake George, Dieskau, Fort William Henry, I I9, I 57, 242, 244, 270; Lévis and Montreuil on conditions (I757-60), 24I, 242; loss of Canada, 45, I 46 ; Louisbourg, 86, I2I, 21 4, 242-244; Louisiana, 3I, 242 ; Marine administration, memoirs, 28, 36, 37; Montcalm, I20, I 55; navigation, sea power, 32, I2I, 242, 243 ; neutral trade, provisions for French colonies, 30-32, 280; Newfoundland, I2I, I25; Oswego, I57, I58, 242 ; papers, II3; prizes, 29, I30, 242; Quebec, I I9, I32, 24I243, 280; references, 245; Ticonderoga, 32, I I9, I 20, I 32,242 ; transport of troops, 75 ; West Indies, 31, 86, I30
French Canadians, genealogical notes, I06

French colonies, acts, I4; administration, 279; attitude of court, 64 ; conservation, prosperity, memoirs, 36, 40, 44, 47, 2I4; documents, papers, calendar, 49, 93, I I 4, I 45 ; English encroachments, 6, I5, 30, 3I, 40, 206, 263; expulsion of foreigners, I 6; French places concerned with history, II6; permit to establish, I5; possible, extension, 27, I79; Turgot on home relations (I776), I2I ; see also Economic conditions; Geography ; Government; Military; Social conditions; colonies and regions by name

French Revolution, letters from American agents ( I 794-96), 38, 39; memoirs on United States (I795), I 43; Monroe, I 42

Freville, Anne François Joachim, translation by, 60

Frézier, Amédée François, correspondence, I47 ; voyages, 252

Frick, Dr. George, letter, 89

Friendship (2 ships), 21, 22

Frobisher, Sir Martin, 48, 207

Frogs, notes on American, 273

Fromaget, - , Compagnie des Indes, 59

Frondad, — de, log-book, 88

Fronsac, Richard Denys, sieur de, concession, letter, 64, I66, I 76

Frontenac, Comtesse de, intrigue, I99

Frontenac, Louis de Buade, comte de Palluau et de, appointments by, I63; Bernou on, I00; Blénac, 252; death, funeral oration, 44, I06, I44, I64; debt, Verjus, I95, I96, I98; decoration, I78; demand, I59; departure, voyage, I95, I96; Dutast, I66; interpreter, 246; Iroquois, 9, 98; Lake Ontario, 54, I 55, 240; La Salle, I Io; Laval, Io; letters, 65, 98, I04I06, I64, I66, I67, I72, I96, I99; letters to, Iо, 98, I09; memoirs, papers, I04-106; on officers, I60; on Provost-Galifet dispute, I69; police, I 55, 240; reference, 64; religious affairs, I68, I99; salary, expenses, I6I, 203; self-justification, I66; siege of Quebec, 225 ; signature, seal, I38; speeches, I55, 240; will, I64

Fulton, Robert, letters to, I33; physics, 93; steamboat, 127

Funck-Brentano, Frantz, Cat. des MSS. de la Bibl. de l'Arsenal, 246

Funeral, Iroquois, 79 ; orations, 44, 77, 106, I 44 Fur trade, cargo, sale in France, I9I; history, 5I ; legal proceedings, 73; memoirs, I05; monopolies, I5, I 53, 218; observations, 40; permits, 70, I64, I66; restrictions, effect, 66; see also Beaver; Coureurs de bois; Liquor

Gabaret, Louis (Jean) (de), complaint against, 20I ; despatches, 20I ; letter, I67; letter to, I 7 ; squadron, I94, 202

Gabun, collection on, 87

Gaëtan, Jean, 8

Gaffarel, Paul, Floride Française, 4; Thevet's France Antarctique, 46

Gaignières, François Roger de, collection, I5 I

Gaillarde, I62, 201 
Galant, 16, 199

Galaup, Jean François de, see La Pérouse

Galbaud-Dufort, Gov. Gen. P. T., letter, slander, 93

Galiet, Sieur, letter to, 2I 7

Galiet, Père Claude, letter, 21 7

Galindo, Col. - , collection, 220

Galinée, René de Brehaut de, letters, III ; voyage, 97

Gallais de la Tour, —, memoir, I7

Gallatin, Albert, letter, 245

Galleons, English blockade, 8o; fleet, 49; foreign merchants' interest, 49; for Portobello, I44; French designs against (1675), 202 ; routes and practice, I79; Santo Domingo, $8 \mathrm{I}$; treasure trove, 69; wartime, I40, 190, 252

Galleys, Arnoul papers, I34; convicts transported as marines, I37; expenditures, 89 ; see also Transportation

Gallifet, Chevalier de, decoration, I78; letters, 66, I65; letters to, II5; memoirs, I39; on slave trade, I 38 ; Provost dispute, I69

Gallinet, _- letter, 68

Gallon, - de, letters, West Indies trade, I67, $20 \mathrm{I}$

Gallut, Armand, letter, I67

Galvan, Maj. Guillaume (?), letter, I22

Galvez, Mariano, 220

Gama, Vasco da, 97

Gambacorta, —, I 100

Gamboa, Capt. Pedro Sarmiento de, see Sarmiento

Gamelin, —, trial, 247

Gannes, - de, decoration, I 57

Ganteaume, Honoré Joseph, comte, letter, 75

Gardyner, George, New World, French translation, 53, I79

Gargot, Nicolas de la Rochette, see La Rochette

Gariseau, Capt. _ letter, 39

Garneau, François Xavier, Canada, I64

Garneau, Hector, I29

Garnier, Charles, 54

Garnier, Père Julien, letters, I04

Garreau, —, trial, 247

Gartigny, de, correspondence (I7II), I37

Garzoni, Constantino, relation, 264

Gaspé, lead mine, I89

Gastebois, see Gatebois

Gastinez, Sieur de, letter, I65

Gatebois (Gastebois), Compagnie des Indes, 59 ; refinery, I36

Gatines, - de, intendant, letter, 2I6

Gaudais, - letter, I76

Gaudais Dupont, Louis (?), letters 183, I87

Gaultier, - , letters, 270

Gauntheliard, M. J., letter, I92

Gautier, Gabriel, concession, I75

Gayot, Jean Baptiste, fur trade drafts, 12

Gazette de Holland, extract, 98

Gazette d'Utrecht, 246

Gébelin, François, Cat. . . Col. Godefroy, 260 Gédéon, 20I

Geffcken, Friedrich Heinrich, Alabama Frage, I 32

Geinoz, Abbé letter, 62
Gémoset, Gov. — de, letter, I67

Genealogy, Biencourt, 107; French Canadian notes, 106; parish registers, 86; West Indies family papers, II 5

General Greene, 22

Genêt, Edmund Charles, letter to, slander, 93; Louisiana plans, I I 4

Gentil, Père — , maps, 226, 267

Gentry, Canadian, I 54

Genty, Abbé Louis, Des Avantages ... de la Déconverte de l'Amérique, 6I

Geoff roy-Sainte-Hilaire, Isidore, letter to, 259

Geography, Africa, 28I ; America, 8, I 5, 43, I 44 , 240, 243, 28I ; ancient and modern, 25; compendium, 73; Delisle on plagiarism, 8, 62, I54; general description, 46; Niceron's bibliography, 73; "Orbis terrarum descriptio", 265; pre-Columbian, 260; relations, 42 ; treatise, 25; West Indies, 243; see also Boundaries; Cosmography; Maps

Geology, American investigation, 274; Fonds Cuvier, 258-260; Maryland, 275; Pennsylvania, 275

Georgia, advertisement (I732), 81 ; charter, 83; Florida operations, I45; land grant to Estaing, I42; memoirs, IrI, II6; Santo Domingo trade, I 48 ; spiders, $27 \mathrm{I}$

Georgia Packet, 22

Géorgienne, play, 85

Gerard, Père - theological propositions, 55

Gérard de Rayneval, Conrad Alexandre, attitude, 245 ; d'Estaing correspondence, I26; papers, 258; rumored arrest, II ; seeds, 274

Gerardin, $D r . \longrightarrow$, letter, 89

Gerault, - - letter to, 245

Gerbier family, 22

Germain, Père, letter to, 199

German Coast, La., notes, i I 6

Germans, see Palatines

Germany, colonization projects, I42, I86, 187 ; princes and Compagnie des Indes Occidentales, 149; Swedish Company, 26r ; see also Hanseatic

Gerritz, Ressel, map, 255

Getz, Nicolas, papers, I I I

Gibraltar, interview (I759), 29

Gigny, -, letter to, 47

Giguière, $\ldots$, notes, I06

Gilbert, Sir Humphry, 48

Gillet, - map, 234

Gilliss, James M., letters, 258

Gilly de Montaud, —, Compagnie des Indes, 59

Ginseng, history, 272

Girard, , missionary, complaint, 27

Girardin, Francois Emmanuel, chevalier de, instructions to, 126

Girardin de Vauvré, Jean Louis, see Vauvré

Girls for colonies, Canada, 16, 197, 201, 203; conducted, 16r ; Guadeloupe, 264; Louisiana, 68,70

Girod-Chantrans, Justin, Voyage, 61

Gironde, 67, 68, I38, 153

Glaciers, Agassiz's lectures, 275

Glandelet, - , letters, 268; return, I64

Gloucester, N. J., plan of action, 230 
Gobert, Gen. ——, Guadeloupe, I I6

Goch, — van, Brazil voyage, 2 I 7

Godefroy, Denis, collection, 253, 260

Godefroy, Jacques, I36; correspondence, I62

Godefroy (?), René (sieur de Linctot), papers, 106

Godefroy, Theodore, collection, 260; dictionary, 263; papers, 208

Godet, Anthony, passage, I63

Godin, Louis, expedition, 256

Godot, Jean, voyages, 43

Gold, American production and method, 4I, 75; assaying, I54; Brazil, 23; California (I706), I 6 ; Canada, 201; reported western, 67

Goltz, Bernard Wilhelm, baron von, despatches, 95

Gombauld, —, letter (1677), 201

Gonaives, Santo Domingo, 21, 39

Gonichon, - Natchez map, 228

Gonneville, Binot Paulmier, sieur de, voyage, I 18,239

Goos, Pieter, map, 258

Goosen, Jean, letter, I93

Gordon, Sir Robert, 263

Gorges, Ferdinando, 48

Gorris de la Guerche, Capt, __, letters, I93

Gosselin, Auguste Honoré, Eglise du Canada, 54; Normands au Canada, I39

Gosselin, Pierre François Joseph, collection, 22I

Gougon de Grondel, see Grondel

Goujon, -

Gould, Benjamin A., letters, 258

Goupil, E. Eugène, 2

Goupil, René, slain, 54

Gourdon, Jean Baptiste, letters, memoirs, I67

Gourgues, Dominique de, birthplace, family papers, I I5; Florida, 4, 26, 54, I I 5, I 50; will, 5

Gourgues, Bishop Jacques Joseph de, letter, I50

Gourgues, N. de, letter, I I 5

Gournay, Henri de, grant, 84

Gousabatz de Villepas, René, see Villepas

Goutin, Mathieu de, letter, memoir, I67; papers, I 06

Government, see Acts; Administration; Finances; Judiciary; Marine; Officials

Governors, commissions, list, I4, I7 I ; oath, I7I ; see also Viceroys; governors by name, especially those of Acadia, Canada, and Louisiana: Ailleboust; Argenson, Pierre; Aubry; Aulnay; Avaugour; Beauharnois; Biencourt; Bienville, Bonaventure; Brouillan; Cadillac: Callières; Chambly; Champlain; Courcelles; Denonville; Du Quesne ; Frontenac; Grandfontaine; Iberville; Kerlérec, La Barre; La Galissonière; La Jonquière; La Poterie; La Tour; Lauzon; Le Moyne de Sérigny; Longueuil; Mézy; Montmagny; Monts; Muy; Périer; Ramezay, Subercase; Vaudreuil; VaudreuilCavagnal

Goyer, Père Olivier, funeral oration, 44, I44

Gradis, David, trade, papers, I45, 247

Granata Nova, map, 279

Grancé, François Rouxel de Médavy, marquis de, letter, 199
Grand Bay, 224

Grande Encyclopédie, I n.

Grande Espérance, 196

Grande St. Pierre, 253

Grandfontaine, Hector Daudigny, chevalier de, Acadia, I97, I98, 201, 202; memoir, 202

Grand Goave, Santo Domingo, map, 234

Grand Gouffre, 227

Grandsire, - - letters to Cuvier, 260

Grand Victoire sur les Anglois [Yorktown], 44 Grant, Gen. James, 230

Grants, see Charters; Commercial companies; Concessions

Granville, France, commerce, 240 ; fisheries, 190I92, 27 I, 280

Granville Locquet, - memoir, 56

Grasse et de Bar, François Joseph Paul, comte de, campaign, Bougainville, I20, I2 I, I23I25; letters, I20, I22, I23; popular resentment, I I

Gravé, Thomas, I03

Gravier, - Mémoire concernant la Marine, I60, 204

Gravier, Charles, see Vergennes

Gravier, Gabriel, Mélanges, IoI

Gravier, Père Jacques, journal, 9; letters, 9, 65

Gray, Asa, letters, 258, 275

Great Britain, see England

Great Lakes, maps, 225, 226, 228 ; tides, I 59 ; see also by name

Green, Jacob, letter, 260

Green (Puants) Bay, tides, I 59

Greene, Nathanael, correspondence, I26

Greenland, description, 73 ; fisheries, 48, 73, 27 I ; information, 48 ; map, 256 ; notes, 43

Grégoire, $A b b e ́$ Henri, papers, 239, 243 ; slave trade, 24I, 243

Grenada, defense (1676), 200 ; Estaing, 125, 235, 24I ; Gémoset's letters, I67; maps, 235; storm, 8I; see also West Indies; Windward Islands

Grenier, Chevalier, wrecked, 40

Greysolon, Daniel, see Du Lhut

Greytown, bombardment, I27

Grifin, Capt. - , Tortuga commission, I80

Grignon, Pomponne II. de Bellievre, sieur de, 47

Grilleau, Estienne, on Nantes, 262

Grillet, Père Jean, letters, relation, 217

Grimaldy, Marquis de, decoration (I698), I78

Grimarest, — de, letter (I702), 68

Griscom, John, letter, 260

Groënlandais, I28

Grondel, Jean Philippe Gougon de, Kerlérec affair, 6r, 249-250

Gros de Boze, Claude, Académie des Inscriptions, 97

Groseilliers, Médard Chouart, sieur des, Bernou on, I00; in New England, I86; papers, I08

Grosier, Sieur Baptiste Augustin (?), map, 234

Gross, Dr. Samuel W. (D.), 90

Gruet, Jean François, 2I I

Guadeloupe, affairs, 52, I83, I 84 ; Carmelites, I 5 ; Compagnie des Indes, I80; conduct of governor (I662), 182; defenses, I89, 267 ; descriptions, history, 43, I I5; Dominican relations, 72; Dugommier and Gobert, I 6 ; 
Du Lion, Compagnie des Indes Occidentales, I6, I89, I93; duties, 70 ; English trade, I7I ; ethnology, 260; house for girls, 264; Lamardelle's works, 9I ; Laspiné concession, I 87 ; letter from (I635), 46; maps, 236, 257 ; memoirs, relatıons, II 5, I30, 267; meteorological observations, 256; papers, 87, I 43; plague, 86; plants, 273; possession, II 5 ; printing, I42; sketches, 270; sugar, I30; suit, I57; Villepars, I95; see also Leeward Islands; West Indies; Windward Islands

Guarany Indians, language, 260

Guatemala, antiquities, 220 ; atlas, 220

Gudin de la Brenellerie, Paul Philippe, Beanmarchais, 77, I 47 ; papers, 239, 244

Guédon, Louis Antoine, voyage, I 28

Guenet, - I95

Guérard, Pierre, 107, 263

Guercheville, Antoinette de Pons, marquise de, 48,107

Guerchy, Claude François Regnier, comte de, letters, 120

Gucrrier, I20

Guettard, Jean Etienne, letters to, 270; on minerals, 270

Guiana, Dutch, boundary, 78; English claim, I85; map, 244; sugar, 199

Guiana, French and general (Cayeme), agriculture and population, products, 79, 80, 93, 272 ; boundaries, 78, 79, 278; Brun, 216; capture from Dutch, 77, I66; claim, I76, I77; commerce, northern, English, 8, I2, 254; commission on claims, 35 ; concessions, regulations, 84; description, 40; discovery and settlement, 9, 84; events, conditions, 84 , I85; expeditions, $64,184,201$; filibustering, I69; Grillet, 217; history, 83, 84; Indians, 79 ; information, 200; Jesuit martyrs, 75; La Barre, I85, I89, I90; memoirs, relations, $74,176,177,217,241$; officers and decorations, I57; officials, charges against, I4, 67, $86,163,248,266,28 \mathrm{I}$; papers, lists, 84,87 , II4, I57; Portuguese occupation (I8Io), 278; ship from (I674), I98; Sisters of Charity 79; sketches, 257 ; slave trade, 176; superior council registers, 84 ; supplies for, flour, I35, 20I; translation of English voyages, 26; transportation of criminals, 64, 250; Turgot, records, $8,86,267$; voyages, 265,277

Guichen, Luc Urbain du Bouexic, comte de, cruises, maps, 230 ; expedition, I22, I 25

Guignac, Léon Michel, letters, I22

Guilbaud, - , correspondence (I709), I37

Guilbert, A., letter to, 75

Guillet, - letter ( 1676 ), voyage, 200

Guillon, —, praised (I665), I89

Guillot, - , voyage (I672), I95

Guinea, Ducasse, II7; Dutch and French, 205 ; French designs (1675), 202; French voyage (I707), 33; Ryswick negotiations, 49; see also Slave trade

Guise, Louis I. de Lorraine, cardinal de, letter, 147

Guitard, Chevalier de. Martinique memoir, I66

Guiton, Pierre René, letter-book, I42
Gulf of California, discovery, 266

Gulf of Mexico, England and (I74I), 280; La Croix's relation, 279 ; maps, $177,227,228$, 23I, 258; marine animals, 274; notes, II 8 ; Spanish defense, 30 ; voyage in western part, I 45

Gulf of St. Lawrence, astronomical observations, I27; Basque discovery, I30; coasts, I59; fishing concession, I76; islands, 276; maps, $223,224,226$; pirate, I 40 ; whaling, 82,136

Gulf of Samana, map, plan, 234, 235

Gumilla, Père Joseph. "Orenoque", 62

Gustavus II. Adolphus of Sweden, commercial company, 252, 253, 26I

Guttenberg, Carl, Paul Jones portrait, I 46

Guy, - Louisiana letter (I73I), 85

Guy, Gov. John, letter, 26I

Guynant, - de, letter, I89

Guyon, - Acadia (1696), i 70

Guyon, $D r$. Jean Louis, letter, 259; papers, 258

Guzman, Francisco, exploration, 7

Guzman, Gaspard de, see Olivares

Hache, Robert, trial, i 6

Haillet de Couronne, Jean Baptiste Guillaume, papers, 74

Haiti, see Santo Domingo

Hakluyt, Richard, Principal Navigations, extracts, 4,97

Halifax, N. S., natives, I32; plan, 224; travel, I 33

Hall, Asaph, letters, 258

Hall, $D r$. Richard P. Willmott, letters, 89

Halley, Pìre Jean, relation, 2I7

Hallwyl regiment, 73

Halma, Abbé Nicolas B. (?), "Martinque", 44

Halphen, $D r$. letter, 238

Hamilton, Sir William, letter, 282; philosophy, 283

Hammond, Surg. Gen. William A., letters, 90

Hancock, John, correspondence, I26

Hannah, 22

Hanseatic League, Spanish colonial trade, 96, 262

Hapel-Lachenaye, - meteorological observations, 256

Happy Return, 22

Harbourville, - d' letters, 65 ; papers, I67

Harcourt, Henri, duc d', letters to, I 5

Harcourt, 165

Hard, James, 39

Hardencourt, - , Compagnie des Indes, 60

Hardy, Siméon Prosper, "Mes Loisirs", 10

Harfleur, fisheries, 53

Haristéguy, Capt. - de Sauba, see Sauba

Harlan, Richard, letters, 259, 260

Harlay de Champvalon, François de, archbishop of Rouen, letters to, 47, 180, 207

Harley, Christophe de, see Beaumont

Harmony (3 ships), 22

Harrisse, Henry, correspondence, I31, 133, 277 , 282; Jean et Sébastien Cabot, 4; Margry, II8, I33; MSS. relatifs à la Nouvelle France, 25 ; Notes sur la Nouvelle France, 25

Haurteraye, - - , trial, 247 
Hautefort, Louis Charles de, see Surville

Havana, "Descriptions de l'estat", I 49 ; history, I 52; Peñalosa's services, I 52; plans, 23I ; reference, 263; slave trade, I39; yellow fever, 238; see also Cuba

Havre, see Le Havre

Hawaiian Islands, affairs, I27

Hawk, 22, 39

Hay, James, see Carlisle

Haydon, John, marriage contract, 219

I Hay du Chastelet, see Du Chastelet

Haynes, Henry W., letters, I4I

Hays, Isaac, letters, 260, 275

Hazard, Ebenezer, extracts, I07

\section{Hazardeux, I66}

Health, certificate in West Indies navigation, I86; Indian remedies, 245; plague, 23, 67, 86; West Indies diseases, I94; see also Hospitals; Medicine; Yellow fever

Hébert, Louis, papers, Io6

Heemskerck, Louvis van, correspondence, journal, I08; naturalized, Io

Héguerty d', Essai sur le Commerce, 86

Héguy, - - , trial, 247

Helms, Anton Zacharias, Voyage, 87

Helvétius, Mme. Anne Catherine de Ligniville, letters to, $4 \mathrm{I}$

Hémery, Joseph d', censured works, 6I, 62 ; collection, 6I

Hennepin, Louis, and Bernou, letter, 99, I52; Renaudot on, I78; sketch, I I6

Henriques Clerque, Carlos, letter, I 55

Henry, Caleb S., letter, 283; on philosophy, 28I

Henry II. of France, letter to, 207

Henry III. of France (duc d'Anjou), letter, 263

Henry IV. of France, Antwerp truce, I3; collection of arrêts, 52 ; correspondence, 44, 2I 6 , 26I, 264; despatches, 25I

Hérault de Séchelles, $M m e$._-, letters to, I I9

Herbert, Mlle. - marriage, 214

Herbert, Philip, see Montgomery

Hercule, 68, I56

Heremboure, - , notes, I33

Heriarte, Mauricio de, Maranhão, I74

Herisson, $\longrightarrow$, map, 23I

Hermand, Emmanuel Louis Joseph d', letters to. I43, I44

Hernandez de Quiros, Pedro, 23

Héros, 68

Herpin, _- - letters, 20I

Hertel, François, papers, Io6

Hesse, - de, Santo Domingo map, 23I

Hessians, news of desertion, I I

Hiberville, Capt. —, fur trade, 36

Hill, Henry, printer, 206

Hilliard d'Áuberteuil. Michel René, Essais, 6I

Hinchazon, as name for disease, 86

Hingston, - and Thoüin, 274

Hirondelle, I69, 201, 202

Hispaniola, see Santo Domingo

"Histoire de la dernière guerre", censured, 6I

Histoire de la dernière Guerre, censured, 60

Histoire de l'Eant-de-Vie, censured, I05

"Histoire de l'Hôtel-Dieu de Quebec", censured, 62

"Histoire de l'Orénoque", censured, 62
"Histoire des Pêches", censured, 62

Histoire des Plantes de l'Amérique, cost, 86

"Histoire militaire des Suisses", censured, 62

Hitt, Robert R., correspondence, I33

Hochelaga, 7

Hocquart, Gilles, biographical notes, I2I ; memoir to, 8I

Hocquet d'Hamecourt, Jean Charles, "Papiers dans le Dépôt de la Marine", 86

Hodge, William, in Bastille, 249

Holker, John, correspondence, I 26

Holl, Dr. B. W., letter, 90

Holland, see Netherlands

Holmes, William H., correspondence, I4I

Holy Family, office in New France, 268

Hombourg, - , ship command, I 54

Honde, Alexander, letter, I 37

Honduras, map, 279

Honfleur, admiralty, 217; English prisoners, I8I ; fisheries, 53, 27I, 280; memoir, I28; port and Compagnie des Indes Occidentales, I86; West Indies trade, 56

Hope, 22

Hopkins, Samuel M., letter to, 245

Hopwood, James, Beaumarchais portrait, I 23

Horadon, $\longrightarrow$, valor, I25

Horqué, see Hocquet

Horses, Guiana-English trade, I2

Hospitalers of St. John, see Malta

Hospitals (Hôtels-Dieu), colonist nuns, 64, 25 I ;

Ile Royale, 70; Montreal, I0, 203, 25I ; Quebec, 55, 62, 268, 270; royal payment, 203

Hôtels-Dieu, see Hospitals

Hoüel, Gov. Charles, I84, 264.

Hoüel, Louis, sieur des Petič-Pré, Compagnie de la Nouvelle France, 52

Houghton, Henry O. (?), letter, 283

House of Commons, debates (I733), 82 ; Journals (I606-10, 1627-29), 219

Howard, Dr. Benjamin, letters, 90

Howe, Timothy O., correspondence, I33

Howe, Sir William, I I, 230

Hualt de Montmagny, Charles Jacques, see Montmagny

Huart du Parc, —- Kerlérec affair, 248

Hubbard, William, extracts, I07

Hubert, H., letters, I84, I87, I89-192; papers, I08

Hubert, Marthe, i 6

Hubertsbourg, treaty of, 60

Hudson Bay, boundaries, claims, 23; coasts, I59; I08, 243; French attacks, Iberville, American Revolution, 26, 36, 65, I23-1 25, I40, I65I67, I74, I75; French trade, 8, 280; fur trade, 36, 84; Joliet's map of route, 225; memoirs, Colbert, 28, I 74; northwest passage, 42, 43; notes, 46; papers, I07, II2; Ryswick negotiations, 47, 49; seals, 27I ; Silvy's journal, I76; Utrecht negotiations, cession, 28, I 5I, I 52, 243

Hudson River, geology, 259; sketches, 270

Hudson's Bay Company, Iberville's queries, 65 ; letter, I75

Hudson Strait, map, I77

Huguenots, Brazil, I74; Carolina ( 1687 ), I 36 ; emigration, 76 ; excluded from colonies, I0, 
70, 204; Florida, Gourgues, 4, 5, 26, 29, 48, 54-56, I I 4, I I 5, I 50, 207, 209, 210; proposed Louisiana settlement, 40; supposed English Mississippi colony, I 78

Huidekoper, Frederic, 283

Humboldt, Alexander von, letters, I46, 259 ; portrait, I 46

Hunter, William, eulogy, 238

Hunting, control over colonial affairs, I58; see also Fur trade

Huntington, Samuel, letter, 4I

Huron Indians, comedy on French and, 244 ; dictionary, 75; Fox war, 8I ; letter in language, 93 ; map, 226; notes, I7 I ; Sagard-Théodat's voyage, I03

Hurons, play, 85

Hurricanes, Grenada, 8I ; Louisiana, 68; Martinique, 65 ; St. Christopher, 192

Hussey, - merchant, letter to, $2 \mathrm{I}$

Hussey, Benjamin, I2

Hussey, George Gorham, I2

Hussey, Isaac, I2

Hustun, Camille d', see' Tallard

Hutchinson, Thomas, extracts, I07

Hyde de Neuville, Jean Guillaume, baron, letter, biography, 75 ; on slave trade, 93 ; praised, 259

Hydrography, Bernou's papers, I 59; Canadian, I74; Franquelin's plans, I66

Iberville, Pierre le Moyne, sieur d', death, 69; decoration, I78; English prizes, 26; estate, 67; Hudson Bay, 65, I 40, I65-I67; ill, 68; King William's War, Newfoundland, 65, 66, I 39, I67 ; letters, 24, I I I, I67, I68; Louisiana establishment, $24,25,56,63,66-68$, 98, I I I, I I2, I I 5, I 55, I76; Mémoire de la Services, II 2 ; memoir on Boston, I I6 ; notes, I I I, I I2; papers, I05, I08, I 2 ; plan against Carolina, I 16 ; Queen Anne's War, Nevis, 20, 68-70, I I I, I I6, I36, I46; queries, 65; wife, 66

Ice, around Newfoundland, 27I

Iceland, coast, 276 ; national-history voyage, 272

Ile, see also Isle

Ile Bourbon, trade, I I7, 264

Ile de Ré, I 82

Ile Percée, fisheries, I73

Ile Royale, see Cape Breton

Ile St. Bonaventure, I72

Ile St. Jean, see Prince Edward Island

Illinois country, comment, 255; Compagnie des

Indes' retrocession, 6o; map, 229; minerals, 270 ; mission, journey, 9, 268, 269; news, 65; papers, I I3; Tonty's letters, I73; wheat, 82 Illinois Indians, 9, I 64, I 75, 248

Imlay, Gilbert (?), Louisiana notes, I08

Immaculate Conception Mission, 9, 65

Immigration, sce Emigration

Impressment, exemption, I 97 ; for colonies, 83

Imprisonment, of foreigners, I 3, I6, 22

Incas, notes, I 7 I

Independence, American, as French consolation, 74 ; verses on, 93
India, commerce, 7 ; description, 7 ; French plans (I778), I22; papers, 87; Pigafetta, 7I ; see also East Indies

Indians, Acadia, 98; Albany trade, 7I ; as French allies, 242; beverages, 272; Canada, I 45; Cass on, I02; census (I736), I05; crania, 259,260 ; customs, languages, vocabularies, 7, 46, 75, I43, 220; description, 87; drawing of villages, 75 ; English intrigue, I75, 266, 268; Eudemare on, 2I7; Far West, 42; French and Indian War, 242, 243; Guiana, 79; hieroglyphic on arrival of white men, 245 ; in France, $80,130,240$; instruction, I64; Louisiana, relations, 24, 25, I 40, $255,266,268,272$; lower South America, 277 ; medicines, 245 ; names of nations, 75 ; notes, I7I, 244; origin, 4, 75, 2II ; pottery, 79 ; presents, graft, 88 ; Recollect relation and trade, I70, 207; slaves, 8I, 85; Tonty and, I75; see also Fur trade; Liquor; Missions; tribes by name: Alabama; Algonquin; Apache; Arkansas ; Capotilles; Carib; Cherokee; Chickasaw; Chippewa; Choctaws; Creek; Delaware; Eskimo; Fox; Guarany ; Huron; Illinois; Iroquois ; Lipan; Mascouten; Missouri; Mohegan; Natchez; Nipissing; Osage; Oto; Ottawa; Pentagouet; Sioux; Taensa; Tunica; Winnebago; Yazoo

Indies, Spanish vice-royalty, I63

Indigo, Louisiana, 40; Santo Domingo, I30

Industry (2 ships), 22

Infante, I80

Information concernant Darien, 24

Infreville, Louis le Roux, chevalier Saint-Aubin d', letter, I92

Innocent XI., pope, letters to, 26, 268

Inquisition, and Peñalosa, I 52

Insects, Virginia, 274

Institut de France, letter to, 4I

Instruction pour etablir les Habitations à la Louisianne, I2

Insurance, ship, 2I 5

Intendants, Canada, instructions, qualifications, I6, I84, I87 ; French-American colonies, I4; list, I27 ; see also intendants by name, especially Canadian: Beauharnois; Begon;

- Bigot; Bouteroue; Champigny; Duchesneau; Dupuy ; Hocquart; Meulles ; Raudot; Hobert; Talon

International relations, private Franco-Spanish, I I 5

Inventaire des Pièces de Thoisy, 53

Inventaire Général des MSS. Firançais, 2

Inventaire Sommaire des Archives: Ille-etVilaine, I7

Ireland, products for French colonies, 58

Iron, Canadian concession, 80 ; mines, search, I6

Iroquois Indians, and English conquest of New Netherland, I86; dictionary, 243; Dutch relations, 47; English intrigue, 84; Fox war, 8I; French parleys, speeches, 9, 79, 98, I32; French peace, 23, 67, 100, 149, 201; French relations, 9, 47; French wars, 5, 67, I 40-I 42, I 54, I75, I86, I 88, I89, I9I, 246; information, I64; King William's War, 65, 
I64, I66; map, 225 ; memoir on extermination, 27 ; missions, Jesuits, 54, 7I, 72, I 09, I3I, I49, I6I, I75, I94, 200; notes, I7I ; Ottawa-Illinois war. I64; payment for support of certain, I6I; relation (c. I700), 266; timber rights, $7 \mathrm{I}$

Isambert, François André, Anciennes Lois Françaises, 6

\section{Isis, 277}

Isle, see also Ile

Isle aux Vaisseaux, map, 227

Isle Beata, 46

Isle Dauphine, information, 84; maps, 227; shoaling, 78

Isle de Bourbon, 264

I Isle de la Chandeleur, map, 227

Isle de la Tortue, 234

I Isle d'Oléron, I30

Isle Grande Terre, Guadeloupe, plans, 236

Isle of California, 229

Isle of Pines, geographical notes, 220

I Isle St. Georges, Newfoundland, I39

I Isle St. Henry, I73

Isles de Mollüe, 88

I Isles du Chef de la Captive, 46

I Isles St. Diegue, Florida, I40

Islet du Massacre, Santo Domingo, map, 233

I Isnard, Albert, Joseph Nicolas Delisle, 227

Isthmian transit, affairs (I853-62), letters, I27, I42; voyage, 90

Italians, for Louisiana, I 30

Italy, librarians, I I 8 ; travel, 259

Iturbide, Augustin, letter, 9I ; portrait, 9I

Ivan III. of Russia, 97

\section{J., J. J., map, 233}

Jackson, Andrew, election, character, 282, letter, 245

Jackson, Miss., 273

Jacmel, Santo Domingo, plan, 234

Jacquin, —-, and West Indies (I670), 20I

Jajolet de la Courbe, see La Courbe

Jal, Auguste, Du Quesne et la Marine, I8I

Jamaica, and Santo Domingo, I52; capture of ships, Ioo; Cromwell's plans, 280; descriptions, proposed attacks, 3I, I44, I 55; documents, 87; D'Oyley, I80; filibusters, I80; French prisoners of war, 38, 87; maps, 23I ; notes, I7I, I80; printing in, I42; vegetables, 272 ; see also West Indies

Jamav, Père Denis, letter, 207

James I. of England, Alexander's patent, 6; and Virginia, 26I

James II. of England, letter, I69; New York patent, $\mathrm{I} 8 \mathrm{I}$

James, Edwin, Long's expedition, 275 ; on Indian languages, 256

James, Henry, 283

Jamestown, N. Y., I3I

Jamestown, Va., sketches, 270

Jamieson, Dr. Thomas W., 90

Janet, Paul, papers, 28I

Janot, - , letters ( I665-67), I87, I89, I9I, I92 Janss, Harmën, map, 222

Janss, Marten, map, 222
Japanese, world map, 223

Jaques de Vaulx, map, 222

Jardin, Edélestan (?), journal of travels, I33

Jardin d'Acclimatation, Indians, I30

Jardin de Hollande, I89, 251

Jaugeon, - Art de l'Imprimerie, 25

Java, objects from, 273

Jay, John, letter, 245; peace negotiations, 255, 256

Jay, John (g. s.), on Paris peace negotiations, 256

Jay Treaty, French attitude, 38

Jeanne Cornélie, 67

Jeannin, Pierre, Antwerp truce, I3, 28, 47, 52, 54, 70, 73, 96, 207, 208, 266; correspondence, $44,205,261$; dedicatory letter, I02; Negociations, extracts, I08

Jefferson, Thomas, letter, 4I

Jehannot, Etienne, see Bartillat

Jenkins's Ear, war of, see Anglo-Spanish War of I739

Jermyn, Henry, see St. Albans

Jesuit Relations, Clement X.'s brief, 27 ; extracts, I03, I08; Le Teune's, 72

Jesuits, advice on, 52; and La Salle, 99, I00; and military officers in colonies, I84; and Missions Etrangères, 268; biographies, 72 ; Canada, conduct, relations, 23, 55, 70, I09, I68; captured, 48; documents, list, notes on papers, I08, I 3 ; expulsion, goods, I05, 212; festivals, 80; Illinois wheat culture, 82 ; Iroquois mission, 54, 7I, 72, I09, I3 I, I49, I6I, I75, I94, 200; land in New France, I04; letters, 9, I04, I63; Lorette fund, I6I ; Louisiana, and Compagnie des Indes, 34, 67, 97, 98, II7; map of Mississippi Valley discoveries, 226; Marie de Médicis, 204; Martinique, and Compagnie des Isles, 52, I 68 ; martyrology, 47, 54, 75; Mexico, 74; Paraguay, $8 \mathrm{I}$

Jeury des Tours, Sieur, Louisiana claim, 278

Jogues, Père Isaac, martyrdom, 54; "Vie", I3 I

John, 2 I

John Carter Brown Library, Champlain MS., 102

Johnson, Thomas M., letter, 283

Johnson, Sir William, defeat (1756), 214

Joint-stock companies, see Commercial companies

Joliet, Louis, Labrador and Eskimo exploration, sketches, I05, I08; map of Hudson Bay route, 225 ; Margry's articles, I29; Mississippi River, 98, I29, 226; notes, I08; papers, I I3

Jolliet de Montigny, François, see Montigny

Joly, Iberville's ship, wrecked, 65

Joly, La Salle's ship, I I0, I35, I74, I8I

Joly de Fleury, - correspondence, 2I 2-2I4

Joly de Fleury family, collection, 2 I I

Joncaire, Daniel, dit Chabert, Bastille papers, I $65,247,249,250$

Jones, - Santo Domingo contract (I797), 2I

Jones, Consul John, letters, 127

Jones, John Paul, affairs, 256; Ariel crew, I22; Blodget, I22; operations, I24; portrait, I46; ship for, Ranger. 122 
Jones, Dr. Joseph, letters, 90

Jones, Silas, I2

Joubert, _- Santo Domingo map, 233

Jourda, Noël de, see Vaux

Journal de la Société des Américanistes, 32

Journal de l'Instruction Publique, I 29

Journal de Médecine Militaire, 238

Journal de Paris, 244

Journal des Savans, 24

Journal de Trévoux, 56

Journal du Siège de Carthagène, I54

Journal du Travail de la Compagnie des Indes, 59

Journal Maritime de Bayonne, 242

Joutel, Guillaume, papers, marriage contract, I09, I I 0

Joutel, Henri, La Salle's expedition, correspondence, I09, I74; Voyage de La Salle, 26, 109

Joutel, Jean, papers, marriage contract, I09, I Io

Jouy, Antoine Louis de Rouillé, comte de, see Rouillé

Joyeuse, Guillaume, cardinal de, letter to, 207

Juan de Estrada, 74

Jubilee, Canadian, 268

Juchereau de St. Denis, see St. Denis

Judiciary, colonial, arrêts of Council of State, 52 ; cases of Parlement of Paris, 2I4; control, I58; Ile Royale, $7 \mathrm{I}$; Louisiana, 34; memoir, 37 ; officials as interested parties, 14 ; see also Councils

Jugements et Déliberations du Conseil Souverain, I04, I 68

Jumelle, —, Santo Domingo, letter to (1797), $2 \mathrm{I}$

June (Juno), 21, 22

Junon, 274

Jusserand, Jean Jules, French Ambassador, 28

Jussieu, Antoine, papers, 272

Jussieu, Antoine Laurent, 27I, 273; papers, 272

Kaempfer, Engelbrecht, map, 223

Kakavet, chief, scalp, 66

Kalb, Johann, baron de, papers, 126

Kamtchatka, 40, I33, I56

Kane, Elisha K., letters, I I 7

Kane, John K., letter, 89

Karrer, François Adam, chevalier de, Swiss regiment, 23

Kaskaskia, registers, extracts, II 3

Kaskaskia (Chepoussea) River, I 77

Katy, 22

Kaulek, Jean, Correspondance Politique de Castillon, 5

Kaunitz-Reitburg, Wenzel Anton, fürst von, despatches to, 94,95

Kearsage, U. S. S., Alabama fight, I 27

Keating, William H., letters, 274, 275; Long's expedition, 275

Kennebec River, letters from, I62

Kennicott, $D r$. J., letter, 89

Kerallain, René de, Français au Canada, II 9

Kergariou de Cosquer, François Louis, marquis de, letters, I22

Kerlérec, Gov. Louis Billouart, sieur de, affair, Bastille papers, 246-248; satire 011, 6I ; Spanish supplies, 30
Keymis, Laurence, Second Voyage to Guiana, 26 Kiché, antiquities, 220 ; vocabulary, 220

Kidnapping, see Impressment

Killingworth, S., transcripts, I80

Kimball, Lt.-Col. Edgar A., 9 I

King George's War, French manifesto, 212; Louisbourg, 20 ; naval, West Indies, 32, I52, I62; prizes, 20

Kingston, Jamaica, 38; map, plan, 23 I

Kingston, Ont., see Fort Frontenac

King William's War, Acadia, I67-I70; AngloDutch fleets, I 40 ; Bastille dossiers, 246; Canada, plans, events, expenses, I60, I64, I66 I67, I69; Chambly, I66; French demands (I694), 47 ; French plans, I I I, I38, I4I, I74; galleons, I40 ; Iberville, 65, 66, I39, I65-I67; Iroquois, 65, 142, 166; medals, 97 ; navigation, convoys, 63, 65, I36, I65, 257; New England, I38, 166, I69; Newfoundland, 63, 66, III, I67; papers, II 2 ; policy and practices of Marine, 33; privateers, I36, 218 ; prizes, I67, I70, 174; references, 245 ; West Indies, Cartagena, $6,23-25,54,56,63,65$, 68, I39, I44, I65-167, I75, 218; see also Ryswick

Kirke, Sir David and Louis, claim, 48; Quebec, 206

Kitty, 22

Klaproth, Heinrich Julius, map collection, 22I

Koch, - letter (I708), I 44

Koch, Christoph Wilhelm von, lectures, 265

Kohler, Charles, Cat. des MSS. de la Bibl. Sainte-Geneviève, 276

Kolly, - , speculation, I 44

Kourou River, French Guiana expedition, 8

Kunz, George F., letters, I4I

La, see also titles beginning Dela

L'Abadie, Jean de, see St. Castin

Labaig, Sicur, St. Castin's suit, I65

La Barre, Joseph Antoine Lefebvre de, appointment, I7I ; at Cayenne, I85; at Martinique, 63 ; Bernou on, I00; letters, I04, I40, I 54, I82, I 84, I85, I90; letters to, I09, I 40; memoir, I00; Montserrat, I9I ; squadron, enterprise, I84, I 85, I 89, I90, I 93, I 95

La Barthe, Jean Pierre, Bastille papers, 247-249, 250

Labat, Pìre Jean Baptiste, Nouveau Voyage, MS., 267

Labatut, - , Santo Domingo (I797), 2I

Labène MSS., 256

La Boderie, Antoine, see Lefèvre de la Boderie

La Boische, Charles de, see Beauharnois

La Boissière, Soeur de, payment to, I6r

Labor, control over colonial affairs, 158; see also Servants; Slaves

La Borde, Jean de, graft, Bastille papers, 24 $\tau_{-}$ 249,250

La Bouisse, - letter to (I828). I24

La Boulaye, - Compagnie de la France Equinoctiale, 9

La Boulaye, memoirs, 6, 85, II6, I39

Laboulinière, Pierre, "De l'Esprit de Conquête ", 73 
abrador, and Newfoundland (I710), I32; La Gournerie, Jules A. B. Maillard de, see coasts, I59; commerce, 239; description, 276; fisheries, 7I ; Joliet, I05; maps, I77. 222; papers, list, I07, II4; sketches, 273; tides, I59; see also Eskimos

a Brousse, - Louisiana (I735), I52

acave, - letter, memoir (I66I), I49

a Chaise, - letter, 228

a Chassaigne, Lt. - Montreal letter (I72I), 157

a Chauvignerie, -

a Chesnaye, Charles Aubert de, captured ship, I96; letter, 201; "Memoire de Canada", I04 achine, papers, 108

a Clède, Pierre, papers, I I3

a Colombe, priory, I7 I

Condamine, Charles Marie de, 243 ; expedition, 256; papers, 108

a Corne, - , letters ( 1763 ), izo

a Corne, Chevalier de, marriage, I6I

acoste, - letter to, 20

ac Ouinipigon (Winnipeg), 226

a Courbe, Michel Jajolet de, letters, 66; narrative of voyages, $7 \mathrm{I}$

a Crenne, see Verdun de la Crenne

a Croix, —, "Etat-général d'Espagne”, 279

a Croix, - letters to (1839), 257

a Croix, Eugène Gabriel de, see Castries

wa Croix Chrevrières des St. Vallier, see St. Vallier

a Dourantaye, Capt. -

adrones, see Mariana Islands

a Durantaye, Oliver Morel, sieur de, I75

aet, Jean de, Nouveau Monde, drawings, 53 afayette, Marie Jean Paul du Motier, marquis de, autographs, I 47 ; Barren Hill, plan, 230 ; Boston, I22; Canadian expedition, II ; correspondence, 75, I22, I26, I46, 282; Gloucester, plan, 230; information, I22; instructions, I22; mentions, 243 ; portraits, I46

a Fayolle, Mme. - , letter, 264

a Ferrière, - , letter (1667), I92

affleur de Kermaingant, Pierre Paul, Ambassade de France, 5

afitau, $\longrightarrow$, memoir, I I I

afitte, Jean, notes on, I43

Fontaine-Belot, complaint against (I667), I9I

aforce, Sieur, Fort Niagara journal, II9

a Forest, —, wrecked (I770), I I4

a Forest, - on steam navigation, I27

a Forest, Guillaume, 99, I06, I I0, I I I, I75

a Galissonière, Rolland Michel Barrin, marquis de, at mines, 270; biographical notes, I28; boundary commissioner, 212 ; instructions, I27; on Cartagena, 24; praised, 270; war memoir, 36

agarde de Belin, - Compagnie des Indes Occidentales, letters, I86

a Gémerais, - Canadian petition, I60 agentière, de, marriage (I728), I6I

a Gigaudière, Capt. —, I87

agny, - de, Compagnie du Nord, 192, I93; letters, I04, I $36,166,167,192$, I93; letters to, I64, I66-I68; memoir, I68

Maillard

La Grandière, — de, on Chesapeake Bay battle, 122

Lagrange de Chessieux, Gilbert, Conduite des François justifiée, censured, 86 ; memoir, 40

La Guerche, see Gorris de la Guerche

La Harpe, Bénard de, exploration, journal, map, 22, 227, 229; memoir, II 7

La Haye, - Compagnie des Indes, 59

La Hestroy, see Le Pottier, Jean

La Hire, Phillipe de, Globes de Marly, 42

La Hontan, Louis Armand de Lom d'Arce, baron de, notes, I28; Voyages, extracts, 74, 75

La Houze, Chevalier de, corresnondence, I68

Laing, David, Royal Letters relating to Nezw Scotland, 6

La Jaille, Marquis de, plan against Hudson Bay, I23

La Jannaye, see Chatou

La Jonquière,Marquis de, article by (1875), I28

La Jonquière, Jacques Pierre (Pierre Jacques) de Taffanel, marquis de, article on, I28; biographical notes, I2I

Lakanal, Joseph, collections, letters, 259

Lake Assiniboine, map, I77

Lake Champlain, maps, 225, 226; military observations (I758), I20; sketches, 270; travel, 274

Lake Christino, map, I77

Lake Erie, animals, 273; maps, I I6, I 77, 228

Lake George, French and Indian. War, II9, I57, $242,244,270$

Lake Huron, maps, 226, 228

Lake Michigan (I1linois), maps, I77, 228

Lake of the Illinois, see Lake Michigan

Lake of the Iroquois, see Lake Ontario

Lake of the Sioux, see Lake of the Woods

Lake of the Woods (Sioux), map, I77

Lake Ontario (Iroquois), Courcelles, 44; Frontenac, 54, I55, 240; maps, I I6, 225, 226; operations (I756), I57, I58; papers, II3; see also Fort Frontenac; Fort Niagara; Oswego

Lake Pontchartrain, map, 228

Lake St. John, Bellin's error, 42

Lake St. Sacrement, see Lake George

Lake Superior, maps, I77, 225, 228; mines, copper, I29, I39, 270; papers, I08, I59

Lake Winnipeg (Ouinipigon), 226

La Lande, - , letters (I677), 201

La Landelle, G. de, letters, I33

La Live, - Compagnie des Indes, 59, 60

Lallemant, $\longrightarrow$, Compagnie des Indes, 60

L'Allemant, Père Gabriel, 54

L'Allemant, Père Jerosme, 54

La Luzerne, Anne César, chevalier de, biographical notes, I 43 ; letters, I22

La Luzerne, César Henri, comte de, letter, 73, I30

La Luzerne, François de Briqueville, comte de, letter, I57

La Magnière, — , suit by widow, 88

La Mallerie,, pension to widow, 156

Lamardelle, G. P. F. de, works, 9I 
La Marque, Jacques, see Montigny

La Marque, Paul de, see Marin

La Marquerie, — de, letter to, 264

La Marre, Antoine, portrait. I68; voyages, I68

La Mauvissière, Michel de Castelnau, sieur de, correspondence, 48, 207

Lambert, Lt. —, salary (I746), I2

Lambert, Aymard, revenue farming, 57, 59

Lambert, Florentin, I02

Lamberville, Père Jean de, escape, 175 ; letters, I04

Lambeth, Charles Malo François, chevalier de, journey, 45

Lamborn, Robert H., letters, I4I

La Mollerie, - de, Tonty's brother-in-law, 65,66

La Morinière, see Noël de la Morinière

La Mothe, Antoine de, see Cadillac

La Motte Gaillard, — de, memoir, I7

La Motte Picquet, see Picquet de la Motte

Lamoureux, Jean Vincent Félix, letter, 259

La Muy, see Muy

Lancelot, Antoine, letter to, 85

Lancet, - de, letter to (I688), 84

Land, grants: Acadia, I60; Canada, II3; Leeward Islands, 37; Louisiana, 7I ; reporting, I53; Jesuit, in New France, I04; tour of Canadian royal domain, I05; see also Plantations; Seigniories

Landriève, - $\longrightarrow$ trial, 247

La Neuville, - , correspondence, I 26

Langford, Golden, letter to, 22

Langle, Comtesse de, letter to, I25

Langle, Paul Antoine Marie Fleuriot de (?), letters, I24, I25

Langlois, 1 , letters to (I 820 ), 269

Langlois, Nicolas, Compagnie de la Nouvelle France, 50; fisheries report, 53

Langloiserie, de, decoration (I705), I78

Langsdorff, Georg Heinrich, baron von, on Brazil, 277

Languages, vocabularies, and dictionaries, Brazil, 74; French-Indian, 7; Huron-Algonquin, 75; Indian, 256, 260; Iroquois, 243 ; notes on American, 75 ; Peruvian and Mexican writing, 25; Spanish-Indian, 220

Languedoc, slave trade, 56

Languedoc, 122.

Lannay, Chevalier de, Bastille dossier, 248

Lannes, Jean (?), see Montebello

Lannion, Comte de, letter, 86

La Noiraye, J. B. Voisin de, see Voisin

La Noüe, Zacharie Robertel (?), sieur de, papers, 108

La Nourse, Père — de, of Martinique, letter, 69

L'Anrivaud, - - letter (I700), 66

La Paÿre, , of Martinique, letter, 183

La Peltrie, Marie Madeleine de, letter to, i 6

La Pérouse, B. de, letter. I24

La Pérouse, Jean François de Galaup, comte de, and Hudson Bay expedition, I23; biography, notes, 36, I24; correspondence, I22I25, 278; movement (I779-8I), instructions, journal, 36 , I22-124; papers, I2I; voyage of discovery, 124
Laplace, $\longrightarrow$, trial, 247

La Place, Elye de, see Russy

La Plaigne, Sieur de, military company, I53

La Plata, bird, 259; map, 33; natives, 278; notes, 220 ; St. Sacrement, controversy, 4I, I77, I78; voyages, 88 , I80; see also Buenos Aires

La Pointe, Sieur de, Louisiana place, 228

La Poipe, —-, praised (1673), I97

La Poix, Christophe Paulin de, see Fréminville

La Popelinière, Henri Lancelot Voisin de, see Voisin

La Porte, $\_$, concession ( I 744), 106

La Porte de Feraucourt, - Compagnie des Indes, 59

La Porte-Lalanne, _- Santo Domingo, 233

La Poterie, Jacques le Neuf de, payment to, $25 \mathrm{I}$

La Potherie,

La Potherie, Le Roy de, see Bacqueville

La Pylaie, Auguste J. M. Bachelot de, correspondence, $259,260,270,273 ; \mathrm{MSS}$. on Newfoundland, 273

La Ravardière, Daniel de la Touche, sieur de, letter to, 204

La Renardière, Sieur de, see Cheffaut

Larevellière-Lépeaux, —Memories, MS., I42; papers, I42

La Reynie papers, 2I 4, 215

La Roche, Abbé P. L. Lefebvre de, see Lefebvre

La Roche, Troilas du (de) Mesgouez, marquis de, I02, 216, 264

La Rochefoucauld, Nicolas de, see Anville

La Rochefoucauld Liancourt, François Alexandre Frédéric, duc de, Voyage, i 30

La Rochelle, admiralty, 2I7; colonial claims (1760), 35; commerce, I2, 35, 36, 53, 56, $68,70,73,74,136,139,182,194,197,198$, 240,280 ; correspondence from, 23 , 162; fisheries, I6I ; Iberville, 67, 69; memoirs, 266, 280; slave trade, 56

La Rochette Gargot, Nicolas de, concession, I07, I 49, 263; letters, I82, I83; voyage, 63, 182

La Rocque, Capt. - convoy, 199

La Rocque, Jean François de, see Roberval

La Roncière, Charles de, catalogues of MSS., 3, I79, 204; mappemonde, 221 ; Marine Française, 4 ; on northwest passage, I47

La Ronde, $\longrightarrow$ ship captain (I7OI), 67

La Ronde, Louis Denys, sieur de, correspondence, I06; papers, 106, I08, I 3

Larrey, Dominique Jean, baron, correspondence, 89

Larrey, Dr. F. H.. correspondence, 89-9I

Larroque, Philippe Tamizey de, see Tamizey

L'Artigue, Sicur, dispute (I7I6), 7I

La Ruë, Gilles de, suit, I65

La Salle, Jean Baptiste Cavelier, sieur de, nobility, arms, I IO

La Salle, Robert Cavelier, sieur de, Bastille, 249; Bernou's letters on enterprises, 98-IOI ; Canadian concessions, Fort Frontenac, IIO, I I ; commissions (I678), I I I ; ( I684), I IO; death, estate, I09; donation, I08; family papers, I Io-I I 3 ; Journal du Dernier Voyage, 26; Joutet's works, I09; Lachine, I08; land exploration, Illinois, 46, 84, 97, 98, III ; 
letters, II I, I 72 ; maps of discoveries, 226 ; memoirs, I09, II6; Mississippi colony expedition, I09-III, I35, I 36, I4I, I 54, I74; nobility, I09-III; notes, I I 3 ; observations on, 64; papers on enterprises, I06, I08, I30, I 72 ; project ( I677), I 72

\section{Las Casas, see Casas}

Laso, Benito, I 27

La Source, Père Dominique Antoine Thaumer de (?), paper, II3

Lassise, - de, of New Orleans, 274

Latin manuscripts, 219

Latitude, ascertaining, 5, 72; Boston, 8

La Touche, Daniel de, see La Ravardière

Latouche, Robert, on Arnoul collection, I34

Latouche-Tréville, Louis René Madeleine le Vassor de la Touche, comte de, I24; biographical notes on, I43; letters, 75, I22; scandal, I25

La Tour, $\longrightarrow$, supercargo ( I673), I62

La Tour, Charles Amador de, Acadia, Aulnay, 46,53, I 81,264 ; letters, I07, 264; news of death, I84; papers, Io7

L'Aubespine, Charles de, northwest passage, I47 Laudonnière, René Goulaine de, Floride, I I4

Lauer, Philippe, Cat. des MSS. de Clairambault, I 5 I

Launay, Chevalier de, comedy, 244

Launay Razilly, Claude de, see Razilly

Laure, Père —, maps, 225

Laurens, John, correspondence, I26

Lauson de Charny, Charles (?), letter, I9I

Laussat, Pierre Clement de (?), letter (I797), 21

Lautier, Guillaume, widow, I62

Lauzon, Jean de, commission, 27, 69, I70

La Vallière, Dame de, request, I 59

La Vallière, Denis de, journey, Io 8

Laval-Montmorency, Bishop François de, announced to Frontenac, Io; Estat présent de l'Église, I05; funeral oration, 40 ; Lauson de Charny, I9I ; letters, 55, I83, I9I, I97, 20I ; letter to, I83; liquor trade, 43 ; nomination, 54 ; passage, I0, 63 ; payment, $25 \mathrm{I}$; proposed return, I 59; St. Vallier's praise, 268

avardin, — - de, letter (I675), 200

-a Vauguyon, André de Bétoulat de la Petitière, comte de, memoir, I3

a Vaysse, see Dauxion la Vaysse

aveaux, Gov. Etienne, collection, letters to, 38, 39

La Vérendrye, Pierre Gautier de Varennes, sieur de, explorations, papers, 79, 8I, 82, I08; Margry's articles, II3, I29: "Mémoire", 8I

-a Vie, Father François de, letter to, 2I7

a Vieuville, Duc de, letter ( I675), I99

a Vigne, Gabriel de, services, I68

-a Ville-aux-Clercs, Antoine de Loménie, sieur de, collection, 95-97

a Villebrune, - de, letter ( I78I), I22

-aw, John, bank, 83, I 44; biographical notes, I43; Compagnie des Indes, 59; letters, 2 I6 aw, in colonies, 37 ea, Isaac, 260
Lead, for Canada, I35; Gaspé mine, I89; see also Mines

Leather, Spanish colonial, 30

Lebaillif de Mesnager, $\longrightarrow$, letter to, IIo

Le Barrois, - Frontenac's secretary, 65

Le Blanc, - Rouen intendant, letter to, I9

Leblanc, - , speculation, I44

Le Blanc, Jean, 55

Leblanc, Vincent, "Histoire de Lindie ocidentalle ", 4; voyages, 47

Le Blond, Jean Baptiste, Voyages, censured, 87

Le Borgne, - - agent, letter to (I797), 2I

Le Borgne, Alexandre, prisoner, I84

Le Borgne, Joseph, I84

Le Borgne du Coudray, Emmanuel, Acadie, Aulnay, memoir, I63, I84, I86, I89, I92; English prisoner, I8I ; instructions, I8I ; letters, I84, I92

Le Bossu, Jean Baptiste, Kerlérec affair, 248

Le Bouthilier, Léon, signature, 50

Le Brasseur, J. A., on colonial administration, 37

Lebreton, Th., "La Salle", IoI

Le Camus, Nicholas, letter, I 88

Le Clerc, - of La Rochelle (I7I6), I2

Le Clerc, Père - complaint, 55

Le Clerc, Jean, Negociations sécrètes, 28

Le Clercq, Chrétien, Premier Etablissement de la Foy, transcripts, 102, 103

Le Cocq, René, 204

Le Cordier, $\longrightarrow, 58$

Lecuy, Jean Baptiste, translation, 6I

Lee, Arthur, dinner, I26; letter to, I22; MercyArgenteau, 94, 95; presented, I I : see also Commissioners at Paris

Lee, Gen. Charles, Santo Domingo correspondence (I776), I 21

Lee, $D r$. Charles A., letter, 90

Lee, Robert E., 90

Leeward Islands, administration, 37 ; concessions, 37; map, 258; packet-boat, 129: see also Santo Domingo; West Indies

Le Febvre, Father Hyacinthe, letter, 199

Lefebvre de la Barre, see La Barre

Lefebvre de la Roche, Abbé P. L., letter to, 4I ; papers, 257

Lefèvre, - , of Marseilles, memoir (I682), 9

Lefèvre, - nephew (1702), 25

Lefèvre, Jean Jacques, bookdealer, collection, 75

Lefèvre de la Boderie, Antoine, correspondence, I3, 70, 95, 96, 207

Lefilles, - - letters to (I 743), I 45

Le Forestier, Madeleine, letters, I Io

Le Frichet de Clodoré, Robert, see Clodoré

Legac, Charles, memoir, 254

Le Gaigneur, -, ship captain ( 1665 ), I85, I88, 202

Le Gardeur, Augustin, see Courtemanche

Legardeur, Jacques, see St. Pierre

Le Gardeur, Louis, see Repentigny

Le Gendre, - Compagnie des Indes, 59, 60

Legge, William, see Dartmouth

Légrand, $A b b e ́$ Joachim, letter, I 54

Le Gras, — Compagnie de la' Nouvelle France,

Le Gras, _- , trial, 247 
Le Havre, admiralty, 217; Arnoul papers, I34; English prisoners, I8I ; fisheries, 53, 194, 280 ; port, American relations, 56, 74, 197, 205

Leisler, Jacob, death, 98

Le Jeune, Père Paul, relation, 72

Leland, Waldo G., on Lesueur, 272

Le Large, F., "Explications des globe terrestre de Marly", 32

Le Loutre, Jean Louis, biography, 268; petition, 27

Le Maire, Mme. —_, letter, I 53

Lemaire, $\longrightarrow$, letter, voyage (I685), I40

Le Maire, Père François, memoir, 39, 272; maps, I 6,227

Le Maire, Isaac, I47, 205, 26I

Le Mascrier, Abbé Jean Baptiste, 240

Le Mercier, François, Bastille papers, 247, 249, 250

Le Mercier, Père François, letter, I9I

Lemoine-Despins, —, trial, 247

Lemonnier, L. G., notes, 270

Lemonnier, Pierre Charles, report, 8

Lemos, Conde de, viceroy, letter to, ${ }_{55} 5$

Lemoyne, - on fisheries, I 47

Le Moyne,, of Rouen (1756), 35

Le Moyne, Antoine, see Chateauguay

Le Moyne, Charles, see Longueuil

Le Moyne, Jean Baptiste, see Bienville

Le Moyne, Pierre, see Iberville

Le Moyne de Sérigny, Joseph, death, estate, 67 , I 2 ; Havana, 68; letters, III, I65

Le Moyne family, papers, II 2

Le Nain, —, of Poitiers, letter, I53

Lenape, see Delaware

Le Neuf de la Poterie, see La Poterie

L'Enfant, Pierre Charles, letter, I2I

Lenni, see Delaware

Le Noir, Abbé, letter to, 269

Lenormant, - Compagnie des Indes, 59

Lenormant, - - on Ile Royale officials, I 57

Le Normant de Mézy, Sebastien François Ange, memoirs, 36,40

Lenot, P., "La Salle", ror

Léogane, Santo Domingo, map and plan, 232

Léonard de Ste. Catherine de Sienne, Frère, 23,25

Le Pelletier, Abbé, 43

Le Pelletier, Jean, memoirs, 20

Le Pers, Père Jean Baptiste, "Memoires de St. Domingue ", 23

Le Pottier, Jean, memoir, 240, 24I, 252

Le Prestre de Vauban, see Vauban

Leprevost, Robert, 4

Leps, Capt. —, log-books, I27

Lequai de Mongiraud, $\longrightarrow$, letter to (1803), 75

Le Ray de Chaumont, Donatien, I22, I 47, 245

Le Rond d'Alembert, Jean, papers, 257

Le' Roux, Jean, 214, 215

Le Roux, Louis, see Infreville

Le Roux de Royville, Sieur de, grant, 9

Le Roy, Claude Charles, see Bacqueville

Le Roy, Jean Baptiste, letter to, I47

Le Roy, Pierre, 276

"Leroy", on Martinique, 88

Le Roy de la Potherie, see Bacqueville
Le Royer, - Santo Domingo map, 233

Lescarbot, Marc, Nouvelle France, extracts, transcripts, 7, 49, I02: papers, I I 3

Les Islets, Canada, county, io

Le Sou—, - , Franklin's letter, 257

L'Espervanche, —, trial, 247

L'Espinasse, - I47

Lespinasse, -

Lespinay, - Canadian petition, I60

Lespiné, Jean de, concession, I 87

Lespine, Noël Danican, sieur de, ships, suit, $6_{5}$

Lestrées, abbey, dispute, I4, I7I

Lesueur, Charles Alexandre, correspondence, 259, 270, 273; New Harmony, 272, 273; on freshwater fish, $27 \mathrm{I}$; on prehistoric animals, 272 ; papers, 272, 273

Le Sueur, Pierre Charles, journal, II2, I39; Louisiana, 25 ; papers, I08, I I3; Sioux expedition, 97

Letandrière, Marquis de, sce Des Herbiers

Le Tellier, - - letter (I685), 2I 4

Letellier, François César, see Courtanvaux

Létombe, —-, consul general, letters, 38, 39; return, 274

Le Tonnelier, Louis Charles Auguste, see Breteuil

Letters of credit, beaver trade. I2; see also Bilis of credit

"Lettre d'un Officier de la Louisiane", 62

Lettres Patentes ... concernant le Commerce . . . de la Louisiane, 57

Lettres Patentes . . . pour le Commerce, 57

Levant, commerce, 9, 5I, I I8, 28I ; freebooters, 33

Le Varlet, —, letter (I687), I69

Le Vasseur, - , of Marseilles, correspondence, I 37

Levasseur, Guillaume, "Art de naviguer" 53; pilot, salary, 33

Levasseur, Jean, pilot, salary, 33

Levasseur de Néré, - decoration, I78

Levasseur-Russouelle, _-, Louisiana journal, 56

Le Vassor de la Touche, Louis René Madeleine, see La Touche-Tréville

Le Vavasseur, Gen. Léon, works, 27 I

Léveillé, Gen. —- letter to (I796), 20

Le Verrier, Urbain Jean Joseph, correspondence, 258

Levesque, François, I 63

Levié, - police inspector, letter, 246

Lévis, Gaston François, chevalier de, letters, 32, 241,242

Levrière, 55

Lévy, Marquis de, exchange (I708), I44

Leyritz, —, essay ( 1801 ), I 43

Lezay-Marnesia, Claude François Adrien, marquis de, archives, 245

Lezay-Marnesia family, papers, 239, 245

Lherminier, F., letter, 260

Lhermite, - , decoration (I7I9), I57

Liberia, 260

Liberty, "Invocation", 93

Libia, 22

Libourne, France, colonial trade, 280

Lieber, Francis, letter, 382

Liénard, Louis, see Beaujeu-Villemonde 
Lièvre, I70

I Lignery, Constant Marchand, sieur de, Indian expedition, 79

I Ligniville, Anne Catherine de, see Helvétius Lima, gardens, 220

I Limon, Sieur de, memoir (1784), 7

I Limonade, Santo Domingo, map, 233

Lincoln, Abraham, I3I

1 Linctot, René Godefroy, sieur de, see Godefroy

I Linde,, Réponse à la Déclaration, 60

I Lino, (?) Mathieu Martin de, dossier, 246

"Lion", affair, 66

I Lionne, Hugues de, I58; letter, I88

Lipan (Cannecis) Indians, 229

1 Liquor, advice on trade, I74; Canadian trade, I32; "Histoire de l'Eau-de-Vie", I05; Indian beverages, 272; Indian trade, 43, 44, 80, 8I, 105, I56, I57; pulque, 272, see also Wine

Lisle, Le Gardeur de (?), papers, I08

I L'Isle Marivault, Sicur de, 9

1 Literary and Historical Society of Quebec, Collection de Mémoires, 43

I Livingston, Edward, correspondence, 282, 283

1 Livingston, Peter William, 93

I Locke, John, Cousin's work, 283

I Locke, Michael, on circumnavigation, 262

I Logan, Sir William E., Remarks on the Mining Region, $\mathrm{I} 29$

Log-books, Brunet's, I6r, I62 ; Frondad's, 88; Massertie's, 3; Newfoundland, r6I ; piratical, 3; West Indies, I27, I62; see also Navigation

Logerie, L. de, letters, I92, 200

1 Lohier-Baupuy, to, 22

Loire, 68, I40

Lombard, J., letters, I87, I88, I92

Lom d'Arce, Louis Armand de, see La Hontan Loménie, Antoine de, see La Ville-aux-Clercs

Loménie, Henri Auguste, see Brienne

London, treaty of, (I604), text, 47; (I686), 26

Long, Stephen H., expedition, 259, 275

Longfellow, Henry W., Evangeline, French translation, notes, I I 6

Long Island, Indian pottery, 79; piracy, 3

Longueuil, Charles le Moyne [2], baron de, decoration, I78; letter, 65; marriage, I6I; pension, 156

Longueuil, Charles le Moyne [3], baron de, marriage, I6I

Lopez de Gomara, Francisco, Indias, I 59

Lorette Mission, fund, I6I

Lorient, 68; Compagnie des Indes, warehouse, 82

Lorimer, _- trial, 247

Lorraine, Louis I. de, see Guise

Lorraine, Philippe Emmanuel de, see Mercoeur

Lory, Pierre, on Nantes, 262

Lotbinière, René Louis Chartier de, pension, I56

Loubois, $\longrightarrow$, signature, I62

Louis XIII. of France, and New France, 27; collection of arrêts, 52 ; documents of reign, 279 ; letter, I07; letters to, I02, 263, 264
Louis XIV. of France, and missions, 55 ; letters, I0, I4, I6, I7, 32, 47, II0, I67, I90, I94, 205; letters to, I67, I69

Louis XV of France, memoir on liquor trade, 8I Louis XVI. of France, American Revolution, 245, 25I ; Lafayette's letter to, I46 ; letters, I $33,25 \mathrm{I}$

Louisbourg, affairs (I756), blockade, I57, 214 ; capture (I745), and French trade, 20 ; commission on claims ( 1760 ), 35; defenses, 243 ; harbor, I2I ; importance, 45 ; maps and plans, 224, 244; memoirs (I760), 86; merchants and Bigot, I28; notes, II 9 ; service at, I33; siege (1758), I2I, 242; view, 244; wartime navigation, 242

Louisiana, American, list of newspapers, I42; relief of Santo Domingo, 243

Louisiana, French, affairs, conditions, 85, 97, 98, I 57, 24I ; and loss of Canada, 28, I20; assessments, 217; Baron's research, 34; boundaries, I20, 243; Canadian communication, 255; Canadian settlers, I20, 255 ; censorship of books on, 62; censuses, 8I, II2, I 6 ; commerce, French, Spanish, supplies, $8,20,30,31,40,68,7 \mathrm{I}, 83,239,255$; commission claims, 35; concessions, I I6, 24I ; courts, 34 ; criminal settlers, soldiers, 70 , I38, 2I I, 250, 255; description, 88; discovery, I04, 240, 255; Drouot, 88; English designs, 40, 266; factions (I704), 68; finances, 32; French and Indian War, 3I, 242; history and geography, notes, I I6, I I9, I29, 240, 255 ; hurricane, 68; Iberville's establishment, $24,25,56,63,66-68,98$, I I I, I I 2, II 5, I 55, I76; Indians, $24,25,78,85,140,240$, $255,266,268,272$; Italians, I 30 ; itinerary from Mexico, 3I; Kerlérec affair, 6I, 246248; land grants, $7 \mathrm{I}$; maps, 39,42 , I IO, I I6, 226-228, 258, 267; marriage contracts, 34; memoirs and relations, narratives, I9, 25, $39,40,45,67,69$, II 2 , II 4, I $30,213,217$, 254, 255; merchandise forbidden, $7 \mathrm{I}$; mines and minerals, I3I, I39, 255, 275; money, card, copper, 83; natural history, 27I-274; officials, list, decorations, 63, I I2; papers, lists, I08, II 2 , II 3 , II4, I57; products, 40, 255 ; proposals (I7I6), 84; proposed investigation, 255; provisions from Santo Domingo, 56 ; religious conditions, missions, $33,34,67,79,86,99$, II 7, 268, 269; royal mercandise, payment, 83 ; servants, 255; settlers, girls, 23, 68, 70, I30, I3I, 255, 266 ; ships in service, $63,67,68,79,157$, $24 \mathrm{I}$; slave trade, 34, I I7, 213; Swiss troops, 23, 62, 254, 266; timber, shipbuilding, 3I ; tobacco, and slaves, 40, II7, 2I3, 279; utility, importance, promotion, I9, 29, 40, 67, I30, I36, I73, 24I; see also Compagnie des Indes; Crozat; LaSalle; Mississippi ; New Orleans

Louisiana, Spanish, affairs, 88; Amiens negotiations, I43; Baudry's ideas, I3I ; commerce, regulation, 3I, 265; effect of cession, 30; French missionaries, I33; French revolt, 3I, I25, I47, 248; Genet's plans, I I4 ; maps, 229; Noyan's claim, 278; papers, 108, I I4; 
proposed French colony, 3I ; retrocession, I 4, I 32

Louisiana Historical Society, Publications, 79

Louisiana Purchase, consideration, .73; papers, II 4

Louisville, serpents, 273

Lourde Martignac, O., letters, 277

Louverture, Isaac, correspondence, 94

Louverture, see Toussaint Louverture

Louvière, $\longrightarrow$, of Acadia, I70

Lovely Lass, 22

Lowell Lectures, 132

Lower Canada, map, I04

Lowery, Woodbury, List of Maps, 222

Luc, André de, letter, 259

Lucas de Montigny, Jean Marie Nicolas, on Mirabeau's note-books, 245

Lucretia, 2I

Lucy, 22

Ludlow Castle, 82

Lübeck, savages at, 97

Lullier, - of Metz, MSS., 208

Lumber and timber, Canada, and wine trade, I37, 197, 200, 204; Compagnie des Indes Occidentales, I94; Indian rights, $7 \mathrm{I}$; Louisiana, 3I, 272; New England, for French colonies, $3 \mathrm{I}$; see also Masts; Shipbuilding

Luneau, Ensign —-, journal on Napoleon, I26

Luyne, Guillaume de, printer, 9

Luzarche, Victor, collection, 245

Lyell, Charles, letter, 275

Lyons, colonial trade, 58; commerce and manufactures, American items, 56; slave trade, 201

Mably, Abbé Gabriel Bonnot de, Observations, censured, 60; on Federal Constitution, 43

Macarty, Mactigue, letters, 248

Macaulay, $D r . \longrightarrow, 260$

Macaulay, Zachary, letter, 243

McDougall, W., letters, I28

Macharis-Bègue, Lt. _, trial, I68

Machault Belmont, Capt. - , letter, 64

Machault d'Arnouville, Jean Baptiste, 230 ; correspondence, 86,88

Machault Rougemont, Capt. - de, letters, 24 ; papers, 109

Mackenzie, Sir Alexander, map of route, 229

Mackinac, see Michilimackinac

Macnemara, Capt. $\longrightarrow$ de, cruise, 75

Macnemara, Daniel, Nantes merchant, I2

Macnemara, Thomas, Nantes merchant, I2

McQueen, Capt. —, voyage (I786), I42

Macquer, P. J., letter to, 4I

Macy, Francis, I2

Madeira, French ships, 185

Madrid, treaty of (I667), I 49

Madry, Jean, barber surveyor, 104

Maestricht, gazette (I 782 ), 248

Magazine of American History, 45

Magdalen Island, concessions, 78, I75; map, 224; sea wolves, 78

Magellan, Fernando, biography, 263; voyage, discoveries, 7, 71, 209, 278

Magellan, strait of, Chauney's petitions, I55; map, 258 ; voyages, 73 , I $31,252,26 \mathrm{I}$
Magne, Jules, "Découverte du Mississippy", II3

Magnin, Padre, "Quito", 84

Mahier, -

Mail for colonies, 34, 202; see also Packet-boats

Maillard, Capt. Vincent, 55

Maillard de la Gournerie, Jules A. B., papers, 256

Maillard de Tournon, Charles Thomas, see Tournon

Maillart, —_, Martinique estate (I7I9), I57

Maillart, $\longrightarrow$, letter to (I797), 22

Maillet du Clairon, - letter, I2I

Mainz, elector of, colonial projects, letter, 84 , I 86, I87

Maisonneuve, Paul de Chomedy, sieur de, notes, I06

Maizerets, Louis Anges de, I64

Majestueux, 230

Malachalle, Mme._- letter to, $4 \mathrm{I}$

Malesherbes, Chrétien Guillaume de, censorship, correspondence, $62,85,86,274$

Mallart, Jehan, "Tous les portz de mer", 4, 42, 73

Mallet, Jean Roland, memoir, 243

Malta, knights of, and West Indies, letters, I07, I $8,207,26$ I

Manach, $\_$, Acadian missionary, 27

Mancrede, Dr. Joseph G., letter, 89

Mandement de l'Archevesque, 44

Mandements .... des Evếques, 80

Mandeville, Antoine Philippe Marigny de, see Marigny

Mandeville, W. de, letter, 259

Manila, see Philippines

Manitoba, bishop of, letters, II 8

Manitoba, pamphlet, I29

Manitou, 226

Mann, Horace, 283

Manufactures, Canadian hats and woolens, II8; English, at Montreal, I I 7 French, 56, 255; memoirs (I672), I95; Philadelphia, 274

Manuscrits relatifs à la Nouvelle France, 6

Maple sugar, value, 67

Maps and plans, America, 25, 26, I54, 216, 257 ; American Revolution, 230; Arctic Ocean, 255; Atlantic Ocean, 255; Barbados, 235, 257; Boston, siege, 123; Canada, I04, I82, 224-226, 244, 257, 267; Chastellux's Journal, II6; Crown Point, I I9; Cuba, 23I ; departmental, list, I I6; Dépôt des Cartes et Plans, inventory, I04; Dépôt des Plans des Colonies, inventory, 85 ; Devaulx's marine, 3 ; Dominica, 235; English colonies, I02, 230; Florida, 140, 229; Fort Duquesne, 228; Fort Rosalie (Natchez), 228, 229; Fort Royal, 236, 257 ; Fort William Henry, 244; general, world, 8, 26, 221-223; Greenland, 256; Grenada, 235; Guadeloupe, 236, 257 ; Guiana, 244, 255; Gulf of St. Lawrence, I40, 223, 224; Ile Royale, 223, 224; Jamaica, 23I; La Plata, 33; Louisiana, 42, I I6, 226-228, 258, 267; Lower Canada, I04; Magellan Straits, 258; Marly Globe, 42; Martinique, 236, 257, Mediterranean, 26; Mexico (New Spain), 258, 279; military, catalogue, 245 , 
Mississippi and Ohio valleys, 24, 66, 226229; Nevis, 236; New England coast, I66; Newfoundland, 26, 256; New France, 39 ; New Mexico, 98, 229; Nolin's plagiarisms, 8, 62, I 54; North America, sections, 7, 42, 73,98 , I77, 256, 265; Nova Scotia, I02, 223, 224; Pacific Ocean, I52, 255, 257; Philippines, 265; portolani, 26; Quebec, 267 ; St. Christopher, 236; St. Eustatius, 236; St. Lucia, 237; St. Martin, 237 ; Santo Domingo, I47, I 48, 276; South America, coasts, 73, 256; Ticonderoga (Carillon), 32, I32; Tobago, 237; Trinidad, 257; United States, 230; West Indies and Gulf of Mexico, I79, 219, 23I, 258

Maranhão, description, I74; French founding, 5 Marcel, Gabriel, Cartographie de la Nouvelle France, 22I ; Champlain ...Pension, 23. II3; Quatrième Centenaire, 22I

Marcel, Henry Camille, Bibliothèque Nationale, I 11 .

March, Francis A., letter, 283

Marchand, Constant, see Lignery

Marchandis, Barthélemi, 9I

Marest, Père Gabriel, papers, II2, I I3

Mareuil, Sieur de, charges against, I68

Mareval, Etienne, 55

Margarita Island, voyage, 87

Margry, Pierre, and Harrisse, I33; autobiographical note, IIO; collection, IOI ; copies of documents printed by, I09; correspondence, II0, II8, I28, I33; Découvertes et Etablissements, 22; "La Vérendrye", I I3; publications, criticisms, I28, I29; "Vie du G1. Cass", i 08

Marguerittes, - , letter to ( 1803 ), 75

Marhal, —, from Carolina, 274

Maria, 20, 22

Mariana Islands, history, 85

Maria Theresa, of Hungary, 146

Marie, I 35

Marie de Médicis, letters, I07, 204

Marie Galante, narrative, 78 ; sketches, 270

Marigaut des Rozeaux, St. Lucia, 237.

Marigny de Mandeville, Antoine Philippe, Kerlérec affair, 248-250

Marin, Paul de la Marque (?), sieur de, I08

Marin, Pedro, printer, 265

Marin, 24, 66

Marine, department of, acts, titles, inventory, I60, 218; archives and papers, calendar, inventory, table of contents, I5, II 8 , I I9, I28, I56, I58-16r, I98; assiento, 34; Bernou's papers, I59; Compagnie des Indes, I 7 ; Conseil, I 2, 33, 39, 70, I33, I 54, I 57 ; expeditions (I678-1810), 89; finances, I2, $33,35,36,8 \mathrm{I}, 25 \mathrm{I}$; foreign despatches, I 58 ; functions, I5, 49, 77, I 58, I6 1,213 ; history of organization and archives, 128 ; investigation of contracts, I 35 ; letters to port officials, I6I ; lists of officials, 44, I 57, I 59, 266; memoirs, collection, 36, I I8; notes, 209; pensions to officers. list, I56; policy and practices, 33, I33, I8I, 252, 266; royal regulations, 252; under Louis XIV., I I8; unprinted regulations, American topics, 33-
35; see also Army; Commerce; French colonies; Navy; colonies by name; ministers by name, especially, Berryer; Boynes; Castries; Choiseul; Choiseul-Praslin ; Colbert; Le Normant de Mézy; Machault d'Arnouville; Maurepas; Morville; Pontchartrain; Rouillé; Sartine; Seignelay

"Marine Gazette", 63

Marines, convicts as, in colonies, I37; discharged, for colonies, I37; esteem, 242; regulations, I6o

Marinière, - - Santo Domingo property, 234

Marly Globe, 42

Marolles, Capt.__, death (I720), I 57

Marquemont, Cardinal de, letter to, I3

Marquette, Père Jacques, and Bernou, 99; exploration, map, notes, 98, I29, 226; letter, 217

Marquis de la Charlotais, I22

Marriages, Canadian lists, ı06, I6r ; French subjects, 2I 4 ; Louisiana contracts, 34 ; Montreal records, II6; Quebec, I90; soldiers, I 6 ; see also Girls

Marrillac, Charles, correspondence, 5

Marrooshen, 26I

Mars, I 56

Marseiller, — of Martinique, memoirs, I56

Marseilles, commerce, 9, 6I, II7, I30, I34; fisheries, 85 , I34, I38; galley papers, I34; munitions, I37; slave trade and sugar refining, I 39, I9I

Marshall, Orsamus H., Margry correspondence, I 8

Martel de Saint-Antoine, Jean Baptiste, Bastille papers, 247, 249, 250

Martelly, Lt. Jean, I37, I38; letters, promotion, I 40, I4I

Martelly, Joseph, letters, I40, I4I

Martial, B., letter, 269

Martilliat, Bishop de, 27

Martin, Père Claude, letter to, 93

Martin, Père Felix, Relation Abrégée, 72

Martin, François de, sugar mills, I83, I84

Martin, Henry, Cat. des MSS. de l'Arsenal, 239

Martinelle, Vincenzo, Histoire du Gouvernement d'Angleterre, $6 \mathrm{I}$

Martinet, Com. - de, squadron ( I7i6), 276

Martinique, amnesty, 78 ; astronomical observations, 277; bids for, sale, II5, I 49; census, 80, II6; clerk's register, extract, I75 ; creoles, 258; defenses, 86, I47, I99; description, 43; Dutch attack, I69, I99; duties, 70; earthquakes, 79; English attack, 65; estates, papers, 37, I 57 ; events, news, 66, 88 ; filibusters, 98 ; flour for, $\mathrm{I} 35$; foreign traders, II7; governor, conduct (I662), I 82; history, 44; hurricane, 65; La Barre, 63; Lamardelle's works, 97 ; letters from, 69,84 , I40, I65, 24I ; maps, 236, 257 ; memoirs, relations, I I5, I30, I39, I52, I60, I66, 2I7; natural history, 27I, 273; New England cattle trade (I776), I2I ; officers, lists, I62, I63; papers, 87, I43, I47, I67, I68; passengers for, list, I 53 ; possession, II 5 ; religious affairs, missionaries, 52, 64, I68; revolts, 37, 78, 80, I44, I88, 274; Roche- 
chouart, I53; servants, I2; ship from, I3; sketches, 270; slave trade, II7; Spanish money, I56; superior council, proceedings, 9I, I 53; Tracy, I 85 ; voyages to, 46 , I 52 ; wine import, I56; see also West Indies; Windward Islands

Martyr, Peter, West Indies, 8

Mary (2 ships), 22

Maryland, charter, I8I; English trade letters (I709-12), I45; geology, 275; Russian trade, 193

Mascouten (Feu) Indians, article on, II3

Massachusetts, Acadia, I 84; education, 282; electing laws, 25I; Indian liquor trade, 43 ; see also New England

Massachusetts Historical Society, Parkman MSS., 45

Massertie, F., log-book, 3

Massiot, Louis, I 36 ; letter to, I 40

Masson, Richard, I76

Massue, Henri de, see Ruvigny

Masts and mast trees, Acadia, I35 ; Canada, 67, I40; for Santo Domingo, I48; Louisiana, 228

Matharel, Louis, letters, I85, I 92

Matos, Antonio de, map, 231

Maty, Mme. de., letter, I9I

Maubec, abbey, I7I, 252

Mauclerc, - letters (c. I700), 67, 68

Mauclerc, Sieur de, instructions to, I4I

Mauléon, - de, packet-boats. I22

Maupassant, Père Eustache, letter, I99

Maupeou, Chevalier de, journal (I706), II 2

Maupeou, Giles de, memoir, 280

Maurellet et Cie., I 39

Maurepas, Jean Frédéric Phélypeaux, comte de, American Revolution, 245; and assiento, 34 ; functions, I 54; letters, I I, 80, 82, 278 ; letters to, 82 , I 44 , I 52 , I 53, I 69 ; on commerce, memoir, 35, 80, 212; on nun, 79

Maurice of Nassau-Siegen, Count John, on Brazil, 77

Mauriel, Bishop, Santo Domingo MS., 24 I

Maurin, François, Bastille papers, 247, 249, 250

Maury, Matthew F., letters, 258

Maximin, Jean Joseph, suit, 280

May, Capt. John, 2 I

Maya civilization, I4I

Mayer, Jacob, consul, letter to, 2 I

Mayflower Compact, 96, 26I

Maynas province, missions, 84

Mazarin, Jules, cardinal, Compagnie du Nord, I80; letter to, 264 ; MSS., 265 ; minutes of letters, I79, I80; papers, I49, I50

Mease, James, letters, notes, 275

Medals, Fleury's, 244; Renaudot's, 97

Medicine, American MSS. of Académie, 238; correspondence of military surgeons, 89, 90 ; plants, 272

Mediterranean Sea, French trade, 9 ; portolano, 26 ; sugar and cod trade, 77,136

Meinat, - , Santo Domingo map, 232

Melani, $A b b^{\prime} \dot{e}$, notes, I3I

Méléagre, 127

Membré, Père Zenobe, 99; letter, I72

Ménager, Sicur, Rouen deputy, memoir, 53
Mendaña, Alvaro de, relation, 23

Menendes de Valdes, Joseph, letter, I 63

Menéndez de Avilés, Pedro, Huguenots, 209, 210

Menou, Charles de. see Aulnay Charnisay

Mentelle, - Cayenne memoir, 93

Mentelle, Edme, "Notice historique des principaux voyageurs", 43

Menu, Sieur, memoir (I662), 263

Mercantile'system, Bayonne memoir, 31 ; foreign trade in French colonies, complaints, I 2 , I $8-20,57,58,82,83,85,89$, I I 7, I 45 , I46, I48, I57, I90, I94, 243, 266, 280; foreign goods for colonies, permits, 56-58; foreign merchants in France, 97 ; French trade in Spanish America, I 4, 40, 213, 262; fund for enforcing, 59; goods for slave trade, 34 ; illegal trade and Anglo-Franco-Spanish relations, 30; Martinique revolt, 37 ; preservation, 266; seizures, 70, 194, 195, 202; see also Commerce

Mercier, Père, letter (I732), 268

Mercoeur, Philippe Emmanuel Lorraine, duc de, 264

Mercure, publication, 43,63

Mercure, ship, I 57

Mercury, 22

Mercy-Argenteau, Florimond Claude, comte de, Correspondance Secrète, despatches, 94, 95

Méricourt, —, ship captain (?), letters, 20I ; Tobago, 20I

Merle, Comte de, memoir, 277

Merville, Capt. $\longrightarrow$, pension (I7OI), I 56

Mesmes, Claude de, see Avaux

Mesmes, Jean Jacques de, see Roissy

Mesnil, Pierre Charles, dossier, 247

Meteorology, co-operative bibliography, 256; Guadeloupe observatory, 256

Metropolitan Museum, -New York, letters, I4I

Meulles, Jacques, chevalier de, corrupt practices, I 40 ; letters, I04, I40; letters to, I4I

Mexicaine, play, 85

Mexicans, Aztec writing, 25; language 75; origin, 4

Mexican War, Du Pasquier's work, I 6

Mexico (New Spain), affairs (I86I-63), I 42 ; Angrand's exploration plan, papers, I42, 220; cacti, 273; commerce, 3I ; Delisle's MSS., 26; descriptions, I44, 241, 265; documents, 2; French and Nueva Vizcaya, I73; French policy ( I859), I33; French prisoner. 64 ; French projects, I73; French trade, confiscation, levy, 8, 12, 14, 40, 194, 195, 213; French voyages, $63,{ }^{1} 67,252,277$; histories, Fournier's MS., 65, 258; information, I 55 ; itinerary to Louisiana, $3 \mathrm{I}$; Jesuits, martyrs, 74,75 ; memoirs, relations, 42, 72, 279 ; mines, I 88 ; money from, I67 ; pulque, 272 ; wartime supplies for Louisiana, 30 ; see also Galleons; Spanish America

Mexico City, description (I6I3), 2ro; map of lake, 72; memoir, 72

Mézeray, François Eudes de, papers, 4

Mézy, Augustin de Saffray, administration, correspondence, I03, I83, I86; death, I 88

Michaud, Capt. _, instructions, I7 
Michaud and Poujoulat, Nouvelle Collection des Mémoires, I3

Michaux, F. André, Louisiana plot, II4

Michaux, François André, Arbres Forestiers, 270; correspondence, II 4, 270; notes, 270

Micheau, Capt. —, letter, I88; recommended, I 88

Michel, —_ de, Jaurnal Historique, 26

Michelant, Henri Victor. Voyage de Carticr, 6

Michigamea, Indian, in France, 80

Michigan, copper mines, Io8

Michigan Historical Collections, I I I

Michilimackinac, description, 87; English expedition (I682), I75; papers, II 2 ; Pinet's sermon, I68; Tonty, 66

Miera y Pacheco, Bernardo, map, 229

Mignarde, — de, letter (I669), I92

Milbert, Jacques Gérard, collections, 259

Milfort, Le Clerc, Creeks, Mémoirs, 4I

Milhet family, memoir, I43

Military, see Army; Defenses; Militia; Navy; wars by name

Militia, Canada, I6; United States, 4I; West Indies, 35, 79

Miller, Emmanuel, collection, 88

Millière, — de, for United States, letter to, 22

Mills, banalité, 7I; Martinique census, 80

Mims, Stewart L., Colbert's West India Policy, 204

Mina, Marqués de la, 67, I64

Minerve, Montreal, clipping, I03

Mines and minerals, Acadia, 68; assay, I3I, I54; Baye de St. Paul, 270; Canada, I45, 270; Illinois, 270; Louisiana, I3I, 255, 275; New Spain, I 88; papers, I08; Roberval's grant, 6 ; see also Copper, and other metals by name

Mines de Cuivre d'Ontonagon, I29

Minet, - - map, 226

Mingan, Canada, 225

Minguet, André, on medicinal plants, 272

Minorca, objects from, 238

Miquelon, animals, 259; astronomical observations, 277 ; coast, 276; flora, 271, 273; Guiana trade, 8; papers, I07; printing, I42; travel, I 33

Mirabeau, Chevalier de, memoir on Marine, 36

Mirabeau, Honoré Gabriel de Riquetti, comte de, note-books, 239, 245

Miramichi, Fronsac's concession, I 66

Mirande, - de, letter (I675), I99

Miroménil, __, Anjou memoir, 266

Miscou Island, concession, 78; map, 224

Missent, Capt. Nicolas, 7

Missions, Acadia, I89; and Compagnie des Indes, II7; Bresley to Algonquins, 156; Canada, condition, 105, I9I, I99; deaths on voyage, I40; Illinois, 268, 269 ; Immaculate Conception, 9, 65; Louis XIV. and, 55; Louisiana, II7, I33, 268, 269; manual, 43; Oriental, 26; papal brief on publications, 27 ; Paraguay, 40, 8I ; St. François de Sales, 9; St. Jean, 54; travels (1644), 217; western (1655), I89; West Indies, I74, I98; see also next title; Benedictines; Capuchins; Car- melites; Dominicans; Jesuits; Pères de le Charité; Récollets; Sisters; Sulpicians

Missions Etrangères, and bishop of Quebec, 697I, I07; and Jesuits, 268; and New York (I82I), 269; history and claims of seminary, I3, 27, I7I; MSS. in Paris seminary, 268, 269

Mississippi River and Valley, Bienville and English, 98; Collot's tour, 228, 229; copper mines, I38; Delisle on mouth, 24; descriptions, $24,244,277$; detachment of upper, from Canada, I00; exploration, 24, 97, 98, I I0, I29, I54, I73, 217; French towns, 244; land journey to mouth, from Quebec, 25; maps, 24, 66, I77, 226-229, 258; memoir, 24; missions, 55 ; navigation, I29; notes, 46 , II I, II9; papers, list. II3, II4; sea route to, 42 ; source, 226, 260; supposed English plans (1698), I78; see also Illinois; Louisiana; Missouri; Ohio

Mississippi Valley Historical Review, 272

Missouri Historical Society, address, I29

Missouri Indians, fort, information, 248

Missouri River, exploration, 260; information, 43; length, 42; maps, I77, 229; mines, 275; mission, 268, 269

Mitchel, Ormsby M., letter, 258

Mitchill, Samuel L., letters, 259, 260, 275

Mithon, Jean Jacques, sieur de Senneville, memoir, 254

Mitty [Milly?], 22

Mobile, Capuchins, 33, 79; importance, 254; information, 84 ; map, 227; Père Davion, 268; ships from, II 3 , I40

Mobile River, exploration, 56; maps, 227-229

Mocquet, Jean, voyages, 277

Modyford, Sir James, I8I

Modyford, Sir Thomas, I8o

Moerenhout, T. A., letters, I27

Mohegan language, 256

Molac, S. de, letter (I672), I95

Molé, — de, Martinique letters, I68

Moles, notes, 272

Môle St. Nicolas, maps, plans, 232-234; trade, I 48

Molinier, Auguste, Catalogue des MSS.... Bibliothèque Mazarine, 265; Inventaire Sommaire de la Collection Joly de Fleury, 2 I I

Mollusca, Gulf of Mexico, 274

Molly, 22

Monceaux, —-, see Auteuil de Monceaux

Monck, George, see Albemarle

Monclova, Conde de la, letter to, I64

Money, arrival of specie, I98; Canada, need, 78 , 140; colonial copper, 71,83 ; foreign in colonies, 89 , I56; from Mexico, I67; lightweight, from New England, I48; Louisiana, 40, 83, 85; West Indies, specie, special, ro, I 56; see also Galleons; Paper money

Moniteur de la Lonisiana, file, I29

Monmouth, battle, plan, 230

Monneron, - de, journal, I26

Monroe, James, Paris, I42

Monsegur, Juan, memoir, 72 
Monseignat, Charles de, death, I69; memoir, Morin, A., correspondence, II2 I 69

Monseignat, Louis de, letter, I69

Monstr'oeil, Claude de, I02

Montagu, Ralph, letter to, I94

Montalais, Capt —, letter, I2I

Montalembert, Santo Domingo, plan, 234

Montaran, —- de, memoirs, 257

Montaud, see Gilly de Montaud

Morisse, _-, Guiana memoir, 8

Morlaix, admiralty archives, I30; commerce, 56 , 205

Morne Bruce, Dominica, plan, 235

Morne de l'Hôspital, Grenada, view, 235

Morne Fortuné, St. Lucia, plan, 237

Morne Garnier, Santo Domingo, plan of fort, 235

Morris, William, 4I

Montausier, Charles de Ste. Maure, marquis de, Morton, Samuel G., letters, 260, 275 letter, I 88

Montbret, sec Coquebert de Montbret

Montcalm-Gozon de St. Véran, Louis Joseph, marquis de, biographical memoir, I20; Doreil on, 243; eulogy, I20; Fort William Henry, 242, 244; letters, II9, 243; Lévis, 243; Quebec, I32; Ticonderoga, 242; Vaudreuil, 242 ; victories, Te Deum, I4

Montebello, Duc de, letter (I828), 282

Monteil, — de, letters, I22

Monterey, Cal., description, I33; Langle, I25

Montgéry, - letter, 259

Montgomery, Phillip Herbert, earl of, grant, I8I

Montholon, François de, and rioters, 83 ; letters, 69, I64

Montigny, François Jolliet de, 24, I59, 268; letter, 97

Montigny, Jacques Testard, dit la Marque, sieur de, papers, II 3

Montigny, Lucas de, 245

Montmagny, Charles Jacques Huault, 69, I06

Montmorency, Henri II., duc de, viceroy of New France, commercial company, I5, 50, 5I, I03, 204, 205, 21 4

Montmorency Laval, François de, see Laval

Montmorin Saint Hérem, Armand Marc, comte de, correspondence, I26

Montortié, Capt. —. Quebec letter, I40

Montreal, baptism and marriage registers, I06; boundaries and streets, I07; capture, 74; descriptions, 87, IZI ; Dumas, 45; earthquake, $8 \mathrm{I}$; fortification, tax, $7 \mathrm{I}$; history, 265 ; manufactures, II7, 247; notes, 23, I06, II8; origins, I03; papers, I03; religious orders, hospital, seminary, Io, 23, 40, 7I, I04, I09, II8, I64, 203, 25I, 252; Société de Villemarie, I06; travel, I3I, 274; troops, roll, 106; Véritables Motifs, 106

Montreuil, Chevalier de, war letters, 242

Monts, Pierre du Guast, sieur de, commission and grant, 96, 103, 208, 209

Montserrat, French attack, I9I ; see also West Indies; Windward Islands

Morangis, - will, 27

Morbihan, — see also Compagnie de la Nouvelle France

Moreau, —, director, 59

Moreau, Jacob Nicolas, collection, 2I6, 22 I

Moreau, Jean Victor, 75 ; letter, I47

Moreau de St. Méry, Médéric Louis Elia, Loix et Constitutions, Io

Morel, Auguste, 2I

Morel de la Durantaye, Oliver, see La Durantaye

Morel-Fatio, Alfred, Catalogue des MSS. Espagnols, 2 ; Recueil des Instructions, I3

Morin, _- Compagnie des Indes. 59, 60

Morville, Charles Jean Baptiste Fleuriau, comte de, policy, I33

Mosquito Coast, description, 40

Mott. Dr. Valentine, letters, 90

Mouchard, —, Compagnie des Indes, 59, 60

Mouchet, J., map, 229

Moulceau, - de, map, 233

Mount Vernon, sketches, 270

Mourand, Capt. — journal, 277

Moussu, Marie Catherine, I 62

Mouton, 20I

Moziño, José Mariano, on Nootka, 220

Münster, treaty of, see Westphalia

Mulet, I $4 \mathrm{I}$

Mun, 14 de, "Mon frère le Sauvage", i 20

Munitions, see Arms

Murat, Capt. —, 29

Murcia, Spain, commerce, 30

Murdoch, Beamish, Nova Scotia, 27

Muscovy Company, privileges, 97

Mushrooms, drawings, 270

Muspa, map, 258

Musset, Georges, Cosmographie par Alfonse de Saintonge, 3, 4

Muy, Nicolas Daneaux, sieur de (1a), commission, I7I

Muyn, L. de, letters, 200, 20I

Muyssart-Desobeaux, Sieur de, drawings, 267; Guadeloupe memoir, 267

Nacquart, - - of Dunkirk, letters, I84, I85, 187

Nancy (5 ships), 22

Nantes, and colonial trade by foreigners, II7; and packet-boats, I28; commerce, I9, 40, 74, II $7,205,240,252,262,280$; commercial complaints, I7; estates on commercial company, $5 \mathrm{I}$; fisheries, I46, I88, 202, 204; memoirs, 53,240 ; prizes at, 48 ; slave trade, 56 ; West Indies trade, 56, 70, I46

Nanteuil, —, Acadians, correspondence, 213

Nantucket, whalers for France, I2

Napoleon I., and Hyde de Neuville, 75 ; plan for flight (I8I5), I26

Narbrough, Capt. John, voyage, 56

Narp, Philibert de, letter, I97

Narrangansett Bay, piratical log-book, 3

Nashville University, Dr. Eve, 90

Nassau, C. F., plans, 236

Natchez, La., description, concession, 24I ; fort, $78,228,229$; maps, 227,228

Natchez Indians, capture, slaves, 85 ; customs, 78 ; death of chief, 98; Grand Soleil, 79; squaw burnt, 80 ; Taensas, 97 ; Tunicas, 80 , 8I ; war, 80, 240, 254

Nation du Feu, see Mascouten 
Natural history, American, specimens, work, 40, 64, 66, 7I ; Baron's research, 34; collection, I54; Denys and Boucher, I02; Fonds Cuvier, 258-260; Paris museum, MSS., 259, 270-275; West Indian drawings, 86

\section{Naturalization, grants, Io}

Naval stores, Canada, I94; see also Masts

Navarre, parlement, I65; ports, I 28

Navigation, Baron's observations, 34 ; beginning of steam, I27; bonus for carrying colonists, 205 ; clerks, I38; Compagnie des Indes Occidentales, I88, I89; condition of ships, I35; conservation of personnel, Io; crime, 20 ; dictionaries, I6I, 263; documents, 49 ; equipment, ship stores, 44, I38, I6I, I9I, 202, 213; flutes for Canada, I88; freight charges, I35; guides, descriptions of coasts, sketches, 3, 63, 219, 273, 276; ill crews, I2I, I 40 ; instruments, 276 ; lists of ships, 44,63 , $79,80,82$, I98-200, 204, 2I5; list through the Sound, 42 ; marine companies in West Indies, I57 ; memoirs, 204, 209, 214; notes, 27I; officers and trading, I6, I35, I36; papers, lack, 70, 96, I99; plans, I 55, 202; Portuguese (1838), 278; private cargo, 201 ; quick voyage, I40; recruiting sailors, I99; regulations in West Indies, health certificates, I36, I86; required transportation of servants and arms, I2, I37, I39, I59, 218; returned sailors, I 40 ; route to Mílssissippi, 42; Ryswick negotiations, 49; season for West Indies sailing, I4I ; ship signals, English, 219; ships to and from: Acadia, 67, I68, I97, 201 ; Canada ( I622-75), 33, I82, I83, I87-I90, I93, I96, 20I, 202, 204, 25I, 263; (I676-I703), 66-68, I35, I36, I40, I4I, I74, 200, 20I ; Guiana, I98; Louisiana, 40, 67,68 , I40; Newfoundland (Placentia), 8, $48,63,66,68,69$, I 30, I 36, I 4 I, I62, I64, I65, I82, I87, I91, I95, I97, I98, 200-202; West Indies (I666-77), I84, I85, I87, I90, I92, I95-203;-Spanish-American, routes, troubles, 29, 49, 26I ; Spanish types, I45; Thevet's work, 46; treatise, 53 ; use of colors, 238; wartime. 5, 63, 65, 68, 69, I87, 242, 243; see also Admiralty; Astronomy; Commerce; Convoys; Fisheries; Galleons; Log-books; Maps; Marine; Naval stores; Navy; Passage; Pilots; Piracy; Ports; Privateering ; Prizes; Shipbuilding; Tonnage; Transportation; Voyages; Wrecks Navy, condition, affairs, 43, I94; documents, 87; English, in West Indies, American trade (I797), 22; impressment, I97; instructions (I582), 207; lists, 77 ; mercantile enrolment, I95; plague, I52 ; Seignelay on English, I81; utility, I38; see also Convoys; Marines; Navigation; Prizes; Privateering; wars by name

Naxouat, I70; fort, I66

Necker, Jacques, American Revolution, 245 ; letter, 278

Nectoux, Hippolyte, correspondence and papers, I30

Négociations de Jeannin, I3
Negroes, and relief of Santo Domingo, 243; documents, 42; "intelligent" American (I800), I 44; laws on free, 93; marks for, I9; origin, 75; see also Santo Domingo; Slaves

Nehemiah Burr, 22

Nell de Bréauté, — , journal, I28

Nelson, - , Frontenac's interpreter, Bastille, 246

Nelson, T., and Sons, American Vieres, I04

Nennagoesche, I69

Neptune, French warship, I23

Neret, Jean Baptiste, fur-trade drafts, I2

Nesmond, André, marquis de, voyage, map, 63, 223

Netherlands, and Compagnie des Indes Occidentales, I86; and England and trade ( I665), I3; and LaSalle, 247; commerce, colonies, West Indies, memoirs, 3, 64, 69, 72, 77, 85, 96 , I32, I38, I83, I 85, I 87 , I 90, I 95,208 , 239 ; decree against Dutch in foreign companies, 83; duties, 2I4; fisheries, 208, 27 I ; French embassy correspondence, I4, 47, 262; French special mission on colonies, I84, I 85 ; goods for French slave trade, 34; Levant trade, 9 ; notes, 208 ; oversea conquests, 215 ; people, I85, I95; pirates of Zeeland, I96; plans against Spanish America, I4; Russian beaver trade, I93; slave trade, I86; treaties, 49, I 49, 208, 263; voyages, 28 ; war-time navigation, I87; whaling, 74 ; see also AngloDutch; Antwerp; Brazil; "Dutch" titles; Franco-Dutch; Guiana; wars by name

Neufville, Antoine de Bordeaux, sieur de, despatches, 48

Neufville, Nicolas de, see Villeroy

Neutrality, Alabama question, I32; AngloFrench treaty on American ( I686), 26, I69; Spanish, in French and Indian War, 32

Neutral trade, American affairs (I796-I8Io), 20-22, 38, 39, 93, I44, I47, 246, 257; French and Indian War, 32, 280; visit and search, 5 Nevis, Iberville, 20, I I I, I46; map, 236; see also West Indies; Windward Islands

New Amsterdam, capture, 28

New Biscay, sce Nueva Vizcaya

New England, Acadia (I690), I39; contraband trade, 30; during American Revolution, 87, I2I; fishing at Ile Royale, 82; French baptism of captives, I06; French prisoners of war, 38 ; Groseilliers, I86; history and geography, 42, 240; Huguenots, 40 ; light-weight money, I48; maps, 39, I02, I66; memoirs, I I I, I I6, I I 8, I39; New Netherland, 28, 205, 207; news, 246; plan against (I70I), I I6; plants, 274; Raboteau, 20; ships, capture, I62; Spanish trade, 30; West Indies trade, 3I, I2I, I 46, I 47, 254; see also divisions by name

Newfoundland (Placentia), affairs, conditions, I83, I87, I9I, 200 ; census, I75; coast, description, sketch, 273; Colbert's interest, 28, I34; commerce, ships to and from, supplies for, $6,8,30,48,63,68,69,74,79,80,91$, I 28 , I30, I36, I41, I45, I6I, I62, I64, I65, I69, I 82, I87, I95, I97, I98, 200-202, 2 I 5 , 
239, 256, 280; concession, I07, I49, 263; convoy, tax, I8, I97, I98, 200; correspondence from, I62; Denys, 72; description, 265; deserters, I63; discovery and settlement, English and French, 6, I5, I I8, I32, I33, I39, I83, I97, 205, 261, 262; English grants, 96, I8I; extracts on voyages, 7 ; finances, I6, I37, I94, I97; Franco-Dutch, I 96, 20I ; freedom of trade, I8; French loss, 266; history and geography, 240, 257; ice, $27 \mathrm{I}$; King William's War, 26, 63, I39, I67 ; log-book, I6I ; maps, 26, 222-224, 255, 256; natural history, 259, 260, 27I-273; need of pilots, I37; notes, 46, I I6; papers, list, I07, I I2, I57; pirates, 3, I36; Placentia as port, regulations, I60, I82, I94; Placentia burned, I82; Queen Anne's War, 68, 70, I36, I38, I64; Ryswick negotiations, 49; shipbuilding for, I94; Ternay's expedition, I2I, I25 Utrecht negotiations, 47, 82, I3I, I5I, I52, 243; warships, I36, 200 ; wrecks, 65 ; see also next title

Newfoundland (Banks) fisheries, affairs, conditions, 9, 20, 30, 53, I33, I81, I82, I86, I92, 200, 262; Alicante trade, I44; annoyances, I99; arrêt, 218; Basques, I30; Brest archives, I30; cargoes, 85; drying project, 214; Dutch war, I96; English interference with French, 5-7, 48, 52, I88; English participation, 280 ; instructions, information, I26, I92; journal of operations, I62 ; Langlois' report, 53; Marseilles trade, 85; memoirs, 5, I7, I26, I3I, 212, 27I, 280; participation, especially St. Malo, I92, I94, I95, 204, 206, 280; permits, 44, I30, I84, I89-I9I, I 95 ; plan, I47 ; protection, 252 ; ships, crews, equipment, 66, I36, I9I, I93, I95, I97-200, 202, 27I ; wreck, I35; see also Fisheries

New France, sce Canada

New Granada, see Colombia

New Hampshire, memoir, I28; sce also New England

New Harmony, Ind., Lesueur, 272, 273

New Madrid, Dupin, I32; plan of fort, 229

New Mexico (Quivira), Barlovento, I39; Crozat's concession, 73; Delisle's MS., 26; description, 265; discovery and conquest, 28 , 84, 88; French project, I73; maps, 42, 98, 229 ; Peñalosa's services, I52; Pike, 87; St. Denis' expedition, 254

New Netherland, English conquest, I86, 206, 207; Iroquois and Canada, 47; maps, 255, 256; New England, 205, 207 ; see also New York

New Orleans, 78 ; census, II2; commerce, 31 ; founding, 78 ; plans, 227, 228; situation, 85 ; see also Louisiana

Nere Orleans Bee, II 3

Newport, R. I., French fleet. I24; travel, I3I

Newport, I67

New Spain, see Mexico

Newspapers, collection, I42

New Sweden, see South Company

New York, description, 98; Dutch expedition against, I99; education, 282, 283; election laws, 25I; French plans against (I689), Norumbega, 279; description (I7th cent.), 265
I74; Indian pottery, 79 ; Leister, 98 ; map, 102; Missions Etrangères, 269; Plée's journey, 274; see also Iroquois; New Netherland

New York City, French sick (I795), 38; geology, 259; packet-boats, 129; privateers (I795), 38; sketches, 270; travel, I3I, I33; yellow fever, 275

New York Colonial Documents, 9 ; Brodhead's mission, IOI, I09

New York Harbor, plan,. 230

New York Historical Society, address, 256

Niagara (Fort Niagara), affairs (I74I), I69; and English trade, 247; fort construction, plan, II7, I69, 229; list of officers, I63; siege, II9

Niagara Falls, communication around, I I6 ; travel, sketches, I33, 270

Nicaragua, Greytown, I27

Niceron, Père Jean Pierre (?), bibliography, 73 Nicholson, Sir Francis, Port Royal, 27

Nicolas, - maps, 235-237

Nicolet, Jean, notes, Io8

Nipissing Indians, petition, 78

Noailles, Adrien Maurice, duc de, letter to, 255 ; report on colonial revenues, I5

Noailles, Louis Antoine, cardinal de, letters to, 55,69

Nobility, and trade, Io, I8; Canadian gentry, I54

Noël, Jacques, concession, I 5, 262 ; papers, I03 Noël, Jean Marc, I63

Noël de la Morinière, Simon Barthélemy Joseph, inscription, 27I ; on fishes, 270, 27I ; papers on Normandy, 74

Nogales, plan of fort, 229

Nogarée de la Fillière, —, letter, voyage, I52

Nointel, — Brittany memoir, 266

Nolin, Jean Baptiste, plagiarism, 8, 62, 66, I 54

Nolin, Jeanne, letters, I03

Nootka Sound, 220, 27 I

Norfolk, Va., commerce, 39; travel, sketches, 270,274

Normand, I6

Normandin, Joseph Laurent, journal, 105

Normandy, admiralties, I05, I86; commerce, ports, memoirs, 53, 74, I28, 280 ; fish trade, I9

Norona, - Oriental collection, 273

North America, descriptions, 265, 276; French and English colonization, 51, 84, 206; geography and history, $8,42,240,243$; list of towns, 277; maps, 37, 73, 98, 256, 265; natural history, 27I, 274; see also English colonies; French colonies; regions by name

Northeast passage, I47

North Pole, see Polar exploration

North Sea, sce Arctic Ocean

Northwest, distances, I76; list of documents, I 4 ; see also West

Northwest coast, journal (I850), I33; La Pérouse, I24; maps, 43 ; voyages, 87,257 , $27 \mathrm{I}$

Northwest passage, Franklin, II7; notes, 262; search, IO, I4, 40, 42, 43, 47, 48, I08, II 7

Northwest Rebellion, I30 
Jotre Dame de la Trappe, I2

Jotté, C. J., Paul Jones portrait, I 46

Vouë, Anne de, martyrdom, 54

Vouette, -, treasurer general, I33

Vouvelle Biographie Générale, 97

Vouvelle Espérance, 218

Vouvelle France, $20 \mathrm{I}$

Vouvelles Archives des Missions Scientifiques, 94

Nova Scotia, Alexander's grant, 6, 26I ; Breedon, I 80; fisheries, 27I ; French commerce, 8; French policy, 86; maps, I02, 223, 224; news of capture (I755), 2I4; travel, I33; see also Acadia

Noyan, Pierre Jacques Payan, chevalier de, Bastille paper, 247, 249, 250; claim, 278; signature, 162

Noyelle, Nicolas Joseph de (des), papers, I08

Nueva Navarra, map, 229

Nueva Vizcaya, French project, I73

Nuñez Cabeça de Vaca, Alvaro, 7

Nuns, dowries, I0, 7I; Santo Domingo, 8I ; see also Dames; Hospitals; Sisters; Ursulines Nymwegen, treaty of, I 54

Oaths, of officials, I7 I

Ochagac, Indian, map, 226

Octroi, Santo Domingo, 89

Officials, colonial, Canadian meritorious, I57; English commissions, I80; Ile Royale, character, I57; interested in commercial companies, 206; lists: Canada, I63; French, I4, 63 ; Louisiana, I I2; Marine, I 57, I 59, 266 ; Martinique, I62; Santo Domingo, I 56, I 57, I6I ;-Louisiana documents, I I4; oaths, I7 I ; office seeking, I67, I69; plantations forbidden, 57 ; privileges, 212 ; see also offices by name, especially Governors; Intendants

Offman, Smith, 22

(Ogden, _— "Quebec", I 28

(Ogé, Pantaléon, papers, I 45

Ogeron de la Bouère, Bertrand d', aid for, I98; and prisoners, I94; commission by, I80; death, burial, I I5; Florida papers, I I5 ; letter, I90; project, 97 ; recommended, I89; salary, 203; Tortuga, I90

(Ogier, François, Journal, 76

Oglethorpe, James Edward, Florida, I45

O'Gorman, Capt. —_, letter, 245

O'Hara, Charles, Scioto Company, 245

Ohio River, Lagrange's work, 86; maps, I77, 226, 228; memoirs, 40; Scioto Company, 239,245 ; steam navigation, I27; see also Fort Duquesne

Ohio Valley, animals, 272, 273; geology, 258, 259; maps, 226-229

(Oil, from Ile Royale, I8, I9

Oklahoma, printing in, I42

Olivarès, Gaspard de Guzman, conde de, Brazil, 264

Olive, 22

Olive Branch, 2I

Oliver, Dr. Henry K., letters, 90

Omont, Henri Auguste, Catalogue Général des $M S S$. Français, 3; Inventaire des MSS. de la Collection Moreau, $2 \mathrm{I} 6$
Ondours, 3I

One Hundred Associates, see Compagnie de la Nouvelle France

Ontcouantagueté, name for La Salle, Ioo

Oran, bishop of, death ( I 729 ), 82

Oregon country, English settlement, I33

O'Reilly, Alejandro, 248

Orient, see Levant

Orinoco, French rights, I76; Gumilla's history, 62 ; map, 258; see also Guiana

Orléans, Louis Philippe Joseph, duc d', gardens, 274 ; papers, 256

Orléans, Philip II., $d u c$ de, letters to, 84 ; memoirs for, I7

Ormeilles, Baron d', commission, 27

Ormsby, Stephen (?), 245

Ornano, Capt. Nicolas, dit Corsette, 55

Ortez Cazdalilha, Diego, 277

Osage Indians, visit to France, I29

Osnabrück, negotiations, see Westphalia

Ossun, Pierre Paul, marquis d', correspondence, 31,32

Oswego (Fort Choïagen), capture, 4I, I 57, I 58, 242; plan of fort, I 5 I

Oto (Outantes) Indians, river, I77

Otranto, Joseph Fouché, duc d', correspondence, I 26

Ottawa country, map, I66

Ottawa Indians, Iroquois war, I64; mission, I94

Oudiette, Jean, revenue farming, 218

Outarde, 29

Ovide, —, pension, I 56

Ovide, $\longrightarrow$ pension ( I 7 I 4), I 56

Oviedo, Gonzalo Fernandez de, Indies, 8

Oyapok River, Dutch on, 77

Oyo River, Wabash, 40

Pacific Ocean (South Sea, Western Sea), Beauchesne, 25, 67, 84; Bougainville, 120, 273; Compagnie des Indes, I 7 ; discoveries, 23, 26, 266; Dutch and English, I38, 280; forbidden to French ships, 70, 77, I37; French ships in, 70, 84, I 54, 252; La Marre, I68; Langle, I24, I 25 ; list of voyages, 277 ; maps, 85 , I 52, 223, 252, 257 ; papers, list, I I3, I I 4; Raveneau, 46 ; relations of voyages, I33, I76; search for, river to, La Vérendrye, 79, 81, 82, 108, 217, 226; Speelberghen, 261 ; see also Demarcation line; Vnvages

Packet-boats, to colonies and United States, I I2, I 24, I 28, I 29, 2 I 3

Pagez, Louis, letters, I92, I93

Pagez, Théodore, I36

Paimboeuf, Capt. — voyage ( I646), I I 5

Paine, Thomas, note, United States sojourn, 4I

Paix, 227; wreck, I89

Pako, Indian, 79

Palatines, for Pennsylvania, I45

Palesme, Sieur, cashier ( 1687 ), 73

Palestine, voyage, 277

Palisot de Beauvois, Ambroise Marie François Joseph, criticism, 259; eulogy, 258; on plants, 272 ; on snake bites, 75

Pallu, Bertrand, see Ruau

Palme, - de, letter, I9I

Pamphili, Benedetto, cardinal, 99 
Pamplona, Spain, French trade, 30

Panama, cotton, I42; Delisle's MS., 26; memorial, I64; piratical log-book, 3; president, 67. 19I; see also Darien; Drake, Sir Francis; Isthmian transit

Pancoast, Dr. Joseph, letter, 90

Pancoast, Dr. William H., letter, 90

Panuco, proposed colony, I77

Paon, 78, 227

Papacy, bulls, 178, 197, 198, 213; French embassy, correspondence, 13 , 14 ; see also Roman Catholic Church

Paper money, bank-notes, 59; Continental, I 42 ; see also Card money

Papillon, 75

Papin, - - trial, 247

Papineau, Louis Joseph, and archives, I02

Pará, description, I74

Paraguay, Delisle's MS., 26; large animal, 259; memoir, 75 ; missions, $40,8 \mathrm{I}$; natives, 278 ; revolt, 83

Parat, Gov. _- Newfoundland census, I75

Pardo, Philippi, letter, 26

Pardo de Figueroa, Balthazar, relation, r8o

Parent de Rosan, - - collection, 278

Paris, archbishop of, see Noailles, Louis Antoine de

Paris, Exposition (I889), I4I ; historic sites of American interest, street names, IIO, I 28; merchants' memoir, 205: siege (r870), I3I ; see also Parlement

Paris, treaty of ( 1763$)$, Canada in negotiations, I 20 ; general conditions, 145

Paris, treaty of (I783), Jay and negotiations, 255, 256; poem, I78; preliminaries, 244; Vergennes on, 245

Paris Chamber of Commerce (I7or), 240

Parishes, map on St. Lawrence, 226

Parisot, Jacques Théodore, naval memoirs, I2I, I23

Parker, Sir Peter, 219

Parker, Theodore, 283

Parkman, Francis, correspondence, Margry, IoI, II0, II8, I28, I3I, I33; Frontenac, I69; La Salle, I74; Pioneers, 4

Parlement of Bordeaux, transportés, 216

Parlement of Dijon, transportés, 216

Parlement of Navarre, I65

Parlement of Paris, Compagnie des Indes, 2I I ; list of acts, I4; MSS., 3; procureur général's papers, 2I I-2I5; registers, 25I, 279

Parliament, English, Act of Trade, I 53; see also House of Commons

Parmentier, Jean and Raoul, 46, IOI, II 8

Parouké Indians (?), river, 177

$\mathrm{Pas}$, Isaac de, see Feuquières

Pascagoula River, map, 228

Pascalis, Dr. Felix, letters, 89,258

Pascaud, - of La Rochelle, 12

Pas de Feuquière, François de, see Rébenac

Passage and passports, free, for overseas trade, 42 ; issue, $5 \mathrm{I}$; requests and grants, 163 ; requirement, I 37 ; to and from Canada, lists, I $4 \mathrm{I}, \mathrm{I} 56, \mathrm{r} 57, \mathrm{I} 87$; to and from Louisiana, lists, I I2, I 52, I64; to and from West Indies, lists, II6, I53, I56; to Newfoundland, I30; see also Navigation

Passports, see Passage

Patoulet, - , Talon's secretary, correspondence, 32, 197 ; salary, voyages, I94-196, 202, 203

Patriot, 2I

Patrocles, de Thoisy, see Thoisy

Paul, François Joseph, see Grasse

Paul V., pope, bull, I 54

Paulmier, Binot, see Gonneville

Paulmy d'Argenson, Marc Antoine René de Voyer, marquis de, library 239, 243

Pavie, Raymond de, see Fourquevaux

Payan de Noyan, Pierre Jacques, see Noyan

Payte, $\longrightarrow$ replies to Dartmouth, 9

Péan, Michel Jean Hugues, Bastille papers, 247, 249

Peccioli, Matteo Nerone, map, 222

Pechon le Conté, Ecuier Crepin, letter, I69

Peckham, George G., French translation of work, 53, I79

Péclavé, - , suit. 88

Pedreros, Dr. — , on New Granada, 220

Pedro II. of Brazil, coronation, 277 ; letters, 277

Peggy, 22

Peiresc, Nicolas Claude Fabri de, portfolios, 208

Pelan, Arthur de, letter to, 169

Pélican, Père Pierre, letter, 46

Pelican, 68, I65

Peller, Leger, case, I69

Pellerin, Sieur, Louisiana letter, 24I

Pellimier, _

Pellot, Claude, correspondence, r87, r92-r94, I 96, I 99

Pemaquid, English fort, I66; French capture, I 70

Peñalosa, Diego Dionisio de, and French plans, I73; memoirs and papers, ro9, I52; proposed expedition, II6

Penhoat, Jérôme Hyacinthe, letter-books, I27; on Alabama-Kearsarge, i 27

Pénicaut, - relation, 45, I 2

Pénissault, Louis André Joseph, Bastille papers, $247,249,250$; suit, 42

Penn, Mary, marriage contract, 219

Penn, Sarah, will, 219

Penn, William, biographical notes, 93

Penn family, papers, 219

Pennsylvania, description, 98; education, 282; geology, 275; Germans, I45; map, ro2

Penobscot (Pentagouet), restitution, 206

Pensacola, and Louisiana ( 1700$), 67,98$; defenses (I775), 267; descriptions, 24I, 255; French capture, I30; maps, 72, I40, 229; Spanish expedition ( 1780 ), I22; Tonty, 268; value ( 1765 ), 30

Pensions for colonists, II3, I56; see also St. Louis, cross of

Pentagouet, see Penobscot

Pentagouet Indians, presents, I70

Perch, American, 273

Père de Famille, wreck, Ir4

Pères de la Charité, Ile Royale, 70, 77 ; Martinique, 64

Perier, Baron de, letter to, 142 
Périer, Gov. ——, census, 8I ; commission, 34; on Natchez defeat, 254

?erinet, - , Compagnie des Indes, 59

Perkins, Charles C., letters, 257

Perkins, James H. (?), I I3, II 4

Perkins, Dr. Stephen H., letters, 90

Perle, 55

Pernambuco, Dutch, 264; see also Brazil

Pérou, —_ letter (I675), I99

Perrault, Paul, Bastille papers, 247, 249, 250 Perronne Dumesnil. see Dumesnil Perronne

Perrot, François Marie, Acadia, I35, I36; Bastille, 249; letters patent (?), Io

Perrot, Nicolas, notes, 108

Perrot de Fercourt, —, letter, I99

Perroud, Henry, letter, 93

Peru, affairs, I45; antiquities, I4I ; Castel dos Rios, I 55; Compagnie des Indes, I I7 ; conquest and settlement, 23, 26, I 54; description, 254; disturbances (I666), I80; Gardens of Lima, 220; MSS., 26, 258; map, 222; natives, language, writing, $4,25,75$, I7I ; notes, I76; Puno Congress, I27; value, 263 ; viceroys, list, 54 ; voyages, scientific expeditions, 26, 56, 252, 254, 256, 277 ; see also Spanish America

Pérusse, ——, marquis de, correspondence, $2 \mathrm{I} 3$

Petit, Sieur, maps, 234

Petit, Emilien, Droit Public des Colonies, 36, 37; memoir, 36; Réflexions, 6r

Petit de Levilliers,

Petit Goave, Santo Domingo, I75, 202; map, 235

Petit Nord, Newfoundland, fishery, 218, 27I

Petraea, bishop of, see Laval-Montmorency

Peyre, Sieur de, map, 237

Peyrottes, - $\longrightarrow$ map, 233

Peysonnel, _ de, "Pacte de famille", I46

Phélipeaux Bay, concession, Io6

Phélypeaux, Jean Frédéric, see Maurepas

Phélypeaux, Jérôme, see Pontchartrain

Phélypeaux, Louis, see Pontchartrain

Phélypeaux, Paul, see Pontchartrain

Phélypeaux, Raymond Balthazard, and foreign traders, 37; estate, 37; memoir (?), I36; on marine clerks, 138

Philadelphia, abolition riots, I44; balloon, 244 ; journeys, impressions, 45, 274, 275 ; manufactures, 274; refugees, I3I, I43; sketches, 270; Société des Amis des Noirs, 2I ; West India trade, I47; see also next title

Philadelphia campaign, Barren Hill, 230; French news, I I

Philip III. of Spain, Antwerp Truce, I3, 73, 96 Philip IV. of Spain, and Hanseatic League, 96 ; mercantile system, I86

Philip V. of Spain, commerce, 49, 82, 83, 265; conditions under, 279; French assiento, 20; French in Santo Domingo, I52

Philippe, Claude, letter, I74

Philippia, Brazil, 26r

Philippines, commercial company, 83, I49; conquest, 85 ; foreign commerce, 8 , II 7 , I 38 ; letters from governor, 26; letters on, 26; maps, $72,255,265$; memoirs and relations, 23, I I8, I30, 2I 3, 279; missionary documents,
26; objects from, 27I, 273; routes, I 54; voyage, I 25

Phillips, Henry, jr., correspondence, I4I

Philosophical Correspondence, 258

Philosophy, American, 283

Phips, Sir William, Quebec, I4I

Phoenix, II2.

Picardy, regiment, Io

Picon, - letter to (I662), I82

Picoté de Bellestre, see Bellestre

Picourt, -

Picquet de la Motte, Toussaint Guillaume, orders, 124

Pictorial material, on Spanish America, 220

Pidausat de Mairobert, Mathieu François, Discussion, 265

Piedcourt, - of Dunkirk, memoir, 74

Piedmarin, — de, letter to (I699), I65

Pierce, James, letter, 275

Pierron, Père Jean, letter, 2 I 7

Pigafetta, Antonio, narrative, French MSS., 7, $7 \mathrm{I}, 277$

Pike, Zebulon M., Voyage, 87

Pillavoine, Armand, 60

Pilling, James C., correspondence, I4I

Pilots, Canadian, I35; for Newfoundland, I 37 ; Thevet's work, 46

Pinart, Alphonse, collection, I42

Pineau, Louis de, see Castillon

Pinet, Père François (Pierre), sermon, I68

Pingault, _ Joly command, I35

Pingré, Père Álexandre Guy, expedition, papers, 276, 277 ; letters, 277

Pinzon, Martin Alonzo, 97

Piou, - Compagnie des Indes, 59, 60

Piracy, English amnesty, 78; log-book, 3; on Banks, I36; privateering against, I2; St. Lawrence (I686), I40; treatise, 28I ; West Indies, 67, 194; see also Filibusters

Pitahaya tree, 272

Pixérécourt, Guilbert de, play, 85

Placentia, see Newfoundland

Plague, Canada, 23 ; in squadron, I 52

Plains of Abraham, battle, 242

Plainte Publique sur le Commerce, 6

Plaisir, - Toussaint's servant, 94

Plancius, Petrus, 6

Plans, see Maps

Plantations, forbidden to officials, 57 ; Louisiana, $24 I$

Planthion, - syndic ( I7Io), I32

Plants and seeds, American, regional, catalogues, 86, 272, 274; Canada, 270, 27 I, 274; Florida, 27 I France, 275 ; Louisiana, 27 I-274; Mexico, 272; Newfoundland, 27I, 273 ; Philippines, 27I ; prehistoric, 274 ; study of tropical, 260; West Indies, 239, 255, 27I-273

Plays, collection, American items, 85

Plée, Auguste, correspondence, 270, 274 ; MSS. of travels, 270

Plessis, Mgr. Joseph Octave, correspondence, 269

Plows, American, 259

Plume d'Or, I96

Plumier, Charles, plates, 239, 255
"Historica Plantarum", 
Plymouth colony, Mayflower Compact, 96, 26I

Pognian, Capt. René, I2

Poincy, Chevalier de, and Patrocles, 53, I70; letters, 204, 264

Pointe-à-Pitre, Guadeloupe, plans, 236

Pointe d'Araye, see Punta Arenas

Pointel, Jean (?), correspondence, 137

Pointis, Jean Bernard Louis Desjean, baron de, and filibusters, 23; Cartagena expedition, 6 , 24, 66, I39, 218; Relation, 6

Point Tapion, Santo Domingo, 233

Poirier, Me., memoir, 25I

Poisset, $\longrightarrow$, trial, 247

Poisson, Jean Baptiste, on Indians, 4

Poitou, Acadians, 213; memoir, 280

Poix, Sieur de, office, I 70

Polar exploration, Burgoa on North Pole, 278; notes, 43 ; see also Arctic Ocean

Police, at ports, I53; control over colonial affairs, I 58; Quebec, 54, I03, I 55, 240

Poll tax, see Capitation

Polly (3 ships), 21, 22

Polverel, François, death, 20 ; letter, 75

Poly, 36, 65

Pomereu, - , letter (1700), I63

Pommeroy, - marriage (I728), I6r

Pompadour, Marquise de, II9

Pomponne, Simon Arnauld, marquis de, letter to, 205

Poncet, Père Joseph, letter, 93

Poncet de Bretigny, Charles, see Bretigny

Poncourt, _ _ request (I687), I 59

Pondicherry, Ryswick negotiations, 49

Pons, Antoinette de, see Guercheville

Pont Audemer, 7

Pontchartrain, Jérôme Phélypeaux, comte de, Arnoul correspondence, I 36 , I37; letters, I65, 218; letters to, 85, I37, I63, I64; policy and practices. $33, \mathrm{I} 33$

Pontchartrain, Louis Phélypeaux, comte de, Arnoul correspondence, I36; foreign despatches, I58; letters to, I64-168, I70, I76, I78; orders, 32 , I38; petition to, 6; policy and practices, $33, \mathrm{I} 33$

Pontchartrain, Paul Phélypeaux, comte de, letters, 7

Ponthez, Baron, on immigration, I I6

Ponthon, Rémy and Co.. fisheries, I87

Pontual, - de, I69

Poore, Benjamin P., I Io

Population, French colonies, I 6 ; Guiana, 93; Louisiana, 40; Martinique, Ir6; United States, 244; see also Aliens; Census; Emigration; Settlers; Vital statistics

Poret, Jules, see Blosseville

Port à l'Ecu, Santo Domingo, map, 234

Port au Prince, Santo Domingo, Bellevue houses, 233, 234; maps, plans, 23I, 233, 234 ; see also Port Républicain

Port (Fort) Dauphin, Santo Domingo, establishment, 81, 83; map, plans, 232-234

Port de la Joye, St. Jean, 224

Port de Paix, Santo Domingo, administration, 22; commerce, 21, 39; plan of fort, 233

Porter, Jacob, letter, 260

Port Loméron, 264
Port Louis, La., I 8, 24, 88

Port Margot, Santo Domingo, map, 232

Portneuf, Pierre Robineau (?), sieur (baron) de, letter, 248

Portobello, capture, r79; described, 40 ; galleons, I 44; slave trade, I39, 2I 3 ; voyage, 68

Porto Cabello, I26

Porto Rico, army, commission, 163; governor, 67; memoirs, 72, r80; seizure at, 70; sketches, 270; see also Spanish America; West Indies

Port Républicain, Santo Domingo, plan, 234

Port Royal (Annapolis), Acadia, attacks, 27, 68; defenses, 168: destroyed, 48, r84; English and Capuchins, 5I; papers, 103; plan, 224; see also Acadia

Port Royal, Jamaica, maps and plan, 231

Ports, abstracts of letters (1678), I6o; Canadian, I05, I93; different naval customs, I28; investigation, 183; Mallart's description, 4, 42, 73; Placentia, I60, I82; police, I53; slave trade, 56 ; various French, colonial trade, memoirs, $18,56,57,73,74,85$, 128, I32, I35, 182, 197, 252, 266, 280; see also Navigation

Portsmouth, sketches, 270

Portugal, bulls on colonies, I78; Cayenne, 278; colonies ( 1838$), 278$; commerce and navigation, 267, 278; complaint against, 209; expeditions, discoveries, 28, 56, I18; French alliance, 264; French ambassadors' correspondence, I77, 205; French and demarcation line, 204, 253, 261 ; notes, 278; portolan, 26 ; St. Sacrement, 4I, I77, I78, 277; slave trade, I38; see also Brazi1

Portuguese MSS., 2

Post, Dr. Alfred C., letter, 90

Potel, Jean Baptiste, widow, I62

Potomac River, sketches, 270

Pottery, Indian, 79

Poulet, Georges, 54, 55

Poulin de Francheville, _- mining concession, 80

Poupardin, René, Catalogue des MSS. de la Collection Baluze, I49

Poutrincourt, Biencourt de, see Biencourt

Poutrincourt family, papers, 107, II 3

Powder, in American Revolution, I20

Pradt, _ de, article by (I829), I 23

Prairie de la Madeleine, mission, 200

Praslin, César, duc de, see Choiseul-Praslin

Praslin, Charles, duc de, see Choiseul-Praslin

Precious stones, Brazil, 8I

Précis Historique de l'Expédition des Kourou. 8

Prehistoric animals, Ohio valley, 272

President, 22

Presidents of United States, list, 4I

Presqu'ile, see Erie

Prévost, Jacques, Bastille papers, 247, 249

Price, Thomas, letter, 75

Prices, Canadian goods, I04

Prince Edward (St. Jean) .Island, concessions, 78, 83, I75, 218; maps, 223, 224; memoirs, resources, 243, $27 \mathrm{I}$

Prince Noir, 25I

Princesse Noire, 25I 
Pringle, Sir John, I 47

Printing, Pinart collection, 142 ; see also Censorship

Prisoners, from Santo Domingo, r94; Roberval's expedition, 244; see also Faux sauniers; Galleys; Transportation

Prisoners of war, English in France, I8I ; Jamaica, 87; Queen Anne's War, 23, I44, I46

Privateering, against pirates, I2; American Revolution, I30, I33, 25I ; Dutch, aiding French, 190, 196; French Revolution, against American ships, 21, 38, 39; prizes, 97; proposed Spanish companies, 207; ransom right, 218; regulations, 5; Spanish (1797), I 44

Privilèges ... de la Compagnie des Indes, 153

Prizes, American Revolution, I26; AngloFrench War (1665), 187, I88, 190; English colonial ships, I30; Franco-Dutch War, I53, 196, I97, 200, 20I ; French and Indian War, 29, 242; King William's War, 20, 26, I62, I67, I70, I74; Queen Anne's War, 218; regulation, 5; royal tenth, 89; Rupert's, French asylum, 48; transporting effects, 70 ; treatise, 28I

Probst, $\longrightarrow$, Scioto Company, 245

Proclamation of I763, French summary (?), 31

Procureur général, Canada, I 2

Products, Guadeloupe, II5; Louisiana, 255

Profond, 69

Projet de Tarif, 266

Property, see Estates ; Land

Protestants, see Huguenots

Prouville, Alexandre de, see Tracy

Provence, fisheries, I34, I 37, I 92 ; ports, I28; squadron, I52; West Indies trade, memoir, 9, I 39, I 50

\section{Providence, I65}

Providence Island, see Bahama

Provisions from France for: Acadia and Newfoundland, I98, 202; Canada, I89, I90; crews, 44; wartime to colonies, I9I ; West Indies, I64, 191, 198, 200-202 ; see also Supplies

Provost, Eustache, Gallifet dispute, 169

\section{Prudent, 22}

Prussia, and American Revolution, papers, Ir, 93

\section{Puants, see Winnebago}

Public debts, American, 38, 4I, I47; colonial, certificates, payment, 57, I33; Marine, audit, 35

Public records, dépôt for colonial, 213

Public works, West Indies, 203; see also Defenses

Puisieux, Pierre Brulard, marquis de, letters to, I3; papers, 260

Pulque, 272

Punishment, coureurs de bois, Io; see also Prisoners

Puno, Peru, Congress, I27

Punta Arenas (Pointe d'Araye), I80

Purchas, Samuel, memoir based on works, 6

Purviance, $2 \mathrm{I}$
Quail, 270

Quakers, Rothschild on, I3 I

Quand et comment l'Amérique a été peuplée, censured, 62

Quatrebarbes, —-, Canadian petition, I60

Quebec, attacks and captures, 29, 87, I I9, I29, I 32, I4I, 206, 225, 24I-243, 280 ; college, 55, 268; Compagnie de la Nouvelle France, I03; descriptions, travel, 87, I7I, 274; ecclesiastical affairs, 69, 7I ; English menace ( 1693 ), 65 ; epidemic, 67 ; expense of château, I6I ; government and police, major, 54, I03, I 55, I69, 240; harbor, I2I ; hospital, 55, 62, 203, 268, 270; inhabitants, I03; La Friponne, 247; Missions Etrangères, 13 ; news ( 1665 ), I8I ; plans, 225, 244, 267; view, sketches, 225, 270 ; see also next titles ; Canada ; Commerce (Canadian); Navigation

Quebec, bishopric of, appointments, I68; autographs of bishops, I02; cathedral, I40; Colbert on, 205; erection, bulls, I7, I98; letter of bishop ( 1763 ?), 269; notes, papers, 23 , I04, I3I; revenue, benefices, European abbeys, I3, I4, 69, 8I, I7I, 203, 25 I, 252; vicar apostolic, 27; see also Dosquet; Laval; St. Vallier; Taschereau

Quebec, province of, census, I02; information, I 28

Quebec Literary and Historical Society, $M e ́-$ moires, 53; Voyage de Découvertes, 7

Quebec Seminary, affairs, finances, Maubec Abbey, I3, 69, I7I, 252, 268, 269; burning, 23; discussions, disputes, 55, 7I, I64, 269; establishment, 27; history, 269; syndic, 263

Queen Anne's War, Acadia, 27, 68; Cartagena, 25; English colonial designs, 56; English naval movements ( 1702 ), I36; fisheries, 136 , 218; Florida, 68; French projects, I38; Iberville, 68-70, I I , I 6 , I 36 ; munitions for Canada, I37; navioation and trade, convoy, 56, 68, 69, I37, I 40, I59: Newfoundland, 68, I64; peace project, 56 ; policy and practices of Marine, 33; prisoners of war, 23, I44, I46; prizes, 218; Spanish America, French protection, 69, 85; West Indies, 20, 56, 68, I I I, I39, I 46, 216; see also Utrecht

Quéluss, $A b b e ́$ de, 23

Quentin, Nicolas, Io

Quétant, Antoine François, translation, 6I

Quicksilver, New Spain, I88

Quinine, see Cinchona

Quiros, see Hernandez de Quiros

Quito, description, 84 ; history, 278; Indian vocabulary, 220

Quivira, see New Mexico

Rabié, —, maps, 232, 233

Raboteau, - , for New England (I796), 20

Radisson, Pierre Esprit, arrest, I I 7 letter, voyage (I678), I74; memoir on discoveries, I 77 ; observations on, 64 , I00; papers, I08

Raffeix, Père Pierre, maps, 225, 226

Rafinesque, Constantine S., 260, 274 ; letters, 259. 275

Ragueneau, Père Paul, letters, I I8, I8I, I86, I88. I89, I9I; letter to, I86; papers, I05 
Railways, United States, 4I ; use of colors, 258 Raleigh, Sir Walter, Guiana, French version, 26; voyages, 28

Ramé, Alfred, Voyage de Carticr, 6

Ramesay, Chevalier de, capitulation, I32; letters, I58; letter to, 132 ; on affairs (1756), I57, 158

Ramezay, Claude de, decoration, I78

Randall, _ , in Santo Domingo, letter to, 21

Ranger, $\mathrm{I} 22$

Ranzani, Camillo, letter, 259

Rassent, H. de, letter, 183

Rastel, Paul de, see Rocheblave

Raudin, Hugues, papers, II 3

Raudot, Antoine Denis, and assiento, 34; Compagnie des Indes, 59, 60; ecclesiastical case, I7I; minutes of letters, 278 ; notes, II3; payment for memoir, II ; "Relation", 105

Raudot, Jacques, notes, II3; papers, I06; passage, 69

Ravardier, - Maranhão, 5

Raveveau, - voyage, 46

Raymond, Jean Louis, comte de, letter, 243

Raynal, Abbé Guillaume Thomas François, Histoire Philosophique, censured, 62,272 ; letters to, 43 ; papers, 8

Raynaud, Gaston, Catalogue des MSS. Anglais, 219

Rayneval, see Gérard de Rayneval

Razilly, Charles de, papers, II 8

Razilly, Claude de Launay, see next title

Razilly, Isaac (and Claude), correspondence, I07, II8; expedition, Maranhão, 5,204 ; inspection of ships, 204 ; memoirs, 5, I I 8,276 ; notes, 107 ; papers, II 8 ; salary, 33

Razilly family, papers, I07

Réals, Chevalier de, letters ( 1677), 201

Rebecca, 22

Rébenac, François de Pas de Feuquière, comte de, embassy, I3

Recherches sur les Emigrants aux Etats-Unis, II 6

Récollets, Canada, affairs, I3, I03, I94, I99; cargo, 263; Ile Royale, 71, 77 ; Indian trade, I70; Jamay, 207; LaSalle, I00, ro8; letter (1682), I72; mandate of bishop, 23; Membré, 99, I72; mortuary table, 44; royal bounty, I6I; Sagard-Théodat's Voyages, I02; seminary, 263

Recueil, de Voyages et de Documents, 3

Redman, R. S., letter, 259

Redouté, P. J., drawings, 270

Redress, 22

Red River, La Harpe's exploration, 227

"Réflexions sur le commerce", 53

Régis, - de, "Sur la Louisiane", censured, 62

Régis de Roulet, $\longrightarrow$, Choctaw journal, I I3

Règlement... concernant le Commerce Estranger, 57

Règlement des Droits et Salaires, 5I

Regnier, - translation by, 7I

Regnier, Claude François, see Guerchy

Reimarus, Johann Albert Heinrich, letters, 258, 259

Relation de la Prise de Chouaguen, 242
Relation du Voyage de la Mer du Sud, 252

Relation inédite du Naufrage de la Bourgogne, 129

Relation par Lettres de l'Amérique Septentrionale, I76; extracts, I05

Religious affairs, Boston, I62; Canada, I68; control over colonial, 158 ; see also Huguenots; Roman Catholic Church

Rémonville, - , letters on Louisiana, 25, I36; see also Renonville

Rémy, Daniel de, see Courcelles

Renards, see Fox Indians

Renaudot, $A b b e ́$ Eusèbe, collection, 97 ; correspondence, 64, III, II 7, I 52, I78; MSS., 3; nemoir on discoveries, 25, 4I, 97 ; papers, La Salle, ro9

Renommée, 24

Renonville, -24 , letter, 68; sce also Remonville

Repentigny, Agathe de St. Pierre de, see St. Pierre

Repentigny, Louis le Gardeur (?), chevalier de, papers, 105

Réponse à la Declaration du Congrès Américan, 60

Reprisal, I22

Reptiles, Gulf of Mexico, 274; see also Snakes

Résolue, 124

Reunion, documents, 87

Revenue, see Finances

Revue Canadienne, 4I

Revue de Rouen, IOI

Revue des Bibliothèques, 2

Revue des Deux Mondes, II

Revre Historique, 5

Revue Maritime, 4

Revue Militaire Française, 129

Revue Rétrospective, 4

Reynaud, —- correspondence on fortifications, I47

Reynolds, John Nicholas, letter to, 22

Rhode Island, French fleet, I24; Indian pottery, 79 ; light-weight money, I48; plan of operations (I 778$), 230$; proposed Ternay monument, I 23; wartime navigation, 242 ; see also New England; Rochambeau

Ribaut, Jacques, Florida, 55

Ribaut, Jean, Florida, 26, 55, 209, 210; record of sale, II 5

Ricard, Chevalier de, on West Indies, 45

Rice, Carolina, 30

Richard, D. L. C., on plants, 272

Richardot, - ambassador, instructions, 208

Richelieu, Armand Jean du Plessis, cardinal de, and colonization, 46 ; commerce, companies, $6,50,52,96,118,205,209,276,279$; letter to, 204; papers, 260; restitution of New France, 49; St. Christopher, II 5

Richelieu River, Tracy's fort, 188

Richmond, Va., sketches, 270

Ricord, - in Haiti ( 1826 ), 260

Ricoüart, Capt. —, de, voyages, 12, 24

Rigaud, see Vaudreuil

Rio Bravo, proposed French colony, I73; map, 229

Rio de Janeiro, fleet from, 82; French colony, $\mathrm{I74}$; see also Brazil 
Rions, see Albert de Rions

Riou, —_ ' 'of Canada (I7I8), 55

Ripley, George, 282; letters, 283

Riquetti, Honoré Gabriel, see Mirabeau

Ritchie, —- of Boston (I82I), 259

Rivera-Maestre, Miguel, Guatemalan atlas, 220; notes on antiquities, 220

Riverin, Denis (?), Cape Breton memoir, I76; letter, I75; papers, I08, II3 ; whaling memoir, I36

Rivers, notes, I7I

Rives, William C., letter, 245

Rivière à Margot, 229, 254

Robbins, Eliza, letter, 283

Robert, Louis (?), papers, Io6

Robertel, Zacharie, see La Noüe

Robertson, James A., Magellan's Voyage, 7 I

Roberval, Jean François de la Rocque, sieur de, commission, 25, 208; expedition, 244; mining grant, 6 ; papers, I03; Renaudot on, 97

Robetaille, Nicolas, I 63

Robineau, Pierre, see Portneuf

Robineau de Bécancourt, see Bécancourt

Robiou, Capt. Jacques, I56

Rochambeau, Donatien Marie Joseph de Vimeur, vicomte de, American memoirs, I43

Rochambeau, Donatien Marie Joseph de Vimeur, comte de, American campaign, correspondence, 44, 75, 91, 93, I22, I 23, I25, I 26, I29, I4I

Rochebilière, A., biographical notes, 86

Rocheblave, $A b b e ́$ de, Kerlérec affair, 248, 250

Rocheblave, Paul de Rastel, chevalier de, Kerlérec affair, 248-250

Rochechouart, Comte de, services, I53

Rochechouart du Bellay, Marquise de, letter, I 53

Roche de Crassay, - letter (I702), 68

Rochefort, - $\longrightarrow$, death (I685), I35, I40

Rochefort, César de, Isles Antilles, extracts, I59

Rochefort, arsenal, 73, I8I ; colonial cadets, 80; colonial entrepôt, services, 73, I32; port affairs, intendants' papers, 63, I34, I56, I94197, 198, 201, 202; port guards, I68

Rochemonteix, Père Camille de, Jésuites, 70; Relation, 105

Rochemore, Mme., Kerlérec affair, 248

Rocquement, see Roquemont

Rohan, Henri, duc de, discourse, 263

Rohan, Louis René Edouard, prince (cardinal) de, 233

Roissy, Jean Jacques de Mesmes (?), sieur de, memoir, 46

Rolland, Pierre Nicolas, map, 233

Romain, _- map, 236

Roman Catholic Church, American dioceses, I Io; Canadian affairs, works on, 69, 72, I02, 105, 268; Cerri's Etat Présent dans le Monde, 255; colonial bishops, 82, 84; expense for monks and priests, I75; Ile Royale, 106; jubilee, 268; Martinique census, 80 ; monopoly in colonies, Io, 70,204 ; rites, 268; Spanish bishop and French territory, 78 ; see also Bishopric; Congrégation; Missions; Papacy; Seminaries

Rongnoust, Jehan Denys, dit, 72
Roquemont, Claude de, Compagnie de la Nouvelle France, 50,52

Rose, George, letter, 246

Rose Roume, Philippe, see Roume

Rossel, — de, maps, 227 ; memoir, 254

Rostain, - de, letters to (I782), I23

Rostan, - de, on Bayonne commerce, I 28

Rostan, C., letter, 260

Rotch, William, I2

Rothschild, Baron Salomon de, journal of travel, I3I

Roubaud, Jean Baptiste, map, 276

Roubeaud, - Santo Domingo (I803), 75

Rouen, archbishop of, sec Harlay de Champvalon

Rouen, admiralty, 239; American cotton, 244; colonial commerce, freedom, $18,20,56,204$, 205; commercial memoirs, observations, 53, 128, 240, 266; fisheries, 204; girls for Canada, I7 ; manufactures, 56 ; notorial records, II5; slave trade, 56 ; tobacco culture, I9

Rouer de Villeray, Louis, instructions, I05; letters, I85, I86; papers, I05, I06; payment, 202; reinstated, I90

Rouillé, Antoine Louis de, censorship correspondence, 86; letter, American commissioners, 212 ; memoir for, 40 ; slave trade, 2 I 3

Rouillé, Pierre de, letter, 23

Roume, Philippe Rose, letters, I43

Rousseau, - letter (I664), I86

Rousseles de Châteaurenault, Marie Sophie de, marriage, I25

Rousselet, François Louis de, see Châteaurenault

Roustan, - _, trial, 247

Rouville, _- trial, 247

Rouxel de Médavy, François, see Grancé

Roy, Joseph Edmond, Rapport, 2

Royale, frigate, 12

Royville, Sieur de, commercial company (I65I), 9

Rozier, J. A. B., letters, 38, I42

Rüette d'Auteuil, see Auteuil

Rumford, Benjamin Thompson, count, eulogies, 258

Rupert, Prince, prizes, 48

Rush, Dr. Benjamin, 275

Russia, and American Revolution, papers, 93; English Adventurers, 97; memoir, 280; Virginia trade, I93; see also Baltic

Russy, Elye de la Place, sieur de, Antwerp Truce, I3, 96

Rutledge, John, correspondence, I26

Ruvigny, Henri de Massue, marquis de, letter, I 92

Ruyter, Michael Adrianzoon de, West Indies, I98, I99

Ryswick, treaty of, French objects, 49 ; negotiations, American affairs, 28, 47, 74, I44; text, 46

Sabana la Mar, Santo Domingo, map, 235

Sabatier, _—, memoir on sugar duties, 85

Sable Island, map, 224; Utrecht negotiations, 28, I 52

Sables l'Olonne, I37; fisheries, 82, 27 I 
Sachez (Sachy)-Sejourné, __, letter, I99; letter to, 202

Sacquespée, - $\longrightarrow$ trial, 247

Saffray Mézy, Gov. Augustin de, see Mézy

Sagard-Théodat, Gabriel, Canada, I02, I59; Voyage du Pays des Hurons, Io3

Sagean, Mathieu, narrative, 25, 67, 69, I08, I77 Saguenay River, 6, 84, 208

Sain, - Huron letter to ( 1676$), 93$

Saineville, Cadet de, see Cadet

St. Aignan, Paul H. de Beauvillier, duc de, letters, I 97, I99

St. Albans, Henry Jermyn, earl of, grant, I80

Saint Antoine, 88

St. Aubin, $\longrightarrow$, mine ( 1677 ), 201

St. Aubin, —, Hudson Bay (I780), I25

St. Aubin, Auguste de, Franklin portrait, 146

Saint Aubun d'Infreville, Louis le Roux, chevalier de, see Infreville

St. Augustine, Fla., English attacks, 68, I45

St. Bartholomew Island, French conquest, 264; letters from, I42; negotiations, 70 ; sketches, 270; see also West Indies: Windward Islands

St. Bernabé (Barnaby) Island, 224, 227, 228

St. Blin, François Paul Duverger de, Bastille papers, 247, 249, 250, 280

St. Bruno, 29

St. Castin, Jean de l'Abadie, baron de, Acadia, neutrality, I65, I67; commission, I43; letter, 98 ; memoir, services, 165

St. Castin, Vincent de, 165

St. Catherine Island, I50, I9I

St. César, _- correspondence, I 26

St. Charles, I93, 205, 252

St. Christopher (Kitts) Island, affairs, relations, I30, I 85, 204, 2I7; a pology for defense, 53 ; attacks, captures, 54, I46, I65, I89, I90, 236; Cahusac, II 5, 263; colonization, II 5, 262 ; commerce, papers, 263 ; Compagnie des Iles d'Amérique, I33, 26I ; hurricane, I92; Knights of Malta, 207, 261; maps, 236; sketches, 270 ; transfers, I6, I52, I92-I94, 205; voyage, 46; see also West Indies; Windward Islands

St. Croix Island, French right (I729), 80; reports, I68, I80; sale to Danes, 82 ; see also Virgin Islands

St. Denis, Louis (Charles) Juchereau de, New Mexico expedition, 254; papers, I06, I08; replaced (I704), 25

Saint Dominque, 156

Ste. Catherine, $\longrightarrow$ de, ambassador, memoirs, 216

Ste. Catherine, territory, Cuba, 23I

Ste. Colombe, - conference (I669), I93; letters, I I I, I93

Ste. Foy, battle, I20, 243

Ste. Marie; $\longrightarrow$, plan of Louisbourg, 224

Sainte Marie, Antoine de, voyage, 26

Ste. Marie-des-Hurons, mission, 93

Ste. Marthe, Gov. A. de, charges against, I63, I69

Ste. Maure, Charles de, see Montausier

Ste. Reine concession, La., 227

St. Esprit, 48, 256
St. Esprit, order of, and Clairambault's collection, Is I

St. Eustatius Island, description, trade, 72, 239 ; plan, 236; sketches, 270; see also West Indies; Windward Islands

St. Florent de Saumur, titular bishop, 29

St. François Xavier Mission, I09

St. Genevieve, abbey of, MSS., 276

St. Geniès, Chevalier de, letter, 64

St. George, Grenada, view, 235

St. Germain, —, trial, 247

St. Germain, — de, letter to (I694), 47

St. Germain-des-Prés, abbey of, MSS., 3

St. Germain-en-Laye, treaty of, commercial matters, 5, 6; text, American articles, 47, $49,206,207,209,215$

Saint-Hilaire, Barthélemy, letters to, 283; papers, 28I

Saint-Hilaire, Geoffroy, letters, 259

St. Jean, Ilé de, see Prince Edward Island

St. Jean, I30, 280

St. Jean Baptiste, vovage, I26

St. Jean de Crèvecoeur, Hector, letters, I32; map, 244 ; on steam navigation, I27; papers, I27

St. Jean de Jérusalem, order of, see Malta

St. Jean de Luz, fisheries, 48, I32, I33, I89; whaling, 81, 82

St. Jean Mission, destroyed, 54

St. John Island, W. I., revolt, 82 ; see also Virgin Islands

St. John' River, N. B., fort, I64, I70; notes, I20 ; restitution, 206

St Joseph, Fla., 217

St. Joseph, Montreal, hospital nuns, Io, 25 I

S.t. Joseph, religious house of, 204

St. Joseph Bay, plan, 227

Saint Just, Baron de, see Biencourt de Poutrincourt, Jean de

St. Laurent, Chevalier de, La Salle papers, I09; memoir, 98 ; St. Kitts, letter (I666), I90

St. Lawrence River, commerce and fisheries, 6, I 8I, I93, 262; described, 207; maps, I40, 224-226; notes, I7I; papers, II3; scenery, views, I04, 270; wrecks, 62, 80, 203; see also Gulf of St. Lawrence

St. Léon, —de, for West Indies (I666), I89, I90

St. Louis, Mo., Chouteau's narrative, I 29 ; plans, 229

St. Louis, cross of, bestowing, I57, I78; lists, 63, I62; pensions, I78

St. Louis College, New Orleans, 269

St. Luc, François d'Épinay de, letter, I 88

St. Lucia, English evacuation, 33, 82; English claims, 7o ; Estrées' concession, 33, 78 ; maps, 237; naval battle, plans, 237 ; papers, I 42 , I47; sketches, 270; see also West Indies; Windward Islands

St. Malo, bishop of, letter ( 1672 ), I95

St. Malo, Cartier papers, I 8,2 I9; commerce, 56 , I63, 204-206, 262, 280 ; commercial memoir, I7, I75, 240 ; expedition against English, 266 ; fisheries, I9, 82, I34, I 53, I 89, I92, I95, 206, 27I; free port, I8; ships in Pacific, 70,84 , I 54,252 ; whaling, I 63 
St. Marc, Santo Domingo, map, plan, view, 232 Saint Martin, Capt. - Guadeloupe plan (I765), 236

St. Martin, Sieur de, on Canadian hydrography ( I677), I74

St. Martin, Sieur de, St. Lucia commandant ( I 7 I 8$), 33,78$

St. Martin, François du Noyer, sieur de, commercial company ( I6I6), 52

St. Martin-Barès, $A b b e ́$ de, fishing permits, I 89

St. Martin Island, French conquest, 264 ; map, 237 ; memoir, 78 ; negotiations, 70

St. Martin River, 227

St. Michael, Sieur de, brother, I40; Canadian pilot ( I686), I35

St. Michel, 20I

Saint-Michel Gourville, —. orders, I69

Saintonge, Alphonse de, see Fonteneau

Saintonge province, ports, I28

St. Ours, - decoration, I78; papers, I05; pension, I 56

St. Ours, Mme. de, marriage, I6I

St. Paul —, letter to (I807), I 47

St. Paul, 52

St. Pierre, Comte de, concessions, 33, 34, 78, 2 I 8

St. Pierre, Jacques Legardeur, sieur de, journal, I 08

St. Pierre, Martinique, list of officers, I 56 ; plan of fort, 236; revolt, I44; see also Martinique

St. Pierre de Repentigny, Agathe de, letters, I I6

St. Pierre Island, animals, 259; astronomical observations, 277 ; coast, 276; colony, 273; flora, 27I, 273; Guiana trade, 8; letters from, I42, I62; papers, I07; printing, I42 ; travel, I 33

St. Romain, - de. ambassador, letter to, 205

St. Sacrement, colony, 277; Portuguese claims, $4 \mathrm{I}, \mathrm{I} 77, \mathrm{I} 78$

St. Sauveur, - , trial, 247

St. Sébasticn, I87, I89, 201, 204

St. Sulpice, Curé de, letter (I757), 2I 4

St. Sulpice, Jean Ebbard, baron de, 209

St. Sulpice Seminary, Baltimore, plan, 230

St. Sulpice Seminary, Montreal, affairs, i 8 ; officials, 40, I09, I64; unclaimed estates, $7 \mathrm{I}$

St. Thomas Island, Dutch, 96; information, I68; see also Virgin Islands

St. Valéry-en-Caux, admiralty, 2I7; fisheries, 280

St. Vallier, Jean Baptiste de la Croix Chevrières des, curés, Ioo; death, 267 ; jurisdiction, 99, I00, I 76, I77; letters, 69, I 40, I64, 268; letters to, 268; missionary relations, seminary, 23, 69-7I, 79, I64; notes, 23 ; on Laval, 268; passage and in France, return, I 59, I64; Poulet, 54, 55; prisoner of war, 23, 69, I 44,146

St. Vincent Island, Carib treaty, 79, 82; negro revolt, 82; see also West Indies; Windward Islands

St. Yves, Georges, "Antilles Françaises", 32 Sal, Antonio del, 220

Salamanders, notes, 273

Salas, Francisco de, 207

Salée River, Guadeloupe, map, 236
Salières (Sertière), Henri de Chapelas, sicur de, for Canada, I87; memoir, 5; pay, 202; pension, I9I

Saliès, —, voyage (I746), 8

Sally, 22, 39

Salmon, Edmond Gatien de, intendant, census, $8 \mathrm{I}$; signature, I62

Salone, Emile, Colonisation, I 53

Salt, Guiana, 80

Samaná, San Domingo, American project, I27; plan, 234

Samaran, Charles, "Gourgues ", 5

Sanches, Domingo, map, 222

Sanchez, - , eulogy on (I784), 238

Sanchez Valverde, Antonio, Idea del Valor, 75

Sand, George, letters, I3I

Sandusky River, Indians, 259

San Francisco, Cal., affairs ( 1873), 90

San Lucas, Duque de, see Olivarès

Sanson d'Ábbeville, Nicolas, maps, 73, 265

Santa Clara, Marqués de, letter to, 22

Santa Fé, N. Mex., quail, 270

Santa Fé, reino de, see Colombia

Santiago de Cuba, maps of region, 23I

Santo Domingo, administration ( I7.83), 37 affairs, news, $6,66,75,8 \mathrm{I}, \mathrm{I} 30, \mathrm{I} 47,263$; agricultural correspondence, I30; American relations (I776), I2I ; ( I789), I32; ( I79497), Sonthonax's letters and papers 20-22, 38, 39, 93, 94; attacks, I39, I75; burial regulations, 8I ; canoes, I7I; Cercle des Philadelphes, I43; coasts, 276; commerce, 80, 83, I 32, I 36, I 46, I 48, 202, 254, 255; Compagnie des Indes, disturbances, $34,60,78,83$, I 47 ; compensation for loss ( 1828 ), 93; criminal transportés, 64 ; decree against foreign commerce, 83 ; defense, $3 \mathrm{I}, 83$, I 47, I48; descriptions, information, $43,46,97,155,243,267$, 276 ; duty on products, I9; emigration to France (I776), I I6; filibuster, pirates, revolt, 66, 97, I94; finances, I32; flood, I2 ; Franco-Spanish boundaries, 3I; freemasonry, 277; French establishment (I665), I 89; galleons at, 8I ; histories, I I 5, 24I ; Iberville, 67 ; Indian slaves, 8I ; Indian war, 8I ; La Salle's expedition, I00, I74; latitude and channels, 277 ; letters from and on, I 32 , I 43; maps, 222, 23I-235; memoirs, 23, 72, 97, I39, I 46, I 48, 254; military commission, I53; natural history, 27 I-273; negro revolution, papers, refugees, Toussaint, 39, 87, 94, I 3 I, I 42, I $43,234,245$; nuns, 8 I ; octroi, 89 ; officials, lists, decorated, 63, I 53 , I 56 , I 57 , I6I ; Ogeron's project, 97 ; papers, lists, 8, 38,87 , I 42, I 43, I 57 ; prisoners from, I 94 ; proposed attack (c. I673), I55; proposed joint expulsion of French (I693), I52; Protestants excluded, 70; provisions for Louisiana, 56; relief, racial discrimination, 243 ; revolt song (I723), 78; simples, 272 ; slave trade, 34,83 , I 7 , I 47,243 ; sugar, 24 ; superior council, I 53 ; tobacco, 2 I 4, 255 ; Valverde's Idca del Valor, 75 ; voyages, 68, I0I, I62; sce also Leeward Islands; West Indies

Santo Domingo, city of, maps, 23I 
Saratoga, N. Y., letters from, I3I; see also Burgoyne, John

Sarrazin, Nicolas, Canadian plants, 27 I

Sartine, Antoine Raymond Jean Gualbert Gabriel de, American Revolution, 245; correspondence, I2I, I22, 21 2, 248, 256, 278; on censured books, 6I, 62 ; privateers, $25 \mathrm{I}$

Saskatchewan, printing and newspapers, I 42

Sauba Haristéguy, Capt. - de, letter, I82

Saujon, Louis César Campet, marquis de, I57 Sautogou, Iroquois, 78

Sauvolle, - , Biloxi, 56

Savalete, —-, Compagnie des Indes, 59

Savannah, plans of siege, 230

Savary, Jacques, Dictionnaire du Commerce, I7 Saxe, Hermann Maurice, comte de, 242

Say, Thomas, Long's expedition, 275

Scapeaux, Vicomtesse de, 233

Sceptre, I23

Schatz, Dr. J., letter, 90

Schefer, Charles, Navigation de Parmentier, 46, IOI

Schoelcher, Victor, collection, 87 ; papers, I44; Touissant Louverture, 38

Schöner, J., globe after, 222

Schoff, S. A., Humboldt portrait, I 46

Schoots, Capt. Samuel, I62

Schweinitz, Louis de, letter, 275

Scioto Company, papers, 239, 245

Scotland, Darien colony, 24, 98

Scott, John, I97, 205

Seal, —, supercargo (I797), 2I

Seals, notes, 27I, 272

Sea power, plan ( 1762$), 32$

Sea serpent, memoir, 273

Sea wolves, slaughter, 78

Secession, Rothschild on, I3I

Sedgwick, Theodore, jr., letter, 283

Sée, Henri, on memoir on Brittany, I7

Seeds, see Plants

Séguier, Pierre, letters to, 216, 264; papers, 5I

Ségur, Philippe Henri, marquis (maréchal) de, censorship, $6 \mathrm{I}$

Seignelay, Jean Baptiste Colbert, marquis de, father's instructions, I8I, 20I; foreign despatches, I58; instructions, 252; La Salle, correspondence, memoirs, I09, II0, I73; letters, 32, I97; letters to, I64, I66, I68, I69, I99; map for, 99; memoirs: collection, I79, I8I ; naval, I8I, 200-202; West India bishopric, 84 ;-memoirs for, 97, I65, I73, I97; minutes, I5: papers, inventory, I34-I36, I 58 ; petition to, I76; policy and practices, 33, I33

Seigniories, condition, I05; land tenure, 7I ; mill banalité, $7 \mathrm{I}$; Talon's, Io

Seine, 67, 140

Seminaries, Baltimore, 230; Montreal, 71, II8; Quebec, I3, 23, 27, 55, 69, 7I, I64, I7 I, $252,263,268,269$

Senate, library, Paris, 279

Senecas, Denonville's expedition. 98, I75; see also Iroquois

Senegal, Compagnie de Cayenne, I85; papers, 87; see also Compagnie du Sénégal; Slave trade

Senneville, Sieur de, see Mithon
Sergent, Benjamin, commission, I 80

Sérigny, Comte Emile de, correspondence, II 2

Sérigny, Joseph le Moyne de, see Le Moyne

Serionne, Joseph Accarias de (?), censorship reports, 61

Sermet, $\longrightarrow$, trial, 247

Sertière, see Salières

Servants (engagés), indentured, contractor, I83; for Canada, I38, I 59, 203, 2 I8; for Louisiana, 255 ; memoir, II 6 ; required transportation, I2, I37, I39, I 59, 21 8

Settlers, act, 262 ; bonus for transportation, 205 ; Canada, 25I, 276; discharged marines and soldiers, r37; encouragement of large families, I6; impressed, 83; insubordinate, I7; Louis XIII.'s policy, 27; Louisiana, 23, 40, 59, I30, I3I, 255; plan for children, 2I2; proposed Huguenot, 40; Protestants excluded, I0, 70, 204; Tortuga, 189; vagabonds, 212; West Indies, I86, see also Passage; Servants; Transportation

Seuil, Pierre Chertemps, sieur de, letters, I82, I83, I9I, I99-201

Sévelinges, Charles Louis de, translation, 87

Seven Years' War, Anglo-Spanish rupture, 3I, 32; Frederick the Great on, I46; French history, 60; papers, I05; see also French and Indian War

Seville, treaty of (I729), 82

Shea, John Gilmary, "Address ... Discovery of the Mississippi ", I29

Shepard, Dr. Elliot F., letter, 90

Shipbuilding, American supplies, timber, 40, I84, I93; Bordeaux, 266; Brazil, I89; Canada, I6, I88, I93, I94, I97, 202 ; for colonial trade, I94; Louisiana, 31; promotion of French, 42 ; see also Masts; Naval stores; Navigation

Ships, see Navigation

Sibbald, - American merchant (r797), 21, 22

Sibilet-Labrousse, Pierre, I 56

Siboure, France, fisheries, I33, I89

Sicard, - memoirs ( 1729 ), I28

Sigourny, Lydia H., letter, 283

Silhouette, Etienne de, 228; and colonial boundaries, 73; commissioner, 212; letter, IIO; on English designs (I747), 40; on tobacco promotion, 40

Silks, colonial culture, 64,96

Sillery, Nicolas Brulart, marquis de, papers, 260

Silliman, Benjamin, letter, 275 ; letter to, 275

Silver, assaying, I 54 ; see also Mines

Silvy, Père Antonio, journey, journal, I08, I76; letter to, 268; "Relation", I05

Simancas, archives, inventory, 95

Simon, - , censorship, 62

Simon, Pedro, on Spanish conquests, 256

Sims, Dr. J. Marion, letters, 90

Sioux Indians, Le Sueur's expedition, 97 ; posts, I08; see also La Vérendrye

Sisters, see also Dames; Nuns

Sisters of Charity, Guiana, 79

Sisters of the Congregation, Canada, 79

Six Indiens . . . au Havre, I29

Slaney, John (Humphrv). letter to, 26I 
Slavery, abolition in French colonies, 93 ; code, I33; Condorcet's papers, 255; control over colonial affairs, I58; essay against, I43; in United States, I3I, I44; papers on French West Indies, I44; see also next titles

Slaves, estates of minors, 58 ; Indians, $8 \mathrm{I}, 85$; in France, status, 77, 78; Louisiana, and tobacco, 40, II7 ; revolts, 82, I44, 20I ; see also Santo Domingo (negro revolution)

Slave trade, account (I7I3), 254; advice (I665), I88; capture by Algerian pirates, I93 ; Compagnie des Indes, 59, 60, 83, I17, 257; Compagnie des Indes Occidentales, 33, I96; convoy, I7; departmental control, 77 ; domaine d'Occident contract, 2I7; domestic, in United States, I44; Dutch, 34, 82, 96, I86; duties, 79; English, 280; freedom, 56; French ports, 56, 74, I30, I36, I39; Grégoire on, 24I, 243; Guiana, I76; history, 279; impediments, 74; Las Casas, 24I ; Louisiana, 34,213 ; memoirs, conditions, 5, 20, 28, 37, $53,56,77,136,205,243,254,257$; monopoly, infringements, I2, 83, I54; needed merchandise, I2; notes (I82I-25), I26; papers, 93, II7, I 38; Portuguese, I38; prices, profits, 9,58 , I82, I 91 ; reference, 254 ; regulations, 58 ; rights of colonial officials, I I7; ships, I95; Spanish America, I39, I55; suppression, 93; to France, I9I, 20I ; West Indies, I38, 202; see also Assiento

Slidell, John, Mexico, I42

Sloane, Hans, 223

Sloet, B. map, 256

Smith College, Studies in History, I 8

Snakes, fascination, $27 \mathrm{I}$; Indian bite remedy, 75 ; Louisiana, 272 ; notes, 273

Social conditions, Boston ( 1676$)$, I62; see also Crime; Education; Health; Liquor; Population; Property; Religion; Slavery

Société des Amis des Noirs, 2I, 255

Société des Bibliophiles de la Guyanne, Publications, 4

Société des Bibliophiles Français, Mélanges, 45

Société des Sciences et Arts de Bayonne, Bulletin, 3

Société de Villemarie, I06

Société Historique de Montreal, Mémoires, 265

Société Patriotique de la Section du Luxembourg, 75

Société Royale de Médecine, John Adams, 238; Mémoires, 272

Sogard-Théodet, Gabriel, extracts, I59

Soldricq, $\longrightarrow, 224$

Solignac, —-, and Bigot, 128

Sombretrette, 3I

Some Remarks on a Pamphlet, I45

Sonthonax, Louis (Léger) Félicité, Santo Domingo letters, 20-22; papers 93, 94 ; Société des Amis des Noirs, 2I

Sorbonne MSS., 28I

Sorel, _ Santo Domingo, 83

Sorret, A. F., translation, 75

Sougé, Mme. de, Santo Domingo affair, ${ }_{52}$

Soulanges, - , Canadian taxes, I 63

Soulanges, Mlle. de, marriage, I6I

Soulé, Pierre, Mexico, I 42
Soult, Marshal Nicolas Jean de Dieu, letter to, I02

Sound, the, list of ships passing (I780-I802), 42

Soupart, $\longrightarrow$, map, 227

Sourdeval de Mendre, - letter (I657), 2I6

Sourdis, Comte de, voyage ( 1671 ) , I94, 200

South America, cacao, 82; commerce, papers, 263; description, I54; expedition, 276; French lieutenant general, 34; geography and history, 4, 8, 42, 240; list of towns, 277 ; maps, coast, $3,7,73,255,256$; narratives, I55; navigation guide, 3 ; north coast settlements, I77; notes, 262; piratical logbook, 3; proposed colony, I9.3; Spanish affairs (1867), I27; Spanish bishop and French territory, 78; see also Brazil ; Guiana; Spanish America

Southampton, Henry Wriothesley, earl of, Virginia Company, 96

Southampton, treaty of, Anglo-Dutch alliance, 208, 263

South Company, Swedish, charter, 209, 252, 253 , $26 \mathrm{I}$

South Sea, see Pacific Ocean

Sovereign Council of New France, creation, 7, I0, 88; registers, extract, I04, I68; registration of concession, IIO; royal minutes and review, I6, I47

Spain, American Revolution, I23, 245, 267; and French exploration, 209; Antwerp Truce, I3, $28,47,52,54,70,73,96,207,208,266$; army orders, 204, 209; Colbert's documents, I79; commerce, foreign colonies, $5,20,30,40$, 77 ; commercial companies, 82, 83, 267; Denis's notes, 278; England and Indies (1569), I47; English treaty (I667), I49; English war (1656), 206, 207; Family Compact, 29, 30, 146; Franco-Portuguese alliance against, 264; French alliance against English colonies, 30, 31 ; French and Indian War, neutrality, rupture, 29-32; French commercial treaties, I5, 30; French embassy, correspondence, papers, I3, 28, 48, I 47, 205 ; Iberville's Mississippi expedition, 24; La Croix's "Etat général", 279; list of possessions, 264; privateers (I797), I44; private French relations, II5; South American affairs (1867), I27; sugar industry, I86; types of colonial trade ships, I45; Virginia, 207; see also Spanish America; colonies, rulers, and wars by name

Spalding, Dr. Lyman, letters, 89

Spanish, Bibliothèque Nationale MSS., 2

Spanish America (West Indies), avarice, I7I ; bill of goods, 276 ; bishoprics, 265 ; Collection Angrand, 220 ; commercial decline, rehabilitation, 85 ; commercial monopoly, 265 ; conditions (I 705), 69; Denis's notes, 278; Dutch plans (I602-6), I4; duties on products, 8I ; English relations, Drake, later, I.3, 47, 56, I47, 264; foreign trade, especially French, treatment, I2, I3, 31, 74, 96, I I 5 I I5 , 192, 21 3, 243, 255, 257, 262; French expansion, I73; French operations (I7I6I8), 77; French preservation, 31, 85, I55; galleons, 49, 69, 80, 8I, I40, I44, I79, I 90 , 
202, 252; government, 98; home relations ( 1776), 121 ; La Croix's relation, 279; mainland conquests, 256; memoirs, I39, I 52, 265 ; naturalists, 260 ; navigation, troubles, 29, 49; neglect, I3; plans against, I55, I76, I $77,205,263$; royal revenue, 69 ; slave trade, I39, I55; wars of liberation, I26, I3I; see also Assiento; colonies and sections by name Spanish Succession, war of the, French declaration, I52; Torcy's relation, 74; see also Queen Anne's War; Utrecht

Sparks, Jared, Louisiana documents for, II3

Specie, see Money

Speelberghen, - - voyage, 26 I

Spence, Thomas, Manitoba, I29

Sphère, 33,

Spiders, American, 271

Spifame, Samuel, see Buisseaux

Spinola, Ambrosio, marquis de, instructions, 208

Spofford, Ainsworth R., and Margry, II8

Squillacé, Marquis de, letters, 32

Squire, Dr. Truman H., letters, 90

Squirrels, notes, 272

Stainville, Duc de, see Choiseul, Etienne François de

Stanley, Hans, letter, 120

Stanley, Henry, letter, 277

State, department of, registers of letters, 27

States, constitutions ( 1778 ), 6I

States General, Dutch, 40, 52, I 80, I86

Steam navigation, beginning, 127 American, I28; in United States, I44

Stora, Abraham, letter, I99

Storms, see Hurricanes

Story, Joseph, Sumner on, 283

Stove, Franklin's, 6I

Stuart, Gilbert, Washington portrait, 146

Subercase, Daniel d'Auger de, decoration, r78; Port Royal, 27

Suffren Saint-Tropez, Pierre André, letters, 126

Sugar and molasses, Baltic trade, 77; duties, drawback, I9, 57, 58, 74, 85; import, I99; La Rochelle trade, I36; Mediterranean trade, 77; mills, I83, I84; New England trade, I46; notes on cane, 272; price, 64; sale (I674), I98; Santo Domingo, 24; Spanish trade, I55; trade impediments, 74; West Indies industry and trade, I30, I32, I86; see also next title

Sugar refineries, French and colonial, I43; La Rochelle, I36; Marseilles, I39; Martinique, 80; memoirs, 272; West Flanders, 254

Sullivan, John, correspondence, I26; Rhode Island operations, 230

Sully, Maximilien de Béthune, duc de, Antwerp Truce, I3; colonial policy, 44; correspondence, $44,205,261$

Sulpicians, Ottawa mission, I94

Sumatra, Parmentier voyage, IoI

Sumner, Charles, letters, 283

Superior councils, Guiana registers, 84 ; Ile Royale, 78; Louisiana, and Crozat, I2, $7 \mathrm{I}$; Martinique, 9I, I53; New France, 7I, 88, I69; Santo Domingo, I 53

Supplies for colonies, Canada, I8I, I92, I94, 201 ; during French and Indian War, 30, 3I;
Guiana, 201 ; Louisiana, 68; Placentia, I69; West Indies, I9I, I95, I98, 213; see also Army; Provisions

Surcouf, Robert (?), sr., letter, 124

Surgères, Chevalier de, decoration, I78; voyage, $24,66,67$

Surinam, see Guiana, Dutch

"Sur les véritables limites ... en Amérique", censured, 62

Surville, Jean François Marie de, voyage, I26 Surville, Louis Charles de Hautefort, marquis de, letter to, Iro

Swain, Thaddeus, I2

Swanton, - correspondence (I782), 248

Sweden, and American Revolution, papers, 93 ; see also South Company

Swiss troops, colonial service, 23, 62, 73, II 8, 266

Syria, voyage, 277

Tacobagai, $2 \mathrm{I} 7$

Tadoussac, I88, 225

Taensa Indians, mission, 97,98

Taft, - , letter to $(1840), 245$

Taglieri, Abbé, I47

Tahiti, I27, 143

Taincturier, -259

Tallard, Camille d'Hustun, duc de, letters to, II 5

Talleyrand-Périgord, Charles Maurice de, Mémoires, MS., 9I

Talon, Jean, brewery, 72 ; correspondence, I03, 104, I62, I89, I94, I95, 205; death, 26; endorsement, I62; ill, 205 ; Le Gaigneur, 202 ; memoirs, Memoire du Canada, ro4; merchandise, 201 ; news, I88, I89; notes, 202; on officials, I57; papers, I06; praised, I9I ; return to Canada, I6, I94, 201, 202; return to France, I93-I96; salary, 202, 203, 25I ; secretary, 202, 203; seigniory, I0; ship for, I93; trade claim, 201

Tamarois mission, 268, 269

Tamizey de Larroque, Philippe; on Gourgues, 4

Tampico, Louisiana trade, 40

Tanguay, Abbé, letters, I 28

Tappan, Henry P., 282 ; letters, 283

Tardiveau, Barthelemi, letter, 245

Tariff, see Duties

Tarin de Cussy, Gov.__ of Santo Domingo, I69

Taschereau, Archb. Elzéar Alexandre, Histoire du Seminaire, MS., 269

Taschereau, Jules Antoine, Rerue Rétrospective, 4

Tate, - , ship captain (I796), 22

Tattonus, G., map, 257

Taxation, Canada, 89, I63; Montreal fortifications, 7I; Santo Domingo octroi, 89; see also Capitation; Duties; Finances

Taylor, Thomas, 283

Taylor, William (?), letter to, 257

Te Deum, French and Indian War victories, I4; Yorktown, 44

Teganissoren, Frontenac parley, 9

Teixeira, Ioaõ, map, 256

Téméraire, 138

Tempête, 140 
Ternaux-Compans, Henri, Archives des Voyages, 7 ; Recueil sur la Floride, 4

Ternay, Charles Louis d'Arsac, chevalier de, American Revolution, letters, 36, I22-125; Newfoundland, I2I, I25; proposed monument, I23

Terrasson, Antoine, letter, I42

Terre aux Bretons, Florida, 209

Terre Firme, see Central America

Terron, Charles Colbert. sieur de, and Chamot, 225, letters (I66I-63), I8I-I89; (I666-70), I89-I93, 202; (I67I-74), I94-I99; letters to, I5-I7, I89, I97, 202, 204; marine order, I62; memoirs, Rochefort, I94-I98, 201, 202, 262 ; praised, 184

Tersmitte, H., letters, I92, I93

Testard, dit la Marque, Jacques, see Montigny

Texas, French plans, 173, I77; question (1837), 75 ; separation from Mexico, 3I

Texte Explicatif . . . relative à la Louisianne, I09

Thaumer de la Source. Père Dominique Antoine, see La Source

Theguayo, discovery, conquest, 25, 88; French project, I73

Thélémaque, - , Santo Domingo judge, letter to, $2 \mathrm{I}$

Thetis, 22

Thévenard, Antoine Jean Marie, comte de, letters, I22, I24

Thevenet, - map, 236

Thévenot, Melchisédech, extracts, I08

Thevet, André, Cosmographie universelle, 5r; description of islands, 5I ; extracts, II8; "Grand Insulaire et pilotage", 46; "Histoire naturelle", 53; "Mexique", 53; papers, 105; Singularitez de la France Antarctique, $5 \mathrm{I}$; voyages, $46,5 \mathrm{I}$

Thévinin, Paul, letters, I8I, I82

Thibault de Chanvallon, see Chanvallon

Thiberge, —, Quebec hearing, 70

Thibout, - Q Quebec hearing, 70

Thierry, - - letter, Compagnie des Indes Occidentales, 186

Thierry, $\longrightarrow$, Quebec letter ( I696), I42

Thierry Beschefer, see Beschefer

Thiersant, - Bastille dossier, 247

Thiersant, Mme. de, memoir, 247

Thiéry de Menonville, Nicolas Joseph, on American plants, 272

Third Estate, Canadian trade, 52

Thirty Years' War, Brazil, 26I ; Dutch-Spanish truce, 263; see also Westphalia

Thoissy (Patrocle), Sieur de, West Indies affair, 53 , II 5, I 70

Thomas,, , consul, letter (I794), 38

Thomas, $D r$., letter, 238

Thomassy, Raymond, Géologie Pratique, I Io

Thompson, Benjamin, see Rumford

Thoré, Louis, letter, 260

Thou, Jacques Auguste de, letter, 262

Thouars, Georges Aristides Aubert Dupetit, notes, I26

Thoüin, André, correspondence, papers, 130, 273-275

Thousand Islands, map, 226
Thoynard, Nicolas, correspondence, papers, I I I

Three Nations, chiefs in France, 80, 240

Three Rivers, Dodier, I62; Iroquois siege, I88; map, plan, 224; Plée's journey, 274

Thumery, Jean de, see Boissise

Thwaites, Reuben G., Jesuit Relations, 9

Tibbits, George (?), 259

Tiberge, - Missions Etrangères, I 3

Tibierge, R., letter, 169

Tiburon, Santo Domingo, plan, 233, 235

Ticknor, George, letter, 283

Ticonderoga (Fort Carillon), affairs, 32 ; attack, observations (I758), I20, 242; capture (I777), II ; defenses, 242; plans, 32, II9, I $32,225,230$

Tierra del Fuego, description, 73 ; natives, 278

Tixerant, _ , attack in Louisiana, 80

Tobacco, Baltic trade, 77, I93; competition with Virginia, 29, 2I4, 255, 279; culture, promotion, 40, 206, 280; English excise, 82; ferme, Compagnie des Indes, 34, 59, 60, I I 7 , 213, 279; Franco-English trade, 30, 280; French trade, regulations, impediments, 18 , 59, 74, I 32, I 36, 145, I98, I99; Louisiana, 40, II 7,2 I3 255,279 ; monopoly or free trade, 20,255 ; price, I 36 ; prize ships, $29,167,242$; prohibition of French growth, I9; treatise, I 47

Tobago, chancery registers, $267 ;$ Franco-Dutch action (I677), 54, I66, 20I, 237; letters from, I42; maps, 201 ; provisions for, 201 ; reoccupation (I725), 79; voyage, 87

Todos Santos, sec All Saints Bay

Tollenare, L. F. de, notes, 278

Tombs, Iroquois, 79

Tonnage, Ile Royale, 8I ; see also Duties

Tonty, Alphonse de, letter by wife, 66; letters, 65,66 ; news, 65,66

Tonty, Henri, and Joutel, I09; capture of English, I75; Florida journey, 268; Illinois (I693), I66; Indians, 175; letter for, 67; letters, 24, 65, 97, 98, I72, I73; map, 24; Mississippi River, La Salle, 24, 97, I09, I Io, 172, I73; news, 23, 65, 66; papers, I09, I10; Renaudot, 97 ; Sur la Découverte, I10

Tonty, Laurens, papers, I Io

Torcy, Jean Baptiste Colbert, marquis de, memoirs, 28,74

Torsi, Chevalier de, 69

Tortoises, notes, 273

Tortuga, Deschamps, 27 ; forced settlers, 189; Ogerón, I80, 190

Toulon, Arnoul intendant papers, I34; slave trade, I9I ; squadron, 29, 2I 2

Toulouse, Louis Alexandre de Bourbon, comte de, letter to, 169

Tourneur, Maurice, Gudin's Beaumarchais, 77; Siméon Prosper Hardy, I I

Tournon, Charles Thomas Maillard, cardinal de, correspondence, 26

Tours, presidial, ro

Toussaint Louverture, Pierre Dominique, collection on, 94 ; letters, 20, 21, 38, 39; trade ordinance, 39

Tower, Charlemagne, letters, 256

Towns, list, 277 
Tracy, Alexandre de Prouville, marquis de, and Bourbon, I90 ; bills of exchange, 202 ; commission, instructions, 63 , I I5, I7 I, I84, I85 ; departure, 184; Estrades on, 184; guards, 27 ; in Canada, reception, I8I, I88; in West Indies, 97, 187, 202; Iroquois, fort, I49, I88, I9I ; letters, I82, I84, I89, I92; personal finances, I82; praised, I89, I9I ; preparations, I83; return, I92 ; salary, 27, 202, 203, 25I ; subordinate, 27 ; supplies, loss, I86, 203 Tradel, Conrad, I9I

Traité ... concernant l'Introduction des Nègres, 20

Traité de Suspension d'Armes, I5I

Traité sur Lettres Patentes, 86

Transportation of criminals and others, at parent's request, I69; Canada, 5, 216; commission for transporté, I62; convicts as marines, I37; English, to colonies, I45; Guiana, 250; Louisiana, 2I I, 2I6, 246, 250 ; vagabonds, 83 , 212,216

Transylvania University, 274

Treasurer, 48

Treasurers general of colonies, 2I I

Treasure trove, English search, 69

Treaties, Anglo-Danish (1665), 263; AngloFrench, and negotiations (I527-I664), 5I, 95, 96, 206; Anglo-French commercial, I5; Anglo-French project on foreign expeditions, 47; Franco-American (1778), 212; Franco-Spanish commercial, 15, 30; see also Amiens; Antwerp; Breda; Compiègne; London; Madrid; Nymwegen; Paris ; Ryswick; St. Germain-en-Laye; Seville; Southampton; Utrecht; Vaucelles; Westminster; Westphalia; Whitehall

Trees, America, 270; California, 272: Louisiana, 272 ; see also Forests

Trenholm, William, letter to, $2 \mathrm{I}$

Trenonay, - 274

Très humbles Remonstrances, 209

Tressan, Vicomte de, letters, I4I

Trinidad, letters from, I42; map, 257; Montgomery grant, I8I; notes, I80; voyage, 87

Trinité, 55

Triomphant, 126

Triomphe du Nouvean Monde, 62

Trompeur, 200

Tronson, Abbé, papers, La Salle's expedition, I09

Troops, see Army

Troyes, Chevalier Pierre de, expedition, I74

Truchet, Père Sébastien, Art de l'Imprimerie, 25

Trudaine, Daniel Charles, memoirs, I32

True, Charles K., letter, 283

Tucker, Dr. A. B., letter, 9I

Tunica Indians, and Natchez, 8I ; burn squaw, 80 ; mission, 97

Turgot, Anne Robert Jacques, American Revolution, 245; Mémoire sur les Colonies, I2I

Turgot, Etienne François, Cayenne affair, correspondence, papers, $8,86,212,266,267,28 \mathrm{I}$

Turkey, papers, I77

Tuttle, Horace P., letter, 258

Tyler, Samuel, letter, 283
Ulloa, Antonio de, letter, 3I ; Louisiana affairs, 88

Unigenitus, bull, 54

Union, $\mathrm{I} 2$

United States, agriculture, 275; Baudry's ideas (I780), I3I ; Beaujour's Aperçu, 87; despatches of diplomats (I789-I8I6), 219; Du Pasquier's work, II6; education, 282, 283; essay on curbing power (1800), I43; fisheries, 27I ; French commerce, 7, 8; Koch's lectures, 265 ; memoirs, 143 ; notes and news, 4I, I 44; plants, 272, 274; Plée's travels, sketches, 270; Rothschild's journal (I8596I), I3I ; territorial expansion, 73 ; western development, 256

University of Maryland, 89

University of Paris, MSS., 28I

Ursulines, Catherine Daubusson, 156 ; Louisiana, and Compagnie des Indes, 34

Uruguay, Jesuit martyrs, 75 ; see also La Plata; St. Sacrement; Spanish America

Usson, François d'. see Bonrepaus

Usson, Jean Louis d', see Bonnac

Utrecht, treaty of, American cessions, I06, I5I, I 52, 243, 265; armistice, I5I ; articles, I5I ; demands, I5I ; fisheries, 82 ; negotiations, 28 ; observations, 28 ; preliminary negotiations and proposals, 47, 55, 131, 21 8

Vache Island, map, 235

Vaches Américaines, play, 85

Vachon de Belmont, François, see Belmont

Vagabonds, transportation, 83, 812, 216

Valbelle, Jean Baptiste, chevalier de, and English squadron, I98

Valcourt, L. de, on steam navigation, 127

Valcourt, M. P. de, Osages, I29

Valdeparaiso, Conde de, letters, 32

Valdony, - for United States, 22

Valentin, Dr. Louis (?), letter to, 275

Valeur, I2

Vallée, Léon, Notice sur les Documents exposés, $22 \mathrm{I}$

Vallée, Paul, suit, ${ }_{56} 6$

Vallogne, Chevalier de, letters, I22

Valois, Noë1, Inventaire des Arrêts, 52

Valton, Prosper, collection, I47

Van Buren, $D r$. William H., letter, 9I

Vanolles (Vanoole), Jean, expedition, 24 ; naturalization, Io

Van Rensselaer, Jeremiah, letter, 275

Vanuxem, Lardner, letter, 275

Vaquieux, Pierre de, "Gourgue", 5

Varennes, Pierre Gautier de, see La Vérendrye

Varlet, Dominique Marie, missionary, letter, 88

Vassan, Jean François, Bastille papers, 247, 249, 250

Vassor, —- de, Martinique letters, 65

Vattemare, Alexandre, letter to, 270

Vauban, Sebastien le Prestre de, I68

Vaucelles, treaty of, and French discoveries, 262

Vaudreuil, Armand de Rigaud, sieur de, suit, I78

Vaudreuil, Louis Philippe de Rigaud, marquis de, letters, I22, I25, I26 
Vaudreuil, Philippe de Rigaud, marquis de, Ville de Rouen, 201, 202

commission by, I43; correspondence, I06, Villefranche, - trial, 247

I57, I64; decoration, I78; .Indian trade, 88, I 45, I56, I57; instructions, I2, I56 ; papers, I08; request, I59; suit, I78

Vaudreuil-Cavagnal, Pierre François de Rigaud, marquis de, Bastille papers, and Bigot case, 247, 249, 280; Fort de Paix, 233; Montcalm, 242 ; papers, 113

Vaugiraud, Pierre René Marie, comte de, journal, I23

Vaulx, Jacques de, map, 222 ; works, 25

Vauvré, Jean Louis Girardin de, letter, 200

Vaux, Noël de Jourda, comte de, expedition, 266

Vegetables, Jamaica, 272

Vendôme, François de, see Beaufort

Vendôme, Louis, duc de, fishery and marine regulations, $44,5 \mathrm{I}$

Venetia, 22

Venezuela, French annexation plans (I863), I43; voyage, 87 ; see also Spanish America

Venice, Levant trade, 9

Venus, 21, 156, 272

Venyard de Bourgmont, see Bourgmont

Vera Cruz, see Mexico

Verchères, Marie Madeleine de, letters, I I6

Verdun, - on Marseilles commerce, I30

Verdun de la Crenne, Jean René Antoine, marquis de, expedition, 276

Vergennes, Charles Gravier, comte de, American policy, 94, 245; Estaing correspondence, I26; letter on peace, 245 ; memoir for, on commerce, 7 ; papers of secretary, 243; poem to, on peace, I78; presents American commissioners, II

Véritables Motifs... de Montréal, Io6

Verjus, Louis de, see Crécy

Vermonnet, Jean Arthur de, letter, services, I43

Vernon, Edward, Cartagena, I45, I52, I 54

Vernoy, - , letter, Iberville voyage, 67

Veron de Forbonnais, see Forbonnais

Verrazano, Giovanni da, Delisle on, 26; papers, I 3 , II 8 ; Renaudot on, 97 ; voyage, 28

Verreycken, - instructions (I608), 208

Verrier, 一, fils, mạps, 224

Versailles, archives on America, I05

Verzel, Berard, 234

Vespucci, Amerigo, biography, 263; portrait, I46; Renaudot on, 97; Viaggi, 87; voyage, 7

Vibaud, - on commerce, 2I 4

Viceroys, for America, 27, I70, I7 I, I82, 205

Viegas, Gaspar, portolano, 222

Vienna, archives, inventory, 95

Vignaud, Henry, letters, I 8,256

Vilemont, Louis, papers, I08

Villardeau, $-\frac{1}{-}$ despatch ( 1703 ), I 56

Villars, _- Louisiana flora, 273, 274; papers, I05

Villars, Pierre, marquis de, letter, I 96

Villebois, see Daubenton

Villebon, - , trial, 247

Villebon, - Robineau, chevalier de, and Dubreuil, I69; Indians, I70; letters, I70, I76; plan against New England, I69

Ville de Bayonne, 165

Ville de Paris, I20, I24

Villegagnon, Nicholas Durand, chevalier de, Brazil, 28, I74

Villemarie, name for Montreal, 23, 40

Villeneuve, - marriage (I757), 2I4

Villeneuve, Sieur de, Quebec map, 225

Villepars, René de Gousabatz de, death, I95; voyages, I88, I89, I95, 202 ; wife's request, 202

Villeray, Louis Rouer de, see Rouer

Villermont, see Cabart de Villermont

Villeroy, Nicolas de Neufville, sieur de, correspondence, despatches, I3, I4, 95, 96, 207, 25I, 26I ; papers, 260

Villers, — de, Bastille papers, 247, 249

Villiers, $\longrightarrow$, request (I689), I59

Villiers du Terrage, Baron Marc de, 240

Villiers-Hotman, Jean de, letters to, 207

Villieu, Claude Charles de, letter, I63

Vimeur, see Rochambeau

Vincelotte, seigniory of, mill banalité, 7I

Vincent, - letters (I665), I87

Vincent, _L "Lettres d'un membre du Congrès Américain ", 6I

Vingboons, Joan, map, 23I

Virginia, Bacon's Rebellion, 215 ; charter, 96, 26I; commerce, 3; Delisle's MS., 26; descriptions, I44, 265; detained French subjects, 48; discovery, 26; Indian pottery, 79; maps, coast, $39,255,256$; natural history, 72, 274; St. Albans grant, I80; settlement, French news, I3, 26, 207; silk and wine, Tames I.'s letter, 96, 26I; tobacco, West Indian competition, French and Russian trade, 29, I93, 2I3, 2I4, 255, 279; wartime navigation plans against, 29, I I I, I39, I67, 242; Yeardley, I80

Virginie, 62

Virgin Islands, information, 9; printing in, I42; see also Danish West India Company ; West Indies; Windward Islands; islands by name

Visconti MSS., 3

Visit and search, regulation, 5

Vital statistics, I06, I 16, I6I ; see also Marriages

Vitrac, Maurice, Siméon Prosper Hardy, I I

Vocabularies, see Languages

Voeu de toutes les Nations, 60

Voisin de la Noiraye, J. B., letter, I86

Voisin de la Popelinière, Henri Lancelot, on Gourgues, 4 ; Trois Mondes, 4

Volant, $3 \mathrm{I}$

Volney, Constantin François Chasseboeuf, comte de, letters, I 42

Voquet, Mme., Canadian petition, I59

Voyage à la Cốte Nord-ouest, censured, 87

Voyage de Découvertes au Canada, 7

Voyages, Accarette, I80; Beauchesne, 67; Bougainville, I20, 273; Carman, 252; Cartier, 67; Chappe, 6I ; Drake, 4; Dumanoir, I30; extracts. 7; Ferrolle, I76; Frondad, 88; Gonneville, II8, 239; historical notes, 43; La Maire, I68; La Pérouse, I24; Leblanc, 4, 7; Locke on circumnavigation, $262 ; \mathrm{Ma}$ gellan, 7I, 209, 278; Mocquet, 277 ; Niceron's bibliography, 73; Northeast passage, I47; 
Northwest coast, 87, 257, 27 I ; Parmentier, IOI ; Pingré, 276, 277; Speelberghen, 26I ; Surville. I26; Thevet, 46, 5I; see also Northwest passage; Pacific Ocean

Voyer d'Argenson, Antoine René, see Paulmy Voyer d'Argenson, Pierre, see Argenson

Vreede, George Gulielmus. Lettres de Buzanval, I 4

Wabash River, animals, 273; comment, 255; maps, I77, 228; memoir, 40

Wagner, Dr. Clinton, letter, 9I

Waily, de, voyage ( I646), II 5

Waldstein, Comte de, letter to, I44

Wall, Richard, letters, 32

War, department of, list of maps, I I6

Warden, David B., District of Columbia, 257 ; letters, 89, 245, 260

Warin, Charles Joseph S., map, 234; see also next title

Warin, Joseph (Charles Joseph S. ?) map, 228

Warner, - - , in Santo Domingo, 22

Warner, James C., letters, 258

Warren, John C., letter, 259

Wars, historical résumé (I7I9-68), 245

Washburne, Elihu B., correspondence, I I8, I33

Washington, George, biographical notes, 93; d'Estaing correspondence, I26; journal (I753), II3; letters, 4I ; mentions, 243; Monmouth, 230 ; neutrality, 39 ; portrait, I 46

Washington, D. C., described, 282; Rothschild on, I3I

Washington, 2I

Wason, Capt. Hugh, 38

Watson, Elkanah (?), letters, I 30

Wayne, James M., correspondence, 245

Weather, heavy snows, I8I; see also Hurricanes; Meteorology

Webster. Daniel, letter, 245

Webster, John W., letter, 275

Wesleyan University, 283

West, Benjamin, letter, 257

West, W., letter, 245

West, development, 256; information on (c. I750), 42, 43; La Harpe's memoir, II7; maps, 42, 43; papers on exploration (I663I753), I08; see also La Vérendrye; Northwest

Western Sea, see Pacific Ocean

West Flanders, commerce, 85, 254

West Indies, acts on (1684-90), 76; AngloSpanish relations ( I654), Cromwell's policy, 207, 280; Baron's research, 34; Buache on, 257 ; cacoa, 82 ; census (I687), I39; Colbert's interest, 28, I34, I98; Compagnie des Indes, I0, I9, I9I ; consumption of cod, 27 I ; convict marines, I37; defense, I39, I99; Delisle's MSS., 26; descriptions, 265, 276; discovery, I7 I ; diseases, yellow fever, I94, 259; English commissions, Carlisle, I80, I8I ; English seizure of ship, I87; expenditures (I666), 203; family papers, I I5; French assumption of possession ( $1663-64)$, Tracy, I83-I85; French manufactures, 255; French rulers, viceroys, commissions, I4, $27,34,53$, I 70, I71, I82; French voyages and cruises, instructions, journals, logbooks, I2, I7, 46, 63, 7I, I21, I22, I27, I6I, I62, I83-I85, 200, 207, 262, 276, 277 ; geography, maps, 42, I79, 23I, 243, 256, 258; geology, 259; health certificates for ships, I86; history, 4; Indian pottery, 79; in truce ( I634), 263; memoirs, relations, 28, 85, I65, I80, I82, 239; militia, 35; money, specie, Io, I56; Münster negotiations, 263; natural history, $86,239,255$; navigation regulations, I36; news, affairs, 66, 67, 69, I65, I67, I82, I83, I87, I9I, I92, I95, 200, 20I; notes, I I6, I I8, I7I, 262 ; officers, list, I63; packetboats, I29; papers, lists, I I4, I34, I6 I, I98; Peñalosa's proposed expedition (I684), I I6; piracy, I2, 67; possible enterprise, I79; printing, newspapers, I42; profile of points, 219; proposed American steamer line, I27; provisions and supplies, I4I, I64, I9I, I95, I98, 200, 202, 213; public works, 203; reference, 207; religious affairs, bishopric, missions, 52, 75, 84, I00, I74, I76, I77, I98; rock temple, 44; Ryswick negotiations, 49; season for sailing, I4I; shipbuilding for trade, I94; ships in service, I6, 79, I92, I95200 ; slaughter of natives, 245 ; slavery, abolition, I44; Spain and sugar industry, I86; Spanish account of French in (I693), I75; Spanish routes, 262 ; transportation of arms and servants, 218 ; travel, I33, 270; troops, I35, I 4I, I43, I98, I99; Utrecht negotiations, I 5 I see also Commerce; Leeward Islands; Spanish America; Sugar; Windward Islands; islands and wars by name

Westminster, treaties of, text (I655), 48 ; text ( I665), 206

Weston, Thomas, 26I

Westphal, —- letter to (I796), 2I

Westphalia, treaty of, Münster and Osnabrück, $28,47,55,76,263,266$

Whales, notes, 272 ; see also next title

Whaling, acts, 76; and Franco-Dutch war, I96; Basques, 73; described, 73; Dieppe, I88; Dutch, loss, 74, 96; English, 48, 214; Franco-Russian oil trade, I93; French abandonment, 7 ; French, by Nantucket men, 12; French rights in north, 5I ; history, 279 ; in I850, I33; journal of whaler, I28; Maurepas' function, I54, I55; memoirs, I3I, 27I ; Normandy, 74; oil duties, I92; report, 80; St. Lawrence, I36; St. Malo, I63 ; ships, list, $8 \mathrm{I}, 82$; treatise, $28 \mathrm{I}$

Wharton, Francis, Digest, 255; letters, 256; on Jay and peace negotiations, French translation, 255

Wheat, cost for Canada, I36; Illinois, 82; New England, for Spain, 30; see also Flour

Wheaton, Henrv. letters, 283

Whippey, Isaac, I2

Whitehall, treaties of, (I662), I49; American neutrality (I687), I69

White River, fossil, 272

Whittlesey, Charles, letters, I 8,275

Wiener, C., voyage, 277

Wight, Orlando W., letters, 283

Wilde, W. de, Dutch minister, letter, 40 
Wilkins, John, Scioto Company accounts, 245 Wilkinson, John, map, I02

William III. of England, claim to Mississippi, 178

William Henry, Prince, 128

Williams, 21

Williams and Miercker, Santo Domingo, 243

Williamsburg, Va., sketches, 270

Willoughby of Parham, William, baron, commission, I 80

Wills, 5, I 53

Windward Islands, administration, government, 126, 244; commerce, 58, 79, 88, 136, 1 57 ; defense, 31; English claim, 80; list of marine companies, I57; maps, 231, 258; militia, 79; officials, list, decorated, 63, I57; packet-boats, I29; papers, I57; see also West Indies; islands by name, especially Martinique

Wine, and Canadian timber trade, 137 ; colonial trade, fraud, I56; English excise, 82 ; Louisiana, 272; royal payment for exploitation, 203; Virginia, 96

Winnebago (Puant) Indians, Lignery's expedition, 79

Winsor, Justin, Cartier to Frontenac, 226; Kohl Collection, 222; Mississippi Basin, 226

Wisconsin Historical Society, Collections, 80

Wolfe, James, Quebec, I32

Woodbridge, William C., letter, 283

Woodhull, Dr. Alfred A., letters, 9I

Woodward, Capt. Ebenezer, 22
Woodward, Dr. William, 9I

Woolens, Canadian manufacture, II8

Wrecks, Bourgogne, I29; Estrees' squadron, I52 ; Grenier's, 40 ; Newfoundland, 65; procès verbal, I65; St. Lawrence, 62, 80, 203 ; ships from Louisiana, II4; Spanish confiscation and imprisonment, 12, I3; treasure trove, 69

Wriothesley, Henry, see Southampton

Writing, Peruvian and Mexican, 25; see also Languages

Yazoo Indians, and English, 268

Yazoo River, map, 229

Yeardley, Gov. George, I80

Yellow fever, Dumont's researches, 86 ; memoir, 238; Mitchell on, 275 ; West Indies, 259

Yellowstone River, fort, 275

York, Duke of, see James II.

Yorktown, Va., sketches, 270; see also next title

Yorktown, siege of, I23-I25, I27; news, II, 278; official imprint, 44; plan, 230 ; Rochambeau on, 75 ; Te Deum, 44

Yosy, Jean P., letter, 260

Young, - - , of Boston, 274

Yucatan, map, 279

Zea, F. A., letter, 259

Zealand, commerce, I86, I87, I90, I95; pirates, 196; see also Netherlands

Zébédée de Breda, 82

Zender, J. D. L., letter, 283 

$\alpha$ 

w 

$\infty$ 
UNIVEROITY OF ILLINOIS-UREANA 